\title{
Devonian Rocks and Lower and Middle Devonian Pelecypods of Guangxi, China, and the Traverse Group of Michigan
}

\section{Introduction}

Overview of the Devonian of Ghina

Correlation of the Lower and Middle Devonian of Guangxi

Devonian Sections in Guangxi from which Pelecypods Were Collected

Pelecypod Assemblages in the Lower and Middle Devomian of Guangxi

Summary of Traverse Group Stratigraphy in Michigan, and Comparison of Faunas

Systematic Paleontology of Devonian Pelecypods of Guangxi and Michigan

U.S. GEOLOGICAL SURVEY PROFESSIONAL PAPER 1394-A-G

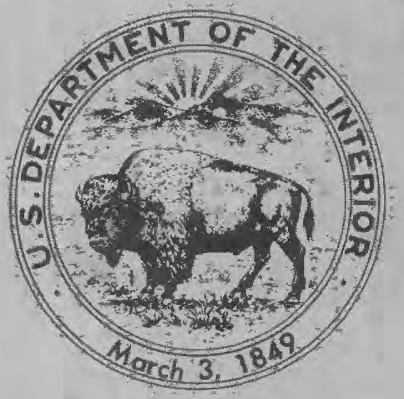




\section{Devonian Rocks and Lower and Middle Devonian Pelecypods of Guangxi, China, and the Traverse Group of Michigan}

Edited by JOHN POJETA, JR.

A. Introduction, by John Pojeta, Jr., and Zhang Renjie

B. Overview of the Devonian of China, by Zhang Renjie and John Pojeta, Jr.

C. Correlation of the Lower and Middle Devonian of Guangxi, by Zhang Renjie and John Pojeta, Jr.

D. Devonian Sections in Guangxi from which Pelecypods Were Collected, by Zhang Renjie and John Pojeta, Jr.

E. Pelecypod Assemblages in the Lower and Middle Devonian of Guangxi, by Zhang Renjie and John Pojeta, Jr.

F. Summary of the Traverse Group Stratigraphy in Michigan, and Comparison of Faunas, by John Pojeta, Jr., and Zhang Renjie

G. Systematic Paleontology of the Devonian Pelecypods of Guangxi and Michigan, by John Pojeta, Jr., Zhang Renjie, and Yang Zunyi

U.S. GEOLOGICAL SURVEY PROFESSIONAL PAPER 1394-A-G

A state-of-the-art summary of the Deronian rocks of China, correlation of the Lower and Middle Devonian of the Guangxi Autonomous Region with the European Standards, and detailed lithologic descriptions of the major Lower and Middle Devonian sections in Guangxi from which pelecypods were collected. Systematic descriptions are given for the Lower and Middle Devomian pelecypods of Guangxi. The Chinese pelecypods are principally compared with the previously little studied Givetian

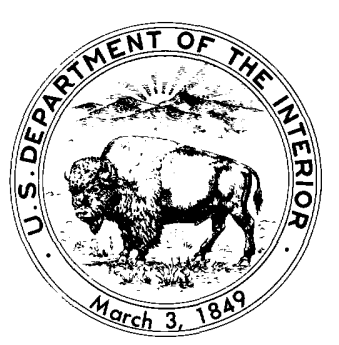
pelecypods of Michigan, which are also described 


\title{
DEPARTMENT OF THE INTERIOR \\ DONALD PAUL HODEL, Secretary
}

\author{
U.S. GEOLOGICAL SURVEY
}

Dallas L. Peck, Director

Library of Congress Cataloging-in-Publication Data

Main entry under title:

Devonian rocks and Lower and Middle Devonian pelecypods of Guangxi, China, and the Traverse Group of Michigan.

(U.S. Geological Survey professional paper ; 1394 A-G)

Bibliography: p. 103

Supt. of Docs. no.: I 19.16:1394A-G

1. Geology, Stratigraphic-Devonian. 2. Bivalvia, Fossil. 3. Paleontology-Devonian. 4. Paleontology-ChinaKwangsi Province. 5. Paleontology-Michigan. I. Pojeta, John, Jr. II. Series: U.S. Geological Survey professional paper ; 1394 A-G.

QE665.D455 $1986 \quad 551.7^{\prime} 4^{\prime} 095128 \quad 85-600186$

For sale by the Book and Open-File Reports Section, U.S. Geological Survey,

Federal Center, Box 25425, Denver, CO 80225 


\section{CONTENTS}

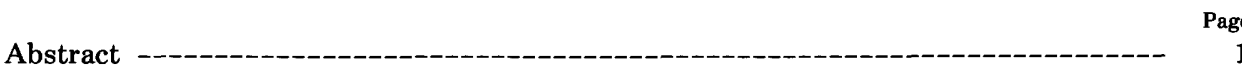

Chapter A. Introduction, by John Pojeta, Jr., and Zhang Renjie ----------------- 3

Acknowledgments --_-_--_. 4

Chapter B. Overview of the Devonian of China, by Zhang Renjie and

John Pojeta, Jr. - -

Junggar-Hinggan or Northern Geosynclinal Region - - 5

Nantianshan or South Tianshan Region -

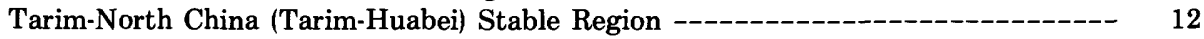

Gudizhonghai or Paleotethys Geosynclinal Region --_--_-_- 13

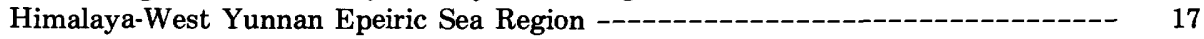

Huanan or South China Region -

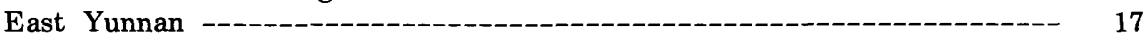

Guangxi -...--

Central Hunan Province --_-_- 19

Dongnan or Southeast China Region --_-_- 20

Chapter C. Correlation of the Lower and Middle Devonian of Guangxi, by

Zhang Renjie and John Pojeta, Jr. -- 23

Lianhuashanian Stage --_-_- 23

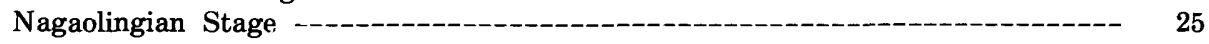

Yujiangian (Yukiangian) Stage --_-_-_-_-_- 27

Sipaian Stage -

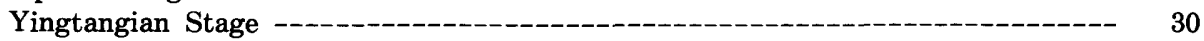

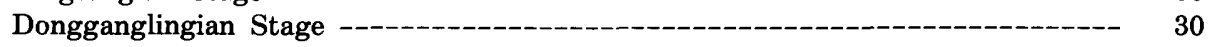

Chapter D. Devonian sections in Guangxi from which pelecypods were collected, by

Zhang Renjie and John Pojeta, Jr. - 33

Section 1 --- 33

Section 2 -- 35

Section 3 -- 38

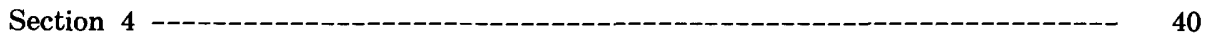

Section 5 ----1 41

Localities 6-12 --

Chapter E. Pelecypod assemblages in the Lower and Middle Devonian of Guangxi, by

Zhang Renjie and John Pojeta, Jr. --_. 45

Lianhuashan Formation ----_-_-_-_-_- 45

Nagaoling Formation -

Yujiang Formation --_-_-- 46

Ertang Formation -

Sipai Formation --

Yingtang Formation --

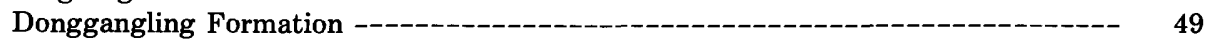

Chapter F. Summary of the Traverse Group stratigraphy in Michigan, and comparison

of faunas, by John Pojeta, Jr., and Zhang Renjie -----c- 51

Traverse Group --- 51

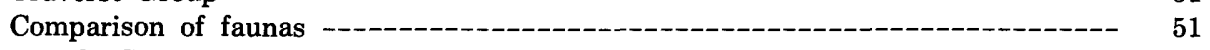

Chapter G. Systematic paleontology of Devonian pelecypods of Guangxi and

Michigan, by John Pojeta, Jr., Zhang Renjie, and Yang Zunyi --.----- 57

Introduction - - 57

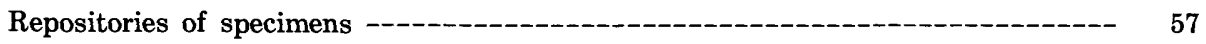

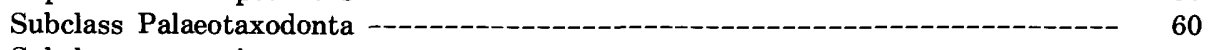

Subclass uncertain --_-_- 67 
Chapter G.-Continued

Subclass Isofilibranchia --_-_-_-_- 71

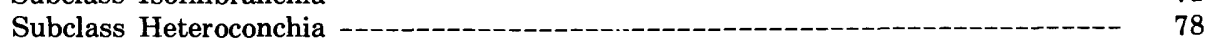

Subclass Anomalodesmata -

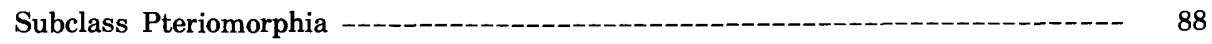

References cited -- 103

\section{ILLUSTRATIONS}

[Plates follow references except as indicated]

Plate 1. Ctenodonta? and Leiodysodonta.

2. Nuculoidea, Nuculopsis?, and Nuculopsis.

3. Nuculoidea, Nuculopsis?, Nuculopsis, Similoconcha?, and Nuculana.

4. Phestioidea, Pseudonuculana, Yoldia, and Phestia.

5. Pseudonuculana.

6. Phestia and Nuculana?.

7. Nuculana?, Palaeoneilo, Nuculites, and Phestia.

8. Nuculites.

9. Dysodonta, Leiodysodonta, Musculus, and Crenella.

10. Leiodysodonta and Eurymyella.

11-13. Modiomorpha.

14. Modiomorpha and Spathella.

15. Modiomorpha.

16. Spathella, Modiomorpha, and Tusayana?.

17. Goniophora (Goniophora), Modiomorpha, and Modiolopsis.

18. Goniophora (Goniophora), G. (Cosmogoniophora), and Crassatellopsis?.

19. Orthonota, Modiomorpha, Mytella, and Goniophora (Goniophora).

20. Leptosolen, Modiomorpha, and Orthonota.

21. Paracyclas.

22. Paracyclas and Cypricardella?.

23. Schizodus and Mecynodon.

24. Nyassa and Sinodora.

25-26. Tanaodon.

27. Sedgwickia?.

28. Orthonota, Radiatodonta?, Sedgwickia, and Grammysioidea.

29. Edmondia and Grammysioidea.

30. Sanguinolites?, Edmondia, Cardiomorpha?, and Sphenotus.

31. Sanguinolites and Cimitaria.

32-33. Fasciculiptera.

34. Mytilarca and Fasciculiptera.

35. Cimitaria, Mytilarca, Carinonychia, Carinonychia?, and Parallelodon.

36-37. Nodonychia.

38. Nodonychia and Parallelodon.

39. Caneyella? and Oxytomoidea.

40-41. Oxytomoidea.

42. Limoptera.

43. Actinodesma (Ectenodesma).

44-45. Leptodesma (Leptodesma).

46. Leptodesma (Leptodesma) and Wuxuanites.

47. Leptodesma (Leptodesma), Wuxuanites, Limoptera, and Pterinopecten (Newellipecten).

48. Ptychopteria (Ptychopteria), Actinodesma (Ectenodesma), Limoptera, and Wuxuanites.

49. Ptychopteria (Ptychopteria), Limoptera, and P. (Actinopteria).

50. Ptychopteria (Actinopteria).

51-52. Lyriopecten, Pterinopecten (Pterinopecten), and P. (Newellipecten).

53. Lyriopecten, Paracyclas, Phenacocyclas?, and Orthonota?.

54. Cimitaria, Cypricardinia, and Schizodus.

55. Cypricardella, Grammysia, and Grammysioidea. 
Plate 56. Cypricardinia, Cypricardella?, and Cypricardella.

57. Mytilarca, Sphenotus, and Gosseletia.

58. Lyriopecten, Pseudaviculopecten, and Aviculopecten.

59. Pseudaviculopecten, Aviculopecten, Leptodesma (Leptodesma)?, and Ptychopteria (Actinopteria).

60. Caneyella and Actinodesma (Ectenodesma).

61. Ptychopteria (Actinopteria), Leptodesma (Leptodesma)?, and Limoptera.

62. Limoptera and Cornellites.

63. Cornellites.

64. Limoptera.

65-66. Photographs of outcrops of Devonian rocks in Guangxi.

67. Correlation chart of the sections of Devonian rocks in Guangxi [in pocket].

68. Distribution of species of pelecypods in the Lower and Middle Devonian rocks of Guangxi, by formation [in pocket].

Figure 1. Generalized map of major tectonic features of China

3. Map of China showing mountain ranges and basins where Devonian rocks crop out

4. Map showing administrative divisions of China -_...-..-

5. Correlation of the Devonian stratigraphic units of China ------_---

6. Map showing paleogeography and sedimentation during the Early Devonian in China -

7. Map showing fossil localities and the location of stratotype areas for the Devonian in Guangxi, South China -.--_-_-

8. Correlation chart of Lower and Middle Devonian rocks of Guangxi, South China

9. Invertebrate fossil zonations or assemblages of the Lower and Middle Devonian of Guangxi, South China -..--

10. Maps showing paleogeography of Guangxi during Sipaian and

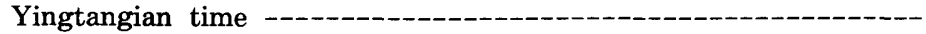

11. Map showing outcrop limits of Traverse Group in Michigan

12. Stratigraphy and correlations of the Traverse Group, Michigan

13. Map of Devonian pelecypod localities in China

14. Hinge lines of antactinodiontids

15. Original drawings of the type specimens of Orthonota undulata Conrad, Sanguinolites discors M'Coy, and Sphenotus arcaeformis (Hall and Whitfield)

16. Original drawings of the type specimens of Leiopteria dekayi Hall and Leptodesma potens Hall

\section{TABLE}





\title{
DEVONIAN ROCKS AND LOWER AND MIDDLE DEVONIAN PELECYPODS OF GUANGXI, CHINA, AND THE TRAVERSE GROUP OF MICHIGAN
}

\author{
JOHN POJETA, JR., Editor
}

\begin{abstract}
This cooperative Chinese-American study presents state-of-the-art summaries of the Devonian of China and the correlation of the Lower and Middle Devonian of the Guangxi Autonomous Region with the European sequences. We present detailed lithologic descriptions of the five major Lower and Middle Devonian sections in Guangxi from which pelecypods were collected. Knowledge of the systematic paleontology of the pelecypods allowed us to define pelecypod assemblages in the Lower and Middle Devonian of Guangxi. The Chinese Devonian pelecypods are compared principally with the Givetian pelecypods of Michigan. The Michigan pelecypods are a major previously unstudied fauna from the United States, which has reasonable stratigraphic data. They allow comparisons to be made with the classical Devonian sections in New York and with Guangxi. The authors are studying the paleobiogeography and paleoecology of Early and Middle Devonian pelecypods on a worldwide scale.

Seven new genera and 28 new species are described out of a total of 57 genera and 99 species. Seventy-one species placed in 48 genera are described from Guangxi, and 28 species placed in 23 genera are described from Michigan. The new genera are Carinonychia,
\end{abstract}

Leiodysodonta, Nodonychia, Oxytomoidea, Phestioidea, Pseudonuculana, and Wuxuanites. In systematic order, the new species are Nuculoidea yongfuensis, $N$. minuta, Nuculopsis gibbosa, Phestioidea obtusa, Pseudonuculana zhaoi, Nuculana? acutirostra, N.? planumbona, Dysodonta angulata, Modiomorpha harrisae, Spathella hepingensis, Goniophora (Cosmogoniophora) marija, Tusayana? liujiangensis, Sphenotus yingtangensis, Sanguinolites nagaolingensis, Cimitaria sinensis, Sedgwickia? yingtangensis, Parallelodon guangxiensis, Carinonychia triangularis, Nodonychia gordia, Actinodesma (Ectenodesma) guangxiensis, Caneyella? yujiangensis, Leptodesma (Leptodesma) guangxiensis, Oxytomoidea elegans, Ptychopteria (Actinopteria) producta, Wuxuanites lanceolatus, W. washingtonensis, Pterinopecten (Pterinopecten) wuxuanensis, and Lyriopecten ertangensis. The only new species from Michigan is Nuculopsis gibbosa Yang. Six of the seven new genera are known only from Guangxi and adjacent areas; the seventh, Wuxuanites, is known from Guangxi and New York. The genera Spathella, Tusayana?, Goniophora (Cosmogoniophora), Crassatellopsis?, Cypricardella?, Mecynodon, Nyassa, Edmondia, Grammysioidea, Caneyella?, and Actinodesma (Ectenodesma) are herein reported from the Devonian of China for the first time.

\section{中国广西泥盆系和早、中泥盆世 斧足类化石以及美国密西根地区的横越群}

\author{
作者 张仁杰、小约翰・帕杰塔、杨遵仪 \\ 编辑 小约翰・帕杰塔
}

\begin{abstract}
内容提要
本文系中、美两国地层古生物学家合作研究的成果。文中对中国泥盆系的最新研究成果作了简略的 介绍; 详细记述了中国广西的下、中泥盆统及其五条代表性剖面, 并与欧洲泥盆系的标准层序作了对比。
\end{abstract}


本文还对中国广西的早、中泥盆世斧足类化石及其组合特征进行了系统描述和总结, 对属及一些属以上 的分类单位进行了详细讨论; 此外还将目前研究程度仍然较差的美国密西根地区吉维特期的斧足类与中 国广西的同期的斧足类作了对比。

本文记述的斧足类化石, 大部分产自文中列举的五条剖面, 共包括五十七属、九十九种。其中新属有 七个, 新种二十八个, 其名单如次:

新属(按属名的拉丁字母顺序): Carinonychia, Leiodysodonta,Nodonychia, Oxytomoidea, Phestioidea, Pseudonuculana 和 Wuxuanites。

新种 (以分类系统为序): Nuculoidea yongfuensis, N. minuta, Nuculopsis gibbosa, Phestioidea obtusa, Pseudonuculana zhaoi, Nuculana? acutirostra, N. ? p lanumbona, Dysodonta angulata, Modio morpha harrisae, Spathella hepingensis, Goniophora(Cosmogonioniophora) marija, Tusayana? liujiangensis, Sphenotus yingtangensis, Sanguinolites nagaolingesnis, Cimitaria sinensis, Sedgwickia? yingtangensis, Parallelodon guangxiensis, Carinonychia triangularis, Nodonychia gordia, Actinodesma(Ectenodesma) guangx iensis, Caneyella? yujiangensis, Leptodesma(Leptodesma) guangxiensis, Oxytomoidea elegans, Ptychopteria(Actinopteria) producta, Wuxuanites lanceolatus, $W$. washingtonensis, Pterinopecten(Pterinopecten) wuxuanensis 和 Lyriopecten ertangensis。

已记述的五十七属中 Spathella, Tusayana?,Goniophora(Cosmogoniophora), Crassatellopsis?， Mecynodon, Nyassa,Edmondia, Grammysioidea, Caneyella? 和 Actindoesma(Ectenodesma) 等十一 属在中国尚属首次报导。七个新属中, 除Wuxuanites 属在中国广西和美国纽约州都有发现外, 其余六 个新属均产自广西及其邻近地区。二十八个新种中, 只有 Nuculopsis gibbosa 是采自密西根地区, 其余均 发现在广西。 


\title{
DEVONIAN ROCKS AND LOWER AND MIDDLE DEVONIAN PELECYPODS OF GUANGXI, CHINA, AND THE TRAVERSE GROUP OF MICHIGAN
}

\section{CHAPTER A. INTRODUCTION}

\author{
By JOHn POJETA, JR., and ZHANG RENJIE ${ }^{1}$
}

This cooperative Chinese-American project is part of a study initiated by the Chinese Ministry of Geology and Mineral Resources and supported by the Chinese Ministry of Education and the U.S. Geological Survey under the 1978 Understanding on the Exchange of Students and Scholars. The study is based on material collected by Zhang and his colleagues in Guangxi; most of the collecting was done in the 1970's. The Chinese material was supplemented from the collections of the U.S. Geological Survey and various American museums. Along with P.E. Cloud, then of Yale University, G. A. Cooper, U.S. National Museum of Natural History, and A. S. Warthin, Jr., Vassar College, Yang Zunyi collected much of the material from Michigan while a student at Yale University. Yang prepared an unpublished Ph.D. thesis at Yale, which included his study of pelecypods from the Traverse Group of Michigan. Zhang worked with Pojeta in 1982 and 1983 as a visiting scholar from China. All specimens were studied at U.S. Geological Survey Laboratories in the U.S. National Museum of Natural History, Smithsonian Institution, Washington, D.C. References for individual chapters are grouped together at the end of the monograph.

Zhang translated a great volume of Chinese literature, both published and internal reports, into English to produce the sections of this paper entitled (B) "Overview of the Devonian of China," (C) "Correlation of the Lower and Middle Devonian of Guangxi," and (D) "Devonian Sections in Guangxi from which Pelecypods Were Collected." Some of the Chinese information was previously available only in unpublished and unattributed committee reports. Because the Chinese literature commonly did not list the authors of taxa, the authors are not included here. Pojeta annotated and edited these sections. Having this large volume of literature summarized in English makes it more generally available

\footnotetext{
${ }^{1}$ Zhang is at the Yichang Institute of Geology and Mineral Resources, Yichang, Hubei, China.
}

to Western geologists. Zhang and Pojeta cooperated in the production of all sections of the monograph; we made extensive use of Yang's unpublished Ph.D. thesis (1939). The paleobiogeography and paleoecology of the Devonian pelecypods of Guangxi remain under study by Zhang and Pojeta.

The Guangxi Autonomous Region is in central South China and has a common border with Vietnam (figs. 4 and 7); the indigenous people of this area are the Chuang. Most of the rocks from which the pelecypods were collected are thick shales, silty shales, or mudstones; some of the rocks are red. Guangxi is important in understanding the Devonian of China because Devonian rocks exposed there have been designated as the stratotype sequences for the Devonian rocks in southeast Asia (Wang and Yu, 1962; Hou H., 1978). During the past 10 years, many Chinese workers have described the rocks and various groups of fossils of Devonian age in Guangxi and adjacent provinces (Bai and others, 1979, 1981; Gao, 1978; Guo, 1980; Hou H., 1978; Hou H. and Xian, 1975; Hou J., 1978; Mu, 1978; Shen, 1975; Wang and Wang, 1978; Wang X., 1977; Xiang and Wei, 1978; Yi and Xiang, 1975; Yu and Kuang, 1980; Yu and Yin, 1978; Zhao and others, 1978; and Zhang, 1977).

For the most part, previous paleontological work in Guangxi has dealt largely with those groups of fossils thought to be most useful for biostratigraphic correlation, such as brachiopods, ammonoids, corals, trilobites, conodonts, and tentaculites. Herein we monograph the abundant Lower and Middle Devonian pelecypods of Guangxi, and extend and supplement the work of Chang (1929), Zhang (1977), and Pojeta and Zhang (1984). The few known Upper Devonian pelecypods from Guangxi were described by Zhang (1977).

The Devonian pelecypods of central South China compare in diversity to those of eastern North America and Germany (Bailey, 1983, p. 198-199, reviewed the Western literature). In southeast Asia, various genera and species of Devonian pelecypods have biostratigraphic 
value, but this was not apparent until they were systematically and carefully collected in stratigraphic sequence. Because pelecypods are the only known fossils in some facies, correlation is necessarily based entirely on the pelecypods.

\section{ACKNOWLEDGMENTS}

The Chinese Devonian pelecypods described here were collected between 1975 and 1979 by Kuang Guodeng, Zhao Minte, Liang Wenji, and Li Jiaxiang (Guangxi Institute of Geology, Guangxi Bureau of Geology); Liu Jingyong (Guangxi Hydrologic Geology Team, Guangxi Bureau of Geology); Wang Saotan (Seventh Geological Team, Guangxi Bureau of Geology); and Jia Huizhen and Zhang Renjie (Yichang Institute of Geology and Mineral Resources, Ministry of Geology). The specimens were systematically collected from the sections at Zhongping and Dale Villages, Xiangzhou County; Liujing Village, Hengxian County; and Luoban Village, Luoxiu Community, Xiangzhou County (fig. 7). We extend our sincere thanks to all our Chinese colleagues.

We are also indebted to many persons in the United States who gave their expertise or lent specimens for comparison with the Chinese material. B. M. Bell, formerly of the New York State Museum, and Ed Landing, New York State Museum, Albany, N.Y.; N. D. Newell, American Museum of Natural History, New York, N.Y.; G. M. Davis, Academy of Natural Sciences of Philadelphia, Philadelphia, Pa.; Karl Waage, Peabody Museum of Natural History, Yale University; and G. A. Cooper, U.S. National Museum of Natural History, Washington, D.C., all kindly lent us specimens or pointed out collections that were significant for our study.
A. G. Harris, J. T. Dutro, Jr., and W. A. Oliver, Jr., U.S. Geological Survey, Washington, D.C., provided invaluable help for our understanding of Devonian correlations based on conodonts, brachiopods, and corals, and guided us to the pertinent Western literature. J. M. Berdan and E. L. Yochelson, U.S. Geological Survey, Washington, D.C., suggested literature to help us in our understanding of eridostracan ostracodes and tentaculites respectively. Marija Balanc, U.S. Geological Survey, Washington, D.C., provided invaluable and necessary help, which included photography, laboratory, curatorial, and montage preparation. Susan Goda, U.S. Geological Survey, Washington, D.C., was particularly helpful in opaquing photographs. Carolyn Hearn, U.S. Geological Survey, Reston, Va., meticulously checked the manuscript for the proper pinyin orthography. G. A. Cooper and J. T. Dutro, Jr., were extremely helpful in their explanations of Michigan Middle-Upper Devonian stratigraphy. G. A. Cooper provided information concerning the stratigraphic occurrences of Devonian pelecypods from Michigan that were collected in the late 1930's. We thank A. J. Boucot, Oregon State University, and D. W. Boyd, University of Wyoming, who kindly provided helpful, timely, and critical reviews of the manuscript. T. R. Waller, Smithsonian Institution, kindly provided information about mantle attachment scars.

Zhang expresses especial thanks to the geologists and staffs of the U.S. Geological Survey and Department of Paleobiology, U.S. National Museum of Natural History, Washington, D.C., for much help and many kindnesses. All of these persons made his prolonged stay away from home and family an enjoyable experience.

[References for all chapters are combined and follow last chapter.] 
DEVONIAN ROCKS AND LOWER AND MIDDLE DEVONIAN PELECYPODS

OF GUANGXI, CHINA, AND THE TRAVERSE GROUP OF MICHIGAN

\title{
CHAPTER B. OVERVIEW OF THE DEVONIAN OF CHINA
}

\author{
By ZHANG RENJIE and JOHN POJETA, JR.
}

The Caledonian Orogeny in China was largely an epeirogenic event that shaped the paleogeographic features of the Nation. The lands formed by the uplift extended from the Sino-Korean Platform to the Tarim Platform (fig. 1). This large continental mass formed the Tarim-North China (Tarim-Huabei) stable region (fig. 2) across central China (Wang and Liu, 1980, p. 165). Present outcrops of the Devonian system in China are controlled by two latitudinal structural belts (figs. 1, 2), which are exposed along the Yinshan and Tianshan Mountains and the Qinling and Kunlun Mountains (fig. 3) in Xinjiang, Neimongu (Nei Monggol, Inner Mongolia), Qinghai, and Shaanxi (fig. 4). Thus, the Devonian rocks of China occur largely in three main terranes, as was first pointed out by Lee (1939).

The northern terrane is mainly the area lying north of the Yinshan and Tianshan Mountains between present lat $41^{\circ}$ and $42^{\circ} \mathrm{N}$. (figs. 2 and 3). Rocks of the northern terrane are typically neritic, terrigenous clastic and volcanic deposits of the geosynclinal facies. In the central terrane, the Tarim-North China (Tarim-Huabei) stable region lies between the Yinshan and Tianshan Mountains and the Qinling and Kunlun Mountains (Hou and others, 1982, p. 165) (figs. 2 and 3); continental red beds are well exposed in the Qilianshan Mountains and around the Tarim basin (fig. 3). The southern terrane, south of the Qinling and Kunlun Mountains (figs. 2 and 3 ), is divided into western and eastern areas. The western area, exposed in Xizang (Tibet) Autonomous Region and western Yunnan Province (fig. 4), is mainly neritic carbonate, sandstone, and shale of the geosynclinal facies; in part, these rocks have been subjected to low-grade regional metamorphism. The eastern region covers most of South China proper (fig. 2), including the Yangtze Platform and the South China fold belt (figs. 1; 2); it is typified by littoral, calcium carbonate cemented sandstones and neritic sediments of the platform facies. In eastern South China there are nonmarine beds of the Old Red Sandstone facies.
On the basis of sedimentary rock facies, stratigraphic history, and paleontological characteristics, the three major terranes are divided into seven distinctive regions (figs. 1 and 2).

\section{JUNGGAR-HINGGAN OR NORTHERN GEOSYNCLINAL REGION}

Devonian rocks of the Junggar-Hinggan or Northern Geosynclinal Region (fig. 2) crop out mainly north of the Yinshan and Tianshan Mountains (fig. 3) in Xinjiang, Gangsu, Neimongu (Nei Monggol, Inner Mongolia) and Heilongjiang (fig. 4) in what have been called the Altai (Altay) and Hinggan geosynclinal areas (fig. 1). Poorly known Devonian rocks of the JunggarHinggan Region are mainly terrigenous clastics intercalated with thick pyroclastics and, locally, with reef limestones; the sequence is characterized by great thickness and many abrupt changes in lithology. The biota is thought to be largely endemic and contains few non-east Asian taxa, although Wang and others (1984) reported what they regarded as some Appalachian genera and species from the Junggar-Hinggan Region.

In western Xinjiang (figs. 4; 5, column 1A), the lowest Devonian is the Utubulake Formation, a tuffaceous sandstone and conglomerate about $460 \mathrm{~m}$ thick. The Utubulake fauna includes the trilobites Encrinurus sp. and Warburgella? conica and the graptolite Monograptus vakatus (Yang and others, 1981, p. 114). Encrinurus ordinarily occurs in Silurian rocks. The overlying Mangeer Formation consists of gray-green tuffaceous sandstone and argillaceous limestone, which is $267 \mathrm{~m}$ thick. Known fossils are the trilobites Calymene junggarensis and Odontochile sinensis. Calymeme ordinarily occurs in Silurian rocks. The upper Lower Devonian is placed in the Mangkelu Formation consisting of calcareous sandstone and sandy limestone about $750 \mathrm{~m}$ thick. Its fauna includes the brachiopods Eodevonaria arcuata, 


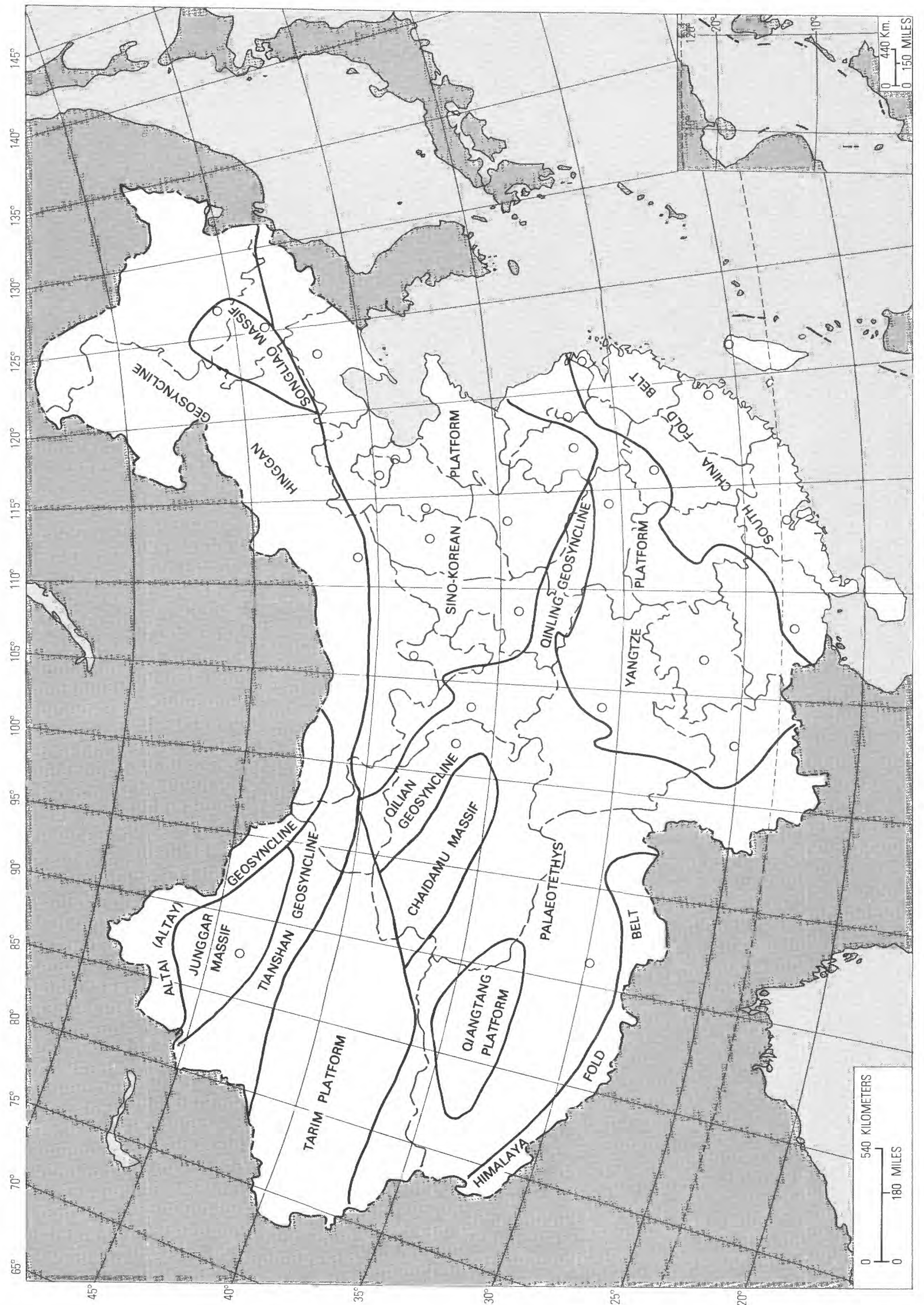




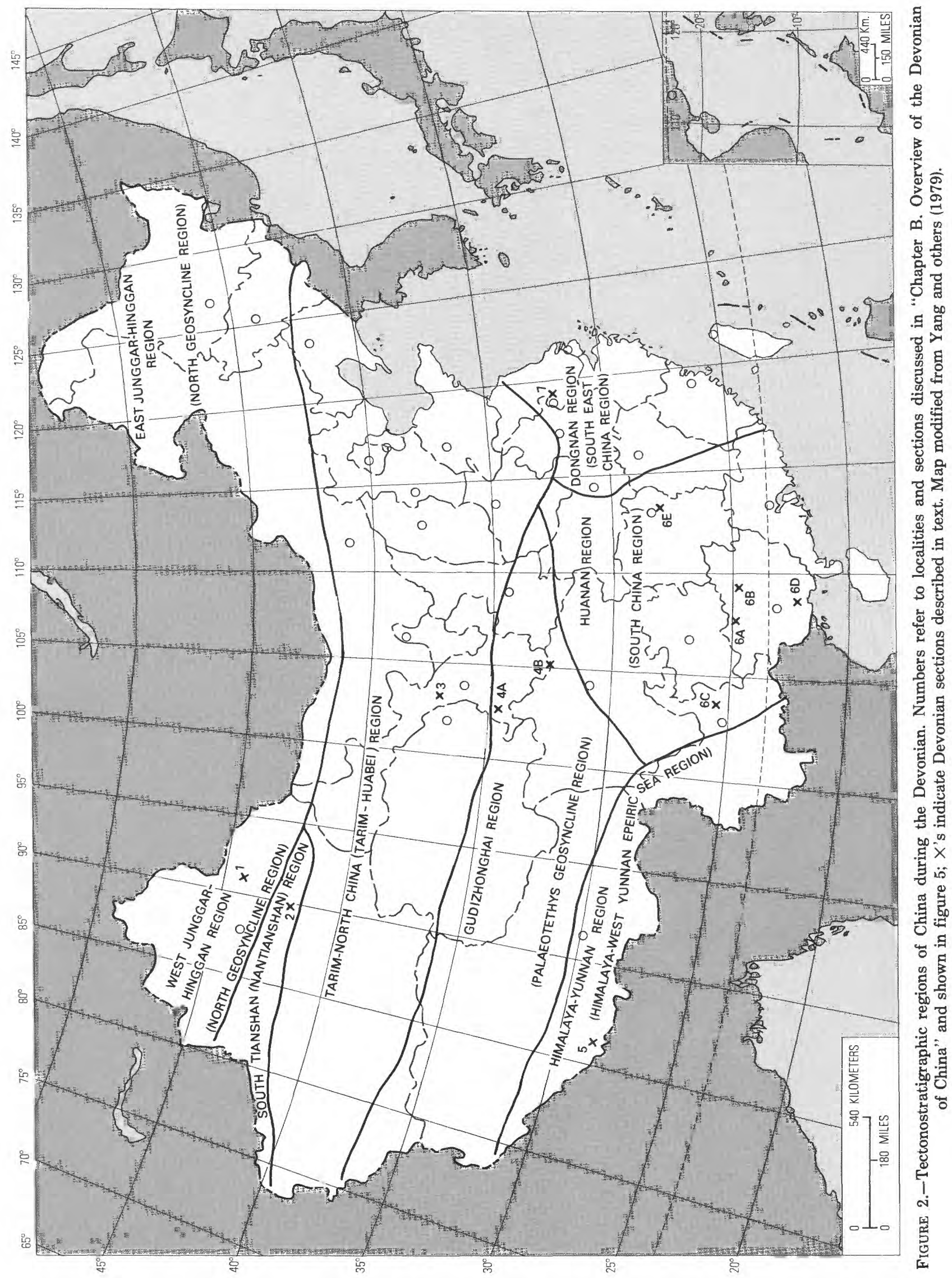




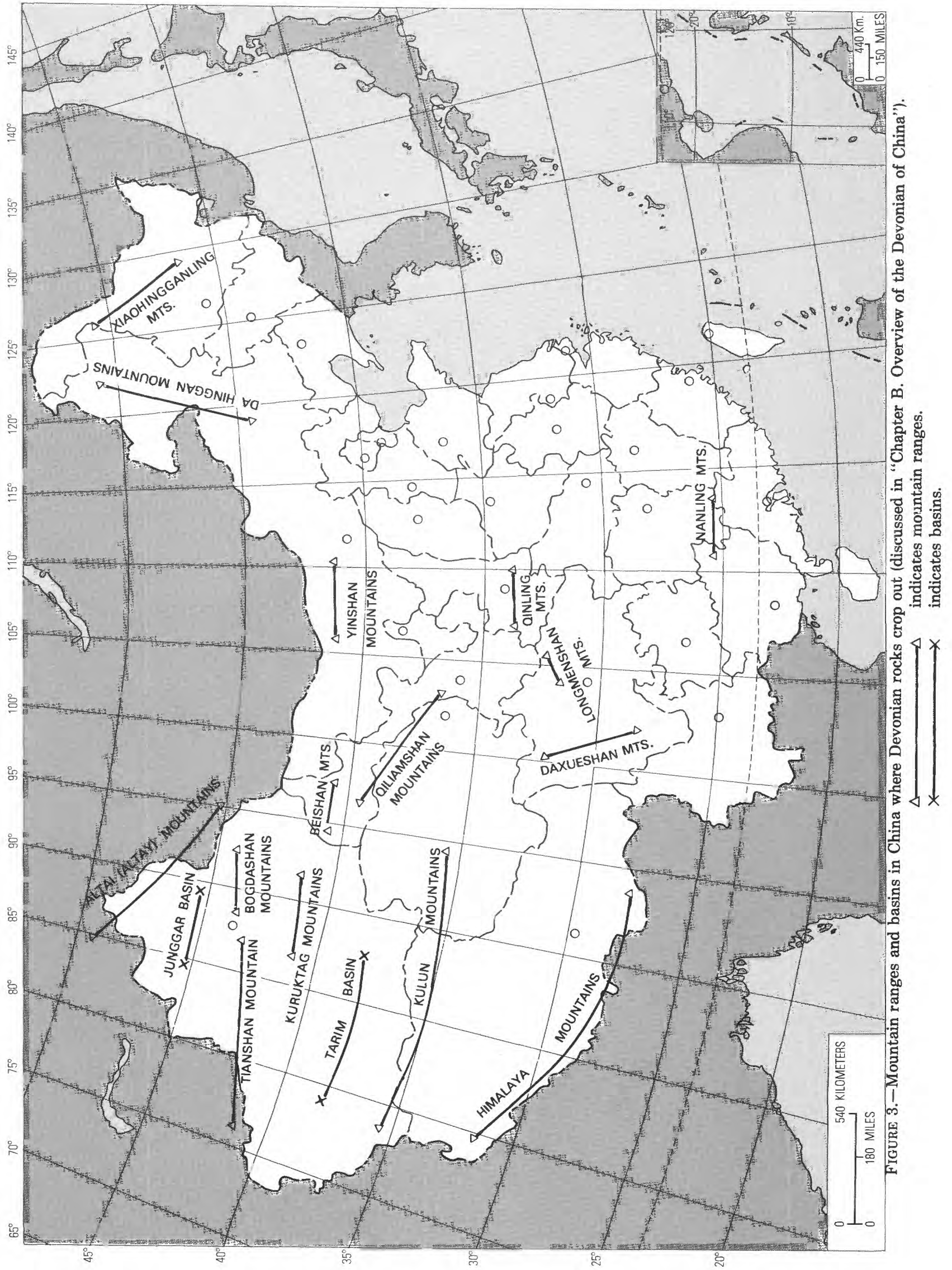




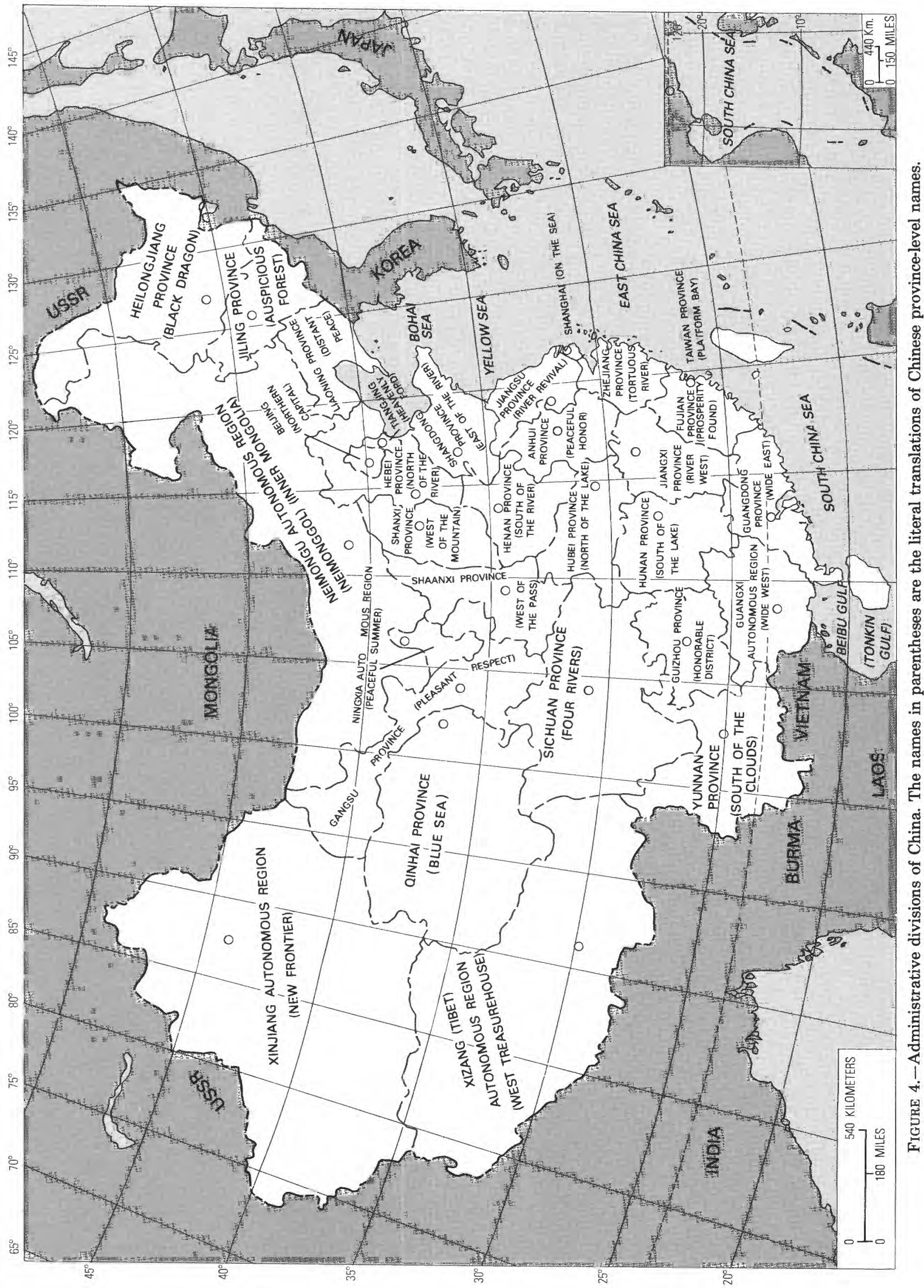




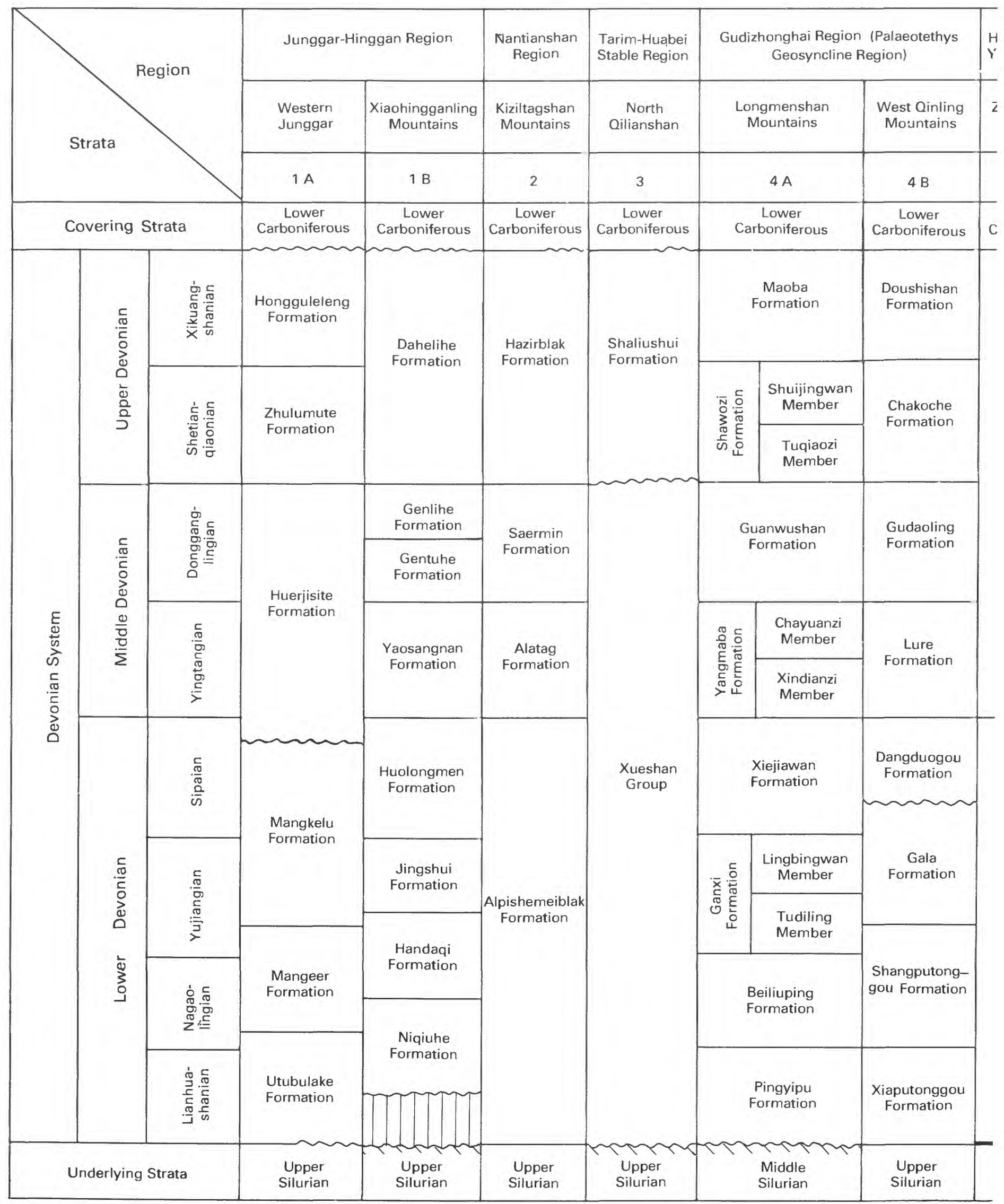

Figure 5.-Correlation of the Devonian stratigraphic units of China. 
OVERVIEW OF THE DEVONIAN OF CHINA

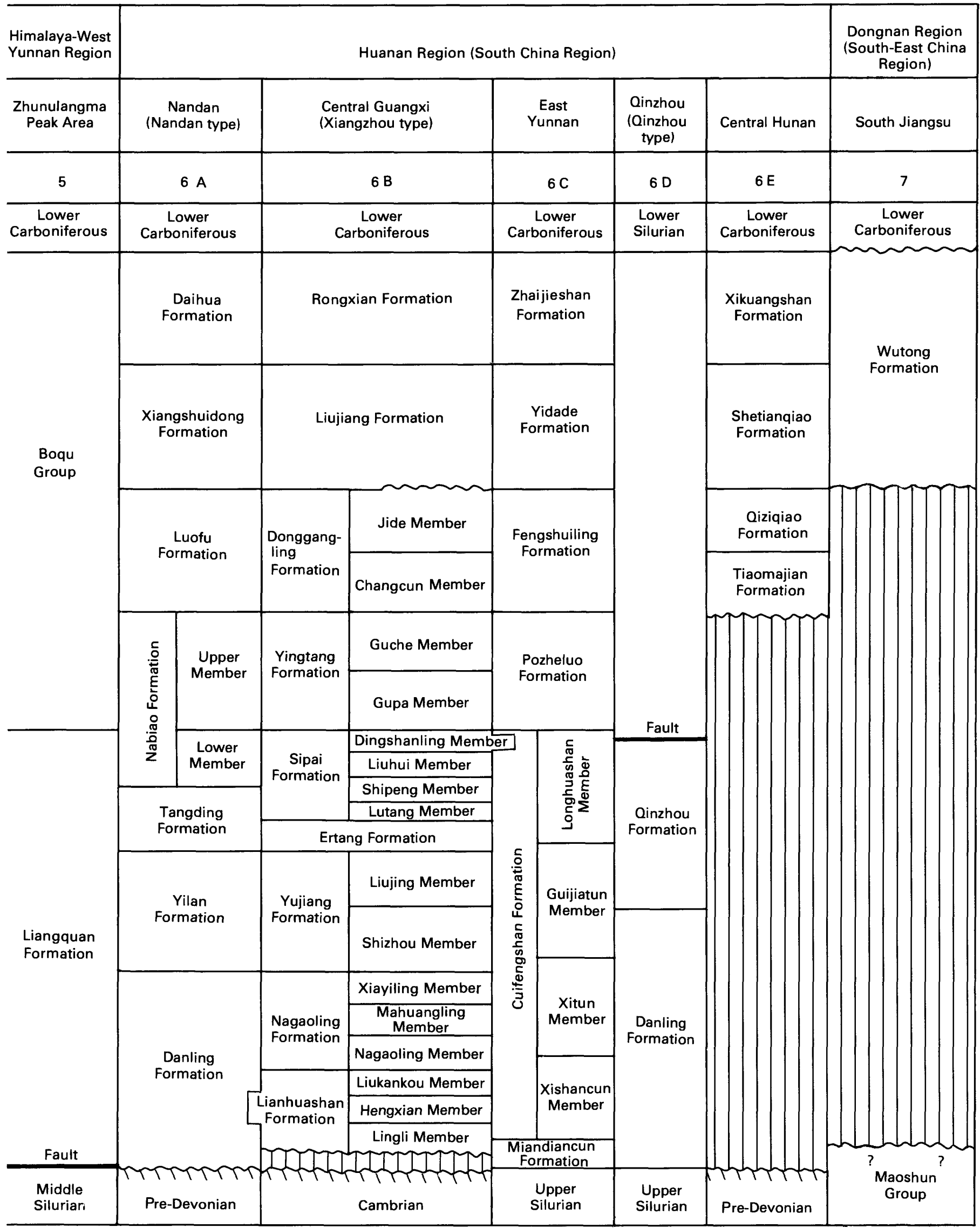

Figure 5.-Continued. 
Leptaenopyxis bouei, Gladiostrophia kondoi, and Paraspirifer gigantea and the trilobite Crotalocephalus sp. Eodevonaria and Paraspirifer are typical of Onondaga age rocks in North America. The Middle Devonian Huerjisite Formation is tuffaceous conglomerate and sandstone about $765 \mathrm{~m}$ thick (Yang, and others, 1981). The Huerjisite is in disconformable contact with the Mangkelu Formation. Known fossils of the Huerjisite include the plants Protoleptodendron scharyanum and Leptodendropsis sp. The Upper Devonian is placed in two formations. The lower Zhulumute Formation consists of sandstone and conglomerate as much as $1,335 \mathrm{~m}$ thick; known fossils are the plants Leptodendropsis arborescens and Lepidosigillaria columnaria. The overlying Hongguleleng Formation consists of sandstone with lenses of limestone and is as much as $595 \mathrm{~m}$ thick; known fossils are the brachiopods Cyrtospirifer sulcifer and Plicatifera alexanderi and the plant Leptophloem rhombicum.

In the Lesser Hinggan Mountains (Xiaohingganling) of northeastern Helongjiang Province (figs. 3; 4; 5, column 1B), the lowest part of the Devonian is absent and the Lower Devonian unconformably overlies the Upper Silurian (Editorial Group, 1979). Lower Devonian rocks are placed in four formations. The lower Niqiuhe Formation consists of shale and arkose and is more than $420 \mathrm{~m}$ thick. It is known to contain the coral Syringaxon bohemica and the brachiopod Pacificocoelia sinica. The Handaqi Formation is composed of intermediate to basic lavas as much as $645 \mathrm{~m}$ thick. The Jingshui Formation consists of siltstone as much as $526 \mathrm{~m}$ thick. The Huolongmen Formation forms the top of the Lower Devonian and is composed of arkose, tuffaceous sandstone, and limestone about $229 \mathrm{~m}$ thick. Its known fossils are the brachiopods Wilsonella grandis, Leptaenopyxis bouei, and Discomyorthis kinsuiensis. The Middle Devonian includes three formations. The lower Yaosangnan Formation is composed of red tuffaceous sandstone and siltstone, which is more than $687 \mathrm{~m}$ thick. The overlying Gentuhe Formation consists of mudstone and shale about $40 \mathrm{~m}$ thick. The only known fossil from this unit is the brachiopod Khinganospirifer paradoxiformis. The overlying Genlihe Formation is composed of quartzose siltstone more than $225 \mathrm{~m}$ thick; the known fossils are the brachiopods Mucrospirifer mucronatus and Elita fimbriata. The overlying Upper Devonian Dahelihe Formation, chiefly siltstone intercalated with tuff and arkose, is more than $321 \mathrm{~m}$ thick. To date, only the brachiopod Cyrtospirifer sp. has been found in the Dahelihe (Yang and others, 1981).

\section{NANTIANSHAN OR SOUTH TIANSHAN REGION}

The Nantianshan or South Tianshan Region (fig. 2) is between the Junggar Massif and the Tarim Platform (fig. 1), and the Devonian rocks form part of what has been called the Tianshan Geosyncline. The poorly known Devonian sequence is thought to be a great thickness of marbles, limestones, schists, and volcanic rocks (fig. 5, column 2). The Lower Devonian Alpishemeiblak Formation is lightly metamorphosed schist and marble and has lenses of limestone. It is more than $1,200 \mathrm{~m}$ thick and conformably overlies the Upper Silurian; fossils include the corals Tryplasma (Pholidophyllum) cf. T. (P.) maximum, Favosites sp., and Squameofavosites sp., and the brachiopods Karpinskia conjugula and Gypidula sp. The Middle Devonian is placed in two formations. The lower Alatag Formation is schist, "metamorphosed limestone," and volcanic rocks that range in thickness from 500 to $1,000 \mathrm{~m}$. The Alatag fauna includes the corals Favosites sp. and Heliolites sp. and the brachiopod Atrypa sp. The upper Saermin Formation consists of clastic rocks intercalated with andesitic porphyry and limestone and ranges in thickness from 250 to $1,200 \mathrm{~m}$. It contains the coral Cyathophyllum sp. and the brachiopods Stringocephalus burtini and S. obesus. The Upper Devonian Hazirblak Formation consists of intermediate to acidic volcanic rocks intercalated with limestone in the upper part and clastic rocks in the lower part. It contains the coral Tabulophyllum sp. and the brachiopods Yunnanellina triplicata, Y. sp., and Yunnanella sp. According to Hou and others $(1979 ; 1982)$ and Yang and others $(1979 ; 1981)$, the Lower Devonian fauna is similar to that of the Ural Mountains of the U.S.S.R. Wang and Liu $(1980$, p. 169) and Hou and others $(1982$, p. 172) regarded the Middle and Upper Devonian faunas as belonging to a South China paleobiogeographical province. Boucot (written commun., Jan. 9, 1985) believes that there is a "South China Lower Devonian and Eifelian age biogeographic REGION (higher than province level)."

\section{TARIM-NORTH CHINA (TARIM-HUABEI) STABLE REGION}

The Tarim-North China (Tarim-Huabei) Stable Region (fig. 2) includes the Tarim Platform, Qilian Geosyncline, and Sino-Korean Platform (fig. 1). The poorly known Devonian rocks are largely continental red beds, which are well exposed on the north and south slopes of the Qilianshan Mountains and around the Tarim Basin (fig. 3). The section at Zhongning Village, Wuwei County, Gangsu Province (figs. 4; 6-3), is a good example of the regional sequence (fig. 5, column 3). The Xueshan Group of Early and Middle Devonian age (Wang and Liu, 1980) is composed of purple-red sandstone, sandy conglomerate, and conglomerate, in places intercalated 
with tuff. The Xueshan Group, as much as 2,900 m thick, is known to contain the plant Lepidodendropsis sp. and the fish Bothriolepis sp.

The Upper Devonian Shaliushui Group unconformably overlies the Xueshan Group. It is $500-840 \mathrm{~m}$ thick (Wang and Liu, 1980), consists of purple-red or brickred conglomerate and sandstone intercalated with limestone, and contains the plant Leptophloeum rhombicum.

\section{GUDI ZHONGHAI OR PALEOTETHYS GEOSYNCLINAL REGION}

This tectonostratigraphic Gudizhonghai or Paleotethys Geosyclinal Region (fig. 2) is in the northern Xizang (Tibet) Autonomous Region, northwestern Sichuan Province, southern Qinhai Province and the southernmost parts of Gangsu and Shaanxi Provinces. Devonian strata of the eastern part of what has been called the Qinling Geosyncline have been studied in detail. The section discussed below (fig. 5 , column 4B) is exposed in Qulu County, Gangsu Province (fig. 6-4B) (Qin and Gan, 1976). (1) The Xiaputonggou Formation is $210-300 \mathrm{~m}$ thick, conformably overlies the upper Silurian, and is divided into three parts. The lower part is dark gray to green gray and slaty and contains a few intercalated thin-bedded limestones. The identified fossils are the corals Entelophyllum uralicum, $E$. carinatum, and Favosites? multiformis; brachiopods Molongia sp., Protathyris sp., Skenidioides sp., Leptostrophia sp., Levenea sp., Protocortezorthis sp., Eospirifer sp., Nanospirifer sp., and Gotatrypa sp; and the conodonts Icriodus woschmidti and Ozarkodina remscheidensis. The middle Xiaputonggou (Qin and Gan, 1976) consists of slaty calcareous beds intercalated with reef limestones and dolomitic limestone. The fauna of the middle Xiaputonggou includes the corals Entelophyllum uralicum, Zelophyllum ludlovense, Tryplasma cf. T. loveni, Embolophyllum sp., Austrophyllum sp., Favosites kunjakensis, and F. effusus, and the brachiopods Mutationella podolica, Protathyris praecursor, $P$. sibirica, Howellella laeviplicata, $H$. angustiplicata, Atrypa nieczlawiensis, Schizophoria antiqua, Protocortezorthis fornicatumcurvata, Katunia subtrigona, Podolella cf. P. rensselaeroides and Linguopugnoides carens. The upper Xiaputonggou (Qin and Gan, 1976) is brown calcareous slate intercalated with dolomitic marl and some beds of coral reef limestone, bearing the corals Implicophyllum sp., Favosites sibiricus, F. brusnitzini, $F$. preplacenta, Mesofavosites sp., and Syringopora sp., and the brachiopods Spiriferina supramarginalis, Gypidulina optata, and Clorinda aff. C. pseudolinguifera. (2) The Shangputonggou Formation is composed of slate intercalated with dolomitic argillaceous limestone and dolomite; it is from 230 to $410 \mathrm{~m}$ thick. The known fauna of the Shangputonggou consists of the coral Squameofavosites sp., and the brachiopods Protathyris sibirica, Leptaena rhomboidalis, and Howellella prolamella (Qin and Gan, 1976). (3) The Gala Formation is medium- to thick-bedded dolomite, which in the upper part is intercalated with siltstone and slate; maximum thickness is $1,091 \mathrm{~m}$. Fossils of the Gala include the corals Favosites shengi minor, F. lazutkini, Crassialvealites sp., Scoliopora sp., Lyriclasma tenuiseptata, Enteralasma sp., and Amplexiphyllum sp.; gastropods Hormotoma kutsingensis and Donaldiella sp.; and the ostracode Leperditia sp. (4) The Dangduogou Formation is bioclastic limestone intercalated with shale in the lower part and sandy shale intercalated with fine granular sandstone above; it is from 73 to $117 \mathrm{~m}$ thick. It is separated from the Gala Formation by a disconformity and contains the brachiopods Otospirifer xijiawanensis, Acrospirifer subgregarius, Howellella sp., and Megastrophia sp. in its lower part, and Acrospirifer cheehiel and A. subtonkinensis in its upper part (Qin and Gan, 1976).

Middle Devonian: (5) The Lure Formation is dark-gray thin-bedded limestone, argillaceous limestone, and shale, from 230 to $300 \mathrm{~m}$ thick. The known fauna is the corals "Nardophyllum" compositum, Utaratuia sp., Sociophyllum sp., Digonophyllum sp., Zonophyllum sp., Trapezophyllum sp., Spongophyllum sp., Zelolasma sp., Favosites sp., Thamnopora sp., and Crassialveolites sp., and the brachiopods Uncinulus parallelopipedus, $U$. mesodeflectus, Athyrisina squamosa, A. heimi, Eoreticularia cf. E. maureri, Indospirifer maoerchuanensis, I. kwangsiensis, Tingella reticularioides, Atrypa desquamata kansuensis, and Megastrophia uralensis; Athyrisina is typically Silurian in age. (6) The Gudaoling Formation is composed of dark-gray limestone, argillaceous limestone intercalated with shale in the lower part, and black shale intercalated with thinbedded limestone and siltstone in the upper part. It is from 500 to $700 \mathrm{~m}$ thick and contains the corals Dialythophyllum sp., Endophyllum sp., Disphyllum sp., and Temnophyllum sp.; the brachiopods Stringocephalus burtini, Bornhardtina speciosa, Rensselandia sp., Atrypa sp., Spinatrypa sp., Schizophoria sp., Hypothyridinia sp., Indospirifer sp., and Cyrtinaella sp.; and the ammonoid Pseudofoordites sp. (Qin and Gan, 1976).

Upper Devonian: (7) The Chakuohe Formation is 173-560 $\mathrm{m}$ of thin-bedded argillaceous limestone intercalated with calcareous shale. In the lower part there is conglomeratic limestone and limestone having chert nodules. The known fauna consists of the corals Disphyllum irregulare, Hexagonaria schucherti, Peneckiella minima, Haplothicia pentagona, Phacellophyllum 


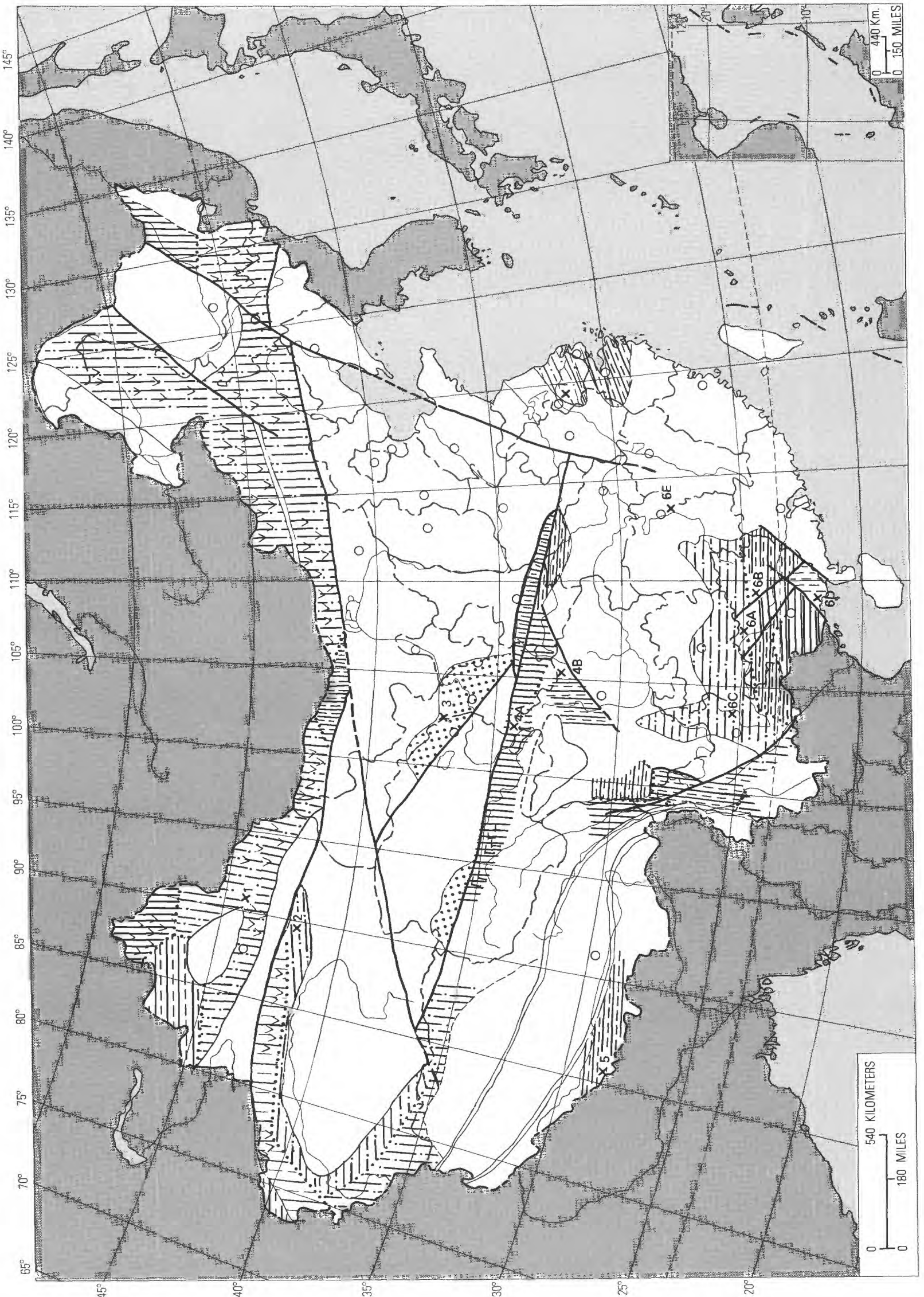


OVERVIEW OF THE DEVONIAN OF CHINA
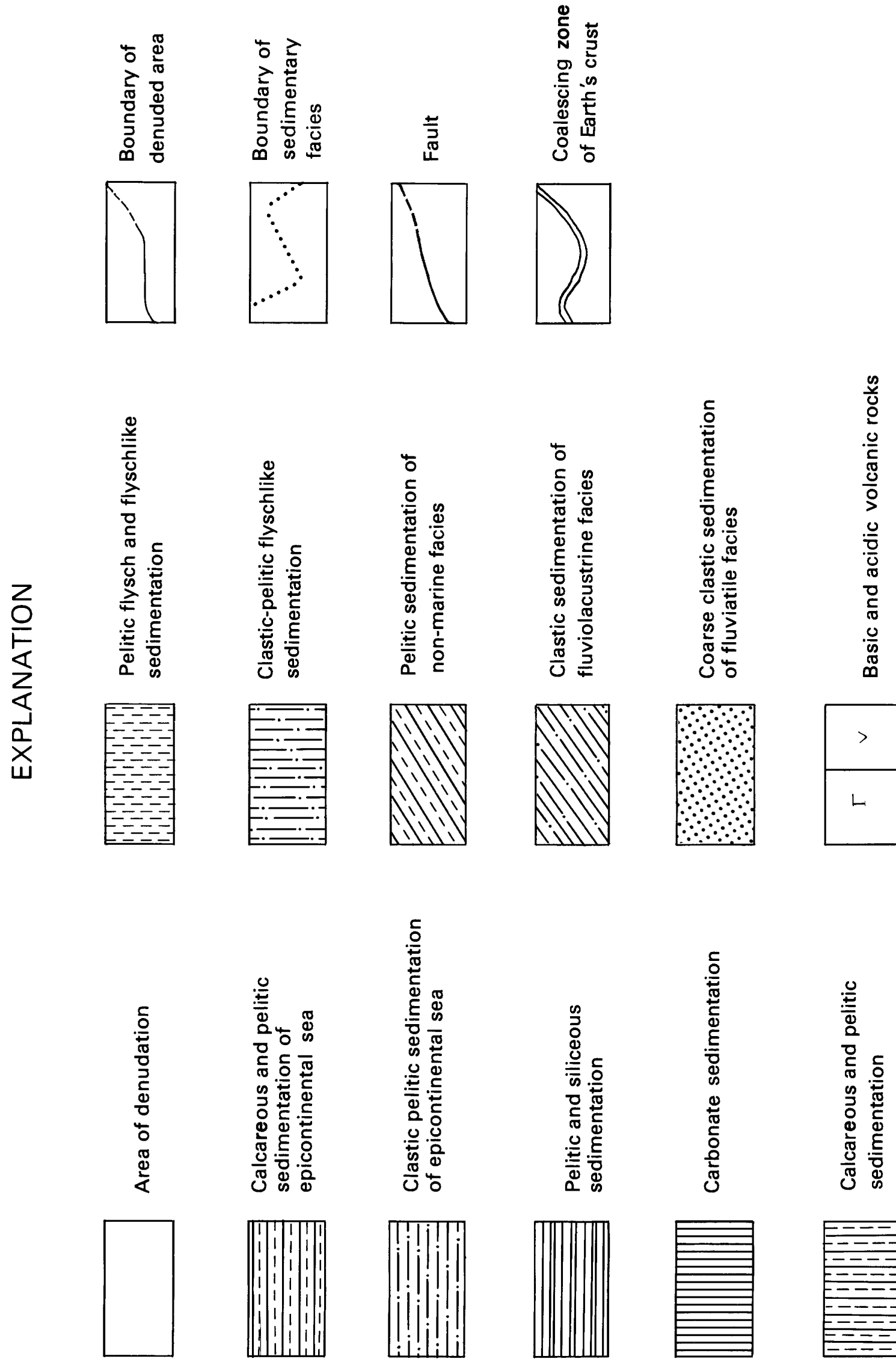

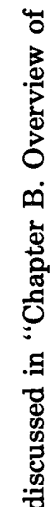

$\frac{0}{0}$
0
.0
$\frac{0}{5}$
0
$\frac{0}{0}$
$>0$
$\frac{0}{0}$
$\frac{0}{0}$
0
$\frac{0}{\pi}$
0
$\frac{0}{9}$
0
0
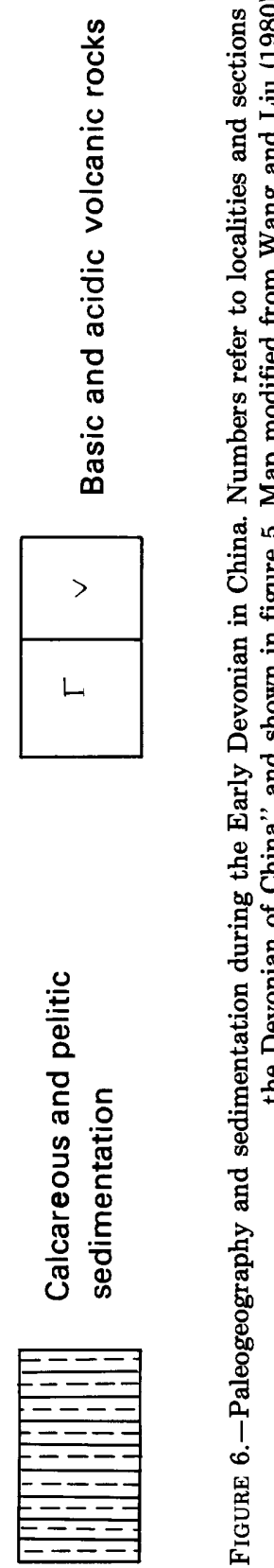
fasciculare, Pseudozaphrentis conica, and Mictophyllum modicum, and the brachiopods Cyrtospirifer sinensis, C. chaoi kueichowensis, Tenticospirifer cf. T. "murchisonianus, "Hunanospirifer ninghsiangensis, Ambocoelia sinensis, and Pugnax limala. (8) The Doushishan Formation is gray, thin- to medium-bedded argillaceous limestone and limestone; in the lower part it is usually intercalated with chert nodules and banded chert. The Doushishan is from 180 to $766 \mathrm{~m}$ thick and contains the corals Hunanophrentis uniforme, Nalivkinella sp., and Pseudozaphrentis sp. and the brachiopods Yunnanella uncinuloides, Y. abrupta, Y. synplicata, Yunnanellina hanburyi, Y. uniplicata, Tenticospirifer tenticulum, and T. supervilis. The Lower Carboniferous conformably overlies the Doushishan Formation (Qin and Gan, 1976).

The Longmenshan Mountain section of north Sichuan Province (figs. $3 ; 4 ; 5$, column $4 \mathrm{~A} ; 6-4 \mathrm{~A}$ ) is on the edge of the Paleotethys Geosyncline (Wang and Liu, 1980) where Devonian rocks are well exposed and rich in fossils. This section is important for understanding the Devonian of China and was described in ascending order by Chen (1978) and Xia (1978).

Lower Devonian: (1) The Pingyipu Formation is made up of gray-white medium-bedded quartz sandstone, finegrained sandstone, and sandy shale as much as 2,000 $\mathrm{m}$ thick. It overlies Middle Silurian rocks with angular unconformity. Fossils include (Chen, 1978, p. 107) the brachiopods Subrensselandia sp. and Tingella? paishihyuensis; the pelecypod Kochia sichuanensis; gastropods; fishes ?Polybranchiaspis sp., Sangiaspis rostrata, Dongfangaspis major, Lungmenshanaspis hiangyouensis, Xinanpetalichthys shendaowanensis, and Neopetlichthys yenmenpaensis; and spores Punctatisporites sp., Retusotriletes sp., Granulatisporites sp., Apiculiretusispora sp., Acanthotriletes sp., Lophotriletes sp., Lophozonotriletes sp., Emphanisporites sp., Convolutispora sp., Stenozonotriletes sp., Archaeozonotriletes sp., and Laevigatesporites sp. (2) The Beiliuping Formation conformably overlies the Pingyipu and consists of yellowish-green shale, sandy shale intercalated with limestone, and sandstone; its maximum thickness is $30 \mathrm{~m}$. Fossils include the brachiopods Protochonetes bailupengensis, Chonetes cf. C. ellipticus, Kwangsirhynchus bailupengensis, Orientospirifer nakaolingensis, and $O$. wangi; the trilobite Gravicalymene sp.; and pelecypods and corals (Chen, 1978; Xia, 1978). (3) The Ganxi Formation is made up of the lower Tudiling Member, which is yellow-gray shale, argillaceous siltstone, fine granular sandstone and marl, and limestone; it is as much as $90 \mathrm{~m}$ thick. Fossils include the brachiopods Chonetes cf. C. ellipticus, Kwangsirhynchus sp., Parathyrisina tangnae, P. tangnae sichuanensis, Athyrisinoidea typica, A. sinensis, Pseudathyrisina fasciata, Orientospirifer wangi, $O$. nakaolingensis, Howellella tudilingensis, $H$. incerta, and Acrospirifer primaevus; tentaculites Nowakia acuaria and Guerichina sp.; and corals, pelecypods, and trilobites. The upper Lingbingwan Member is made up of yellowish-green shale, sandy shale intercalated with thin-bedded marl, and limestone; it is as much as $81 \mathrm{~m}$ thick. Fossils include the coral Calceola sp.; the abundant brachiopods Parachonetes kwangsiensis, Nadiastrophia yukiangensis, Eosophragmophora sinensis sichuanensis, Dicoelostrophia punctata, D. annamitica (which is commonly Middle Devonian, but here is of Early Devonian age), Uncinulus longmenshanensis, Parathyrisina tangnae, Howellella papaoensis, $H$. cf. $H$. inchcans, $H$. cf. $H$. angustiplicatus, Acrospirifer tonkinensis and $A$. hemirotundus; and pelecypods and trilobites (Chen, 1978; Xia, 1978). (4) The Xiejiawan Formation is gray-yellow to yellowish-green siltstone, and sandstone, shale, marl, and limestone and is as much as $138 \mathrm{~m}$ thick. Known fossils are the coral Calceola sp.; the brachiopods Euryspirifer paradoxus xijiawanensis, Acrospirifer tonkinensis, Nadiastrophia sp., and Parachonetes sp.; and ammonoids and pelecypods (Chen, 1978; Xia, 1978).

Middle Devonian: (5) The Yangmaba Formation conformably overlies the Lower Devonian and is $500 \mathrm{~m}$ thick. The lower Xindianzi Member is sandy calcareous shale, limestone, and marl. Fossils include the corals Calceola sandalina, Hexagonaria sp., and Favosites sp.; and brachiopods Xenospirifer fongi, Athyrisina heimei, A. heimialpheus, Schizophoria striatula, Kwangsia yohi, Indospirifer sp., Nadiastrophia sp., Carinatina sp., and Gypidula biplicata. The upper Chayuanzi Member is thick to massive limestone and dolomitic limestone and contains the coral Sociophyllum sp. and the brachiopods Zdimir pseudobaschkirica, Z. sp. and Gypidula biplicata. (6) The Guanwushan Formation is gray to gray-black argillaceous limestone, yellow-gray sandstone, and sandy shale in its lower part, and black massive limestone with ribbon chert in its upper part. It is 580-850 m thick and contains the corals Hexagonaria sp., Temnophyllum sp., Cyathophyllum sp., Atelophyllum sp., Keriophyllum sp., Thamnopora sp., and Digonophyllum sp.; brachiopods Stringocephalus transversa, S. obesus grandis, S. burtini, Gypidula planisinosa, Uncinulus pentagonus pentagonus, $U$. primipilatus, U. simplexi, Leiorhynchus awoknak, Emanuella pentagona, E. transversa, E. takwaensis, Diazona weichouensis, Reticulariopsis sichuanensis, Undispirifer cf. U. undiferus, Indospirifer changuliensis, Atrypa sp., Spinatrypa sinensis, Rensselandia cf. $R$. johanni, Subrensselandia sp.; and pelecypods, trilobites, and tentaculites (Chen, 1978; Xia, 1978).

Upper Devonian: (7) The Shawozi Formation is made up of the lower Tuqiaozi Member, which is black-gray, 
argillaceous limestone and shale as much as $320 \mathrm{~m}$ thick, containing the brachiopods Schizophoria cf. S. excellens, Devonoproductus toqiaoziensis, Gypidula planisinosa, G. parva, "Pugnax" rectangularis, Hypothyridina lungtungpeensis, Leiorhynchus mansuyi, $L$. obesus, L. kwangsiensis, L. russelli, Porostictia sinensis, and "Atrypa" douvilli. The upper Shuijingwan Member is gray dolomite, and dolomitic limestone and limestone as much as $600 \mathrm{~m}$ thick, bearing the brachiopods $\mathrm{Cy}$ tospirifer sinensis, Hypothyridina lungtungpeensis, "Atrypa" douvilli, Gypidula sp., Sinocoelia sinensis, Schizophoria excellens, and Reticulariopsis sp., and the ammonoid Manticoceras sp. (8) The Maoba Formation is pale gray to gray-white or gray-black limestone as much as $150 \mathrm{~m}$ thick. It has the brachiopods Camerotoechia hsikuangshanensis, Hunanospirifer ninghiangensis, Productella sp., Yunnanellina sp., and Tenticospirifer sp. Lower Carboniferous rocks conformably overlie the Maoba Formation (Chen, 1978; Xia, 1978).

\section{HIMALAYA-WEST YUNNAN EPEIRIC SEA REGION}

The Himalaya (Ximalaya)-West Yunnan Epeiric Sea Region (fig. 2) lies mostly south of lat $30^{\circ} \mathrm{N}$. in the Xizang Autonomous Region (Tibet) and western Yunnan Province (fig. 4). The section here is known only from reconnaissance studies (Wang, 1974). The base of the Devonian is in fault contact with Middle Silurian rocks (fig. 5, column 5).

The Lower Devonian Liangquan Formation, light-gray silt and shale as much as $29 \mathrm{~m}$ thick, in the lower part contains the graptolites Neomonograptus himalayensis, $N$. atopus rigidus, $N$. latus, Monograptus thomasi, $M$. yukonensis, $M$. nyalamensis, and $M$. immuturus, and the tentaculites Nowakia acuaria and Styliolina? sp. In the upper part, the Liangquan is gray-white shale interbedded with gray-black thin-bedded limestone as much as $11 \mathrm{~m}$ thick containing the brachiopod Crurithyris sp.; the pelecypod Leiopteria sp.; nautiloid Michelinoceras (Kopanionoceras) nyalamense; and the tentaculites Guerichina xizhangensis, Nowakia acuaria, N. lepida, Crassillina praevia, Viriatellina exigua, Metastyliolina nyalamensis, and Styliolina cf. S. minuta (Wang, 1974).

In its lower part, the Middle and Upper Devonian Boqu Group is light-gray quartzose sandstone as much as $38 \mathrm{~m}$ thick overlain by $218 \mathrm{~m}$ of light-gray mediumbedded quartzose sandstone with fragments of plant fossils (Wang, 1974).

\section{HUANAN OR SOUTH CHINA REGION}

The Huanan Region or South China Region (fig. 2) includes all Guizhou Province, Hunan Province, and
Guangxi Autonomous Region, most of Guangdong and Hubei Provinces, eastern Sichuan and eastern Yunnan Provinces, and western Jiangxi Province. The Devonian is well exposed and extensively developed in this region. The transgressive Lower and Middle Devonian are principally platform deposits overlapping from the southwest toward the northeast. The basal Devonian usually rests with angular unconformity on the pre-Devonian.

Several different depositional facies occur in this region; we discuss three. The Xiangzhou facies represents near-shore, shallow-water environments, which were reasonably turbulent and rich in oxygen (figs. 5, columns $6 \mathrm{~B}, \mathrm{C} ; 6 ; 10$ ), and the rocks contain abundant shelly benthic fossils. The Nandan facies represents an off-shore, deeper water environment having a biota rich in shelly pelagic fossils such as ammonoids and tentaculites (figs. 5, column 6A; 6; 10). The Qinzhou depositional facies has the smallest outcrop area and represents a deep, offshore, oxygen-poor environment having a biota dominated by the pelagic graptolites and tentaculites (figs. 5 , column $6 \mathrm{D} ; 6 ; 10$ ).

\section{EAST YUNNAN}

In East Yunnan, the Lower Devonian rocks are conformable on the Upper Silurian. The Xiangzhou facies Devonian rocks and biota were described in ascending order by Wu (1977), Li and Cai (1977), Yun (1978), Liao and others (1978), and $\mathrm{Li}$ and Cai (1978), and the section shown in figure 5 , column $6 \mathrm{C}$, is a composite for this area.

Lower Devonian: (1) The Miandiancun Formation is black shale from 40 to $200 \mathrm{~m}$ thick. The fauna in the upper part of this formation includes the fishes Polybrachiaspis sp. and Yunnanolepis sp.; in the lower part are found the trilobite Warburgella rugulosa sinensis, and the conodonts Pelekysgnathus sp. and Trichonodella symmetrica. (2) The Cuifengshan Formation consists of four members. (i) The Xishancun Member is dense and well-cemented quartzose sandstone, intercalated with yellowish green and black shale, the percentage of shale increases upward; it is as much as $150 \mathrm{~m}$ thick. The Xishancun has a rich biota of fishes Polybranchiaspis liaojiaoshanensis, P. minor, and Diandongaspis xishancunensis; ostracodes Leperditia sp., Beyrichia sp., and Cryptophyllus sp.; gastropods Platyostroma sp. and Straparollus sp.; plants Zosterophyllum sp., Uncatella yerticulata, and Chovanella sp.; and spores Leiotriletes 24 percent, Punctatisporites 32 percent, Calamospora 2 percent, Retusotriletes 9 percent, Apiculiretusispora 12 percent, Granulatisporites 4 percent, Cyclogranisporites 8 percent, Acanthotriletes 2 percent, Brochotriletes 1 percent, Emphanisporites 0-1 percent, and Stenozonotriletes 5 percent; acritarchs 
Leiofusa sp. and Leiosphaeridia sp; and chitinozoans Anyrochitina sp. and Angochitina sp. (ii) The Xitun Member is yellowish-green to grayish-green shale, mudstone, and siltstone intercalated with some red mudstone in its upper part. Near the middle, the member is thin-bedded argillaceous limestone. The Xitun is $350-400 \mathrm{~m}$ thick and also has a rich biota including fishes Geleaspis changi, Nanpanaspis microculus, Polybranchiaspis liaojaoshanensis, Laxaspis qujingensis, L. rostrata, Yunnanolepis chii, Tsuifengshanolepis diantungensis, and Proantiarchilepis xitunensis; ostracodes Leperditia sp., Beyrichia sp., Bythocypris sp., and Cavellina sp.; pelecypods Dysodonta deprati and $D$. sp.; brachiopod Lingula sp.; and plants Uncatoella vertecillata, Sacheocladus ambiguus, and Discinella cuifengshanensis. (iii) The Guijiatun Member is purple-red mudstone intercalated with paleyellow thin-bedded sandstone; it is $350-400 \mathrm{~m}$ thick. The known biota includes fishes Asiacanthus sp. and Yunnanolepis sp.; gastropods Euryzone cf. E. latitor$n a t a$; pelecypods Dysodonta deprati and $D$. sp.; and plants Zosterophyllum myretonianum and Sporogonites sp. (iv) The Longhuashan Member is brown-yellow sandstone intercalated with red mudstone; it is as much as $400 \mathrm{~m}$ thick. Many fossils have been found in this member including the fish Galeaspis xujiachongensis; pelecypods Goniophora spatulata and Dysodonta sp.; plants Drepanophycus spinaeformis, Zosterophyllum yunnanicum, $Z$. spathulatum, Cooksonia zhanyiensis, Taeniocrada robusta, Sacheocladus ambiguus, and Emplectophous yunnanensis; and spores Apiculiretusispora plicata, Leiotriletes ornatua, Retusotriletes communis, R. triangulatus, Punctatisporites, Calamospora, Granulatisporites, Cyclogranisporites, Verrucosisporites, Acanthotriletes, Apiculatisporites, Stenozonotriletes, Densosporites, Hymenozotriletes, Corystisporites, and Cymbosporites.

Middle Devonian: (3) The Pozheluo Formation is mudstone intercalated with limestone or siliceous sediment; it is from 198 to $380 \mathrm{~m}$ thick. Three tentaculite zones, in ascending order, are the Nowakia cancellata zone, Nowakia richteri zone, and Nowakia sulcata zone (Mu, 1978). Other fossils are corals Tryplasma sp., Favosites sp., and Thamnophyllum sp.; brachiopod Zdimir pseudobashkirica; trilobite Nandanoaspis laevigatus; and conodonts Polygnathus parawebbi, $P$. linguiformis linguiformis, Hindeodella priscilla, $H$. adunca, Lonchodina sp., and Angulodus curvata. (4) The Fengshuiling Formation is siliceous shale as much as $154 \mathrm{~m}$ thick containing the tentaculites Nowakia otimaria and Styliolina sp. In some parts of East Yunnan, strata equivalent in age to the Fengshuiling Formation are placed in the Huaning Formation, a unit of Xiangzhou depositional type that consists of limestone and dolomite intercalated with sandstone and is more than $1,500 \mathrm{~m}$ thick. The lower Huaning fauna includes the corals Dendrostella trigemme and Alveolitella cf. A.cella; brachiopods Bornhardtina uncitoides and Acrothyris nanpanjiangensis; fishes Bothriolepis panqiensis, B. longithoraca, and Asterolepis sp.; plants Protolepidodendron cf. P. scharyanunm, Lepidodendropsis sp., and Sycidiam melo. The upper Huaning fauna includes the corals Endophyllum yunnanense and Hexagonaria quadrigemina; brachiopods Stringocephalus burtini and Spinatrypa aspera; and tentaculite Nowakia otomari.

Upper Devonian: (5) The Yidade Formation is darkgray limestone, marl partly intercalated with dolomite, and dolomitic limestone; it is from 14 to $500 \mathrm{~m}$ thick and contains the corals Disphyllum irregulare, $D$. cylindricum, Hunanophrentis aff. H. zaphrentoides, and Cyathophyllum hunanense; brachiopods Cyrtospirifer sp. and Tenticospirifer sp.; and the ammonoid Manticoceras sp. (6) The Zhaijieshan Formation consists of dolomite and limestone from 50 to $600 \mathrm{~m}$ thick, bearing the brachiopods Cyrtospirifer sp., Yunnanella sp., Tenticospirifer sp., and Camarotoechia sublivoniciformis, and the ostracode Leperditia sp. The Mississippian conformably overlies the Zhaijieshan Formation.

\section{GUANGXI}

The Devonian section at Luofu Village, Nandan County, Guangxi (figs. 2-6A; 5, column 6A), represents the Nandan depositional type of offshore deposits containing abundant pelagic shelly fossils. The summary of the section given here is from Shen (1975), Xiang and Wei (1978), Hou and others (1979), Liao and others (1978), and Wei (1982).

The Devonian rests with erosional unconformity on pre-Devonian rocks of different ages in northwest Guangxi. The Lower Devonian is divided into three formations, and its base is not exposed at Luofu Village. The lowest lithostratigraphic unit is the Danling Formation, which is represented by about $570 \mathrm{~m}$ of gray to gray-white argillaceous sandstone, siltstone, sandy mudstone, and quartz sandstone that is ferruginous near the middle of the exposed Danling. The fauna is sparce, but, near the top of the Danling, the brachiopod Orientospirifer wangi has been found. The overlying Yilan Formation is $35 \mathrm{~m}$ of mudstone ranging in color from gray green to gray.yellow to dark gray and gray black at the top. About $20 \mathrm{~m}$ above the base of the Yilan is a 7-m-thick unit of gray-yellow to gray thin-bedded mudstone containing a fauna that includes the coral Calceola sp.; the brachiopods Rostrospirifer tonkinensis, Dicoelostrophia annamitica, and Cymostrophia sp.; 
and trilobites Calymene sp., Gravicalymene maloungkaxensis and Dechenella liujingensis. The next young. est Lower Devonian is placed in the Tangding Formation, which is about $380 \mathrm{~m}$ of varicolored mudstone that is dark and carbonaceous in many places. The lowermost Tangding has a fauna dominated by the tentaculites Nowakia praecursor, N. zlichovensis, and $N$. subtilis. The middle $195 \mathrm{~m}$ of the Tangding has a rich fauna of ammonoids including Anetoceras (A.) recticostatum, A. obliquecostatum, Erbenoceras solitarius, $E$. ellipticum, E. lineare, E. elegantulum, Teichertoceras nandanense, T. ilanense, and Mimagoniatites fecundus; this part of the Tangding also contains the tentaculites Nowakia elegans and $N$. barrandei.

The Nabiao Formation crosses the Lower-Middle Devonian boundary and is about $150 \mathrm{~m}$ of dark, carbonaceous mudstone in places intercalated with graywhite mudstone. The lower member of the Nabiao Formation is $110 \mathrm{~m}$ of dark carbonaceous mudstone, intercalated with gray-white mudstone. It has a varied fauna of ammonoids Latanarcestes noeggerati, Mimagoniatites bohemicus, and Convoluticeras discordans; tentaculites Nowakia holynensis, $N$. richteri, and $N$. cancellata; and trilobites Plagiolaria nandanensis, Phacops luofuensis, $P$. guangxiensis and $P$. transver salis. The upper member of the Nabiao Formation is $36 \mathrm{~m}$ of dark carbonaceous mudstone bearing ammonoids Pinacites jugleri, Foordites platyplers $a, F$.occultus, and Paraphyllites tabuloides; trilobites Ductina vietnamica, Cyphaspides orientalis, and C. paradoxus; and tentaculite Nowakia sulcata. The brachiopods from the Nabiao were identified by Xu $(1977,1979)$ as Costanoplia faceta, Holynatrypa mirabilis, Luofugia delicata, Muriferella pygmaea, Nabiaoia pusilla, Orbiculoidea tarda, Paracostanoplia mirabilis, Paraplicanoplia nana, Perichonetes mirabilis, Plectospira minor, Plectodonta sanglangensis, Salopina aspera, and Tangxiangia delicata; it is not clear whether these are from the lower or upper members, or from the entire formation. The remainder of the Middle Devonian is placed in the Luofu Formation, which is about $580 \mathrm{~m}$ of grayblack to black mudstone, calcareous mudstone, carbonaceous mudstone, and marl. The fauna is dominated by tentaculites, including Viriatellina multicostata, Styliolina sp., and Nowakia otomari.

The Upper Devonian is grouped into two formations. The lower Xiangshuidong Formation is gray-black, thinbedded siliceous rocks about $100 \mathrm{~m}$ thick containing the ammonoids Eobeloceras sp. and Mesobeloceras cf. $M$. acutum; the tentaculites Styliolina domanicensis and Uniconus sp.; and ostracodes Richterina latior and Entomozoe (Richteria) serratostriata. The upper Daihua Formation is gray to gray-black marl and limestone about $220 \mathrm{~m}$ thick containing the tentaculite Uniconus sp. Mississippian limestones conformably overlie the Daihua Formation.

At Nali and Xiaodong villages Qinzhou County, Guangxi (fig. 2-6D), the graptolitic Qinzhou facies is well developed (figs. 2-6D; 5, column 6D). Qinzhou County is the only area in South China where the lowermost Devonian is in graptolitic facies; the area is structurally complex, outcrops are discontinuous, and no complete section of the Lower Devonian is known. The following brief summary of the Lower Devonian lithostratigraphy is taken from Wang (1977) and Bai and others $(1979,1982)$.

The lowest Devonian is placed in the Danling Formation, which is about $315 \mathrm{~m}$ of siltstone, fine sandstone, sandy mudstone, and silty pelite of various colors that are in places interbedded with green-gray mudstone. About $50 \mathrm{~m}$ above the base of the Danling, a 25-m interval contains the graptolites Monograptus uniformis uniformis, $M$. uniformis sinensis, $M$. macrodon, and $M$. cf. $M$. angustidens. Higher in the Danling, in Qinzhou County, the fauna includes the tentaculite Paranowakia bohemica and the graptolite Neomonograptus hercynicus. The lowermost Danling is in conformable contact with Upper Silurian sandstone and mudstone containing the graptolite Pristiograptus transgrediens proximus.

Overlying the Danling are $35 \mathrm{~m}$ of gray-black to black thin-bedded sandy mudstone and silty pelite, which are placed in the Qinzhou Formation. The known fauna of the Qinzhou is the tentaculites Nowakia acuaria, $N$. zlichovensis, and Viriatella harcynica, and the graptolites Monograptus (M.) aequabilis notaequabilis and $M$. (M.) yukonensis fangchensis. Thrust over the Qinzhou Formation are rocks of Early Silurian age.

\section{CENTRAL HUNAN PROVINCE}

Middle and Upper Devonian rocks rich in fossils are well developed and widely distributed in central Hunan Province (figs. 2-6E; 5, column 6E). These rocks include the stratotypes for the Middle-Upper Devonian boundary and the Upper Devonian of South China. The synoptic description presented here is from Zhao and others (1978) and Yang and others (1981). Middle Devonian: (1) The Tiaomajian Formation is $100-343 \mathrm{~m}$ of purplered quartz sandstone, argillaceous sandstone, siltstone, and sandy shale; the bottom of this unit is, for the most part, conglomeratic. The lower contact of the Tiaomajian is an uncomformity on pre-Devonian rocks of different ages. Fossils are the pelecypods Glossites sp., Praecardium sp., and Radiatodonta shaodongensis; fishes Bothriolepis sinensis and Hunanolepis tieni; plants Lepidodendropsis cf. L. arborescens, Sublepidodendron sp., and Taeniocrada? sp.; spores Leiotriletes 
sp., Retusotriletes sp., Punctatisporites minor, Cymbosporites cf. C. micromenifestus minor, and Chelispora sp. (2) The Qiziqiao Formation is $150-502 \mathrm{~m}$ of graywhite to dark-gray limestone, dolomitic limestone intercalated with calcareous mudstone, and dolomite; from south-central Hunan toward the northeast part of Hunan, the percentage of argillaceous clastic rocks increases. The Qiziqiao is rich in fossils, including corals Disphyllum peneckielloidea, Macgeea cylindrica, Endophyllum xiangxiangensis, E. vorticum, Crassialveolites mirus, Crassialveolitella multipora, Caliapora battersbyi, Alveolitella densata, Roemeripora zhongguoensis, Scoliopora muricata, and Syringopora zhonggouensis; bryozoans Fistulipora tiaomajianensis and Fistuliramus intermedius; stromatoporoids Amphipora rudis, Hammatostroma tschussovense, Stromatoporella solitaria, Atelodictyon dahekouense, Actinostroma clathratum, Idiostroma hunanense, and Stachyodes radiata; brachiopods Schizophoria kutsingensis, S. striatula beta, S. excellens, Leptostrophia maccarthyi, Productella tiaomajianensis, Desquamatia auriculata, D. peshiensis, Atrypa hunanensis, Spinatrypina changuliensis, $S$. bodini, Spinatrypa subkwangsiensis, Buchanathyris subplana, Ilmenia sinensis, Emanuella plicata, and Stringocephalus burtini beta; pelecypods Similoconcha symmetrica, "Ctenodonta" cf. " $C$." insignis, Nuculoidea cf. N. opima, Bicrenula hunanensis, B. quadrata, Palaeoneilo tiaomajianensis, $P$. cf. $P$. planiformis, Glyptoleda nuculiformis, G. elongata, Praecardium sp., Paracyclas tiaomjianensis, Cypricardinia scalaris, Limoptera orbicularis, L. nodosa, Ptychopteria (Actinopteria) changshaensis, $P$. (A.) hunanensis, $P$. (A.) taiomajianensis, $P$. (A.) paradoxa, Leptodesma (Leptodesma) zhuzhouensis, L. (Leiopteria) gabbi, Crenipecten primita, Opisthocoelus hunanensis, Orthonota undulata, O. curta, Glossites hunanensis, Sphenotus gigantus, Paleodora tiaomajianensis, and Buchiola minuta.

Upper Devonian: (3) The Shetianqiao Formation consists of four parts. The basal beds are siliceous shale and siliceous limestone; the next higher beds are mudstone intercalated with argillaceous siltstone; the third part is limestone and siltstone; and the upper part is marl intercalated with limestone. The Shetianqiao is $580 \mathrm{~m}$ thick and contains the corals Disphyllum frechi, D. cylindricum, Sinodisphyllum simplex, Tabulophyllum gigantum, T. curvatum, Hunanophrentis uniforme, H. zaphrentoides, Pseudozaphrentis curvatum, P. conicum, Cyathophyllum flexuosum, Hexagonaria orientalis, Phillipsastrea hennahi, Billingsastraea bowerbanki, and $B$. verrilli; brachiopods Cyrtospirifer martellii, C. sinensis, Tenticospirifer tenticulum, T. vilis, Camarotoechia shetienchiaoensis, C. pleuroden, Atrypa shetienchiaoensis, Productella shetienchiaoensis, $P$. linglingensis, and Schuchertella hunanensis; pelecypods Buchiola retrostriata, B. zhuzhouensis, and Posidonia venusta; and ammonoids Manticoceras kweipingensis, $M$. sinensis, and $M$. cordatum. (4) The Xikuangshan Formation is divided into three members which, in ascending order are (i) Changlongjie Shale Member, graygreen to gray shale intercalated with argillaceous limestone or limestone from 30 to $50 \mathrm{~m}$ thick. The known fauna consists of the brachiopods Yunnanellina hanburyi, Y. uniplicata, Cyrtospirifer sinensis, Athyris gurdini, Sinoproductella hemisphaerica, and Productella sp.; and pelecypods Pterinopecten lanshanensis, Buchiola rectrostriata, and $B$. zhuzhouensis. (ii) The Magunao Limestone Member is argillaceous limestone and limestone intercalated with shale as much as $280 \mathrm{~m}$ thick containing the brachiopods Yunnanella synplicata, Y. hunanensis, Y. supersynplicata, Tenticospirifer supervilis, Cyrtospirifer subextensus, Ptychomalotoechia hsikuangshanensis, and Hunanospirifer wangi, and the pelecypod Schizodus hengshanensis. (iii) Aiyiechong Member, sandstone and siltstone as much as $120 \mathrm{~m}$ thick bearing the fish Bothriolepis sp.; plants Lepidodendropsis hirmeri, Cyclostigma kiltorkense, Lepidostrobus grabaui, and Sublepidodendron mirabile; spores Vallatisporites pusillites, Cymbosporites parvibasilaris, C. lasius minor, Hymenozonotriletes lepidophytus, Calamospora microrugosa, Punctatisporites sp., Granulatisporites sp., Verrucosisporites sp., Lophotriletes sp., Lophozonotriletes sp., Dibolisporites sp., and Stenozonotrites sp.

\section{DONGNAN OR SOUTHEAST CHINA REGION}

In the Dongnan or southeast China Region (fig. 2), the Devonian rocks of Jiangsu, Zhejiang and Anhui Provinces consist of continental clastic rocks (figs. 2; 5 , column 7). The age of the Maoshan group is debated. On the basis of its contained fish, it is regarded as Early Devonian; on the basis of spores and chitinozoans, it is regarded as Late Silurian; and on the basis of its stratigraphic position, the Maoshan has been called transitional beds of Silurian-Devonian age (Hou and others, 1982, p. 176). The Maoshan group is composed of purple-red to yellowish-green fine granular sandstone with intercalated siltstone and sandy shale as much as $1,600 \mathrm{~m}$ thick. The only known fishes are Sinacanthus wuchangensis, S. fancunensis, and Ninggoulepis fancunensis. The Middle Devonian is absent. The Upper Devonian Wutong Formation is $80-617 \mathrm{~m}$ of yellow or gray quartzite, fine granular sandstone, and shale, having quartzose conglomerate at its base. The Wutong is disconformable on the Maoshan. In the upper part of the Wutong, the fossils are the fishes Sinolepis 
macrocephala, S. wutungensis, Asterolepis sinensis, Holoptychius nankinensis, Laccognathus? sp., and Paraholoptychus lungtanensis; plants Leptophloeum rhombicum, Platyphyllum sp., Sublepidodendron mirabile, Lepidodendropsis hiemeri, Sphenophyllum lungtanense, and Asterocalamites scrobiculites; and spores Cymbosporites scabellus, C. sp., Hymenozono- triletes lepidophytus, Stenozonotriletes sp., Leiotriletes pallatus, Acanthotriletes ignotus, Lophozonotriletes curvatus, Dibolisporites sp., Lophotriletes macrogrumosus, Retusotriletes sp., and Apiculatisporites sp. The information here summarized on eastern South China was taken from Xia (1978) and Pan and others (1978). [References for all chapters are combined and follow last chapter.] 



\author{
DEVONIAN ROCKS AND LOWER AND MIDDLE DEVONIAN PELECYPODS \\ OF GUANGXI, CHINA, AND THE TRAVERSE GROUP OF MICHIGAN
}

\title{
CHAPTER G. CORRELATION OF THE LOWER AND MIDDLE DEVONIAN OF GUANGXI
}

\author{
By Zhang Renjie and JOHn POJETA, JR.
}

The Lower and Middle Devonian stratotype sections for South China (Huanan Region) are in the Guangxi Autonomous Region and Hunan Province (fig. 7). Six provincial stages have been proposed for these rocks (figs. 5, 8, and 9). These are discussed by Hou Hongfei (1978), Liao and others (1978), and Yang and others $(1979,1981)$. South China may have been a series of islands in Early and Middle Devonian time (Hou Hongfei, 1978); this proposal is based on lithic facies changes, thicknesses of rock units, and a benthic fauna that includes many endemic species.

The marine Devonian of South China is divided into depth-controlled facies, of which the Nandan and Xiangzhou facies are the most widespread (figs. 5, columns $6 \mathrm{~A}, \mathrm{~B} ; 6$; and 10). The Nandan rocks are deeper water deposits than Xiangzhou rocks, they have a smaller areal extent, and are more easily correlated with those of western Europe by means of ammonoids, tentaculites, and conodonts. Correlation of Nandan rocks with Xiangzhou rocks is based on a few ammonoids, tentaculites, and conodonts common to the two facies, or which occur in either facies and in western Europe. A preliminary correlation of the Lower and Middle Devonian rocks of Guangxi with western Europe and North America is shown in figure 8. The Lower and Middle Devonian stages of South China are named after formations in the Xiangzhou facies and are discussed below. At present, most of the stages include one thick formation, which is divided into members (figs. 5, column $6 \mathrm{~B}$; and 8 ). The distributions of major groups of fossils are shown in figure 9.

\section{LIANHUASHANIAN STAGE}

The Lianhuashanian Stage is the lowest stage in the Devonian of South China. It is represented by the Lianhuashan Formation (pl. 65, figs. 1, 2; pl. 66, fig. 3) in the Xiangzhou facies, which is thought to be the equivalent of the lower Danling Formation of the Nandan facies, and is regarded as early Gedinnian in age. The Lianhuashan Formation was named for Lianhuashan Hill, Shilong Village, Guixian County, Guangxi (fig. 10A), but the stratotype section for the Lianhuashan Stage is at Xiayiling Hill, north of the Liujing Village, Hengxian County, Guangxi (fig. 10A), which is $100 \mathrm{~km}$ west of Lianhuashan Hill and exposes the Lianhuashan Formation.

The Lianhuashan Formation is largely purple-red silty mudstone and siltstone having some argillaceous limestone and quartzose sandstone; it is conglomeratic at the base. The lower contact is unconformable on Cambrian rocks, and the upper contact is gradational with the overlying Nagaoling Formation. Thickness is about $340 \mathrm{~m}$.

The lowermost Devonian is unknown in central Guangxi because the Lingli Member of the Lianhuashan Formation has not yet yielded any fossils. The middle and upper Hengxian and Liukankou Members of the Lianhuashan have yielded faunas consisting of the pelecypods Dysodonta angulata, Leiodysodonta guangxiensis, and L. elliptica; ostracodes Primitia, Beyrichia, and Kloedenella; and fishes Asiacanthus suni, A. kaoi, Asiaspis expansa, Lianhuashanolepis 


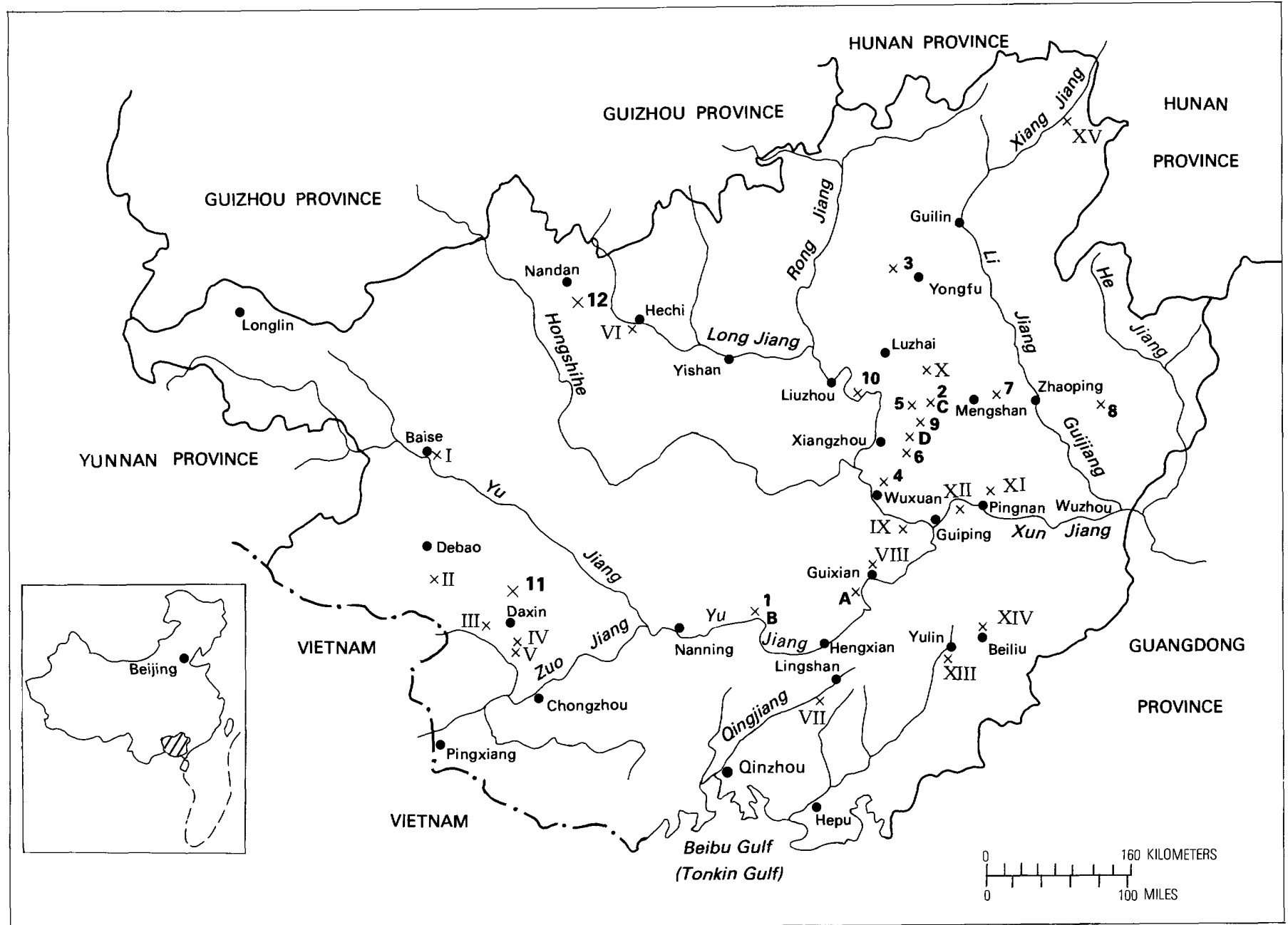

Figure 7.-Fossil localities and the location of stratotype areas for the Devonian in Guangxi, South China.

$\mathrm{X}-1-12=$ Fossil localities that are described in "Chapter D. Devonian Sections in Guangxi from which Pelecypods Were Collected." (1) Liujing Village, Hengxian County; (2) Dale Village, Xiangzhou County; (3) Heping Village, Yongfu County; (4) Liufengshan Hill, Wuxuan County; (5) Luobang Village, Luoxiu Community, Xiangzhou County; (6) Miaohaung Village, Xiangzhou County; (7) Xinxu Village, Mengshan County; (8) Zhangmu Village, Zhaoping County; (9) Zhongping Village, Xiangzhou County; (10) East Bank of the Liujiang River, Liujiang County; (11) Changming Reservoir, Daxin County; (12) Changlaoxu Village, Hechi County.

$\mathrm{X}-\mathrm{I}-\mathrm{XV}=$ Fossil localities from which pelecypods were described previously by Zhang (1977). (I) Baise County; (II) Qingjia Village, Jingxi County; (III) Naling Village, Daxin County; (IV) Lantan Village, Daxin County; (V) Zouzhou Village, Daxin County; (VI) Huimacun Village, Hechi County; (VII) Tanxu Village, Lingshan County; (VIII) Tianpingshan Hill, Guixian County; (IX) Shilong Village, Guiping County; (X) Sipai Village, Luzhai County; (XI) Anhuai Village, Pingnan County; (XII) Mugui Village, Guiping County; (XIII) Yuling County; (XIV) Beiliu County; (XV) Daxijiang Village, Quangzhou County.

$\mathrm{X}-\mathrm{A}-\mathrm{D}=$ Stratotype areas for Lower and Middle Devonian of Guangxi described in "Chapter C. Correlation of the Lower and Middle Devonian of Guangxi." (A) Shilong Village, Guixian County; (B) Xiayiling Hill, Hengxian County, and Liujing Village, Hengxian County; (C) Dale Village, Xiangzhou County, and Yingtang Village, Xiangzhou County; (D) Doupengling Hill, Xiangzhou County.

liukingensis, Orientolepis neokwangsiensis, and Yunnanolepis sp. The lower Cuifengshan Formation of east Yunnan (fig. 5, column 6C) is correlated with the middle and upper Lianhuashan Formation on the basis of the common presence of the fishes Yunnanolepis and Asiaspis, and species of the pelecypod Leiodysodonta. L. elliptica (Zhang, 1977), described herein from Guangxi, is synonymized with Dysodonta planidentata (Guo, 1980) from Yunnan.
The fish and pelecypod faunas of the Lianhuashan Formation are not widely distributed. They are found in the lower Cuifengshan Formation of Yunnan where they occur with the plant Zosterophyllum myrtinianum; this species is also known from the Gedinnian of England and the Coblenzian of Siberia (Li and Cai, 1977). Some spores and chitinozoans from the Cuifengshan Formation are also known from the upper Downtonian to lower Dittonian of south England and 


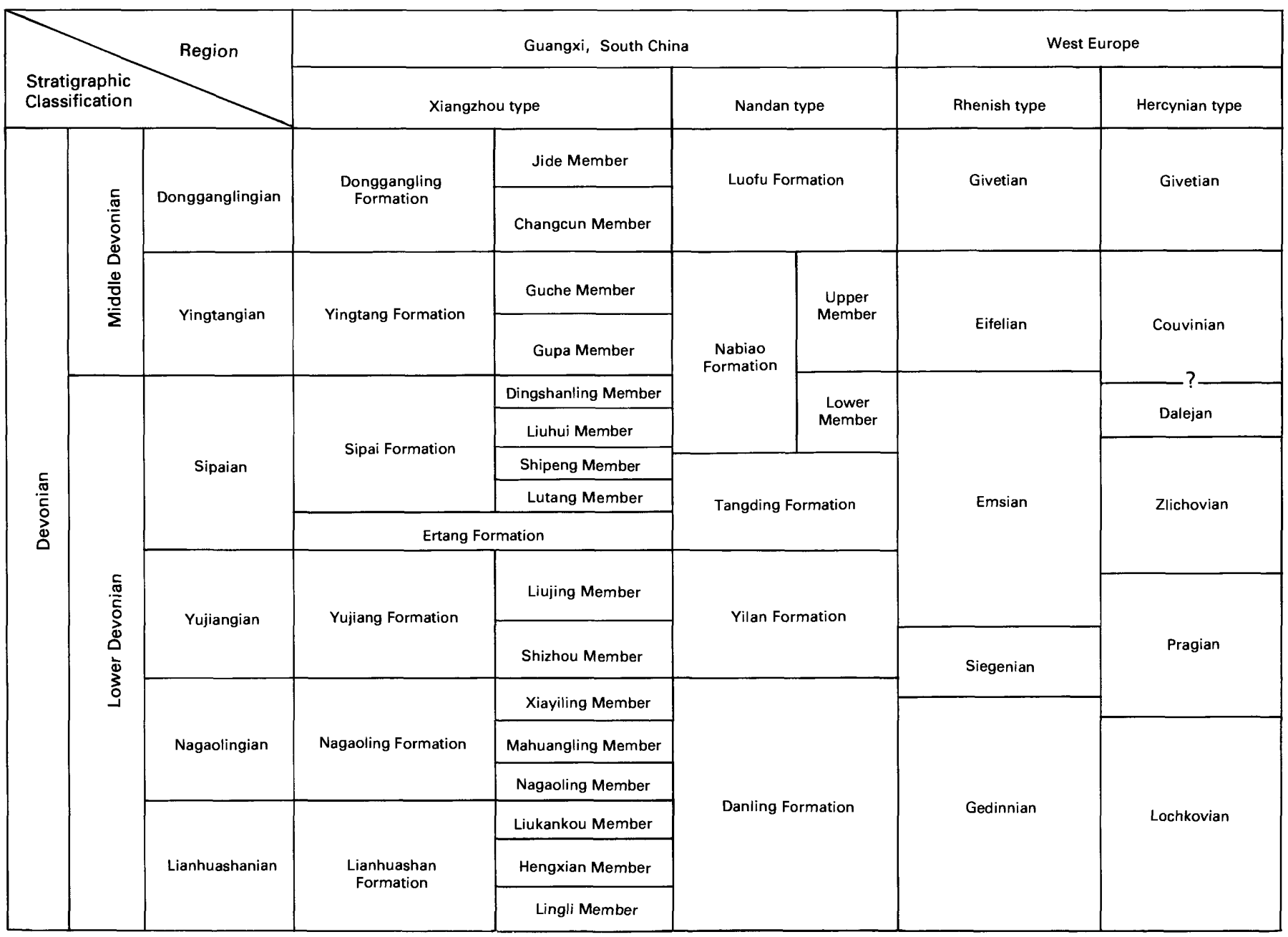

Figure 8.-Correlation chart of the Lower and Middle Devonian rocks of Guangxi, South China. Correlations with the European type sequences are approximate.

from the Red Bay Group of Spitzbergen Island (Gao, 1978). Thus, the Lianhuashanian of Guangxi is probably Gedinnian (or Lochkovian) in age in terms of the European sequences.

Wang and $\mathrm{Yu}(1962)$ regarded the Lianhuashan Formation as a nonmarine deposit because of the abundant, presumably freshwater, fishes. Hou (1978) and Wang and Liu (1980) thought of the Lianhuashan as an upper littoral deposit because of Lingula in the upper twothirds of the unit. Most recently, the discovery of marine ostracodes, the marine palaeotaxodont(?) pelecypods Dysodonta angulata, Leiodysodonta guangxiensis, and L. elliptica and the marine pteriacean pelecypod Leptodesma (Leptodesma) venusta indicate that the middle and upper parts of the Lianhuashan Formation are shallow marine deposits; at the very least, they indicate that marine sedimentary tongues are present. This interpretation is supported by the presence of a few beds of silty dolomite and marl in the middle and upper members of the Lianhuashan.

\section{NAGAOLINGIAN STAGE}

The Nagaolingian Stage is represented by the Nagaoling Formation (pl. 65, fig. 3; pl. 66, fig. 4) in the Xiangzhou facies, thought to be equivalent to the upper Danling Formation of the Nandan facies, and regarded as late Gedinnian to early Siegenian in age (figs. 8 and 9). The type section is at Nagaoling Hill, Liukankou Reservoir, Liujing Village, Hengxian County, Guangxi (fig. 10A). At the type section, the Nagaoling Formation is mainly grayish-green calcareous mudstone containing limestone lenses in the lower part and mainly fine-grained sandstone in the upper part. Thickness is $180 \mathrm{~m}$. Away from the type section, the Nagaoling Formation is red in most places and is difficult to distinguish from the underlying Lianhuashan Formation. The fossils of the two formations are very different, and the occurrence of the brachiopods Orientospirifer wangi and $O$. nakaolingensis is used to mark the Nagaoling Formation. 
DEVONIAN ROCKS AND PELECYPODS OF GUANGXI, CHINA, AND OF MICHIGAN

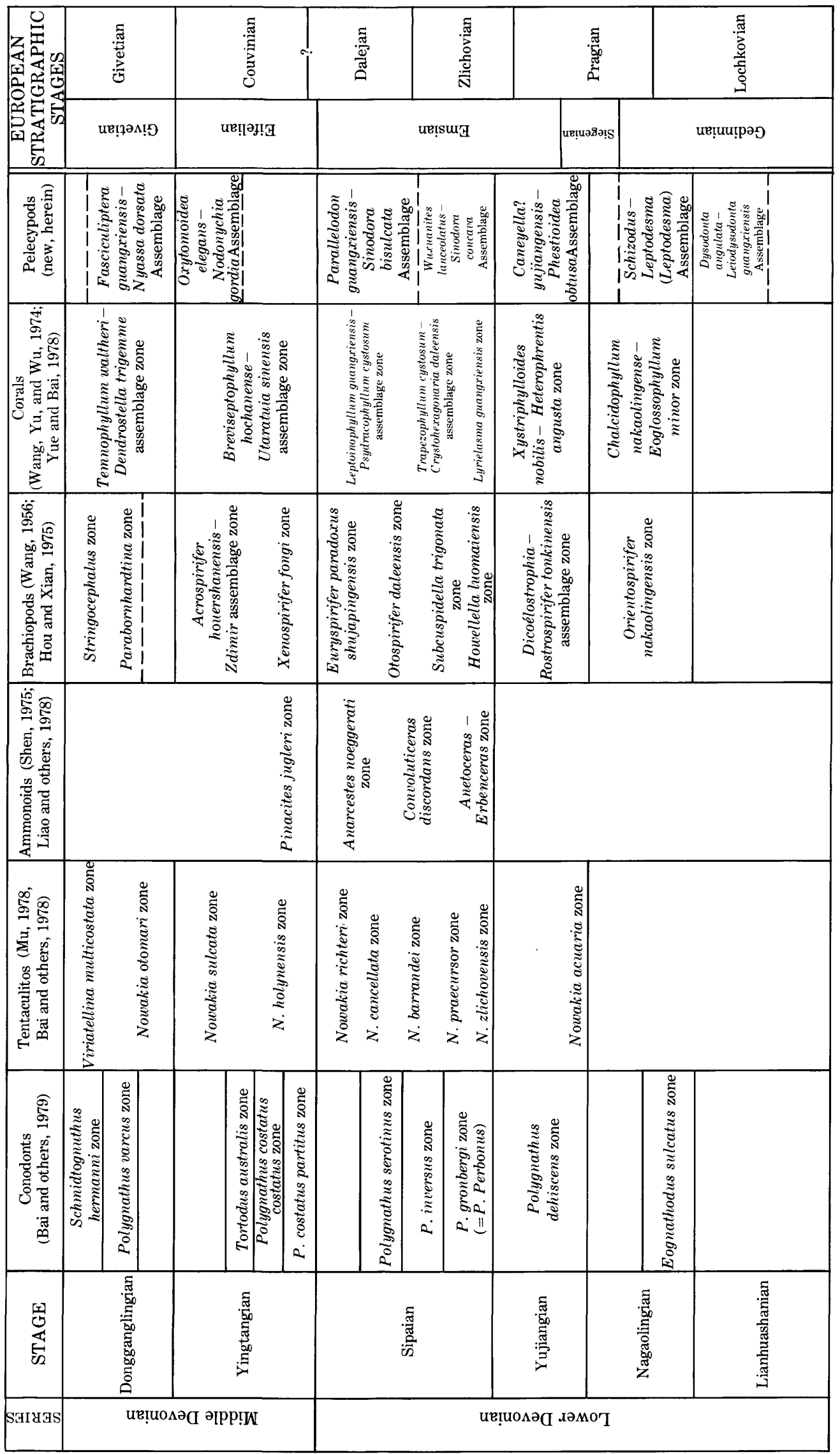

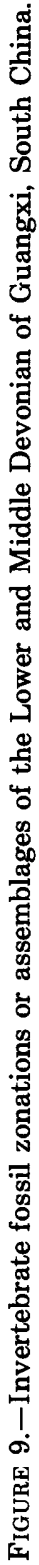


The Nagaoling Formation has a highly diverse fossil biota composed of other brachiopods Aseptalium guangxiensis, Corvinopugnax globosus, Protathyris praexursor, "Chonetes" ellipticus, and C. sarcinulatus; corals Chalcidophyllum nakaolingensis and Eoglossophylum minor, tentaculite Paranowakia sp.; pelecypods Nuculoidea minuta, Nuculites sp. A, Leiodysodonta elliptica and L. levis, Cypricardella? spp., Sanguinolites nagaolingensis, Radiatodonta? sp. A, Schizodus aff. S. cuneus, $S$. aff. $S$. appressus, Mecynodon aff. $M$. carinatus, Leptodesma (Leptodesma) deprati, L. (L.) guangxiensis, and $L$. (L.) venusta; ostracode Guangxichia ovata; conodonts Eognathodus sulcatus and $E$. sp.; fishes Asiaspis expansa and Nakaolingnaspis devonica; chitinozoans Ancyrochitina ancyrea, $A$. spinosa, A. tumida, Angochitina globosa, A. comosa, A. devonica, Sphaerochitina sp., Conochitina sp., Cyathochitina sp., Desmochitina cf. D. densa, D. bohemica, $D$. cf. $D$. urna, Rhabochitina esthonica, and $R$. sp. Spores and acritarchs are also present.

Although brachiopods are abundant in the Nagaoling Formation, most of them are endemic. An exception is Protathyris praecursor, which is found in the Gedinnian of western Europe (Kozlowski, 1929). The coral Chalcidophyllum has been reported from Siegenian-Emsian rocks in Australia (Pedder, 1965). The conodont Eognathodus sulcatus is characteristic of a thin interval that spans the Lochkovian-Pragian boundary in Europe (Klapper and Johnson, 1980). The chitinozoans Ancyrochitina ancyrea and Angochitina devonica are used as zonal fossils in the Lochkovian of north Africa (Magloire, 1967), but in Spain they have been reported in rocks ranging in age from Late Silurian through Emsian (Cramer, 1964; 1967). Gao (1978), in evaluating the spores and acritarchs of the Nagaoling, regarded them as closest to those in rocks ranging in age from Gedinnian to middle Siegenian in western Europe and north Africa. From this wealth of conflicting stratigraphic information, we herein suggest that the Nagaolingian rocks of Guangxi correspond in age to the late Gedinnian-early Siegenian stages or to the upper Lochkovian-lower Pragian interval (fig. 8).

\section{YUJIANGIAN (YUKIANGIAN) STAGE}

The Yujiangian (Yukiangian) Stage is represented by the Yujiang Formation (pl. 65, fig. 3; pl. 66, fig. 1) in the Xiangzhou facies, which is thought to be the equivalent of the Yilan Formation of the Nandan facies, and is regarded as Siegenian to early Emsian (late Pragian to early Zlichovian) in age (figs. 8 and 9). The Yujiang Formation is typically developed along the northern bank of the Yujiang River in the vicinity of
Nanning City (capital of the Guangxi Autonomous Region) extending to the Liujing railway station (fig. $10 A$ ). The stratotype is at the hill slope extending from $1 \mathrm{~km}$ to $5 \mathrm{~km}$ northwest of the Liujing railway station, Hengxiang County. The Yujiang Formation consists of mudstone, calcareous siltstone, argillaceous limestone, and marl intercalated with biogenic limestone. Thickness is $170 \mathrm{~m}$.

The Yujiang Formation is characterized by an abundant benthic shelly biota, except for a 10-m interval $95 \mathrm{~m}$ above the base of the formation. The fauna is rich in brachiopods, corals, bryozoans, pelecypods, nautiloids, trilobites, and ostracodes. The brachiopod assemblage has been called the "Rostrospirifer tonkinensis fauna," and about 30 genera of brachiopods have been reported from the Yujiang Formation (Hou and Xian, 1975). Many of these genera are endemic, and it has been suggested that they are representative of an independent Devonian paleobiogeographic region in east Asia (Hou Hongfei, 1978).

Two coral assemblage zones are recognized in the Yujiang Formation (fig. 9): a lower Xystriphylloides nobilis - Heterophalactis semicrassa Zone and an upper Heterophrentis angusta - Amplexiphyllum hamiltoniae Zone (Yang and others, 1979). Generally speaking, the coral faunas of the Yujiangian of Guangxi differ from those elsewhere in the world. Furthermore, taxa that are known to occur elsewhere in the Middle Devonian (Amplexiphyllum hamiltoniae, Microcyclus, and some subspecies of Calceola sandalina) are found in the Lower Devonian Yujiang Formation of Guangxi (Wang and others, 1974).

Pelecypods of the Yujiang Formation are Phestioidea obtusa, Pseudonuculana zhaoi, Leiodysodonta guangxiensis, Orthonota sp. indet., Grammysioidea sp. indet., Cimitaria sinensis, Mytilarca cf. $M$. chemungensis, $M$. cf. M. oviformis, Caneyella? yujiangensis, Ptychopteria $(P$.$) zhongguensis, and P$. (A.) cf. $P$. (A.) producta. Trilobites are represented by the taxa Dechenella liujingensis, Gravicalymene maloungkaensis, and Proetus indosinensis. Conodonts include the taxa Polygnathus dehiscens, Pandorinellina exigua guangxiensis, $P$. optimus, Ozarkodina denckmanni, Hindeodella priscilla, Belodella resima, and $B$. triangularis.

In the Yilan Formation of the Nandan facies, which is composed of more than $100 \mathrm{~m}$ of dark-gray to grayblack mudstones and shales intercalated with marls, the following fossils occur: brachiopods, Dicoelostrophia annamitica, D. guibeiensis, D. punctata, Elytha sp., Howellella papaeonsis, Nadiastrophia nitida, and Rostrospirifer tonkinensis (Wei, 1982); pelecypods, Ptychopteria (Actinopteria) guangxiensis, Grammysioidea, and Guangxiconcha hechiensis (Zhang, 1977); ammonoids, Agoniatites cf. $A$. unilobatus and $A$. 

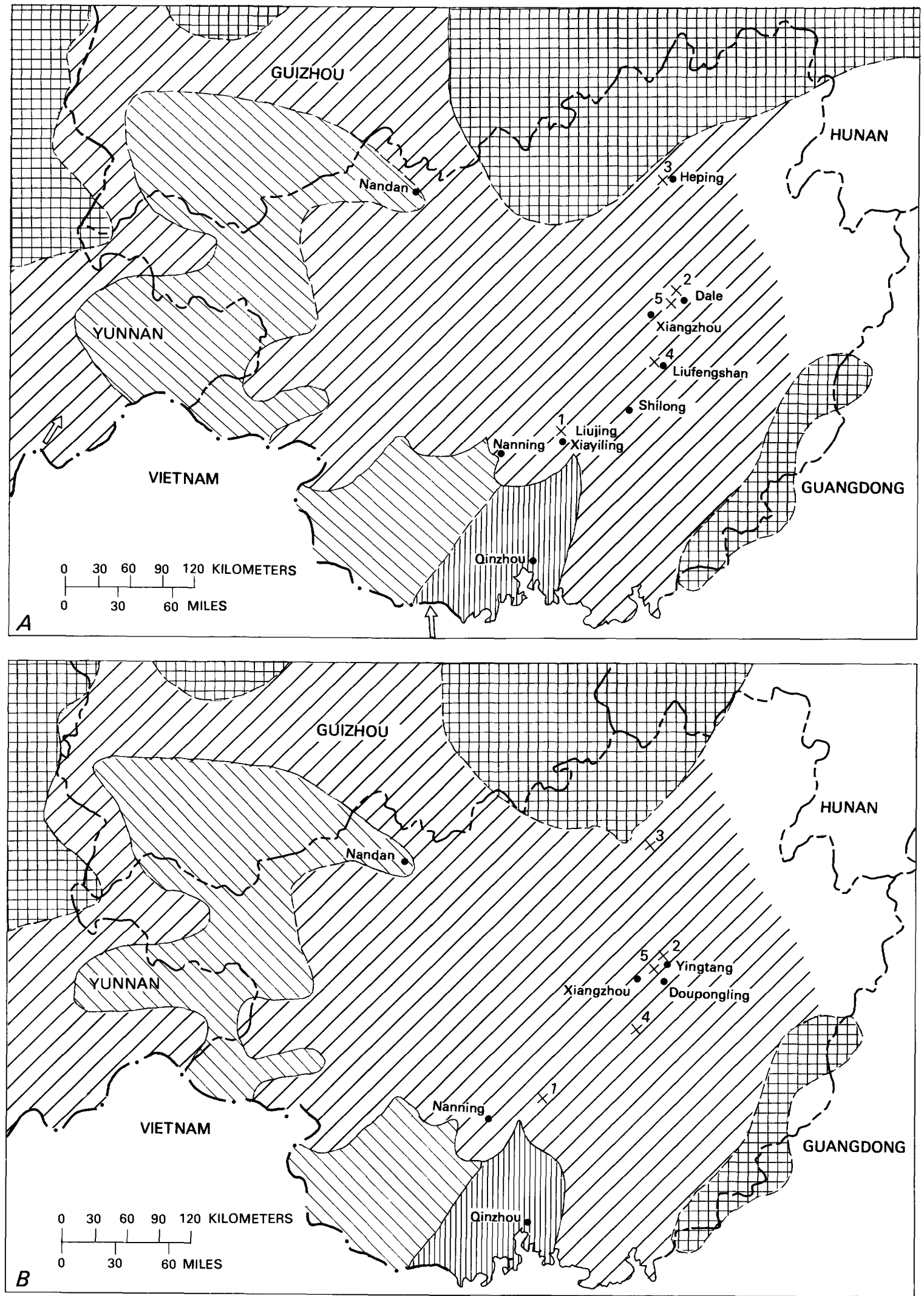
EXPLANATION
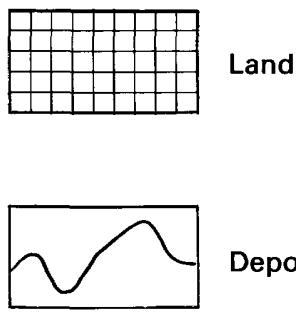

Deposit area boundaries

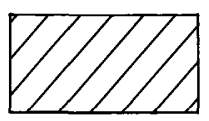

Xiangzhou deposit facies

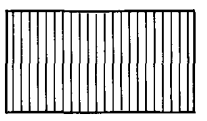

Qinzhou deposit facies

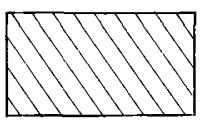

Nandan deposit facies

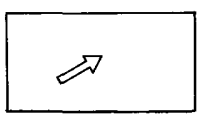

Direction of transgression

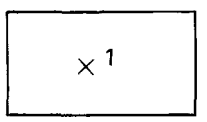

Section locations and numbers

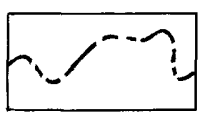

Province boundaries

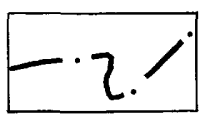

Country boundaries

- Dale

Place name

4 Figure 10.-Paleogeography of Guangxi. $A$, During Sipaian time (late Early Devonian). $B$, During Yingtangian time (early Middle Devonian). The maps show the distribution of land and Xiangzhou, Nandan, and Qinzhou facies. Numbers indicate the sections that are mentioned in "Chapter D. Devonian Sections in Guangxi from which Pelecypods Were Collected." Maps modified and simplified from $\mathrm{Wu}$ and Kuang (1979). cf. A. floweri; bactritoid, Lobobactrites sp.; and trilobite Phacops fecundus (Wei, 1982; Liao and others, 1978). Most of the biostratigraphic information is consistent with a late Siegenian-early Emsian age for the Yujiangian stage, about equal to the upper Pragian to lower Zlichovian interval in the Hercynian sequences (fig. 8). This interpretation of the brachiopod faunas of the Yujiangian is close to that of Hou and Xian (1975) and is supported by the presence of the conodont Polygnathus dehiscens, which occurs at about the Pragian-Zlichovian boundary (Klapper and Johnson, 1980). In the Tangding Formation, which overlies the Yilan Formation in the Nandan facies, the ammonoids Anetoceras, Erbenoceras, Mimagoniatites, and Teichertoceras have been found; they indicate an early Emsian age for the lower Tangding Formation.

\section{SIPAIAN STAGE}

The Sipaian Stage is represented by the Ertang and Sipai Formations in the Xiangzhou facies, which are thought to be equivalent to the Tangding Formation and lower member of the Nabiao Formation of the Nandan facies, and are regarded as Emsian (ZlichovianDalejan) in age (figs. 8 and 9). The stratotype is located at a prominent ridge at Dale Community, about $40 \mathrm{~km}$ northeast of Xiangzhou County, eastern Guangxi (fig. 10A).

Sipaian-age rocks are generally light colored and are characterized by abrupt vertical lithological changes. They include biogenic limestone, dolomite intercalated with dolomitic limestone, siltstone, mudstone, and marl. Near Dale, the Ertang is about $340 \mathrm{~m}$ thick, and the Sipai is about $400 \mathrm{~m}$ thick. In the Nandan environment, the rocks of the Tangding Formation and lower Nabiao Formation are dark mudstones and silty mudstones.

In the Xiangzhou facies, four assemblage zones are recognized largely on the basis of brachiopods and corals. In descending order, they are (fig. 9) (Hou and others, 1982):

4. Euryspirifer paradoxus shujiapingensis - Psydracophyllum cystosum Zone. Other fossils from this assemblage zone include the corals Leptoinophyllum subvermiculare, Pseudomicroplasma laticystata, Tryplasma cancabotabulata, and Zelolasma elegantula, and brachiopods Athyrisina yohi, Lazutkinia lata, Reticulariopsis indifferens, and Euryspirifer kwangsiensis.

3. Otospirifer daleensis - Trapezophyllum cystosum Zone. Other fossils from this assemblage zone include the corals Cystohexagonaria daleensis and Phacellophyllum daleensis; brachiopod Alatiformia aff. A. alatiformis; cephalopod Nathoceras 
sianghsiensis; trilobite Shipaia hexospina; and conodont Polygnathus perbonus.

2. Subcuspidella trigonata - Paramoelleritia xiangzhouensis magna Zone. Other fossils from this assemblage zone include the brachiopod Athyrisina plicata, and the ostracode Paramoelleritia miaohuangensis.

1. Howellella luomaiensis - Lyrielasma guangxiensis Zone. Other fossils known from the Sipian Xiang. zhou facies include the pelecypods Nuculoidea yongfuensis, N. minuta, Similoconcha? sp. A, Nuculana? acutirostra, Nuculites sp. B, Palaeoneilo sp. A, Palaeoneilo sp. B, Modiomorpha paradoxa, $M$. harrisae, M. oblonga, Spathella hepingensis, Spathella sp., Goniophora (G.) spatulata, G. (G.) sp. A, $G$. (G.) sp. B, Sinodora concava, S. semiglabra, S. bisulcata, S.? zhongguoensis, Orthonota guangdongensis, Paracyclas rugosa, Crassatellopsis? sp. A, Schizodus aff. S. appressus, Cimitaria sinensis, Parallelodon guangxiensis, Fasciculiptera sp. A, Carinonychia triangularis, Mytilarca cf. $M$. chemungensis, Leptodesma (Leptodesma) guangxiensis, L. (L.) venusta, L. (L.)? sp., Limoptera sp., Ptychopteria (P.) zhongguensis, $P$. (A.) producta, Wuxuanites lanceolatus, $W$. washingtonensis, Pterinopecten (P.) wuxuanensis, $P$. (N.) guangxiensis, and Lyriopecten ertangensis; cephalopod Erbenoceras ellipticum; tentaculites Nowakia barrandei, $N$. praecursor and $N$. richerti; and the conodonts Polygnathus inversus and $P$. serotinus.

The Nandan facies can be zoned on the widely occurring tentaculites and ammonoids. In Guangxi, five tentaculite and three ammonoid zones are recognized. In descending order, they are

Tentaculites

5. Nowakia richerti Zone

4. N. cancellata Zone

3. N. barrandei Zone

2. $N$. praecursor Zone

1. N. subtilis-N. zlichoviensis Zone

Ammonoids

3. Anarcestes noeggerati Zone

2. Convoluticeras discordans Zone

1. Anetoceras-Erbenoceras elegantum Zone

The conodonts, ammonoids, and tentaculites all indicate a Zlichovian-Dalejan (Emsian) age for the Sipaian Stage of Guangxi. Erbenoceras ellipticum and Nowakia praecursor indicate a Zlichovian age. Polygnathus inversus and $P$. serotinus indicate a late Emsian (Dalejan) age. Thus, the Sipaian marks the top of the Lower Devonian in Guangxi.

\section{YINGTANGIAN STAGE}

The Yingtangian Stage is represented by the Yingtang
Formation in the Xiangzhou facies, which is thought to be the equivalent of the upper Nabiao Formation of the Nandan facies, and is regarded as Eifelian in age (figs. 8 and 9). The Yingtang Formation is largely gray and green shale and limestone intercalated with marl. Thickness is $230 \mathrm{~m}$. The stratotype is at Yingtang Village, Dale Community, Xiangzhou County (fig. 10B). The Nabiao consists mostly of black mudstone.

In the Xiangzhou facies, two assemblage zones are recognized on the basis of brachiopods and corals. In descending order, they are

2. Acrospirifer houershanensis-Utaratuia sinensis Zone. Other fossils from this assemblage zone include the corals Breviseptophyllum kochanensis, Hexagonaria simplex, Microplasma devoniana, Neospongophyllum tenue, $N$. gomerulatum, and Sociophyllum minor; and the brachiopods Athyrisina squamaeformis, Desquamatia richtofeni, Uncinulus goldfussi, $U$. parallelepedus, and $U$. pentagona.

1. Xenospirifer fongi-Eospiriferina lachrymosa Zone. Other fossils from this assemblage zone include the brachiopods Ambothyris transversa, Dalerhynchus dingshanlingensis, Indospirifer cf. I. padaukpinensis, Productella sinensis, Squamularina parva, and Yingtangella sulcatilis.

Associated with the corals and brachiopods are the pelecypods Sinodora semiglabra, Nuculopsis? sp. A, Similoconcha? sp. A., Pseudonuculana zhaoi, Nuculana? planumbona, Goniophora (G.) spatulata, G. (C.) marija, Tanaodon louderbacki, Paracyclas rugosa, Cardiomorpha? sp. indet., Sphenotus yingtangensis, Sedgwickia yingtangensis, Nodonychia gordia, Mytilarca cf. $M$. chemungensis, Limoptera sp., Oxytomoidea elegans, Ptychopteria (A.) producta, and Pterinopecten (N.) guangxiensis; and the conodont Icriodus cornigeri. The brachiopods Ambothyris, Eospiriferina, Indospirifer, and Uncinulus, taken together with the conodont Icriodus cornigeri, indicate an Eifelian (early Middle Devonian) age for the Yingtang Formation (Weddige, 1977).

The Nabiao Formation has the following fossils: ammonoids Foordites sp. and Pinacites jugleri; tentaculite Nowakia sulcata; and trilobites Cyphaspides orientalis, C. paradoxus, and Ductina vietnamica. Nowakia sulcata also indicates an Eifelian age for this unit (Lardeux, 1969).

\section{DONGGANGLINGIAN STAGE}

The Dongganglingian Stage is represented by the Donggangling Formation (pl. 66, fig. 2) in the Xiangzhou facies, thought to be the equivalent of the Luofu Formation of the Nandan facies, and regarded 
as Givetian in age (figs. 8; 9). The Donggangling Formation is largely light-colored argillaceous limestone, limestone, and biogenic limestone. Thickness is $420 \mathrm{~m}$. The stratotype is at Doupengling Hill, Xiangzhou County (fig. 10B). The Donggangling Formation is widely distributed in Guangxi. The Luofu Formation is darkcolored mudstone intercalated with siliceous shale, marl, and dolomite. Thickness is $500 \mathrm{~m}$.

The Donggangling Formation has a rich shelly fauna and has been divided into two brachiopod and three coral zones. In descending order, they are:

Brachiopods

2. Stringocephalus Zone

1. Parabornhardtina Zone

\section{Corals}

3. Sunophyllum Zone

2. Temnophyllum Zone

1. Dendrostelloides Zone

In addition, the following fossils have been identified from the Donggangling Formation: corals Cyathophyllum expansum, Cystiphylloides kwangsiensis, Dendrostella trigemme, Dialithophyllum crassum, Grypophyllum tenus, Levibiseptum dushanensis, Macgeea cylindricum, Neospongophyllum sp., Pseudomicroplasma fongi, Stringophyllum isactis, and Temnophyllum waltheri; brachiopods Acrothyris kwangsiensis, Bornhardtina spicisa, Emanuella takwanensis, Rhynchospirifer liujingensis, Schizophoria striatula, Stringocephalus burtini, and Undispirifer; pelecypods Ctenodonta? dubiiformisa, Palaeoneilo sp. B, Modiomorpha paradoxa, Spathella hepingensis, Spathella sp., Goniophora (G.) sp. A., Nyassa dorsata, Tusayana? liujiangensis, Edmondia aff. E. subovata, E. aff. E. philipi, Fasciculiptera guangxiensis; Mytilarca cf. M. oviformis, Actinodesma (Ectenodesma) guangxiensis, Limoptera sp., and Ptychoptera $(A$.) producta; tentaculite Nowakia otomeri; and conodonts Icriodus difficilis, Polygnathus linguiformis linguiformis, $P$. overinodosus, $P$. varcus, and Schmidtognathus hermanni.

The Luofu Formation has the following known fossils: coral Pseudomicroplasma fongi; brachiopods Atrypa richthofeni, Schizophoria kutsingensis, and Stringocephalus burtini; tentaculites Nowakia otmari, Styliolina sp., and Viriatellina multicostata; and trilobite Phacops sp.

Stringocephalus burtini and Nowakia otomeri indicate that Dongganglingian age strata in Guangxi are Givetian (upper Middle Devonian) in age (Cloud, 1942; Boucot and others, 1966; and Lardeux 1969).

[References for all chapters are combined and follow last chapter.] 



\title{
DEVONIAN ROCKS AND LOWER AND MIDDLE DEVONIAN PELECYPODS \\ OF GUANGXI, CHINA, AND THE TRAVERSE GROUP OF MICHIGAN
}

\section{CHAPTER D. DEVONIAN SECTIONS IN GUANGXI FROM WHICH PELECYPODS WERE COLLECTED}

\author{
By Zhang Renjie and JOHn POJETA, JR.
}

The Chinese pelecypods described in this paper were collected in sequence from five sections in central Guangxi and as grab samples from seven other localities (fig. 7); all, except locality 12, are from rocks of the Xiangzhou depositional facies, which represents nearshore, shallow-water environments that are rich in benthic shelly fossils. The description of each section is in descending order. The grab-sample localities are listed after the section descriptions. A few pelecypods listed are not included in "Systematic Paleontology of Devonian Pelecypods of Guangxi and Michigan"; Zhang identified these before the present study was made.

\section{SECTION 1}

Section 1 is near Liujing Village, Hengxian County, Guangxi, about $70 \mathrm{~km}$ east of the city of Nanning (figs. 7 and 10; pl. 67). Here Lower Devonian rocks unconformably overlie Cambrian shales intercalated with sandstones containing Protospongia sp. Section 1 is used as the Devonian regional stratotype sequence for South China, and the rocks exposed here have been described by Hou and Xian, 1975, and in unpublished and (or) unattributed committee reports by the Guangxi Institute of Geology (Kuang, 1982).

Upper Devonian

Rongxian Formation:

Thickness

45. Gray-white thick-bedded bioclastic limestone containing the coral Peneckiella sp., and the brachiopod Atrypa sp. The uppermost part of Rongxian Formation is not present in this section

44. Dark-gray thin-bedded bioclastic limestone, which is lenticular in most places

43. Gray, thin- to medium-bedded, bioclastic limestone intercalated with flint nodules and containing the corals Temnophyllum sp., Smithiphyllum sp., and Barrandeophyllum sp., and the brachiopod Atrypa sp
Upper Devonian-Continued

Thickness Rongxian Formation-Continued

42. Dark-gray thin-bedded bioclastic limestone intercalated with brown argillaceous beds and containing the corals Temnophyllum sp. and Barrandeophyllum sp.; brachiopod Atrypa sp.; and conodonts Polygnathus asymmetricus and Palmatolepis crepida --------------

Incomplete thickness of the Rongxian

Formation

$41 \mathrm{~m}$
$107 \mathrm{~m}$

Middle Devonian

Donggangling Formation:

41. Thick-bedded, bioclastic limestone containing the coral Phillipsastrea sp. --_--_-_-_----

40. Gray thin-bedded limestone having argillaceous beds intercalated with bioclastic limestones and containing the coral Temnophyllum sp., and the brachiopods Atrypa sp., Bornhardtina sp., and Stringocephalus sp.

39. Dark-gray medium-bedded bioclastic dolomitic limestone containing the corals Stringophyllum sp., Acanthophyllum sp., Grypophyllum sp., Pseudomicroplasma sp., and Spongophyllum sp., and the brachiopods Hypothyridina sp. and Bornhardtina sp.

38. Gray thin-bedded limestone intercalated with lenticular, bioclastic limestone containing the corals Grypophyllum sp., Pseudomicroplasma sp., and Acanthophyllum sp.; brachiopods Bornhardtina sp. and Stringocephalus sp.; tentaculite Nowakia otomeri; and conodonts Polygnathus varcus and $P$. linguiformis

37. Greenish-gray medium-bedded, fossiliferous, bioclastic dolomitic limestone, containing the brachiopods Stringocephalus sp. and Bornhardtina sp., and bryozoans ---_-----------

Total thickness of the Donggangling Formation

Middle-Lower Devonian

Nabiao Formation:

36. Greenish-gray, thin- to medium-bedded recrystallized dolomite 
Middle-Lower Devonian-Continued

Nabiao Forınation-Continued

35. Greenish-gray, medium-bedded dolomite, in the upper part covered by regolith --_---_----

34. Dark-gray, medium-bedded dolomite containing calcareous dolomite, intercalated with thinbedded siliceous rocks and nodules and containing the ammonoids Teichertoceras nandanense and Erbenoceras elegantulum, and the tentaculite Nowakia barrandei

33. Green-gray dolomite containing a few brachiopods and the conodonts Polygnathus gronbergi, $P$. inversus, and $P$. serotinus

Total thickness of Nabiao Formation -----

Lower Devonian

Yujiang Formation:

Liujing Meinber:

32. Gray to dark-gray medium-bedded argillaceous limestone containing the brachiopods Levenea depressa, Dicoelostrophia punctata, and Rostrospirifer tonkinensis multiplicatus --

31. Dark-gray inedium-bedded bioclastic limestone containing the brachiopods Rostrospirifer tonkinensis, Nadiastrophia yukiangensis, Eosophragmophora sinensis, Acrospirifer subregularis, Parachonetes nasutes, and $P$. ovalis

30. Yellowish-green fossiliferous calcareous unudstone and marl containing the corals Heterophrentus angusta and Amplexiphyllum sp.; brachiopods Levenea depressa, Nadiastrophia yukiangensis, Dicoelostrophia annamittica, $D$. punctata, Parachonetes kwangsiensis, $P$. nasutus, Parathyrisina tangnae, Howellella papaoensis, $H$. yukiangensis, Cymostrophia quadrata, C. semispheroidea, Leptaenopyxis intermedia, Ferganella parasappho, Uncinulus mesodeflectus, U. fasciger, Schizophoria sp., Undispirifer transversus, $U$. ovatus, Acrospirifer ordinaris, A. hemirotundus, $A$. subregularis, Elymospirifer kwangsiensis, Rostrospirifer tonkinensis, and Gypidula loczyi; and pelecypods

29. Yellowish-green calcareous mudstone intercalated with lenticular limestone having the pelecypods Phestioidea obtusa and Pseudonuculana zhaoi

28. Dark-gray argillaceous bioclastic limestones, rich in brachiopods. The genera and species of brachiopods in this bed are much like those in bed 31 , and the pelecypods are Nuculoidea sp., Mytilarca sp., Paracyclas sp., and Schizodus sp.

27. Grayish-green silty pelite intercalated with lenticular limestone containing the brachiopods Levenea depressa, Dicoelostrophia punctata, Parachonetes kwangsiensis, Athyris grandis, Elymospirifer kwangsiensis, and Rostrospirifer tonkinensis --- ----------

Total thickness of Liujing Meinber ----
Thickness | Lower Devonian-Continued

Yujiang Formation-Continued

Shizhou Meinber:

$71 \mathrm{ln}$

26. Yellowish-green inudstone, having a bed of calcareous siltstone at the bottom, and containing the brachiopods Leptostrophia sp., Dicoelostrophia punctata, and Nadiastrophia yukiangensis

25. Yellowish-green thin-bedded inudstone intercalated with marl, rich in the brachiopods Nadiastrophia yukiangensis, Dicoelostrophia annamitica, Leptostrophia sp., Cymostrophia semispheroides, Howellella papaoensis, and $H$.

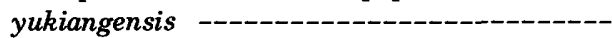

24. Yellowish-gray thin-bedded mudstone intercalated with calcareous siltstone; at the base are the brachiopods Rostrospirifer tonkinensis and Dicoelostrophia sp.

23. Gray medium-bedded argillaceous limestone interbedded with calcareous siltstone and yellowish-green, silty mudstone containing the coral Xystriphylloids nodilis; brachiopods Parachonetes kwangsiensis, Nadiastrophia yukiangensis, Dicoelostrophia annamitica, $D$. punctata, Cymostrophia semispheroidea, Howellella cf. $H$. nucula, $H$. yukiangensis, and Rostrospirifer tonkinensis; and the conodont Polygnathus dehiscens

3 in

22. Pale yellowish-brown silty pelite containing the brachiopods Parachonetes kwangsiensis, Dicoelostrophia annamitica, Howellella cf. $H$. nucula, and Rostrospirifer tonkinensis ------

21. Yellowish-brown medium- to thin-bedded argillaceous siltstone containing the brachiopods Atrypa sp. and Rostrospirifer tonkinensis, and pelecypods Caneyella? yujiangensis, Cimitaria sinensis, Grammysioidea sp., Mytilarca cf. $M$. chemungensis, Orthonota sp. indet., Ptychopteria (Actinopteria) cf. P. (A.) producta, and Sanguinolites? sp.

20. Grayish-green thin-bedded micaceous mudstone containing the brachiopods Howellella papaoensis, $H$. cf. $H$. nucula, Parachonetes nasutus, Dicoelostrophia annamitica, Leptostrophia sp., Cymostrophia semispheroidea, and Rostrospirifer tonkinensis, and pelecypods ---------Total thickness of Shizhou Meınber

$7 \mathrm{in}$

$5 \mathrm{~m}$

16 in

$18 \mathrm{~m}$

$1 \mathbf{m}$

$21 \mathrm{~m}$

15 in

Nagaoling (Nakaoling) Formation:

Xiayiling Meinber:

19. Pale-gray Inedium- to thin-bedded argillaceous sandstone and fragments of brachiopods ----

18. Light-purple-red to grayish-white thin-bedded argillaceous siltstone, containing the brachiopods Acrospirifer sp., Howellella sp., and Orientospirifer wangi

$5 \mathrm{in}$

17. Pale-brown thin-bedded mudstone intercalated with silty pelite and containing the brachiopods Orientospirifer wangi, Howellella cf. $H$. nucula, and Protathyris praecursor ---_--------

16. Light brown medium-bedded silty quartzite containing the brachiopod Acrospirifer sp. -----Total thickness of Xiayiling Member ----- 
Lower Devonian-Continued

Nagaoling (Nakaoling) Formation-Continued:

Mahuangling Member:

15. Gray thick-bedded mudstone having quartzose silt

Thickness

reenish-gray,thick-bedded micaceous quartzose siltstones having the brachiopods Corvinopugnax globosus, Aseptalium guangxiensis, Orientospirifer nakaolingensis, and $O$. wangi -----

13. Pale-brown medium-bedded mudstone having quartzose silt containing inarticulate brachiopods, and pelecypods Cypricardella? sp., Leiodysodonta levis, Leptodesma (Leptodesma) deprati, Nuculoidea minuta, Sanguinolites nagaolingensis, and Schizodus aff. S. cuneus---

12. Grayish-black mudstone, containing the brachiopods Corvinopugnax globosus, Orientospirifer nakaolingensis, and $O$. wangi, and the pelecypods Cypricardella? sp., Leptodesma (Leptodesma) venusta, and Sphenotus sp.-------

Total thickness of Mahuangling Member -

Nagaoling Member:

11. Grayish-black dolomitic mudstone containing the brachiopods Protathyris praecursor, Kwangsirhynchus liujingensis, Orientospirifer nakaolingensis, and $\mathrm{O}$. wangi --_---_---

10. Dark-gray medium-bedded shelly limestone interbedded with grayish-green silty pelite and containing the brachiopods Orientospirifer nakaolingensis, $O$. wangi, Protathyris praecursor, and Areostrophia sp., and the pelecypods Cypricardella? sp., Leiodysodonta levis, Leptodesma $(L$.$) venusta, L$. $(L$.$) deprati, L$. $(L$.$) guang-$ xiensis, Sanguinolites nagaolingensis, Schizodus aff. $S$. appressus, and $S$. aff. $S$. cuneus -----

9. Light-brown thick-bedded mudstone containing the brachiopods Kwangsirhynchus liujingensis and Corvinopugnax globosus, and the pelecypods Schizodus peregrins, Pterinea sp., and Sphenotus sp.

8. Grayish-green thick-bedded siltstone containing the brachiopod Kwangsirhynchus liujingensis

Total thickness of Nagaoling Member ----
3 in

$36 \mathrm{~m}$

$2 \mathrm{~m}$

$61 \mathrm{~m}$

$31 \mathrm{~m}$

$11 \mathrm{~m}$

$11 \mathrm{~m}$

$69 \mathrm{~m}$

Grab samples from various levels in the Nagaoling Formation have yielded the following fossils: corals Chalcidophyllum nakaolingensis and Eoglossophyllum minor; ostracode Guangxichia ovata; conodont Eognathodus sulcatus; fish Nakaolingaspis devonica; chitinozoans Sphaerochitina communisa, Ancyrochitina ancyrea, and A. spinosa; and spores Leiotriletes simplex, L. parvus, Punctatisporites punctatus, $P$. pallatus, Calamospora microrugosa, Retusotriletes simplex, $R$. rotundus, Acanthotriletes cuspidatus, and Stenozonotriletes angulatus (Gao, 1978; Hou, 1978; Kuang, 1982).

Lianhuashan Formation:

Thickness

Liukankou Member:

7. Grayish-purple-red argillaceous siltstone interbedded with grayish-green argillaceous sandstone and bearing the pelecypods Leiodysodonta elliptica and Cypricardella? sp.; ostracodes Beyrichia

Lianhaushan Formation-Continued

Liukankou Member-Continued

sp., Kloedenella sp., Bythocypris sp., and Leperditia sp.; and fishes Asiaspis expansa, Yunnanolepis sp., Asiacanthus suni, and $A$. kaoi

6. Grayish-purple-red silty pelite intercalated with grayish-green silty pelite and fine-grained sandstone and with the pelecypod Leiodysondonta guangxiensis, and the ostracode Kloedenella sp.

Total thickness of Liukankou Member --

$\frac{15 \mathrm{~m}}{121 \mathrm{~m}}$

Hengxian Member:

5. Gray to grayish-yellow thin- to medium-bedded silty dolomite containing the brachiopod Lingula sp.; pelecypods Cypricardella? sp., Sanguinolites? sp., Parallelodon sp., Dysodonta angulata, Leiodysodonta guangxiensis, L. elliptica, and Leptodesma (L.) venusta; ostracodes Beyrichia sp., Kloedenella sp., and Primitia sp.; and fishes Yunnanolepis sp., Lianhuashanolepis liukingensis, and Orientolepis neokwangsiensis

4. Grayish-purple-red and gray-yellow thin-bedded argillaceous siltstone and fine granular sand-

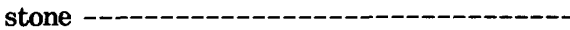

Total thickness of Hengxian Member ---

$\frac{118 \mathrm{~m}}{126 \mathrm{~m}}$

Lingli Member:

3. Grayish-yellow to grayish-red thin-bedded pelitic fine granular sandstone in the upper part, and grayish-white to grayish-yellow quartzose sandstone in the middle and lower parts ------

2. Grayish-purple-red thin-bedded argillaceous siltstone and pelitic fine granular sandstone --

1. Gray medium-bedded siltstone and fine- to medium-granular quartzose sandstone; the base of this unit is sandy conglomerate ------ $21 \mathrm{~m}$ Total thickness of Lingli Member ----- $89 \mathrm{~m}$

The Lingli Member uncomformably overlies Cambrian shales and sandstones containing Protospongia sp.

\section{SECTION 2}

Section 2 is near Dale and Zhongping Villages, northeast Xiangzhou County, Guangxi (figs. 7 and 10; pl. 67; $=$ Section 2 of Pojeta and Zhang, 1984). The structure of the Devonian rocks here is not complex, and they dip to the west at $20^{\circ}-30^{\circ}$. The basal Lianhuashan Formation is unconformable on Cambrian strata, and the total thickness of Devonian rocks is about 3,000 m (Yue and Bai, 1978; Hou and Xian, 1975; Zhang, 1977).

Upper Devonian

Thickness

Liujiang Formation:

50. Gray thin-bedded limestone intercalated with darkgray beds of flint in the lower part; gray-white bedded to massive limestones in the upper part. The fauna consists of the brachiopods Yunnanellina uniplicata, Y. triplicata, and Tenticospirifer cf. T. tenticulum and conodonts Palmatolepis perlobata, $P$. glabra, and $P$. delicatula, about 
Upper Devonian-Continued

Liujiang Formation-Continued:

49. Dark-gray medium-bedded limestone having the brachiopod Leiorhynchus kwangsiensis; tentaculites; and conodonts Polygnathus asymmetricus and Palmatolepis gigas --_--------

Incomplete thickness of Liujiang Formation

Middle Devonian

Donggangling (Tungkangling) Formation:

48. Gray to dark-gray medium-bedded limestone, having beds of black fiint, containing the brachiopods Stringocephalus sp. and Bornhardtina

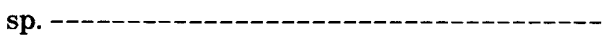

47. Grayish-black medium-bedded limestone, and one bed of green shale, containing the brachiopods Desquamatia kansuensis, Emanuella takwanensis, Schizophoria striatula gamma, and Chonetes

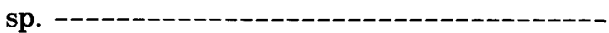

46. Grayish-black limestone intercalated with grayishgreen shale, having the brachiopods Desquamatia kansuensis, Emanuella sp., Schizophoria striatula gamma, and Bornhardtina sp. -----

45. Grayish-green shale intercalated with limestone and marl and having the brachiopods Emanuella takwanensis, E. transversa, Desquamatia kansuensis, Schizophoria striatula, Bornhardtina sp., Stringocephalus obesus, S. burtini, and Cyrtina sp.

44. Grayish-green thin-bedded marl, limestone, and shale and containing the brachiopods Stringocephalus sp., Desquamatia auriculata, Emanuella sp., and Cyrtina sp. ------------

43. Gray argillaceous limestone containing the brachiopods Stringocephalus obesus, S. cf. S. transversa, Bornhardtina speciosa, B. (Parabornhardtina) sp., and Desquamatia kansuensis ----------

42. Grayish-green shale, and three beds of lenticular limestone

41. Grayish-green shale interbedded with dark-gray limestone, and bearing the brachiopods Stringocephalus sp. and Bornhardtina sp.

40. Dark-gray, medium-bedded limestone containing the brachiopods Stringocephalus obesus, S. burtini, Bornhardtina sp., and B. (Parabornhardtina) sp.

39. Grayish-green calcareous shale containing stromatoporoids

38. Grayish-green shale interbedded with mud-cracked limestone

37. Grayish-green shale intercalated with marl and limestone, and having the brachiopods Bornhardtina sp. and Emanuella transvera -.--_-_--

Total thickness of Donggangling Formation

Grab samples from various levels in the Donggangling Formation, have yielded the following fossils: corals Pseudozaphrentis curvata, Microplasma sp., Hexagonaria sp., Disphyllum sp., Temnophyllum sp., and Stringophyllum sp.; pelecypods Ctenodonta? dubiïformisa, Mytilarca cf. M. oviformis, Nuculoidea $79 \mathrm{~m}$

$119 \mathrm{~m}$ $20 \mathrm{~m}$

$58 \mathrm{~m}$

$23 \mathrm{~m}$

$61 \mathrm{~m}$

$11 \mathrm{~m}$

$3 \mathrm{~m}$

$14 \mathrm{~m}$

$15 \mathrm{~m}$

$18 \mathrm{~m}$

$8 \mathrm{~m}$

$26 \mathrm{~m}$

$66 \mathrm{~m}$

$323 \mathrm{~m}$
Thickness

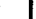

F Microplasma deuniana; brachiopods Athyrisina squamosa Rhipidothyris sulcatilis, Indospirifer padaukpingensis, Productella subaculeata, Schizophoria sp., and Squamularina parva; pelecypod Tanaodon guangxiensis; tentaculite Nowakia sulcata; and conodont Icriodus corniger.

sp., Palaeoneilo sp. B, and Fasciculiptera guangxiensis; tentaculite Nowakia otomeri; and conodonts Polygnathus varcus, $P$. linguiformis, $P$. ovatinodosus, Icriodus difficilis, Palmatolepis subrecta, and Ozarkodina longesta.

Yingtang Formation:

Thickness

Guche Member:

36. Grayish-green shale having a 3-m thick limestone in the middle; in the top is a 3-m thick limestone with mudcracks bearing the brachiopods Uncinulus parallelepipedus and Atrypa sp. --------

35. Grayish-green shale intercalated with yellow mudcracked limestone and having the corals Calceola sandalina acuminata, C. sandalina intermediata, C. sandalina nanningensis, Cystiphylloides sp., Microplasma devoniana, Syringopora eifeliensis beiliuensis, Utaratuia sinensis, and Sociophyllum sp., and brachiopods Uncinulus parallelepipedus, $U$. goldfussi, $U$. pentagonus, $U$. longdonshuiensis, Desquamatia kansuensis, Rhynchospirifer sp., and Productella productoides sinensis

34. Grayish-green shale intercalated with grayish black limestone and having the corals Cystiphylloides sp. and Utaratuia sinensis, and brachiopods Acrospirifer houershanensis, Athyrisina squamosaeformis, Uncinulus parallelepipedus, Yingtangella minor, Desquamatia kansuensis, Productella productoides sinensis, and Subrensselandia? sp.

33. Gray thin-bedded to medium-bedded limestone containing the corals Diplochone sp. and Atelophyllum sp., and brachiopods Uncinulus longdongshuiensis, Yingtangella minor, Athyrisina squamosaeformis, Indospirifer maoerchuanensis, and Xenospirifer fongi --_-----_--_-------

Total thickness of Guche Member

\section{$\frac{48 \mathrm{~m}}{200 \mathrm{~m}}$}

Gupa Member:

32. Grayish-green shale having two beds of lenticular limestone and having the brachiopods Eospirifer lachrymosa, Athyrisina yohi, Xenospirifer fongi, Indospirifer extensa, Uncinulus signatus, Yingtangella sulcatilis, Productella productoides sinensis, and Chonetes sp. --_-_-_-_-_--

31. Grayish-yellow argillaceous limestone intercalated with grayish-green shale and bearing the corals Cylindrophyllum agglomeratum and Phacellophyllum daleensis, and brachiopods Indospirifer extensus, Athyrisina yohi, Xenospirifer fongi, and Eospiriferina lachrymosa -------------

Total thickness of Gupa Member

Grab samples from various levels in the Yingtang ormation have yielded the following fossils: coral 
Lower Devonian

Sipai Formation:

Dingshanling Member:

30. Dark-gray thick-bedded limestone containing flint nodules and the brachiopod Reticulariopsis indifferens

29. Gray thick-bedded limestone intercalated with argillaceous limestone and bearing the brachiopods Reticulariopsis indifferens, Lazutkinia lata, and Nadiastrophia nitida, and ostracodes

28. Gray medium-bedded limestone and some yellow mudstone and containing the brachiopods Nadiastrophia nitida and Athyrisina squamosa, and rugose corals --_-_-_-_-_-

27. Purplish-gray thin-bedded argillaceous limestone intercalated with calcareous mudstone and bioclastic limestone and having the brachiopods Euryspirifer paradoxus shujiapingensis, Athyrisina yohi, and A. squamosa. In the bottom part is one bed of limestone rich in tabulates -

Total thickness of the Dingshanling Member

Liuhui Member:

26. Gray limestone containing some ostracodes -

25. Thin-bedded argillaceous limestone intercalated with calcareous mudstone; along strike to the northeast, the unit is entirely argillaceous limestone. It is rich in the brachiopods Otospirifer shipaiensis, $O$. daleensis, Athyrisina yohi, $A$. squamosa, and Nadiastrophia nitida ------

24. Gray thick-bedded shelly limestone intercalated with a few calcareous mudstones

23. Gray medium-bedded limestone containing some siliceous nodules and intercalated with calcareous mudstone and marl and bearing the brachiopods Athyrisina yohi and Otospirifer shipaiensis --_--_-_-_-_-_-_-_-----

22. Calcareous mudstone interbedded with marl and with one $0.3-\mathrm{m}$-thick bed of limestone. Fossils are the brachiopods Otospirifer shipaiensis and Athyrisina yohi -

21. Gray nodular argillaceous limestone interbedded with dark-gray bioclastic limestone; in the upper $10 \mathrm{~m}$ are abundant rugose corals, and in the middle $10 \mathrm{~m}$ are the brachiopods Nadiastrophia nitida, Athyrisina squamosa, Atrypa sp., and Otospirifer shipaiensis --.-----

20. Gray calcareous mudstone intercalated with lenticular limestone bearing the pelecypod Nuculoidea sp.

19. Dark-gray medium-bedded dolomitic, argillace-

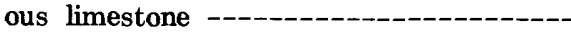

18. Gray nodular argillaceous limestone interbedded with dark-gray dolomitic limestone having the coral Favosites sp.

17. Gray shelly limestone containing abundant tabulates. Identified fossils are the corals Trapezophyllum cystosum and Embolophyllum acanthophylloides, and the brachiopod Xenospirifer heterosinus ---.-------

Total thickness of the Liuhui Member --
Thickness Lower Devonian-Continued

Sipai Formation-Continued:

Shipeng Member:

16. Dark-gray medium-bedded dolomitic limestone intercalated with limestone and some nodular argillaceous limestone, and bearing the ostracodes Paramoelleritia sp. and Leperditia sp. -

15. Gray argillaceous bioclastic limestone intercalated with marl and mudstone having the brachiopods Athyrisina palicata and Subcuspidella trigonata ------------------

14. Gray argillaceous limestone containing tabu-

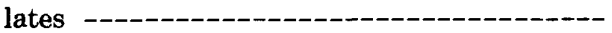

13. Medium-bedded gray to dark-gray limestone intercalated with shelly limestone that is almost entirely composed of the ostracodes Paramoelleritia sp. and Leperditia sp. ------

12. Medium-bedded mudstone and nodular marl bearing the ostracodes Paramoelleritia guangxiensis, $P$. xiangzhouensis, Leperditia xiangzhouensis, L. pulchra, and Hypotetragona sp.

$8 \mathrm{~m} \mathrm{11.} \mathrm{Light-gray} \mathrm{dolomitic} \mathrm{limestone} \mathrm{having} \mathrm{one} \mathrm{bed}$ of shelly limestone bearing ostracodes and

Thickness

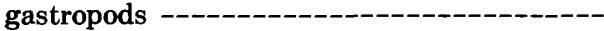

Total thickness of the Shipeng Member

$66 \mathrm{~m}$

$14 \mathrm{~m}$

Lutang Member:

10. Yellowish-brown to gray shale and dolomite bearing the ostracode Paramoelleritia xiangzhouensis, and the brachiopods Subcuspidella trigonata and Athyrisina plicata ----------

$200 \mathrm{~m}$

\section{m}

Fossils from grab samples in the Sipai Formation at this section are corals Pseudomicroplasma laticystata, $P$. corniculum, Tryplasma guangxiensis, T. concavotabulata, Cystohexagonaria planotabulata, C. daleensis, Leptoinophyllum subvermiculare, L. simplex, Psydracophyllum irregulare, Zelolasma elegantula, Favosites goldfussi eifelensis, $F$. antipertusus, Syringopora sp., Pachyfavosites ertangensis, Embolophyllum acanthophylloides, Trapezophyllum cystosum, and Hillaeopora spica; brachiopods Indospirifer extensa, I. quadriplicatus, Athyris multiplicata, Xenospirifer heterosinus, Lazutkinia lata, Dalerhynchus dingshanlingensis, and Alatiformia alatiformis; trilobite Shipaia hexaspina; conodonts Polygnathus perbonus, $P$. inversus serotinus, and Ozarkodina denckmanni; and tentaculites Nowakia richteri and $N$. barrandei.

Ertang Formation:

Thickness

$31 \mathrm{~m}$ 9. Dark-greenish-gray mudstone intercalated with bioclastic limestones and, in the upper part, having dolomitic limestone. Known fossils are the pelecypods Pterinopecten $(N$.) spp. and Paracyclas sp. -------------

$45 \mathrm{~m}$

$17 \mathrm{~m}$

8. Dark-greenish-gray mudstone, which is eich in the pelecypods Pterinopecten (N.) guangxiensis, $P$. (N.) guipingensis, Lyriopecten sp., Ptychopteria (Actinopteria) sp., Sinodora(?) zhongguoensis, $S$. sp., Nuculites sp. B, and Paracyclas rugosa --
7. Gray thin-bedded calcareous mudstone interbedded argillaceous limestone and bearing the brachiopod Howellella yukianensis ------_-_-_----
$66 \mathrm{~m}$

$2 \mathrm{~m}$

$0 \mathrm{~m}$

$36 \mathrm{~m}$

$3 \mathrm{~m}$

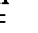


Lower Devonian-Continued

Ertang Formation-Continued

6. Gray, medium-bedded fossiliferous mudstone intercalated with gray thin-bedded calcareous mudstone and marl and having the brachiopods Howellella yukianensis and Acrospirifer sp. -

5. Gray calcareous mudstone interbedded with argillaceous limestone and having the pelecypod Ptychopteria (Actinopteria) sp. and brachiopods and corals

4. Dark-gray medium-bedded dolomite -------Total thickness of the Ertang Formation -

Thickness $31 \mathrm{~m}$ $37 \mathrm{~m}$ $174 \mathrm{~m}$

Fossils from grab samples from this formation at this section include the brachiopods Nadiastrophia yukiangensis, Howellella papaoensis and Lyrielasma sp.; pelecypods Leptodesma (L.) venuta, Limoptera sp., Modiomorpha paradoxa, Mytilarca cf. $M$. chemungensis, Nuculites sp. B, and Pterinopecten (N.) guangxiensis; ammonoid Erbenoceras ellipticus (collected by geologists of the Yichang Institute of Geology, 1981); and conodonts Polygnathus perbonus and $P$. gronbergi.

Yujiang Formation:

Thickness

3. Gray to greenish-gray siltstone and mudstone intercalated with calcareous mudstone and having sandstone at the base. Fossils are the coral Calceola sandalina; brachiopods Rostrospirifer tonkinensis, Nadiastrophia yukiangensis, Dicoelostrophia annamitica, D. punctata, Athyris grandis, Cymostrophia quadrata, Acrospirifer medius, A. subregularis, and Elymospirifer kwangsiensis; ostracode Primitia yungchunensis; and conodont Polygnathus dehiscens ---

Nagaoling Formation:

2. Purple-red fine-grained sandstone and greenishgray quartzose sandstone. Contact with the underlying Lianhuashan Formation is gradational

Lianhuashan Formation:

1. Purple-red sandstone interbedded with siltstone; conglomerate present at the base of the formation

$\underline{1,200 \mathrm{~m}}$

The Lianhuashan Formation unconformably overlies Cambrian sandstone and shale.

\section{SECTION 3}

Section 3 of Devonian rocks is at Heping Village, Yongfu County, Guangxi (= Section 3, Pojeta and Zhang, 1984). This section was described in an unpublished and unattributed report by the Regional Geological Survey Team of Guangxi (figs. 7 and 10; pl. 67) and is reproduced here in English. At Heping village, the Devonian rocks are conformably overlain by Lower Carboniferous rocks. Upper Devonian Rongxian Formation:

Thickness

Upper Member:

42. The upper part is dark-gray limestone, and the lower part is pale-gray limestone ---.-- $300 \mathrm{~m}$
Upper Devonian-Continued

Rongxian Formation-Continued:

Middle Member:

41. Grayish-black limestone -

40. Gray, dolomitic bioclastic limestone containing stromatoporoids and the bryozoan Actinostroma sp.

39. Gray massive calcareous dolomite and limestone 38 . White to pale-gray massive oolitic limestone --

37 . White-gray to gray massive limestones containing dolomitic nodules and the conodonts Pugnoides? sp., Palmatolepis sp., and P. glabra -

36. Gray to dark-gray thick-bedded limestone intercalated by thin-bedded spotted limestone having muddy clasts bearing the conodonts Palmatolepis minuta, P. subperilobata, P. glabra, and $P$. tenuipuncta

35. Dark-gray medium-bedded crinoidal limestone containing the conodonts Palmatolepis subperilobata, $P$. sp. and Icriodus sp. --------

Total thickness of Middle Member

Lower Member:

34. Grayish-black massive limestone having some wavy argillaceous beds. Fossils are the brachiopods Atrypa douvillii and Emanuella takwanensis, and conodonts Palmatolepis quadratinodosalobata and Polygnathus sp. ------

33. Light-gray to gray medium- to thin-bedded spotted limestone with muddy clasts, and limestone interbedded with thin shale. Fossils are the conodonts Palmatolepis glabra and P. sp. ---

32. Gray thick-bedded limestone containing flint nodules, the corals Barrandeophyllum sp., Temnophyllum sp., and Tabulophyllum sp., and the brachiopod Spinatrypa aspera kwangsiensis -

31. Black siliceous rocks intercalated with siliceous limestone and limestone. Fossils are the tentaculite Homoctenus sp., and conodonts $\mathrm{An}$ cyrodella sp., Palmatolepis punctata, and Polygnathus sp. --_-_-_--_-_-_------

30. Gray to dark-gray limestone intercalated with siliceous rocks bearing the brachiopod Hypothyridina sinensis; ammonoids Probeloceras sp. and Tornoceras sp.; and the tentaculite Costolatostyliolina pauciostata ------------

29. Grayish-black thin-bedded limestone intercalated with paper-thin beds of dolomitic limestone bearing the conodont Ozarkodina sp. -

Total thickness of Lower Member

$31 \mathrm{~m}$

$24 \mathrm{~m}$

$45 \mathrm{~m}$

$45 \mathrm{~m}$

$46 \mathrm{~m}$

$47 \mathrm{~m}$

$238 \mathrm{~m}$

Middle Devonian

Donggangling Formation:

Upper Member:

28. Gray to dark-gray, thin-bedded bioclastic limestone intercalated with a 4-m-thick dolomite. The known fauna is composed of the brachiopod Stringocephalus sp., and coral Temnophyllum sp. -----------------------------

27. Dark-gray, medium-bedded dolomite intercalated with thin-bedded dark-gray limestone having fragments of gastropods, brachiopods, and crinoidal debris

Total thickness of Upper Member

$27 \mathrm{~m}$

$101 \mathrm{~m}$ 
Middle Devonian-Continued

Donggangling Formation-Continued:

Middle Member:

26. Gray, thick-bedded to massive dolomite intercalated with dolomitic limestone

Thickness

Lower Member:

25. Gray to grayish-black limestone and bioclastic limestone intercalated with dolomite; fossils are the corals Tabulophyllum sp., Hexagonaria sp., and Temnophyllum sp.; brachiopod Spinatrypa aspera kwangsiensis; and stromatoporoid Berronostroma sp. --------

24. Nodular limestone and marl intercalated with a 5-m thick siltstone with gravels and having the corals Striatopora sp. and Temnophyllum sp.; brachiopods Desquamatia kansuensis, Stringocephalus sp., Emanuella takwanensis, and Schizophoria striatula; and pelecypods Nyassa dorsata and Paracyclas rugosa---

23. Gray shale intercalated with argillaceous limestone and marl; fossils are the coral Stereolasma sp; brachiopods Desquamatia kansuensis, and Emanuella takwanensis; and pelecypods cf. Byssopteria sp., Goniophora (G.) sp. A, Modiomorpha paradoxa, Spathella sp., S. hepingensis, Actinodesma (E.) guangxiensis, $E d m o n d i a$ aff. $E$. subovata, $E$. aff. $E$. philipsi, Fasciculiptera guangxiensis, Limoptera sp., Ptychopteria (A.) producta, and Sanguinolites? sp.

Total thickness of Lower Member ------

Yingtang Formation:

Upper Member:

22. Gray shale intercalated with siderite and sandstone; the percentage of sandstone is greatest in the lower part, conglomeratic near base. Known fossil is the pelecypod Nuculoidea sp.

21. Upper part is purple-red shale and silty shale with sandy beds; lower part is dark-gray shale; fossils are the pelecypods Mecynodon sp., modiomorphids, and Nuculoidea cf. $N$. hunanensis; brachiopod Lingula sp.; and tentaculites Uniconas sp. and Homoctenus sp. ------

20. White thick-bedded to massive sandstone intercalated with medium-bedded sandstone ---

19. Pale-grayish-white medium-grained sandstone and siltstone intercalated with argillaceous siltstone; only known fossils are the pelecypods Sinodora sp. and Ptychopteria (Actinopteria) sp.

Total thickness of Upper Member

Middle Member:

18. Grayish-green shales intercalated with thin- to medium-bedded sandstone --.---.--

17. Purple-red and green shale intercalated with purple sandstone having arthrodire fish and pelecypods

Total thickness Middle Member -.---- $135 \mathrm{~m}$

Lower Member:

16. Pale-gray to grayish-green argillaceous sandstone, siltstone, and sandy shale having arthrodire fish and bryozoans
Middle Devonian-Continued

Yingtang Formation-Continued:

Lower Member-Continued

15. Gray to grayish-green shale intercalated with beds of siderite

14. Light-gray to grayish-yellow thin-bedded sandstone containing arthrodire fish and bryozoans

Total thickness Lower Member -...--_-

Lower Devonian

Sipai Formation:

$10 \mathrm{~m}$

$30 \mathrm{~m}$

$24 \mathrm{~m}$

$64 \mathrm{~m}$

28

$30 \mathrm{~m}$

$67 \mathrm{~m}$

$39 \mathrm{~m}$

$98 \mathrm{~m}$

7. Graye rostroconch Conocardium sp.

. Gray and pale-purple-red quartzose sandstone intercalated with siltstone and argillaceous

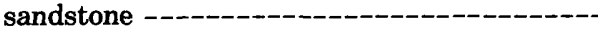

Incomplete thickness of Yujiang Formation

Nagaoling Formation:

6. Purple-red fine-grained sandstone, siltstone intercalated with argillaceous siltstone, and a few shales

Thickness

$71 \mathrm{~m}$

$21 \mathrm{~m}$

$143 \mathrm{~m}$ Similoconcha? sp. A, Nuculoidea minuta, Nuculites sp. B, Palaeoneilo sp. A, Paracyclas rugosa, Orthonota guangdongensis, Sinodora Sanguinolites? sp., Crassatellopsis? sp., Parallelodon guangxiensis, Sinodora Thychopteria (A.) producta, and morpha sp., and the brachiopod Glyptospirifer quadriplicatus --with shale having the pelecypods Palaeoneilo sp. B, Paracyclas sp.,and Parallelodon guangxienis, and ostracodes

$\frac{76 \mathrm{~m}}{166 \mathrm{~m}}$

$90 \mathrm{~m}$

Ertang Formation:

11. Grayish-green silty shale and siltstone containing infundibulum, and pe Sinodora sp., Orthonota cf. O. guangdongensis, Palaeoneilo sp., Nuculoidea yongfuensis, and Paracyclas rugosa

laceous siltstone intercalated with siltstone and Nuculana? acutirostra, Modiomorpha paradoxa, M. harrisae, Spathella sp., S. hepingensis, Oriophora $(G$.) spatulata Carinonychia? sp. A Cimitaria sinensis, Carinonychia triangularis, and Mytilarca cf. M. chemungensis --------

Yujiang Formation:

9. Light-gray to grayish-green quartzose sandstone intercalated with siltstone -------
$153 \mathrm{~m}$

$231 \mathrm{~m}$

$110 \mathrm{~m}$

$78 \mathrm{~m}$

$\frac{41 \mathrm{~m}}{166 \mathrm{~m}}$

$15 \mathrm{~m}$

$100 \mathrm{~m}$ 
Lower Devonian-Continued

Nagaoling Formation-Continued:

5. Purple-red silty shale intercalated with shale and dolomite --.--

Total thickness of Nagaoling Formation --

Lianhuashan Formation:

Upper Member:

4. Purple-red medium- to thick-bedded siltstone intercalated with sandstone and dolomitic siltstone

$150 \mathrm{~m}$

Middle Member:

3. The upper part is gray-white medium-bedded quartzose sandstone and some dolomitic conglomerate; lower part is gray-white thick bedded quartzose sandstone -..-..-----

2. The upper part is purple-red siltstone intercalated with fine-grained cross-bedded sandstone; lower part is argillaceous siltstone and

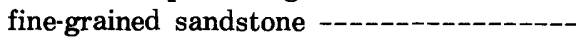

Total thickness of Middle Member ------

Lower Member:

1. The upper part is covered; lower part is purplered medium-bedded siltstone with argillaceous interbeds and some shale ---.-------

Total thickness of Lianhuashan Formation

$\frac{>140 \mathrm{~m}}{>590 \mathrm{~m}}$

The Lianhuashan Formation is in fault contact with Cambrian shales and sandstones.

\section{SECTION 4}

Section 4 of the Lower Devonian Ertang Formation is at Liufengshan Hill, Wuxuan County (Yu and Yin, 1978; figs. 6, 7, and 10; pl. 67 herein) (= Section 1, Pojeta and Zhang, 1984). Covering strata are placed in the Lower Devonian Guangchao Dolomite, a gray medium-thick bedded dolomite more than $200 \mathrm{~m}$ thick, which is in conformable contact with the Ertang Formation.

Lower Devonian

Ertang Formation:

Upper Member:

37. Gray thin-bedded limestone containing the coral Sinocladopora sp., and brachiopods Undispirifer ovatus, U. sp., Acrospirifer sp., and Athyris sp. ---

36. Dark-gray to black thin-bedded mudstone and calcareous mudstone containing the pelecypods Leptodesma (L.)? sp. A, Nuculites sp. B, Sinodora concava, and Paracyclas rugosa -

35. Dark-gray to black shale intercalated with a few marly beds and argillaceous limestone containing the brachiopods Glyptospirifer sp. and Howellella cf. $H$. yukiangensis, and pelecypods Leptodesma (L.) guangxiensis and Wuxuanites lanceolatus

34. Dark-gray shale intercalated with thin-bedded limestone having the brachiopods Howellella sp., Undispirifer ovatus, and Parachonetes sp.; tentaculite Styliolina sp.; and pelecypods Leptodesma (L.) guangxiensis, L. (L.)? sp. A, Wuxuanites lanceolatus, and W. washingtonensis
Thickness

Thichness

$20 \mathrm{~m}$

$7 \mathrm{~m}$

$20 \mathrm{~m}$

$0 \mathrm{~m}$

$19 \mathrm{~m}$
Lower Devonian-Continued

Ertang Formation-Continued:

Upper Member-Continued

33. Black shale intercalated with thin-bedded argillaceous limestone containing the brachiopods Undispirifer ovatus and Acrospirifer subregularis; tentaculite Styliolina sp.; and pelecypods Modiomorpha paradoxa, Sanguinolites? sp., Leptodesma (L.) guangxiensis, and $L$. (L.)? sp. A

32. Dark-gray to black shale intercalated with a few marly beds having the conodonts Polygnathus perbonus, $P$. cf. $P$. serotinus, $P$. gracilis, Plectospathodus alternatus, Drepanodina subcircularis, D. robustus, Hindeodella sp., Ligonadina salopia, Neoprionioidus conjuctus, $N$. bicurvatus, and Ozarkodina ziegleri devonica, and pelecypods Leptodesma (L.) guangxiensis, $L$. (L.)? sp. A, and Wuxuanites washingtonen-

31. Dark-gray to black shale intercalated with a few marly beds containing the pelecypods Modiomorpha oblonga, Pterinopecten (P.) wuxuanensis, $P$. (N.) guangxiensis, and Wuxuanites lanceolatus -_-_-_-_-_-_-_-_-------

30. Dark-gray argillaceous limestone containing the pelecypods Nuculites sp. B, Leptodesma $(L$. guangxiensis, $L$. (L.) venusta, Limoptera sp., and Lyriopecten ertangensis

29. Dark-gray medium-bedded limestone containing the brachiopods Undispirifer ovatus, $U$. sp., and Howellella? sp.

28. Gray thin-bedded marl --_-_-_-_-_-_--

27. Gray to dark-gray shale intercalated with thinbedded argillaceous limestone and limes-

26. Gray to pale-greenish-gray thin-bedded limestone containing the corals Thecostegites $\mathrm{sp}$. and Pseudomicroplasma sp.; brachiopods Acrospirifer papoensis, A. sp., Glyptospirifer sp., and Undispirifer sp.; and tentaculite Nowakia sp.

25. Dark-gray to black shale intercalated with thinbedded nodular argillaceous limestone bearing the corals Cladopora sp. and Favosites sp.; brachiopod Undispirifer sp.; and tentaculite Nowakia sp.

24. Pale-gray to dark-gray thin-bedded limestone containing the brachiopods Acrospirifer ordinaris, $A$. sp., and Undispirifer sp.

23. Gray medium-bedded limestone intercalated with thin-bedded nodular limestone having the corals Favosites sp., Squameofavosites sp., Cladopora sp., Zonophyllum simplex, and Z. crassimarginatum; brachiopods Acrospirifer subregularis, A. sp., Howellella sp., Undispirifer sp., and Nadiastrophia sp.; tentaculite Tentaculites sp.; and cephalopods Steretoceras sp. and Hipparionoceras sp.

22. Gray thin-bedded nodular marl intercalated with limestone bearing the corals Favosites sp. and Squameofavosites sp.; brachiopods Glyptospirifer sp. and Eospirifer sp.; and cephalopod Steretoceras sp. -------------------

21. Gray thin-bedded marl

$13 \mathrm{~m}$ $6 \mathrm{~m}$ 
Lower Devonian-Continued

Ertang Formation-Continued:

Upper Member-Continued

20. Dolomitic limestone with chert nodules having the corals Favosites sp., Pachyfavosites sp., Alveolites sp., Thamnopora sp., Cladopora sp., Syringopora sp., Lyrielasma guangxiensis and Xiangzhouphyllum minor; stromatoporoids Anostylostroma tuntouense, Stromatopora liujingensis, Parallelostroma kwangsiense, and Atopostroma tuntouense; and brachiopods Acrospirifer sp., Howellella cf. $H$. nucula, and $H$. sp.

Total thickness of Upper Member -----

Lower Member:

19. Pale-gray to black shale with the brachiopod Glyptospirifer sp; tentaculite Nowakia sp.; and pelecypods Leptodesma (L.) guangxiensis, Lyriopecten ertangensis, and Mytilarca cf. $M$. chemungensis --

18. Dark-gray to black thin-bedded limestone ---

17. Thin-bedded limestone intercalated with shale having the pelecypods Mytilarca cf. $M$. chemungensis, Nuculites sp. B, Ptychopteria $(P$.$) zhongguoensis, and Wuxuanites lanceo-$ latus

16. Thin-bedded limestone and shale containing the brachiopod Glyptospirifer sp.

15. Gray-white dolomitic limestone --

14. Gray shale --

13. Covered --_-

12. Brownish-gray to black shale -..--_-_-

11. Greenish-gray mudstone intercalated with a few thin-bedded marls having the corals Pachyfavosites sp. and Cladopora sp.; brachiopod Glyptospirifer sp; and pelecypods Nuculites sp. B, Paracyclas rugosa, Leptodesma (L.) guangxiensis, $L$. (L.) venusta, $L$. (L.)? sp. A, Mytilarca cf. M. chemungensis, Pterinopecten (P.) wuxuanensis, and Wuxuanites lanceolatus

10. Gray thin-bedded limestone with the coral Syringopora sp.; brachiopods Acrospirifer subregularis, $A$. ordinaris, $A$. sp., and Glyptospirifer sp.; and pelecypod Paracyclas rugosa

9. Gray thin-bedded mudstone and shale containing pelecypods Leptodesma (L.) venusta, Limoptera sp., and Pterinopecten (N.) guangxiensis --_-

8. Dark-gray to black thin-bedded limestone, which in the lower part is intercalated with dark thinbedded mudstone bearing the brachiopod Acrospirifer? ordinaris, and pelecypods ---

7. Covered --_-

6. Gray to black thin-bedded limestone intercalated with thin-bedded mudstone having the coral Pachyfavosites sp.; brachiopod Glyptospirifer sp.; and pelecypods Goniophora (G.) sp. A, Leptodesma (L.) guangxiensis, and Wuxuanites lanceolatus

5. Greenish-gray to dark-gray shale ---_-----

4. Dark-gray thin-bedded limestone, which in the lower part is intercalated with dark-gray shale

Thickness

Lower Devonian-Continued

Ertang Formation-Continued:

Lower Member-Continued

having the corals Pachyfavosites sp., Squameofavosites sp., Alveolites sp., Cladopora sp., Syringopora sp., and Syringoporella sp.; brachiopods Athyrisina cf. A. tellitula, A.? squamosa, and $A$. sp.; and pelecypod Modiomorpha harrisae ------------

Total thickness of Lower Member ------- $237 \mathrm{~m}$

Shanglun Dolomite:

$26 \mathrm{~m}$

3. Pale-gray thick-bedded dolomite having a few ribbon cherts ----------------------

2. Pale-gray dolomite, which in the middle and lower parts is intercalated with a few ribbon cherts

Thickness

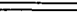

. Gray massive dolomite containing the corals Favosites sp. and Heterophrentis undulata, and brachiopods

Total thickness of Shanglun Dolomite ----

$10 \mathrm{~m}$

$70 \mathrm{~m}$

$19 \mathrm{~m}$

$5 \mathrm{~m}$

The Shanglun Dolomite conformably overlies the Lower Devonian Yujiang Formation, which is limestone, but for which there is as yet no detailed described section.

$14 \mathrm{~m}$

$23 \mathrm{~m}$

$10 \mathrm{~m}$

$10 \mathrm{~m}$

$21 \mathrm{~m}$

$27 \mathrm{~m}$

$11 \mathrm{~m}$

$4 \mathrm{~m}$

$18 \mathrm{~m}$

$28 \mathrm{~m}$

$6 \mathrm{~m}$

$4 \mathrm{~m}$

\section{SECTION 5}

Section 5 consists of Lower-Middle Devonian rocks from Luobang Village, Luoxiu Community, Xiangzhou County (figs. 7; 10; pl. $67=$ Section 4, Pojeta and Zhang 1984.)

Middle Devonian

Donggangling Formation (lower part only):

27. Dark-gray medium-bedded limestone intercalated with thin-bedded marl

26. Greenish-gray shale and mudstone intercalated with marl

25. Greenish-gray to yellowish-gray shale and mudstone

24. Greenish-gray thin-bedded to medium-bedded argillaceous limestone intercalated with shale, containing the brachiopods Emanuella sp. and Desquamata kansuensis ---------------

Incomplete thickness of Donggangling Formation

Thickness

$17.3 \mathrm{~m}$

$9.0 \mathrm{~m}$

$44.2 \mathrm{~m}$

$37.5 \mathrm{~m}$

$108.0 \mathrm{~m}$

Yingtang Formation:

Upper Member:

23. Medium-gray medium-bedded limestone ----

22. Yellowish-gray shale and mudstone; the lower beds are shale intercalated with lenticular limestone bearing the brachiopod Indospirifer maoerchuanensis, and pelecypods Limoptera orbicularis, Goniophora (G.) spatulata, Nodonychia gordia, and Ptychopteria (A.) producta

21. Greenish-gray shale intercalated with calcareous shale, having the brachiopod Indospirifer maoerchuanensis, and pelecypods Nuculoidea hunanensis, Cardiomorpha? sp., and Ptychopteria $(A$.) producta --_-_-_-_-_---
$8.7 \mathrm{~m}$

$35.5 \mathrm{~m}$

$23.3 \mathrm{~m}$ 
Middle Devonian-Continued

Yingtang Formation-Continued:

Upper Member-Continued

20. Greenish-gray shale intercalated with thinbedded mudstone and fossiliferous marl having cephalopods, gastropods, and the pelecypod Ptychopteria (A.) producta --------------

19. Yellowish-green shale and mudstone intercalated with marl and limestone having the pelecypods Goniophora (C.) marija, Limoptera sp., Pterinopecten (N.) guangxiensis, and Ptychopteria (A.) producta ---------

18. Shale intercalated with marl and mudstone containing the coral Pseudomicroplasma sp.; brachiopod Uncinulus longdongshuiensis; and pelecypods Tanaodon louderbacki, Sinodora semiglabra, and Ptychopteria (A.) producta

17. Greenish-gray shale intercalated with mudstone and having trilobites

16. Greenish-gray mudstone intercalated with marl and limestone, bearing the brachiopods Yingtangella sulcatilis and Productella sp.; pelecypods Nuculopsis? sp. A, Similoconcha? sp. A, Pseudonuculana zhaoi, Nuculana? planumbona, Sedgwickia? yingtangensis, Sphenotus yingtangensis, Paracyclas rugosa, Mytilarca cf. $M$. chemungensis, Oxytomoidea elegans, and Ptychopteria (A.) producta; and trilobites

Total thickness of Upper Member of Yingtang Formation

\section{$26.5 \mathrm{~m}$ \\ $280.5 \mathrm{~m}$}

Lower Member:

15. Gray argillaceous limestone intercalated with limestone. The lower beds are argillaceous limestone intercalated with limestone that contains chert nodules; fossils include the coral Syringopora eifeliensis, and brachiopod Indospirifer cf. I. maoerchuanensis --_------_-------

14. Dark-gray limestone containing chert nodules and having the coral Pseudomicroplasma sp.

13. Medium-gray marl interbedded with argillaceous limestone and limestone --------

12. Greenish-gray shale intercalated with mudstone; the basal part is argillaceous limestone, having the brachiopods Eospiriferina lachrymosa, Xenospirifer fongi, Qiansispirifer speciosus, and Yingtangella sulcatilis

Total thickness of Lower Member of Yingtang Formation

$35.1 \mathrm{~m}$

$20.3 \mathrm{~m}$

$54.7 \mathrm{~m}$

$76.4 \mathrm{~m}$

$\overline{\underline{280.5 m}}$

$19.7 \mathrm{~m}$

$24.3 \mathrm{~m}$

$9.5 \mathrm{~m}$

$89.2 \mathrm{~m}$

$142.7 \mathrm{~m}$

The following fossils have been identified from grab samples of the Yingtang Formation: corals Syringopora eifeliensis, S. sp., Pseudomicroplasma sp., Thamnopora sp., and Breviseptophyllum sp.; brachiopods Indospirifer extensus, I. maoerchuanensis, $I$. sp., Cyrtina heterodita intermedia, Athyrisina sp., Xenospirifer fongi, Chonetes sp., Eospirifer lachrymosa, Acrospirifer sp., Qiansispirifer speciosus, Undispirifer? sp., Yingtangella sulcatilis, Productellana sp., Schizophoria sp., Uncinulus longdongshuiensis, $U$. sp., and Ambothyris transversa; and pelecypods.
Lower Devonian

Sipai Formation:

Dingshanling Member:

11. Gray medium-bedded limestone ----------

10. Medium-gray argillaceous limestone intercalated with marl and bioclastic limestone, containing the coral Hexagonaria sp., and the brachiopod Undispirifer sp.

Thickness

$12.0 \mathrm{~m}$

Dark-gray argillaceous limestone intercalated with marl and bioclastic limestone having the corals Cladopora sp. and Favosites sp. ---

Total thickness of Dingshanling Member

Luhui Member:

8. Medium-gray thin- to medium-bedded limestone interbedded with argillaceous limestone having the brachiopods Euryspirifer paradoxus shujiapingensis and Otospirifer daleensis, and the ostracode Leperditia xiangzhouensis --

7. Greenish-gray shale and mudstone, having the brachiopod Chonetes sp. ---

Total thickness of Luhui Member

$96.6 \mathrm{~m}$

$9.8 \mathrm{~m}$

$106.4 \mathrm{~m}$

Shipeng Member:

6. Medium-gray marl interbedded with argillaceous limestone and limestone bearing the coral Favosites sp.

$41.1 \mathrm{~m}$

5. Dark-gray medium-bedded limestone containing the coral Favosites sp. --_--_-

4. Dark-gray argillaceous limestone ---------

3. Dark-gray limestone intercalated with argillaceous limestone in the upper part; in the mid. dle and lower parts limestone intercalated with shale having the brachiopod Acrospirifer sp. and the pelecypod Paracyclas sp. -----

2. Medium-gray argillaceous limestone interbedded with limestone and shale, having the ostracodes Paramoelleritia sp. and Leperditia sp.

Total thickness of the Shipeng Member

$74.0 \mathrm{~m}$ $87.0 \mathrm{~m}$

$110.8 \mathrm{~m}$

$10.8 \mathrm{~m}$

$323.7 \mathrm{~m}$

Lutang Member:

1. Yellowish-green shale intercalated with gray limestone; the top part is dolomite, having the ostracode Paramoelleritia sp. ---_-_---

Incomplete thickness of Lutang Member

$\frac{>8.0 \mathrm{~m}}{8.0 \mathrm{~m}}$

The Lutang Member is in fault contact with the $\mathrm{Yu}$ jiang Formation. The following fossils have been identified from grab samples of the Sipai Formation: corals Favosites sp., Thamnopora sp., Spongonaria simplex, Acanthophyllum? sp., Psydracophyllum sp., Leptoinophyllum sp., and Chaetetes sp.; brachiopods Reticulariopsis sp., Ilmenia sp., Athyrisina sp., Acrospirifer? sp., Undispirifer sp., Otospirifer daleensis; ostracodes Paramoelleritia sp., Leperditia xiangzhouensis, $L$. sp.; and pelecypods.

\section{LOCALITIES 6-12}

In addition to the collections made in sequence from Sections 1-5, a few specimens are described from grab samples made at Localities 6-12. These localities are listed below and are shown on figure 7 . 
LOCALITY 6.-Miaohuan Village, Xiangzhou County, samples from the Lower Devonian Ertang Formation. LOCALITY 7.-Xinxu Village, Mengshan County, samples from the Lower Devonian Nagaoling Formation and the Middle Devonian Yingtang Formation.

LOCALITY 8.-Zhangmu Village, Zhaoping County, samples from the Lower Devonian Nagaoling and Ertang Formations, and the Middle Devonian Donggangling Formation.

LOCALITY 9.-Zhongping Village, Xiangzhou County, samples from the Lower Devonian Ertang Formation.
LOCALITY 10.-East Bank of Liujiang River, Liujiang County, samples from the Middle Devonian Donggangling Formation.

LOCALITY 11.-Changming Reservoir, Daxin County, samples from the Lower Devonian Yujiang Formation.

LOCALITY 12.-Changlaoxu Village, Hechi County, samples from the Lower Devonian Yilan Formation (Nandan Facies).

[References for all chapters are combined and follow last chapter.] 

DEVONIAN ROCKS AND LOWER AND MIDDLE DEVONIAN PELECYPODS

OF GUANGXI, CHINA, AND THE TRAVERSE GROUP OF MICHIGAN

\title{
CHAPTER E. PELEGYPOD ASSEMBLAGES IN THE LOWER AND MIDDLE DEVONIAN OF GUANGXI
}

\author{
By ZHANG ReNJIE and JOHN POJETA, JR.
}

The pelecypod assemblages reported here are either acme-assemblages or range-assemblages. They are proposed as working hypotheses for comparison with biozones established on other groups of organisms (fig. 9). For the most part, the pelecypod faunas of each formation are known from only one section. However, from the superposition of the formations, and their ages determined from other fossils, we know the succession of pelecypod faunas through the Lower and Middle Devonian of Guangxi. Seven assemblages corresponding to each of the seven formations in the Lower and Middle Devonian of Guangxi are recognized. For the most part, the assemblages represent only part of a formation. Insofar as possible, we relate the assemblages to environments of deposition; however, Pojeta has not examined the Devonian rocks of Guangxi in the field.

We use the word "endemic" to mean that, to our knowledge, the taxon does not occur outside southeast Asia nor, for the most part, outside Guangxi. The paleobiogeography of Devonian pelecypods has been little studied (Pojeta, Kriz, and Berdan, 1976; Bailey, 1978). Many taxonomic concepts of Devonian pelecypods are vague, and, as pointed out in the sections on Pteriacea and Pectinacea, meaningful generic concepts in these groups will be established only by redescription of, and comparison with, type species. In various taxa, at all levels, philosophies of classification need to be developed, rather than only ad hoc descriptions of new taxa, as has been commonplace. Then, these important Devonian shallow-water shelly fossils can be used in much more meaningful ways to establish biostratigraphies and paleobiogeographies.

In spite of these shortcomings in understanding the Devonian pelecypod record, even brief perusals of the classical American and German monographs of Devonian pelecypods (Hall, 1883, 1884, 1885; Beushausen, 1895; Frech, 1891) show the similarity of those faunas to the one of Guangxi.
Taxa listed below but not described in the taxonomic section of this paper are marked with an (@) sign; these taxa were identified by Zhang, but were not available for our joint study.

\section{LIANHUASHAN FORMATION}

The Lianhuashan Formation crops out in Sections 1-3. Pelecypods have been found only in the uppermost part of the Hengxian and Liukankou Members in Section 1 (pls. 67, 68). The total known pelecypod fauna of seven species is distributed as follows:

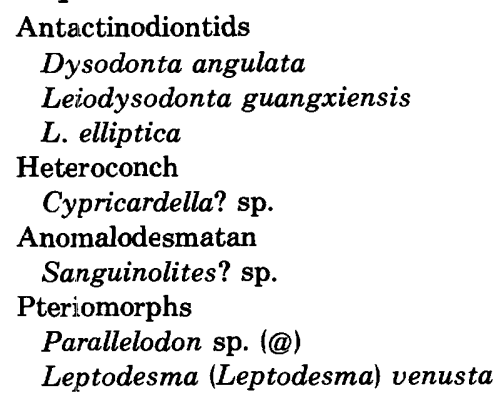

As used herein, Cypricardella? sp. and Sanguinolites? sp. are form taxa based on poorly preserved specimens, and have no biostratigraphic value. Parallelodon sp. (@) is an unpublished taxon. Leptodesma (Leptodesma) venusta is a taxon with simple morphology that ranges into the overlying Nagaoling and Ertang formations.

Antactinodiontids are abundant in both diversity and numbers of specimens in the uppermost Hengxian Member in Section 1; Leiodysodonta elliptica also occurs abundantly in the Liukankou Member. In some beds, specimens assigned to Dysodonta and Leiodysodonta are crowded together and oriented at various angles to bedding. This suggests rapid transport and burial of the specimens. The fact that many specimens are articulated and tightly closed suggests that transport was for only short distances, or that a storm event 
disinterred the shells and some specimens were subsequently buried alive. The pelecypods of the Lianhuashan occur in silty carbonates, silty pelite, fine granular sandstone, and argillaceous siltstone and sandstone; this suggests shallow nearshore depositional environments. We term the pelecypod fauna from the uppermost Hengxian and Liukankou Members of the Lianhuashan Formation the Dysodonta angulataLeiodysodonta guangxiensis assemblage. Because the specimens assigned to both genera are various kinds of molds, which are oriented at different angles to bedding, they are distorted in a variety of ways. Thus, discrimination of species is difficult, and single specimens cannot always be classified below the level of genus.

Above the Lianhuashan Formation, L. guangxiensis occurs in the Yujiang Formation (Zhang, 1977, p. 477 $=L$. beiliuensis Zhang), and L. elliptica occurs in the Nagaoling Formation (Zhang, 1977, p. 477). In Guangxi, Dysodonta angulata is not known above the Lianhuashan; however, in northern Vietnam it occurs in Emsian age rocks (see taxonomic description of this species). Antactinodiontids are endemic to southeast Asia. They are known only from Gedinnian-Emsian age rocks in Guangxi and Yunnan, China, and northern Vietnam. The other genera known from the Lianhuashan fauna have worldwide distributions.

\section{NAGAOLING FORMATION}

Beginning in the Nagaolingian and extending until the end of Emsian time, generic endemism decreases in the Lower Devonian rocks of Guangxi. At the species level, most of the fauna of the Nagaoling Formation is endemic to southeast Asia, but the only endemic genus is Leiodysodonta.

The Nagaoling Formation crops out in Sections 1-3. Pelecypods have been found only at Section 1. Although they occur throughout the Nagaohing in this section, they are best known from the Nagaohing and Mahuangling Members (pl. 68). The total known Nagaohing pelecypod fauna at Section 1 consists of 13 species distributed as follows:

Palaeotaxodont

Nuculoidea minuta

Antactinodiontid

Leiodysodonta levis

Heteroconchs

Cypricardella? sp.

Schizodus peregrinus (@)

$S$. aff. $S$. appressus

$S$. aff. $S$. cuneus

Anomalodesmatans

Sphenotus sp. (@)

Sanguinolites nagaolingensis

Pteriomorphs

\author{
Leptodesma (Leptodesma) venusta \\ L. (L.) deprati \\ L. (L.) guangxiensis \\ Pterinea sp. (@) \\ Actinodesma (Actionodesma)@
}

In the Nagaohing Formation at Locality 7, the following species have been found: palaeotaxodont $N$ uculites sp. A (two specimens), isofilibranch Radiatodonta? sp. A (one specimen), and heteroconch Mecynodon aff. $M$. carinatus (one specimen).

In the Nagaoling Formation, undoubted palaeotaxodonts appear for the first time in the local section, as do identifiable anomalodesmatans and the heteroconch Schizodus. The genus Leptodesma undergoes diversification, whereas the antactinodiontids are less diverse and are represented by only a small number of individuals. Specimens assigned to Leptodesma (Leptodesma) and Schizodus are abundant and crowded together in some beds. Closed articulated specimens are not known. In most collections, single valves or articulated spread valves are found parallel to bedding and convex side up. This suggests gentle transport, but not burial while alive. The fact that specimens are not size sorted suggests that transport was not far.

The pelecypods of the Nagaoling Formation occur in mudstone, shelly limestone, and silty pelite, which indicate depositional environments farther offshore, or in deeper water, than those of the Lianhuashan Formation and suggest small-scale transgression. We term the pelecypods from the Nagaoling and Mahuangling Members of the Nagaoling Formation the SchizodusLeptodesma (Leptodesma) assemblage.

\section{YUJIANG FORMATION}

The Yujiang Formation crops out in Sections 1-3. Pelecypods have been found in Sections 1 and 3 , where they occur low in both the Shizhou and Liujing Members in Section 1 (pl. 68). The known pelecypod fauna in Section 1 consists of 13 species distributed as follows:

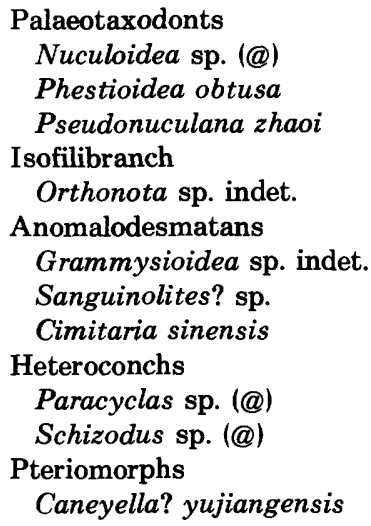

Palaeotaxodonts

Nuculoidea sp. (@)

Phestioidea obtusa

Pseudonuculana zhaoi

Isofilibranch

Orthonota sp. indet.

Anomalodesmatans

Grammysioidea sp. indet.

Sanguinolites? sp.

Cimitaria sinensis

Heteroconchs

Paracyclas sp. (@)

Schizodus sp. (@)

Pteriomorphs

Caneyella? yujiangensis 
Mytilarca sp. (@)

$M$. cf. $M$. chemungensis

Ptychopteria (Actinopteria) cf. P. (A.) producta

Four species are known from the Yujiang Formation at Section 3, the palaeotaxodont Nuculoidea sp. (@), the heteroconch Paracyclas rugosa (@) and the anomalodesmatans Cimitaria guangxiensis (@) and Sanguinolites? sp. Zhang (1977, p. 496) identified Ptychopteria (Ptychopteria) zhongguoensis from the Yujiang Formation of Guangxi. The youngest known antactinodiontid in Guangxi, Leiodysodonta guangxiensis, was reported from the Yujiang Formation of Beiliu County by Zhang (1977, p. 477, as Dysodonta beiliuensis Zhang).

Phestioidea and Pseudonuculana are endemic to the Devonian of Guangxi. Orthonota, Grammysioidea, Cimitaria, Caneyella?, Mytilarca, and Ptychopteria are not endemic to southeast Asia, and their occurrences in the Yujiang Formation are the first known in the Devonian of Guangxi. Caneyella? represents the oldest known occurrence of this genus. At the species level, most of the Yujiang pelecypods are endemic to Guangxi. None of the genera of the Yujiang Formation are represented by more than one species.

Although the pelecypod fauna of the Yujiang Formation is as diverse as that of the Nagaoling Formation, none of the taxa of the Yujiang are represented by large numbers of specimens, and none of them are abundant enough to form beds. In numbers of specimens and species, the fauna of the Yujiang is dominated by brachiopods and corals.

Upward in Section 1, the pelecypods of the Yujiang occur in argillaceous siltstone, argillaceous bioclastic limestone, and calcareous mudstone, which suggest slight deepening of the water up section and water depths about the same as in the Nagaoling Formation. We term the pelecypod fauna from the Shizhou and Liujing members of Yujiang Formation the Caneyella? yujiangensis-Phestioidea obtusa assemblage. These two species bracket the total known range of pelecypods in the Yujiang Formation at Section 1 and are not known to occur above or below that unit. The top of the Yujiang Formation in Section 3 is fault bounded and not useful biostratigraphically.

\section{ERTANG FORMATION}

The Ertang Formation crops out in Sections 2-4. Pelecypods have been found throughout the formation in all three sections, and the Ertang is by far the best sampled formation available to us in Guangxi (pl. 68). The total known pelecypod fauna consists of 39 species distributed as follows (the number(s) after each species name indicates the section(s) in which the species has been found):

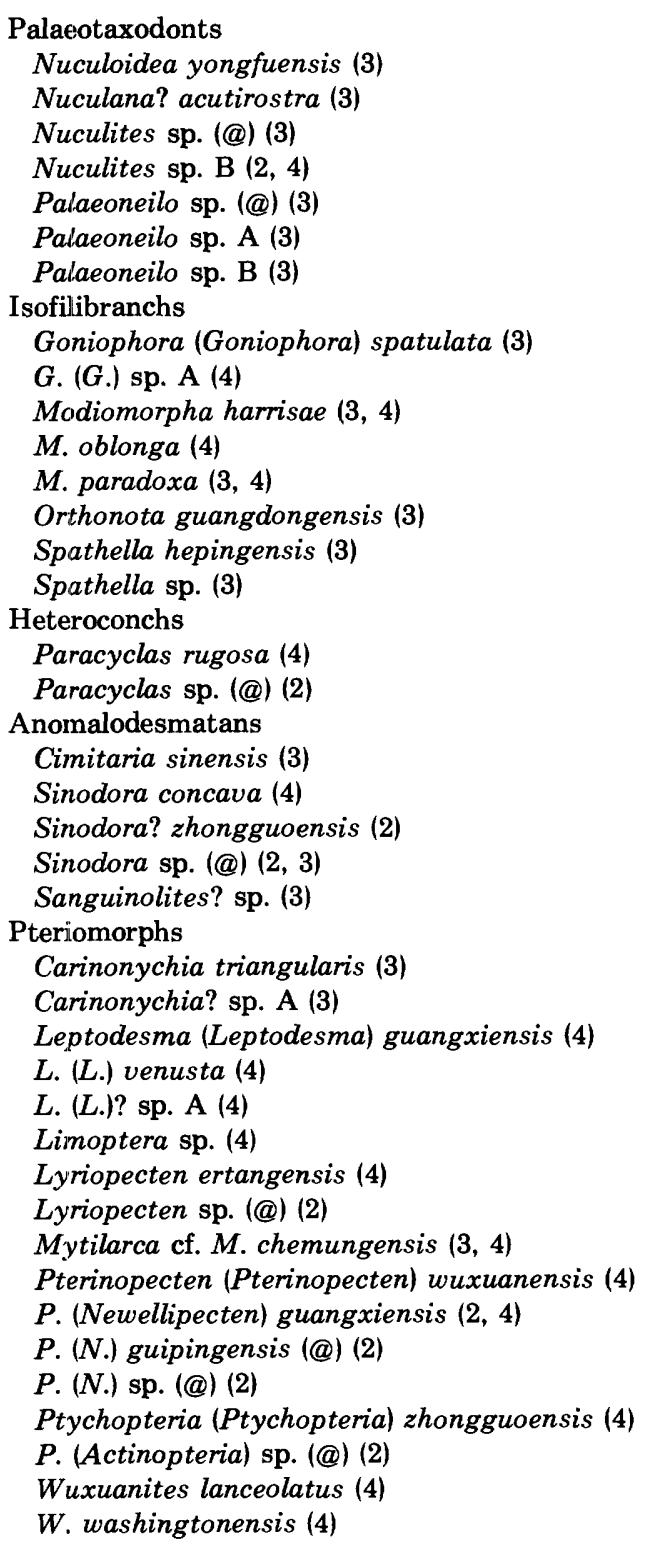

In the Ertang Formation, only the genera Sinodora and Carinonychia are endemic to Guangxi. However, most of the species are endemic to this Autonomous Region of China. Nuculana?, Palaeoneilo, Goniophora (Goniophora), Modiomorpha, Spathella, Limoptera, Lyriopecten, Pterinopecten (Pterinopecten), P. (Newellipecten), and Wuxuanites have their first known occurrences in the Devonian of Guangxi in the Ertang Formation. Specimens of Pterinopecten (Newellipecten) are commonly found covering bedding planes or forming thin beds. They are disarticulated single valves oriented convex side up. In addition to occurring at Sections 2 and $4, P$. (N.) guangxiensis also occurs at Xiangzhou and Longtang, Guiping County, Guangxi.

The Ertang Formation pelecypod fauna is particularly diverse in species of the byssally attached subclasses Isofilibranchia and Pteriomorphia, which together 
represent 64 percent of the fauna. The large number of geographically widespread genera suggests normal marine conditions and open seaways connecting to other shelf areas of the world.

In Section 2, Ertang pelecypods occur in calcareous mudstone, argillaceous limestone, mudstone, and bioclastic limestone. In Section 3, they occur in argillaceous siltstone, silty shale, siltstone, and sandstone. In Section 4, they occur in shale, limestone, mudstone, marls, argillaceous mudstone, calcareous mudstone, argillaceous limestone, and black shales (pl. 68). This suggests that the rocks in Sections 2 and 4 were deposited in deeper water than those in Section 3 , although probably not much deeper than the water during the deposition of the upper Yujiang Formation. In modern seas, byssally attached pelecypods are most abundant in inner shelf and shallower environments, and the Ertang Formation may have been deposited in similar environments. We term the pelecypod fauna from the Ertang Formation the Wuxuanites lanceolatus-Sinodora concava assemblage.

\section{SIPAI FORMATION}

The Sipai Formation crops out in Sections 2,3 , and 5 ; however, only in Section 3 is there a significant pelecypod fauna composed of 16 species distributed as follows:

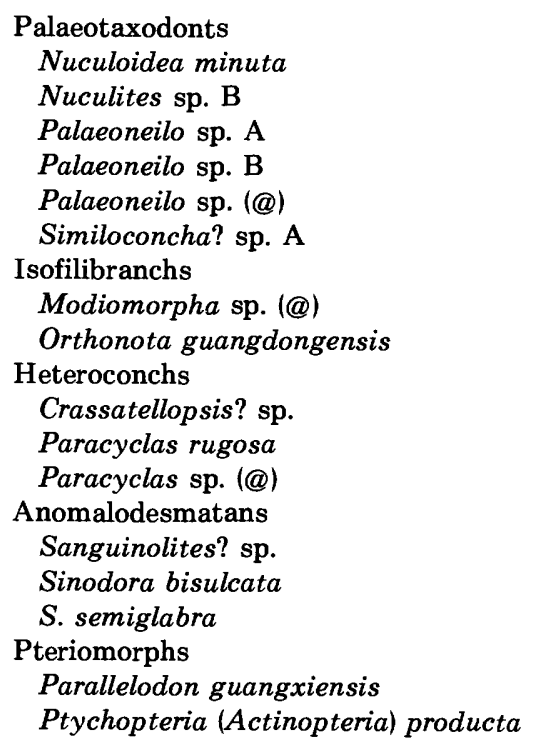

The only pelecypod known from Section 2 is Nuculoidea sp. (@), and the only one known from Section 5 is Paracyclas sp. (@).

In the Sipai Formation, only the genus Sinodora is endemic to Guangxi; Similoconcha is endemic to southeast Asia. However, most species are endemic to Guangxi. The only genera that show first occurrences in the Sipai are of uncertain classification-Similoconcha? and Crassatellopsis?. The literature about first occurrences of pelecypods in the Sipai, Ertang, and Yujiang Formations is confusing (Zhang, 1977). This is because the Yujiang and Sipai were originally broadly defined, and the Ertang has only recently been defined (Pojeta and Zhang, 1984, p. 1024). The ranges of pelecypod taxa given herein for the Yujiang, Ertang, and Sipai Formations supersede all previous information.

In the Sipai Formation, the diversity of pelecypods returns to about the same level as in the Yujiang Formation. The major difference between Sipai and Ertang pelecypod faunas is the marked decrease in the epifaunal and semi-infaunal byssally attached isofilibranchs and pteriomorphs. The reasons for this are not entirely clear. The lower Sipai is fine-grained sandstone intercalated with shale, and the upper Sipai is shale and calcareous shale intercalated with argillaceous limestone. These sediments suggest little environmental change in depositional regimes since Ertang time. The difference in faunal diversity may be more apparent than real, as much more collecting has been done from the Ertang Formation than from either the Yujiang or Sipai Formations. Of the taxa known from the Sipai, only Similoconcha?, Crassatellopsis?, and Parallelodon are not known from the Ertang. Perhaps additional collecting from the presently defined Sipai will yield more species of pelecypods. We term the pelecypod fauna from the Sipai Formation the Parallelodon guangxiensis-Sinodora bisulcata assemblage.

\section{YINGTANG FORMATION}

The Yingtang Formation crops out in Sections 2, 3, and 5 . No pelecypods have been reported from Section 2 , and the sparse pelecypod fauna from Section 3 was not available for this study. However, the rich pelecypod fauna from the upper Yingtang Formation at Section 5 (pl. 68) was studied in detail by us. Twenty species are present in the upper Yingtang Formation at Section 5 , and are distributed as follows:

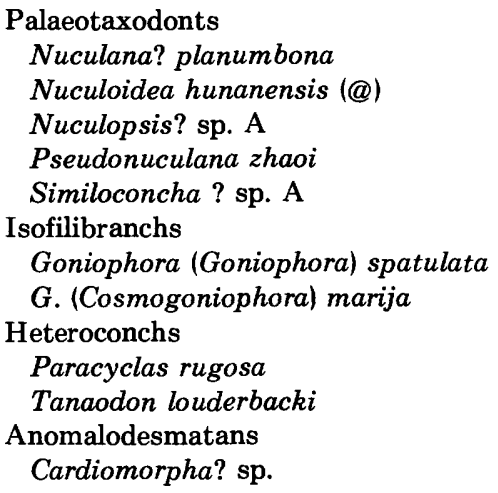


Sedgwickia? yingtangensis

Sinodora semiglabra

Sphenotus yingtangensis

Pteriomorphs

Limoptera orbicularis

Limoptera sp.

Mytilarca $\mathrm{cf}$. M. chemungensis

Nodonychia gordia

Oxytomoidea elegans

Pterinopecten (Newellipecten) guangxiensis

Ptychopteria (Actinopteria) producta

The only taxon reported from Section 3 that does not occur at Section 5 is Mecynodon sp. @.

In the upper Yingtang Formation, most of the species are endemic to Guangxi. Of the 19 known genera, 5 are endemic to southeastern China-Similoconcha?, Pseudonuculana, Oxytomoidea, Sinodora, and Nodonychia. Tanaodon is known from both China (Guangxi, Hunan, and Sichuan) and Australia. In absolute numbers, this is a higher degree of generic-level endemism than in the Lianhuashan. The endemism is also a reversal of a trend seen in the Nagaoling-Sipai sequence, and it occurs at the Emisan-Eifelian boundary (fig. 8).

The byssally attached pteriomorphs underwent a second period of diversification in Yingtangian time. However, the isofilibranchs did not diversify, and the species-level diversity of byssally attached species is about one-third that of the Ertang Formation. This too, may be a function of collecting, as the Ertang Formation has been much more extensively collected than the Yingtang.

In Section 5 (pl. 68), the upper Yingtang pelecypods occur in fine clastic rocks, which may be calcareous or intercalated with marls and limestones, suggesting an environment of deposition similar to that of the upper Sipai Formation. In Section 3, Yingtang pelecypods occur in coarser clastic rocks lacking carbonate and including sandstone, siltstone, argillaceous siltstone, shale, and shale with siderite. These rocks suggest a shallower environment more like that of the lower Sipai.

A considerable faunal turnover occurs at the SipaiYingtang boundary. Of the genera present in the Sipai Formation, Similoconcha?, Nuculoidea, Paracyclas, Sinodora, and Ptychopteria (Actinopteria) also occur in the Yingtang. The same species of Similoconcha?, Paracyclas, and Ptychopteria (Actinopteria) are found in both the Sipai and Yingtang. This turnover does not seem to be related to environments of deposition. The faunal turnover may be correlated with the increase in generic-level endemism. Both may be related to a changing paleogeography, which could affect ocean currents and faunal exchange. Oliver $(1973,1976,1977)$ showed that, in the North Atlantic, there was a considerable breakdown in endemism in corals in post-Emsian time. Boucot and Gray (1979) showed a similar happening for brachiopods. The opposite seems to have happened to the Devonian pelecypods of Guangxi.

We term the pelecypod fauna of the upper Yingtang Formation the Oxytomoidea elegans-Nodonychia gordia assemblage, and thus stress the apparent endemism of the pelecypods of the formation.

\section{DONGGANGLING FORMATION}

The Donggangling formation crops out in Sections 1 , 2, 3, and 5. Pelecypods are known from the Lower Member of the Donggangling in Section 3; they are poorly known from grab samples in Section 2 . Fourteen species are present in the lower Donggangling at Section 3 (pl. 68), distributed as follows:

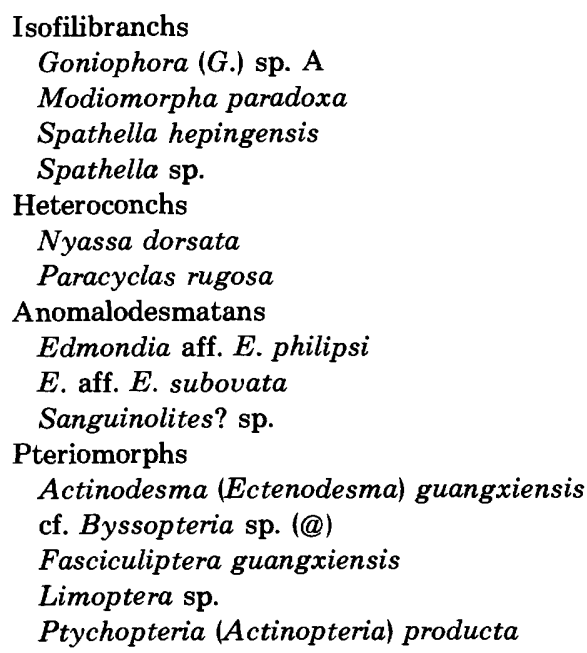

From grab samples of the Donggangling Formation, at Section 2, two palaeotaxodonts have been identified-Ctenodonta? dubiiformisa and Palaeoneilo sp. B. The heteroconch Tusayana? liujiangensis is known from the Donggangling at Locality 10. Zhang (1977, pl. 193, fig. 5) identified the pteriomorph Mytilarca cf. $M$. oviformis and the praecardiid Buchiola cf. B. sexacostata (Zhang, 1977, p. 525) from the Donggangling Formation. The only known endemic genus from the Donggangling Formation is Fasciculiptera. Six of the species have very wide distributions-Edmondia aff. $E$. philipsi, $E$. aff. E. subovata, Nyassa dorsata, Paracyclas rugosa, Buchiola cf. B. scxacostata, and Mytilarca cf. $M$. oviformis. The other species are endemic to Guangxi.

At Section 3, the Donggangling pelecypods occur in shales intercalated with argillaceous limestone and marl and nodular limestone and marl, suggesting environmental conditions similar to those of the upper Yingtang Formation. 
The Donggangling Formation is our most poorly sam- $\mid$ we use the designation Fasciculiptera guangxiensispled unit, and we suspect that the number of pelecypod taxa will increase as more samples are collected. For the pelecypod fauna of the lower Donggangling Formation, $\mid$ [References for all chapters are combined and follow last chapter.] 


\title{
DEVONIAN ROCKS AND LOWER AND MIDDLE DEVONIAN PELECYPODS \\ OF GUANGXI, CHINA, AND THE TRAVERSE GROUP OF MICHIGAN
}

\section{CHAPTER F. SUMMARY OF THE TRAVERSE GROUP STRATIGRAPHY IN MICHIGAN, AND COMPARISON OF FAUNAS}

\author{
By JOHn POJETA, JR., and Zhang RenjIE
}

\section{TRAVERSE GROUP}

Most of the Devonian pelecypods described from Michigan are from outcrops of the Traverse Group (Givetian; fig. 11) at the northern end of the southern peninsula. A few specimens are from the overlying Jordan River Formation (Frasnian). The Traverse Group has a maximum thickness of 800 feet. Many of the specimens studied were collected in the late 1930's by P. E. Cloud, Yang Zunyi, who were then both at Yale University, G. A. Cooper, Smithsonian Institution, and A. S. Warthin, Jr., Vassar College. Many of the specimens were collected before the modern stratigraphy of the area was developed. Cooper continued to collect until 1965.

Warthin and Cooper (1943) developed the stratigraphy for the Traverse Group in Alpena and eastern Presque Isle Counties, in the eastern area of outcrop (fig. 11). Most of our material was collected from Alpena County. We have carefully checked formation occurrences with Cooper, who graciously gave of his time and knowledge in helping us relate the collections to the modern stratigraphy; we give him our sincere thanks. As a result of this help, our formation designations for specimens may differ from those on the museum labels. The only species that we have from Presque Isle County are Gosseletia triquetra and Cornellites fasciculatus. The stratigraphic column shown in figure $12 A$, for the Traverse Group in the eastern area of outcrop, is taken from Warthin and Cooper (1943), Sanford (1967), Cooper and Dutro (1982), and from conversation with Cooper (December 1984). The Squaw Bay Limestone overlies the Traverse Group in the east. The Traverse Group is regarded as Givetian in age. The top is probably below the occurrence of the base of the conodont defined Lower Polygnathus asymmetricus Zone. W. A. Oliver (oral commun., Nov. 16, 1984) noted that the Devonian
Subcommission has submitted a proposal that the base of the Lower Polygnathus asymmetricus Zone be taken as the Middle-Upper Devonian boundary to the International Commission on Stratigraphy.

Figure $12 B$ shows the stratigraphic column for the Traverse Group to the northwest and west of Alpena and Presque Isle Counties. It was taken from Kelly and Smith (1947), Sanford (1967), Kesling, Segall, and Sorensen (1974), Cooper and Dutro (1982), and conversation with Cooper (December 1984). The Jordan River Formation overlies the Traverse Group in the west. We have few collections from the western outcrops, and only 9 of the 28 species recognized by us from Michigan are in Emmet, Cheboygan, and Charlevoix Counties. Table 1 shows the occurrence of species by formation in Michigan.

\section{COMPARISON OF FAUNAS}

The pelecypod fauna of the Traverse Group of Michigan is most like that of the Hamilton Group of New York as described by Hall and Whitfield (1869, $1870)$ and Hall $(1883,1884$, and 1885). Sixteen of the 28 known species from Michigan also occur in the Hamilton Group of New York, or are closely allied to species in that State. The species are:

\footnotetext{
Palaeotaxodonts

Nuculoidea cf. $N$. lirata (Norway Point Formation)

Phestia cf. P. brevirostra (Alpena Limestone)

Palaeoneilo emarginata (Potter Farm and Jordan River Formations)

Isofilibranchs

Modiomorpha mytiloides (Norway Point and Thunder Bay Formations)

Orthonota undulata (Norway Point Formation)

Orthonota? parvula (Norway Point Formation)
} 


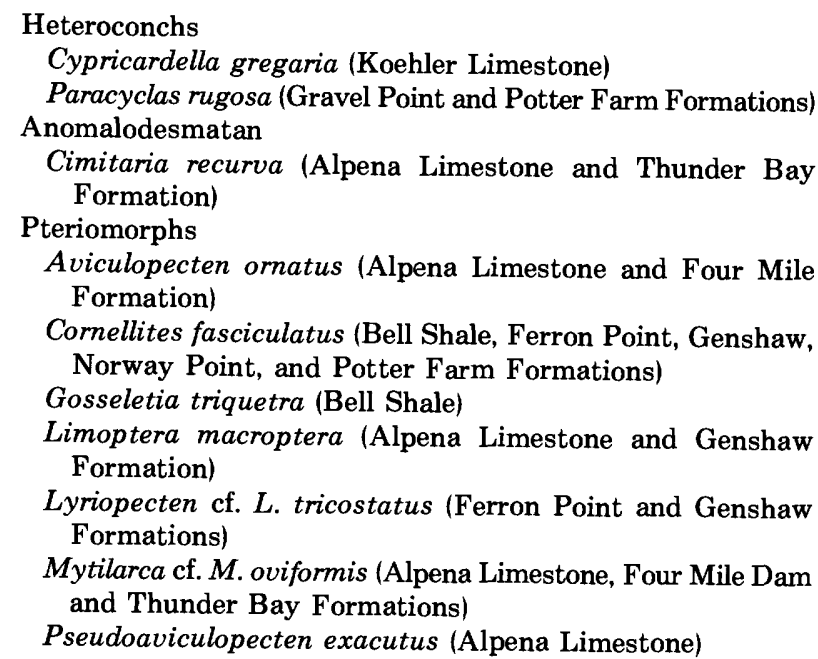

Warthin and Cooper (1943, p. 574) noted that “***the Traverse group is interpreted as including rocks of both Hamilton and post-Hamilton ages***The correlation with the Devonian of New York is based on the occurrence of a few identical or closely related species, a number of rare generic types, and a total generic composition like that of certain beds in the New York Section."

Sanford (1967, p. 976) showed the Traverse Group as being Givetian in age. He placed the Squaw Bay Limestone in the lower Frasnian. Rickard $(1975,1984)$ regarded the Hamilton Group of New York as including the Marcellus, Skaneateles, Ludlowville, and Moscow Formations, or the rocks between the Onondaga and Tully Limestones. He showed the Hamilton as being Givetian in age, marked the lower and upper boundaries of the Givetian with question marks, and placed the Hamilton Group in the Cazenovian and Tioughniogian Provincial Stages.

Cooper and Dutro $(1982$, p. 17) placed the top of the Hamilton Group of New York (Moscow Formation) above the Norway Point Formation of Michigan. They correlated the Ludlowville (including the Centerfield Limestone) with the Norway Point and Four Mile Dam Formations of Michigan. The lower Traverse Group was correlated with the lower Hamilton Group. Cooper and Phelan (1966) placed the lower Traverse Group in the Givetian and the upper Cazenovian Provincial Stage. The Michigan units above the Norway Point were placed in the Taghanician and Fingerlakesian Provincial Stages.

Of the 16 species of pelecypods in common between the Traverse Group and the Hamilton Group, 14 occur in the Norway Point Formation or older rocks in Michigan. Thus, there is close comparison of pelecypod faunas from the two groups, and the pelecypods reinforce the correlations indicated by Cooper and Dutro.
The pelecypods of the Hamilton Group of New York have not been well studied in the 20th century. Bailey (1983) described a fauna of 14 species from the Solsville Member of the Marcellus Formation in New York. This fauna has four species in common with the Traverse Group of Michigan-Cornellites fasciculatus, Gosseletia triquetra, Modiomorpha mytiloides, and Paracyclas rugosa. In Michigan, C. fasciculatus, $M$. mytiloides, and $P$. rugosa, occur in or below, as well as above, the Norway Point Formation. G. triquetra occurs only in the Bell Shale in Michigan.

The data from Hall and Whitfield, Hall, and Bailey, all support the correlation of the pelecypod faunas of the Traverse Group of Michigan with those of the Hamilton Group of New York. These data are at variance with the suggestion of Bailey $(1978$, p. 124; 1979) that Nuculopsis gibbosa, from the Potter Farm Formation in Michigan, suggests faunal endemism of Traverse Group pelecypods. Before our study, Traverse Group pelecypods of Michigan were virtually unknown (Winchell, 1866; Yang, 1939).

The pre-Traverse pelecypods of Michigan were studied by LaRocque (1950). His work is now difficult to use because his material was not well preserved and because generic concepts have evolved since 1950. As best we can tell, the following genera are common to both the Traverse and pre-Traverse rocks of Michigan: Cornellites (Dundee Limestone), Limoptera (Rogers City Limestone), Goniophora (Rogers City Limestone), Paracyclas (Dundee and Rogers City Limestones), Phenacocyclas? (Dundee and Rogers City Limestones), Ptychopteria (Bois Blanc Formation and Rogers City Limestone), Leptodesma (Detroit River Group, Dundee and Rogers City Limestones), and Schizodus (Rogers City Limestone). Genera that occur in the pre-Traverse Devonian of Michigan, but are not known from the Traverse Group, are Actinodesma (Dundee Limestone), Liromytilus (Rogers City Limestone), Panenka (Bois Blanc Formation, Amherstburg Dolomite, and Dundee Limestone), and Solenomorpha (Rogers City Limestone). Other generic names used by LaRocque either were applied to specimens that we cannot identify from his photographs (Pterinea, Leiopteria, Gosseletia, Modiomorpha, Nuculoidea, Palaeoneilo, and Cypricardinia), or were placed in synonymy by Newell and LaRocque (1969a) (Follmanella and Actinopterella $=$ Ptychopteria and Diodontopter $a=$ Leptodesma).

Bailey (1978, p. 124) correctly stressed the occurrence of the genus Liromytilus in the Rogers City Limestone of Michigan and the Middle Devonian of Manitoba as indicating the distinctiveness of the pre-Traverse fauna of Michigan from rocks of the same age in the Appalachians. Cooper and Phelan (1966) reported Liromytilus and Stringocephalus from the Miami Bend 
TABLE 1.-Occurrences of species of pelecypods in the Traverse Group of Michigan

\begin{tabular}{|c|c|}
\hline 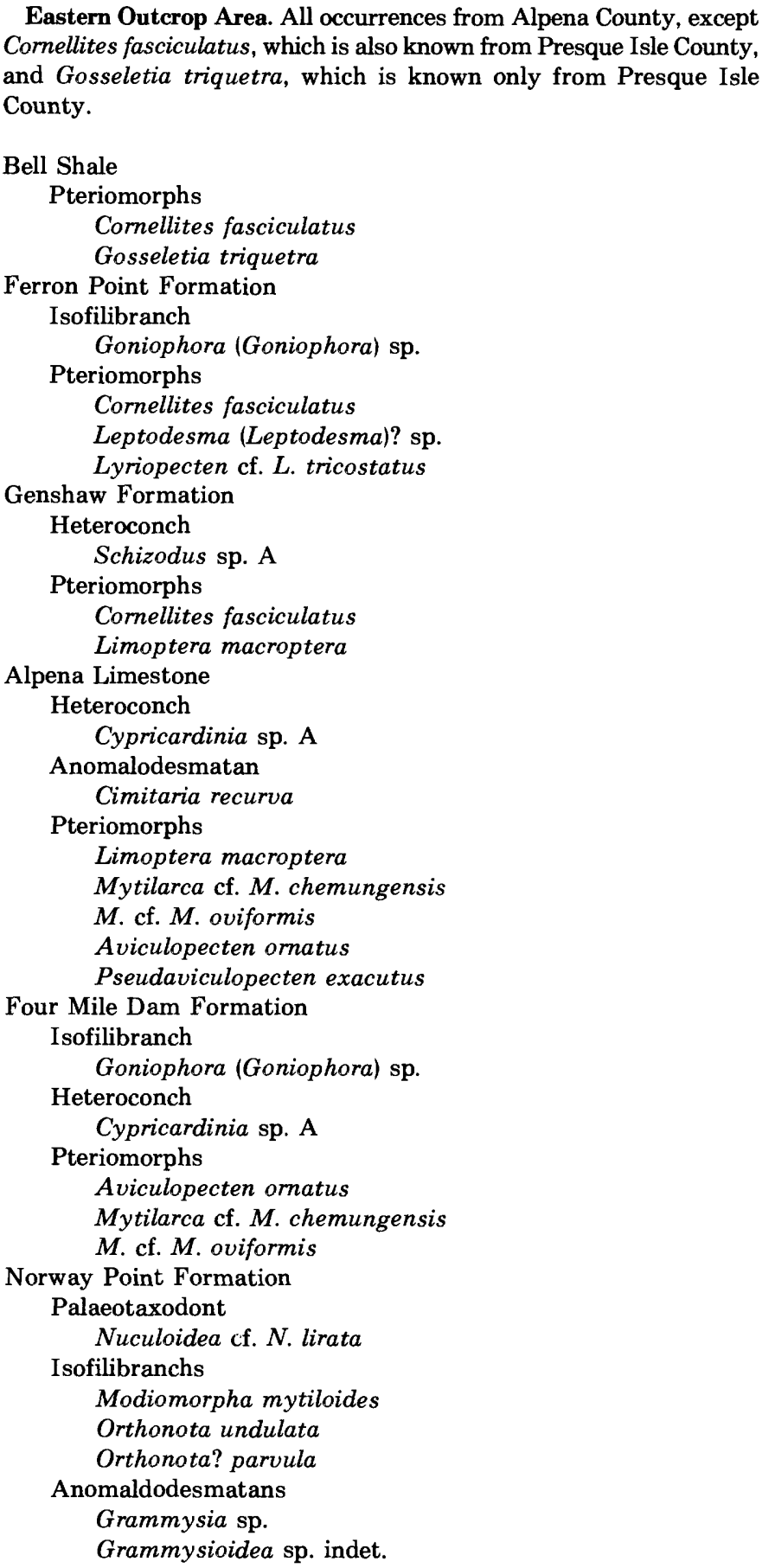 & $\begin{array}{l}\text { Western Outcrop Area. Counties of occurrence indicated after } \\
\text { species names. } \\
\text { Koehler Limestone } \\
\text { Heteroconch } \\
\text { Cypricardella gregaria (Cheboygan County) } \\
\text { Gravel Point Formation } \\
\text { Heteroconchs } \\
\quad \text { Paracyclas rugosa (Gorbut Member, Cheboygan County) } \\
\text { Phenacocyclas? sp. (Emmet County) } \\
\text { Pteriomorphs } \\
\quad \text { Leptodesma (Leptodesma)? sp. (Charlevoix County) } \\
\quad \text { Lyriopecten cf. L. tricostatus (Charlevoix and Emmet } \\
\text { Counties) } \\
\text { Charlevoix Formation } \\
\text { Heteroconch } \\
\quad \text { Cypricardella? sp. (Emmet County) } \\
\text { Petoskey Formation } \\
\text { Palaeotaxodont } \\
\text { Phestia sp. A (Emmet County) } \\
\text { Jordan River Formation (Frasnian) } \\
\text { Palaeotaxodont } \\
\quad \text { Palaeoneilo emarginata (Charlevoix County) } \\
\text { Pteriomorph } \\
\text { Ptychopteria (Actinopteria) aff. P. (A.) epsilon (Charlevoix } \\
\text { County) }\end{array}$ \\
\hline
\end{tabular}

Formation of Indiana. Stringocephalus is regarded as a leading fossil of the Givetian Stage, and the Indiana occurrence is the first known in the Eastern United States.

Comparison of Traverse Group pelecypods to the
Givetian age Donggangling Formation of Guangxi is difficult because we had much more extensive collections from the Givetian of Michigan than from that stage in Guangxi. The pelecypod fauna of the Donggangling Formation is given on page 49. Genera and 


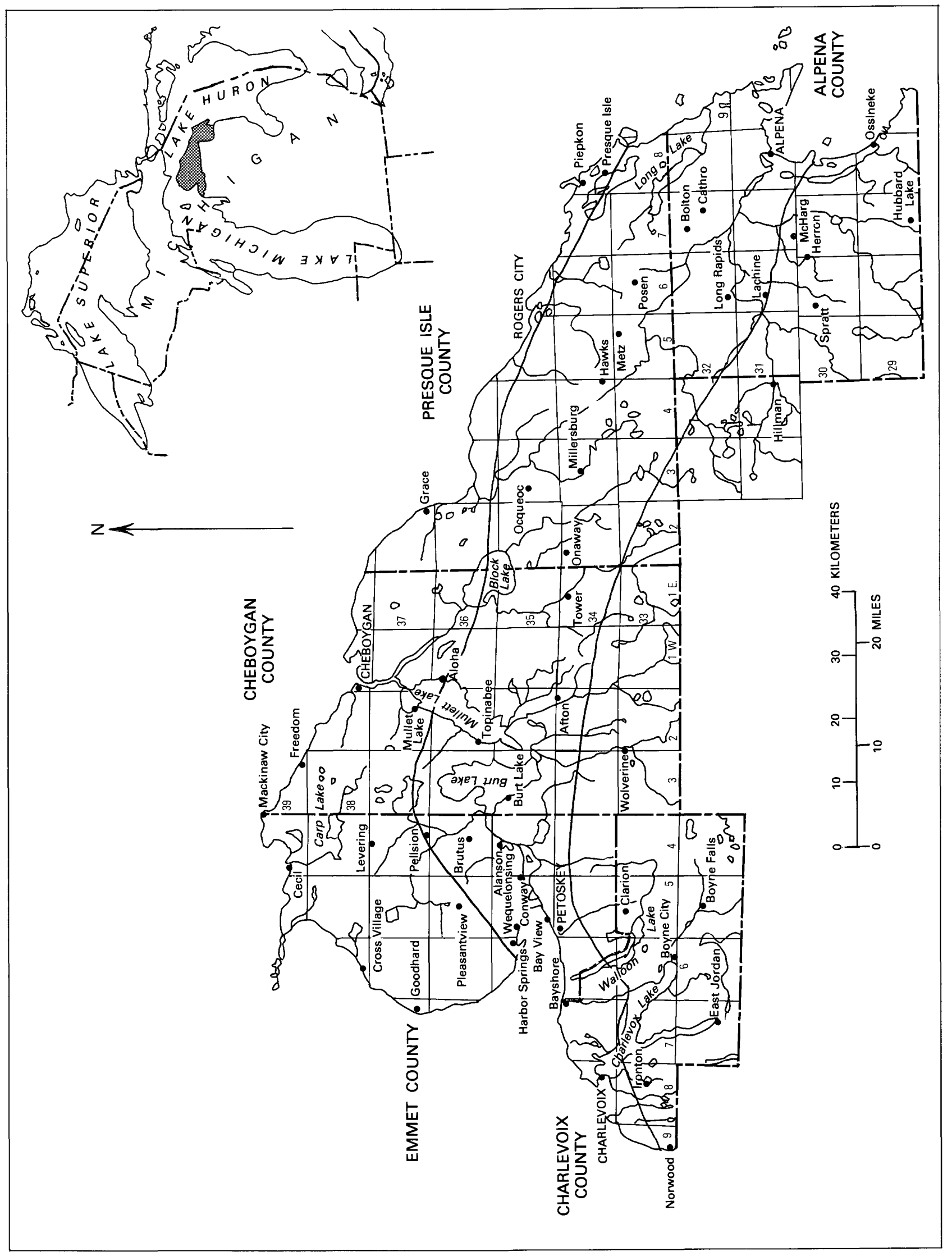

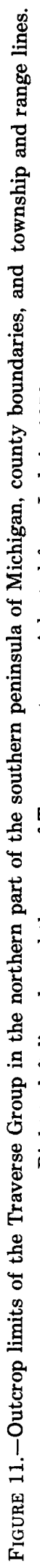




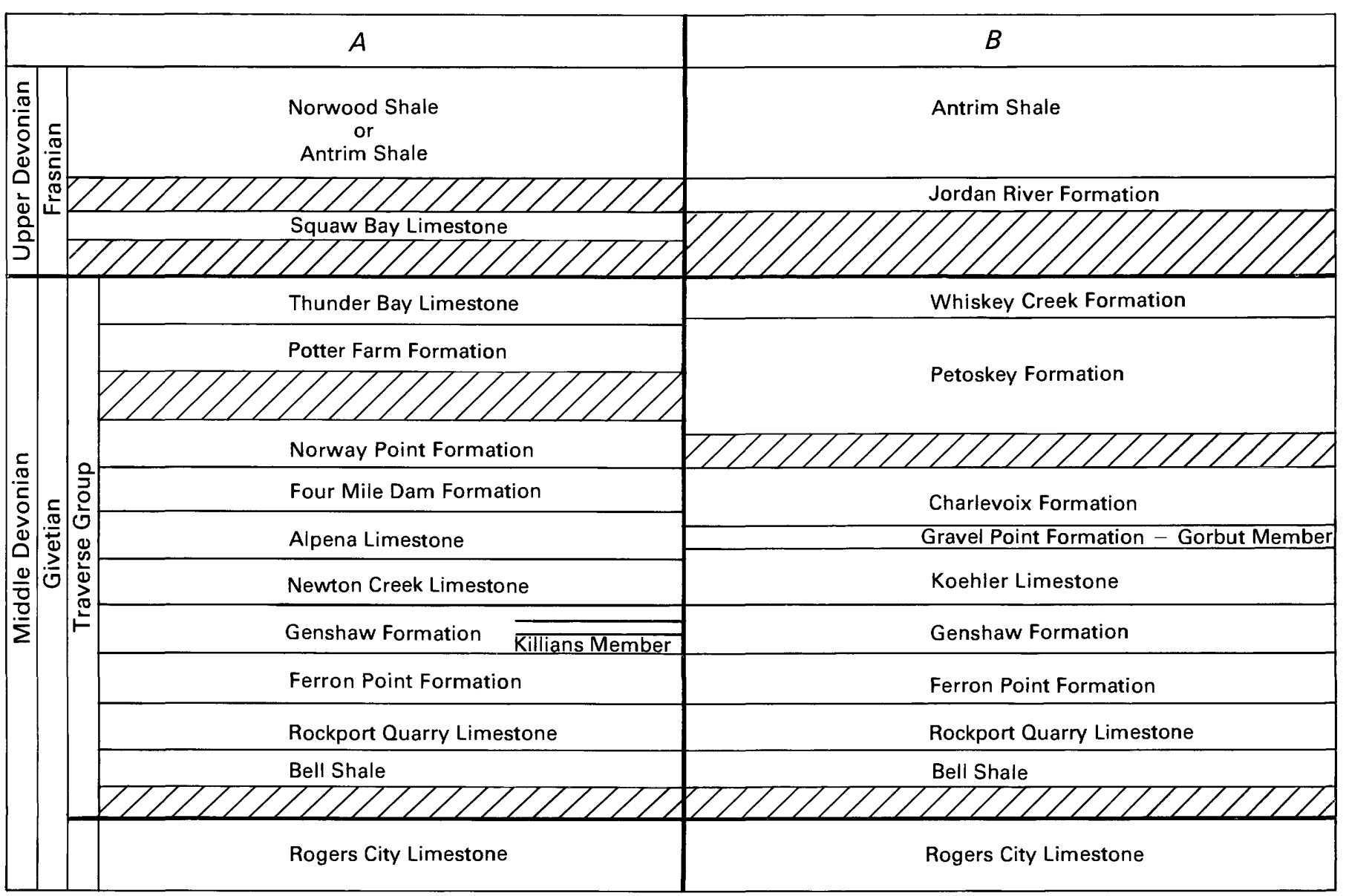

FIGURE 12.-Stratigraphy and correlations of the Traverse Group in the northern part of the southern peninsula of Michigan. $A$, East side of outcrop area. $B$, West side of outcrop area.

species in common with the Traverse Group are Palaeoneilo, Modiomorpha, Goniophora (Goniophora), Paracyclas rugosa, and Mytilarca cf. $M$. oviformis. These genera and species also occur in the Hamilton Group of New York. In addition, the following taxa are also common to the Givetian rocks of Guangxi and New York: Spathella, Nyassa dorsata, and Ptychopteria (Actinopteria).

[References for all chapters are combined and follow last chapter.] 

DEVONIAN ROCKS AND LOWER AND MIDDLE DEVONIAN PELECYPODS

OF GUANGXI, CHINA, AND THE TRAVERSE GROUP OF MICHIGAN

\title{
CHAPTER G. SYSTEMATIC PALEONTOLOGY OF DEVONIAN PELECYPODS OF GUANGXI AND MICHIGAN
}

\author{
By JOHN POJETA, JR., ZHANG RENJIE, and YANG ZUNYI ${ }^{2}$
}

\section{INTRODUCTION}

The taxonomic descriptions of the pelecypods include both the Chinese and the Michigan species in proper systematic order; Chinese species are marked with a "+," and American species are marked with an "**." A few species are from other parts of the world and are unmarked. On the plates, the Chinese and American palaeotaxodonts, and some of the isofilibranchs, are figured in proper sequence; however, most of the Michigan species are figured after the Chinese species. Michigan Devonian pelecypods have been little studied; the major published work on the group is LaRocque's (1950) study of pre-Traverse species. Yang's (1939) $\mathrm{Ph} . \mathrm{D}$. thesis on Michigan Traverse species was not published. His material, housed at Yale University and the U.S. National Museum of Natural History, is described here.

Although Devonian pelecypods are very abundant in China (fig. 13), until recently they have been little studied. Before 1949, only eight species, placed in eight genera, had been described (Loczy, 1899; Mansuy, 1913; Kirk, 1927; Reed, 1927; and Chang, 1929). In the unattributed book "Fossil Lamellibranchiata of China" (written by the Writing Group on Fossil Lamellibranchiata of China, Nanjing Institute of Geology and Paleontology, Academia Sinica, 1976), only nine species, placed in eight genera, were documented.

Zhang (1977) published the results of the study of more than 3,000 specimens of Devonian pelecypods from central South China-Guangdong, Guangxi, Hunan, and Hubei (fig. 4). Most of this material had been collected over a period of years by the Research Group of the Geology and Mineral Resources Institute of central South China, Ministry of Geology. Zhang

\footnotetext{
${ }^{2}$ Yang Zunyi is from Beijing Graduate School, Wuhan College of Geology, Beijing, China.
}

(1977) described 89 species placed in 49 genera; about half of the species were from Guangxi. This work, and the present study, which describes 71 species placed in 48 genera, are the major monographs on the Devonian pelecypods of China. For our study we had about 1,000 specimens from the Gedinnian-Givetian rocks of Guangxi, and about 700 from the Givetian rocks of Michigan.

Other recent papers deal with the Devonian pelecypods of China. Liang (1981) described 13 species placed in 10 genera from northeast China (Heilongjiang, Jiling, and Liaoning Provinces) (fig. 4); these species are regarded as belonging to a different faunal province than those of South China. Yin and Gan (1978) described seven species, placed in seven genera, of Middle and Upper Devonian pelecypods from Guizhou Province (fig. 4) of southwest China. Guo (1980) described seven species from the Lower Devonian rocks of Yunnan Province in South China (fig. 4). To date, Upper Devonian pelecypods from China are poorly known.

\section{REPOSITORIES OF SPECIMENS}

Most of the Chinese specimens described here are from the collections at the Yichang Institute of Geology and Mineral Resources, Yichang, Hubei; the specimens have numbers preceded by the letters GXD-(Guangxi, Devonian). Some of the Chinese specimens are at the Geology Museum (GM-) of the Ministry of Geology and Mineral Resources, Beijing. Eventually, the specimens at Yichang may be transferred to the Geology Museum.

American specimens are at the following institutions: Academy of Natural Sciences of Philadelphia, Philadelphia, Pa. (ANSP); New York State Museum, Albany, N.Y. (NYSM); American Museum of Natural History, New York, N.Y. (AMNH); Peabody Museum 


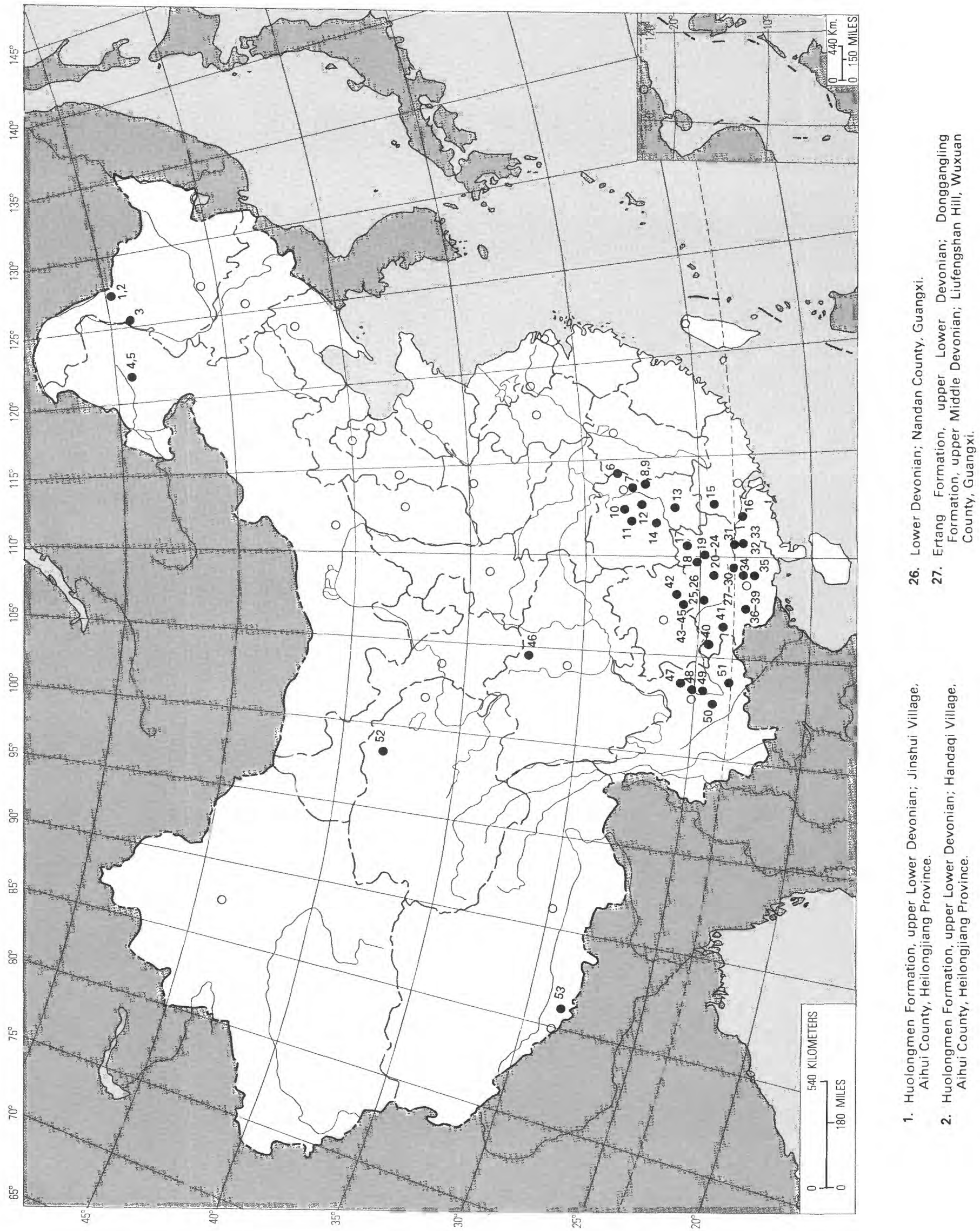



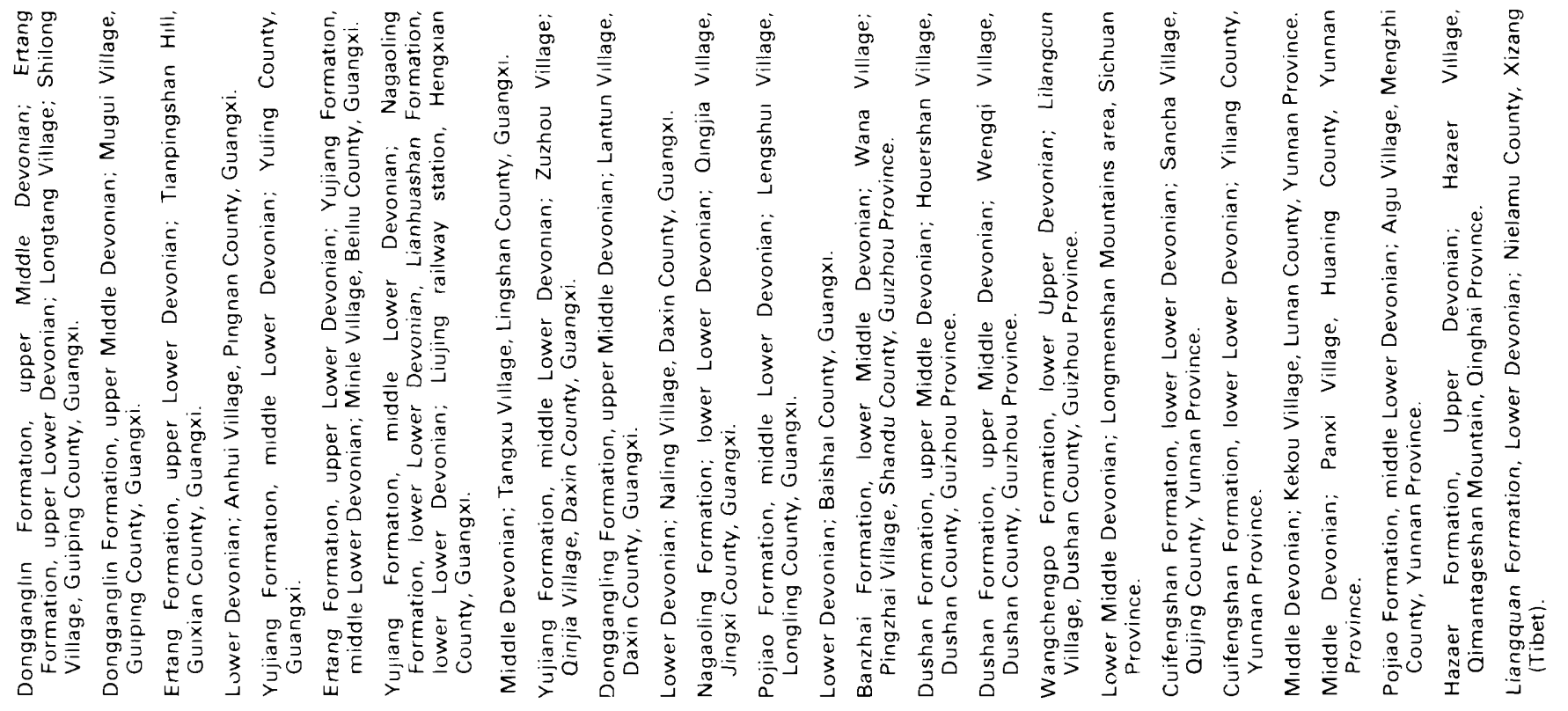

$\stackrel{\infty}{\sim}$

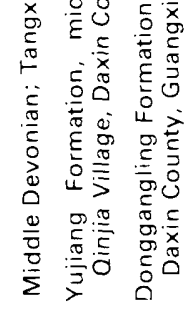

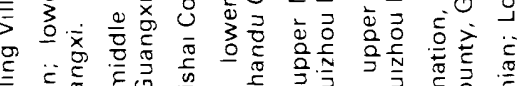

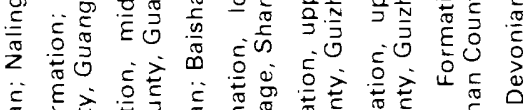

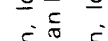

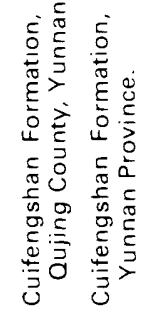

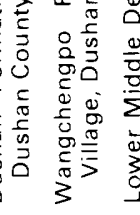

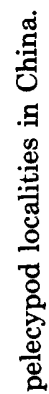
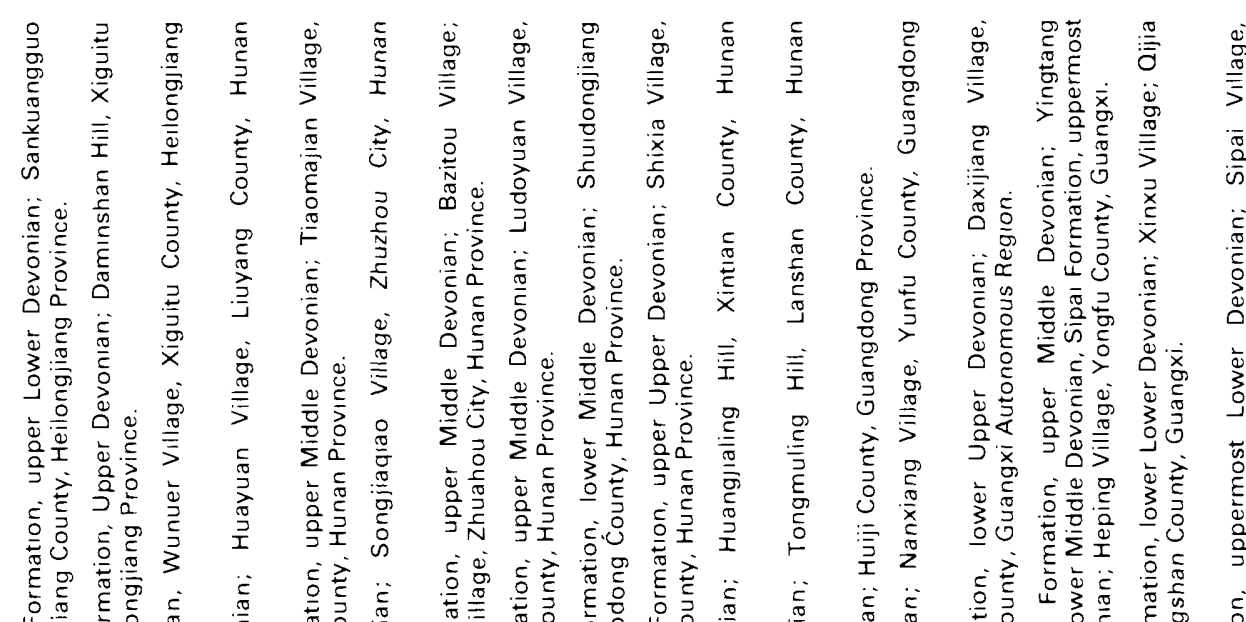

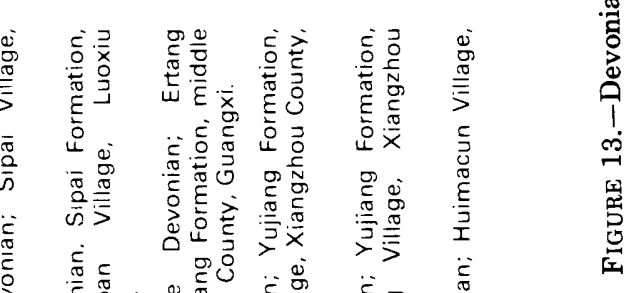

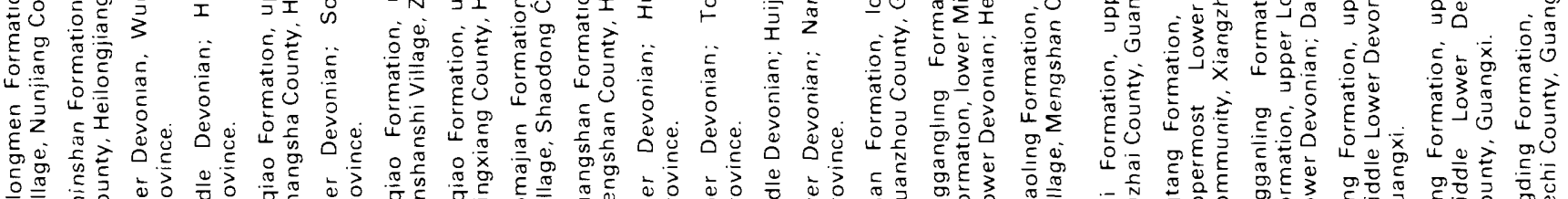

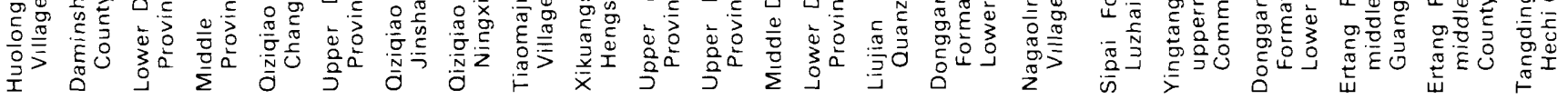
í
is
$\dot{i} \infty$ 
of Natural History, Yale University, New Haven, Conn. (YPM); and Department of Paleobiology (USNM) and Division of Mollusks (USNMDM), U.S. National Museum of Natural History, Smithsonian Institution, Washington, D.C.

\section{Phylum MOLLUSCA Cuvier Class PELECYPODA Goldfuss Subclass PALAEOTAXODONTA Korobkov Order NUCULOIDA Dall \\ Superfamily CTENODONTACEA Wöhrmann Family CTENODONTIDAE Wöhrmann}

\section{Genus CTENODONTA Salter, 1852}

Diagnosis.-Large, opisthogyrate nuculaniform ctenodontids having external opisthodetic, parivincular ligament set in narrow external ligament grooves.

Ctenodonta? dubiiformisa Zhang, 1977+

Plate 1, figures 1-8

1977. Ctenodonta? dubiiformisa Zhang, p. 473, pl. 189, figs. 3-4.

Discussion.-Four of the six known specimens of this species (GXD-001-004) are figured here (pl. 1, figs. 1-8); all specimens are poorly preserved internal molds. Zhang (1977) assigned the specimens with question to the genus Ctendonta Salter on the basis of the large size of the holotype (Zhang 1977, pl. 189, fig. 3) and because the beaks are near the midlength of the shell.

Ctenodonta s.s. is not known in post-Ordovician rocks (Pojeta 1971, 1978), and the type species C. nasuta (Hall) differs significantly from C.? dubiiformisa in being nuculaniform and markedly elongated posteriorly (Pojeta, 1971, pl. 4, figs. 1-24; 1978, pl. 3, figs. 2-5). None of the known specimens of $C$. ? dubiiformisa preserve any features that unequivocally demonstrate the species to be a palaeotaxodont. Two specimens (pl. 1, figs. 2, 7) show teardrop-shaped depressions to one end of the beaks. These depressions were probably made by the ligament. The beaks (pl. 1, figs. 2, 7) point away from the depressions; thus, C.? dubiiformisa was probably prosogyrate. Ctenodonta is opisthogyrate. An inset, external opisthodetic ligament (Trueman, 1969, p. N61, fig. C), such as seems to be present in C.? dubiiformisa, is not characteristic of ctenodontids. Ctenodontids have the classical C-spring, external opisthodetic parivincular ligament set in external ligament grooves (Trueman, 1969, p. N61, fig. D; Pojeta, 1971, pl. 4, figs. 4, 5).

If the hinge axis of $C . ?$ dubiiformisa is placed horizontally (pl. 1, figs. 1, 5, 6, 8), the lateral profile of this species is similar to the Ordovician palaeotaxodont Tancrediopsis Beushausen (Pojeta, 1971, pl. 6, figs. 9-15; 1978, pl. 3, figs. 12, 13). However, like Ctenodonta, Tancrediopsis is opisthogyrate. In addition, Tancrediopsis has prominent taxodont teeth, whereas C.? dubiiformisa seems to have only cardinal teeth (pl. 1, figs. 3,4$)$. The presumed dentition of C.? dubiiformisa is not well preserved, but the ventral trace of the articulated teeth seems to be present in one specimen. Because the structures interpreted as cardinal teeth in C.? dubiiformisa are not well preserved, additional specimens of the species are needed to determine its taxonomic placement. It is probably not a ctenodontid. C.? dubiiformisa is anteroventrally elongated like various lower Paleozoic solemyoid palaeotaxodonts (Pojeta and Runnegar 1985, fig. $10 \mathrm{~A}-\mathrm{G})$, which seem to be descended from ctenodontids (Pojeta and Runnegar, 1985, fig. 10H$\mathrm{K})$. It may be that C.? dubiiformisa is related to solemyoids. The dentition of lower Paleozoic solemyoids is not known, but they are opisthogyrate.

Types.-C.? dubiiformisa is known from the type suite and four topotypes. A topotype (GXD-004) shown on plate 1 , figure 5 , is an incomplete articulated internal mold whose largest dimension is $54.4 \mathrm{~mm}$. Three other topotypes (GXD-001-003) are shown on plate 1, figures 1-4, 6-8; they too are articulated internal molds. All specimens were collected in place from argillaceous limestone, and they are free of matrix.

Type locality.-All known specimens are from the Donggangling Formation (Givetian), at Section 2, near Dale Village, Xiangzhou County, Guangxi; the bed from which they came is not known.

\section{Superfamily NUCULACEA Gray}

Posteriorly truncate and usually anteriorly elongate palaeotaxodonts lacking a pallial sinus.

\section{Family NUCULIDAE Gray}

Nuculaceans with resilifer and internal ligament.

Genus NUCULOIDEA Williams and Breger, 1916

Diagnosis.-Inequilateral Paleozoic nuculids having erect umbos and prosogyrate beaks pointing toward elongated anterior end of shell.

Discussion.-The Chinese specimens here placed in Nuculoidea are not well preserved. They are included in this genus largely because of their erect umbos and prosogyrate beaks which point toward the elongated anterior end of the shell (pl. 2, figs. 1-5, 11; Bradshaw, 1974). The more-or-less similarly shaped genus Nuculopsis Girty has opisthogyrate beaks pointing toward the shorter posterior end of the shell (pl. 2, figs. 7-9; pl. 3, figs. 5-7). Deceptrix Fuchs (Pojeta, 1971, pl. 5, figs. $7-20$ ) includes species that also have shapes similar to Nuculoidea, and Deceptrix also has prosogyrate beaks. However, Deceptrix has an external ligament and lacks a resilifer. Nuculoidea is the most common Devonian nuculid; Nuculopsis and Deceptrix are relatively rare in Devonian age rocks. Nuculopsis is common in the 
Carboniferous, and Deceptrix is common in the Ordovician.

The nuculids from the Devonian of Guangxi available for this study do not preserve any ligament structures nor the microornament and inner marginal pectinations considered to be characteristic of Nuculoidea by Bailey (1983). However, some of the specimens from Guangxi (pl. 2, figs. 1-5) are much like N. opima (Hall) in shape (McAlester, 1968, pl. 13, figs. 6-15), which is the type species of Nuculoidea. Two general forms of Nuculoidea are present in the Devonian of Guangxi: (1) specimens $1-2 \mathrm{~cm}$ long in which the peaks of the umbos are posterior to the midlength of the valves (pl. 2, figs. 1-5), and (2) specimens less than $1 \mathrm{~cm}$ long, which have subcentral umbonal peaks (pl. 2, figs. 10, 11, 13). Each of these forms is here treated as a species.

Nuculoidea yongfuensis n. sp. +

Plate 2, figures 1-5

Description.-Large (1-2 cm long), anteriorly elongated shells having all shell margins convex, and the peaks of the umbos located posterior to shell midlength; shape very similar to $N$. opima (Hall). Dentition and muscle scars poorly known, comarginal ornament poorly known, and ligament structures unknown.

Types and material. $-N$. yongfuensis is known only from the type suite, which contains four specimens (GXD-031-033, 042). The holotype (GXD-033) is an articulated internal mold and is shown on plate 2 , figures 1,2 ; it measures $13.2 \mathrm{~mm}$ long, $11.2 \mathrm{~mm}$ high, and $6.3 \mathrm{~mm}$ wide (both valves). All known specimens are internal molds occurring in muddy siltstone.

Type locality.-All known specimens of $N$. yongfuensis are from the Ertang Formation (Emsian), Section 3, Bed 11, Heping Village, Yongfu County, Guangxi.

Etymology.-This species is named after Youngfu County in northeast Guangxi, about $75 \mathrm{~km}$ northwest of Guilin City.

Remarks and comparisons. $-N$. yongfuensis is very similar in shape and placement of the peaks of the umbos to $N$. opima (Hall), the type species of the genus (McAlester, 1968, pl. 13, figs. 6-15). Unfortunately, the specimens from Guangxi preserve very little of the comarginal external ornament. In addition to comarginal ornament, $N$. opima also has fine radial ornament. Thus, ornament cannot be compared in the two species. We have placed the Chinese material in a new species; more material of $N$. yongfuensis is needed to compare differences, or additional similarities, with $N$. opima.

Nuculoidea minuta n. sp. +

Plate 2, figures $10-13$

Description.-Small Nuculoidea (less than $1 \mathrm{~cm}$ long) in which peaks of umbos are subcentral in position.
Ornament poorly preserved, consists of comarginal growth increments. Internal features unknown.

Types and material. - N. minuta is known from many specimens, all of which are various types of molds preserved in muddy siltstone; many of the specimens are distorted. The holotype (GXD-024) is shown on plate 2, figure 11; it measures $5.5 \mathrm{~mm}$ long and $4.5 \mathrm{~mm}$ high. Three paratypes (GXD-012, 016, 026) are figured (pl. 2, figs. 10, 12, 13).

Type locality-The holotype and many paratypes are from the Sipai Formation (Emsian), Section 3, Bed 13, Heping Village, Yongfu County, Guangxi.

Distribution.-In addition to the type locality, $N$. minuta is known from many paratypes on a small slab (GXD-034) from the Mahuangling Member, Nagaoling Formation (Gedinnian), Section 1, Bed 13, Liujing Village, Hengxian County, Guangxi.

Etymology.-Latin minutus, meaning small, referring to the size of the shell.

Remarks.-Many small molds placed in N. minuta are distorted; in some, the height is accentuated (pl. 2, fig. 10); in some, the length is increased (pl. 2, fig. 12). The holotype (pl. 2, fig. 11) is one of the least distorted specimens.

\section{Nuculoidea cf. N. lirata (Conrad), 1842*}

Plate 3, figure 1

Discussion.-A single free articulated distorted composite mold (USNM 374549) having erect umbos from Michigan, is herein assigned to Nuculoidea. The shell shape is typical of the genus, and the ornament is most similar to N. lirata (Conrad) (pl. 3, figs. 2-4). Bailey (1983, p. 255) suggested that $N$. lirata differs from $N$. opima (type species of Nuculoidea) only in its coarsely lirate, normally nonfasciculate growth increments. He went on to say that some specimens are intermediate in ornament between $N$. lirata and $N$. opima (pl. 3, fig. 3; McAlester, 1968, pl. 13, figs. 6-15) and that perhaps the two names have been applied to the extremes in ornament variation of a morphocline. However, Bailey continued to recognize $N$. lirata as a distinct species. Both $N$. opima and N. lirata are common in Hamiltonian (Middle Devonian) rocks of New York, and species close to $N$. opima are known from the Lower and Middle Devonian of Germany (Beushausen, 1895, pl. 4, figs. $13,15,16)$ and the Emsian of China (pl. 2, figs. 1-5).

Nuculoidea is a common genus in the Middle Devonian of New York; however, only the single specimen shown on plate 3 , figure 1 , was found in the collections available to us from Michigan. This specimen is from the Norway Point Formation at Norway Point Dam, Thunder Bay River, Alpena County, Mich.

\section{Genus NUCULOPSIS Girty, 1911}

Diagnosis.-Inequilateral Paleozoic nuculids with opisthogyrate beaks and umbos pointing toward shorter posterior end of shell. 
Discussion.-Nuculopsis is a cosmopolitan postDevonian Paleozoic nuculid, which has a geographically more restricted Devonian distribution (Bailey, 1979). Externally, Nuculopsis is most readily separated from Nuculoidea by its strong opisthogyrate umbos, the beaks of which point posteriorly (pl. 2, fig. 9). Internally, Nuculopsis lacks the marginal pectinations of Nuculoidea (Bailey, 1983, fig. 26G) and, according to Bailey (1979), has a more protruding resilifer. Bradshaw (1974, p. 449) noted that the inner ventral margin of some Nuculoidea is microscopically crenate.

Hall $(1883,1885$, pl. 46, all figs. except 35,36$)$ figured three species of nuculids from the Middle Devonian (Hamiltonian) of New York that have opisthogyrate umbos and externally are much like Nuculopsis - "Nucula" bellistriata (Conrad), " $N$." varicosa Hall and Whitfield, and " $N$." corbuliformis Hall and Whitfield. None of Hall's figures or discriptions indicate the presence of marginal pectinations or the preservation of the resilifer. Specimens of $N$. corbuliformis available to us (pl. 3, figs. 5, 6) do not show marginal pectinations and do not preserve the resilifer. On the basis of external features, the species described by Hall $(1883,1885)$ are assignable to Nuculopsis. However, Bailey (1983, p. 245) noted: "Except for the occurrence of Nuculopsis Girty in the Michigan Basin (Bailey, 1979), all other North American Devonian bona fide nuculids I have examined belong to a single genus, Nuculoidea." Bailey (1979) placed "Nucula" corbuliformis in Nuculoidea and regarded it as ancestral to Nuculopsis. Bailey (1983, p. 254-255) noted: "***a fine specimen [of Nucula corbuliformis] from the Skaneateles of New York shows the characteristic hinge and resilifer [of Nuculoidea] ${ }^{* * *}$ "No mention is made of marginal pectinations. The resilifer of most species of Nuculoidea is not known, and in at least one species of Nuculopsis from the Pennsylvanian of Texas (pl. 3, fig. 7), the resilifer differs little from Nuculoidea deceptriformis Bailey (1983, fig. 26).

Yang (1939) named and described the Michigan Basin Devonian species of Nuculopsis as Nuculoidea gibbosa n. sp. Unfortunately, his Ph.D. thesis relating to this species was not published. Yang herein notes that, on the basis of new knowledge gained since his manuscript was written, his proposed species $N$. gibbosa should be assigned to Nuculopsis. Herein, this species is treated as Nuculopsis gibbosa Yang n. sp. in Pojeta, Zhang, and Yang (below). Bailey (1979) regarded the Michigan Basin Devonian Nuculopsis as a new species but did not name it.

Nuculopsis gibbosa Yang n. sp.*

Plate 2, figures 7-9

1939. Nuculoidea gibbosa Yang, The Molluscs of the Traverse Group (Middle Devonian) of Michigan. A dissertation presented to the faculty of the Graduate School of Yale University in Candidacy for the Degree of Doctor of Philosophy, p. 7, pl. 1, figs. 1-5; unpublished.

Description.-Small, anteriorly elongated shells; ventral shell margin gently convex, anterior and posterior shell margins convex and about equally rounded; peaks of gibbous opisthogyrate umbos located posterior to shell midlength; anterodorsal margin almost straight, posterodorsal margin concave; ornament of comarginal growth lines, not well preserved. Dentition of long anterior and short posterior rows of taxodont teeth separated by a resilifer, all poorly preserved. Muscle scars not preserved.

Types and material. $-N$. gibbosa is known only from the type suite that contains 44 silicified specimens, most of which are articulated. The holotype (YPM 16426; pl. 2, figs. 8,9 ) is $9.3 \mathrm{~mm}$ long, $7 \mathrm{~mm}$ high, and $5.6 \mathrm{~mm}$ wide (both valves). In addition to the holotype, a paratype (USNM 374548) is figured on plate 2, figure 7; all unfigured paratypes are cataloged under USNM 388220.

Type locality.-All known specimens are from the Potter Farm Formation 0.25 miles south of Four Mile Dam, Alpena County, Mich.

Etymology.-Latin gibbus, meaning protuberant, referring to the umbos and width of the articulated valves.

Comparisons. - In general shell form, $N$. gibbosa is most similar to some of the specimens of "Nucula" corbuliformis figured by Hall $(1883,1885$, pl. 46, figs. 31,32$)$.

\section{Nuculopsis? sp. A+ \\ Plate 2, figure 6}

Discussion.-One specimen from Guangxi (GXD-041), which is a composite mold, may belong to Nuculopsis. The specimen is squashed in mudstone, but it does have the beak turned toward the shorter end of the shell and there appears to be a small resilifer. The specimen has a shape similar to that of Nuculanella piedmontia Tasch (McAlester, 1968, pl. 13, figs. 1-5), which Dickins (1963) treated as a subgenus of Nuculopsis, but which McAlester (1969a) regarded as a synonym of Nuculopsis. The general shape of Nuculopsis? sp. A is somewhat similar to the shape of Similoconcha symmetrica Zhang (1977, pl. 189, fig. 2); however, the latter species has an upright umbo, whereas Nuculopsis? sp. A has the umbo turned toward the shorter end of the shell. Specimen GXD-041 is from mudstone of the Yingtang Formation (Eifelian), Section 5, Bed 16, Luoban Village, Luoxiu Community, Xiangzhou County, Guangxi.

\section{Genus SIMILOCONCHA Zhang, 1977}

Diagnosis.-Equilateral Paleozoic nuculids having erect beaks and umbos; resilifer erect and separating tooth rows. 
Similoconcha? sp. At

Plate 3, figures 8, 9

Discussion.-Two approximately equilateral internal molds (GXD-039, GXD-040) from two localities are tentatively assigned to Similoconcha Zhang (1977). One of the specimens shows remnants of taxodont dentition (pl. 3, fig. 9) and suggests the presence of a resilifer below the beaks (pl. 3, figs. 8, 9). Similoconcha is among the oldest known nuculids to show a resilifer.

Similoconcha? sp. A occurs in the calcareous shale of the Sipai Formation (Emsian), Section 3, Bed 13, Heping Village, Yongfu County, Guangxi, and mudstone of the Yingtang Formation (Eifelian), Section 5, Bed 16, Luobang Village, Luoxiu Community, Xiangzhou County, Guangxi.

Superfamily NUCULANACEA Adams and Adams

Posteriorly elongate palaeotaxodonts with or without resilifer and pallial sinus.

Family NUCULANIDAE Adams and Adams

Nuculanaceans with resilifer and internal ligament.

Genus PHESTIOIDEA n. gen.

Type species.-Phestioidea obtusa $\mathrm{n}$. sp. is here designated the type species of the new genus Phestioidea.

Diagnosis.-Paleozoic nuculanids, which are not strongly attenuated posteriorly, lack thickened internal umbonal ridges, and have arcuate ventral margin.

Description.-Small- to medium-sized nuculanids, as long as $30 \mathrm{~mm}$; ornament probably only comarginal growth increments; shell highest in region of beaks, obtusely attenuated and blunt posteriorly, broadly rounded anteriorly and ventrally; beaks probably opisthogyrate. Anterior and posterior taxodont tooth rows interrupted by resilifer; adductor muscle scars isomyarian, one pair of posterior pedal retractor muscle scars confluent with and extending forward from the dorsal part of the posterior adductor muscle scars, pallial line integripalliate, other muscle scars not preserved.

Stratigraphic distribution.-Yujiangian (Pragianlower Zlichovian) of Guangxi, China.

Etymology.-The generic name is derived from the genus Phestia Chernyshev and the Greek suffix -oidea meaning having the form of. Gender feminine.

Remarks and comparisons.-Phestioidea obtusa has a resilifer, which interrupts the taxodont tooth rows beneath the beak (pl. 4, figs. 1-6), and is one of the oldest known species to have this internal ligament support. The known specimens of $P$. obtusa are internal molds and do not preserve the beaks well, but the curvature of the beaks is probably opisthogyrate (pl. 4, figs. 2, 6).
None of the known specimens of $P$. obtusa unequivocally preserve the external ornament, but comarginal ornament is characteristic of nuculanids. Orientation of fossil palaeotaxodonts is difficult to determine because living species can be elongated anteriorly or posteriorly. Nuculanids are posteriorly elongated, and many have an elongate, posterior pedal retractor muscle scar extending anteriorly from the dorsal side of the posterior adductor muscle scar (Bradshaw, 1978, figs. 4, 6B, 7B, 8B, 9) as in Phestioidea (pl. 4, figs. 3, 6). In many nuculanids, the anterior pedal muscle scars are not elongate (Bradshaw, 1978, figs. 4, 9, 12B, 13).

In shape, Phestioidea is most like the Paleozoic palaeotaxodont Phestia (pl. 4, figs. 9, 10), but Phestioidea is not strongly attenuated posteriorly; also, Phestioidea lacks the characteristic thickened internal umbonal ridge, or ridges, present in Phestia (pl. 4, figs. $9,10)$.

\section{Phestioidea obtusa n. sp. + \\ Plate 4, figures 1-6}

Diagnosis.-Narrow Phestioidea.

Description.-Posteriorly elongate, narrow shells having convex anterior, ventral, and posterior shell margins.

Types and material. $-P$. obtusa is known only from the type suite which contains four specimens. The holotype (GXD-070) is shown on plate 4, figures 4-6 and measures $23.5 \mathrm{~mm}$ long, $18.7 \mathrm{~mm}$ high, and $6 \mathrm{~mm}$ wide (both valves). A paratype (GXD-068) is shown on plate 4, figures 1-3. All types are free internal molds and were collected in place from calcareous mudstone. The narrowness of the molds may have been exaggereated by post-depositional compaction.

Type locality.-All known specimens are from the Liujing Member, Yujiang Formation (Pragian-lower Zlichovian), Section 1, Bed 29, Liujing Railway Station, Hengxian County, Guangxi.

Etymology.-Latin obtusus, meaning blunt, referring to the lack of pronounced posterior shell attenuation.

Remarks.-Phestioidea obtusa is at present the only known species assigned to Phestioidea.

\section{Genus PSEUdONUCULANA n. gen.}

Type species.-Pseudonuculana zhaoi is here designated the type species of the new genus Pseudonuculana.

Diagnosis.-Paleozoic nuculanids that are not posteriorly attenuated, lack internal umbonal ridges, and have ventral margin subparallel to dorsum.

Description.-Small nuculanids, as long as $25 \mathrm{~mm}$; ornament of comarginal growth lines with broad comarginal rugae in mature part of shell; shell highest in region of beaks, elongated but not attenuated posteriorly, 
posterodorsal and posteroventral margins subparallel, extreme posterior area may be turned dorsally; anterior and posterior shell margins broadly rounded; beaks opisthogyrate. Teeth taxodont, posterior tooth row horizontal and forming an obtuse angle with the oblique anterior tooth row; adductor muscle scars isomyarian, occurring at the distal ends of the tooth rows; single pair of posterior pedal muscle scars located dorsal and anterior to posterior adductor muscle scars, not confluent with the latter; single pair of accessory muscle scars anterior to posterior pedal retractor muscle scars may represent the insertions of the posterior visceral floor muscles; other muscle scars not preserved. Ligament internal, supported by resilifer.

Stratigraphic distribution.-Yujiangian (Pragianlower Zlichovian)-Yingtangian (Eifelian) of Guangxi, China.

Etymology.-Greek pseudo, meaning false, and the generic name Nuculana Link, gender feminine.

Remarks and comparisons.-One specimen of Pseudonuculana zhaoi preserves the filling of the resilifer ( $\mathrm{pl}$. 5, figs. 1-3), a second shows very small taxodont teeth (pl. 5, fig. 4) in the region of the beak; this is a similar arrangement of the resilifer and teeth to that found in living Yoldia (pl. 4, fig. 8), in which very small taxodont teeth are above the resilifer in the region of the beaks.

Pseudonuculana differs from Phestioidea in having a length-height ratio approaching $2 / 1$, whereas in Phestioidea the length is only about one-third more than the height; the ventral margin of Pseudonuculana is about straight, whereas that of Phestioidea is broadly arcuate. Both Nuculana (pl. 3, fig. 10) and Phestia (pl. 4, figs. 9, 10) are markedly attenuated posteriorly, whereas in Pseudonuculana the posterodorsal and posteroventral margins are subparallel, and the height of the posterior part of the shell is about the same as that of the anterior end.

Pseudonuculana zhaoi n. sp. +

Plate 4, figure 7; plate 5 , figures $1-10$

Diagnosis.-Pseudonuculana with peglike teeth.

Description.-Posteriorly elongated wide shells with convex anterior and posterior shell margins, ventral shell margin almost straight, may be upturned posteriorly; ornament in mature part of shell consists of a few broadly defined growth rugae.

Types and material. $-P$. zhaoi is known only from the type suite that has 13 specimens. The holotype (GXD-078) is an internal mold shown on plate 5, figures $1-3$, and measures $21.8 \mathrm{~mm}$ long, $13 \mathrm{~mm}$ high, and $8.2 \mathrm{~mm}$ wide (both valves). Seven paratypes are figured on plate 4, figure 7 , and plate 5, figures 4-10. All types are internal or composite molds collected in place from mudstones or calcareous mudstones. The internal molds (pl. 5, figs. 1-4, 8) are articulated, were collected from calcareous mudstones, and show no post-depositional distortion; the composite molds (pl. 5, figs. 5-7, 9, 10) are disarticulated single valves occurring in mudstones and show compaction of the width of the shell so that the umbos are not as prominent as in the articulated internal molds.

Type locality.-The holotype and five paratypes of $P$. $z$ haoi are from the Liujing Member, Yujiang Formation (Pragian-lower Zlichovian), Section 1, Bed 29, Liujing Railway Station, Hengxian County, Guangxi.

Distribution.-In addition to the occurrence at the type locality, paratypes also occur in the Upper Member, Yingtang Formation (Eifelian), Section 5, Bed 16, Luoban Village, Luoxiu Community, Xiangzhou County, Guangxi.

Etymology.-The species is named for Zhao Mente, Guangxi Institute of Geology, who helped Zhang collect the material described here.

Remarks.-Pseudonuculana zhaoi is, at present, the only species assigned to Pseudonuculana. "Nuculana" lodenensis Beushausen (1895, pl. 4, fig. 30) from the Emsian (upper Coblenzian) of Germany has a shape very much like that of Pseudonuculana zhaoi; however, "Nuculana" lodenensis is known only from one poorly figured specimen.

\section{Genus PHESTIA Chernyshev, 1951}

Diagnosis.-Paleozoic nuculanids having internal umbonal ridge or ridges.

Discussion.-For many years, Paleozoic opisthogyrate nuculaniform shells with fine external ornament were placed in the genus Nuculana Link (=Leda Schumacher) (pl. 3, fig. 10), which they closely resemble in shape (pl. 6; pl. 7, figs. 1-3, 12). McAlester (1962) suggested that the name Nuculana is inappropriate for Paleozoic species; in part, this was because Carboniferous species lack the pallial sinus of living forms. McAlester (1969b, p. N237, N239) limited the name Nuculana to Mesozoic and Cenozoic species and indicated that the name Phestia Chernyshev is appropriate for Devonian-Lower Triassic nuculanids that are not yoldiaform. Phestia has simple comarginal ornament, lacks a pallial sinus, and has internal umbonal ridges (pl. 4, figs. 9, 10). Polidevcia Chernyshev (1951) and Culunana Lintz (1958) are generally regarded as synonyms of Phestia (McAlester, 1969b, p. N238). Paleozoic nuculaniform shells with strong external ornament are placed in Girtyana Elias (1956) and Glyptoleda Fletcher (1945) (McAlester, 1968, pls. 35, 36).

North American Devonian nuculanids are known largely from external molds (Hall, 1883, 1885; Pohl, 1929; McAlester, 1962). They show variation in the strength of the comarginal ornament, curvature of the dorsal margin, and the amount and length of the attenuated posterior rostral end of the shell (pl. 6, figs. 1-4, 
6-11). It is not known whether most of the American Devonian species have the internal umbonal ridge(s) characteristic of the genus Phestia, and the pallial line of most species is not known. One species (pl. 6, figs. $8-10$ ) has a small shell thickening posterior to the dorsalmost umbonal muscle scar and lacks a pallial sinus (pl. 6, fig. 10). The small umbonal ridge of this species does not compare in size to that of younger Paleozoic species (pl. 4, figs. 9, 10). Two Michigan species of opisthogyrate posteriorly attenuated nuculanids have fine comarginal ornament. One of these (pl. 6, fig. 11) shows a prominent umbonal ridge, the other is known only from silicified articulated replicas; both species are herein placed in Phestia.

The Chinese opisthogyrate posteriorly attenuated nuculaniform specimens available for this study are preserved in siltstone or in leached limonitic mudstone as composite or internal molds (pl. 6, fig. 5; pl. 7, figs. $1-3,12)$. They do show various details of dentition, musculature, and resilifer; none of them show any internal umbonal ridges and none preserve the pallial line. Some (pl. 7, figs 1,3) show an internal posterodorsal ridge similar to that known in some Holocene species of Nuculana (pl. 3, fig. 10). The Chinese species are herein placed in Nuculana?.

\section{Phestia ef. P. brevirostris (Hall \& Whitfield), 1869*}

Plate 6, figures 3, 4

Discussion.-In Michigan, this taxon is known from numerous small silicified specimens that have a short posterior rostral attenuation resulting in a ratio of the length of the shell between the anterior end and the peaks of the umbos to the total length of the shell of 0.35-0.40. In Phestia diversa (Hall), this ratio is about 0.30 (pl. 6, figs. 1,2 ), and in $P$. rostellata (Conrad) it is about $0.20-0.28$ (pl. 6, figs. $6-10$ ).

No interiors of the Michigan specimens of $P$. cf. $P$. brevirostris are known, and thus whether they possess the internal umbonal ridge(s) typical of Phestia is uncertain. The shell shape and the ratio of the length of the shell between the anterior end and the peaks of the umbos to the total length of the shell of $P$. cf. $P$. brevirostris are very close to those of the type species of Phestia, Leda inflatiformis Chernyshev (Chernyshev, 1951, pl. 1; McAlester, 1968, pl. 34).

According to the label, $P$. cf. $P$. brevirostris is known from the "Potter Farm Formation, on the road between 0.25 and 0.6 miles south of 4-Mile Dam, center of sec. 18, T. 31 N., R. 8 E., Alpena County, Michigan."

Phestia sp. A*

Plate 6, figure 11

Discussion.-This species is known from one posteriorly incomplete internal mold, which preserves subequal anterior and posterior tooth rows, a slight internal umbonal ridge, and a posterodorsal sulcus. The area of the mold beneath the beak is highly crystalline, and presence of a resilifer cannot be determined with certainty, but this seems likely. This specimen is from the Petoskey Formation at the Northern Lime Company Quarry (locality 18, Pohl, 1930), Petoskey, Emmet County, Mich.

\author{
Genus NUCULANA Link \\ Nuculana? acutirostra n. sp.+ \\ Plate 6, figure 5; plate 7, figure 12
}

Diagnosis.-Posteriorly strongly attenuated and lacking a posterodorsal rib.

Description.-Posteriorly elongated and attenuated shells that are more gibbous than those of Phestioidea. Anterior shell margin convex, ventral shell margin a broad arc that posteriorly forms an acute angle with the dorsal shell margin. Beaks opisthogyrate, external ornament of fine growth lines. Teeth peglike, muscle scars poorly known, adductors isomyarian.

Types and material.-N.? acutirosta is known only from the type suite, which contains three specimens. The holotype (GXD-072) is a composite mold, shown on plate 6 , figure 5 , and measures $26.9 \mathrm{~mm}$ long, $17.3 \mathrm{~mm}$ high, and more than $4.1 \mathrm{~mm}$ wide (single valve, umbo distorted parallel to bedding). All types are composite molds of single valves preserved in matrix and collected in place.

Type locality.-The holotype and both paratypes of $N$.? acutirostra were collected from the black silty mudstone of the Ertang Formation (Emsian), Section 3, Bed 10, Heping Village, Yongfu County, Guangxi.

Etymology.-Latin acutus, meaning sharp or pointed, and Latin rostrum, meaning beak or snout, referring to the acute, attenuated posterior end of the shell.

Remarks and comparisons.-Nuculana? acutirosta differs from $N$.? planumbona in its length-height ratio, in its width of a single valve, in being more rostrate posteriorly, in having inflated umbos, and in lacking an internal posterodorsal rib.

\section{Nuculana? planumbona n. sp. + \\ Plate 7, figures 1-3}

Diagnosis.-Not as posteriorly attenuated as $N . ?$ acutirostra and having a posterodorsal rib on the posteroumbonal slope.

Description.-Posteriorly elongated, but not strongly attenuated shells which are less gibbous than those of $N$. acutirostra and which have a single internal posterodorsal rib on the posteroumbonal slope. Anterior 
and posterior shell margins convex, ventral shell margin broadly arcuate. Beaks opisthogyrate, umbo not inflated, ornament unknown. Resilifer present, teeth unknown, adductor muscle scars isomyarian.

Types and material. -N.? planumbona is known only from the type suite, which contains six specimens; all are disarticulated internal molds, and the external ornament is not known. The holotype (GXD-076) is shown on plate 7, figure 3 , and measures $16.5 \mathrm{~mm}$ long, $7.4 \mathrm{~mm}$ high, and $1.9 \mathrm{~mm}$ wide. All types are single valves preserved in matrix and collected in place.

Type locality.-All known specimens of N.? planumbona were collected from the lower part of the Upper Member, Yingtang Formation (Eifelian), Section 5, Bed 16, Luoban Village, Luoxiu Community, Xiangzhou County, Guangxi.

Etymology.-Latin planus, meaning even, flat, and Latin umbo, meaning boss or knob, referring to the lack of umbonal inflation of the shell.

\section{Family MALLETIIDAE Adams and Adams}

Nuculanaceans lacking a resilifer and having an external ligament.

Discussion.-In the lower Paleozoic, there are two main groups of malletiids. Group 1 has a well-developed, commonly narrow and prominent, anterior buttress on each valve separating the anterior adductor muscle scar from the umbonal cavity. Most members of Group 1 are placed in Nuculites Conrad which has a stratigraphic range of Llanvirnian-Upper Devonian (Upper Carboniferous?, Zhang, 1977, 1980). Group II includes the malletiids, which lack the well-developed anterior buttresses, show greater generic diversity than Group I, and are known from rocks as old as Tremadocian; in the Devonian of Guangxi, Group II is represented only by the genus Palaeoneilo Hall and Whitfield.

\section{Genus NUCULITES Conrad, 1841}

Diagnosis.-Paleozoic malletiids having prominent anterior buttresses behind anterior adductor muscle scar.

Discussion.-The range of shape variation included in Nuculites is great and in the Devonian encompasses the following types of shells: Type 1 includes elongated species that show a rectangular lateral profile, such as the type species of the genus $N$. oblongatus Conrad (pl. 8 , figs. 5-7), in which the shell is only slightly attenuated posteriorly, length is significantly greater than height, and the posterior end of the shell is erect or broadly rounded. Type 2 includes species that show a subsquare lateral profile, such as $N$. triqueter Conrad (pl. 8, fig. 8), in which length and height are subequal. Type 3 includes elongated cuneiform species that have a prominent posteroumbonal carina, such as $N$. cuneiformis Conrad (Hall, 1883, pl. 47, figs. 13-15), in which the shell is wedgeshaped and attenuated toward the posteroventral point so that there is a marked decrease in shell height posteriorly. Type 4 includes elongated species such as $N$. solenoides (Goldfuss) (Beushausen, 1895 , pl. 5, figs. 17-19), in which the shell is nuculaniform, attenuated toward the posterodorsal point, and may have a concave dorsal margin (Nuculites sp. B, pl. 8, figs. 1-4). Bailey (1983, fig. 39) showed how these various shapes may intergrade. Because of the relatively simple conchology of Nuculites and the intergrading shell shapes, traditonal guides to subdividing a pelecypod complex into generic level taxa cannot be used. For the present, Nuculites continues to be a very broad concept, based largely on the presence of prominent anterior buttresses; it is not certain that Nuculites forms a phylogenetic entity.

Most of the specimens of Nuculites from Guangxi are distorted and not well preserved, but two of the four types of shells mentioned above are present; these are treated in open nomenclature.

$$
\begin{gathered}
\text { Nuculites sp. } \mathbf{A}+ \\
\text { Plate 7, figures 7, } 8
\end{gathered}
$$

Discussion. - Nuculites sp. A has a Type 1 shell shape and is similar to $N$. oblongatus. Two specimens (GXD-051, GXD-052) are known from Locality 7 at Xinxu Village, Mengshan County, Nagaoling Formation (Gedinnian).

\author{
Nuculites sp. B+ \\ Plate 8, figures 1-4
}

Discussion. - Nuculites $\mathrm{sp.} \mathrm{B} \mathrm{has} \mathrm{a} \mathrm{Type} 4$ shell shape and is known from 15 fairly complete specimens from the Ertang Formation (Emsian), Section 4, Beds 11, 17, 30 , and 36, Liufengshan Hill, Wuxuan County, Guangxi (GXD-043-050; 061-064); the Sipai Formation (Emsian), Section 3, Bed 13, Heping Village, Yongfu County, Guangxi (GXD-080); and the Ertang Formation (Emsian), Section 2, bed unknown, Dale Village, Xiangzhou County, Guangxi (GXD-521A), and from Bed 8 at the same section (unpub. data, Zhang).

\section{Genus PALAEONEILO Hall and Whitfield, 1869}

Diagnosis.-Paleozoic malletiids lacking prominent anterior buttresses.

Discussion.-Palaeoneilo, like Nuculites, is a widely used generic name for species ranging in age from Tremadocian to Jurassic. The species included in the genus are longer than high, generally have dominant comarginal ornament, and lack well-developed buttresses; some have a shell thickening behind the anterior adductor muscle scar (Bailey, 1983). Some specimens of Palaeoneilo constricta (Conrad), the type species of the genus, have a sulcus on the posterior umbonal slope 
that extends to the posteroventral shell margin (McAlester, 1968, pl. 15, figs. 5, 7), and at least two species, including $P$. constricta, have a pallial sinus (McAlester, 1963, Bailey, 1983). The range of shell-shape variation is less than that in Nuculites (Hall, 1883, pls. 48-50; McAlester, 1963, pls. 121-122; Bailey, 1983, figs. 40-44). In a general way, in Devonian rocks, comarginally marked malletiids, lacking a well-formed buttress, are placed in Palaeoneilo; McAlester (1969c) listed nine synomyms of Palaeoneilo described from rocks ranging in age from Ordovician to Pennsylvanian. Because of the relatively simple conchology, it is not clear that the concept Palaeoneilo is phylogenetic; Paleoneilo may be a name for a morphological grade of organization for convergent homeomorphs.

As with Nuculites, the specimens from Guangxi assigned to Palaeoneilo are not well preserved. Two general types of Palaeoneilo are present in the Devonian of Guangxi and are treated in open nomenclature.

Palaeoneilo sp. A+

Plate 7, figure 10

Discussion.-This taxon is represented by two specimens, which are much like a topotype of $P$. constricta figured by McAlester (1968, pl. 15, figs. 2, 11) in shape. This kind of Palaeoneilo is characterized by a markedly arcuate ventral margin, which is not subparallel to the dorsal margin. Specimens GXD-053 and GXD-063 are from the Ertang Formation, Section 3, Bed 10, and the Sipai Formation, Section 3, Bed 13, Heping Village, Yongfu County, Guangxi.

Palaeoneilo sp. B+

Plate 7 , figures $11,13-15$

Discussion.-This taxon is characterized by a less markedly arcuate ventral shell margin than in $P$. sp. A. The ventral shell margin is subparallel to the dorsal margin as in P. beushauseni (Kegel) (Bailey, 1983, fig. 41L) and $P$. filosa (Conrad) (Bailey, 1983, fig. 44F, J, L). $P$. sp. B is known from five specimens. Specimens GXD-065-067 are from the Donggangling Formation (Givetian), Section 2, Bed unknown, Dale Village, Xiangzhou County, Guangxi. Specimen GXD-062 is from the Ertang Formation (Emsian), Section 3, Bed 10, Heping Village, Yongfu County, Guangxi; specimen GXD-054 is from the Sipai Formation (Emsian), Bed 12 , at the same section.

Palaeoneilo emarginata (Conrad), 1841*

Plate 7, figures 4-6

Discussion.-P. emarginata is the oldest name available for a group of species assigned to Palaeoneilo, which have prominent comarginal rugae and a pronounced sulcus or fold on the posterior umbonal slope.
In addition to $P$. emarginata, included in this group are $P$. perplana Hall and Whitfield, $P$. truncata Hall, $P$. sulcatina (Conrad), and $P$. corrugata Pohl. Bailey (1983) has considered the possible synonyms of $P$. emarginata both in America and in Germany. Sulci and folds in the posterior umbonal slope of Palaeoneilo are variably developed and can be prominent as in the above species, or they can be subdued (Hall, 1885, pls. 48, 49; Beushausen, 1895, pl. 7; Pohl, 1929, pl. 4; McAlester, 1968, pl. 15; Bailey, 1983, figs. 41, 44P).

The specimens here placed in $P$. emarginata are from the Potter Farm Formation, Alpena Cemetery Pits, Alpena County, Mich. (YPM 16429), and the Jordan River Formation, 1 mile north of Norwood, Charlevoix County, Mich., on the shore of Lake Michigan (YPM 16427, 16428). The stratigraphic occurrence in Michigan is consistent with information from New York where Hall (1885) and Bailey (1983) recorded $P$. emarginata as occurring in the Hamilton and lower Chemung Groups (Middle-Upper Devonian), and Wisconsin where Pohl (1929) recorded $P$. corrugata from the Milwaukee Formation (Givetian). Bailey (1983) regarded $P$. corrugata as a synonym of $P$. emarginata. $P$. perplana occurs in the Hamilton Group of New York; $P$. truncata and $P$. sulcatina are from the Lower Mississippian of Ohio. To date, no species of Palaeoneilo similar to $P$. emarginata have been found in the Devonian of South China.

Palaeoneilo bisulcata Hall and Whitfield was made the type species of Bicrenula Williams and Breger (McAlester, 1968, pl. 25, figs. 1, 2). It is very similar to Palaeoneilo emarginata but has two posteroumbonal sulci. Bicrenula occurs in the Chemung (Upper Devonian) stage of New York. Zhang (1977, p. 476) reported Bicrenula from the Middle Devonian Qiziqiac Formation (Givetian) of Hunan Province. Metapalaeoneilo Lamcke (McAlester, 1968, pl. 25, figs. 3-11) from the Upper Silurian erratics of Germany has ornament very much like that of Palaeoneilo emarginata, but has pronounced anterior buttresses.

\section{Subclass UNCERTAIN Order UNCERTAIN Superfamily UNCERTAIN \\ Family ANTACTINODIONTIDAE Guo, 1980}

Type genus.-Antactinodion Guo, 1980.

Description.-Posteriorly elongated, small to medium-sized, equivalved pelecypods that have comarginal ornament of variable strength. Hinge with bladelike cardinal teeth radiating from beneath the beak, and several posterior lateral teeth commonly subparallel to the dorsal margin; the cardinal and posterior lateral teeth are separated by an edentulous space. Ligament type uncertain. Anterior adductor muscle scar 
deep, commonly with a buttress on its posterior side; posterior adductor muscle scar poorly known, shallow, subanisomyarian to anterior adductor muscle scar. Pedal muscle scars and pallial line unknown.

Stratigraphic and geographic distribution.-Lower Devonian (Gedinnian-Emsian) of Guangxi and Yunnan, China, and adjacent parts of northern Vietnam. To date, this family is endemic to southeast Asia, and its relatively restricted stratigraphic range indicates usefulness of its constituent taxa as index fossils.

Constituent genera.-Antactinodion Guo, 1980, (Gedinnian), Yunnan and Guangxi, China; Dysodonta Mansuy, 1913 (Gedinnian-Emsian), Guangxi and Yunnan, China, and northern Vietnam; and Leiodysodonta n. gen. (Gedinnian-Emsian), Guangxi and Yunnan, China, and northern Vietnam.

Comparisons and remarks.-Antactinodion is posteriorly attenuated, unlike Dysodonta and Leiodysodonta, which are higher posteriorly than anteriorly. Dysodonta has ornament of comarginal rugae, whereas Leiodysodonta has ornament of fine growth lines.

The best known genus in the family is Dysodonta, which has previously been considered by Mansuy (1913), McAlester (1968, 1969c), Liu (1976, 1979), Zhang (1977) and Guo (1980). Dysodonta is usually classified as a palaeotaxodont, but its family placement in that subclass has been varied. Typically, palaeotaxodonts have chevron-shaped taxodont teeth (pl. 4, figs. 9, 10), and many have a resilifer interrupting the tooth rows below the beak (pl. 3, figs. 7, 10; pl. 4; pl. 5, figs. 1-3).

There is confusion in the literature about whether or not Dysodonta has a resilifer, and none of the published figures show this structure in an unequivocal way. Our new material is not well enough preserved to resolve this question, and we recommend that the ligament of Dysodonta be regarded as unknown. Our review of the literature has given us the impression that a large edentulous space is present between the cardinal and posterior lateral teeth of Dysodonta (Guo, 1980, figs. 3-5) and thus the presence of a palaeotaxodontlike resilifer (pl. 3, figs. 7, 10; pl. 4, figs. 9, 10) supporting an internal ligament is unlikely.

The dentition of antactinodiontids is not typically palaeotaxodont in the following ways: (1) Although considerable variation is seen in the shape of palaeotaxodont teeth, chevron-shaped teeth are typical, and none of the teeth of antactinodiontids are chevron shaped.

FIGURE 14.-Hinge lines of antactinodiontids, all based on internal or composite molds. A, Antactinodion cuneatum Guo, left valve, $\times$ 2.3. B, Dysodonta obtusa Liu, left valve, $\times 2.3$. C, E, Leiodysodonta elliptica (Zhang), right and left valves, $\times 5 . D$, Antactinodion biradiatum Guo, left valve, $\times 5$. All from Guo (1980).
(2) There seems to be an edentulous space between the radiating cardinal teeth and the subhorizontal posterior
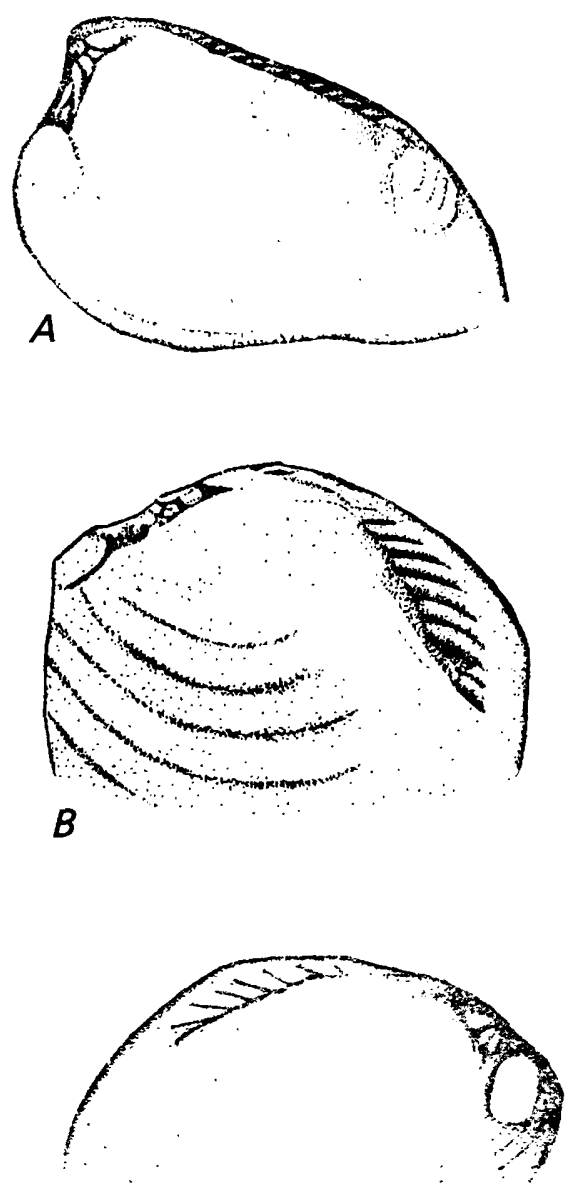

C
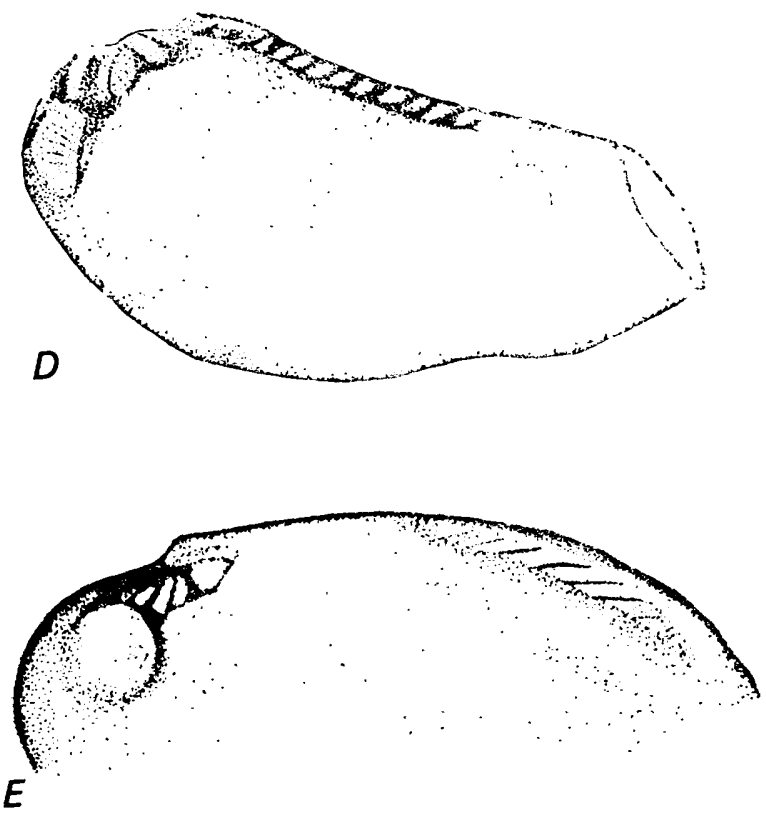
lateral teeth (Guo, 1980, figs. 1-5; fig. 14 herein) that is much larger than that ordinarily occupied by a resilifer. (3) Palaeotaxodonts ordinarily do not have subhorizontal teeth. Allen and Sanders (1973, fig. 36) described some living deep-sea palaeotaxodonts with subhorizontal teeth; these have only a small edentulous space for the resilifer, and at least in some of them the subhorizontal teeth are clearly derived from chevronshaped teeth (Pojeta and Runnegar, 1985). (4) Guo (1980) noted that the teeth of Dysodonta have denticles, which are not typical of palaeotaxondonts.

Some living mytilaceans have short suberect to subhorizontal posterior teeth similar in position to those of antactinodiontids (pl. 9, figs. 5, 12). Some mytilaceans as old as the Middle Ordovician have short teeth that radiate from beneath the beak (Pojeta, 1978, pl. 13, figs. 10, $11,14,15)$. Some arcoids, ranging widely in age, have teeth that radiate from beneath the beak and subhorizonatal lateral teeth; in the Ordovician, various arcoids have denticles on the teeth (Pojeta, 1978, pl. 9). Antactinodiontids may be palaeotaxodonts, but their subclass assignment is uncertain, and probably can be determined only when more information about their pedal and umbonal muscle scars (if any) and ligament becomes available.

Genus DYSODONTA Mansuy, 1913

Type species.-Dysodonta deprati Mansuy, 1913 (p. 9), by monotypy.

Diagnosis.-Antactinodiontids which are higher posteriorly than anteriorly, and which have comarginal rugae.

Description.-Small (a maximum of about $25 \mathrm{~mm}$ long) antactinodiontids with ornament of comarginal growth lines and rugae; shell highest posterior to beaks; numerous subhorizontal, elongate posterior teeth.

Stratigraphic and geographic distribution.-Lower Devonian (Gedinnian-Emsian) of Guangxi and Yunnan, China, and northern Vietnam. Mansuy (1913) thought that the genus was Silurian in age, but no species of Dysodonta have been found in the Silurian System as presently defined.

\section{Dysodonta angulata n. sp. +}

Plate 9, figures 1-4

1913. Dysodonta deprati Mansuy, [partim] p. 9, pl. 1, figs. 14a, b, [non] pl. 1, fig. 13a, b, 14c-f.

1968. Dysodonta deprati Mansuy [partim] McAlester, pl. 31, fig. 3, [non] figs. 1, 2, 4.

Diagnosis.-Dysodonta with strong angulation in rugae on posterior umbonal slope.

Description.-Subquadrate to posteriorly elongate shell with strong angulation in rugae on posterior umbonal slope; rugae asymmetric with short arm posterior, directed toward beaks, and subparallel to height.
Types and material. $-D$. angulata is known only from the type suite, which contains seven specimens. The holotype (GXD-091) is shown on plate 9, figure 1, and measures $7 \mathrm{~mm}$ long, $3.5 \mathrm{~mm}$ high, and $0.9 \mathrm{~mm}$ wide (one valve). Three paratypes are shown on plate 9 , figures 2-4 (GXD-092, -095, -097). All types were collected in place in red siltstones and are probably composite molds, but show no internal features. The length of the known specimens ranges from about $2 \mathrm{~mm}$ to $8 \mathrm{~mm}$.

Type locality.-The types are from the Hengxian Member, Lianhuashan Formation, (Gedinnian) Section 1, Bed 5, Liujing Village, Hengxian county, Guangxi. Distribution.-The species probably occurs in the Schists de Ban Hom (Emsian), Ban Hom Village, Van Yen District, Black-water River Basin, Nghia Lo Province, northern Vietnam (Mansuy, 1913; Liu, 1979). Mansuy (1913) considered the Schists de Ban Hom to be Silurian in age.

Etymology.-Latin angulus, meaning corner or angle, referring to the angulation in the rugae.

Remarks and comparisons. $-D$. angulata is placed in Dysodonta because of its strong rugae. $D$. angulata differs from all other species in the genus in the presence of the angulation in the rugae, which is present throughout ontogeny (pl. 9, fig. 4). The specimen of $D$. deprati figured by Mansuy $(1913$, pl. 1, figs. 14a, b) probably belongs to $D$. angulata as defined here. This specimen (McAlester 1968, pl. 31, fig. 3) shows the subhorizontal posterior lateral teeth and anterior adductor muscle scar.

\section{Genus LEIODYSODONTA n. gen.}

Type species.-Dysodonta guangxiensis Zhang, 1977 is here designated the type species of the new genus Leiodysodonta.

Diagnosis.-Antactinodiontids which are higher posteriorly than anteriorly and which have fine comarginal growth increments.

Description.-Small to medium-sized (as long as $30 \mathrm{~mm}$ ) antactinodiontids with ornament of fine growth lines, rugae absent; shell highest posterior to beaks. Anterior adductor, anterior buttress, and teeth typical of family.

Etymology.-Greek leios, meaning smooth, referring to the lack of rugae, and the genus Dysodonta, which Leiodysodonta resembles in other ways. Gender feminine.

Stratigraphic and geographic distribution.Gedinnian-Emsian (Lower Devonian), Guangxi and Yunnan, China, and northern Vietnam.

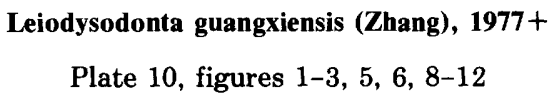

1977. Dysodonta guangxiensis Zhang, p. 477, pl. 189, fig. 24. 1977. Dysodonta beiliuensis Zhang, p. 477, pl. 189, fig. 25. 
Diagnosis.-Posteroventrally elongate Leiodysodonta. Description.-Shells posteroventrally elongate so that angle of obliquity between dorsal margin and midumbonal ridge is more than $50^{\circ}$, umbos narrowly rounded. Dorsal shell margin short, almost straight; anterior shell margin broadly rounded; anteroventral shell margin oblique and almost straight; posterior shell margin oblique, forming a broad arc or almost straight. Anterior teeth not known, posterior lateral teeth subhorizontal. Anterior adductor muscle scar deeply impressed with a buttress along its posterior edge.

Types and material.-The holotype (GM-IV55031) of $L$. guangxiensis is shown on plate 10 , figure 8 ; it is about $20 \mathrm{~mm}$ long and $15 \mathrm{~mm}$ high. The holotype (GMIV55034) of Dysodonta beiliuensis is shown on plate 10, figure 1; it is about $12 \mathrm{~mm}$ long and $10 \mathrm{~mm}$ high. In addition to the holotypes of these synonyms, we had 18 other specimens of Leiodysodonta guangxiensis; 6 of these are figured on plate 10 , figures $2,3,5,6,9-12$. All specimens of $L$. guangxiensis are internal or composite molds that were collected in place.

Type locality.-The holotype is from the Lianhuashan Formation (Gedinnian), at Changtang Village, Yongning County, Guangxi.

Distribution.-L. guangxiensis is also known from the Yujiang Formation (Pragian-lower Zlichovian), Minle Village, Beiliu County, Guangxi (holotype of Dysodonta beiliuensis) and the silty Liukankou and Hengxian Members, Lianhuashan Formation (Gedinnian), Section 1, Beds 5, 6, Liujing Village, Hengxian County, Guangxi.

Remarks and comparisons.-In general shape, $L$. guangxiensis is much like Ordovician species of Eurymya Ulrich (Pojeta, 1978, pl. 13, figs. 1, 3,6) and Silurian species of Eurymyella Williams (pl. 10, figs. 4, 7), both of which have a few cardinal teeth radiating from beneath the beak and strongly impressed anterior adductor muscle scars and buttresses. Eurymya and Eurymyella lack posterior teeth and appear to be related to the modiomorphid isofilibranchs.

L. guangxiensis occurs in silty mudstones, the shell is not preserved, and the molds are readily distorted. The amount and direction of distortion depends on the position of the specimens in the rock relative to bedding. Single valves parallel to bedding commonly have the umbos flattened (pl. 10, fig. 10). Articulated valves with the dorsal-ventral direction at right angles to bedding are compressed in that direction so that the umbos are accentuated and the shell elongated anteriorly-posteriorly (pl. 10, fig. 3). Many articulated valves at other directions to bedding have the umbos flattened and more angular than normal (pl. 10, figs. 5 , 9, 11).
Leiodysodonta elliptica (Zhang) 1977+

Plate 1, figures 9-13

1913. Dysodonta cf. D. deprati Mansuy, p. 10, pl. 1, fig. 13a, b. 1977. Dysodonta elliptica Zhang, p. 477, pl. 189, fig. 23.

1980. Dysodonta planidentata Guo, p. 53, pl. 1, figs. 5, 6.

Diagnosis.-Posteriorly elongate Leiodysodonta.

Description.-Shells posteriorly elongate so that angle of obliquity between dorsal margin and midumbonal ridge is less than $50^{\circ}$. Umbos broadly rounded. Dorsal shell margin long, almost straight, all other shell margins broadly rounded. Anterior teeth radiate from below beak, posterior lateral teeth at slight angle to dorsal margin. Anterior adductor muscle scar deeply impressed with a buttress along its posterior edge.

Types and material.-The holotype (GM-IV55030) of L. elliptica is shown on plate 1 , figure 11 ; it is about $25 \mathrm{~mm}$ long and $12.5 \mathrm{~mm}$ high. In addition to the holotype, we have eight specimens of this species, three of which are shown on plate 1 , figures $9,10,13$. All specimens seen by us are composite molds collected in place.

Type locality.-The holotype is from the Nagaoling Formation (Gedinnian), Qinjia Village, Daxin County, Guangxi.

Distribution.-Other specimens are known from the Lianhuanshan Formation (Gedinnian), Hengxian and Liukankou Members, Section 1, Beds 5, 7, Guangxi; Xiaxishancun Formation (Guo, 1980) (=Xishancun Member, Cuifengshan Formation herein fig. 5, column 6C) (Gedinnian), Sancha Village, Qujing County, Yunnan; Schists de Ban Hom (Emsian) Ban Hom Village, Van Yen District, Black-water River Basin, Nghia Lo Province, northern Vietnam (Mansuy, 1913; Liu, 1979).

Remarks and comparisons. - L. elliptica differs from L. guangxiensis in its smaller angle of obiquity, longer dorsal margin, and broadly rounded umbos. Dysodonta planidentata Guo lacks the rugae characteristic of Dysodonta and has the shell shape, proportions, and angles of Leiodysodonta elliptica; it is here treated as a synonym of $L$. elliptica.

\section{Leiodysodonta levis (Guo), 1980+ \\ Plate 9, figures 6-11}

1980. Dysodonta levis Guo, p. 54, pl. 1, fig. 8

Diagnosis.-Leiodysodonta with subcentral beaks.

Description.-Shells suberect, beaks subcentral, dorsal shell margin more-or-less straight, all other shell margins broadly arcuate. Anterior teeth radiate from below beak, posterior lateral teeth subhorizontal. Anterior adductor muscle scar deeply impressed with a buttress along its posterior edge.

Material.-We have 11 specimens of this species, of which 3 are figured. The largest specimen measures 
$19 \mathrm{~mm}$ long and $17 \mathrm{~mm}$ high. All known specimens are composite molds.

Distribution.-Nagaoling Formation (Gedinnian), Section 1, Beds 10, 13, Liujing Village, Hengxian County, Guangxi. Xiaxishanian Formation (Guo, 1980) (=Xishancan Member, Cuifengshan Formation herein, fig. 5, column 6C) (Gedinnian), Xicun Village, Qujing County, Yunnan.

Remarks and comparisons. - L. levis differs from all other species assigned to Leiodysodonta in its nearly erect umbos and subcentral beaks. In shell proportions, it is most like Dysodonta obtusa Liu (1976) from which it differs in being more erect and in lacking comarginal rugae.

\section{Subclass ISOFILIBRANCHIA Iredale Order MYTILOIDA Férussac \\ Superfamily MODIOMORPHACEA Miller Family MODIOMORPHIDAE Miller}

Discussion.-The systematic position of the Modiomorphidae (=Modiolopsidae) has been a point of debate. Newell (1969a) and Bailey (1983) placed modiomorphids in the subclass Palaeoheterodonta Newell. Pojeta (1971, 1978), Morris (1978), and Pojeta and Runnegar (1985) regarded the Palaeoheterodonta as a mixture of taxa that were better assigned to the subclasses Isofilibranchia and Heteroconchia. As defined by LaRocque and Newell (1969), the Modiomorphidae included (1) various modioliform genera, which are probably ancestral to the late Paleozoic and younger mytiloids; (2) Colpomya Ulrich, which is now included with the genera Colpantyx Pojeta and Gilbert-Tomlinson, Xestoconcha Pojeta and Gilbert-Tomlinson, and Eurymya Ulrich, in the family Colpomyidae Pojeta and Gilbert-Tomlinson, 1977 (Pojeta and Runnegar, 1985); and (3) the actinodontoids Redonia Rouault (Redoniidae Babin, 1966) and Tanaodon Kirk (herein placed in the Lyrodesmatidae Ulrich, 1894). Various genera placed in the Modiomorphidae by LaRocque and Newell are still poorly understood, and their taxonomic placement remains uncertain. Colpomyids are now regarded as isofilibranchs, and they may be ancestral to anomalodesmatans (Pojeta and Runnegar, 1985). Actinodontoids are now regarded as belonging to the subclass Heteroconchia (Pojeta, 1971; Morris, 1978; Pojeta, in press; Pojeta and Runnegar, 1985).

The type genus of the Modiomorphidae is Modiomorpha Hall and Whitfield (1869), which has the type species Pterinea concentrica Conrad (1838) by subsequent designation of Hall (1885). Modiomorpha concentrica was first described from the Hamilton Group (Middle Devonian) of New York (Bailey, 1983), and is now one of the morphologically best known Paleozoic pelecypods. Bailey (1983) illustrated many of the details of the conchology of $M$. concentrica. He indicated the presence of lateral teeth and ligament supports. New specimens of $M$. concentrica from the lower Hamiltonian (Romney Shale) of West Virginia are figured here (pl. 11; pl. 12, figs. 1-6; pl. 14, figs. 8, 9). These show that the species does not have lateral teeth, and suggest a different interpretation of the ligament insertion than that offered by Bailey (1983).

The material of $M$. concentrica from West Virginia, which consists of extremely well-preserved internal molds, was collected by G. A. Cooper, Smithsonian Institution. Some of the more weathered specimens have the growth increments of the ligament area accentuated (pl. 14, fig. 9) so that they appear to have elongated lamellar toothlike structures (also see Bailey, 1983, fig. 47A). The well-preserved specimens clearly show that the hinge of $M$. concentrica lacks elongate lamellar lateral teeth (pl. 11, figs. 2-6; pl. 12, figs. 4, 5). The feature interpreted by Bailey (1983, fig. 47D) as a lateral tooth in the right valve is sinuous. Ordinarily elongate lamellar teeth in pelecypods are straight to gently arcuate, but not sinuous. This feature of $M$. concentrica is probably not a lateral tooth; it may be adventitious. The feature interpreted by Bailey $(1983$, fig. $47 \mathrm{E})$ as a lateral tooth of the left valve seems to be the ventral side of the high ligament area of Modiomorpha $(\mathrm{pl} .11$, fig. 5). Distortion of this part of the hinge of modiomorphids is fairly common (Pojeta, 1971, pl. 14, figs. 2, 4). Alternatively, the feature that Bailey called a lateral tooth in the left valve possibly may be the anterior part of a shell thickening, which is present in some specimens ventral to the posterior part of the ligament and anterior to the posterior adductor (pl. 11, fig. 2). Other species of Modiomorpha are also known to lack lateral teeth (pl. 17, fig. 3). A cardinal tooth is present in the left valve (pl. 12, fig. $3 ;$ pl. 17, fig. 3), and a corresponding cardinal socket occurs in the right valve (pl. 11, fig. 2).

Bailey's (1983, p. 292) strong assertion that the ligament of $M$. concentrica is external is correct in the sense that the ligament could be seen from the outside when the shell was closed. However, the ligament was probably not of the C-spring type (Trueman, 1969, fig. 52D, D'). The ligament of $M$. concentrica was probably depressed and located between the valve margins rather than above them. This is well shown by a specimen of $M$. concentrica figured by Hall $(1883,1885$, pl. 36 , fig. $13)$. Thus, the ligament of $M$. concentrica was probably much like that of Mytilus (pl. 12, fig. 7; Trueman, 1969, fig. 52C). In common with other modiomorphids, the ligament of $M$. concentrica lacks the ventral resilial ridge of mytilaceans. The ligament insertion grooves found by Bailey (1983, fig. 47E) also may be seen in the West Virginia material (pl. 12, fig. 5). These grooves are high 
on the ligament area and probably represent only the insertion of the lamellar layer of the ligament; the fibrous layer was probably below them as suggested by the specimen figured by Hall $(1883,1885$, pl. 36, fig. 13). The high ligament area of Modiomorpha is much like that of such Ordovician modiomorphids as Modiolopsis Hall and Modiolodon Ulrich (Pojeta, 1971, pl. 13, figs. 6,8 ; pl. 14, figs. 2, 4, 5; 1978, pl. 13, figs. 11, 15). The ligament of Modiomorpha concentrica is closely comparable to that of living mytiloids and reinforces the concept that modiomorphids are ancestral to mytilaceans. The terms external and internal ligament should not be used without explanation. The similarity of Modiomorpha to mytilaceans and the lack of lateral teeth in the genus suggest that modiomorphids are not closely related to the Carditacea and Crassatellacea as suggested by Bailey (1983).

\section{Genus MODIOMORPHA Hall and Whitfield, 1869}

Diagnosis.-Modioliform modiomorphids with lirate to rugose growth increments and cardinal teeth. Point attachments of the mantle commonly present.

Discussion.-The specimens of Modiomorpha concentrica from West Virginia provide the following new information about the species: (1) Reinterpretation of the hinge as lacking lateral teeth and as having an opisthodetic ligament placed between the dorsal valve margins rather than above them. (2) The presence of two anterior byssal-pedal retractor muscle scars in each valve (pl. 12 , fig. 6). (3) The presence of both quick and catch muscle fiber insertions on the anterior adductor muscle scar (pl. 11; pl. 12, figs. 1-6); this feature is also known in other species of Modiomorpha (pl. 17, figs. 6, 7). (4) Many point attachments of the general surface of the mantle (pl. 11; pl. 12, figs. 1-6). Such point attachments of the general surface of the mantle are also known in other species of Modiomorpha (pl. 17, figs. 6, 7) and are readily compared with similar scars in Mytilus (pl. 12, fig. 7). Although such mantle point attachemnt scars are often called muscle scars, Smith $(1983$, p. 67$)$ noted that in the unionoids: "****Mantle attachment involves modification of mantle epithelial cells and associated connective fibers within the mantle. The connective fibers within the mantle do not appear to have contractile properties, but along with the attachment cells probably provide support for the mantle." In addition to all the standard conchological information now known for Modiomorpha concentrica, Carter and Tevesz (1978) described the shell microstructure of the species and noted that it is much like that of younger mytiloids.

The Chinese specimens of Modiomorpha (pls. 13-15) show few morphological details. They are placed in the genus on the bases of their modioliform shells, which are much higher posteriorly than anteriorly, and the presence of rugose comarginal ornament on some of the specimens.

Modiomorpha paradoxa (Zhang), 1977+

Plate 13, figures 1-7; plate 14, figures 7,10

1977. Sanguinolites paradoxus Zhang, p. 529, pl. 201, fig. 8.

Diagnosis.-Modiomorpha with prominent byssal sinus.

Description.-Shell having straight dorsal margin, convex anterior margin, convex posteroventral margin, oblique posterodorsal margin, and a byssal sinus causing concavity in the anteroventral margin; prominent anteroumbonal sulcus present.

Types and material.-The holotype (GM-IV55087) was figured by Zhang (1977, pl. 201, figs. 8a, 8b). Nine hypotypes are figured here; most of these are distorted in one way or another. The least distorted is shown on plate 13 , figure 1 , and plate 14 , figure 7 .

Type locality.-The holotype is from the Ertang Formation (Emsian), Section 2, Bed unknown, near Dale Village, Xiangzhou County, Guangxi.

Distribution.-Two of the hypotypes are topotypes (GXD-527, -521; pl. 13, figs. 1, 6; pl. 14, fig. 7). The remaining figured hypotypes are from the following localities: GXD-539 (pl. 13, fig. 2) and GXD-552 (pl. 14, fig. 10) are from the Ertang Formation (Emsian), Section 3, Bed 10, Heping Village, Yongfu County, Guangxi; GXD-536 and GXD-530 (pl. 13, figs. 3 and 5) are from the Donggangling Formation (Givetian), Section 3, Bed 23, Heping Village, Yongfu County, Guangxi; and GXD-522 and GXD-524 (pl. 13, figs. 4, 7) are from the Ertang Formation (Emsian), Section 4, Bed 33, Liufengshan Hill, Wuxuan County, Guangxi.

Remarks and comparisons.-M. paradoxa is here placed in Modiomorpha rather than Sanguinolites M'Coy as was done by Zhang (1977). M. paradoxa lacks the prominent posteroumbonal carina considered characteristic of Sanguinolites by Newell and LaRocque (1969b). M. paradoxa differs from $M$. harrisae n. sp. and $M$. oblonga Zhang in having a well-developed byssal sinus. $M$. oblonga has stronger comarginal ornament and is much larger than $M$. harrisae. The prominent byssal sinus of $M$. paradoxa is stronger than in most species of Modiomorpha figured by Hall $(1883,1885)$, McAlester (1962), and Bailey (1983). M. arcuata Hall $(1883,1885$, pl. 36 , fig. 21$)$ also has a prominent byssal sinus, but is more nasute anteriorly and more elongated posteriorly.

Modiomorpha harrisae n. sp. +

Plate 15, figures 1-9

Diagnosis.-Small Modiomorpha lacking a welldeveloped byssal sinus and having ornament of fine growth increments. 
Description.-Shell with straight dorsal margin, convex anterior margin, convex posteroventral margin, oblique posterodorsal margin, anteroventral margin straight to convex and lacking a byssal sinus concavity. Anteroumbonal sinus lacking.

Types and material.-The type suite consists of eight specimens. The holotype (GXD-541) is a right valve (pl. 15 , fig. 2) internal mold that preserves a ghost of the anterior adductor muscle scar; it measures $23 \mathrm{~mm}$ long, $15.1 \mathrm{~mm}$ high, and $3.5 \mathrm{~mm}$ wide. Six of the paratypes (pl. 15, figs. 1, 3-7, 9) are composite molds, the other paratype (pl. 15, fig. 8) is an internal mold.

Type locality.-The holotype (pl. 15, fig. 2) and six paratypes (pl. 15, figs. 1, 3-5, 8, 9) are from the Ertang Formation (Emsian), Section 3, Bed 10, Heping Village, Yongfu County, Guangxi.

Distribution.-In addition to the occurrence at the type locality, $M$. harrisae is known from the Ertang Formation (Emsian), Section 4, Bed 4, Liufengshan Hill, Wuxuan County, Guangxi (pl. 15, figs. 6, 7).

Etymology.-The species is named for Anita G. Harris, U.S. Geological Survey, Washington, D.C., who kindly provided much information for us about the stratigraphic significance of conodonts in the Devonian rocks of Guangxi.

Modiomorpha oblonga Zhang, 1977+

Plate 16, figure 2

1977. Modiomorpha oblonga Zhang, p. 481, pl. 190, figs. 15, 16.

Discussion.-One poorly preserved specimen (GXD-520) is herein assigned to this species on the basis of its large size. The specimen is from the Ertang Formation (Emsian), Section 4, Bed 31, Liufengshan Hill, Wuxuan County, Guangxi.

Modiomorpha mytiloides (Conrad), 1841*

Plate 19, figures 6,7 ; plate 20 , figure 2

Discussion.-M. mytiloides differs from $M$. concentrica and $M$. paradoxa in having weaker comarginal ornament (pl. 13, fig. 7; pl. 14, fig. 8; pl. 20, fig. 2) and from $M$. concentrica in having a more prominent anterior lobe so that the beaks are set well back from the anterior margin. Bailey (1983) listed an extensive synonymy for $M$. mytiloides and noted that the species occurs in the Middle Devonian of Wisconsin, New York, Ohio, Indiana, and Pennsylvania; $M$. mytiloides is herein reported from the Middle Devonian of Michigan. In shape and ornament, $M$. mytiloides is much like the Holocene species Mytella guyanensis (Lamarck) (pl. 19, fig. 8), which is widely distributed in Central and South America (Soot-Ryen, 1955, p. 50).

In Michigan, Modiomorpha mytiloides is known from three specimens from the Norway Point Formation
(USNM 374574), Thunder Bay River, 0.75 miles southeast of Four Mile Dam, Alpena County, and the Thunder Bay Limestone (USNM 374575; YPM 16471) at Partridge Point, sec. 11 and east half of sec. 10, T. 30 N., R. 8 E., 3 miles south of Alpena City Line, Alpena County.

\section{Genus SPATHELLA Hall, 1885}

Diagnosis.-Lithophagaform modiomorphids with coarse comarginal ornament.

Discussion.-The concept Spathella is used for elongate cylindrical shells with prominent comarginal ornament that are not significantly higher posteriorly than anteriorly. McAlester (1962) compared the shape of the type species, S. typica Hall, with the Holocene rock-boring genus Lithophaga Bolten. In older rocks, Whiteavesia Ulrich has a shape and an ornament much like those of Spathella (Pojeta, 1971, pl. 17). The conchology of Spathella is not well known, but the genus is usually classified with modiomorphids (McAlester, 1962; LaRocque and Newell, 1969). The specimens described here are the first representatives of Spathella reported from Asia.

Spathella hepingensis n. sp.+

Plate 14, figures 1-4

Diagnosis.-Spathella with nasute anterior end.

Description.-Shell large (as much as $60 \mathrm{~mm}$ long), beak on best preserved specimen about one-sixth of the length from the anterior end.

Types and material.-Spathella hepingensis is known only from the four specimens of the type suite. The holotype (GXD-551) is a composite mold of a left valve (pl. 14, fig. 4); it measures $60.2 \mathrm{~mm}$ long, $22.8 \mathrm{~mm}$ high, $5.2 \mathrm{~mm}$ wide, and the beak is about $9.2 \mathrm{~mm}$ from the anterior end. Two of the paratypes (GXD-553,-555) preserve remnants of the anterior adductor muscle scar (pl. 14, figs. 1, 2).

Type locality.-The holotype is from the Ertang Formation (Emsian), Section 3, Bed 10, Heping Village, Yongfu County, Guangxi.

Distribution.-The three paratypes are from the Donggangling Formation (Givetian), Section 3, Bed 23, Heping Village, Yongfu County, Guangxi.

Etymology.-The species is named for Heping Village, Yongfu County, Guangxi.

Remarks and comparisons.-Spathella hepingensis is much like $S$. typica Hall the type species of the genus (McAlester, 1962, pl. 19, figs. 1-13). The major differences between the two is that $S$. hepingensis can be as much as twice as long as S. typica, and in S. typica the beak is only about one-tenth of the length from the anterior end. 
Spathella sp. +

Plate 14, figures 5, 6; plate 16, figures 1,3

Discussion.-Four poorly preserved specimens are herein assigned to Spathella because their shells are not significantly higher posteriorly than anteriorly. Three of these specimens (pl. 14, fig. 5; pl. 16, figs. 1, 3) are from the Ertang Formation (Emsian), Section 3, Bed 10, and the other (pl. 14, fig. 6) is from the Donggangling Formation (Givetian), Section 3, Bed 23, Heping Village, Yongfu County, Guangxi. These may all be poorly preserved specimens of $S$. hepingensis.

\section{Genus GONIOPHORA Phillips, 1848}

Diagnosis.-Trapezoidal to rhomboidal modiomorphids with prominent lateral carina.

Disscussion.-Goniophora is a widely used generic name for Ordovician-Permian modiomorphids having a strong umbonal carina extending from the beak to the posteroventral angle of the valve and trapezoidal to rhomboidal shell shape. Ordinarily two subgenera are recognized: Goniophora (Goniophora) lacks fine radial costae and is not known above rocks of Devonian age. $G$. (Cosmogoniophora) McLearn has radial ornament and has been reported from rocks of Ordovician age. Both subgenera are present in the Devonian rocks of Guangxi where G. (Goniophora) is known from six specimens and $G$. (Cosmogoniophora) is known from three specimens.

Goniophora (Goniophora) spatulata Mansuy, 1913+

Plate 18, figures 5-7

1913. Goniophora spatulata Mansuy, p. 21, pl. 3, figs. 4a-d.

Discussion.-This large species is known from two specimens in Guangxi, the largest of which is $57 \mathrm{~mm}$ long (pl. 18, figs. 5, 6). One specimen (GXD-543) is highly weathered, and the other (GXD-546) is squashed; GXD-543 is from the Yingtang Formation (Eifelian), Section 5, Bed 22, Luoban Village, Luoxiu Community, Xiangzhou County, Guangxi; GXD-546 is from the Ertang Formation (Emsian), Section 3, Bed 10, Heping Village, Yongfu County, Guangxi. In northern Vietnam, $G$. (G.) spatulata is from the Schistes de Muong-Thé (Givetian, Saurin, 1958).

\section{Goniophora (Goniophora) sp. A+}

Plate 17, figures 1, 2

Discussion.-This species is characterized by rugose comarginal ornament anterior to the umbonal carina and a nearly smooth shell posterior to the carina. It is most similar to $G$. $(G$.) rheana Beushausen (1895, pl. 17, figs. $10,11)$ from the Siegenian (lower Coblenzian) of Germany and Goniophora suberecta Hall (1885, pl. 42, figs. 14, 15) from the Chemung Group (Upper Devonian) of New York.
The two specimens from Guangxi placed here were found in mudstones and have undergone considerable distortion and shortening. The specimen shown in figure 2 , plate 17 , is articulated, the commissure is at right angles to bedding, and the specimen may be in original life position. The specimen shown on plate 17 , figure 1 , is parallel to bedding, is intersected by low angle cleavage planes, or bedding planes, has been shortened and flattened, and also does not show the original shape. Ordovician specimens of Modiolopsis modiolaris (Conrad) are also in shaly rocks, but in a platform environment; the specimen at right angles to bedding (pl. 17 , fig. 5) shows considerable shortening, whereas the specimen parallel to bedding (pl. 17, fig. 4) shows only slight flattening of the umbo.

Specimen GXD-642 (pl. 17, fig. 2) is from the Ertang Formation (Emsian), Section 4, Bed 6, Liufengshan Hill, Wuxuan County, Guangxi. Specimen GXD-547 (pl. 17, fig. 1) is from the Donggangling Formation (Givetian), Section 3, Bed 23, Heping Village, Yongfu County, Guangxi.

Goniophora (Goniophora) sp. B+

Plate 18, figure 1

Discussion.-This species is known from one specimen that has a broadly rounded umbonal carina and is similar to $G$. (G.) bipartita Roemer (Beushausen, 1895, pl. 17, fig. 15). The specimen number is GXD-548, and it is from the Ertang Formation (Emsian), Locality 6, Miaohuan Village, Xiangzhou County, Guangxi.

Goniophora (Goniophora) spp. indet.*

Plate 19, figure 9

Discussion.-In the collections from Michigan, Goniophora (Goniophora) is known from three poorly preserved specimens. One (YPM 16623) is from the Ferron Point Formation, Alpena County, another (USNM 20959) is from the Potter Farm Formation, Stony Point, Lake Huron, about 1.5 miles south of the mouth of Thunder Bay River, Alpena County, and the third specimen (USNM 374621) is from the Four Mile Dam Formation at Four Mile Dam, Thunder Bay River, sec. 7, T. 31 N., R. 8 E., Alpena County.

Goniophora (Cosmogoniophora) marija n. sp.+

Plate 18, figures 2-4

Diagnosis.-Goniophora (Cosmogoniophora) having both radiating ribs and pustulose ornament.

Description.-Shell small having umbonal carina sharp, not broadly rounded, radial ornament present anterior and posterior to carina, pustulose ornament only anterior to carina.

Types and material.-G. (Cosmogoniophora) marija is known from the holotype (GXD-549; pl. 18, fig. 2), 
and two paratypes (GXD-545, -741 , pl. 18, figs. 3, 4). The holotype is a composite mold that measures $16 \mathrm{~mm}$ long, $7.9 \mathrm{~mm}$ high, and $1.2 \mathrm{~mm}$ wide.

Type locality.-All known specimens are from the Yingtang Formation (Eifelian), Section 5, Bed 19, Luoban Village, Luoxiu Community, Xiangzhou County, Guangxi.

Etymology.-The species is named for Marija Balanc, U.S. Geological Survey. The help and extra time she gave us allowed us to complete this project.

Remarks and comparisons.-G. (Cosmogoniophora) marija has the characteristic trapezoidal shape and umbonal carina of Goniophora; however, it differs from most modiomorphids in having pustulose ornament, a feature most common among members of the subclass Anomalodesmata.

\section{Genus RADIATODONTA Dahmer, 1921}

Diagnosis.-Modiomorphids having flattened posteroumbonal slope and several cardinal teeth.

Discussion.-Radiatodonta was proposed for pelecypods from the Lower Devonian of Germany that have a flattened posteroumbonal slope and several cardinal teeth (Dahmer, 1921, pl. 10, figs. 6, 7). LaRocque and Newell (1969, p. N398) placed the genus in the Modiomorphidae with question. Zhang (1977, pl. 190, fig. 17) figured a specimen of $R$. shaodongensis Zhang, which in shape is like $R$. goslariensis Dahmer, the type species of Radiatodonta. In $R$. goslariensis, the cardinal teeth radiate outward from the beak. However, in $R$. shaodongensis, the cardinal teeth are subparallel to the dorsum, overlap one another posteriorly, and approach the actinodont condition (Pojeta, in press). $R$. shaodongensis is from the Tiaomajian Formation (Dongganglingian, Givetian) of central Hunan Province.

One internal mold (GXD-619, pl. 28, fig. 4) from the Nagaoling Formation (Nagaolingian, Gedinnian), Locality 7 , Xinxu Village, Mengshan County, Guangxi, is very similiar to $R$. goslariensis in shape and flattening of the posteroumbonal slope. This specimen is here placed in Radiatodonta? sp. A. The umbo on the specimen has been removed to show two raised conical structures separated by a groove that may represent the fillings of teeth and sockets, although it is unusual for those structures to be conical in form.

\section{Family ORTHONOTIDAE Miller, 1877}

Discussion.-The Orthonotidae is an OrdovicianPermian taxon, which contains gaping soleniform shells. Many orthonotids have strong comarginal ornament, and some have one or more radial ribs. The systematic position of orthonotids has been under review for several years. Newell and LaRocque (1969c, p. N818) placed the orthonotids in the subclass Anomalodesmata along with edmondiids, grammysiids, and pholadomyids. Pojeta (1971) noted that it was not clear how Paleozoic soleniform pelecypods such as Cymatonota Ulrich, Palaeosolen Hall, Solenomorpha Cockerell, and Prothyris Meek were related to typical Paleozoic anomalodesmatans such as Rhytimya Ulrich, Cuneamya Hall and Whitfield, Edmondia de Koninck, Grammysia de Verneuil, and Wilkingia Wilson, and suggested that the two groups represented separate lineages. Runnegar (1974) tentatively removed orthonotids from the Anomalodesmata, suggested a relationship of orthonotids to solenaceans, and transferred orthonotids to the subclass Heterodonta. Pojeta and GilbertTomlinson (1977) followed Runnegar's suggestion and placed the Orthonotidae in the superfamily Solenacea of the subclass Heteroconchia (Heterodonta). Pojeta (1978) placed the Orthonotidae in the then new subclass Orthonotia and tentatively suggested that the solenaceans are not closely related to the heterodonts. He also suggested that because some Ordovician orthonotids approached Ordovician isofilibranchs in shape, there might be a phylogenetic relationship between the two groups (compare Pojeta, 1978, pl. 14, fig. 1 with pl. 15, fig. 10). Pojeta and Runnegar (1985) and Pojeta (in press) stressed the similarity in shell form of some Ordovician orthonotids and modiomorphids, classified orthonotids in the subclass Isofilbranchia, and abandoned the use of the subclass Orthonotia; this procedure is also followed herein.

The relationship of orthonotids to solenids remains unclear. The two taxa contain species that are conchologically very similar (pl. 20, figs. 1 (solenid), 4 (orthonotid)). However, a stratigraphic gap of about 100 million years separates the youngest known Upper Permian orthonotid from the oldest known Lower Cretaceous solenid (Runnegar, 1974, p. 926). Morris (1978) and Pojeta and Runnegar (1985) explained why stratigraphic gaps in the history of various hneages of pelecypods are not interpreted as indicating homeomorphic convergence. For example, Paleozoic limids show a stratigraphic gap of about 80 million years (Pojeta and Runnegar, 1985) between the Upper Ordovician and the Mississippian; Paleozoic lucinoids show a stratigraphic gap of about 90 million years between the Devonian and Permian (Boyd and Newell, 1979); and megalodontaceans show a stratigraphic gap of about 140 million years between the Devonian and Triassic (Morris, 1978). The oldest and younger species of limids, lucinoids, and megalodontaceans are morphologically very similar; some of the species of Triassic megalodontaceans are virtually identical to Devonian species (Morris, 1978, p. 267). Such close morphological similarity is interpreted to indicate lack of discovery rather than convergence. The gap indicated for lucinoids was 
thought to be larger until the discovery of a Permian species (Termier and Termier, 1977; Boyd and Newell, 1979).

Other groups of mollusks also show stratigraphic gaps. Lower Paleozoic tryblideacean monoplacophorans are so similar to living ones that the gap of about 360 million years in their stratigraphic record is attributed to a change in the environment in which they lived rather than to convergence; lower Paleozoic species lived in shallow-water environments and living species are found in deeper water environments.

On the other hand, convergent homeomorphy is recognized in various groups of pelecypods. Pojeta and Zhang (1984) noted that the Lower-Middle Devonian genus Sinodora Pojeta and Zhang is probably homeomorphic to the Cenozoic pandoracean pelecypods. Sinodora differs from pandoraceans in ornament, pallial sinus, the presence of buttresses associated with the adductor muscles, and details of dentition. These morphological differences suggest that the stratigraphic gap between the two taxa (about 275 million years) indicates that no ancestor-descendant relationship exists between them. Newell and Boyd (1970) noted homeomorphy in various oysterlike pelecypods. Newell (1942) and Pojeta (1966) noted the convergence between ambonychiaceans and mytilaceans.

Some Devonian orthonotids are conchologically very similar to Cretaceous solenids (pl. 20, figs. 1, 4; Soot-Ryen, 1966). Anatomically, solenids are heterodonts (Owen, 1959); we have relatively little information about orthonotids from which to interpret anatomy. However, Runnegar $(1974$, p. 926) noted a gross similarity of the anterior musculature of Permian orthonotids and living solenids. He also noted that the Permian species have small hinge teeth comparable to the small hooklike teeth of Solen and Ensis. If, as seems likely, orthonotids are descended from modiomorphid isofilibranchs, and if they are ancestral to solenids, then the solenids should be classified with the isofilibranchs and are convergent to heterodonts.

\section{Genus ORTHONOTA Conrad, 1841}

Type species.-Orthonota undulata Conrad (1841) by subsequent designation of Conrad (1866, p. 103).

Diagnosis.-Orthonotids with prominent anterior comarginal rugae; posterior part of shell having radial ornament.

Stratigraphic range.-Lower Devonian (Emsian) Middle Devonian (Givetian). Older species, which were sometimes placed in Orthonota, are now usually assigned to the genera Cymatonota Ulrich, Sphenosolen Pojeta and Gilbert-Tomlinson, and Palaeosolen Hall.
Orthonota undulata Conrad, 1841*

Plate 19, figures 1, 2; plate 20, figures 4-9; plate 28, figure 1

Diagnosis.-Orthonota in which the anterior comarginal rugae are weak over the umbo and having a prominent umbonal sulcus.

Distribution.-Conrad $(1841$, p. 51$)$ gave the locality of $O$. undulata as "Near Smyrna [New York], Chenango County ***" and placed it in the then broadly defined Silurian System. In F. B. Meek's copy of Conrad (1841), on p. 51, the following penciled annotations are present "Ham Gr." and "Ham." next to the description of $O$. undulata. Hall $(1883$, pl. $78 ; 1885$, p. 479 , pl. 78$)$ noted that $O$. undulata occurs in the Hamilton Group. Rickard and Zenger $(1964$, p. 86) noted the presence of $O$. undulata in the Panther Mountain Formation in the Richfield Springs and Cooperstown Quadrangles of eastern New York. The Panther Mountain Formation includes strata equivalent to the Skaneateles and Ludlowville Formations (upper Hamilton Group; Rickard, 1975).

O. undulata seems to occur throughout the Hamilton Group in the classical exposures in New York and Ontario. On the basis of the USNM collections, $O$. undulata is here noted as having been found in the following Hamilton Group Formations in New York: (1) Panther Mountain Formation (USNM 101812), (2) Delphi Station Shale (USNM 374622), (3) Ludlowville Formation (USNM 374623), (4) Moscow Formation (USNM 101811), and (5) Kashong and Windom Shales (USNM 374624, $101816,101817)$. The oldest specimens of 0 . undulata in the USNM collections are from the Arkona Shale of Ontario, Canada (USNM 101824), which Rickard (1984, p. 825) correlated with the upper Marcellus Formation of New York (lower Hamilton Group); Cooper and others (1942) correlated the Arkona Shale with the Skaneateles Formation.

In Michigan, $O$. undulata is known from 11 specimens (USNM 374625, 374626; YPM 16473, 16634) from the Norway Point Formation, Norway Point Dam, NE1/4 sec. 12, T. 31 N., R. 7 E., Alpena County (pl. 20, figs. 6-8).

Zhang (1977, p. 527) described $O$. undulata as occurring in the Qiziqiao Formation (Givetian) of central Hunan Province. His specimen (1977, pl. 200, fig. 23) is not as well preserved as the New York material, but it has the same ornament and a midumbonal sulcus.

Remarks.-Conrad (1841) gave a brief description of Orthonota undulata, but as far as we can tell, he never figured the species. Hall (1862, pl. 11, fig. 6) was apparently the first person to illustrate $O$. undulata. In 1862, Hall was having a dispute with Elkanah Billings about the genus Cypricardites Conrad, which was proposed by Conrad in the same 1841 publication that described Orthonota. Hall maintained that some copies of Conrad (1841) had been distributed with a lithographic 
plate of fossils, whereas other copies did not have the plate of illustrations. We have examined three copies of Conrad (1841), including the personal copies of F. B. Meek and E. O. Ulrich, and none of these have the plate mentioned by Hall. According to Hall (1862, p. 192), Billings accused Hall of "***it now appears that he [Conrad] prepared a figure-which however remained in Professor Hall's hands eighteen years without publication.***" In response, Hall $(1862$, p. 193$)$ answered: “*** I cannot, in justice to Mr. Conrad and myself do otherwise than communicate a copy of the lithographic plate *** which was published with his Report in 1841, and circulated with some but not all copies." A copy of Hall's 1862 figure of Orthonota undulata Conrad is shown here as figure $15 \mathrm{~A}$.

T.A. Conrad was closely associated with the Academy of Natural Sciences of Philadelphia, and some of his type and figured specimens of post-Paleozoic species are at that institution. Among the collections of the Academy are four specimens of Orthonota undulata (ANSP 61406, 61407). The documentation with these specimens consists of one typed and two hand-written labels. One of the hand-written labels reads "Hamilton Shale, Orthonotus undulatus"; the other hand-written label reads "Orthonota undulata, Con., Ham. gr., N. Y."; and the typed label reads "Orthonotus undulata Conrad, Hamilton Formation, New York."

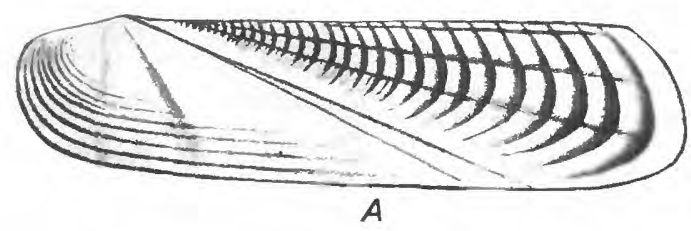

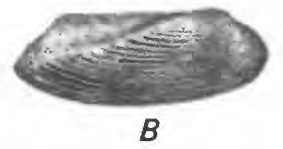
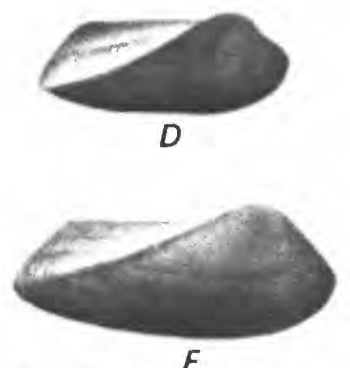

$F$

FIGURE 15.-Original drawings of the type specimens of the type species of Orthonota Conrad, Sanguinolites M'Coy, and Sphenotus Hall. A, Orthonota undulata Conrad, lectotype (from Hall, 1862, pl. 11, fig. 6). B, Sanguinolites discors M'Coy, 1844, pl. 8, fig. 4. $C-G$, Sphenotus arcaeformis (Hall and Whitfield), syntypes (from Hall, 1885, pl. 65, figs. 7-11). No scales given on original drawings.
The best preserved of the four specimens of 0 . undulata (ANSP 61406) is shown here on plate 28, figure 1 ; it is an articulated specimen with the valves spread apart parallel to bedding. The left valve of this specimen is almost identical with the idealized drawing of the specimen figured by Hall (1862, pl. 11, fig. 6). Hall said that this drawing was prepared for Conrad, and the specimen shown on plate 28 , figure 1 , was found at the Academy of Natural Sciences of Philadelphia, with which Conrad had a close association. Although it cannot be proved conclusively, ANSP 61406 is here made the lectotype of Orthonota undulata Conrad, 1841, p. 51. The other specimens found with the lectotype are not well preserved and are not figured; they are made paralectotypes (ANSP 61407). Even if others do not accept ANSP 61406 as the lectotype of $O$. undulata, it is clearly the same species as that figured by Hall $(1862, \mathrm{pl} .11$, fig. 6), which figure Hall maintained was prepared for Conrad's 1841 report.

Comparisons.-Orthonota undulata differs from $O$. carinata Conrad (pl. 19, figs. 3, 5; pl. 20, fig. 3) in lacking strong posterior radial ornament and in having prominent comarginal rugae on the posterodorsal margin and posteroumbonal slope of the shell. $O$. guangdongensis Zhang differs from $O$. undulata in lacking the umbonal sulci and the prominent comarginal rugae in the posterior part of the shell.

Orthonota guangdongensis Zhang, 1977+

Plate 28, figures 2, 3

1977. Orthonota guangdongensis Zhang, p. 528, pl. 201, fig. 1.

Diagnosis.-Orthonota with subdued posterior radial and comarginal ornament and lacking a midumbonal sulcus.

Material.-O. guangdongensis is known from two composite molds in the Lower Devonian of Guangxi. Specimen GXD-721 (pl. 28, fig. 2) is from the Ertang Formation (Emsian), Section 3, Bed 10, Heping Village, Yongfu County. Specimen GXD-720 (pl. 28, fig. 3) is from the Sipai Formation (Emsian), Section 3, Bed 13.

Distribution.-In addition to the occurrences of $O$. guangdongensis in the Lower Devonian of Guangxi, the species is known from the Lower Devonian of Guangdong Province (Zhang, 1977). A poorly preserved specimen of Orthonota sp. indet. (GXD-722) is known from the Yujiang Formation (Siegenian-Emsian) at Section 1, Bed 21.

\section{Orthonota? parvula Hall and Whitfield, 1870*}

Plate 53, figure 3

Discussion.-This species was named by Hall and Whitfield (1870) and assigned to Orthonota. Hall (1885, p. 482) placed it in Orthonota with question. The species 
has a distinct umbonal carina, but not the strong comarginal rugae of $O$. undulata and $O$. carinata $(\mathrm{pl} .19$, figs. 1-5), and it is not clear how $O$. ? parvula differs from species of Goniophora (pl. 18, figs. 1-5). Very little is known about the details of the morphology of $O$ ? par$v u l a$, and for this reason the species is herein retained in Orthonota with question.

In Michigan, two specimens of $0 . ?$ parvula (YPM 16472; USNM 374643; pl. 53, fig. 3) are known from the Norway Point Formation, Norway Point Dam, Alpena County, and are much like specimens assigned to $0 . ?$ parvula by Hall (1885, pl. 78, figs. 30-32). In New York, O.? parvula is known from the lower Windom Shale (Moscow Formation, Givetian; USNM 101814, 101818).

The history of the publication of Hall and Whitfield $(1869,1870)$ is complicated and has been reviewed by Cooper (1931); Cooper demonstrated that both publications were written by Hall and Whitfield.

\section{Subclass HETEROCONCHIA Hertwig Order ACTINODONTOIDA Douvíle Family LYRODESMATIDAE Ulrich}

Description.-Actinodontoids having elongate posterior pseudolateral teeth that overlap shorter pseudocardinal teeth, which in turn radiate outward from beneath the beak; the pseudolateral teeth may reach the beak, or they may overlap other elongate pseudolateral teeth, and no edentulous space separates pseudocardinal from posterior pseudolateral teeth; teeth with denticles and mounted on a hinge plate. In one lineage, the pseudolateral teeth become very short (Pojeta, 1978, pl. 6, figs. 7-13).

Stratigraphic range.-Lower Ordovician (Arenigian) Middle Devonian (Givetian).

Discussion.-The use of the terms pseudolateral and pseudocardinal teeth herein follows that of Pojeta (in press); dentition composed of pseudolateral teeth and pseudocardinal teeth is termed actinodont, but does not necessarily imply classification as an actinodontoid (Pojeta, in press). The usual stratigraphic range given for lyrodesmatids is Middle-Upper Ordovician (Newell and LaRocque, 1969d, p. N471). Pojeta (1971) pointed out that the family occurs in Lower Ordovician rocks; Ziegler and others (1968), Harrison and Harrison (1975), Pojeta and Gilbert-Tomlinson (1977), and Pojeta (1978) noted that the family is found in the Lower Silurian. Heidecker (1959) noted that Neoactinodonta Heidecker, from the Middle Devonian (Givetian) of Queensland, Australia, is a lyrodesmatid. LaRocque and Newell $(1969$, p. N399) regarded Neoactinodonta as a junior subjective synonym of Tanaodon Kirk (1927), an opinion with which we concur. The type species of the two genera are shown on plate 25, figures 1-8. Morris (1978, p. 263) regarded Tanaodon as an actinodontoid.
Tanaodon is the only lyrodesmatid known from the Lower and Middle Devonian of China (pl. 25, figs. 1-4; pl. 26). Zhang (1977, p. 481) placed Tanaodon in the family Tanaodontidae Liu (1976), which is a junior subjecive synonym of Lyrodesmatidae Ulrich, 1894. Until the work of Zhang (1977) and the information presented here, Tanaodon was a poorly understood genus known only from the three specimens of the type species $T$. louderbacki Kirk. Kirk (1927) placed Tanaodon in the family Megalodontidae, and LaRocque and Newell (1969, p. N399) placed it in the Modiomorphidae with question. We place Tanaodon in the Lyrodesmatidae because its dentition is much like that of the genera Noradonta Pojeta and Gilbert-Tomlinson (1977, pl. 27; Pojeta, 1978, pl. 6, fig. 6) and Tromelinodonta Babin (1982, p. 425). The nominate genus of the family, Lyrodesma Conrad (Pojeta, 1978, pl. 6), does not have elongate pseudolateral teeth; however, Babin (1982) documented the progressive reduction of the lamellar posterior pseudolateral teeth from such forms as Noradonta to the pseudocardinal teeth of Lyrodesma, all of which radiate from the beak. In some species of Lyrodesma (Pojeta, 1978, pl. 6, figs. 7, 10), the posterior pseudocardinal teeth are arcuate and considerably longer than the rest of the pseudocardinal teeth; such teeth probably represent reduced pseudolaterals (Babin, 1982 , p. 425 , fig. 1). The lineage of lyrodesmatids to which Tanaodon belongs did not reduce the length of the posterior pseudolateral teeth.

Pojeta (1978) stressed the likelihood of a relationship of Lyrodesma to the trigoniaceans, and Newell and LaRocque (1969d, p. N471) assigned Lyrodesma to the Trigoniacea with question. Harrison and Harrison (1975, pl. 2, figs. 14-17) figured the hinges of small Lyrodesmas, ranging in size from $0.6-2.0 \mathrm{~mm}$. These hinges of baby Lyrodesmas are markedly similar to the hinges of various late Paleozoic trigoniaceans (Newell and Boyd, 1975). The middle and late Paleozoic trigoniaceans may have evolved from Silurian lyrodesmatids through the neotenous retention of the hinge of the latter (oral commun., W. B. Harrison, 1980).

Genus TANAODON Kirk, 1927

1927. Tanaodon Kirk, Proc. U. S. Nat. Mus., v. 70, p. 1.

1927a. [Non] Tanaodon Simpson, Amer. Jour. Sci., v. 13, p. 410.

1927b. [Non] Tanaodon Simpson, Amer. Jour. Sci., v. 14, p. 71.

1959. Neoactinodonta Heidecker, Univ. Queensland Papers, Dept. Geol., v. 5, no. 2, p. 3.

Type species.-Tanaodon louderbacki Kirk, 1927, by original designation and monotypy.

Diagnosis.-Lyrodesmatids with terminal beaks.

Description.-Posteriorly elongated lyrodesmatids having terminal prosogyrate beaks and strong comarginal ornament. All teeth with denticles and mounted 
on large hinge plate, numerous and variable in number. Ligament opisthodetic, elongate, inset. Muscle scars not well known; anterior adductor scar attached to myophore, located immediately below, and touching, anterior hinge plate; posterior adductor scar located posterior to teeth; anterior portion of pallial line incised, posterior portion not known; pedal muscle scars not known. The lunule and escutcheon mentioned by Kirk (1927) seem to be the result of compaction, which has decreased the inflation of the umbos and the width of the shell (compare pl. 25, figs. 3 and 7).

Distribution.-Tanaodon is known from three species in China, one of which also occurs in Australia. According to the museum label accompanying the types of the type species, T. louderbacki Kirk, the specimens are from the "Middle Devonian, Tung Kou District, Szechwan [Sichuan], China." Zhang here notes that in 1985 many additional specimens of $T$. louderbacki have been found in the Devonian at Tongkou Village, Jiangyou County, Sichuan Province. This is probably the type locality for the species. Specimens of $T$. louder backi are described herein from the Yingtang Formation (Yingtangian, Eifelian) at Section 5, Bed 18, Luoban Village, Luoxiu Community, Xiangzhou County, Guangxi.

Zhang (1977, p. 481) described two other species of Tanaodon from China. T. guangxiensis Zhang is from the Yujiang Foramation (Yujiangian, SiegenianEmsian), Guangxi, and T. parcidonta Zhou is from the Middle Devonian Tiaomajian Formation (Dongganglingian, Givetian) of Hunan. Zhang herein notes that in 1977 the Yujiang Formation was broadly defined. New knowledge and revision of the stratigraphy show that T. guangxiensis is from the Yingtang Formation (Eifelian). T. amygdalina (Heidecker), 1959, is from Givetian age rocks in Queensland, Australia, and is a likely synomym of $T$. louderbacki.

Comparisons.-Tanaodon is the only known lyrodesmatid that has terminal beaks.

Tanaodon louderbacki Kirk, 1927+

Plate 25, figures 1-8; plate 26, figures 1-8

1927. Tanaodon louderbacki Kirk, Proc. U.S. Nat. Mus., v. 70, p. 2. 1959. Neoactinodonta amygdalina Heidecker, Univ. Queensland Papers, Dept. Geol., v. 5, no. 2, p. 3.

Diagnosis.-Tanaodon lacking a midumbonal carina and without closely spaced comarginal rugae.

Types and material.-The type suite of $T$. louderbacki Kirk consists of three syntypes. The specimen figured on plate 25, figure 2 (USNM 102049; Kirk, 1927, pl. 1, fig. 4), is herein chosen as the lectotype of the species. The other two specimens (USNM 374627, $374628)$ are paralectotypes. In addition to the type suite, we have 30 specimens of $T$. louderbacki from the Yingtang Formation (Yingtangian, Eifelian), at Section 5, Bed 18.

Type locality.-As noted above, Zhang strongly suspects that the type locality of $T$. louderbacki is probably at Tongkou Village, Jiangyou County, Sichuan Province.

Comparisons.-The umbos of the three type specimens of $T$. louderbacki are all distorted, even though the shell is preserved. On the lectotype (USNM 102049) the umbo is displaced medially, as are the umbos on one paralectotype (USNM 374627, pl. 25, fig. 3). The unfigured paralectotype (USNM 374628, Kirk, 1927 , pl. 1, figs. 3, 5) shows a dorsoventral compression, which forms prominent carinas on the posteroumbonal slopes. The new material of $T$. louderbacki (pl. 25, fig. 4; pl. 26) shows no umbonal carina and an evenly rounded umbo; all the new material is internal or composite molds. The overall lateral profile of $T$. louderbacki (pl. 25, fig. 1) is extremely similar to that of $T$. amygdalina (pl. 25, fig. 6). Likewise, the dorsal shell profile of the two is very similar if the umbos of $T$. louderbacki are restored to their probable size (compare pl. 25, fig. 3 , with fig. 7). There is no significant difference in the hinges or anterior muscle scars of T. louderbacki and T. amygdalina (compare pl. 25, fig. 2, with fig. 5 , and with Heidecker, 1959, pl. 1, figs. 1a, 1b). The type specimens of $T$. louderbacki do not preserve denticles. The new material of $T$. louderbacki shows that the hinge is highly variable in the number of teeth present (pl. 26). Thus, T. louderbacki and T. amygdalina are herein regarded as subjective synonyms.

$T$. guangxiensis Zhang differs from T. louderbacki in the presence of a midumbonal carina. $T$. parcidonta Zhou differs from all other species now placed in Tanaodon in the presence of strong, regularly spaced external rugae.

\section{Order TRIGONIOIDA Dall Superfamily TRIGONIACEA Lamarck Family SCHIZODIDAE Newell and Boyd, 1975}

Discussion.-Newell and Boyd $(1975$, p. 86) noted that well-preserved specimens of Devonian trigoniaceans are very rare. As a result, the group is not well understood in this time interval, and specimens are difficult to classify. Unfortunately, the Chinese material described here fits this general pattern-the specimens are poorly preserved composite molds generally distorted parallel to bedding (pl. 23).

Genus SCHIZODUS de Verneuil and Murchison, 1844

Discussion.-As a matter of convenience, most poorly preserved Devonian trigoniaceans are usually placed in 
the genus Eoschizodus Cox. Cox (1969a, p. N473) gave the stratigraphic range of Eoschizodus as DevonianPermian and said that the genus had a cosmopolitan distribution. However, Newell and Boyd $(1975$, p. 91) showed Eoschizodus to be a rare taxon and gave its stratigraphic range as upper Middle Devonian, and a possible occurrence in the Upper Devonian (1975, p. 86). Newell and Boyd $(1975$, p. 91, 96) gave the range of Schizodus as Upper Silurian-Permian, cosmopolitan; Cox (1969a, p. N475) gave the range of this genus as Carboniferous-Permian, cosmopolitan. The work of Newell and Boyd is followed here; they made an extensive search of European and American collections and had access to new material not used by Cox.

Because of the distortion of the Chinese material, it is not possible to make meaningful length/height and height/convexity measurements, which were two of the exterior criteria used by Newell and Boyd $(1975$, p. 95) to recognize Schizodus. However, the Chinese specimens show the following external morphological features ascribed to Schizodus by Newell and Boyd: (1) maximum convexity slightly posterior to beak (pl. 23, figs. 1-7); (2) umbos typically prominent, submedian, and slightly prosogyrous (pl. 23, figs. 5, 7); (3) beaks strongly incurved approaching hinge line (pl. 23, fig. 1); (4) anterior and ventral outlines without conspicuous interruptions in curvature (pl. 23, fig. 1); (5) posterior outline usually somewhat obliquely truncate (pl. 23 , figs. $1,5,6) ;(6)$ posterior ridge broadly rounded in most species; corselet poorly differentiated and plane to slightly concave (pl. 23, fig. 7); and (7) ornament lacking or limited to weak, closely spaced comarginal annulae mainly on the anterior slope (pl. 23, figs. 4, 7). The Chinese specimens are here placed in Schizodus even though internal features are not known.

The Chinese material includes two morphotypes: (1) shells that are trapezoidal in shape with the posterior end strongly obliquely truncated and contracted (pl. 23, figs. 1-3, 5, 6), and (2) shells that are semielliptical in shape with a broadly rounded posterior end without the pronounced posterior decrease in height seen in type 1 (pl. 23, figs. 4, 7). Each of these morphotypes is herein treated as a species.

\section{Schizodus aff. S. cuneus Hall, 1883+}

Plate 23, figures 1-3, 5, 6

Discussion.-The trapezoidal Chinese specimens are much like the Lower Mississippian species $S$. cuneus Hall (1883, pl. 75, figs. 29, 30; 1885 , pl. 75, figs. 29, 30) in shape, size, and ornament, and are classified as having affinities to that species. The Chinese material consists of numerous specimens from the Mahuangling and Nagaoling Members of the Nagaoling Formation
(Nagaolingian, Gedinnian), Section 1, Beds 10, 13, Liujing Railway Station, Hengxian County, Guangxi.

Schizodus aff. S. appressus (Conrad), 1842+

Plate 23, figures 4, 7

Discussion.-The semielliptical Chinese specimens are much like the Hamiltonian age species $S$. appressus (Conrad) (Hall, 1883, pl. 75, figs. 3-9; 1885, pl. 75, figs. 3-9) in shape, size, and ornament, and are classified as having affinities to that species. The Chinese material consists of three specimens; two are from the Nagaoling Member of the Nagaoling Formation (Nagaolingian, Gedinnian), Section 1, Bed 10, Liujing Station, Hengxian County, Guangxi; the third specimen is from the Ertang Formation (Sipaian, Emsian), at Locality 9, Zhongping Village, Xiangzhou County, Guangxi.

\section{Schizodus sp. A*}

Plate 54, figure 10

Discussion.-One schizodid in our collections is from Michigan (USNM 374631); it is a subquadrate weathered mold which in shape is most like $S$. rhombeus (Hall) (Hall, 1883, pl. 75, figs. 19-23; 1885, pl. 75, figs. 19-23) and S. chemungensis (Conrad), 1842 (McAlester, 1962, pl. 28). Both of these species are from the Upper Devonian rocks of New York. The Michigan specimen is from the Genshaw Formation from an abandoned shale pit, Alpena Portland Cement Company, Alpena County.

\section{Order UNIONOIDA Stoliczka Superfamily ANTHRACOSIACEA Amalitsky Family PALAEOMUTELIDAE Weir \\ Genus NYASSA Hall and Whitfield, 1869}

Diagnosis.-Elongate palaeomutelids having fasciculate comarginal ornament and actinodont dentition.

Discussion.-Nyassa was a poorly conceptualized generic name until Bailey (1983) discovered material that established the type of dentition that is present. Nyassa has a large number of teeth along almost the entire dorsal margin similar to those of the Ordovician genus Copidens Pojeta and Gilbert-Tomlinson (1977, pl. 28, fig. 4). Posteriorly the teeth are elongate lamellae, whereas anteriorly they are short. Because the teeth overlap one another, they cannot be separated into cardinals and laterals. As noted under the description of Lyrodesmatidae above, such a dentition is termed actinodont, but does not necessarily imply classification as an actinodontoid (Pojeta, in press); the term pseudotaxodont (Cox, 1969c; Bailey, 1983) for the dentition of Nyassa is not used herein.

\section{Nyassa dorsata (Goldfuss), 1840+}

Plate 24, figures 1-7

Discussion.-As noted by Bailey (1983, p. 300-303), Nyassa dorsata, from the Middle Devonian (EifelianGivetian) of Germany, is a senior subjective synonym 
of N. arguta Hall and Whitfield (1869), described from the Hamiltonian age rocks of New York. The Chinese specimens placed in this species are very similar to those from New York (compare pl. 24, fig. 2 with fig. 6) and are also placed in $N$. dorsata (Goldfuss). Thus, $N$. dorsata has an extensive geographic distribution in Middle Devonian rocks and should be looked for elsewhere.

The Chinese specimens confirm the presence of an integripalliate pallial line, which lies close to the shell margin throughout its length (pl. 24, figs. 5-7), and also confirm that the posterior adductor muscle scar is rounded and lies close to the dorsal margin (pl. 24, fig. 6). All the Chinese specimens are from the lower member of the Donggangling Formation (Dongganglingian, Givetian), Section 3, Bed 24, Heping Village, Yongfu County, Guangxi.

\section{Order VENEROIDA Adams and Adams Superfamily LUCINACEA Fleming Family MACTROMYIDAE Cox}

Genus PARACYCLAS Hall, 1843

Diagnosis.-Devonian lucinaceans with subcentral beaks.

Discussion.-McAlester (1963, p. 994) noted that most North American Lower and Middle Devonian specimens of Paracyclas in the Yale Peabody Museum fall into two distinct morphological groups. A smaller, less inflated form that has strong, more-or-less regular, comarginal sculpture is represented by many composite molds from the dark calcareous shales and mudstones of the New York Middle Devonian and also by a few specimens from the calcareous Middle Devonian units in Indiana. A larger, more inflated form that has finer, less regular sculpture is represented by many articulated composite molds, as well as numerous specimens that preserve the original shell material from the Devonian limestones of Ohio, Indiana, and Kentucky. Most of the specimens in the USNM collections also fall into these two categories, although not many of them are from New York.

These two forms have traditionally been called Paracyclas lirata (Conrad) and P. elliptica Hall respectively (Hall, 1885, pl. 72, figs. 1-30). A similar distinction is seen in the Rhenish Lower and Middle Devonian where a smaller, more strongly sculptured shale-matrix form is usually called $P$. rugosa (Goldfuss) and a larger, calcareous-matrix form is known as $P$. proavia (Goldfuss). McAlester (1963, p. 995) went on to suggest that the degree of inflation and sculptural regularity in Paracyclas lirata and P. elliptica are phenotypic features and not good specific characters. However, McAlester did not make nomenclatural changes because he believed that a complete species-level revision of Lower and Middle Devonian Paracyclas was necessary to resolve species limits and nomenclature.

Bailey $(1983$, p. 306) synonymized $P$. lirata (Conrad) with $P$. rugosa (Goldfuss). Conrad (1838, p. 116) placed $P$. lirata in the genus Posidonia; the three copies of Conrad's 1838 paper that we examined do not have the unnumbered plate with a figure of this species as cited by Bailey (1983, p. 306). Goldfuss (1837, p. 216) originally placed Paracyclas rugosa in the genus Lucina. Bailey (1983, p. 311) did not synonymize $P$. rugosa (lirata) with P. elliptica. Bailey (1983), McAlester (1963), and LaRocque $(1950$, p. 310$)$ all pointed out the difficulty of using the name $P$. elliptica. LaRocque suggested that the name be limited to the holotype of the species and that $P$. proavia (Goldfuss) was the suitable name for American specimens formerly assigned to $P$. elliptica. Bailey $(1983$, p. 309$)$ also regarded $P$. proavia as a senior subjective synonym of $P$. elliptica.

All the Chinese specimens described here are from mud-rich clastic beds and in ornament and shape are very much like those described from New York and Germany by Bailey (1983) under the name Paracyclas rugosa; we place the Chinese specimens in this species. The Chinese specimens show shape and ornament, but no details of internal morphology; some of them show considerable distortion (pl. 21, fig. 8; pl. 22, figs. 5, 6). Only two specimens of Paracyclas are in our collections from Michigan. Both are poorly preserved, small, and have ornament like that of $P$. rugos $a$, in which species we place them (pl. 53, figs. 4, 5).

\section{Paracyclas rugosa (Goldfuss), 1837+*}

Plate 21, figures 1-9; plate 22, figures 3-8; plate 53, figures 4, 5

Discussion.-The reasons for the use of this species name and for the placement of the Chinese and Michigan specimens under it are given above.

Distribution in Guangxi.-P. rugosa has a known range from the Ertang Formation to the lower part of the Donggangling Formation (Emsian-Givetian) in Guangxi. The species is especially abundant in the Ertang Formation where it occurs in Section 3, Beds 10, 11; Section 4, Beds 10,11, and 36; and at Localities 6 and 8. P. rugosa has also been found in the Sipai Formation, Section 3, Bed 13; Yingtang Formation, Section 5, Bed 16; and the Donggangling Formation, Section 3, Bed 24.

Distribution in Michigan.-In Michigan, $P$. rugosa is known from the Gorbut Member, Gravel Point Formation, Cheboygan County, and the Potter Farm Formation, Alpena County.

\section{Genus PHENACOCYCLAS LaRocque, 1950}

Diagnosis.-Devonian lucinaceans with beaks posterior to midlength. 
Phenacocyclas? sp. A*

Plate 53, figure 6

Discussion.-One specimen from Michigan is a lucinacean, but is probably not assignable to Paracyclas. This specimen (pl. 53, fig. 6, USNM 374638) differs from Paracyclas in being anteriorly elongated like Ilionia Billings (Whiteaves, 1884, p. 13) and Phenacocyclas LaRocque $(1950$, p. 312$)$. LaRocque $(1950$, p. 305,312$)$ stressed that various Devonian species placed in Ilionia by Pohl (1929, p. 69-70) probably do not belong to that genus and should be placed in Phenacocyclas. The specimen here placed in Phenacocyclas? sp. A is a composite mold that shows no internal features and is flattened parallel to bedding; it is from the Gravel Point Formation at the west end of the Penn-Dixie Quarry, 2.5 miles west southwest of Petoskey, Emmet County, Mich.

\section{Superfamily CRASSATELLACEA Férussac Family ASTARTIDAE d'Orbigny}

Genus CYPRICARDELLA Hall, 1858

Discussion.-The Chinese specimens here placed in this genus are assigned with question because of their poor state of preservation; they are figured on plate 22 , figures 1,2,9,10. The specimens from Michigan are well preserved and reinforce the interpretation of the dentition given by Boyd and Newell (1968, p. 22).

Cypricardella gregaria (Hall and Whitfield), 1869*

Plate 55, figures 1-5; plate 56, figure 9

Discussion.-As noted by McAlester (1962, p. 70), C. gregaria is distinguished from C. bellastriata (Conrad) only by its finer and less regular comarginal ornament; small specimens and predominantly internal composite molds are distinguishable only by association with more typical specimens.

The Michigan material of $C$. gregaria consists of numerous specimens, five of which are shelled and well preserved and two of which are well-preserved internal molds showing morphological detail. One left valve (pl. 55, figs. 1, 2; USNM 383621) shows cardinal dentition of 1-0 - 1 from posterior to anterior, the same as indicated by Boyd and Newell (1968) for C. subelliptica Hall, the type species of the genus. Two other left valves were not prepared correctly enough to show the correct dentition; the museum label for one of these (USNM 374639; pl. 55, fig. 4) reads: "hinge slightly carved." A right valve (USNM 383622, pl. 55, fig. 3) shows cardinal dentition of (0) - 1 - 0 from posterior to anterior, the same as indicated by Boyd and Newell (1968) for $C$. subelliptica. Two internal molds (pl. 56, fig. 9) show the adductor muscle scars and the pallial line.

Distribution.-The Michigan specimens of $C$. gregaria are from the Koehler Limestone and, according to the field label, were collected from "a rock pile 100 yards north of center S. line 30-35N-1W, Cheboygan Co."

Cypricardella? sp. A*

Plate 56, figures 5-8

Discussion.-Several internal molds from the Charlevoix Formation, Northern Lime Co. Quarry, Petoskey, Emmet County, Mich. (YPM 16628-16630), show cardinal teeth (pl. 56, fig. 8), adductor muscle scars, anterior pedal retractor muscle scars, pallial line, impressions of the radial mantle muscles (pl. 56, figs. 6, 7), and some have a prominent posterior umbonal ridge (pl. 56, fig. 5). Because of the presence of cardinal teeth and the posterior umbonal ridge, these specimens are assigned to Cypricardella? sp. A.

Cypricardella? spp.+

Plate 22, figures $1,2,9,10$

Discussion.-A number of Chinese specimens that are poorly preserved, and sometimes distorted molds, have shape or ornament reminiscent of Cypricardella. All the specimens are from the Lianhuashan or Nagaoling Formations (Gedinnian) of Guangxi.

\section{Genus CRASSATELLOPSIS Beushausen, 1895}

Crassatellopsis? sp. A+

Plate 18 , figures 8,9

Discussion.-Several specimens on two chips of rock from the Sipai Formation (Emsian) at Section 3, Bed 13, Heping Village, Yongfu County, Guangxi, are here placed with question in Crassatellopsis. The Chinese specimens have the shape of various crassatellaceans (Boyd and Newell, 1968, figs. 11-12), and one of them (pl. 18, fig. 9) seems to have a resilifer and septum (Boyd and Newell, 1968, fig. 4). Some Paleozoic trigoniaceans also have a cardinal hinge similar to the Chinese specimens placed in Crassatellopsis? (Newell and Boyd, 1975, p. 96, fig. 31). However, one of the Chinese specimens has a posterior lateral socket (pl. 18, fig. 9), which is characteristic of crassatellaceans rather than trigoniaceans. The Chinese specimens do not have the shape of Crassatellopsis hauchecornei Beushausen (1895, pl. 11, figs. 1-4), which is the type species of the genus.

\section{Family CARDINIIDAE Zittel}

\section{Genus CYPRICARDINIA Hall, 1859}

Diagnosis.-Cardiniids having imbricating comarginal rugae between which are $\mathrm{V}$-shaped divaricate ridges.

Discussion.-In our collections, this genus is represented by 24 specimens, all from Michigan; the stratigraphic range in the Traverse Group is from the 
Newton Creek Formation through the Four Mile Dam Formation (Givetian). Several of the Michigan specimens preserve the unusual external ornament of lamellose growth increments and divaricate ridges meeting to form "V's" (pl. 54, figs. 8, 9; pl. 56, figs. 1-3). This type of ornament is present in species of Cypricardinia from the Upper Silurian (Krasilova, 1963, pl. 14), Hamilton Group of New York (Hall, 1885, pl. 79, figs. 14), Devonian of Victoria, Australia (Talent, 1963, pl. 68, figs. A4, 7, 8), and perhaps the Lower Mississippian of Ohio (Hall, 1885, pl. 79, fig. 18). Morris (1978, p. 263) did not regard Cypricardinia as belonging to the Cardiniidae. He placed it doubtfully in the Cycloconchidae Miller.

\section{Cypricardinia sp. A $^{*}$}

Plate 54, figures 8,9 ; plate 56 , figures $1-4$

Discussion.-Numerous species have been placed in Cypricardinia, and they range in age from Ordovician to Permian. The specimens from the Givetian of Michigan could easily be placed in one or more new species. However, that procedure is not followed herein; we place all of the specimens in open nomenclature as Cypricardinia sp. A. Monographic study of Cypricardinia throughout its stratigraphic range is very much needed.

\section{Family HIPPOPODIIDAE Cox}

Discussion.-This family name is credited to Cox (1969b, p. N582); two genera are listed: (1) Hippopodium J. Sowerby and (2) ?Tusayana Stoyanow. After the family name is the notation: "Materials for this family prepared by L. R. Cox with addition by Aurele LaRocque." At the end of the listing of genera (p. N583) is the notation: "Inclusion of the Paleozoic Tusayana in this family is very dubious.-Ed." Also on p. N583, just before the listing of genera is the following statement: "This family is known only by its type genus***" Because of all this equivocation, it is difficult to determine what concept is indicated by the name Hippopodiidae, who is responsible for that concept, and what is the stratigraphic range of the family.

Hippopodium is large, thick-shelled, covered with irregularly rugose growth laminae, and Jurassic in age; internally it has a broad hinge plate. Tusayana is known from incomplete specimens that are thick-shelled, have a broad hinge plate, and are from the Devonian of Arizona (Stoyanow, 1948, p. 787). Both Hippopodium and Tusayana have cardinal and lateral teeth. Unfortunately, when Stoyanow described Tusayana, he oriented the specimens with the beaks up, so that he thought of them as being subcentral and the shell as subcircular. If the specimens are oriented with the hinge axis horizontal, it is apparent that a large part of each of his specimens is missing and that the beaks are nearly terminal. His statement $(1948$, p. 788$)$ "There is no cavity under the hinge plate," reflects the preservation of the specimens. On the specimen shown on his plate 120 , figure 15 , the space is filled by matrix; the specimen shown on his plate 120 , figure 12 , suggests the presence of a cavity. Two Chinese specimens are here tentatively assigned to Tusayana and are discussed below.

\section{Genus TUSAYANA Stoyanow, 1948}

Diagnosis.-Hippopodiids? having cardinal hinge plate bearing several teeth.

Discussion.-Two specimens from Guangxi (pl. 16, figs. 4-6) are assigned to Tusayana with question. The Chinese material is not well preserved, although the shell is present. The specimens are thick shelled; have terminal beaks; the anterior adductor muscle scar is deeply impressed; hinge plate broad, cardinal teeth are not preserved on it, lateral teeth were probably in each valve. More material from both Guangxi and Arizona is needed to fully determine the taxonomic placement of the species of Tusayana on the two continents.

\section{Tusayana? liujiangensis n. sp. +}

Plate 16, figures 4-6

Description.-Posteriorly elongated, beaks terminal, ornament of comarginal growth lines, not well known, shape much like that of Hippopodium, shell thick. Anterior adductor muscle scar deeply impressed with prominent ventral ridge as in Tusayana, other muscle scars unknown. Teeth on a broad hinge plate, cardinal teeth not preserved on anterior part of hinge plate, left valve has one posterior lateral tooth, right valve with probable posterior lateral tooth at ventral margin of hinge plate. Ligament opisthodetic, elongate.

Types.-T.? liujiangensis is known from two shelled and articulated specimens, one of which was broken open to reveal the internal morphology (GXD-517). Specimen GXD-517 is the holotype (pl. 16, figs. 5-6); it is incomplete posteriorly. Specimen GXD-518 (pl. 16, fig. 4) is the paratype; it is $78.2 \mathrm{~mm}$ long, $48.5 \mathrm{~mm}$ high, and $30 \mathrm{~mm}$ wide (both valves); posteriorly the shell is about $3 \mathrm{~mm}$ thick. Anteroventrally, the shell of the holotype is $6 \mathrm{~mm}$ thick.

Type locality.-Both known specimens of T.? liujiangensis are from the Donggangling Formation (Givetian) at Locality 10, east bank of the Liujiang River, Liujiang County, Guangxi.

Etymology.-The name of the species is derived from Liujiang County, Guangxi.

Remarks.-At first we thought that the cardinal hinge plate of each of the two valves of the holotype represented cardinal teeth, particularly because in the right valve the cardinal hinge plate is not connected to 
the posterior hinge plate (pl. 16, fig. 6). However, after the two valves of the holotype were restored to their unbroken condition, we saw that the right and left cardinal hinge plates were opposed and not alternate. The needle marks above the right cardinal hinge plate indicate that its connection to the posterior hinge plate was removed during preparation.

$T$.? liujiangensis differs from $T$. cibola Stoyanow in having terminal beaks. The two species are similar in having prominent anterior adductor muscle scars, the ventral margins of which are marked by high ridges, broad hinge plates, posterior lateral teeth, and elongate opisthodetic ligaments. In shape, T.? liujiangensis is much like Hippopodium ponderosum Sowerby from the Jurassic of England (compare pl. 16, fig. 4 with Cox, 1969b, fig. E8, 2, p. N582).

\section{Superfamily ARCTICACEA Newton \\ Family MECYNODONTIDAE Haffer \\ Genus MECYNODON Keferstein, 1857}

Discussion.-Previous to this study, Mecynodon was known to occur only in the Devonian rocks of Germany (Beushausen, 1895; Haffer, 1959) and North America (Williains and Breger, 1916). One specimen of the genus is now known from the Lower Devonian (Gedinnian) of Guangxi (pl. 23, fig. 8). Superficially, Mecynodon looks much like Goniophora (Goniophora) (pl. 18, fig. 1) because both genera have a prominent external carina. However, Mecynodon has prominent hinge teeth and Goniophora (Goniophora) does not.

Mecynodon aff. M. carinatus Goldfuss, 1837+

Plate 23, figure 8

Discussion.-The single known Chinese specimen of Mecynodon is very similar to a specimen of $M$. carinatus figured by Beushausen (1895, pl. 16, fig. 19) in its triangular shape and the presence of one horizontal and one oblique posterior lateral tooth. The Chinese specimen differs from the German specimen in having weaker ornament; its midumbonal carina divides the shell into two nearly equal halves, whereas the umbonal carina of the German specimen is on the posterior umbonal slope and does not divide the shell into equal halves.

The Chinese specimen (GXD-640) is a composite mold from the Nagaoling Formation, (Gedinnian), Locality 7, Xinxu Village, Mengshan County, Guangxi. It measures $15.1 \mathrm{~mm}$ long, $12.2 \mathrm{~mm}$ high, and about $2.7 \mathrm{~mm}$ wide (single valve).

\section{Subclass ANOMALODESMATA Dall Order PHOLADOMYOIDA Newell Superfamily PHOLADOMYACEA Gray}

Discussion.-Runnegar (1974) presented a thorough analysis of this subclass, and his classification is used herein. He placed all Paleozoic species in the superfamily Pholadomyacea, which contains equivalved species having an external opisthodetic ligament. Pojeta and Zhang (1984) announced the discovery of Sinodora Pojeta and Zhang, an inequivalved Devonian genus, which may have an internal ligament; they placed it in the Pholadomyacea with question. Herein, we propose the superfamily Sinodoracea (nomen translatum, ex Pojeta and Zhang, 1984). This procedure preserves the definition of the Pholadomyacea and stresses the idea that Sinodora is a convergent homeomorph of the Pandoracea.

\section{Family EDMONDIIDAE King}

Discussion.-Runnegar and Newell (1974) gave a thorough review of this family and demonstrated the presence of an external ligament and a deeply furrowed hinge plate on each valve. The furrow, previously interpreted as a ligainent groove, contains a row of small suspensory muscle scars. The presence of the hinge-plate furrow distinguishes the Edmondiidae from otherwise similar representatives of the family Grammysiidae.

The Chinese specimens of Edmondiidae are not well preserved. They are either composite molds or internal molds, most of which are articulated. In two of them, the hinge furrows, indicating the presence of hinge plates (pl. 29, figs. 2, 3), are preserved.

\section{Genus EDMONDIA de Koninck, 1842+}

Discussion.-The Chinese specimens of Edmondia fall into two morphogroups. (1) Anteriorly-posteriorly elongated specimens (pl. 29, figs. 1-3), which are much like $E$. subovata Hall (1885, pl. 74, figs. 18-21). All five Chinese specimens of this type are from the Donggangling Formation (Givetian), Section 3, Bed 23, Heping Village, Yongfu County, Guangxi. (2) Subcircular specimens (pl. 29, figs. 4-6; pl. 30, fig. 2), which are much like E. philipi Hall and Whitfield, 1870 (Hall, 1885, pl. 74, figs. 12-14). All four Chinese specimens of this type are from the Donggangling Formation (Givetian), Section 3, Bed 23, Heping Village, Yongfu County, Guangxi.

Hall (1885) noted that both E. subovata and E. philipi occur in the Chemung Group of New York. McAlester $(1962$, p. 65$)$ regarded $E$. philipi and $E$. subovata as synonyms; $E$. philipi has priority; he noted that the species is common in the Chemung Stage and in postChemung Upper Devonian rocks of New York and northern Pennsylvania (Caster, 1930, p. 221). McAlester (1962, p. 65) was able to demonstrate considerable size and shape variation in $E$. philipi, and a tendency toward greater elongation as size of the shell increased. He noted (p. 66): "***that only a consideration of variation in large samples can lead to meaningful species in this genus [Edmondia]." 
We have nine specimens of Edmondia from Guangxi. The two shapes among these may represent the extremes of variation of a single species; this interpretation is reinforced by the fact that all specimens of both shapes are from the same bed. However, the subcircular specimens from Guangxi are all as high as, or higher than, the elongate specimens; in our material we do not see the tendency toward greater elongation with increasing size of shell. The Chinese specimens are placed in Edmondia with affinities to $E$. subovata and $E$. philipi.

Genus CARDIOMORPHA de Koninck, 1842+

Discussion.-One specimen (GXD-714) from the Yingtang Formation (Eifelian), Section 5, Bed 21, has the strongly prosogyral anteriorly placed beaks, shell shape, and small oval anterior adductor muscle scar of Cardiomorpha as figured by Runnegar and Newell (1974, p. 9). The Chinese specimen is an internal mold, which is not particularly well preserved (pl. 30 , figs. 3 , 4); however, it does seem to have a cardinal tooth in each valve (pl. 30 , fig. 4), the tooth of the left valve lying ahead of that of the right valve. Runnegar and Newell $(1974$, p. 6, 7) noted that Permian specimens of Scaldia possess cardinal teeth, Edmondia and Cardiomorpha do not; however, in Scaldia, the cardinal tooth of the right valve lies ahead of that of the left. A second specimen (GXD-715, unfigured) has the same beak and shell shape as GXD-714 and is from the same bed; however, it does not preserve any other details of morphology.

The Chinese specimens GXD-714, -715 are here classified as Cardiomorpha? sp. indet. on the basis of shape and beaks. They may represent a new taxon; however, more specimens must be found before their taxonomic position can be firmly established.

\section{Family GRAMMYSIIDAE Miller}

Genus GRAMMYSIA de Verneuil, 1847

Discussion.-In our collections, Grammysia is represented by two poorly preserved and distorted specimens (pl. 55, fig. 7) from Michigan; they preserve two radial umbonal grooves (USNM 374644a, b). We follow McAlester (1962) and Runnegar (1974) in limiting the name Grammysia to species that have rugose comarginal ornament and the characteristic double umbonal grooves of the type species $G$. bisulcata (Conrad); all other similar species whether ungrooved or with one groove are placed in Grammysioidea Williams and Breger, 1916. The Michigan specimens of Grammysia sp. (USNM 374644) are from the Norway Point Formation, Norway Point Dam, Thunder Bay River, Alpena County.

\section{Genus GRAMMYSIOIDEA Wilkiams and Breger, 1916}

Discussion.-In our collections, Grammysioidea is represented by five poorly preserved specimens. Four of the specimens are from Guangxi (GXD-723, -724, $-725,-726$ ), and one is from Michigan (USNM 374645). Specimen GXD-723 (pl. 29, fig. 7) is from the Yujiang Formation (Siegenian-Emsian), Locality 11; specimen GXD-724 (pl. 28, fig. 7) is crushed and is from the $\mathrm{Yu}$ jiang Formation (Siegenian-Emsian), Section 1, Bed 21; specimens GXD-725 (pl. 28, fig. 6), and GXD-726 are from the Yilan Formation of the Nandan Facies, (Siegenian-Emsian), Locality 12; specimen USNM 374645 (pl. 55, fig. 6) is from the Norway Point Formation, 0.75 miles southeast of Four Mile Dam, Alpena County. In the present state of knowledge, these weathered and (or) distorted specimens of Grammysioidea provide occurrence data for the stratigraphic intervals involved, and are classified as Grammysioidea sp.

\section{Genus SPHENOTUS Hall, 1885}

Diagnosis.-Grammysiids having one or more radial ribs dorsal to the posteroumbonal ridge and fine comarginal ornament anterior to the ridge.

Discussion.-Newell and LaRocque (1969b, p. N823) placed the genus Sphenotus in synonymy with Sanguinolites M'Coy (1844). Sanguinolites is not well conceptualized, as indicated by Runnegar (1974) in his monograph of the Anomalodesmata, where the genus is mentioned twice, and only in passing, on p. 930. Even the type species of Sanguinolites has been disputed. According to Driscoll (1965), the type species is Sanguinolites angustatus (Phillips), by original designation of M'Coy (1862, p. 48); M'Coy, 1844, was reissued in 1862 with a new title page (Driscoll, 1965, p. 110). We have examined Frank Springer's copy of the 1862 edition of M'Coy, and nowhere on p. 48, or on any of the other pages dealing with Sanguinolites, can we find any statement that suggests a type species designation for the genus. Newell and LaRocque $(1969 \mathrm{~b}, \mathrm{p}$. N823) noted that the type species of Sanguinolites is $S$. discors M'Coy, 1844, from the Mississippian of Ireland, by subsequent designation of Stoliczka (1871). Stoliczka 1871 (1870?), p. xix, listed the typical species of Sanguinolites M'Coy, 1844, as $S$. discors M'Coy; on p. 270 (1871), he listed $S$. discors as the type of Sanguinolites M'Coy. Newell and LaRocque (1969b, p. N821) copied M'Coy's (1844) figure of $S$. discors; his figure is shown here on figure $15 B$. The figure is of a right valve about $2.5 \mathrm{~cm}$ long having a prominent posteroumbonal ridge anterior to which are rugose growth increments, and dorsal to which the shell is smooth. Hind $(1900$, p. 362) placed $S$. discors in synonymy with $S$. angustatus (p. 362,366) and regarded the latter as the type species of Sanguinolites. Hind (1900, pl. 40, fig. 2) figured a specimen which he called the type of $S$. discors; his figure is much like that of M'Coy $(1844$, pl. 8, fig. 4), but is of a left valve. 
Sphenotus has the type species Sanguinolites arcaeformis Hall and Whitfield (1869, p. 40), by subsequent designation of Miller (1889, p. 513) from Hamiltonian age rocks of New York. Hall's figures of $S$. arcaeformis (1885, pl. 65, figs. 7-11) are shown here on figure $15 C-G$. They are of shells that average about $2.5 \mathrm{~cm}$ in length and have a posteroumbonal ridge, anterior to which is fine comarginal ornament, and posterior to which are one or two radial ribs. Specimens of $S$. arcaeformis are here figured on plate 57, figures 5-8; they show that the comarginal ornament can vary in strength, but in the specimens we have seen, comarginal ornament was not as strong as in Sanguinolites discors.

Runnegar (1974, p. 932) suggested the possibility that the types of Sphenotus arcaeformis (fig. $15 C-G$ ) might be juveniles of a species of Cimitaria Hall and Whitfield because, in part, specimens of both are known from the Hamilton Group at Delphi, N.Y., from where the types of Sphenotus arcaeformis were found (Hall, 1885, pl. 65, figs. 7-11), and also because $S$. tiogensis McAlester bears shape similarities to Cimitaria angulata (McAlester, 1962, pl. 26). McAlester regarded Sphenotus tiogensis as being closely allied to $S$. arcaeformis, even though it has anterior rugae and only one specimen has posterodorsal ribs. Small Cimitarias can be much like Sphenotus/Sanguinolites in shape (compare pl. 31, fig. 1, with pl. 54, fig. 1, and see Hall, 1885, pl. 77). In Guangxi, Sphenotus occurs with Cimitaria at two localities-Yujiang Formation, Section 1, Bed 21, and Ertang Formation, Section 3, Bed 10; however, at several other localitites, only Sphenotus is known. In Michigan, we have found Cimitaria at two localities, and at neither one is Sphenotus known. A significant morphological difference between Cimitaria and Sphenotus arcaeformis is that all external and composite molds of Cimitaria seen by us have a prominent midumbonal sulcus (pl. 54, figs. 1-6; Hall, 1885, pl. 77), which is lacking in Sphenotus (pl. 30, figs. 5-7; pl. 57, figs. 5-8; Hall, 1885 , pl. 65 , figs. $7-11 ;=$ fig. $15 C-G$ herein). This feature was part of the original definition of Cimitaria (Hall and Whitfield, 1869, p. 66). Until a good growth series of Cimitaria is known, it is best to consider Cimitaria a different concept from Sphenotus.

Herein, the name Sanguinolites is used for species that have rugose comarginal ornament anterior to the posteroumbonal ridge and lack radial ornament dorsal to the ridge. Sphenotus is used for species that have one or more radial ribs dorsal to the posteroumbonal ridge and may have a finer comarginal ornament anterior to the ridge than do species placed in Sanguinolites. Cimitaria is used for scimitar-shaped species having variable strength of comarginal ornament, with or without ribs dorsal to the posteroumbonal ridge, and with a midumbonal sulcus. Runnegar (1974) placed
Cimitaria in the Grammysiidae and included both Sphenotus and Sanguinolites in this family with question.

\author{
Sphenotus yingtangensis n. sp. + \\ Plate 30, figures 5-7
}

Description.-Average size Sphenotus (between 20 and $25 \mathrm{~mm}$ long), umbos not projecting significantly above dorsal margin; anterior margin strongly convex, ventral margin gently convex to almost straight, posterior margin oblique, truncate; posterior umbonal ridge broadly angular; posterior dorsal area with two ribs.

Types. $-S$. yingtangensis is known from four specimens. All are preserved as compressed composite molds in mudstone. The holotype is a left valve (GXD-746) shown on plate 30 , figure 6 , which measures $22.5 \mathrm{~mm}$ long and $12.8 \mathrm{~mm}$ high. Two paratypes are shown on plate 30, figures 5, 7 (GXD-740, -747).

Type locality.-All known specimens are from the Yingtang Formation (Eifelian), Section 5, Bed 16, Luoban Village, Luoxiu Community, Xiangzhou County, Guangxi.

Etymology.-The species is named for Yingtang Village, Guangxi.

Comparisons. $-S$. yingtangensis differs from $S$. arcaeformis (pl. 57, figs. 5-8) in having a broadly angular posteroumbonal ridge rather than a sharply angular one.

Genus SANGUINOLITES M'Coy, 1844

Diagnosis.-Grammysiids having rugose comarginal ornament anterior to posteroumbonal ridge; lacking radial ornament posterior to ridge.

Sanguinolites nagaolingensis n. sp. +

Plate 31 , figures 1-6

Description.-Sanguinolites much like $S$. discors in shape, but with comarginal rugae increasing by bifurcation and intercalation.

Types. $-S$. nagaolingensis is known from six specimens. All are preserved as compressed composite molds in mudstone. The holotype is a left valve (GXD-743) shown on plate 31 , figures 5,6 , which measures $27.5 \mathrm{~mm}$ long and $11.1 \mathrm{~mm}$ high. Four paratypes are figured on plate 31 , figures $1-4$.

Type locality.-All known specimens are from the Nagaoling Formation, Section 1, Beds 10, 13, near Liujing Village, Hengxian County, Guangxi. The holotype (GXD-743, pl. 31, figs. 5, 6) is from Bed 10.

Etymology.-The Species is named for Nagaoling Hill, Liukankou Reservoir, Liujing Village, Guangxi.

Remarks. - None of the specimens of $S$. nagaolingensis are well preserved, but all of them show at least relict 
preservation of the comarginal rugae, and several show the posterodorsal auricle very well; clearly, no posterior dorsal ribs are in the known material. The holotype shows the method of increase of the comarginal rugae (pl. 31, figs. 5, 6).

$$
\begin{aligned}
& \text { Sanguinolites? spp. }+ \\
& \text { Plate } 30 \text {, figures 1, } 8
\end{aligned}
$$

Discussion.-A number of crushed poorly preserved or distorted composite molds are included under this designation. Some of them have shapes more-or-less like those of Sphenotus or Sanguinolites; they all lack apparent posterior dorsal ribs and are all herein arbitrarily placed in Sanguinolites? sp. in the faunal lists given with the sections from which they were collected.

\section{Genus CIMITARIA Hall and Whitfield, 1869}

Diagnosis.-Scimitar-shaped grammysiids having comarginal ornament of varying strength, with or without ribs dorsal to the posteroumbonal ridge, and with a midumbonal sulcus.

\section{Cimitaria sinensis n. sp. +}

Plate 31 , figures 7,8 ; plate 35 , figure 1

Description.-Cimitaria having broadly angular posteroumbonal ridge that more-or-less intersects the posteroventral angle of shell; dorsal margin shallowly concave.

Types. $-C$. sinensis is known from two specimens. The holotype (GXD-718) is an internal mold which has been flattened parallel to bedding (pl. 31, fig. 8) and which preserves the anterior adductor muscle scar. Because it is an internal mold and has been flattened, it does not show the midumbonal sulcus. The holotype is $68.3 \mathrm{~mm}$ long and $26 \mathrm{~mm}$ high at midlength of the shell; it is from the Ertang Formation (Emsian), Section 3, Bed 10, Heping Village, Yongfu County, Guangxi.

The paratype (GXD-748) is a poorly preserved composite mold with spread valves, which are flattened parallel to bedding (pl. 31, fig. 7; pl. 35, fig. 1). The right valve is better preserved than the left and shows the shallowly concave dorsal margin. The midumbonal region is weathered; compaction has distorted the shell so that the posteroventral region is not in proper perspective. The paratype is from the Yujiang Formation (Siegenian-Emsian), Section 1, Bed 21, near Liujing Village, Hengxian County, Guangxi.

Type locality.-The type locality is the Ertang Formation (Emsian), Section 3, Bed 10, Heping Village, Yongfu County, Guangxi.

Etymology.-Latin Sinae, an oriental people mentioned by Ptolemy, and now generally applied to things pertaining to China and the Chinese.
Comparisons. $-C$. sinensis differs from other species of Cimitaria in its broadly rounded posteroumbonal ridge, which more or less intersects the posteroventral angle. It is difficult to compare $C$. sinensis with $C$. guangxiensis Zhang $(1977$, pl. 201, figs. 11, 12) from the Sipai Formation (Emsian) of Guangxi, because the known specimens of $C$. guangxiensis are anteriorlyposteriorly compressed. However, C. guangxiensis does seem to have a narrowly angular posteroumbonal ridge.

Cimitaria recurva (Conrad), 1842*

Plate 54, figures 1-7

Discussion.-This species is known from two specimens in Michigan. Specimen USNM 374646 is preserved as part and counterpart. The part is an external mold, the anterior end of which has been reconstructed in plaster of paris by Yang (pl. 54, fig. 3). A wax impression of the external mold is shown on plate 54, figure 4 (YPM 16498). These two figures clearly show the angular posteroumbonal ridge, growth lines, midumbonal sulcus, and strongly concave dorsal margin. The counterpart is an incomplete composite mold of the anterior half of the shell (pl. 54, figs. 1, 2), which shows shape similarities to Sphenotus/Sanguinolites (compare with pl. 31, fig. 1) but clearly shows the midumbonal sulcus. The counterpart is unusual in that it is articulated and inflated showing little evidence of compaction. This specimen is from the upper Alpena Limestone (Givetian), Four Mile Dam, Alpena County.

The other specimen (USNM 374647; pl. 54, figs. 5-7) is an articulated composite mold, which also shows little compaction and demonstrates that the species is equivalved. The specimen is weathered dorsally and does not show the posteroumbonal ridge well. It is from the Thunder Bay Limestone, Partridge Point, Alpena County.

\section{Genus SEDGWICKIA M'Coy, 1844}

Discussion.-Runnegar (1974, p. 932) provided the most recent concept of the genus Sedgwickia. One specimen figured by him (1974, pl. 2, fig. 14) has a midumbonal sulcus, across which the comarginal rugae increase in number by intercalation (pl. 28 , fig. 5 , herein), and has fine radial ornament; this specimen is from the Pennsylvanian of Texas.

From Guangxi, we have several specimens, which are flattened parallel to bedding; they also have a midumbonal sulcus and rugose comarginal ornament that increases in number by intercalation across the sulcus ( $p l$. 27). These specimens are herein placed in Sedgwickia with question. They are much less high anteriorly than is Sedgwickia sp. (pl. 28, fig. 5), and some of them suggest that radial ornament may have been present ( $p l$. 27 , figs. $2,3,5,6)$. 
Sedgwickia? yingtangensis n. sp. +

Plate 27, figures 1-8

Description.-Sedgwickia-like shells, with midumbonal sulcus, which are considerably less high anteriorly than posteriorly. Ornament of comarginal rugae that increase in number across the midumbonal sulcus by intercalation; posterodorsally some rugae also show increase in number by subdivision.

Types. - S.? yingtangensis is known from 13 reasonably complete composite molds and a number of fragmentary ones. The holotype (GXD-630) is the specimen that best preserves the ornament (pl. 27, fig. 8); it is 23.1 $\mathrm{mm}$ long. The paratype shown on plate 27 , figure 4 (GXD-634) is $26.9 \mathrm{~mm}$ long, $17.5 \mathrm{~mm}$ high at the posterior end, and $11.3 \mathrm{~mm}$ high near the anterior end. All known specimens are preserved as flattened composite molds in mudstone.

Type locality.-All known specimens of S.? yingtangensis are from the Yingtang Formation (Eifelian), Section 5, Bed 16, Luoban Village, Louxiu Community, Xiangzhou County, Guangxi.

Etymology.-The species is named for Yingtang Village, Guangxi.

Remarks.-Poorly preserved specimens of S.? yingtangensis (pl. 27, fig. 3) look much like specimens of Cypricardinia crenistria (Sandberger and Sandberger) from the Devonian of Victoria, Australia (Talent, 1963, pl. 62, figs. 2, 11), but differ in the absence of divaricate ornament. Several of our specimens of Sedgwickia? yingtangensis show the intercalation of the comarginal rugae across the umbonal sulcus (pl. 27, figs. 1, 6, 7, 8); only two specimens show the increase in number of rugae posterodorsally (pl. 27, figs. 7,8 ).

All known specimens of $S$.? yingtangensis are compressed parallel to bedding. The compression makes them difficult to photograph; hence a very low angle light was used for the pictures on plate 27 . Within the philosophy of classification of grammysiids, S.? yingtangensis probably will require placement in a new genus when the species is better known.

\section{Superfamily SINODORACEA Pojeta and Zhang, 1984 (nomen translatum, herein, ex Sinodoridae Pojeta and Zhang, 1984) \\ Family SINODORIDAE Pojeta and Zhang, 1984 \\ Genus SINODORA Pojeta and Zhang, 1984}

Diagnosis.-Right convex shells having radial costellae and weak comarginal ornament.

Discussion.-This genus was monographed by Pojeta and Zhang (1984). It is mentioned here briefly for completeness of the present monograph and because one new bit of morphological information has been obtained.
Sinodora concava Pojeta and Zhang, $1984+$

Plate 24, figure 8

Discussion.-Several new specimens of right valves have been found in the Ertang Formation (Emsian), Section 4, Bed 36, Liufengshan Hill, Wuxuan County, Guangxi, which show the characteristic single posterodorsal sulcus and large umbo of $S$. concava. The specimens are the only ones known to show the ornament. They demonstrate that the ornament of the right valve of $S$. concava is much like that of $S$. semiglabra in that radial ribs are absent from the anterior end of the shell. The two species can readily be told apart by the umbos and posterodorsal sulci.

\section{Subclass PTERIOMORPHIA Beurlen Superorder PRIONODONTA MacNeil Order ARCOIDA Stoliczka \\ Superfamily ARCACEA Lamarck \\ Family PARALLELODONTIDAE Dall \\ Subfamily PARALLELODONTINAE Dall}

Genus PARALLELODON Meek and Worthen, 1866

Discussion.-The generic level nomenclature of Paleozoic parallelodonts is extremely complicated and not fully resolved. It has been reviewed a number of times, and Driscoll (1961) provided the most recent evaluation. Paleozoic species placed in Parallelodon have been little studied. Although a number of names exist for them, no monographic treatment has been made of the group. McAlester (1962) placed an Upper Devonian parallelodont in the genus Grammatodon Meek and Hayden; both he and Driscoll (1965) used the name Cosmetodon Branson for Paleozoic species. McAlester (1962, p. 24) treated Cosmetodon as a subgenus of Grammatodon, whereas Driscoll (1965, p. 98-99) treated it as a subgenus of Parallelodon. All three names, Parallelodon, Grammatodon, and Cosmetodon, have type species of Jurassic age.

All our specimens of parallelodonts are from Guangxi; none are in our Michigan collections. The Chinese specimens do not show the critical hinge features used by Newell (1969b, p. N256-257) to separate subfamilies of parallelodonts. Newell has provided the most recent attempt to divide parallelodonts into subfamilies, groups, and genera; we use his pragmatic approach to the classification of Paleozoic species. Except for one species, which was included with question in the Parallelodontidae (Newell, 1969b, p. N258), Newell placed all Paleozoic species in the single genus Parallelodon, which he did not divide into subgenera.

Parallelodon guangxiensis n. sp. +

Plate 35, figure 2; plate 38 , figures $3,4,6,7$

Description.-Parallelodon having shell covered by simple costellae, which may show occasional intercalation; 
small anterior ribbed auricle present; greatest length of shell below hinge line and at about midheight; ventral margin lacking sinus; midumbonal sulcus absent; internal features unknown.

Types. $-P$. guangxiensis is known from seven specimens, of which five are figured. The holotype (GXD-038) is a shelled specimen shown on plate 38, figure 3; it measures $11.9 \mathrm{~mm}$ long, $5.8 \mathrm{~mm}$ high, and $1.2 \mathrm{~mm}$ wide.

Type locality.-All known specimens are from the Sipai Formation (Emsian), Section 3, Beds 12, 13, Heping Village, Yongfu County, Guangxi. Paratype GXD-656 is from Bed 12; all other specimens are from Bed 13.

Etymology.-The species is named for the Autonomous Region of Guangxi.

Comparisons.-Parallelodon guangxiensis differs from many Devonian species of the genus in the presence of radial ribs covering the entire shell. $P$. hamiltonae (Hall and Whitfield) (Hall, 1885, pl. 51, figs. $1-7,9,10)$ has radial markings, but these are interrupted by comarginal lamellae, and the radial ribs are strongest posteriorly. In P. guangxiensis, the strongest radial markings are on the anterior side of the umbo, and comarginal ornament is weak.

\section{Superorder ANISOMYARIA Neumayr Order PTERIOIDA Newell \\ Suborder PTERIINA Newell Superfamily AMBONYCHIACEA Miller Family AMBONYCHIIDAE Miller}

Discussion.-Pojeta $(1962,1966)$ and Pojeta and Gilbert-Tomlinson (1977) have provided the modern monographs of this lower Paleozoic family. Pojeta and Runnegar (1985) have demonstrated the presence of the duplivincular ligament in ambonychiids. Ambonychiids had their greatest radiation in the Late Ordovician, from which about 17 genera are known; only 3 genera are known in the Silurian; and until our work only 7 Devonian genera were known. Two new genera of Devonian ambonychiids are described here, and a third, which was previously described by Zhang (1977), is extensively documented.

\section{Genus FASCICULIPTERA Zhang 1977}

Type species.-Fasciculiptera guangxiensis Zhang, 1977 , p. 493 , by original designation and monotypy.

Diagnosis.-Ambonychiids having small anterior lobe, beaks subterminal; radial ribs arranged in fascicles with a strong central costa to either side of which are costellae; dentition consists of a single cardinal tooth in the right valve and a single socket in the left valve; byssal sinus prominent, byssal gape absent.

Stratigraphic distribution.-Sipaian (Emsian)Dongganglingian (Givetian) of Guangxi, China.
Comparisons.-Fasciculiptera is only one of four known genera of Devonian ambonychiids to have radial ornament; one of these is Carinonychia, which is described as new herein. Only Fasciculiptera is known to have fascicled ribs. Carinonychia is simplicicostate over most of the shell with the umbonal rib bifurcating. Byssopteria Hall has a complex multicostate ornament consisting of ribs that both bifurcate and intercalate, although many of the costae remain simple. Follmannia Dreverman shows increase in costae by bifurcation, although various ribs remain simple; it was reported from the Devonian of Yunnan by Pojeta (1966, p. 141). Stappersella Maillieux is simplicicostate.

Among older taxa, two genera of Ordovician ambonychiids show increase in the number of radial ribs by both intercalation and bifurcation. The costae of Maryonychia Pojeta are not fascicled. The ribs of Opisthoptera Meek are bunched, but they are costellae; there is no strong central costa, and Opisthoptera has an enormous posterior wing.

Fasciculiptera guangxiensis Zhang, 1977+

Plate 32, figures 1-10; plate 33, figures 1-7

1977. Fasciculiptera guangxiensis Zhang, p. 493, pl. 193, figs. 7-9, 17.

1977. Byssopteria? sp. Zhang, p. 493, pl. 193, fig. 6 .

Diagnosis. -Fasciculiptera with one or more umbonal ribs having raised growth lamellae or small spines.

Stratigraphic distribution.-Several shelled specimens (pl. 32, figs. 1-6; pl. 33, figs. 1-4) are known from the Donggangling Formation (Givetian), Section 2, bed unknown, near Dale Village, Xiangzhou County, Guangxi; the specimens figured by Zhang (1977) came from this locality, and it is the type locality of the species. One internal mold showing the cardinal dentition (pl. 32, figs. 7-9) and a large number of complex composite molds (pl. 32, fig. 10; pl. 33, figs. 5-7) are from the Donggangling Formation (Givetian), Section 3, Bed 23, Heping Village, Yongfu County, Guangxi.

Remarks. $-F$. guangxiensis has complex ornament, which is affected by the method of preservation. The ornament is best shown on shelled specimens. The major ribs are plicae, as is shown on plate 32 , figure 4 , where they interdigitate along the ventral commissure. The fascicled ribs are best shown on plate 33, figure 3, but are also discernible on plate 32 , figures 3,6 , and plate 33 , figures 1,4 . Raised lamellose growth increments on the umbonal rib(s) can be seen on plate 32 , figure 6 , and plate 33 , figures 1,4 . Small spines on the umbonal rib(s) can be seen on plate 32 , figure 1 , and plate 33, figure 2. Ribs on the anterior lobe can be seen on plate 32 , figure 5 .

On internal molds, only the major ribs are preserved (pl. 32, fig. 7), and they interdigitate on the ventral 
margin. Internal molds also show the small anterior lobe (pl. 32, fig. 9) and the cardinal teeth (pl. 32, fig. 8).

On the complex composite molds (pl. 32, fig. 10; pl. 33 , figs. 5-7), the fasciculation of the ribs is not always apparent (pl. 32, fig. 10). This suggests that these may be molds of the inside of the outer shell layer where the costae would show more readily than the costellae. Internal molds do not show the costae extending to the apex of the shell (pl. 32, fig. 7). Subdivision of the ribs and a hint of fasciculation can be seen on some of the complex composite molds (pl. 33, figs. 5, 6). In addition, most specimens show raised growth lamellae on the umbonal ribs (pl. 33, figs. 5-7), and some show ribs on the anterior lobe (pl. 33, fig. 7). Comarginal ornament indicates that some specimens had a small posterodorsal wing (pl. 33, fig. 6).

\section{Fasciculiptera sp. A+ \\ Plate 34, figures 4-7}

Discussion.-Five poorly preserved and (or) distorted complex composite molds are herein placed in Fasciculiptera $\mathrm{sp}$. A. These specimens show some subdivision of the radial ribs and a hint of fasciculation (pl. 34, figs. $4,6,7)$. Two of them show ribs on the anterior lobe (pl. 34, fig. 5). Fasciculiptera sp. A is from the Ertang Formation (Emsian), Locality 8, Zhangmu Village, Zhaoping County, Guangxi.

\section{Genus CARINONYCHIA n. gen.}

Type species.-Carinonychia triangularis $\mathbf{n}$. sp. is here designated the type species of the new genus Carinonychia.

Diagnosis.-Ambonychiids having bifurcating midumbonal carina.

Description.-Small- to medium-sized ambonychiids with terminal prosogyral beaks, below which is a small anterior lobe; radial ornament mostly of simple costae, midumbonal costa bifurcates, and one specimen shows costal bifurcation on the posterodorsal auricle; byssal sinus prominent, byssal gape absent; no internal features known.

Stratigraphic distribution.-Sipaian (Emsian) of Guangxi, China.

Etymology.-Latin carina, meaning ridge and referring to the bifurcating midumbonal costa; Greek onyx meaning claw or talon. Although onyx is not a Latin word, -onychia is a standard combining form for genera of the Ambonychiidae. Gender feminine.

Remarks.-The differences between Carinonychia and other radially ribbed Devonian ambonychiids are discussed above under the genus Fasciculiptera. One specimen of Carinonychia triangularis shows some posterodorsal bifurcation of costae (pl. 35, fig. 10).
Carinonychia triangularis $\mathbf{n}$. sp. +

Plate 35, figures 6-10

Description.-Carinonychia having strongly triangular lateral profile; length and height subequal; dorsal margin straight.

Types.-C. triangularis is known from six specimens, four of which are figured. The holotype (GXD-235) is a fairly complete specimen (pl. 35 , figs. 9,10 ), which clearly shows the lack of a byssal gape; it measures $16.8 \mathrm{~mm}$ long, $14 \mathrm{~mm}$ high, and $3.7 \mathrm{~mm}$ wide at the umbo (single valve).

Type locality.-All known specimens of C. triangularis are from the Ertang Formation (Emsian), Section 3 , Bed 10, Heping Village, Yongfu County, Guangxi. Etymology.-Latin triangularis, referring to the triangular shape of the specimens.

Remarks.-C. triangularis is, at present, the only species unequivocally assigned to Carinonychia.

Carinonychia? sp. A+

Plate 35, figure 11

Discussion.-One specimen from the Ertang Formation (Emsian), Section 3, Bed 10, has a bifurcate midumbonal costa, but is otherwise poorly preserved. We place it in Carinonychia with question.

Genus NODONYCHIA n. gen.

Type species.-Nodonychia gordia $\mathrm{n}$. sp. is here designated the type species of the new genus Nodonychia. Diagnosis.-Ambonychiids with umbonal nodes.

Description.-Medium-sized ambonychiids having terminal prosogyral beaks, anterior lobe lacking; comarginal ornament of growth lines and lirae or rugae, which are lamellose, umbos marked by a distinct row of nodes, radial ornament absent; byssal sinus very shallow, byssal gape absent; the only known internal feature is duplivincular ligament grooves.

Stratigraphic distribution.-Yingtangian (Eifelian) of Guangxi, China.

Etymology.-Latin nodus, meaning knot or swelling and referring to the umbonal nodes; Greek onyx, meaning claw or talon. Although onyx is not a Latin word, -onychia is a standard combining form for genera of the Ambonychiidae. Gender feminine.

Comparisons.-Nodonychia is the only known ambonychiid that has umbonal nodes.

Nodonychia gordia n. sp. +

Plate 36, figures 1-6; plate 37 , figures 1-7; plate 38 , figures $1,2,5$

Description.-Nodonychia with small posterior wing. Types.-Nodonychia gordia is known from 28 specimens, 13 of which are figured. The holotype (GXD-221) 
is a composite mold (pl. 37, figs. 4, 5) preserved in leached limestone. The specimen is distorted and measures $35 \mathrm{~mm}$ high and $37.2 \mathrm{~mm}$ long.

Type locality.-All known specimens of $N$. gordia are from the Yingtang Formation (Eifelian), Section 5, Bed 22, Luoban Village, Xiangzhou County, Guangxi.

Etymology.-Latin Gordius, Phrygian king noted for his intricate knot, which Alexander untied in classical military fashion. This is an allusion to the degree of difficulty in working with the highly distorted specimens of the species, trying to separate zoological features from diagenetic and tectonic features, and deciding on the number of species of Nodonychia present in the collection.

Remarks.-The known specimens of $N$.gordia are all distorted. Some of them are highly compressed in an anterior-posterior direction. For example, examine the series from least compressed to most compressed going from plate 36 , figure 1 , to plate 36 , figure 2 , to plate 37 , figure 4 , to plate 38 , figure 5 , to plate 37 , figure 3 . The coarse and fine radial marks seen on most of these specimens are probably the result of compression and are not zoological in origin. Some specimens seem to have been distorted primarily in a dorsal-ventral direction; in these the linear marks trend primarily fore-andaft on the shell (pl. 36, fig. 6). Some specimens seem to have had multiple fates (pl. 36, figs. 4, 5).

Regardless of how the specimens have been distorted, they all show a row of umbonal nodes, which we regard as zoologically made structures. The nodes could function to help balance this byssally attached species on its anterior face. Within the philosophy of classification of the Ambonychiidae, Nodonychia gordia clearly qualifies for placement in a genus separate from all other known genera; at present, it is the only species placed in Nodonychia.

\section{Genus MYTILARCA Hall and Whitfield, 1869}

Diagnosis.-Ambonychiids having comarginal ornament, posteriorlateral and cardinal teeth, and lacking anterior lobe and byssal gape.

Discussion.-Pojeta (1966) figured and briefly described most of the North American species placed in Mytilar$c a$. He noted (p. 156) that the genus is a broad concept, because most species are poorly known, and the conchology of all species is very simple. Like Nuculites and Palaeoneilo, Mytilarca is probably a form taxon and not a phylogenetic entity.

The Chinese specimens from Guangxi are not well preserved. All were found in fine clastic rocks, and most show evidence of distortion by compaction (pl. 34, fig. 9 ; pl. 35, fig. 3).

The Chinese material shows about the same range of shape variation as does Mytilarca chemungensis

(Conrad), which is the type species of the genus (McAlester, 1962, pl. 15; pl. 16, fig. 1; Pojeta, 1966, pl. 37, figs. 8-18; pl. 38, figs. 1-5, 10). M. chemungensis also occurs in fine clastic rocks; much of the shape variation of the known specimens is probably due to taphonomic distortion, and the species is characterized by an acute angle gamma (Pojeta, 1966, p. 137). Most of the Chinese specimens are herein classified as $M$. cf. $M$. chemungensis. One figured (pl. 34, figs. 2,3) and three unfigured highly weathered or distorted specimens have the erect to obtuse angle gamma of Mytilarca oviformis (Conrad) and are compared with that species.

In Michigan, a number of specimens preserved in limestone fit the current concept of Mytilarca. Those that have an erect to obtuse angle gamma are compared with $M$. oviformis; those that have an acute angle gamma are compared with $M$. chemungensis.

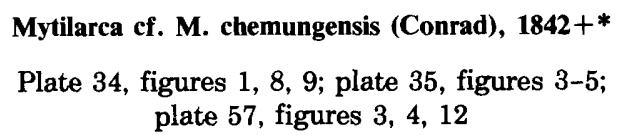

Discussion.-Numerous specimens of Mytilarca from Guangxi and Michigan are compared with M. chemungensis from Frasnian and Famennian age rocks in New York. Following is a listing of the specimens of $M$. cf. $M$. chemungensis figured here, and the figures of $M$. chemungensis with which they should be compared in Pojeta (1966):

Specimens figured here

Plate 34, figure 1 --

Plate 34, figures 8,9

Plate 35 , figures 3,4

$\mathrm{Pl}$

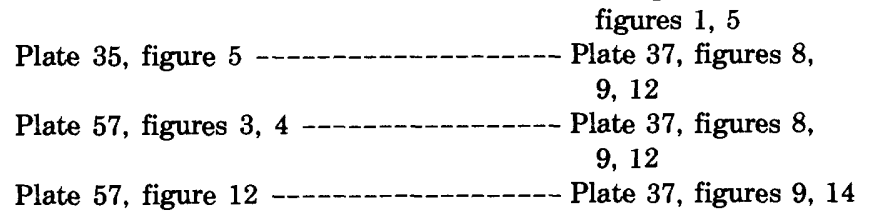

Stratigraphic distribution.-In Guangxi, $M$. cf. $M$. chemungensis is known from the Yujiang Formation (Siegenian-Emsian; GXD-181), Section 1, Bed 21, Hengxian County; Ertang Formation (Emsian), Section 2, bed unknown (GXD-183), Xiangzhou County, Section 3, Bed 10 (GXD-176), Yongfu County, and Section 4, Bed 11 (GXD-186), Bed 17 (GXD-182), and Bed 19 (GXD-177, -178, -240), Wuxuan County; and Yingtang Formation (Eifelian; GXD-175), Section 5, Bed 16, Xiangzhou County.

In Michigan, $M$. cf. $M$. chemungensis is known from numerous specimens from the upper Alpena Limestone and the Four Mile Dam Formation (YPM 16441-16443, 16445a, b, 16625, 16632 and USNM 383651, 388215). 
Mytilarca cf. M. oviformis (Conrad), $1842+*$

Plate 34, figures 2, 3; plate 57, figures 1, 2

Discussion.-In Michigan and Guangxi, this taxon is known from a total of 13 specimens, which have the characteristic erect to obtuse angle gamma and strongly prosogyral umbos (Pojeta, 1966, pl. 41, figs. 3, 4, 7, 8) of $M$. oviformis. The Michigan specimens are from the upper Alpena Limestone (YPM 16449, 16449a, 16631) at Four Mile Dam, Alpena County; Four Mile Dam Formation (USNM 383607), at the same locality; and the Thunder Bay Formation (USNM 383608) at Partridge Point, 4 miles south of Alpena, Alpena County. In New York, $M$. oviformis is known from Hamiltonian age rocks.

In Guangxi, $M$. cf. $M$. oviformis is here reported from the Yujiang Formation (Siegenian-Emsian), Section 1, Bed 21, Hengxian County (GXD-172-174, -185). Zhang (1977, pl. 193, fig. 5) compared a specimen from the Donggangling Formation (Givetian) of Guangxi with $M$. oviformis.

\section{Genus GOSSELETIA Barrois, 1882}

Diagnosis. - Ambonychiids having comarginal ornament, well-developed cardinal and posterior lateral teeth, anterior lobe present, byssal gape lacking.

Gosseletia triquetra (Conrad), 1838*

Plate 57, figures 9-11

Discussion.-This genus and species have been discussed extensively by Pojeta (1966), Carter and Tevesz (1978), and Bailey (1983). Our eight specimens from Michigan (USNM 383609, 383616, 388216, 388217 ) show that the species occurs in the lower Bell Shale (Givetian), in a quarry east of Rogers City, in the northeast corner SW1/4NW1/4, sec. 36 , T. 35 N., R. 6 E., Presque Isle County. In New York, G. triquetra is usually listed as occurring in Hamiltonian age rocks (Pojeta, 1966). Bailey (1983) has shown that the species occurs in the Solsville Member of the Marcellus Formation of New York, and has listed it as occurring in the Silica Shale, Prout Limestone, and Plum Brook Shale of Ohio (upper Givetian).

\section{Superfamily PTERIACEA Gray Family PTERINEIDAE Miller}

Discussion.-More than 50 generic names have been proposed for Paleozoic Pteriacea. All of them are placed in the family Pterineidae (Newell and LaRocque, 1969a, p. N298-N302), which ranges from the Middle Ordovician (Llanvirnian) through Late Permian. Many of the genera are poorly conceptualized, are based on inadequately known type species, and are difficult or impossible to use in a meaningful and consistent way. At least half of the proposed generic names have been used for Devonian species. Newell and LaRocque (1969a, p. N299) noted:

Many genera of Pterineidae have been based on slight variations in obliquity, form, dentition, and strength of the myophoric buttress. Others are based on supposed stratigraphic or geographic restrictions. Since most are known only from rare or poorly preserved material, it is difficult to evaluate these variations. In comparison with living Pteriidae, many may be of specific rather than generic significance.

No philosophy of generic level classification has yet been developed for the Pterineidae, and the type species of many genera should be recollected and restudied. Available museum collections of the type species of the genera are, for the most part, inadequate for the purpose of developing a philosophy of classificiation for the family.

In Guangxi, Devonian pteriaceans are abundant and diverse; in Michigan they are abundant, but not diverse. Except for one species in Michigan, in neither place are pteriaceans particularly well preserved. We have followed the generic level classification of Newell and LaRocque (1969a), and where possible we have made comparisons with the type species of the genera used.

In spite of all the caveats given above about the generic level classification of pterineids, we propose two new genera for Devonian pteriaceans. We do this because the type species of each is unique in morphology, and by using a philosophy of classificiation similar to that followed in other families of Paleozoic pelecypods, we believe that they warrant placement in new genera. Genera are discussed in alphabetical order.

\section{Genus ACTINODESMA Sandberger, 1854}

\section{Subgenus ECTENODESMA Hall, 1883}

Diagnosis.-Actinodesma with multicostellate ribs. Type species.-Ectenodesma birostratum Hall (1883, pl. 23, figs. 27-30), by monotypy and subsequent designation of Miller (1889, p. 478).

Discussion.-Our use of the name Ectenodesma is based on the following information: (1) Hall's (1883, pl. 23 , figs. 27-30) illustrations of the type specimens of the type species; (2) an additional specimen illustrated by Hall (1884, pl. 84, fig. 20); (3) Newell and LaRocque's description of the taxon (1969a, p. N299); and (4) a new specimen of Actinodesma (Ectenodesma) birostratum (USNM 100902) from the Upper Devonian of Pennsylvania (pl. 60, figs. 6, 7).

We apply the name Actinodesma (Ectenodesma) to species that have prosocline to opisthocline malleiform shells and multicostellate ribs, and the anterior and posterior auricles extended well beyond the body of the shell. Actinodesma (Actinodesma) is used for species which are similar in shape and auricles, but which lack radial ornament (Sandberger and Sandberger, 1854, pl. 29, figs. 17, 17a; Frech, 1891, pl. 7, fig. 1a; pl. 8, 
figs. 5, 5a). For the date of Sandberger's work, we follow unpublished information, 1959, provided to Curt Teichert (University of Rochester) by H. K. Erben (University of Bonn).

\section{Actinodesma (Ectenodesma) guangxiensis n. sp.+}

Plate 43, figures 1-5; plate 48, figure 4

Description.-Shell large (as much as $50 \mathrm{~mm}$ high), left valve convex, right valve flat; both auricles ornamented with costellae, anterior auricle as much as $50 \mathrm{~mm}$ long in a shell $43 \mathrm{~mm}$ high, posterior auricle as much as $75 \mathrm{~mm}$ long in a shell $50 \mathrm{~mm}$ high; radial ornament increase is by intercalation in the left valve, method of increase in the right valve uncertain, possibly by intercalation; byssal sinus shallow. Internal features unknown.

Types. $-A$. (E.) guangxiensis is known from five composite molds, all of which are figured. The holotype (GXD-400) is shown on plate 43 , figure 1 ; it measures $43 \mathrm{~mm}$ high, and the length of the anterior auricle is $50 \mathrm{~mm}$. Other measurements cannot be made because of the preservation of the specimen. The posterior end is missing and the specimen has been compressed parallel to bedding. The other four specimens are paratypes.

Type locality.-All known specimens are from the Donggangling Formation (Givetian), at Section 3, Bed 23, Yongfu County, Guangxi.

Etymology.-The species is named for the Autonomous Region of Guangxi.

Comparison. $-A$. (E.) guangxiensis differs from $A$. (E.) birostratum in lacking bifurcate ribs on the left valve (pl. 60, figs. 6, 7) and in having ribs on the anterior auricle.

\section{Genus CANEYELLA Girty, 1909}

Diagnosis.-Pterineids having multiple costellae, right valve less convex than left valve, poorly developed nonprotruding anterior auricle, and lacking posterior wing.

Type species.-Caneyella richardsoni Girty (1909, p. 38 ), by original designation.

Discussion.-The two syntypes of $C$. richardsoni are composite molds found on the same rock chip (USNM $120768,383624)$. Both are articulated, the valves partially spread parallel to bedding (pl. 60 , figs. 5). The shell is prosocline, subquadrate, and slightly elongated. Both valves are convex, with the left valve slightly more inflated than the right. The radial ornament is costellae, which on both valves increase in number by both bifurcation and intercalation (pl. 60, figs. 1-4). Comarginal ornament is prominent and rugose on both valves; areas of cancellate ornament are present. Small nonprotruding anterior auricle present on both valves with a poorly developed byssal sinus; posterior auricle absent.

From Guangxi, we have four left-valve composite molds, which have shape, ornament, and lack of a posterior wing similar to those of Caneyella richardsoni (pl. 39, figs. 1-3). None of the Chinese specimens preserve the part of the shell where one would expect to find the anterior auricle, and in shape are much like the Silurian genus Amphicoelia Hall (Pojeta, 1966, pls. $24,25)$. We place the Chinese specimens in Caneyella with question. Caneyella has previously been recognized only in rocks of Late Mississippian age.

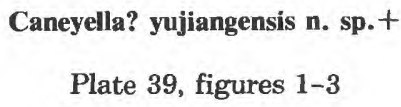

Description.-Shell medium (as much as $40 \mathrm{~mm}$ long), left valve convex, right valve unknown; anterior auricle unknown, posterior auricle lacking; radial ornament of left valve increases by both intercalation and bifurcation; comarginal ornament rugose; areas of cancellate ornament present.

Types.-C.? yujiangensis is known from four specimens, three of which are figured. The holotype (GXD-278) is shown on plate 39, figure 3; it measures $40 \mathrm{~mm}$ long, $35 \mathrm{~mm}$ high, and is compressed parallel to bedding.

Type locality.-All known specimens are from the Yujiang Formation (Siegenian-Emsian), at Section 1, Bed 21, Hengxian County, Guangxi.

Etymology.-The species is named for Yujiang River, Guangxi.

Comparison.-The only known significant difference between the type specimens of $C$. richardsoni and $C$.? yujiangensis is size. The largest syntype of $C$. richardsoni is $20 \mathrm{~mm}$ long, whereas C.? yujiangensis reaches $40 \mathrm{~mm}$ long. When it is determined whether or not $C$. ? yujiangensis had an anterior lobe, and when the right valve is found, other differences may be discovered.

\section{Genus CORNELLITES Williams, 1908}

Diagnosis.-Pterineids having flat to concave right valve that possesses only comarginal ornament; left valve convex, with radial costae and costellae; anterior auricle protruding, small posterior wing present.

Discussion.-The name Cornellites has been variously used in the past quarter of a century. McAlester (1962) recognized it as a genus. Newell and LaRocque (1969a) placed it in subjective synonymy with Ptychopteria Hall. Bailey (1983) treated it as a subgenus of Ptychopteria. It is here treated as a genus, because the type species Pterinea fasciculata Goldfuss has a distinctively ornamented left valve (Bailey, 1983) and ornament is a major generic criterion in many groups of Paleozoic pelecypods (Newell, 1938; Pojeta, 1966; Runnegar, 1974). 
Cornellites fasciculatus (Goldfuss), 1836*

Plate 62, figures 4-6; plate 63, figures 1-10

Discussion.-Bailey $(1983$, p. 214) has provided a recent exhaustive evaluation and analysis of this species. American specimens of this species have traditionally been placed in Cornellites flabellus (Conrad), 1842. However, we follow Bailey's suggestion and place that name in subjective synonymy with Cornellites fasciculatus (Goldfuss).

C. fasciculatus is well known from Middle Devonian rocks in New York (Hall, 1884, p. 93; Bailey, 1983, p. 214). The Michigan specimens compare very favorably with the New York specimens in ornament, shape, and muscle scars. The dentition of the Michigan specimens is not known.

In Michigan $C$. fasciculatus is known from the Bell Shale (USNM 383637), Ferron Point Formation (YPM 16431-16433), Genshaw Formation (USNM 383638), Norway Point Formation (USNM 383639), and the Potter Farm Formation (YPM 16633). C. fasciculatus is the best preserved, longest ranging, and most abundant Traverse pelecypod known from Michigan.

\section{Genus LEPTODESMA Hall, 1883}

Diagnosis.-Pterineids lacking radial ornament; biconvex, left valve more convex than right; posterior wing prominent.

Discussion.-We follow Newell and LaRocque (1969a, p. N300) in using this name for Paleozoic pteriaceans that lack radial ornament, have the left valve more convex than the right, possess a prominent posterior wing, and have variable dentition. They recognized two subgenera: Leptodesma (Leptodesma) and Leptodesma (Leiopteria) Hall, 1883. Hall (1883, p. 4) treated each taxon as a genus and distinguished them as follows:

Leiopteria, n. g. Aviculoid resembling Actinoptera in form. Anterior extremity auriculate; wing large, extremely produced. Test without prominent rays. Leptodesma, n. g. In its prevailing form, like Leiopteris [sic], except that the anterior end is nasute and acute, instead of auriculate and rounded. Hinge-line narrow.

The difference in the shape of the anterior auricle remained the major taxobasis for separating the two taxa in Hall $(1884$, p. xii), although by then he had information about the dentition and ligament. Newell and LaRocque (1969a, p. N300-301) continued to separate the two taxa on the basis of the anterior auricle as follows: "L. (Leptodesma). Anterior auricle angular and nasute*** L. (Leiopteria) $)^{* * *}$ anterior auricle lobate***"

The differences in the anterior auricles are shown on figure 16, which was taken from figures of the type specimens of the type species of the two taxa (Hall, 1883). For Leiopteria dekayi Hall (1883, pl. 20, figs. 16-19), the anterior auricle is lobate, rounded above and below, has a prominent byssal sinus, and is separated
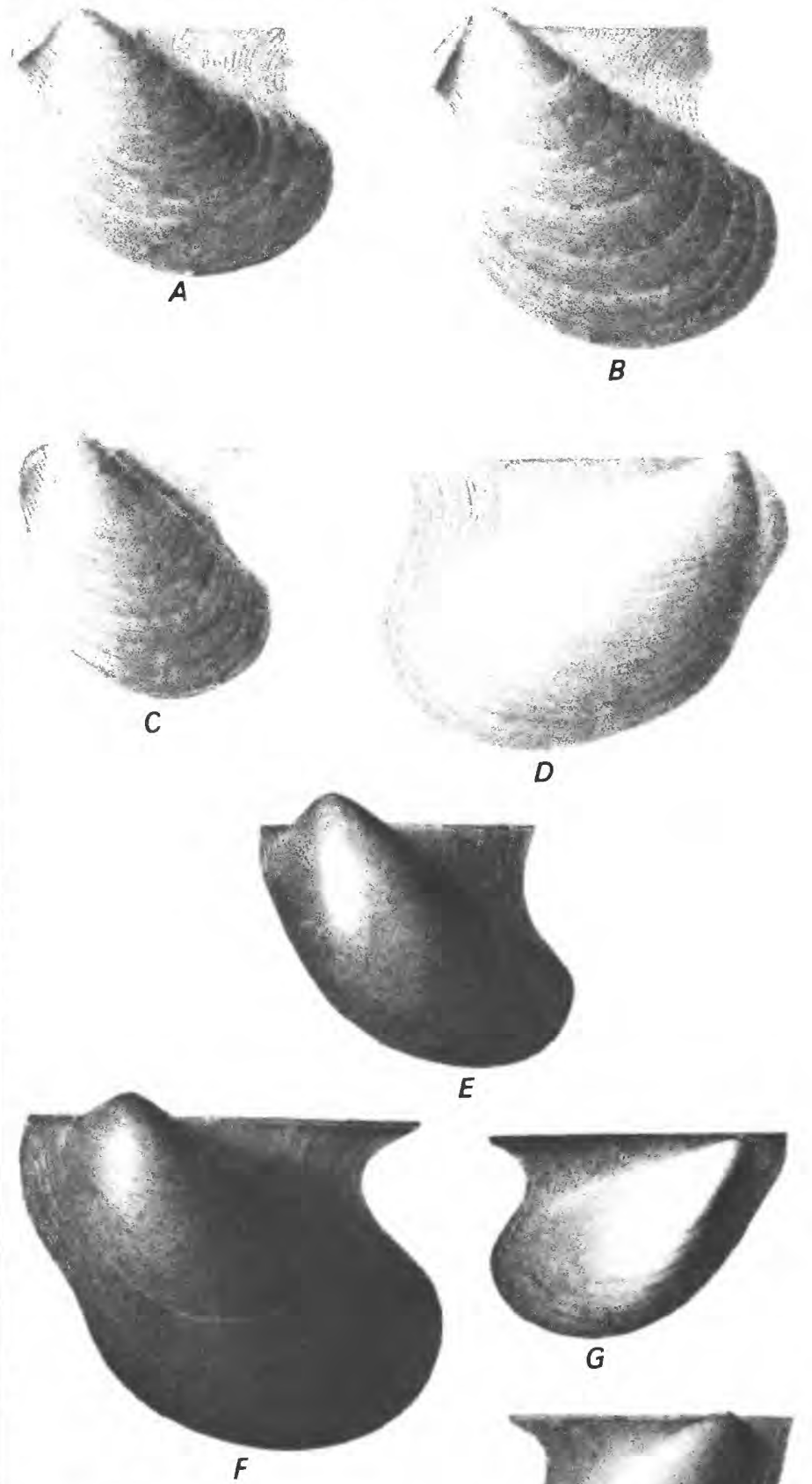

G

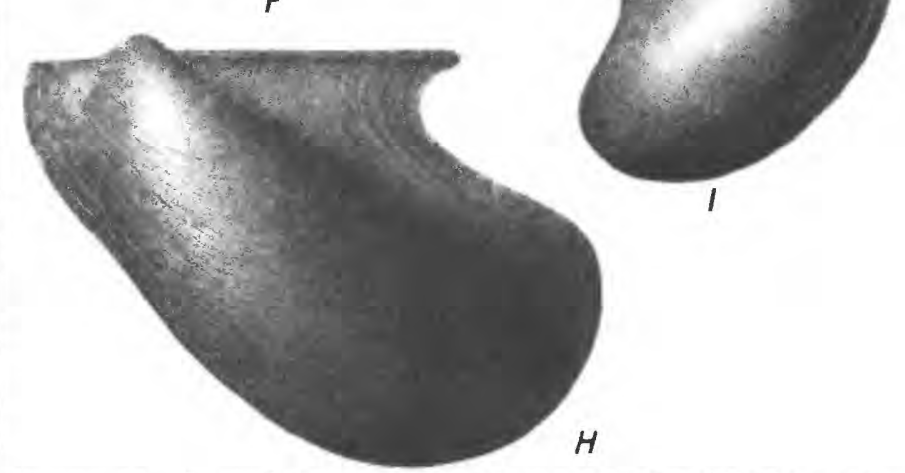

FIGURE 16.-Original drawings of the type specimens of the type spe cies of Leptodesma Hall and Leiopteria Hall. A-D, Leiopteria dekayi Hall, syntypes, (from Hall, 1883, pl. 20, figs. 16-19). E-I, Leptodesma potens Hall, syntypes (from Hall, 1883, pl. 21, fig. 21; pl. 22, figs. 11, 12, 19, 21). No scale on original drawings. 
from the body of the shell by a sulcus (fig. $16 A-D$ ). The left valve assigned to this species by Hall $(1883$, pl. 19, fig. 1) has radial ornament and probably belongs to $A c$ tinopteria Hall.

For Leptodesma potens Hall (1883, pl. 21, fig. 21; pl. 22 , figs. $11,12,19,21$ ), the anterior auricle is not lobate (fig. $16 E-H$ ). It meets the dorsal margin at nearly a right angle, ventrally the byssal sinus is shallow or absent, and the anterior auricle has no prominent sulcus separating it from the body of the shell. L. (Leptodesma) potens is from the Chemung Group; L. (Leiopteria) dekayi is from the Hamilton Group.

None of the Chinese specimens studied by us have the type of anterior lobe seen in L. (Leiopteria) dekayi, and we place all of them in Leptodesma (Leptodesma). We suspect that both taxa are form genera and not phylogenetic concepts.

\section{Subgenus LEPTODESMA (LEPTODESMA) Hall, 1883}

Type species.-Leptodesma potens Hall $(1883$, p. 9) by subsequent designation of Miller (1889, p. 484).

Leptodesma (Leptodesma) guangxiensis n. sp. +

Plate 44, figures 1-9, 12; plate 45, figures 1-11

Description. - Shell small (about $30 \mathrm{~mm}$ long), longer than high, biconvex, having left valve more inflated than right; anterior auricle upright and typical of the subgenus, posterior auricle forming a small wing; ornament of comarginal lirae or rugae in left valve, subdued in right valve; shallow byssal sinus; umbonal sulcus in each valve, right valve with one or two posterior lateral teeth.

Types. $-L$. (L.) guangxiensis is known from many composite molds and several partially shelled weathered specimens. The holotype is an articulated, partially shelled specimen shown on plate 45 , figures $2-4$ (GXD-342); it measures $30.5 \mathrm{~mm}$ long, $17.9 \mathrm{~mm}$ high, and $10.1 \mathrm{~mm}$ wide (both valves).

Type locality.-The holotype and six paratypes (GXD-352-357) are from the Ertang Formation (Emsian), Section 4, Bed 6, Wuxuan County, Guangxi.

Distribution.-In addition to the above occurrence, $L$. (L.) guangxiensis is known from the Ertang Formation, Section 4, Beds 11, 19, 30, 32, 33, 34, and 35. An incomplete specimen (pl. 44, fig. 12) from the Nagaoling Formation (Gedinnian), Section 1 , Bed 10, is assigned to this species (compare with pl. 44, fig. 3).

Etymology.-The species is named for the Autonomous Region of Guangxi.

Comparisons. $-L$. (L.) guangxiensis differs from other species of $L$. (Leptodesma) known from Guangxi and from $L .(L$.$) potens in being longer than high. Because$ we have articulated specimens of $L$. (L.) guangxiensis, we can be sure that we have the correct association of left and right valves.
Leptodesma (Leptodesma) venusta Zhang, 1977+

Plate 44, figures $10,11,13,14$; plate 47 , figures 8,9

1977. Leptodesma (Leptodesma) venusta Zhang, p. 499, pl. 194, figs. $17-18$

Diagnosis.-Leptodesma (Leptodesma) having subequal length and height, oblique anterior margin, and posterior wing not projecting beyond body of shell.

Distribution.-Zhang (1977) described this species from the Liujiang Formation (lower Upper Devonian) of Guangxi. The same shell form occurs in the Lower Devonian as follows: (1) Lianhuashan Formation (Gedinnian), Section 1, Bed 5 (GXD-282, -284, -286, -287); (2) Nagaoling Formation (Gedinnian-Siegenian), Section 1, Beds 10, 12 (GXD-292, -296, -305); and (3) Ertang Formation (Emsian), Section 2, bed unknown (GXD-326, -327), and Section 4, Beds 9, 11, 30 (GXD-334, -335, -336, -325).

Leptodesma (Leptodesma) deprati (Mansuy), 1912+

Plate 46, figures 4, 5

1912. Actinopteria (Pteronites) deprati Mansuy, p. 47, pl. 7, fig. 7a, [non] fig. $7 \mathrm{~b}$.

1977. Leptodesma (Leiopteria) deprati (Mansuy), Zhang, p. 500, pl. 194 , fig. 22 , [non] fig. 23.

Diagnosis.-Leptodesma (Leptodesma) having subequal length and height, erect anterior margin, and small posterior wing.

Distribution.-Mansuy (1912) described this species from the Devonian of eastern Yunnan. Zhang described a specimen from the Lower Devonian of Guangxi. Herein we note the presence of the species in the Nagaoling Formation (Gedinnian-Siegenian), Section 1 , Beds 10, 13 (GXD-288, -290, -292, -295, -300, -304).

Leptodesma (Leptodesma)? sp. A+

Plate 46, figures 1-3

Discussion.-One distinctive taxon is here placed in Leptodesma (Leptodesma) with question. It is known from several left valves that preserve the shell or are composite molds, and occurs in the Ertang Formation (Emsian), Section 4, Beds 11, 32, 33, 34, and 36. These specimens have closely spaced comarginal lirae and a posterior wing that projects beyond the body of the shell.

In shape and ornament, the specimens are much like Leptodesma (Leptodesma) furcistria LaRocque (1950, pl. 5, figs. 1-5) from the Rogers City Formation (Givetian) of Michigan, and one specimen assigned to $L$. (Leiopteria) deprati by Zhang (1977, pl. 194, fig. 23) from the Lower Devonian of Guangxi. The specimens also resemble the left valve of Pteronitella retroflexa (Wahlenberg) in shape (Walmsley, 1962). P. retroflexa is the type species of Pteronitella, but it does not have 
closely spaced comarginal lirae. $P$. retroflex $a$ occurs in Upper Silurian rocks of Sweden, Wales, and Nova Scotia.

The taxa figured here and by LaRocque (1950) and Zhang (1977) are known only from left valves; whether they show the distinctive actinodont dentition of Pteronitella is not known. Therefore, we assign the Chinese specimens to Leptodesma (Leptodesma) with question.

\section{Leptodesma (Leptodesma)? spp.*}

Plate 59, figures 11-13; plate 61, figure 5

Discussion.-Three poorly preserved specimens from Michigan are placed in this category. The anterior auricle of these either is poorly preserved or does not conform to the subgeneric criterion established on the basis of the type species of the subgenera.

Specimen USNM 383634 (pl. 59, fig. 11) has a prominent sulcus posterior to the anterior auricle, but lacks a prominent byssal sinus and is not rounded above. The specimen is small, and perhaps the anterior auricle changed shape ontogenetically in Leptodesma (Leiopteria) dekayi. The specimen is from the Gravel Point Formation west of Charlevoix, Charlevoix County, Mich.

Specimen USNM 383635 (pl. 59, figs. 12, 13) has a weathered anterior auricle. It has a prominent byssal sinus, but the anterior auricle lacks a posterior sulcus. It is not possible to tell the dorsal shape of the auricle. The specimen is from the upper Ferron Point Formation, Alpena County, Mich.

Specimen USNM 383636 (pl. 61, fig. 5) is missing the entire anterior auricle. It too is from the upper Ferron Point Formation, Alpena County, Mich.

\section{Genus LIMOPTERA Hall and Whitfield, 1869}

Type species.-Lima macroptera Conrad (1838, p. 117), by original designation (p. 16).

Diagnosis. -Simplicicostate, biconvex pterineids with reduced anterior lobe; right valve less convex than left.

Discussion.-L. macroptera is a large erect to slightly prosocline species having a well-developed posterior wing and a small anterior auricle (pl. 61, figs. 2-4, 6-8; pl. 62 , figs. $1-3,7,8)$. The body of the shell is orbicular. The shell is biconvex; the right valve is less convex than the left (pl. 61, figs. 3, 7; pl. 64, figs. 3, 5). The radial ornament is simplicicostellate and has occasional intercalation of new ribs on both valves; on some, comarginal ornament is prominent, and areas of cancellate ornament may be present. The posterior adductor muscle scar is posterocentral (pl. 62, fig. 7; pl. 64, figs. 1, 4), the pallial line is entire and high in the shell (pl. 64, figs. $1,3,4$ ), the anterior adductor muscle is obsolete (pl. 64, figs. 1, 3, 4), various accessory muscle scars are present (pl. 64, figs. 1, 2, 4, 5), two cardinal teeth are in each valve (pl. 64, fig. 5), and a duplivincular ligament is present (pl. 61, fig. 6).

The Chinese specimens here placed in Limoptera are not well preserved. Most of them are large, several have a prominent posterior wing, they all have simple costellae, and all are erect having orbicular shell bodies. One specimen (pl. 47, fig. 11) shows two posterior lateral teeth in the right valve. A second specimen shows a single posterior lateral tooth in the left valve (pl. 49, fig. 6). Another specimen (pl. 42, fig. 2) shows an anterior auricle that is more prominent than in any of the species placed in Limoptera by Hall (1884, pls. 26-29, 92). A fourth specimen (pl. 48, fig. 1) has an anterior auricle similar to that on the specimens figured by Hall. Because the Chinese specimens are not well preserved, we place them in open nomenclature as Limoptera spp.

Limoptera macroptera (Conrad), 1838*

Plate 61, figures 2-4, 6-8; plate 62, figures 1-3, 7, 8; plate 64, figures 1-5

Discussion.-New material of this species, which is figured from Hamiltonian age rocks in New York (pl. 61, fig. 6; pl. 62, figs. 1-3, 7) and West Virginia (pl. 64, figs. 1-5), shows the shape, ornament, muscle scars, ligament, cardinal teeth, and point attachments of the mantle (USNM 17651, 26092, 139573, 383633, 388222). An articulated specimen (USNM 383632) from the Silica Shale (Givetian; Rickard, 1984) of northwestern Ohio is a well-preserved composite mold showing the valve convexity (pl. 61, figs. 7, 8). The species is here identified from Michigan (pl. 61, figs. 2-4; pl. 62, fig 8), where it occurs in the lower Alpena Limestone and the Genshaw Formation (USNM 383630, 383631).

The specimen from West Virginia (pl. 64, figs. 1-5, USNM 388222) is an unusually well preserved internal mold. It shows most muscle scars, including (1) small scars interpreted as pedal elevators by analogy with Pteria Scopoli, although in Pteria, such muscles are placed more anteriorly (Cox, 1969c, fig. 34B), and (2) pallial retractors by analogy with Malleus Lamarck (Yonge, 1968).

Limoptera is monomyarian. The arrangement of the posterior adductor-posterior byssal-pedal muscle scars is most like that of ambonychiids (Pojeta, 1962, pl. 22, fig. 6; pl. 23, fig. 1; 1966, pl. 27, figs. 2, 5; pl. 31, figs. 1,2 ), and myalinids (Newell, 1942, fig. 6B, C, E, G). In Limoptera, ambonychiids, and myalinids, the posterior byssal-pedal retractor scar projects anterodorsally from the posterior part of the posterior adductor scar (pl. 64, figs. $1,2,4)$. In this regard, these taxa are most like mytilaceans (Newell, 1942, fig. 6A, D). Living pteriaceans, such as Pteria, Pinctada Roding, Isognomom Lightfoot, Malleus, and Pinna Linneaus, have the 
posterior byssal-pedal retractor located on the anterior side of the posterior adductor, and the adductor partially surrounds the retractor (Cox, 1969c, figs. 34A, B, $\mathrm{E} ; 35 \mathrm{C}, \mathrm{E}$; Yonge, 1968, fig. 1A). In this feature, Limoptera is more like ambonychiaceans than ostreoids (Waller, 1978, p. 349).

\section{Limoptera spp. +}

Plate 42, figures 1-5; plate 47, figure 11; plate 48, figure 1; plate 49 , figure 6

Stratigraphic distribution.-In Guangxi, Limoptera spp. occurs in the following units: (1) Ertang Formation (Emsian), Section 2, bed unknown (GXD-464) and Section 4, Beds 9, 30 (GXD-482-485); Yingtang Formation (Eifelian), Section 5, Bed 19 (GXD-482); and (3) Donggangling Formation (Givetian), Section 3 , Bed 23 (GXD-399, -417, -488).

\section{Genus OXYTOMOIDEA n. gen.}

Type species.-Oxytomoidea elegans $\mathrm{n}$. $\mathrm{sp}$. is here designated the type species of the new genus Oxytomoidea.

Diagnosis.-Prosocline pterineids having flat right valve; ornament of right valve multicostellate, left valve paucicostellate.

Description.-Small to medium-sized pterineids; shell prosocline, posteriorly elongated, with a posterior wing, left valve convex, right valve flat; radial ornament of left valve paucicostellate, may increase by bifurcation or intercalation, interspaces between costellae broader than ribs; ribs of right valve multicostellate, may increase in number by bifurcation or intercalation, interspaces between ribs narrow; comarginal ornament fine, closely spaced; in both valves, posterior wing bears radial ribs; anterior auricle has ribs in left valve, but only comarginal ornament in right valve; right anterior auricle with byssal notch; beaks prosogyral. Internal features unknown.

Stratigraphic distribution.-Yingtangian (Eifelian) of Guangxi, China.

Etymology.-The generic name Oxytoma Meek and the combining form -oid, which is derived from the Greek work meaning like or having the form of. Oxytomoidea reminded us of the Mesozoic genus Oxytoma.

Remarks and comparisons.-One specimen of $O x y$ tomoidea elegans is articulated (pl. 40, figs. 1, 2). When found, it showed only the ornament of the left valve (pl. 40, fig. 1). By breaking away part of the left valve, we were able to expose the ornament of the underlying right valve (pl. 40, fig. 2). Thus, we are sure that we have the correct association of right and left valves for this species.

Oxytomoidea differs from Oxytoma in having a fully ribbed right valve; the right valve of Oxytoma is smooth or has weak radial ornament. Oxytomoidea differs from Ptychopteria in the broad interspaces between primary ribs of the left valve, which have few or no secondary ribs; it differs from Limoptera in being prosocline and having a triangular body of the shell.

$$
\text { Oxytomoidea elegans n. sp. }+
$$

Plate 39, figures 4-6; plate 40, figures 1-9; plate 41, figures 1-7

Description.-Shell small (as much as $35 \mathrm{~mm}$ long); dorsal margin long, straight; byssal sinus of left valve weak; ribs on anterior auricle of left valve strong.

Types.-O. elegans is known from many composite molds, 19 of which are figured. The holotype is a right valve (GXD-274) shown on plate 40, figure 7 ; it measures $35 \mathrm{~mm}$ long and $14.5 \mathrm{~mm}$ high. All other specimens are paratypes.

Type locality.-All known specimens are from the Yingtang Formation (Eifelian), at Section 5, Bed 16, Xiangzhou County, Guangxi.

Etymology.-Elegans, Latin for choice or select, referring to what we regard as the esthetically pleasing appearance of the species.

Remarks.-O. elegans is the only species presently assigned to the genus Oxytomoidea.

\section{Genus PTYCHOPTERIA Hall, 1883}

Diagnosis.-Prosocline pterineids with well-developed anterior auricles and posterior wings; both valves have multicostellate radial ornament.

Discussion.-We use this genus in the sense of Newell and LaRocque (1969a, p. N302). It is applied to prosocline shells having well-developed anterior auricles and posterior wings. The left valve has closely spaced radial ribs and is more convex than the right valve. The right valve is less convex, to flat or concave, and has radial ornament of varying strength. Dentition is highly variable.

Like Leptodesma, Ptychopteria is a broad concept, and may be a form taxon rather than a phylogenetic entity. Ptychopteria is divided into subgenera on the basis of the form of the anterior auricle. Two subgenera were recognized by Newell and LaRocque (1969a). $P$. (Ptychopteria) has an anterior auricle like that of Leptodesma (Leptodesma), whereas the anterior auricle of $P$. (Actinopteria) Hall (1884) is lobate like that of Leptodesma (Leiopteria) and has a prominent byssal sinus in the left valve. Both subgenera of Ptychopteria occur in Guangxi.

\section{Subgenus PTYCHOPTERIA (PTYCHOPTERIA) Hall, 1883}

Type species.-Ptychopteria eugenia Hall $(1883$, p. 10) $=P$. salamanca Hall $(1884$, p. 131 ; objective synonym), by subsequent designation of Miller (1889, p. 508). 
Ptychopteria (Ptychopteria) zhongguoensis Zhang, 1977+

Plate 48, figures 2, 3; plate 49, figures 1-5, 7

1977. Ptychopteria (Ptychopteria) zhongguoensis Zhang, p. 496, pl. 194, fig. 1.

Description.-Shell small (as much as $33 \mathrm{~mm}$ high), oblique, length greater than height; left valve regularly convex; right valve gently convex in region of umbo, planar to concave in mature part; body and posterior wing of both valves covered with simple, numerous closely spaced costellae; costellae absent from anterior auricle of both valves. Internal features unknown.

Stratigraphic distribution.-Zhang (1977) identified this species from the Yujiang Formation (SiegenianEmsian) of Guangxi. Our new material is from the Ertang Formation (Emsian) at Locahties 6 and 9 and Section 4, Bed 17 (GXD-379).

Comment and comparison.-We have one articulated specimen of $P$. $(P$.$) zhongguoensis and thus are sure that$ we have the correct association of right and left valves for the species (pl. 49, figs. 2-4). This species differs from $P$. $(P$.) eugenia in having a nearly flat right valve; the right valve of $P$. $(P$.$) eugenia is convex.$

Subgenus PTYCHOPTERIA (ACTINOPTERIA) Hall, 1884

Type species.-Avicula decussata Hall, 1843, by subsequent designation of Bassler (1915, p. 16).

Ptychopteria (Actinopteria) producta n. sp.+

Plate 49, figures 8-10; plate 50, figures 1-6

Description.-Shell small to medium (a maximum of $46 \mathrm{~mm}$ long), oblique to suberect, length greater than height; left valve regularly convex, right valve flat; body and posterior wing of both valves covered with numerous closely spaced costellae, which may increase in number by intercalation or bifurcation; anterior auricle of left valve commonly without ribs, anterior auricle of right valve without ribs; comarginal ornament commonly of fine growth increments, some of which define broad rugae; byssal sinus prominent, broad sulcus separates anterior auricle from body of shell in left valve, small byssal notch in right valve. Left valve has a single posterior lateral tooth; ligament duplivincular.

Types. $-P$. (A.) producta is known from numerous composite molds of which eight are figured. The holotype is a left valve (GXD-427) shown on plate 49, figure 10; it measures $27.5 \mathrm{~mm}$ long, $20.1 \mathrm{~mm}$ high, and $2.3 \mathrm{~mm}$ wide. All other specimens are paratypes.

Type locality.-The holotype and 10 paratypes (GXD-422, -426, -428, -430, -438a, b, -446, -453, -475, -476) are from the Yingtang Formation (Eifelian), at Section 5, Bed 19, Xiangzhou County, Guangxi.

Distribution.-In addition to the type locality, $P$. (A.) producta was found in the Yingtang Formation (Eifelian), at Section 5, Bed 16 (six left valves, paratypes), Bed 18 (two left valves, paratypes), Bed 20 (five left valves, paratypes), Bed 21 (one left valve, paratype), and Bed 22 (17 left valves and one right valve, paratypes).

Away from the type area, $P$. (A.) producta is known from (1) one specimen (GXD-481) from the Sipai Formation (Emsian), Section 3, Bed 13; (2) two specimens (GXD-402,-450) from the Donggangling Formation (Givetian) at Locality 8 and Section 3 , Bed 23; and (3) four large specimens (GXD-418-421) (pl. 50, fig. 6) from the Yujiang Formation (Siegenian-Emsian), Section 1, Bed 21, are compared with $P$. (A.) producta.

Etymology.-Produce, to draw out or lengthen, in reference to the drawn out anterior auricle.

Remarks and comparisons.-We do not have any articulated specimens of this species, and thus cannot be entirely sure of the proper association of right and left valves. The rock chip bearing the left valve of the holotype (pl. 49, fig. 10) also bears two right valves (pl. 50 , fig. 3). We believe that this close association indicates that the two valves belong to the same species.

$P$. (A.) producta differs from $P$. (A.) decussata in having more prominent and longer anterior and posterior auricles, and in having a strongly ribbed right valve.

Ptychopteria (Actinopteria) aff. P. (A.) epsilon (Hall), 1883*

Plate 59, figure 10; plate 61, figure 1

Discussion.-A left and a right valve (YPM 16438, 16435) from the Jordan River Formation near Norwood, Charlevoix County, Mich. (Schizophoria-Actinopteria beds, Kesling, Segall, and Sorensen, 1974, p. 114) are erect shells with a highly oblique anteroventral margin. The left valve (pl. 59, fig. 10) does not preserve the anterior auricle; the right valve (pl. 61, fig. 1) has a poorly preserved anterior auricle. In shape, these specimens from Michigan are most like the specimens of $P$. (A.) epsilon (Hall) (1884, pl. 23, figs. 4, 5) and are classified as having affinities to that species. $P$. (A.) epsilon is from the Upper Devonian (Chemung) of New York.

\section{Genus WUXUANITES n. gen.}

Type species.-Wuxuanites lanceolatus $\mathbf{n}$. sp. is here designated the type species of the new genus Wuxuanites.

Diagnosis.-Strongly prosocline pterineids lacking radial ornament and having anterior and posterior wings coming to points.

Description.-Small pterineids, strongly prosocline, biconvex to planoconvex; anterior and posterior wings long and attenuated, coming to a point and projecting well beyond the body of the shell; ornament of both valves consists of comarginal lirae or rugae that extend onto the wings, ornament of right valve may be subdued; byssal sinus shallow or absent; beaks prosogyral. Internal features unknown. 
Stratigraphic distribution.-Emsian-Frasnian. In China, Wuxuanites is known from the Sipaian (Emsian) of Guangxi. In North America, the species Leptodesma extenuatum Hall (1883) is here transferred to Wuxuanites; it occurs in Frasnian age rocks (Chemung) of New York.

Etymology.-The genus is named for Wuxuan County, Guangxi.

Remarks and comparisons.-The highly elongated shell form of $W$. lanceolatus is not due to distortion. On the same bedding planes as that species, specimens of Ptychopteria (P.) zhongguoensis (GXD-379), Pterinopecten sp. (GXD-491a), and Nuculites sp. B (GXD-383) were found. None of these show dorsoventral shortening. $W u$ xuanites differs from Leptodesma in having the pointed elongated anterior lobe, and from Actinodesma (Ectenodesma) in being prosocline and lacking radial ornament.

Wuxuanites lanceolatus n. sp. +

Plate 46, figure 8; plate 47, figures $1-5,10$

Description.-Shell small, highly oblique, angle between umbonal ridge and dorsal margin (angle alpha) $20^{\circ}-25^{\circ}$; right and left valves have about the same degree of convexity; ornament on umbo rugose, growth increments on wings finer and more closely spaced.

Types. $-W$. lanceolatus is known from 19 composite molds, of which 7 are figured. The holotype (GXD-363) is a right valve shown on plate 46 , figure 8 . It measures $14.8 \mathrm{~mm}$ long and $3.5 \mathrm{~mm}$ high. All other specimens are paratypes.

Type locality.-The holotype is from the Ertang Formation (Emsian), Section 4, Bed 34, Wuxuan County, Guangxi.

Distribution.-In addition to the above occurrence, paratypes of $W$. lanceolatus are known from the Ertang Formation, Section 4, Bed 6 (GXD-388); Bed 11 (GXD-373, -374, -380-386, -406, -407); Bed 17 (GXD-378); Bed 31 (GXD-375, -377, -387, -491); Bed 35 (GXD-364).

Etymology.-Lanceola, Latin, diminutive for a light spear, in reference to the elongated pointed shape of the species.

Remarks and Comparisons.-We have no articulated specimens of $W$. lanceolatus, but the distinctive shape of the species suggests that we have correctly associated right and left valves. $W$. lanceolatus differs from both W. extenuatum (Hall) and W. washingtonensis $\mathrm{n}$. sp. in its very small angle alpha of $20^{\circ}-25^{\circ}$; the other two species have an angle alpha of $40^{\circ}-45^{\circ}$.

Wuxuanites washingtonensis n. sp. +

Plate 46 , figures 6,7 ; plate 48 , figure 5

Description.-Shell not as oblique as that of $W$. lanceolatus, angle alpha $40^{\circ}-45^{\circ}$; left valve convex, right valve almost flat; ornament of left valve consists of closely spaced lirae, which may be grouped into rugae; ornament of right valve subdued over body of shell, prominent on anterior auricle.

Types. $-W$. washingtonensis is known from three composite molds, all of which are figured. The holotype (GXD-360) is side-by-each left and right valves shown on plate 48 , figure 5 . The left valve measures $27.9 \mathrm{~mm}$ long (incomplete posteriorly) and $9.9 \mathrm{~mm}$ high.

Type locality.-The holotype is from the Ertang Formation (Emsian), Section 4, Bed 32, Wuxuan County, Guangxi.

Distribution.-In addition to the above occurrence, the two paratypes (GXD-359, -362) are from the same section, Bed 34.

Etymology.-The species is named for the city of Washington, where most of the work for this manuscript was done in U.S. Geological Survey Laboratories, and as testimony to the cooperative spirit that exists between the Chinese and American Nations.

Remarks and comparisons.-Although we have no articulated specimens of this species, the side-by-each occurrence of the two valves of the holotype indicates that these two valves belong to the same individual. $W$. washingtonensis differs from $W$. extenuatum in having an almost unornamented right valve.

\section{Order OSTREOIDA Waller Suborder PECTININA Waller}

Superfamily AVICULOPECTINACEA Meek and Hayden (nomen translatum, Waller, 1978, ex Aviculopectinidae Meek and Hayden) Family PTERINOPECTINIDAE Newell

Discussion.-Devonian scallops are a poorly understood group; generic concepts are vague, overlapping, contradictory, and difficult or impossible to use. The three generic names most commonly used for Devonian scallops are Lyriopecten Hall, Pseudaviculopecten Newell, and Pterinopecten Hall. Pterinopecten is usually divided into several subgenera. McAlester (1962, p. 49) doubted that the type species of Lyriopecten (Avicula orbiculata Hall) and the type species of Pterinopecten (Pterinopecten undosus Hall) were generically distinct. Both species occur in Hamiltonian (Givetian) age rocks in New York (Hall, 1885). McAlester (1962) continued to use both generic names on the authority of Newell (1938). McAlester noted that the type species of both Lyriopecten and Pterinopecten appear to have much less distinct auricles in the left valve than does $P$ seudaviculopecten princeps (Conrad), the type species of the genus Pseudaviculopecten. He regarded this feature as a consistent one to use to differentiate Pseudaviculopecten from the other two genera.

N. D. Newell, of the American Museum of Natural History, has put a great deal of effort into trying to understand Paleozoic scallops. Most of his work has 
been with Carboniferous and Permian taxa. However, Newell (1969c, p. N332-334) summarized his views on how to discriminate Devonian genera of the Pterinopectinidae; we follow his generic-level criteria herein. Pterinopecten is regarded as including those species that have intercalating costae and a poorly differentiated rear auricle. Lyriopecten is regarded as including those species that are similar to Pterinopecten, except that the ornamentation of the left valve is coarser. Pseudaviculopecten has intercalating costae, and includes those species in which the auricles are subequal and well differentiated from the body of the shell in form and commonly in ornament.

As pointed out by McAlester (1962, p. 49), Newell (1938) showed that both Lyriopecten and Pterinopecten had the duplivincular type of ligament found in Pseudaviculopecten. This feature is the primary taxobasis for separating the Pterinopectinidae from the Aviculopectinidae. None of our specimens, from China or Michigan, preserve any features of the ligament. All the Chinese taxa are known only from left valves; two of the American species are known from both right and left valves.

\section{Genus PTERINOPECTEN Hall, 1883}

Diagnosis.-Pterinopectinids having intercalating radial costae and a poorly differentiated posterior auricle.

\section{Subgenus PTERINOPECTEN Hall, 1883}

Diagnosis.-Pterinopecten, having the length of the hinge margin shorter than the shell height.

Stratigraphic range.-Upper Silurian-Upper Devonian, cosmopolitan.

Pterinopecten (Pterinopecten) wuxuanensis n. sp.+

Plate 51, figures 2, 3; plate 52, figure 3

Description.-Shell of medium size (as much as $25 \mathrm{~mm}$ high), left valve gently convex, right valve unknown; left valve shows distinct anterior auricle with ribs, posterior auricle small, not clearly differentiated from rest of shell. Ornament of composite molds of left valve composed of first- and second-order costellae; most second-order costellae intercalate, but a few costellae bifurcate. Comarginal ornament fine, widely spaced.

Types. $-P$. (P.) wuxuanensis is known from three composite molds, all of which are figured. The holotype (GXD-515) is shown on plate 51 , figure 3 ; it measures $25 \mathrm{~mm}$ high, $22.7 \mathrm{~mm}$ long, $2 \mathrm{~mm}$ wide (compressed parallel to bedding) and the hinge margin is $18.5 \mathrm{~mm}$ long.

Type locality.-All known specimens are from the Ertang Formation (Emsian) at Section 4, Wuxuan County, Guangxi. The holotype (GXD-515) and the paratype
(GXD-516), which is shown on plate 52 , figure 3 , are from Bed 31; the other paratype (GXD-512) is from Bed 11 (pl. 51, fig. 2).

Etymology.-The species is named for Wuxuan County, Guangxi.

Comparisons. $-P$. (P.) wuxuanensis differs from $P$. $(P$. undosus, the type species of Pterinopecten (Pterinopecten), in lacking broad comarginal rugae (Newell, 1938, pl. 2, figs. 4a-c). P. (P.) wuxuanensis differs from $P$. $(P$.) strictus Hall in lacking reticulate ornament, and from $P$. (P.) suborbicularis Hall in lacking beaded ribs (McAlester, 1962, pl. 23, figs. 1-10).

Subgenus NEWELLIPECTEN Ruzicka, Prantl, and Pribyl, 1959

Diagnosis.-Pterinopecten having the length of the hinge margin longer than the shell height.

Stratigraphic range.-Lower Devonian of Europe and China.

Pterinopecten (Newellipecten) guangxiensis (Zhang), 1977+

Plate 47 , figures 6,7 ; plate 51 , figures 4,5 ; plate 52 , figures $1,6,7$

1977. Newellipecten (Newellipecten) guangxiensis Zhang, p. 503, pl. 195, fig. 11.

Description.-Shell of small size (a maximum of $20 \mathrm{~mm}$ high), left valve gently convex, right valve unknown; left valve shows distinct anterior auricle with ribs; posterior auricle small, little developed. Ornament of left valve composed of first-order costae and second-order intercalated costellae; all ribs closely spaced. Comarginal ornament prominent, closely spaced.

Material. $-P$. (N.) guangxiensis is known from nine specimens, of which five are figured here. The holotype (GM-IV55162) was figured by Zhang (1977, pl. 195, fig. 11). The specimen shown here on plate 51 , figure 5 (GXD-510), measures $22.2 \mathrm{~mm}$ long, $16.4 \mathrm{~mm}$ high; the hinge margin is $21 \mathrm{~mm}$ long, but width could not be measured because the specimen is virtually flattened parallel to bedding.

Distribution.-The holotype and three topotypes figured here (GXD-505, -506, -510; pl. 51, fig. 5; pl. 52, figs. 6, 7), are from the Ertang Formation (Emsian), Locality 9, Zhongping Village, Xiangzhou County, Guangxi. Two figured (GXD-507, -509; pl. 51, fig. 4; and pl. 52, fig. 1) specimens and one unfigured specimen (GXD-508) are from the Ertang Formation (Emsian), Section 2, Bed 8, Dale and Zhongping Villages, Xiangzhou County, Guangxi. Two unfigured hypotypes are from the Ertang Formation (Emsian), Section 4, Beds 9 (GXD-511) and 31 (GXD-514), Wuxuan County, Guangxi. One figured hypotype (GXD-643) (pl. 47, fig. 6) is from the Yingtang Formation (Eifelian), Section 5, Bed 19, Xiangzhou County, Guangxi.

Comparisons. $-P$. (N.) guangxiensis differs from $P$. (N.) 
niobe (Barrande), the type species of the subgenus, in having stronger, more closely spaced radial ribs. In $P$. $(N$.) niobe, the ribs are weaker and are separated from one another by wide interspaces (Ruzicka, Prantl, and Pribyl, 1959, pl. 5, figs. 5, 6). P. (N.) guangxiensis differs from $P$. (N.) guipingensis (Zhang), 1977, in having a small anterior auricle, which does not project as far forward as the body of the shell, and in having fewer intercalated costellae; $P$. $(N$.) guipingensis occurs in the Ertang Formation (Emsian) of Guangxi.

Genus LYRIOPECTEN Hall in Miller, 1877

Diagnosis.-Like Pterinopecten, but having coarser ornament in left valve.

\section{Lyriopecten ertangensis n. sp. +}

Plate 51, figure 1; plate 52, figures $2,4,5$; plate 53 , figures 1,2

Description.-Shell of large size (as much as $81 \mathrm{~mm}$ long), left valve gently convex, right valve unknown; left valve lacks distinct anterior auricle, posterior auricle distinct. Ornament of left valve composed of strong first-order costae, which may or may not subdivide; interspaces between costae broad, and some contain intercalated costellae. Comarginal ornament prominent, closely spaced.

Types.-L. ertangensis is known from 12 specimens, of which 6 are figured. The holotype (GXD-493) is shown on plate 51 , figure 1; it measures $81 \mathrm{~mm}$ long, $62.3 \mathrm{~mm}$ high, $5.9 \mathrm{~mm}$ wide, and the hinge margin is $73.9 \mathrm{~mm}$ long. All specimens are compressed parallel to bedding.

Type locality. - The holotype (GXD-493), two figured paratypes (GXD-495, -504; pl. 52, fig. 5; pl. 53, fig. 1), and one unfigured paratype (GXD-494) are from the Ertang Formation (Emsian), Section 4, Bed 30, Wuxuan County, Guangxi.

Distribution.-One figured paratype (GXD-501, pl. 53, fig. 2) and two unfigured paratypes (GXD-496, -597) are from Bed 19 at the same locality as the holotype. Two figured paratypes (GXD-499, -502; pl. 52 , figs. 2,4$)$ and three unfigured paratypes (GXD-498, $-500,-503$ ) are from the Ertang Formation (Emsian) at Locality 6, Xiangzhou County, Guangxi.

Etymology.-The species is named for the Ertang Formation.

Comparisons. $-L$. ertangensis differs from $L$. orbicularis in having much stronger first order costae (Hall, 1885, pl. 4, figs. 3-8), and from the Hamiltonian age species $L$. macrodontus Hall in not having regularly intercalated costellae (Hall, 1885, pl. 8, figs. 9, 10).

Lyriopecten cf. L. tricostatus (Vanuxem), 1842*

Plate 58, figures 3,4

Discussion.-Three specimens from Michigan are compared with Lyriopecten tricostatus, which has a stratigraphic range of Fingerlakesian-Cohoctonian (Givetian-Frasnian) in New York (McAlester, 1962). The Michigan specimens are not well preserved, but they do show the large radial ribs and fine radial ribs between them, and concentric ridges forming a reticulate network. These features were regarded as characteristic of L. tricostatus by McAlester $(1962$, p. 52$)$.

Stratigraphic occurrence.-Specimen YPM 16465 is from the upper Ferron Point Formation, and was found in a shale pit of the Alpena Portland Cement Co., NW1/4SE1/4, sec. 18, T. 32 N., R. 9 E., Alpena County, Mich. Specimen USNM 383619 is from the Gravel Point Formation, and was found in a quarry of the Penn Dixie Company, Petosky, Emmet County, Mich. Specimen USNM 383620 is from the Gravel Point Formation, about 1 mile south of Gravel Point, Grand Traverse Bay, Charlevoix County, Mich.

\section{Genus PSEUDAVICULOPECTEN Newell, 1938}

Diagnosis.-Like Pterinopecten but auricles subequal and well-differentiated from body of shell.

Pseudaviculopecten exacutus (Hall), 1883*

Plate 58, figures 1,2 ; plate 59 , figure $1-3$

Discussion.-The Michigan specimens of this species compare very favorably with those figured by Hall (1883, 1885, pl. 3, figs. 18-22) and Newell (1938, pl. 2, figs. 1-3). In both valves, ribs increase by intercalation on the body of the shell (pl. 58, figs. 1, 2; pl. 59, figs. $1-3$ ); the left valve has well-defined auricles (pl. 58, fig. 2 ; pl. 59, fig. 2); and the right valve has a prominent byssal notch (pl. 58, fig. 1; pl. 59, fig. 3). Shell shape is slightly prosocline (pl. 58, fig. 1). One specimen shows the right and left valves articulated (pl. 58, fig. 2), so that we are sure that we have made the correct association of valves. The valves are of about equal convexity.

In New York, $P$. exacutus is known from Hamiltonian age rocks. In Michigan, 11 specimens are known from the upper Alpena Limestone at Four Mile Dam, Alpena County (YPM 16464, USNM 383642-383644), and the Four Mile Dam Formation at the same locality (USNM 383641).

\section{Family AVICULOPECTINIDAE Meek and Hayden}

Genus AVICULOPECTEN M'Coy, 1851

Diagnosis.-Aviculopectinid having radial ornament on body of left valve increasing by intercalation, and on right valve by bifurcation.

Discussion.-One species from Michigan, known from 19 specimens, is here assigned to Aviculopecten as used by Newell (1938). Since Newell's work, Aviculopecten has been thought to be absent from Devonian rocks. For the most part, Devonian species formerly assigned to Aviculopecten are now placed in Pseudaviculopecten. 
Two major external features separate Pseudaviculopecten from Aviculopecten. In Pseudaviculopecten, increase in the radial ribs on the body of the shell of both valves is by intercalation (pl. 58, fig. 2); in Aviculopecten, rib increase on the body of the shell is by intercalation in the left valve (pl. 58, figs. 6,8 ; pl. 59, figs. $4,7-9$ ) and by bifurcation in the right valve (pl. 58 , fig. 7; pl. 59, figs. 5, 6). Pseudaviculopecten (pl. 58, fig. 2) has biconvex valves, whereas in Aviculopecten, the right valve is flat (pl. 58, fig. 7). In these two features, the Michigan specimens are like Aviculopecten. Nothing is known of the ligament of the Michigan specimens, and whether they had a resilifer or duplivincular grooves and ridges cannot be determined.

Aviculopecten ornatus Hall, 1883*

Plate 58, figures 5 8; plate 59, figures 4-9

Discussion.-The Michigan specimens are similar in shape and ornament to the specimen of $A$. ornatus figured by Hall $(1883,1885$, pl. 2, fig. 8). Articulated specimens are known from Michigan, and thus we are sure that we have made the correct association of right and left valves (pl. 58, fig. 7; pl. 59, fig. 4). In the left valve, both anterior and posterior auricles are ribbed (pl. 59, fig. 9) and the body of the shell shows a single intercalated costella between primary costellae (pl. 59, figs. 8, 9). In the right valve, both anterior and posterior auricles have ribs (pl. 58, fig 7; pl. 59, figs. 4-6), and the body of the shell shows double bifurcation of the costellae (pl. 59, figs. 5, 6). The first bifurcation is high on the shell and the second is at about midheight.

In New York, A. ornatus is known from Hamiltonian age rocks. In Michigan, it is known from the upper Alpena Limestone (YPM 16461-16463, 16621, 16622) and the Four Mile Dam Formation (USNM 383645-383647) at Four Mile Dam, Alpena County. 


\section{REFERENCES CITED}

Allen, J.A., and Sanders, H.L., 1973, Studies on deep-sea Protobranchia (Bivalvia); the families Siliculidae and Lametilidae: Museum of Comparative Zoology Bulletin 145, p. 263-309.

Babin, Claude, 1966, Mollusques bivalves et céphalopodes du Paleozoique Armoricain: Imprimerie Commerciale et Administrative, Brest, $471 \mathrm{p}$.

1982, Tromelinodonta nov. gen., Bivalve Lyrodesmatidae (Mollusca) del'Arenigien (Ordovician Inférieur): Geobios, v. 15, p. 423-427.

Bai Shunliang, Jin Shanyu, and Ning Zhongshan, 1982, The Devonian biostratigraphy of Guangxi and adjacent areas: Peking University Press, Beijing, 203 p. (in Chinese).

Bai Shunliang, Jin Shanyu, Ning Zhongshan, and Ho Jinhan, 1979, Devonian conodont sequence and stratigraphic boundaries in South China: Second All-China Stratigraphic Congress, 1979: Beijing, 10 p. (in Chinese, English abstract).

Bailey, J.B., 1978, Provincialism and migrations of Lower and Middle Devonian pelecypods: Palaeogeography, Palaeoclimatology, and Palaeoecology, v. 23, p. 119-130.

1979, Michigan Basin Devonian endemism and the evolution of Nuculopsis Girty (Bivalvia): Geological Society of America Abstracts with Programs (North-Central Section), v. 11, no. 5, p. 225.

1983, Middle Devonian Bivalvia from the Solsville Member (Marcellus Formation), central New York State: American Museum of Natural History Bulletin 174, p. 193-325.

Barrois, C., 1882, Recherches sur les Terrains Anciens des Asturies et de la Galice (Espagne): Société Géologique du Nord Mémoir 2 , no. 1, p. 273-276.

Bassler, R.S., 1915, Bibliographic index of American Ordovician and Silurian fossils: U.S. National Museum Bulletin 92, 1521 p.

Beushausen, L., 1895, Die Lamellibranchiaten des rheinischen Devon mit Ausschluss der Aviculiden: Königlich Preussischen geologischen Landesanstalt, Neue Folge, v. 17, 514 p. (Atlas of 38 plates bound separately.)

Boucot, A.J., Gray, Jane, 1979, Epilogue, in Gray, Jane, and Boucot, A.J., eds., Historical biogeography, plate tectonics, and the changing environment: Oregon State University Press, Corvallis, p. 464-482.

Boucot, A.J., Johnson, J.G., and Struve, W., 1966, Stringocephalus, ontogeny and distribution: Journal of Paleontology, v. 40, p. 1349-1364.

Boyd, D.W., and Newell, N.D., 1968, Hinge grades in the evolution of Crassatellacean bivalves as revealed by Permian genera: American Museum of Natural History Novitates 2328, 51 p.

1979, Permian pelecypods from Tunisia: American Museum of Natural History Novitates 2686, 22 p.

Bradshaw, M.A., 1974, Morphology and mode of life of the bivalves Nuculoidea vespa $\mathrm{n}$. sp. and Nuculoidea umbra $\mathrm{n}$. sp. from the Devonian of New Zealand: New Zealand Journal of Geology and Geophysics, v. 17, p. 447-464.

1978, Position of soft parts in fossil palaeotaxodont bivalves as suggested by features of the shell interior: Alcheringa, v. 2, p. $302-315$.

Carter, J.G., and Tevesz, M.J.S., 1978, Shell microstructure of a Middle Devonian (Hamilton Group) bivalve fauna from central New York: Journal of Paleontology, v. 52, p. 859-880.

Caster, K.E., 1930, Higher fossil faunas of the upper Allegheny: Bulletins of American Paleontology, v. 15, no. 58, 322 p.

Chang Hsichih, 1929, A preliminary report on the identification of some Lower Devonian brachiopods and pelecypods of Kwangsi Province: Geological Survey of Kwangtong and Kwangsi Special Publication 3, p. 1-9.
Chen Yuanren, 1978, On some stratigraphic problems of the Devonian System in Longmenshan District, Sichuan Province: Professional Paper for the Symposium on the Devonian System of South China, 1974: Beijing, Geological Press, p. 104-122 (in Chinese).

Chernyshev, B.I., 1951, Semeystvo Ledidae iz Kamennougol'nykh otlozheniy SSSR: Trudy Akademia Nauk Ukraine, SSR, Kiev, Series Stratigrafi i Paleontologi, v. 2, 40 p.

Clarke, J.M., 1909, Early Devonic History of New York and eastern North America: New York State Museum Memoir 9, part 2, 166 p.

Cloud, P.E., Jr., 1942, Terebratuloid brachiopods of the Silurian and Devonian: Geological Society of America Special Paper 38, 182 p.

Conrad, T.A., 1838, Report on the Palaeontological Department of the Survey, State of New York, No. 200, In Assembly, Communication from the Governor, Relative to the Geological Survey of the State, p. 107-119. (New York Geological Survey, Annual Report 2.)

1841, Fifth Annual Report on the palaeontology of the State of New York: State of New York, No. 150, In Assembly, Communication from the Governor, transmitting several reports relative to the Geological Survey of the State, p. 25-57. (New York Geological Survey, Annual Report 5.)

1842, Observations on the Silurian and Devonian Systems of the United States, with descriptions of new organic remains: Academy of Natural Sciences of Philadelphia Journal, v. 8, p. 228-280.

1858, Observations on a group of Cretaceous fossil shells found in Tippah County, Miss., with descriptions of 56 new species: Academy of Natural Sciences of Philadelphia Journal, second series, v. 3, p. 323-336.

1866, Observations on Recent and fossil shells, with proposed new genera and species: American Journal of Conchology, v. 2, p. 101-103.

Cooper, G.A., 1931, Concerning the authorship of the "Preliminary notice of the lamellibranch shells of the Upper Helderberg Hamilton, and Chemung Groups, etc., Part 2": Washington Academy of Sciences Journal, v. 21, p. 459-467.

Cooper, G.A., and Dutro, J.T., Jr., 1982, Devonian brachiopods of New Mexico: Bulletins of American Paleontology, v. 82, 83, 215 p.

Cooper, G.A., and Grant, R.E., 1972, Permian brachiopods of west Texas, I: Smithsonian Contributions to Paleobiology, no. 14, 230 p.

Cooper, G.A., and Phelan, Thomas, 1966, Stringocephalus in the Devonian of Indiana: Smithsonian Miscellaneous Collections, v. 151, no. $1,20 \mathrm{p}$.

Cooper, G.A., and others, 1942, Correlation of the Devonian sedimentary formations of North America: Geological Society of America Bulletin, v. 53, p. 1729-1794.

Cox, L.R., 1969a, Family Myophoriidae, in Moore, R.C., ed., Treatise on Invertebrate Paleontology, pt. N, Mollusca 6, v. 1, Bivalvia: New York and Lawrence, Kans., Geological Society of America and University of Kansas Press, p. N472-N476.

1969 b, Family Hippopodiidae, in Moore, R.C., ed., Treatise on Invertebrate Paleontology, pt. $\mathrm{N}$, Mollusca 6, v. 2, Bivalvia: New York and Lawrence, Kans., Geological Society of America and University of Kansas Press, p. N582-N583.

1969 c, General features of the Bivalvia, in Moore, R.C., ed., Treatise on Invertebrate Paleontology, pt. N, Mollusca 6, v. 2, Bivalvia: New York and Lawrence, Kans., Geological Society of America and University of Kansas Press, p. N30-N51.

Cramer, F.H., 1964, Microplankton from three Palaeozoic formations in the Province of Leon (NW Spain): Leidsche Geologische Mededeelingen, v. 30, p. 253-361.

1967, Chitinozoans of a composite section of upper Llandoverian to basal lower Gedinnian sediments in northern Leon, Spain: a preliminary report: Bulletin Societe Belge Geologique, v. 75, p. 66-129. 
Dahmer, G., 1921, Studien über die Fauna des Oberharzer Kahlebergsandsteins. II: Preussischen Geologischen Landesanstalt zu Berlin, 1919, Bd. 40, Teil II, Heft 2, p. 161-306.

Dickins, J.M., 1963, Permian pelecypods and gastropods from Western Australia: Australian Bureau of Mineral Resources, Geology, and Geophysics Bulletin 63, 203 p.

Driscoll, E.G., 1961, Another nomenclatorial review of the Carboniferous lamellibranchs Macrodon, Grammatodon, Parallelodon, and Beushuasenia: Journal of Paleontology, v. 35, p. 1090-1093.

1965, Dimyarian pelecypods of the Mississippian Marshall Sandstone of Michigan: Palaeontographica Americana, v. 5, no. 35, p. 67-128.

Editorial Group, 1979, On regional stratigraphic scale of Heilongiiang Province, 1979. The regional stratigraphic scale of northeast China, Heilongjiang fascicle: Geological Publishing House, Beijing, 300 p. (in Chinese).

Elias, M.K., 1956, Upper Mississippian and Lower Pennsylvanian formations of southcentral Oklahoma, in Petroleum geology of southern Oklahoma-a symposium, v. 1: Tulsa, Oklahoma, American Association of Petroleum Geologists, p. 56-134.

Fletcher, H.O., 1945, A new genus Glyptoleda and a revision of the genus Nuculana from the Permian of Australia: Australian Museum Records, v. 21, p. 293-312.

Frech, F., 1891, Die devonischen Aviculiden Deutschlands. Abhandlungen zur geologischen Specialkarte von Preussen und den Thüringischen Staaten Bd. 9, Heft 3, 261 p. (Atlas of 18 plates bound separately.)

Gao, Lianda, 1978, Some spores and acritarchs of the Nagaolingian, Early Devonian, from Liujiang, Hengxiang County, Guangxi: Professional Paper for the Symposium on the Devonian System of South China, 1974: Beijing, Geological Press, p. 346-358 (in Chinese).

Girty, G.H., 1909, Fauna of the Caney Shale of Oklahoma: U.S. Geological Survey Bulletin 377, 106 p.

1911 , On some new genera and species of Pennsylvanian fossils from the Wewoka formation of Oklahoma: New York Academy of Science Annals, v. 21, p. 119-156, 1912. (50 preprints were distributed in August 1911.)

Goldfuss, G.A., 1833-1840, Petrefacta Germaniae, Theil 2, (a) p. 1-65, pl. 72-96 (1833); (b) lief 5, p. 66-140, pl. 97-121 (1836); (c) lief 6, p. 141-224, pl. 122-146 (1837); (d) lief 7, p. 225-312, pl. 147-165 (1840): Arnz, Dusseldorf.

Guo Fuxiang, 1980, Antactinodiontidae, a new family of Early Devonian Bivalves: Acta Palaeontologica Sinica, v. 19, p. 51-56 (in Chinese).

Haffer, Jürgen, 1959, Der Schlossbau früh-heterodonter Lamellibranchiaten aus dem rheinischen Devon: Palaeontographica, v. 112 , abt. A, p. 133-192.

Hall, James, 1843, Survey of the Fourth Geological District: Natural History of New York, Geology of New York, Part 4, 683 p.

1858, Description of new species of fossils from the Carboniferous limestones of Indiana and Illinois: Albany Institute Transactions, v. 4 , p. $1-36$ (1856?).

1859, Descriptions and figures of the organic remains of the Lower Helderberg Group and the Oriskany Sandstone: Natural History of New York, Geological Survey New York, Palaeontology 3, part 1, $533 \mathrm{p}$.

1862, Note on the genus Cypricardites: 15th Report on the New York State Cabinet of Natural History, p. 192-193.

1883, Lamellibranchiata plates and explanations: Natural History of New York, Geological Survey of New York, Palaeontology, v. 5, pt. 1,20 p., pls. 1-34, 36-41, 43-80.

1884 , Descriptions and figures of the Monomyaria of the Upper Helderberg, Hamilton, and Chemung Groups: Natural History of New York, Geological Survey of New York, Palaeontology, v. 5, pt. 1, Lamellibranchiata 1, 268 p.
1885, Descriptions and figures of the Dimyaria of the Upper Helderberg, Hamilton, Portage, and Chemung Groups: Natural History of New York, Geological Survey of New York, Palaeontology, v. 5, pt. 1, Lamellibranchiata 2, 540 p.

Hall, James, and Whitfield, R.P., 1869, Preliminary notice of the lamellibranchiate shells of the Upper Helderberg, Hamilton, and Chemung Groups, with others from the Waverly sandstones, Part 2: Albany, 80 p.

1870 , Preliminary notice of the lamellibranchiate shells of the Upper Helderberg, Hamilton, and Chemung Groups, with others from the Waverly sandstones, Part 2: Albany, $97 \mathrm{p}$.

Harrison, W.B., III, and Harrison, L.K., 1975, A Maquoketa-like molluscan community in the Brassfield Formation (Early Silurian) of Adams County, Ohio: Bulletins of American Paleontology, v. 67, p. 193-234.

Heidecker, Eric, 1959, Middle Devonian molluscs from the Burdekin Formation of north Queensland: University of Queensland Papers, Department of Geology, v. 5, no. 2, 11 p.

Hind, Wheelton, 1900, Monograph of the British Carboniferous Lamellibranchiata, v. 1, part 5-Coelonotidae, Solenomyidae, Conocardiidae, Cardiidae: London, Palaeontographical Society, p. 361-487.

Hou Hongfei, 1978, Devonian System in South China: Professional Paper for the Symposium on the Devonian System of South China, 1974: Beijing, Geological Press, p. 214-230 (in Chinese).

Hou Hongfei, Wang Shitao, Gao Lianda, Xian Siyuan, Bai Shunliang, Cao Xuando, Pan Jiang, Jin Shanyu, and Hou Jingpeng, 1982, The Devonian System of China, in Stratigraphy of China, No. 1, An outline of the stratigraphy of China, edited by the Chinese Academy of Geological Sciences: Geological Publishing House, Beijing, 1982, p. 165-186 (in Chinese, English abstract).

Hou Hongfei, Wang Shitao, Gao Lianda, Xian Siyuan, Bai Shunliang, Cao Xuando, Pan Jiang, and Liao Weihua, 1979, The Devonian System of China: Stratigraphy of China (abstract), Edited by Chinese Academy of Geological Sciences, Second All-China Stratigraphic Congress, 1979, p. 19-22.

Hou Hongfei and Xian Siyuan, 1975, The Lower and Middle Devonian brachiopods from Guangxi and Guizhou: Professional Papers of Stratigraphy and Paleontology, no. 1, p. 1-85: Beijing, Geological Press (in Chinese).

Hou Jingpeng, 1978, Some Chitinozoans of the Nagaoling Formation, Lower Devonian, Liujing, Hengxian County, Guangxi: Professional Paper for the Symposium on the Devonian System of South China, 1974: Beijing, Geological Press, p. 359-372 (in Chinese).

Imbrie, John, 1959, Brachiopods of the Traverse Group (Devonian) of Michigan, pt. 1: American Museum of Natural History Bulletin 116 , p. 349-409.

Keferstein, Wilhelm, 1857, Ueber einige deutsche devonische Conchiferen aus der Verwandtschaft der Trigoniaceen und Carditaceen: Deutsche Geologische Gesellschaft Zeitschrift, v. 9, p. 148-162.

Kelly, W.A., and Smith G.W., 1947, Stratigraphy and Structure of Traverse Group in Afton-Onaway area, Michigan: American Association of Petroleum Geologists Bulletin, v. 31, p. 447-469.

Kesling, R.V., Segall, R.T., and Sorensen, H.O., 1974, Devonian strata of Emmet and Charlevoix Counties, Michigan: University of Michigan, Museum of Paleontology, Papers on Paleontology $7,187 \mathrm{p}$.

Kirk, Edwin, 1927, Tanaodon, a new molluscan genus from the Middle Devonian of China: United States National Museum Proceedings, v. 70. Art. 12, 4 p.

Klapper, Gibert, and Johnson, J.G., 1980, Endemism and dispersal of Devonian conodonts: Journal of Paleontology, v. 54, p. 400-455.

Koninck, L.G., de, 1842-1844, Description des animaux fossils, qui se trouvent dans de le terrain carbonifere de Belgique: Liege, $650 \mathrm{p}$. 
Kozlowski, Roman, 1929, Les Brachiopodes Gothlandies de la Podolie Polonaise: Palaeontologia Polonica 1, p. 1-254.

Krasilova, I.N., 1963, Stratigraphy and pelecypods of the Upper Silurian and Lower Devonian from northeast Pribalkhash'ya: Akademia Nauk SSSR, Moscow, v. 75, 200 p.

Kuang Guodun, 1982, The Devonian rocks, sedimentary facies, and biota of Liujing, Guangxi, in The Devonian System of Liujing and Luofu, Guangxi: Guangxi Institute of Geology, p. 1-73. (This is an internal publication, in Chinese.)

Lardeux, Hubert, 1969, Les Tentaculites D'Europe Occidentale et D'Afrique du Nord: Paris, Cahiers de Paleontologie, Editions du Centre national de la Recherche Scientifique, p. 1-238.

LaRocque, Aurele, 1950, Pre-Traverse Devonian pelecypods of Michigan: University of Michigan, Museum of Paleontology Contributions, v. 7, p. 271-366.

LaRocque, Aurele, and Newell, N.D., 1969, Superfamily Modiomorphacea, in Moore, R.C. ed., Treatise on Invertebrate Paleontology, pt. N, Mollusca 6, v. 1, Bivalvia: New York and Lawrence, Kans., Geological Society of America and University of Kansas Press, P. N393-N399.

Lee, J.S., 1939, The Geology of China: London, Thomas Murphy \& Co., p. 1-528.

Li Xingxue, and Cai Chongyang, 1977, Early Devonian Zosterophyllum-remains from Southwest China: Acta Palaeontologica Sinica v. 16, no. 1, p. 12-36 (in Chinese, English abstract).

1978, The type section of Lower Devonian strata in Southwest China with brief notes on the succession and correlation of its plant assemblages: Acta Geologica Sinica 1978, p. 1-14 (in Chinese, English abstract).

Liang Zhongfa, 1981, Mollusca, in Palaeontological Atlas of Northeast China, Paleozoic Volume: Beijing, Geological Publishing House, p. 429-467 (in Chinese).

Liao Weihua, Xu Hahkui, Wang Chengyuang, Ruan Yiping, Cai Chongyang, Mu Daocheng, and Lu Lichang, 1978, The subdivision and correlation of Devonian stratigraphy of Southwest China: Professional Paper for the Symposium on the Devonian System of South China, 1974: Beijing, Geological Press, p. 214-230 (in Chinese).

Lintz, Joseph, 1958, The fauna of the Ames and Brush Creek shales of the Conemaugh formation of western Maryland: Journal of Paleontology, v. 32, p. 97-112.

Liu Lu, 1976, In Fossil Lamellibranchiata of China: Beijing, Science Press, (edited by Editorial group on Fossil Lamellibranchiata of China), p. 1-522 (in Chinese).

1979, The geological age of the genus Dysodonta (Bivalvia): Acta Palaeontologica Sinica, v. 18, p. 197-201 (in Chinese).

Loczy, L., 1899, Palaeozoische und Mesozoische wirbellose Thiere, in Wissenschaftliche Ergebnisse der Reise des Graten Bela Szechengyi in Ostasien, Bd. 3, p. 54-157.

McAlester, A.L., 1962, Upper Devonian pelecypods of the New York Chemung stage: Yale University Peabody Museum of Natural History Bulletin 16, 88 p.

1963, Pelecypods of the Snyder Creek Shale (Upper Devonian) of Missouri: Journal of Paleontology, v. 37, p. 981-1000.

1968, Type species of Paleozoic nuculoid bivalve genera: Geological Society of America Memoir 105, $143 \mathrm{p}$.

1969a, Genera Nuculoidea and Nuculopsis, in Keen, A. M., Family Nuculidae, in Moore, R.C., ed., Treatise on Invertebrate Paleontology, pt. N, Mollusca 6, v. 1, Bivalvia: New York and Lawrence, Kans., Geological Society of America and University of Kansas Press, p. N231. 1969b, Genera Paleyoldia and Phestia in Puri, N. S., Family Nuculanidae, in Moore, R.C., ed., Treatise on Invertebrate Paleontology, pt. N, Mollusca 6, v. 1, Bivalvia: New York and Lawrence, Kans., Geological Society of America and University of Kansas Press, p. N237-N239. 1969c, Family Malletiidae, in Moore, R.C., ed., Treatise on Invertebrate Paleontology, pt. N, Mollusca 6, v. 1, Bivalvia: New York and Lawrence, Kans., Geological Society of America and University of Kansas Press, p. N231-N235.

M'Coy, Frederick, 1844, A synopsis of the characters of the Carboniferous fossils of Ireland: Dublin, University Press, $271 \mathrm{p}$.

1851, Descriptions of some new Mountain Limestone fossils: Annals and Magazine of Natural History, second series, v. 7, p. $167-175$.

1862, A synopsis of the characters of the Carboniferous fossils of Ireland: Dublin, Williams and Northgate, $271 \mathrm{p}$.

Magloire, L., 1967, Etude stratigraphic, par Palynologie des dé pots argilo-gréseux du Silurian et du Devonian inferiur dans la region du Grand Erg Occidental (Sahara Algérien), in Oswald, D.H. ed., International Symposium on the Devonian System, Calgary, 1967: Alberta Society of Petroleum Geologists, v. 2, p. 473-491.

Mansuy, H., 1912, Paleontologie, in Deprat, J., and Mansuy, H., Etude Géologique du Yun-Nan oriental: Service Géologique de l'Indochine Memoires, v. 1, fasc. 2, p. 47.

1913, Contribution a l'étude des faunes paleozóiques et triasiques du Tonkin, pt. 1 , of Nouvelle contribution a la paléontologie de l'Indochine: Service Géologique de Indochine Memoires, v. 2, fasc. 5 , p. 6-29.

Meek, F.B., and Worthen, A.H., 1866, Descriptions of Paleozoic fossils from the Silurian, Devonian, and Carboniferous rocks of Illinois and other western states: Chicago Academy of Science Proceedings, v. 1 , p. 11-23.

Miller, S.A., 1877, The American Paleozoic Fossils, published by the author, Cincinnati, 245 p.

1889, North American Geology and Paleontology, published by the author, Cincinnati, $664 \mathrm{p}$.

Morris, N.J., 1978, The infaunal descendants of the Cycloconchidae: An outline of the evolutionary history and taxonomy of the Heteroconchia, superfamilies Cycloconchacea to Chamacea: Royal Society of London Philosophical Transactions, Ser. B, v. 284, p. 259-274.

Mu Daocheng, 1978, On the Devonian tentaculite zones of South China, 1974: Professional Paper for the Symposium on the Devonian System of South China: Beijing, Geological Press, p. 270-279 (in Chinese).

Newell, N.D., 1937, Late Paleozoic pelecypods: Pectinacea: Kansas Geological Survey, v. 10, pt. 1, 123 p. (1938).

1942, Late Paleozoic pelecypods: Mytilacea: Kansas Geological Survey, v. 10 , pt. 2,110 p.

1969a, Order Modiomorphoida, in Moore, R.C., ed., Treatise on Invertebrate Paleontology, pt. N, Mollusca 6, v. 1, Bivalvia: New York and Lawrence, Kans., Geological Society of America and University of Kansas Press, p. N393.

1969b, Family Parallelodontidae, in Moore, R.C., ed., Treatise on Invertebrate Paleontology, pt. N, Mollusca 6, v. 1, Bivalvia: New York and Lawrence, Kans., Geological Society of America and University of Kansas Press, p. N256-N259.

1969 c, Family Pterinopectinidae, in Moore, R.C., ed., Treatise on Invertebrate Paleontology, pt. N, Mollusca 6, v. 1, Bivalvia: New York and Lawrence, Kans., Geological Society of America and University of Kansas Press, p. N332-N334.

Newell, N.D., and Boyd, D.W., 1970, Oyster-like Permian Bivalvia: American Museum of Natural History Bulletin 143, p. 221-281.

1975, Parallel evolution in early trigoniacean bivalves: American Museum of Natural History Bulletin 154, p. 57-162.

Newell, N.D., and LaRocque, Aurele, 1969a, Family Pterineidae, in Moore, R.C., ed., Treatise on Invertebrate Paleontology, pt. N, Mollusca 6, v. 1, Bivalvia: New York and Lawrence, Kans., Geological Society of America and University of Kansas Press, p. N298-N302. 
1969b, Family Grammysiidae, in Moore, R.C., ed., Treatise on Invertebrate Paleontology, pt. N, Mollusca 6, v. 2, Bivalvia: New York and Lawrence, Kans., Geological Society of America and University of Kansas Press, p. N819-N823.

1969c, Family Orthonotidae, in Moore, R.C., ed., Treatise on Invertebrate Paleontology, pt. N, Mollusca 6, v. 2, Bivalvia: New York and Lawrence, Kans., Geological Society of America and University of Kansas Press, p. N818-N819.

1969d, Family Lyrodesmatidae, in Moore, R.C., ed., Treatise on Invertebrate Paleontology, pt. N, Mollusca 6, v.1, Bivalvia: New York and Lawrence, Kans., Geological Society of America and University of Kansas Press, p. N471.

Oliver, W.A., Jr., 1973, Devonian coral endemism in eastern North America and its bearing on palaeogeography: Palaeontological Association, Special Papers in Palaeontology 12, p. 318-319.

1976, Biogeography of Devonian rugose corals: Journal of Paleontology, v. 50, p. 365-373.

1977, Biogeography of Late Silurian and Devonian rugose corals: Palaeogeography, Palaeoclimatology, Palaeoecology, v. 22, p. 85-135.

Owen, G., 1959, Observations on the Solenacea with reasons for excluding the family Glaucomyidae: Royal Society of London Philosophical Transactions, Ser. B, v. 242, p. 59-97.

Pan Jiang, Wang Shitao, Gao Lianda, and Hou Jingpeng, 1978, Devonian continental sedimentary formations of South China: Professional Paper for the Symposium on the Devonian System of South China, 1974: Beijing, Geological Press, p. 240-269 (in Chinese).

Pedder, A.E.H., 1965, A revision of the Australian Devonian corals previously referred to Mictophyllum: Royal Society of Victoria Proceedings, v. 78, pt. 2, p. 201-220.

Phillips, John, 1848, The Malvern Hills compared with the Paleozoic districts of Abberlet, etc.: Geological Survey of Great Britain Memoir 2, pt. 1, p. 1-330.

Pohl, E.R., 1929, The Devonian of Wisconsin, pt. 1, Lamellibranchiata: Public Museum of the city of Milwaukee Bulletin 11, p. 1-100. 1930, The Middle Devonian Traverse Group of rocks in Michigan, a summary of existing knowledge: U.S. National Museum Proceedings, v. 76, art. 14, $34 \mathrm{p}$.

Pojeta, John, Jr., 1962, The pelecypod genus Byssonychia as it occurs in the Cincinnatian at Cincinnati, Ohio: Palaeontographica Americana, v. 4, p. 169-216.

1966, North American Ambonychiidae (Pelecypoda): Palaeontographica Americana, v. 5, p. 129-241.

1971, Review of Ordovician pelecypods: U.S. Geological Survey Professional Paper 695, 46 p.

1978 , The origin and early taxonomic diversification of pelecypods: Royal Society of London Philosophical Transactions, Ser. B, v. 284, p. 225-246.

(in press), Class Pelecypoda, in Boardman, R., Cheetham, A., and Rowell, A.J., Textbook of Invertebrate Paleontology: Palo Alto, Blackwell Scientific Publications, Inc.

Pojeta, John, Jr., and Gilbert-Tomlinson, Joyce, 1977, Australian Ordovician pelecypod molluscs: Australian Bureau of Mineral Resources, Geology, and Geophysics Bulletin 174, 64 p.

Pojeta, John, Jr., Kriz, Jiri, and Berdan, J.M., 1976, Silurian-Devonian pelecypods and Paleozoic stratigraphy of subsurface rocks in Florida and Georgia and related Silurian pelecypods from Bolivia and Turkey: U.S. Geological Survey Professional Paper 879, 32 p.

Pojeta, John, Jr., and Runnegar, Bruce, 1985, The early evolution of diasome mollusks, in Trueman, E.R., and Clarke, M.R., The Mollusca, v. 10, Evolution: Orlando, Fla., Academic Press, p. 295-336.

Pojeta, John, Jr., and Zhang Renjie, 1984, Sinodora n. gen.-A
Chinese Devonian homeomorph of Cenozoic pandoracean pelecypods: Journal of Paleontology, v. 58, p. 1010-1025.

Qin Feng, and Gan Yiyan, 1976, The Paleozoic stratigraphy of the western Qinling Range: Acta Geologica Sinica, 1976, p. 74-97 (in Chinese, English abstract).

Reed, F.R.C., 1927, Paleozoic and Mesozoic fossils from Yunnan: Palaeontologia Indica, new series, Memoir, v. 10, no. 1, p. 129-296.

Rickard, L.V., 1975, Correlation of the Devonian rocks in New York: New York State Museum and Science Service Map and Chart Series 24 , pl. 3.

1984, Correlation of the subsurface Lower and Middle Devonian of the Lake Erie region: Geological Society of America Bulletin, v. 95, p. $814-828$.

Rickard, L.V., and Zenger, D.H., 1964, Stratigraphy and paleontology of the Richfield Springs and Cooperstown Quadrangles, New York: New York State Museum and Science Service Bulletin 396, $101 \mathrm{p}$.

Runnegar, Bruce, 1974, Evolutionary history of the bivalve subclass Anomalodesmata: Journal of Paleontology, v. 48, p. 904-939.

Runnegar, Bruce, and Newell, N.D., 1974, Edmondia and the Edmondiacea, shallow-burrowing Paleozoic pelecypods: American Museum of Natural History Novitates 2533, 19 p.

Ruzicka, Bohuslav, Prantl, Ferdinand, and Pribyl, Alois, 1959, Some pectinoid pelecypods from the Silurian and Devonian of central Bohemia: Národniho Musea v Praze Sborni'k, v. 15, Ser. B, p. 1-59.

Salter, J.W., 1852, Note on the fossils above mentioned from the Ottawa River: British Association for the Advancement of Science, 21st meeting, 1851, Notices and Abstracts, etc., p. 63-65.

Sandberger, Guido, and Sandberger, Fridolin, 1850-1854, Die Versteinerungen des rheinischen Schichtensystems in Nassau, (a) Lief 1, 2, p. 1-72, pl. 1-8 (1850); (b) Lief 3, p. 73-104, pl. 9-13 (1851); (c) Lief 4, 5, p. 105-168, pls. 14-23 (1852); (d) Lief 6-8, p. 169-564, pls. 24-39 (1854): Wiesbaden, Kreidel \& Nieder. (Plates bound separately from text.) Information on dates of publication provided by H. K. Erben, University of Bonn, Federal Republic of Germany, to Curt Teichert, University of Rochester, on July 20, 1959.

Sanford, B.V., 1967, Devonian of Ontario and Michigan, in Oswald, D.H., ed., International Symposium on the Devonian System, Calgary, 1967: Alberta Society of Petroleum Geologists, v. 1, p. 973-999.

Saurin, E., 1958, Lexique Stratigraphique International, v. 3 Asie, Fasc. 6a Indochine: Paris, Centre National de la Resherche Scientifique, $141 \mathrm{p}$.

Shen, Yaoting, 1975, On the occurence of the primitive ammonite fauna from Nandan County, Guangxi and its significance: Professional Paper of Stratigraphy and Paleontology, no. 1, p. 86-104 (in Chinese).

Simpson, G.G., 1927a, Mesozoic Mammalia, 6, Genera of Morrison Pantotheres: American Journal of Science, Ser. 5, v. 13, p. 409-416. 1927b, Tathiodon, new genus to replace Tanaodon Simpson non Kirk: American Journal of Science, Ser. 5, v. 14, p. 71.

Smith, D.G., 1983, On the so-called mantle muscle scars on shells of the Margaritiferidae (Mollusca, Pelecypoda), with observations on mantleshell attachment in the Unionoida and Trigonioida: Zoologica Scripta, v. 12 , p. $67-71$.

Soot-Ryen, Helen, 1966, The Middle Ordovician of the Oslo Region Norway, 21, A new pelecypod of the genus Palaeosolen Hall, 1885: Norsk Geologisk Tidsskrift, v. 46, pt. 1, p. 21-26.

Soot-Ryen, Tron, 1955, A report on the family Mytilidae (Pelecypoda): Allan Hancock Pacific Expeditions, v. 20, no. 1, 174 p.

Stoliczka, Ferdinand, 1870-1871, Cretaceous fauna of southern India, the Pelecypoda, with a review of all known genera of this class, fossil and Recent: Geological Survey of India, Palaeontologia Indica, Memoirs, v. 3, ser. 6, 537 p. 
Stoyanow, Alexander, 1948, Molluscan faunule from Devonian Island Mesa Beds, Arizona: Journal of Paleontology, v. 22, p. 783-791.

Talent, J.A., 1963, The Devonian of the Mitchell and Wentworth Rivers: Geological Survey of Victoria Memoir 24, 118 p.

Termier, H., and Termier, G., 1977, Genus Gigantocyclus, in Termier, H., Termier, G., and Vachard, D., Monographie paleontologiques des affleurements Permiens du Djebel Tebaga (Sud Tunisien): Palaeontographica Abt. A., Bd. 156, 109 p.

Trueman, E.R., 1969, Ligament, in Moore, R.C., ed., Treatise on Invertebrate Paleontology, pt. N, Mollusca 6, v. 1, Bivalvia: New York and Lawrence, Kans., Geological Society of America and University of Kansas Press, p. N58-N64.

Ulrich, E.O., 1894, The Lower Silurian Lamellibranchiata of Minnesota: From volume 3 of the Final Report, Minnesota Geological and Natural History Survey, p. 475-628. (Published under separate cover before the entire volume 3 was published.)

Vanuxem, Lardner, 1842, Survey of the Third Geological District: Natural History of New York, Geology of New York, Part 3, $307 \mathrm{p}$.

Verneuil, P.E.P. de, 1847, Note sur le parallélisme des roches dépots paleozoiques del'Amérique septentrionale avec ceus de l'Europe, suivie d'un tableau des espéces fossiles communes aux deux continents, avec l'indication des éstages ou elles se rencontrent, et terminée par un examen critique de chacune de ces espéces: Société Géologique de France Bulletin, 2d ser., v. 4, p. 646-710.

Verneuil, P.E.P. de, and Murchison, R.I., 1844, Note sur les équivalents du systéme permien en Europe, suivie d'un coup d'oeil general sur l'ensemble de ses fossiles, et d'un tableau des espéces: Société Géologique de France Bulletin, 2d ser., v. 1, p. 475-517.

Waller, T.R., 1978, Morphology, morphoclines, and a new classification of the Pteriomorphia (Mollusca: Bivalvia): Royal Society of London, Philosophical Transcations, Series B, v. 284, p. 345-365.

Walmsley, V.G., 1962, The identity and a new description of Pteronitella retroflexa (Wahlenberg) from the Upper Silurian of Gotland and the Welsh Borders: Sartryck ur Geologiska Foreningens Forhandlinger, Bd. 84, p. 351-362.

Wang Chengyuan, and Wang Zhihao, 1978, Early and Middle Devonian conodonts of Guangxi and Yunnan: Professional Paper for the Symposium on the Devonian System of South China, 1974: Beijing, Geological Press, p. 334-345 (in Chinese).

Wang Hongzhen, 1982, The main features of the tectonic development of China: Printed by the Advanced Study School for Geologists, Ministry of the Metallurgical Industry, p. 1-39. (This is an internal report, in Chinese.)

Wang Hongzhen, and Liu Benpei, 1980, A course in Stratigraphy: Beijing, Geological Press, p. 1-352 (in Chinese).

Wang Xiaofeng, 1977, Discovery of the Late Silurian and Early Devonian monograptids from Qinzhou, Gunagxi and their significance: Acta Geologica Sinica 1977, p. 190-205 (in Chinese, English abstract).

Wang Yigang, 1974, The Devonian System in the Qomolongma Peak Region: A report of the scientific expedition in the Qomolonga Peak Region (1966-1968), Geological fascicle 1: Beijing, Science Press, p. 48-52 (in Chinese).

Wang Yu, 1956, Some new brachiopods from the Yukiang Formation of southern Kwangsi Province: Acta Palaeontologica Sinica, v. 4, p. 190-206.

Wang Yu, Boucot, A.J., Rong Jia-Yu, and Yang Xue-Chang, 1984, Silurian and Devonian biogeography of China: Geological Society of America Bulletin, v. 95, p. 265-279.

Wang Yu, and Yu Changmin, 1962, Devonian System of China: Beijing, Science Press, 140 p. (in Chinese).

Wang Yu, Yu Changmin, and Wu Qi, 1974, Advances in Devonian biostratigraphy of South China: Nanjing Institute of Geology and Paleontology, Memoirs 6, Academia Sinica, p. 1-44 (in Chinese).

Warthin, A.S., Jr., and Cooper, G.A., 1943, Traverse Rocks of Thunder Bay Region, Michigan: American Association of Petroleum Geolo gists Bulletin, v. 27, p. 571-595.

Weddige, Karsten, 1977, Die Conodonten der Eifel-Stufe im Typusgebiet und in benachbarten Feziesgebieten: Senckenbergiana Leathea, Band 58, p. 271-419.

Wei Renyan, 1982, The Devonian section at Luofu, Nandan, Guangxi, in The Devonian System of Liujing and Luofu, Guangxi: Guangxi Institute of Geology, 1982, p. 76-123. (In Chinese; this is an internal report.)

Whiteaves, J.F., 1884, Palaeozoic Fossils, v. 3, pt. 1: Geological and Natural History Survey of Canada, Montreal, p. 1-43.

Williams, H.S., 1908, On the revision of the mollusk genus Pterinea, Goldfuss: U.S. National Museum Proceedings, v. 34, p. 83-90.

1912, Some new Mollusca from the Silurian formations of Washington County, Maine: U.S. National Museum Proceedings, v. 42 , p. $381-398$.

Williams, H.S., and Breger, C.L., 1916, The fauna of the Chapman Sandstone of Maine: U.S. Geological Survey Professional Paper 89, $347 \mathrm{p}$.

Winchell, A.M., 1866, The Grand Traverse Region, a report on the geological and industrial resources of the counties of Antrim, Grand Traverse, Benzie, and Leelanlaw in the lower peninsula of Michigan: Ann Arbor, Dr. Chase's Steam Printing House. 97 p. (includes appendix, p. 83-97).

Writing Group on Fossil Lamellibranchiata of China, Nanjing Institute of Geology and Paleontology, Academia Sinica, 1976: Beijing, Science Press, 522 p. (Some sections, which include new taxa, can be attributed to authors; see Liu, 1976.)

Wu Hongji, 1977, Comments on new genera and species of SilurianDevonian trilobites in Southwest China and their significance: Acta Palaeontologica Sinica, v. 16, p. 95-117 (in Chinese, English abstract).

Wu Yi, and Kuang Guoden, 1979, The distribution laws of Early and Middle Devonian rocks and fossils of Guangxi and adjacent areas: Second All China Stratigraphic Congress, Beijing, 16 p. (in Chinese).

Xia Shufang, 1978, On the Lower Boundary of the Devonian of South Jiangsu Province: Professional Paper for the Symposium on the Devonian System of South China, 1974: Beijing, Geological Press, p. 189-192 (in Chinese).

Xia Zhongshi and others, 1978, A short guide to the Devonian System of Sichaun Province: Professional Paper for the Symposium on the Devonian System of South China, 1974: Beijing, Geological Press, p. 93-103 (in Chinese).

Xiang Liwen, and Wei Renyan, 1978, On the marine Nandan type Devonian System (ammonite-trilobite facies) of South China: Professional Paper for the Symposium on the Devonian System of South China, 1974: Beijing, Geological Press, p. 231-239 (in Chinese).

Xu Hankui, 1977, Early Middle Devonian Plicanoplis from Nandan in Guangxi: Acta Palaeontologica Sinica, v. 16, no. 1, p. 59-70.

1979. Brachiopods from the Tangxiang Formation (Devonian) in the Nandan of Guangxi: Acta Palaeontologica Sinica, v. 19, no. 4 , p. $362-381$.

Yang Shihpu, P'an Kiang, and Hou Hongfei, 1979, The Devonian System of China: Acta Geologica Sinica, 1979, p. 192-202.

1981, The Devonian System in China: Geological Magazine, v. 118 , p. $113-138$

Yang Zunyi (Tsun-Yi), 1939, The molluses of the Traverse Group (Middle Devonian) of Michigan-Pelecypoda: A dissertation presented to the faculty of the Graduate School of Yale University in Candidacy for the Degree of Doctor of Philosophy, p. 1-102; unpublished. 
Yi Yongen, and Xiang Liwen, 1975, Some middle Devonian trilobites from Nandan County, Guangxi: Professional Papers of Stratigraphy and Paleontology, no. 1, p. 105-110 (in Chinese).

Yin Hongfu, and Gan Xiuming, 1978, Lamellibranchiata, in Palaeontological Atlas of Southwest China, Guizhou volume: Beijing, Geological Publishing House, p. 337-393 (in Chinese).

Yonge, C.M., 1968, Form and habit in species of Malleus (including the "hammer oysters"), with comparative observations on Isognomon isognomon: Biological Bulletins, v. 135, p. 378-405.

Yu Changmin, and Kuang Guodun, 1980, Rugose corals from the Devonian Ertang Formation of Central Guangxi: Acta Palaeontologica Sinica v. 19, p. 175-180 (in Chinese, English abstract).

Yu Changmin, and Yin Baoan, 1978, The Ertang Formation, a new unit of Devonian stratigraphy in central Guangxi: Journal of Stratigraphy, v. 2, p. 23-31 (in Chinese).

Yue Senxun, and Bai Shunliang, 1978, The Devonian stratigraphy of Dale, Xiangzhou County, Guangxi: Professioanl Paper for the Symposium on the Devonian System of South China, 1974: Beijing, Geological Press, p. 43-62 (in Chinese).
Yun Ya, 1978, The subdivision and correlation of Devonian System of East Yunnan Province: Professional Paper for the Symposium on the Devonian System of South China, 1974: Beijing, Geological Press, p. 151-166 (in Chinese).

Zhang Renjie, 1977, Bivalves, in Zhang Renjie, Zhou Zuren, and Wang Deyou, Paleontological Atlas of Central South China, pt. 2: Beijing, Geological Press, p. 471-533 (in Chinese).

1980, Bivalves from the Middle Carboniferous, Dongfang County, Hainan Island, Guangdong Province: Geological Review, v. 26 , p. $281-286$ (in Chinese).

Zhao Ruxuan, Zhang Caifan, Xia Zhifen, Zho Zibi, and Liu Zuhan, 1978, Devonian System of Hunan Province: Professional Paper for the Symposium on Devonian System of South China, 1974; Beijing, Geological Press, p. 68-89 (in Chinese).

Ziegler, A.M., Cocks, L.R.M., and Bambach, R.K., 1968, The composition and structure of Lower Silurian marine communities: Lethaia, v. 1, p. 1-27. 


\section{PLATES 1-66}

Contact photographs of the plates in this report are available, at cost, from the U.S. Geological Survey Library, Federal Center, Denver, CO 80225. 


\section{PLATE 1}

Figures 1-8. Ctenodonta? dubiiformisa Zhang, 1977 (p. 60)+

1-4. Internal mold. (1) Right-lateral view; (2) dorsal view showing teardropshaped depression (probable ligament area, arrow) posterior to beaks; (3) anterodorsal view showing deflection of commissure toward right valve (arrow) suggesting the presence of cardinal teeth; and (4) similar view to figure 3 but with beaks more tipped toward observer. (1-4, $\times 2.5$ ) Donggangling Formation (Givetian), Section 2. GXD-002, topotype.

5. Internal mold, right-lateral view of incomplete paratype $(\times 1.5)$. Horizon and locality the same as in figures 1-4 above. GXD-004.

6 , 7. Internal mold, left-lateral view, and dorsal view showing teardropshaped depression (probable ligament area, arrow) posterior to beaks $(\times 2.5)$. Horizon and locality the same as in figures $1-4$ above. GXD-003, topotype.

8. Internal mold, left-lateral view of topotype $(\times 2)$. Horizon and locality as in figures 1-4 above. GXD-001 (=USNM 374546).

9-13. Leiodysodonta elliptica (Zhang), 1977 (p. 70)+

9. Composite mold, left-lateral view showing some of the posterior teeth (X 2.5). Lianhuashan Formation (Gedinnian), Section 1, Bed 7 . GXD-109 (=USNM 374557).

10. Composite mold, left-lateral view $(\times 2)$. Horizon and locality the same as in figure 9 above. GXD-138.

11, 12. Composite mold, left-lateral view of holotype showing anterior adductor muscle scar, buttress, and some of the posterior teeth $(\times 2)$, and enlargement of anterior end showing remnants of anterior teeth, adductor muscle scar and buttress $(\times 4)$. Nagaoling Formation (Gedinnian), Qinjia Village, Daxin County, Guangxi. GM-IV55030.

13. Composite mold, dorsal view showing valve equality $(\times 2.5)$. Lianshuashan Formation (Gedinnian), Section 1, Bed 5. GXD-102. 
GEOLOGICAL SURVEY
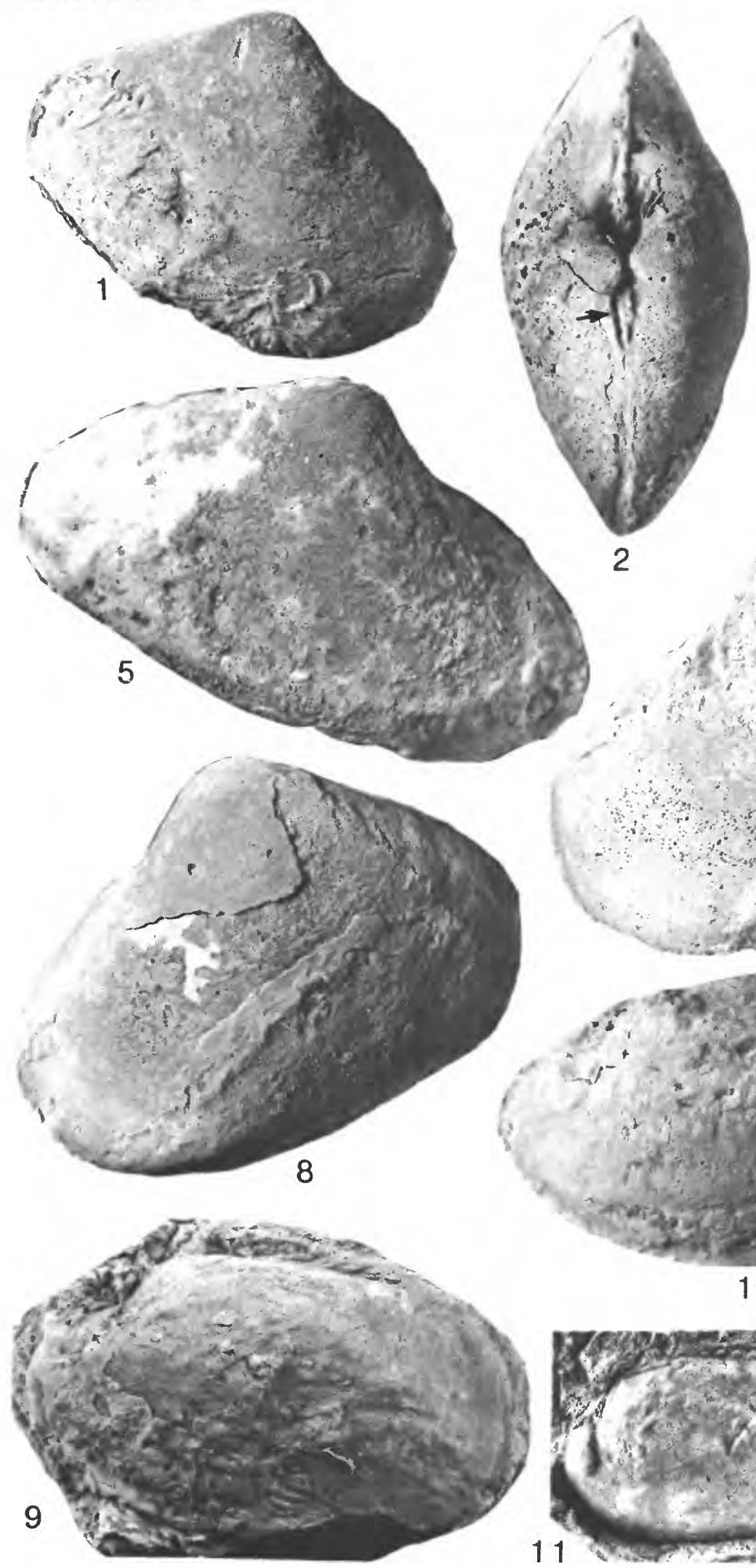

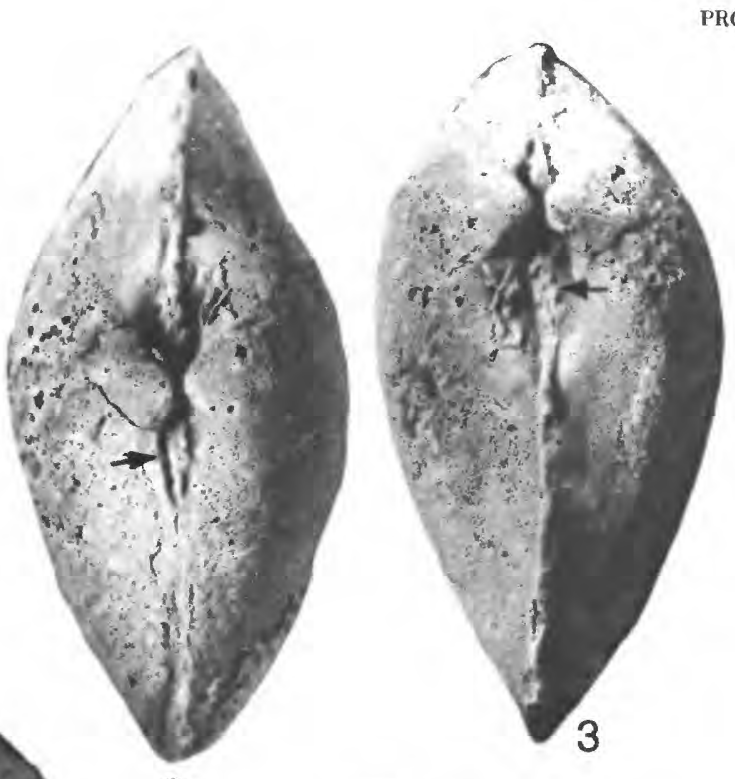

PROFESSIONAL PAPER 1394 PLATE I

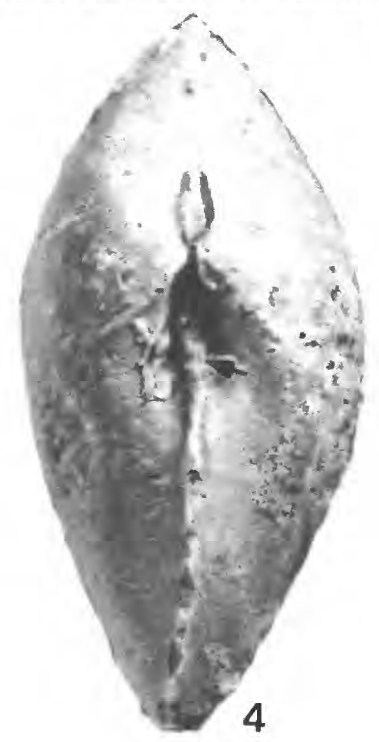

CTENODONTA?, AND LEIODYSODONTA 


\section{PLATE 2}

1, 2. Internal mold, right-lateral view showing remnants of the adductor muscle scars, and dorsal view showing valve equality $(\times 5)$. Ertang Formation (Emsian), Section 3, Bed 11. GXD-033, holotype.

3. Internal mold, left-lateral view showing remnant of posterior adductor muscle scar (arrow) ( $\times 5$ ). Horizon and locality the same as in figures 1, 2 above. GXD-042 (=USNM 374570), paratype.

4. Internal mold, right-lateral view $(\times 5)$. Horizon and locality the same as in figures 1, 2 above. GXD-032, paratype.

5. Composite mold, left-lateral view showing remnants of the comarginal ornament and adductor muscle scars $(\times 5)$. Horizon and locality the same as in figures 1,2 above. GXD-031, paratype.

6. Nuculopsis? sp. A (p. 62)+

Composite mold, right-lateral view showing ornament, dentition, and probable resilifer (arrow) $(\times 6)$. Yingtang Formation (Eifelian), Section 5, Bed 16. GXD-041.

7-9. Nuculopsis gibbosa Yang n. sp. (p. 62)*

7. Silicified replica, interior view of right valve showing tooth rows $(X$ 5). Potter Farm Formation, Alpena County, Mich. USNM 374548 , paratype.

8 , 9. Silicified replica, left-lateral and dorsal views $(\times 5)$. Horizon and locality the same as in figure 7 above. YPM 16426, holotype.

10-13. Nuculoidea minuta n. sp. (p. 61) +

10. Composite mold, left-lateral view; distorted anterior umbonal slope causes an apparent accentuation of height $(\times 10)$. Sipai Formation (Emsian), Section 3, Bed 13. GXD-012, paratype.

11. Composite mold, right-lateral view showing little, if any, apparent distortion $(\times 10)$. Horizon and locality the same as in figure 10 above. GXD-024, holotype.

12. Composite mold, left-lateral view, specimen distorted so that length is accentuated $(\times 10)$. Horizon and locality the same as in figure 10 above. GXD-016, paratype.

13. Composite mold, left-lateral view $(\times 10)$. Horizon and locality the same as in figure 10 above. GXD-026, paratype. 
GEOLOGICAL SURVEY

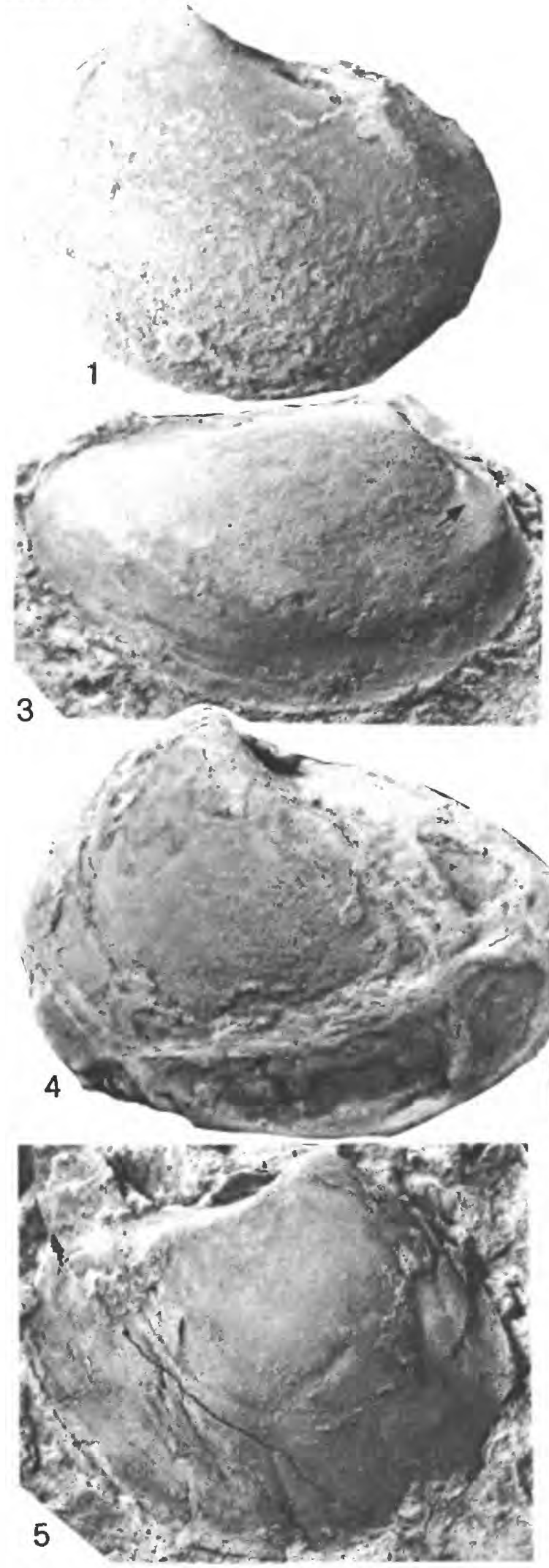

PROFESSIONAL PAPER 1394 PLATE
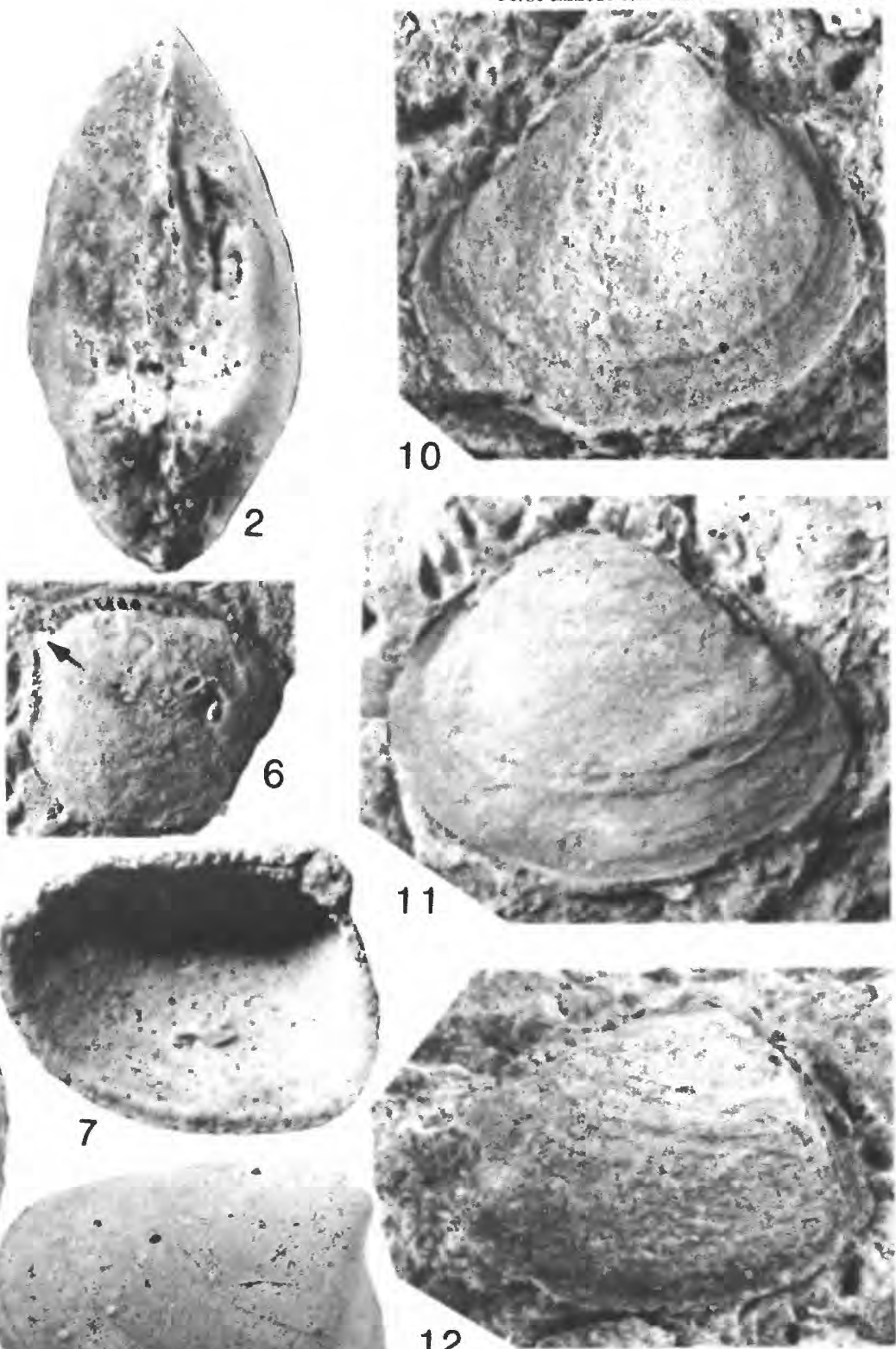

12
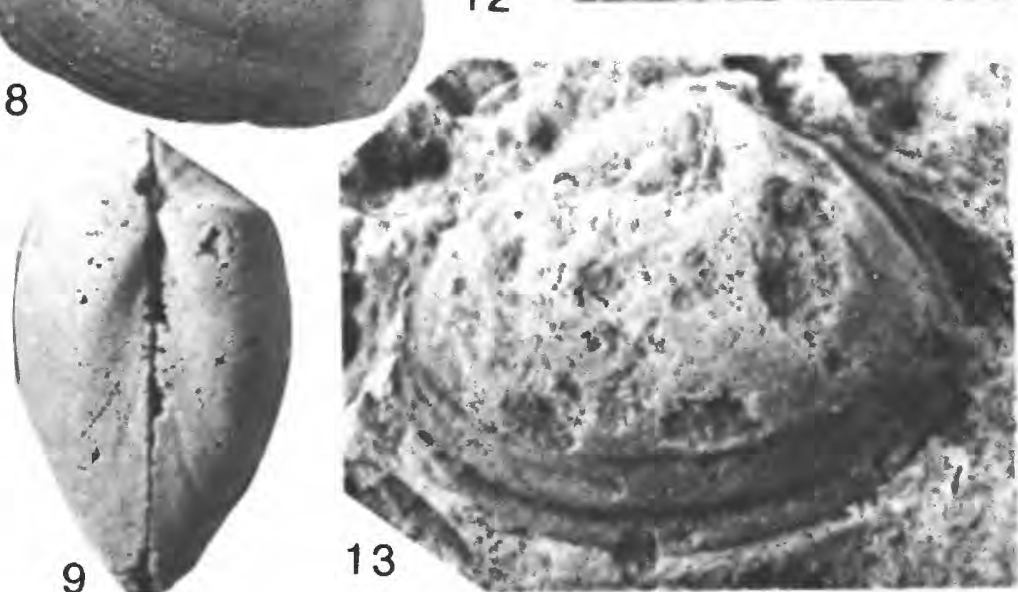


\section{PLATE 3}

1. Nuculoidea cf. $N$. lirata (Conrad), 1842 (p. 61)*

Composite mold, left-lateral view $(\times 4)$. Norway Point Formation (Givetian), Alpena County, Mich. USNM 374549.

2-4. Nuculoidea lirata (Conrad), 1842 (p. 61)*

2. Composite mold, right-lateral view $(\times 4)$. Hamilton Group (Middle Devonian), Moravia, N.Y. USNM 14069.

3. Composite mold, right-lateral view showing fine radial ornament and comarginal ornament approaching that of $N$. opima $(\times 4)$. Tully Formation (Givetian), 1 mile northeast of Laurens, N.Y. USNM 90354.

4. Composite mold, right-lateral view $(\times 4)$. Hamilton Group (Middle Devonian), Moravia, N.Y. USNM 374550.

5, 6. Nuculopsis? corbuliformis (Hall and Whitfield), 1869 (p. 62)*

Left-lateral and dorsal views of internal mold with adhering fragments of pyritized shell ( $\times 8$ ). Compare with Nuculopsis gibbosa (pl. 2, figs. 7-9). Hamilton Group (Middle Devonian), Wende Station, Erie County, N.Y. USNM 33566.

7. Nuculopsis sp. (p. 62)*

Internal view of right valve showing dentition and small resilifer (arrow) ( $X$ 3). Compare with Nuculopsis? corbuliformis (figs. 5, 6 above) and N. gibbosa (pl. 2, figs. 7-9). Graford Formation (Upper Pennsylvanian), Martins Lake, 1.5 miles southwest of Bridgeport, Tex. USNM 374551.

8, 9. Similoconcha? sp. A (p. 63)+

Internal mold, lateral view showing possible filling of resilifer (arrow), and oblique dorsal view showing possible filling of resilifer and ventral trace of a few taxodont teeth (arrow) ( $\times$ 4). Sipai Formation (Emsian), Section 3, Bed 13. GXD-039.

10. Nuculana sp. (p. 64)*

Interior of left valve showing teeth, resilifer separating tooth rows, and posterodorsal internal rib (arrow) $(\times 3)$. Holocene, about 3 miles east of Freytogilulet, Hebron Fjord, Labrador, at 100 fathoms. USNMDM 605169. 
GEOLOGICAL SURVEY
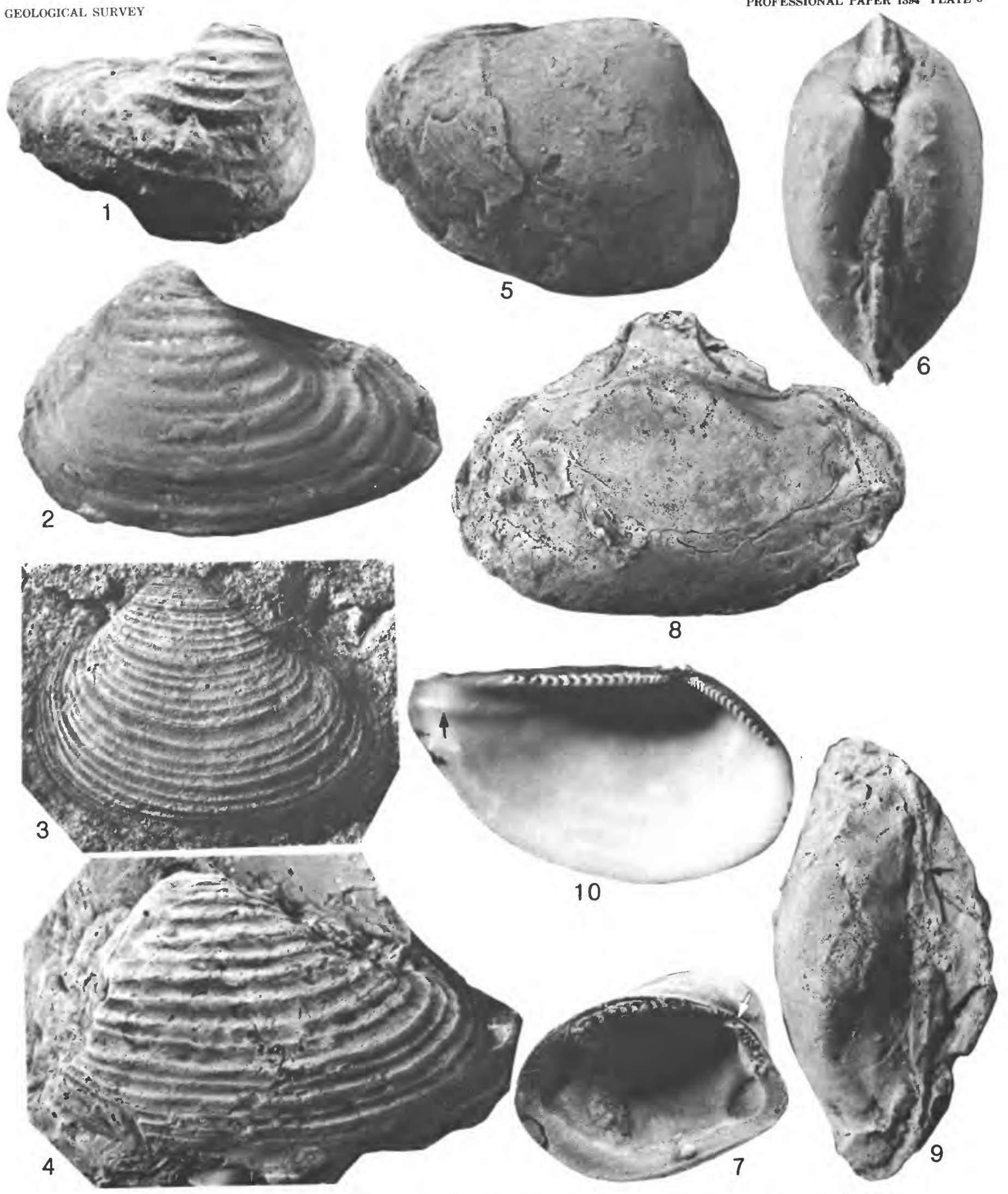

PROFESSIONAL PAPER 1394 PLATE 3 


\section{PLATE 4}

Figures 1-6. Phestioidea obtusa n. sp. (p. 63)+

1-3. Internal mold. (1) Right-lateral view showing remnant of posterior adductor muscle scar (black arrow) and filling of resilifer (white arrow) ( $\times 3$ ); (2) left-lateral view showing remnants of adductor muscle scars, small length of anterior pallial line, and filling of resilifer ( $\times 3$ ); (3) and dorsal view showing filling of resilifer (oblique arrow), posterior adductor muscle scars, and elongate posterior pedal retractor muscle scars (horizontal arrow) extending forward from posterior adductor muscle scars $(\times 4)$. Liujing Member, Yujiang Formation (Pragian-lower Zlichovian), Section 1, Bed 29. GXD-068, paratype.

4-6. Internal mold. (4) Right-lateral view showing adductor muscle scars, filling of resilifer, and anterior portion of pallial line (arrow); (5) leftlateral view showing adductor muscle scars, filling of resilifer, and posterior portion of pallial line, which is integripalliate (arrow); and (6) dorsal view showing ventral trace of taxodont teeth (arrow), adductor muscle scars, and elongate posterior pedal retractor muscle scars extending forward from posterior adductor muscle scars (all $\times 3$ ). Horizon and locality the same as in figures 1-3 above. GXD-070, holotype.

7. Pseudonuculana zhaoi n. sp. (p. 64)+

Dorsal view of internal mold showing posterior adductor muscle scars and on right side two small accessory muscle scars (arrows) anterior to the posterior adductor scar; on the left side only the anterior of the accessory muscle scars is preserved $(\times 4)$. The right-lateral view of this specimen is shown on plate 5, figure 8. Liujing Member, Yujiang Formation (Pragian-lower Zlichovian), Section 1, Bed 29. GXD-079, paratype.

8. Yoldia limatula Say (p. 64)*

View of resilifer area of right valve showing tooth rows extending above resilifer $(\times 5)$. Holocene, specimen recovered from stomach of a coot, North Haven, Maine. USNMDM 455403. Compare with Phestia rostellata, plate 6 , figures 8,9 .

9, 10. Phestia spp. (p. 64)*

9. Silicified replica, interior view of right valve showing resilifer, anterior buttress, adductor muscle scars, tooth rows, opisthogyrate beak and prominent umbonal ridge $(\times 3)$. Road Canyon Formation (Leonardian, Lower Permian), Texas, Cooper and Grant (1972, p. 142), locality 703 c. USNM 374522 .

10. Internal view of left valve showing the same features as in figure 9 above $(\times 3)$. Graford Formation (Adams Branch Limestone, Upper Pennsylvanian), Signal Peak, 13 miles north on Palo Pinto Road, Palo Pinto County, Tex. USNM 374553. 


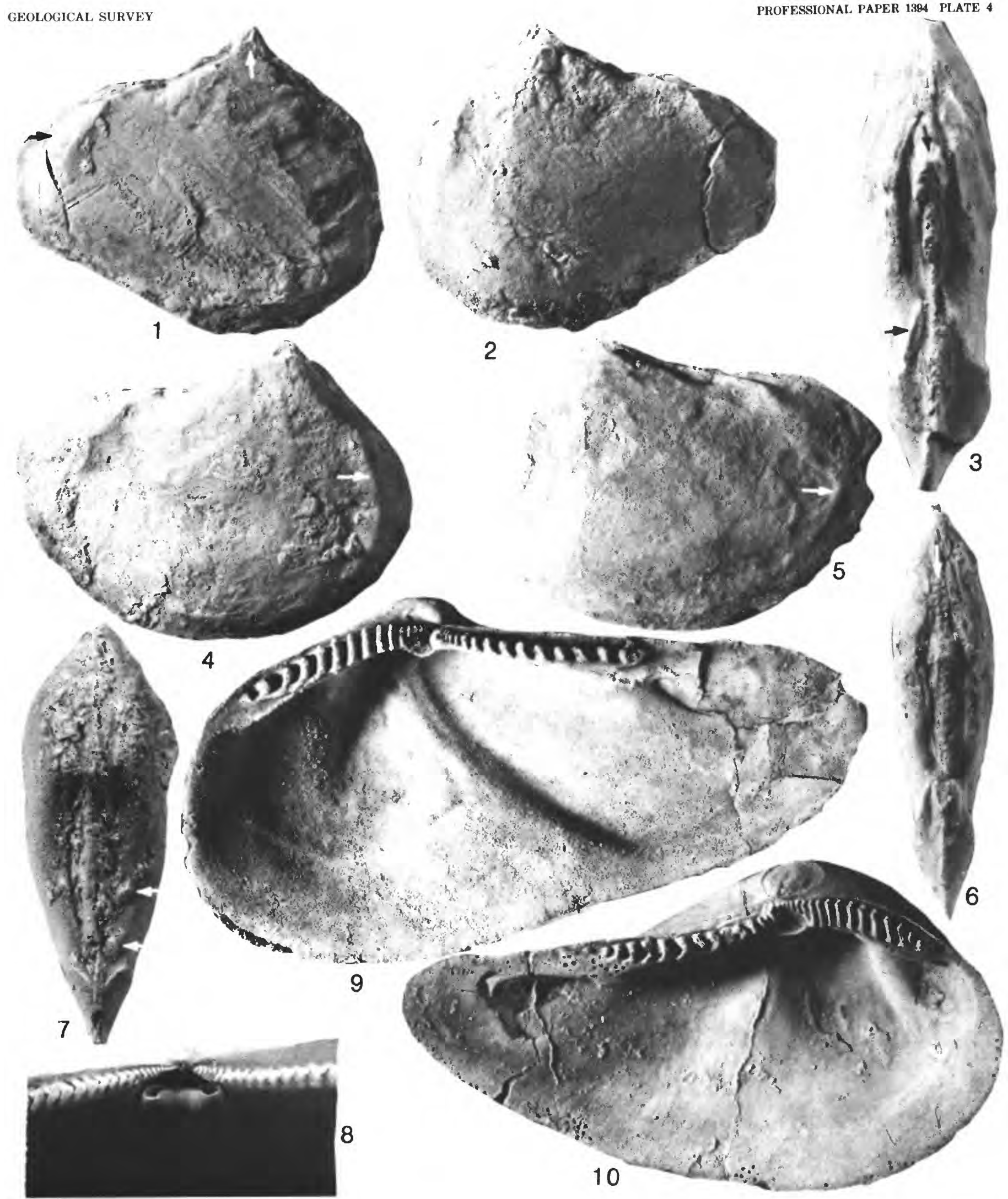

PHESTIOIDEA, PSEUDONUCULANA, YOLDIA, AND PHESTIA 


\section{PLATE 5}

Figures 1-10. Pseudonuculana zhaoi n. sp. (p. 64)+

1-3. Internal mold. (1) Left-lateral view showing resilifer filling and posterior adductor muscle scar (arrow) ( $\times 3$ ); (2) right-lateral view showing adductor muscle scars (vertical arrows), and filling of resilifer (horizontal arrow) $(\times 4)$; and (3) dorsal view, which anteriorly shows remnants of ventral trace of taxodont teeth, posterior adductor muscle scars, two scars anterior to posterior adductor scars (arrows), and filling of resilifer $(\times 4)$. Liujing Member, Yujiang Formation (Pragian-lower Zlichovian), Section 1, Bed 29. GXD-078, holotype.

4. Dorsal view of incomplete internal mold showing ventral trace of taxodont teeth and a single accessory muscle scar on right side (arrow) $(\times 4)$. Horizon and locality the same as in figures 1-3 above. GXD-083, paratype.

5. Composite mold of left valve showing remnants of dentition posteriorly (X 4). Upper Member, Yingtang Formation (Eifelian), Section 5 , Bed 16. GXD-085 (=USNM 374554), paratype.

6. Composite mold of left valve showing growth rugae and remnants of dentition (X 4). Horizon and locality the same as in figure 5 above. GXD-084, paratype.

7. Composite mold of left valve showing dorsal upturn of posterior end of shell $(\times 4)$. Horizon and locality the same as in figure 5 above. GXD-089, paratype.

8. Internal mold of right valve showing posterior adductor muscle scar $(\times 4)$; same specimen as shown in plate 4 , figure 7 .

9. Composite mold of right valve showing remnants of dentition $(\times 5)$. Horizon and locality the same as in figure 5 above. GXD-088, paratype.

10. Composite mold of right valve $(\times 4)$. Horizon and locality the same as in figure 5 above. GXD-088a, paratype. 
GEOLOGICAL SURVEY

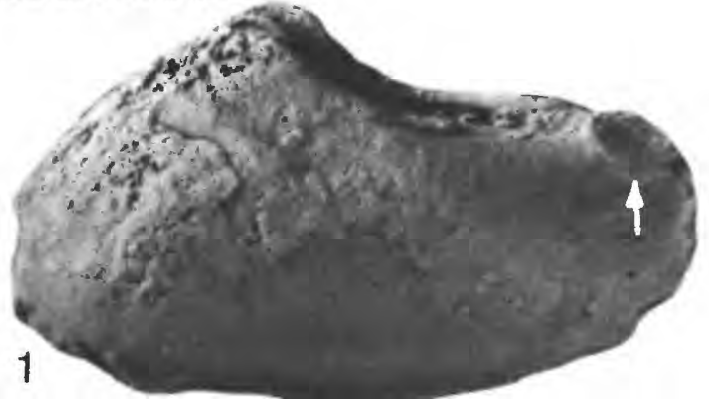

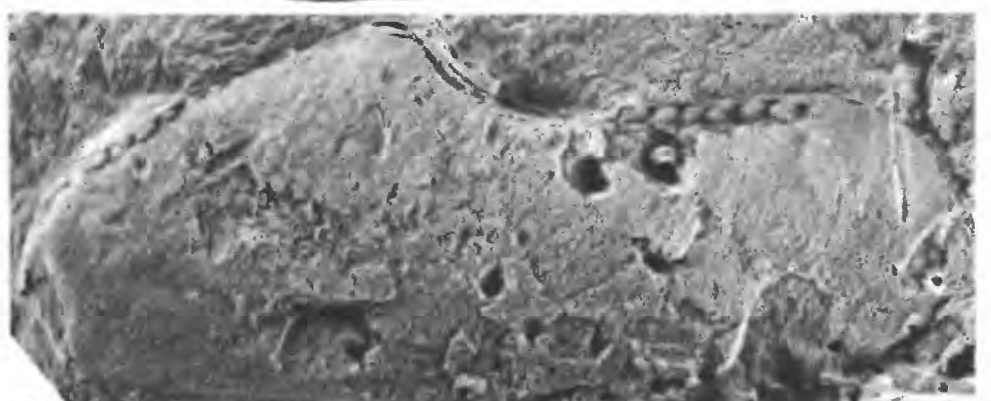

5

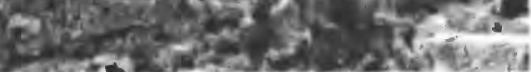
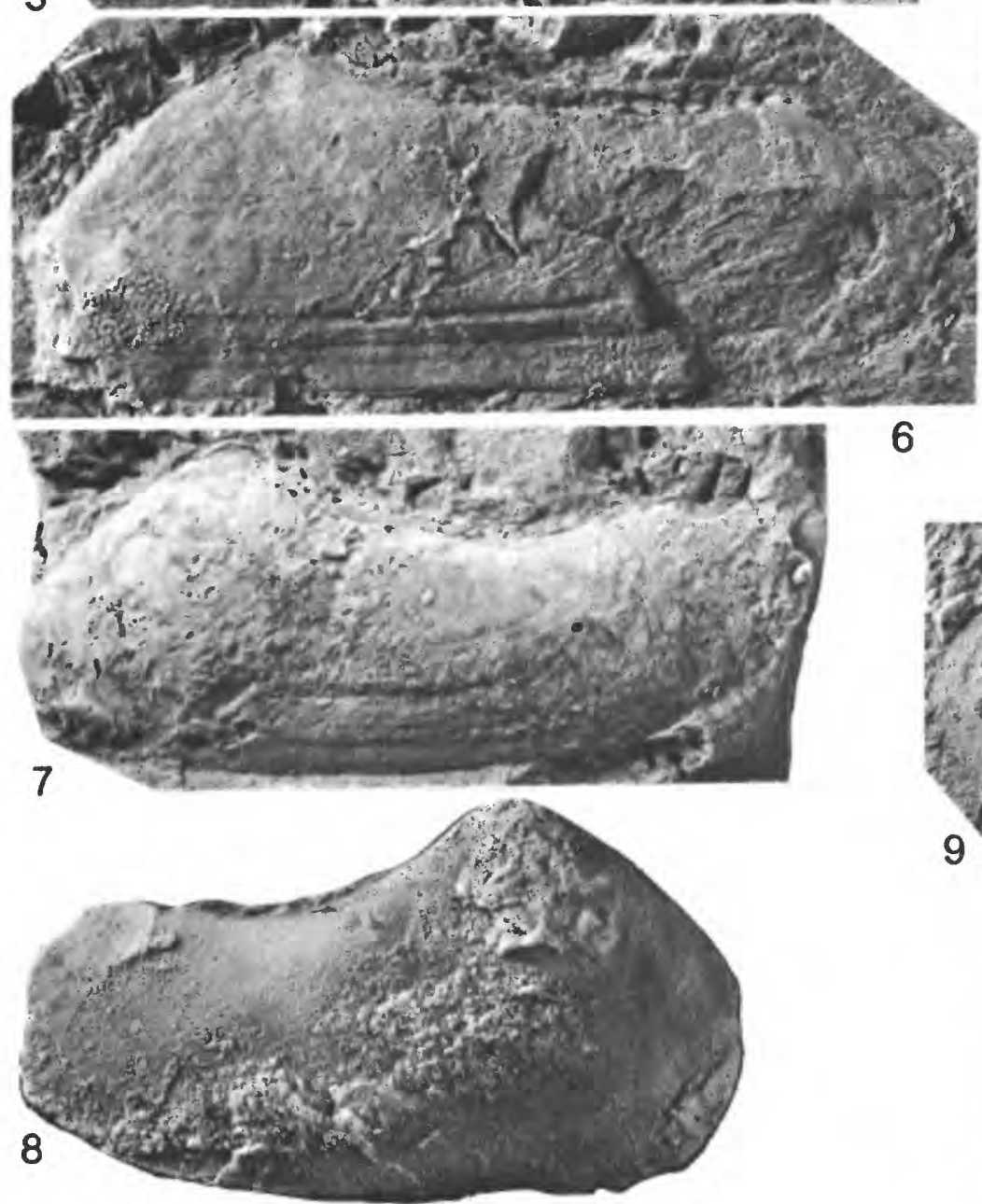

6
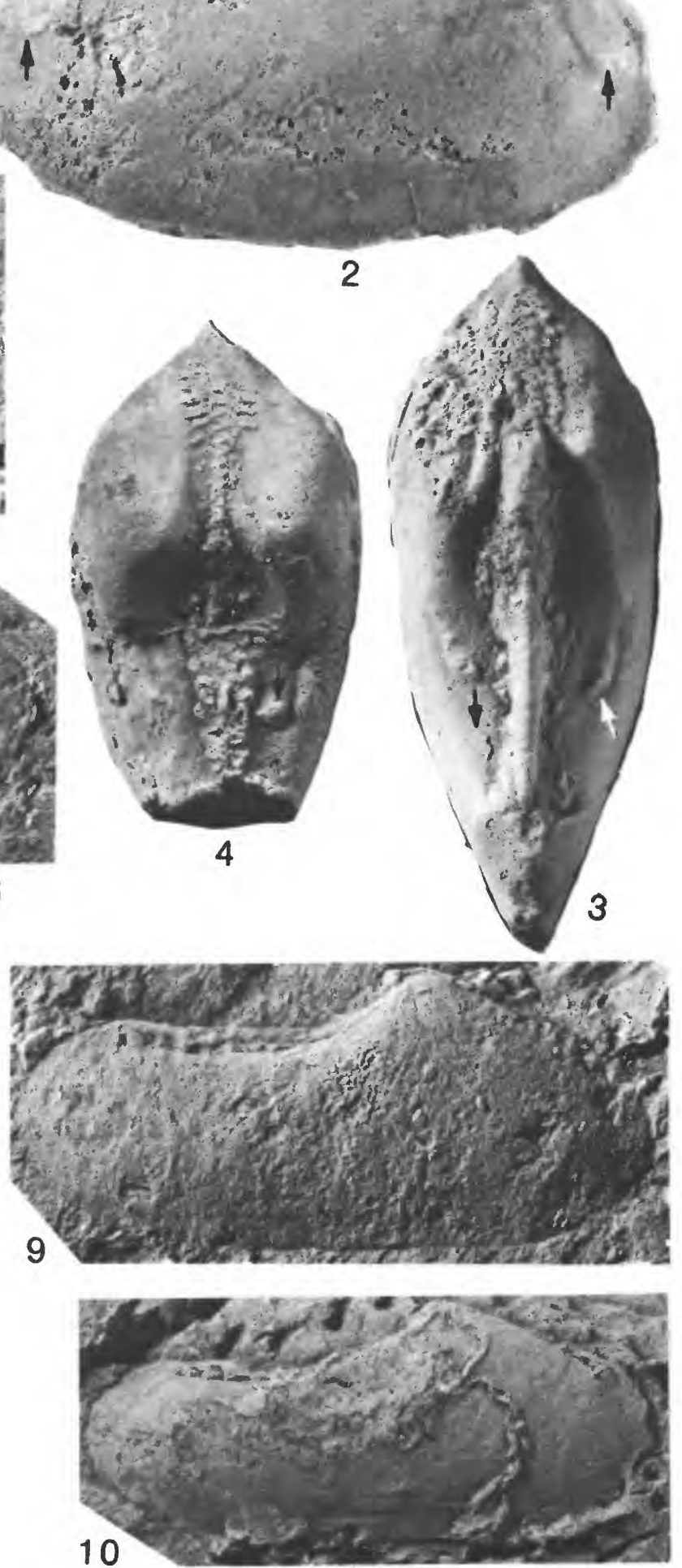


\section{PLATE 6}

Figures 1, 2. Phestia diversa (Hall), 1883, (p. 65)*

Right and left valve exteriors $(\times 10)$. Hamilton Group (Middle Devonian), Moravia, N.Y. USNM 14091, 374571.

3, 4. Phestia cf. P. brevirostris (Hall and Whitfield), 1869, (p. 65)*

Silicified replica, dorsal and right-lateral views $(\times 12)$. Potter Farm Formation, Alpena County, Mich. YPM 16430.

5. Nuculana? acutirostra n. sp. (p. 65)+

Composite mold of right valve showing remnants of dentition posteriorly and posterior adductor muscle scar (arrow) ( $\times 2.5$ ). Ertang Formation (Emsian), Section 3, Bed 10. GXD-072, holotype.

6-10. Phestia rostellata (Conrad), 1841 (p. 65)*

6, 7. Left and right valve exteriors $(\times 8)$. Hamilton Group (Middle Devonian), Moravia, N.Y. USNM 14090, 374572.

8 , 9. Internal mold right and left valves showing filling of resilifer (horizontal arrows), adductor muscle scars, some of pallial line, and umbonal muscle scars, the largest of which has a small ridge behind it (oblique arrow) $(8, \times 8 ; 9, \times 10)$. Compare teeth above resilifer with Yoldia limatula, plate 4, figure 8. Hamiltonian (Middle Devonian), Bartlells Mills, Ontario, Canada. USNM 26497.

10. Internal mold, left valve showing the same features as in figures 8 , 9 above and the lack of a pallial sinus (arrow) $(\times 10)$. Horizon and locality the same as in figures 8,9 above. USNM 374555 .

11. Phestia sp. A (p. 65)*

Incomplete internal mold of right valve showing remnants of teeth and umbonal ridge (arrow) $(\times 8)$. Petoskey Formation, Petoskey, Mich. USNM 388221. 

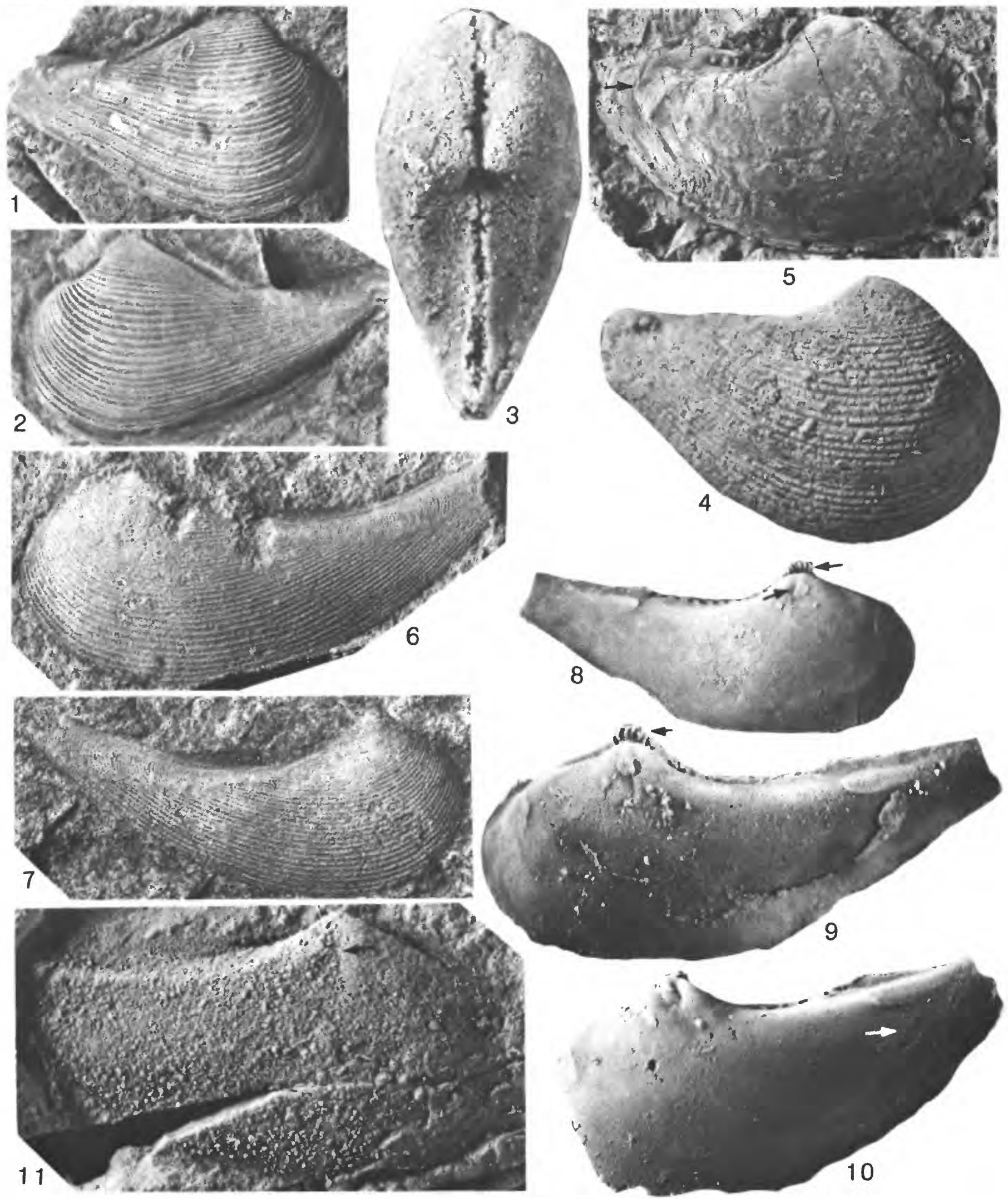

PHESTIA AND NUCULANA? 


\section{PLATE 7}

Figures 1-3. Nuculana? planumbona n. sp. (p. 65) +

1. Squashed internal mold of left valve showing anterior adductor muscle scar (oblique arrow) and posterodorsal internal rib (vertical arrow) $(\times 5)$. Upper Member, Yingtang Formation (Eifelian), Section 5, Bed 16. GXD-074, paratype.

2. Internal mold of right valve showing resilifer (arrow); eroded posterodorsally (X 5). Horizon and locality the same as in figure 1 above. GXD-074A, paratype.

3. Internal mold of right valve showing posterodorsal internal rib (arrow) $(\times 5)$. Horizon and locality the same as in figure 1 above. GXD-076, holotype.

4-6. Palaeoneilo emarginata (Conrad), 1841 (p. 67)*

4. Exterior of left valve $(\times 3)$. Jordan River Formation Norwood, Mich. YPM 16427.

5. Exterior of right valve $(\times 4)$. Potter Farm Formation, Alpena County, Mich. YPM 16429.

6. Exterior of right valve $(\times 3)$. Horizon and locality the same as in figure 4 above. YPM 16428.

7, 8. Nuculites sp. A (p. 66)+

Two poorly preserved right valves showing buttresses (horizontal arrows). The specimen shown in figure 7 has remnants of the posterior taxodont teeth (vertical arrow) $(\times 4, \times 3$ ). Nagaoling Formation (Gedinnian), Locality 7 . GXD-051, - 052 .

9. Phestia rostellata (Conrad), 1841 (p. 65)*

Dorsal view of specimen shown on plate 6 , figures 8 and 9 . Arrow points to filling of resilifer $(\times 10)$.

10. Palaeoneilo sp. A (p. 67)+

Left valve of composite mold ( $\times 2.5$ ). Ertang Formation (Emsian), Section 3, Bed 10. GXD-053.

11. Palaeoneilo sp. B (p. 67) +

Left valve of composite mold $(\times 2)$. Horizon and locality the same as in figure 10 above. GXD-062.

12. Nuculana? acutirostra n. sp. (p. 65)+

Composite mold of left valve $(\times 3)$. Horizon and locality the same as in figure 10 above. GXD-073, paratype.

13-15. Palaeoneilo sp. B (p. 67)+

13. Internal mold showing left valve with anterior adductor muscle scar ( $\times 2$ ). Donggangling (Givetian), Section 2 (Bed unknown). GXD-067.

14,15 . Internal mold, left valve and dorsal views. Dorsal view shows remnants of the ventral trace of the taxodont teeth (arrow) $(\times 2)$. Horizon and locality the same as in figure 13 above. GXD-065. 
GEOLOGICAL SURVEY
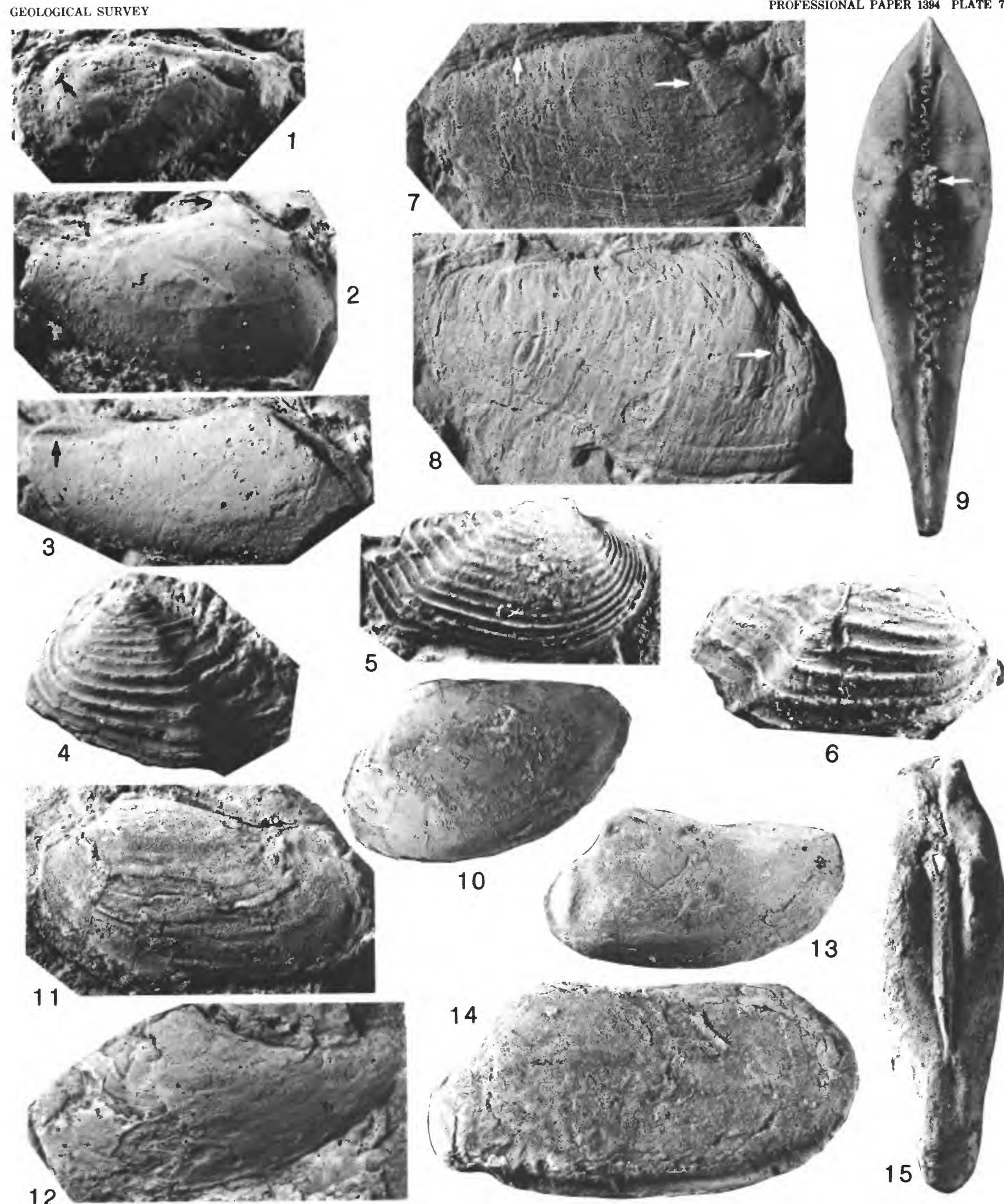

10
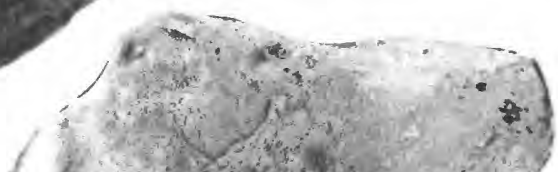

13

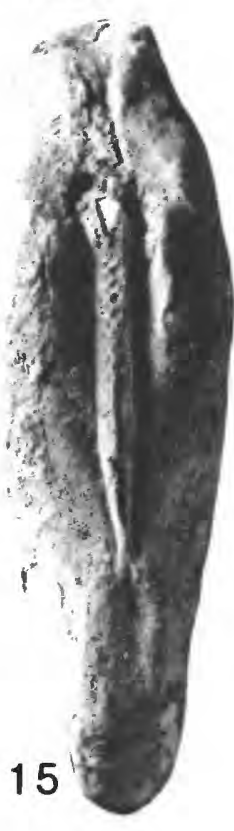

NUCULANA?, PALAEONEILO, NUCULITES, AND PHESTIA 


\section{PLATE 8}

Figures 1-4. Nuculites sp. B (p. 66)+

1. Right valve, internal mold, showing the buttress (arrow) and remnants of the posterior taxodont teeth $(\times 6)$. Ertang Formation (Emsian), Section 4, Bed 17. GXD-048.

2. Left valve, composite mold showing buttress and remnants of taxodont teeth $(X 5)$. Ertang Formation (Emsian), Section 2 (Bed unknown). GXD-521A.

3. Left and right valve composite molds $(\times 10)$. Ertang Formation (Emsian), Section 4, Bed 30. GXD-044.

4. Left valve composite mold $(\times 6)$. Ertang Formation (Emsian), Section 4 , Bed 11. GXD-064.

5-7. Nuculites oblongatus Conrad, 1841 (p. 66)*

5. Internal mold of left valve showing teeth, integripalliate pallial line (arrow) buttress, adductor muscle scars, pedal muscle scars, and at least eight pairs of accessory muscle scars $(\times 3)$. Hamiltonian (Middle Devonian), Cumberland, Md. AMNH 42072.

6. Internal mold of right valve showing most of the features seen in figure 5 above $(\times 5)$; highlight from right. Horizon and locality the same as in figure 5 above. AMNH 5288/10.

7. Composite mold of right valve $(\times 2)$. Horizon and locality the same as in figure 5 above. AMNH 5288/10A.

8. Nuculites triqueter Conrad, 1841 (p. 66)*

Left valve composite mold showing long and thin buttress (arrow) $(\times 4)$. Delphi

Station Member, Skaneateles Formation (lower Givetian), on U.S. Route 20,

1.25 miles east of Pompey Center, N.Y. USNM 374556. 
GEOLOGICAL SURVEY

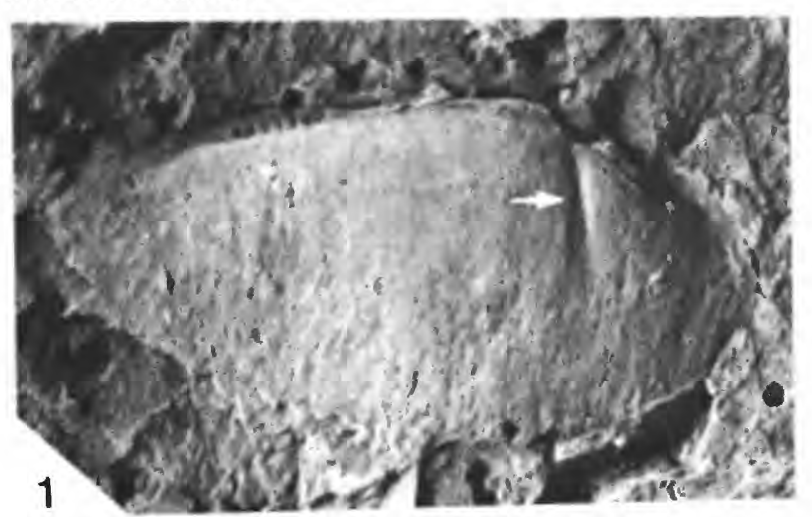

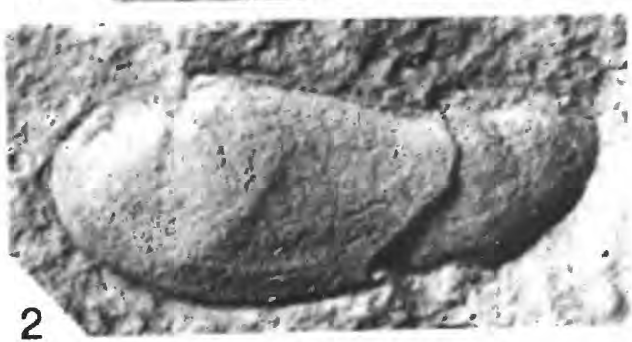

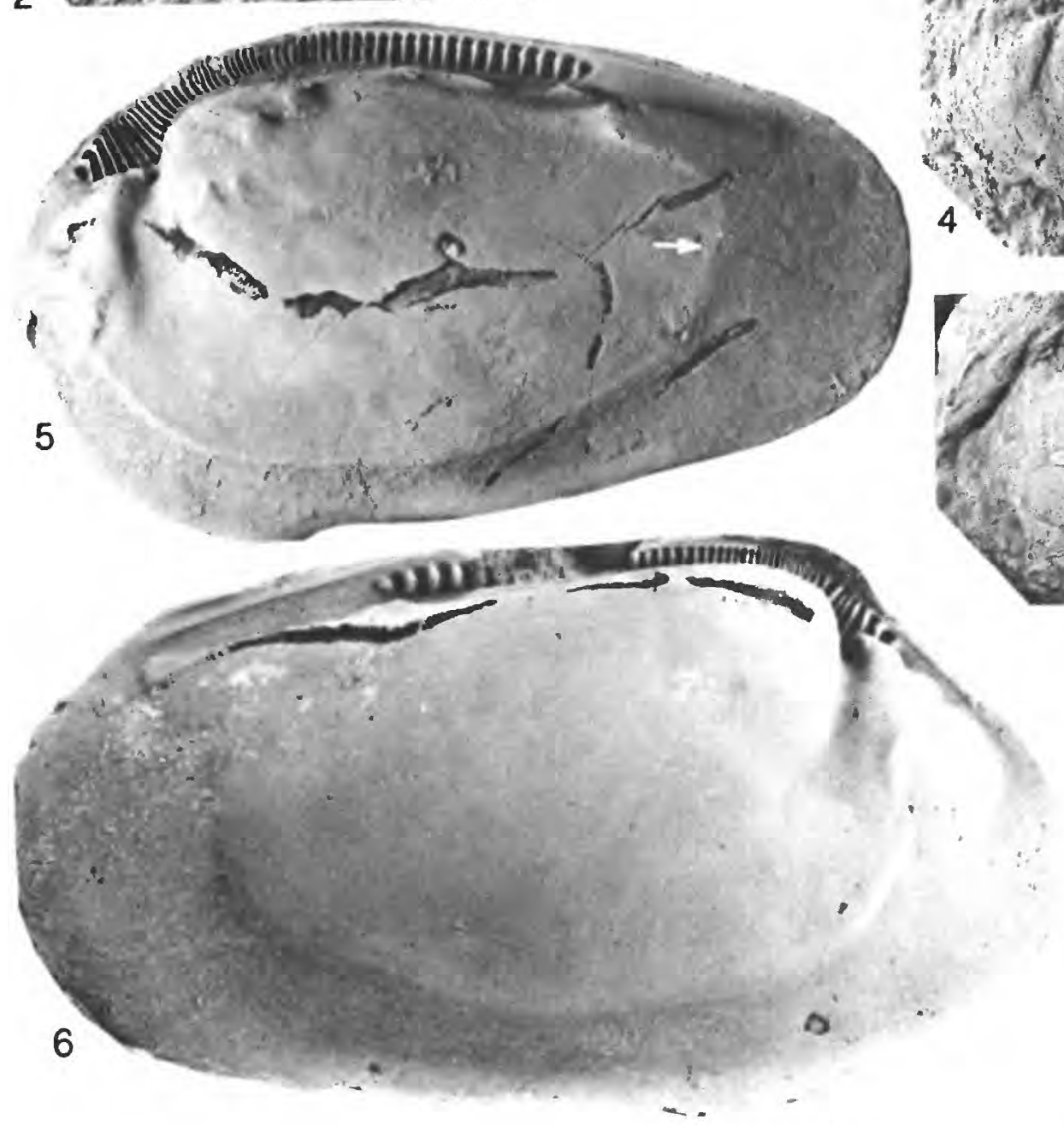

PROFESSIONAL PAPER 1394 PLATE 8

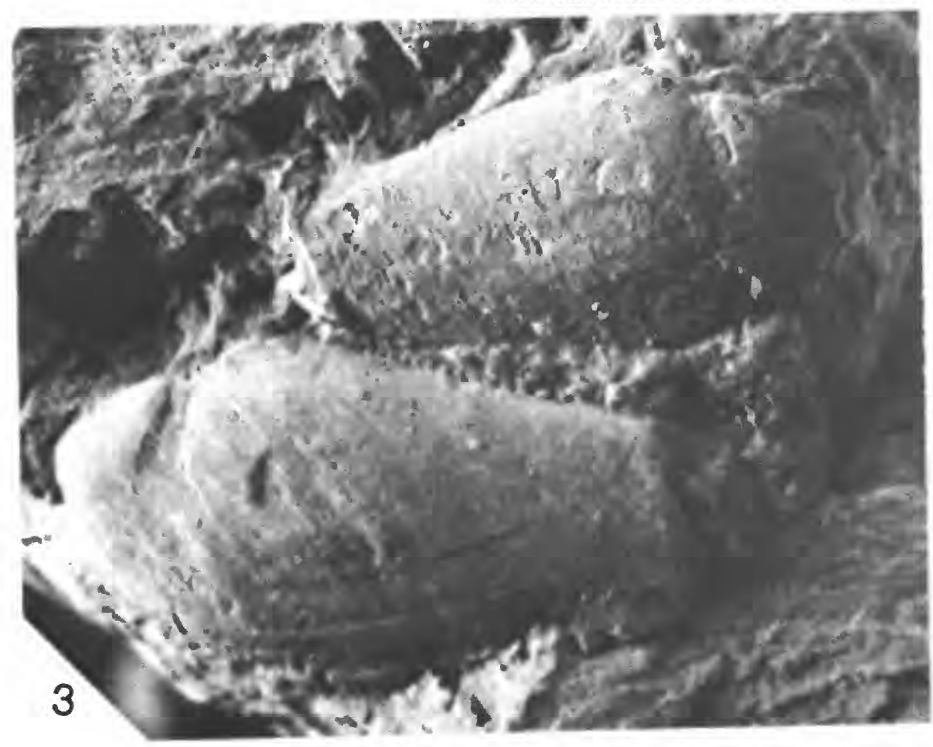

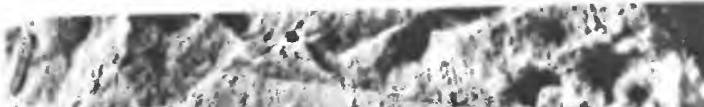

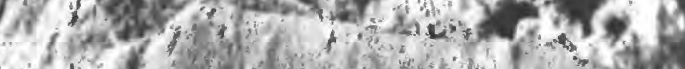

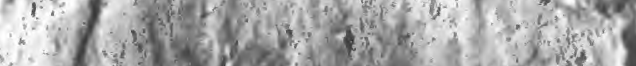

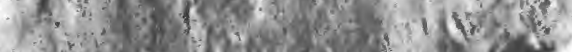

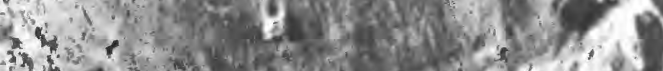
4 tylat

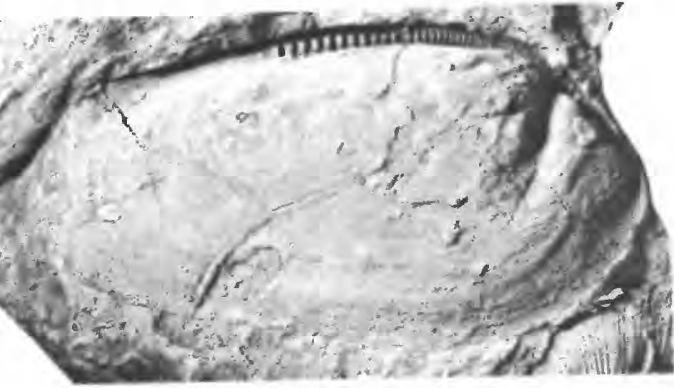
7

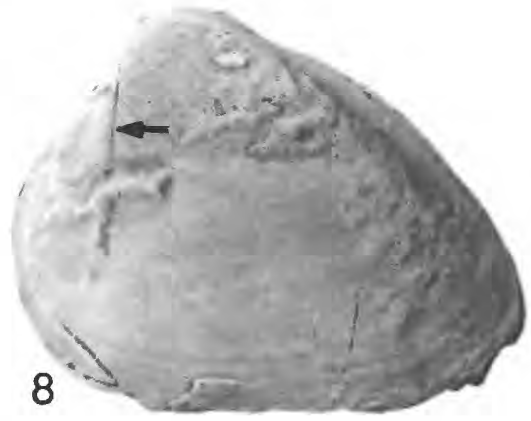




\section{PLATE 9}

1-4. Dysodonta angulata n. sp. (p. 69)+

Composite molds showing ornament. (1) Left valve (holotype, GXD-091), (2) right valve (paratype, GXD-095), (3) right valve (paratype, GXD-097 = USNM 374573), (4) left valve (paratype GXD-092). (1-3, $\times 5$; 4, × 36.) Hengxian Member, Lianhuashan Formation (Gedinnian), Section 1, Bed 5.

5. Musculus sp. (p. 69)

Hinge of right valve showing posterior teeth at an angle to hinge axis similar to those of antactinodiontids (arrow), and widely separated from anterior teeth by ligament $(\times 2)$. Holocene, Okhotsk Sea, east coast of Sakhalin, at 75 fathoms. USNMDM 204527.

6-11. Leiodysodonta levis (Guo), 1980 (p. 70)+

6. Right valve, composite mold showing poorly preserved posterior teeth (arrow) $(\times 3)$. Nagaoling Formation (Gedinnian), Section 1, Bed 10. GXD-124.

7, 8. Left valve compressed composite mold showing anterior adductor muscle scar, buttress, and remnants of anterior teeth(arrow) $(\times 4)$. Enlargement of anterodorsal part of specimen shown in figure 7 $(\times 8)$. Horizon and locality the same as in figure 6 above. GXD-140.

9, 10. Composite mold, left-lateral and dorsal views $(\times 5)$. Lianhuashan Formation (Gedinnian), Section 1, Bed 5. GXD-154.

11. Right-lateral view of composite mold $(\times 5)$. Horizon and locality the same as in figures 9 and 10 above. GXD-154a.

12. Crenella impacta Hermann (p. 69)

Interior of left valve showing posterior teeth at an angle to the hinge axis (arrow) similar to those of antactinodiontids. Anterior teeth widely separated from posterior teeth by ligament $(\times 3)$. Holocene, New Zealand. USNMDM 531493. 
GEOLOGICAL SURVEY

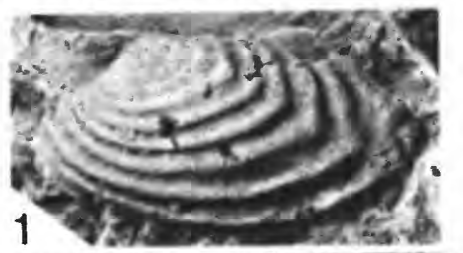

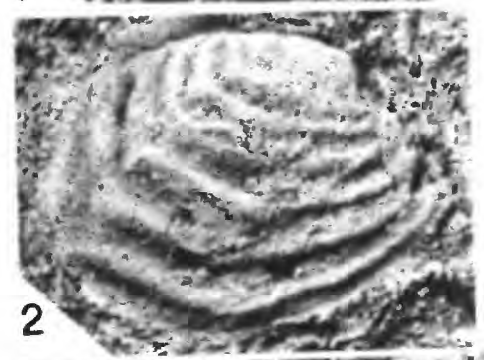

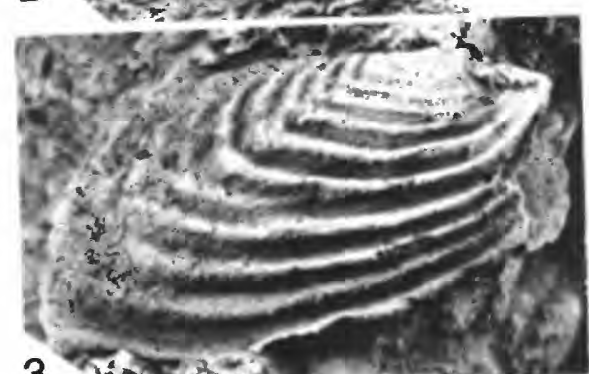

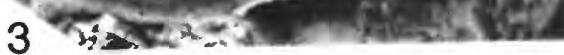
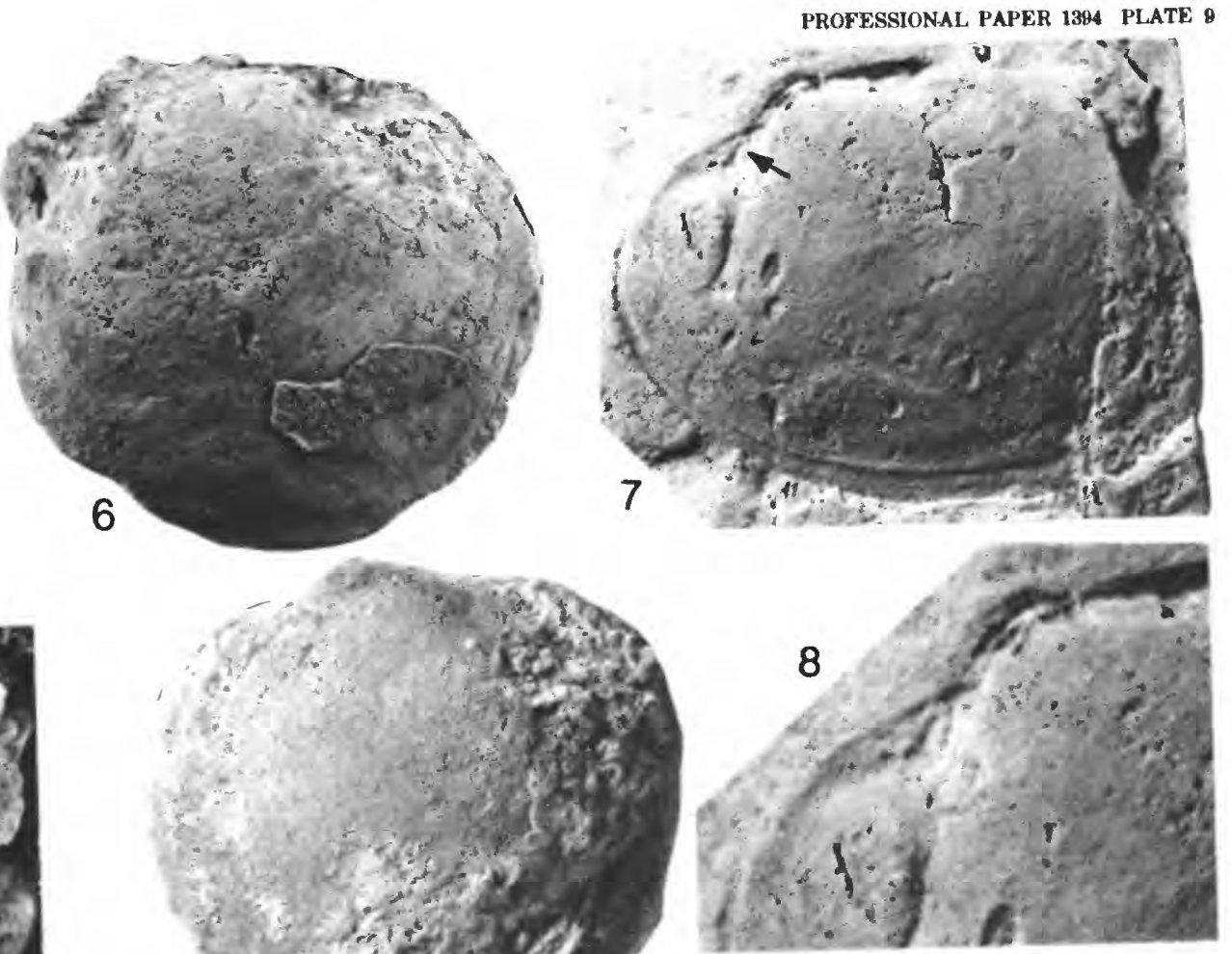

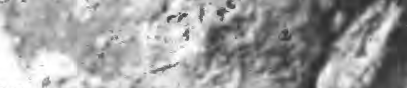

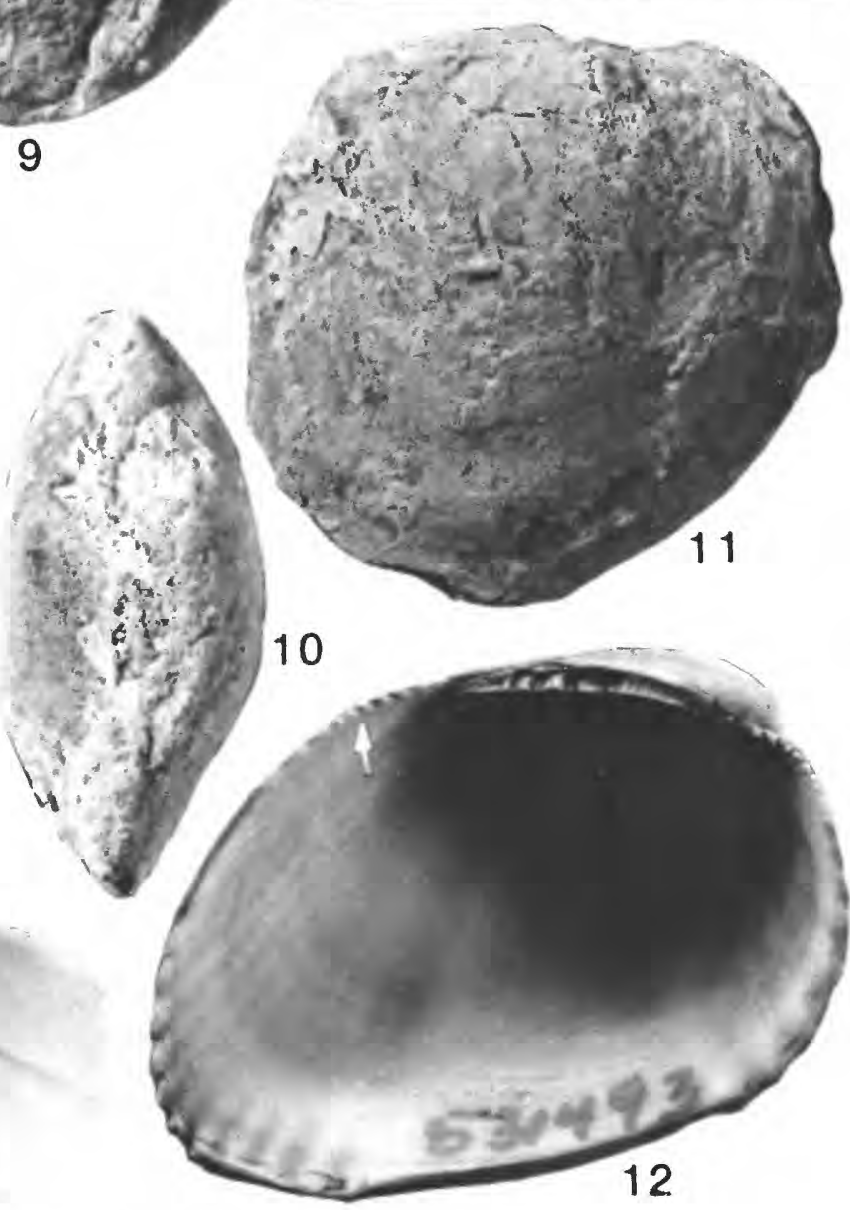

DYSODONTA, LEIODYSODONTA, MUSCULUS, AND CRENELLA 


\section{PLATE 10}

FigurES 1-3, 5, 6, 8-12. Leiodysodonta guangxiensis (Zhang), 1977 (p. 69)+

1. Composite mold of right valve showing remnants of posterior teeth, anterior adductor muscle scar (arrow) and anterior buttress $(\times 4)$. Yujiang Formation (Pragianlower Zlichovian), Minle Village, Beiliu County, GMIV55034 (holotype of Dysodonta beiluensis).

2. Composite mold of right valve $(\times 3)$. Lianhuashan Formation (Gedinnian), Section 1, Bed 5. GXD-130.

3. Distorted right valve has been compressed dorsoventrally ( $\times 3)$. Lianhuashan Formation (Gedinnian), Section 1, Bed 6, GXD-132.

$5,9,11$. (5) Right-lateral, (9) left-lateral, (11) and dorsal views of a composite mold showing teeth; distorted so that the umbos are unevenly acentuated. Left side view shows remnants of posterior teeth (arrow) $(\times 3)$. Horizon and locality the same as in figure 2 above. GXD-103.

6. Left-lateral view of composite mold showing posterior teeth $(\times 4)$. Horizon and locality the same as in figure 3 above. GXD-098.

8. Left-lateral view of composite mold showing remnants of adductor muscle scars (arrow) $(\times 2)$. Lianhuashan Formation (Gedinnian), Changtang Village, Yongning County, Guangxi. GM-IV55031, holotype.

10. Left-lateral view showing ornament; umbo flattened parallel to bedding $(\times 3.5)$. Horizon and locality the same as in figure 2 above. GXD-134 (=USNM 374557).

12. Right-lateral view showing ornament $(\times 3)$. Horizon and locality the same as in figure 3 above. GXD-133.

4. Eurymyella shaleri Williams, 1912 (p. 70).*

Right-lateral view of composite mold showing profile, for comparison with Leiodysodonta guangxiensis in figure 1 above $(\times 3)$. Eastport Formation (Gedinnian), Maine. USNM 58433.

7. Eurymyella denbowensis Williams, 1912 (p. 70).*

Left-lateral view of a partially shelled specimen showing profile, for comparison with Leiodysodonta guangxiensis in figure 10, anterior adductor muscle scar (arrow), and anterior pedal retractor muscles scar $(\times 2)$. Pembroke Formation (Upper Silurian), Washington County, Maine. USNM 58449. 
GEOLOGICAL SURVEY

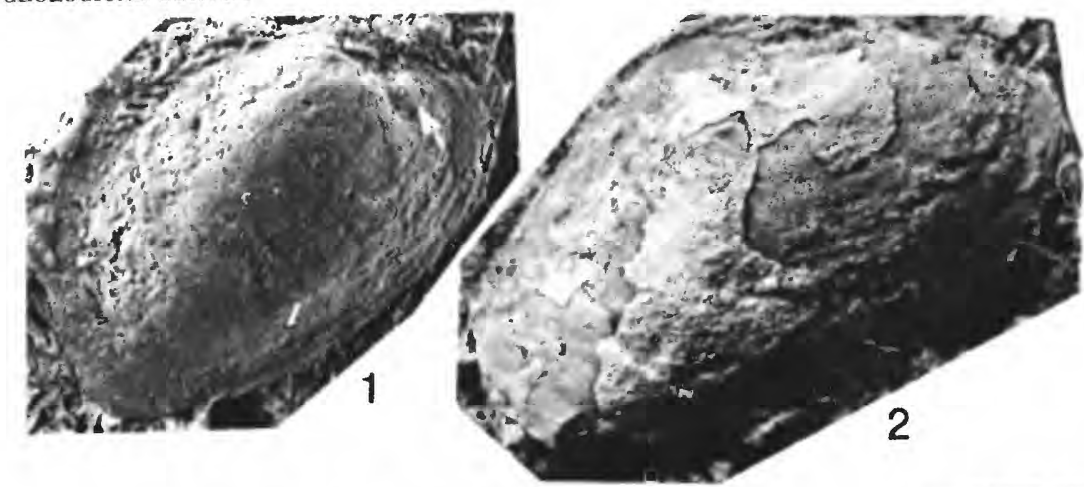

PROFESSIONAL PAPER 1394 PLATE 10
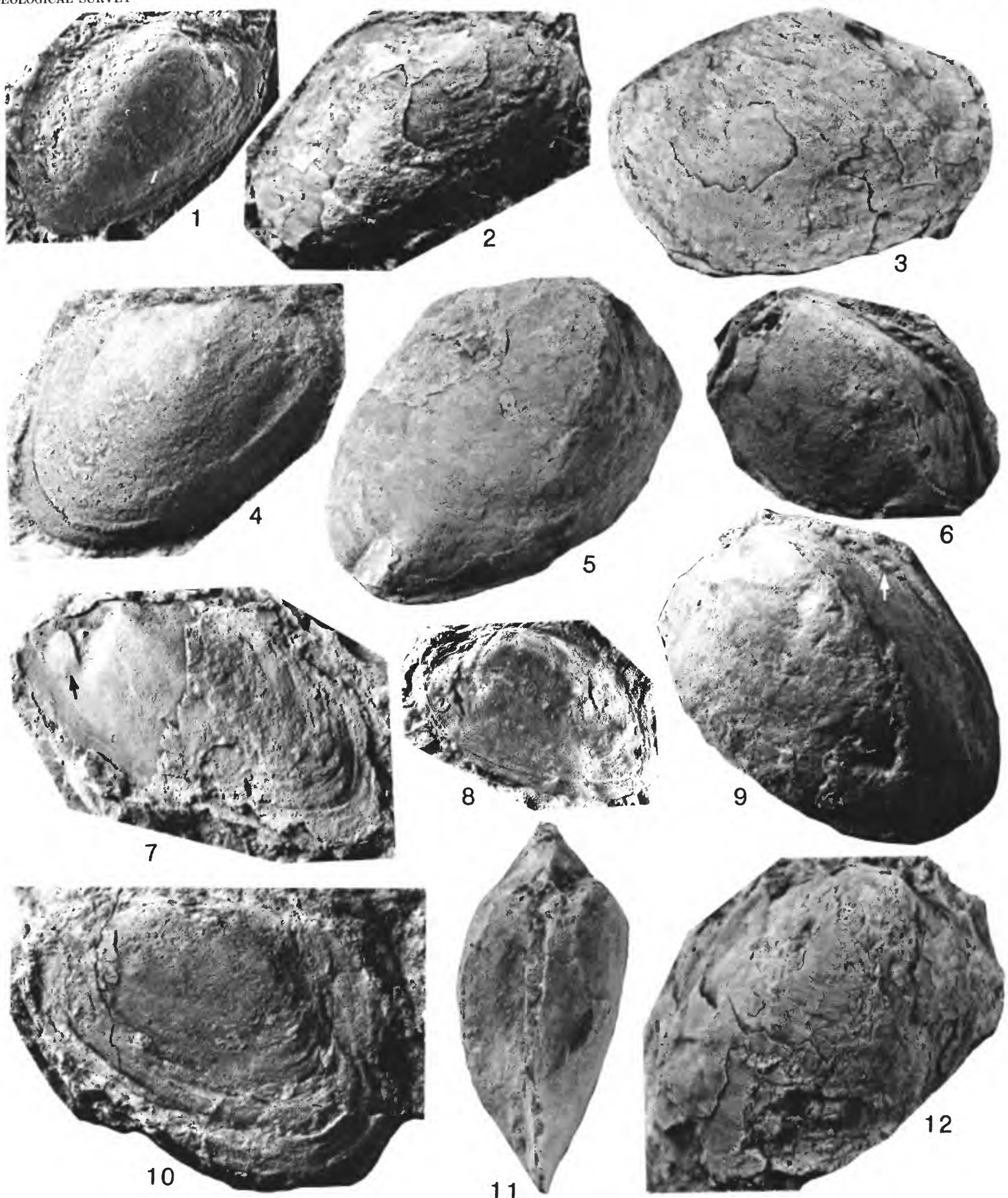

LEIODYSODONTA AND EURYMYELLA 


\section{PLATE 11}

Figures 1-6. Modiomorpha concentrica (Conrad), 1838 (p. 71)*

1-3. Right valve, internal mold. (1) Enlargement of anterior end showing cardinal socket (black arrow), mantle point attachment scars, and quick and catch portions of anterior adductor muscle scar (white arrows) ( $\times 3)$. (2) Latex replica showing hinge with cardinal socket (short arrow) and without lateral teeth, slight shell thickening posterior and ventral to hinge (long arrow), various muscle scars, and mantle point attachment scars $(\times 2)$. (3) Entire specimen showing the features seen in figure 2 above in negative relief $(\times 1.3)$. Lower Hamilton Group (Romney Formation), 4-5 miles east of Springfield, W. Va., just outside Points, W. Va., on Springfield-Points Road. USNM 374558.

4-6. Left valve internal mold showing the same features as in figures 1-3 above. (4) Entire specimen showing features in negative relief $(X$ 1.5). (5) Latex replica showing groove for attachment of lamellar layer of ligament (vertical arrow) and cardinal tooth (oblique arrow) ( $X$ 2). (6) Enlargement of anterior end, arrow marks anterior byssal-pedal retractor muscle scar $(\times 2)$. Horizon and locality the same as in figures 1-3 above. USNM 374559. 
GEOLOGICAL SURVEY

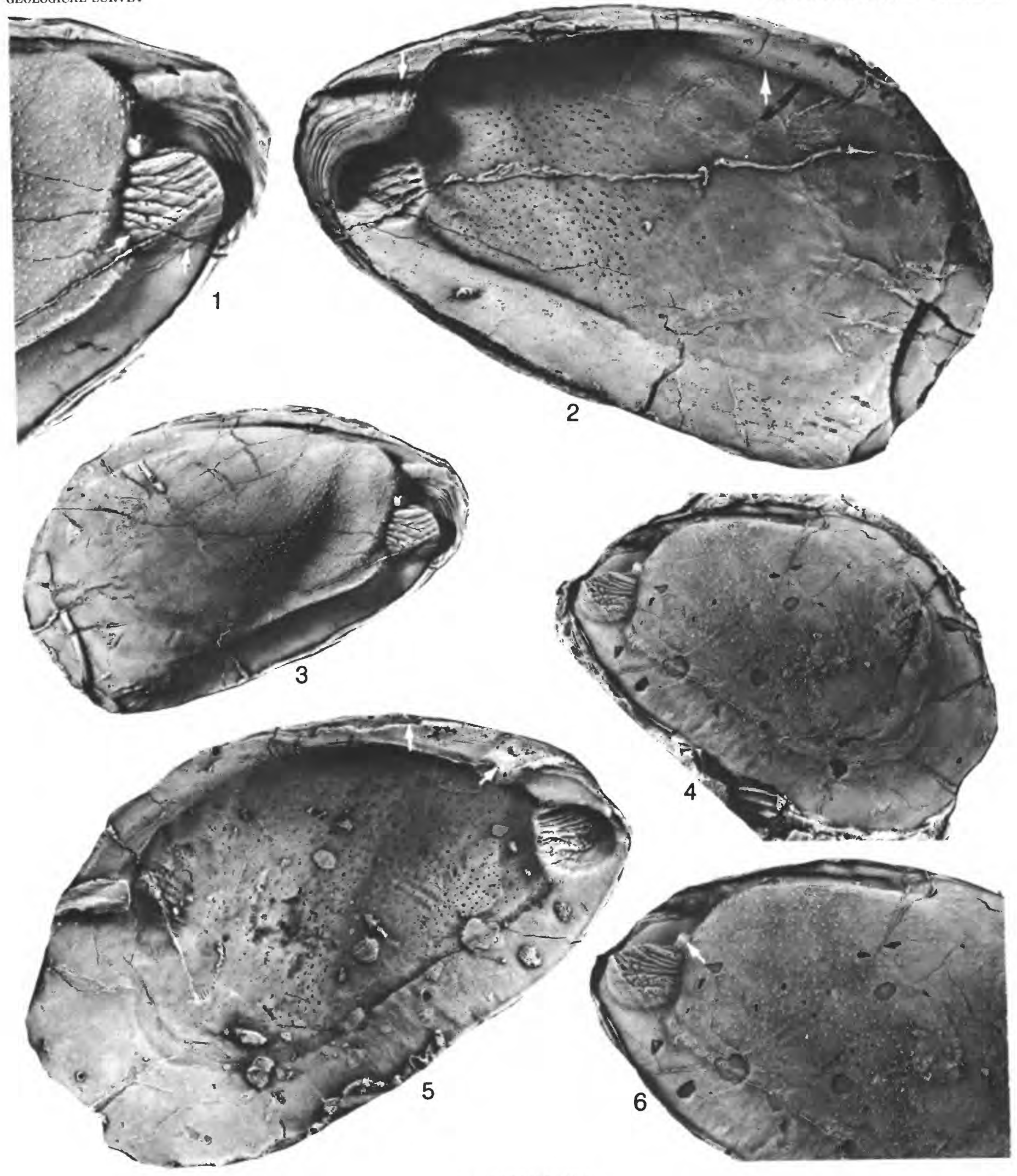

MODIOMORPHA 


\section{PLATE 12}

Figures 1-6. Modiomorpha concentrica (Conrad), 1838 (p. 71)*

1, 2. (1) Latex replica of right valve $(\times 2)$. (2) Anterior view of specimen showing cardinal socket quick and catch portions of anterior adductor muscle scar (arrows), mantle point attachment scars, and so forth (X 2.5). Horizon and locality the same as in figures 1-3, plate 11 . USNM 374560 .

3. Enlargement of anterior features of latex replica shown in figure 5, plate $11(\times 3)$.

4-6. Left valve, internal mold. (4) Specimen showing muscle scars, hinge, and mantle point attachment scars $(\times 2)$. (5) Latex replica showing hinge without lateral teeth and with groove for attachment of lamellar layer of ligament (arrow) ( $\times 3$ ). (6) Enlargement of anterior end showing quick and catch portions of anterior adductor muscle scar and two anterior byssal-pedal retractor muscle scars (arrows) (X 3 ). Horizon and locality the same as in figures 1-3, plate 11 . USNM 374561.

7. Mytilus californianus Conrad (p. 71)*

View of hinge and anterior interior part of shell, right valve, showing resilial ridge (arrow) below fibrous layer of ligament, lamellar layer of ligament above fibrous layer, and mantle point attachment scars $(\times 2)$. Holocene, California. USNM 374562. 


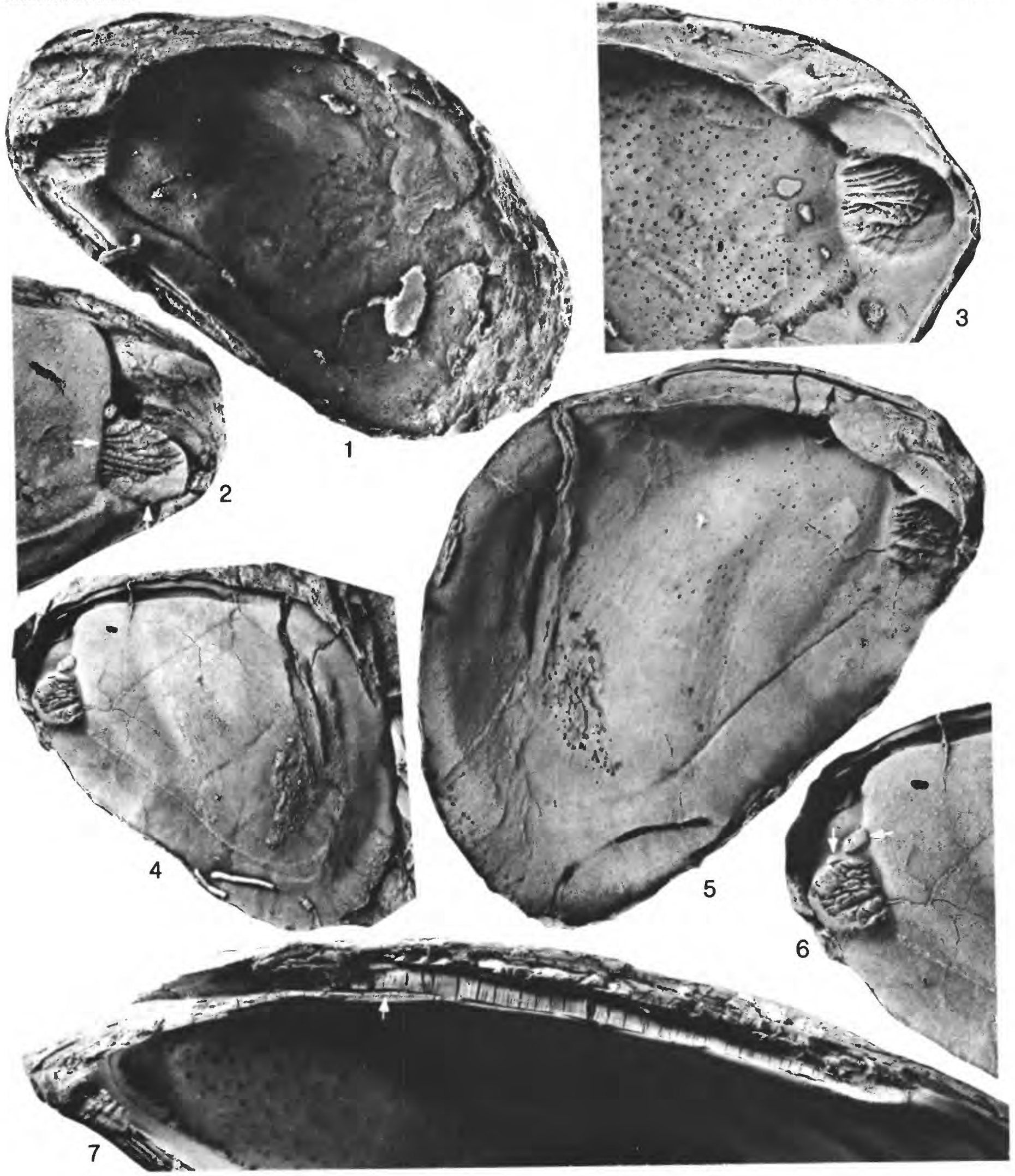

MODIOMORPHA AND MYTILUS 


\section{PLATE 13}

Figures 1-7. Modiomorpha paradoxa (Zhang), 1977 (p. 72)+

1. Left-lateral view of composite mold $(\times 2)$. Ertang Formation (Emsian), Section 2 (bed unknown). GXD-527 (=USNM 374563), topotype.

2. Left-lateral view of composite mold with shallow byssal sinus $(\times 3)$. Ertang Formation (Emsian), Section 3, Bed 10. GXD-539.

3. Left-lateral view of composite mold, distorted to the point where the byssal sinus is obliterated $(\times 2)$. Donggangling Formation (Givetian), Section 3, Bed 23. GXD-536.

4. Left-lateral view of composite mold, flattened parallel to bedding $(\times 2)$. Ertang Formation (Emsian), Section 4, Bed 33. GXD-522 (=USNM 374564).

5. Right-lateral view of composite mold, crushed parallel to bedding ( $X$ 2). Horizon and locality the same as in figure 3 above. GXD-530.

6. Dorsal view of spread valves of composite mold $(\times 2)$. Horizon and locality the same as in figure 1 above. GXD-521, topotype.

7. Left-lateral view of a composite mold, distorted so as to accentuate byssal sinus $(\times 3)$. Horizon and locality the same as in figure 4 above. GXD-524. 
GEOLOGICAL SURVEY
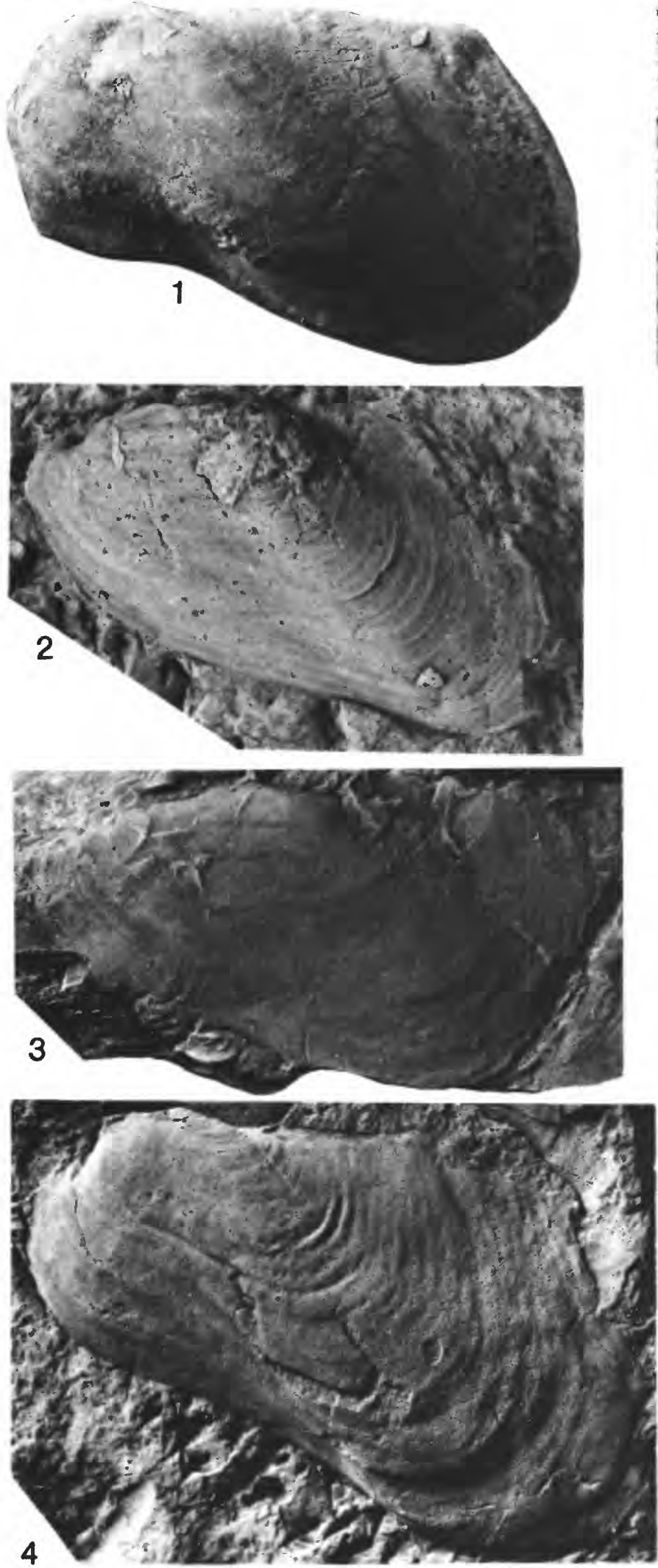

PROFESSIONAL PAPER 1394 PLATE 13
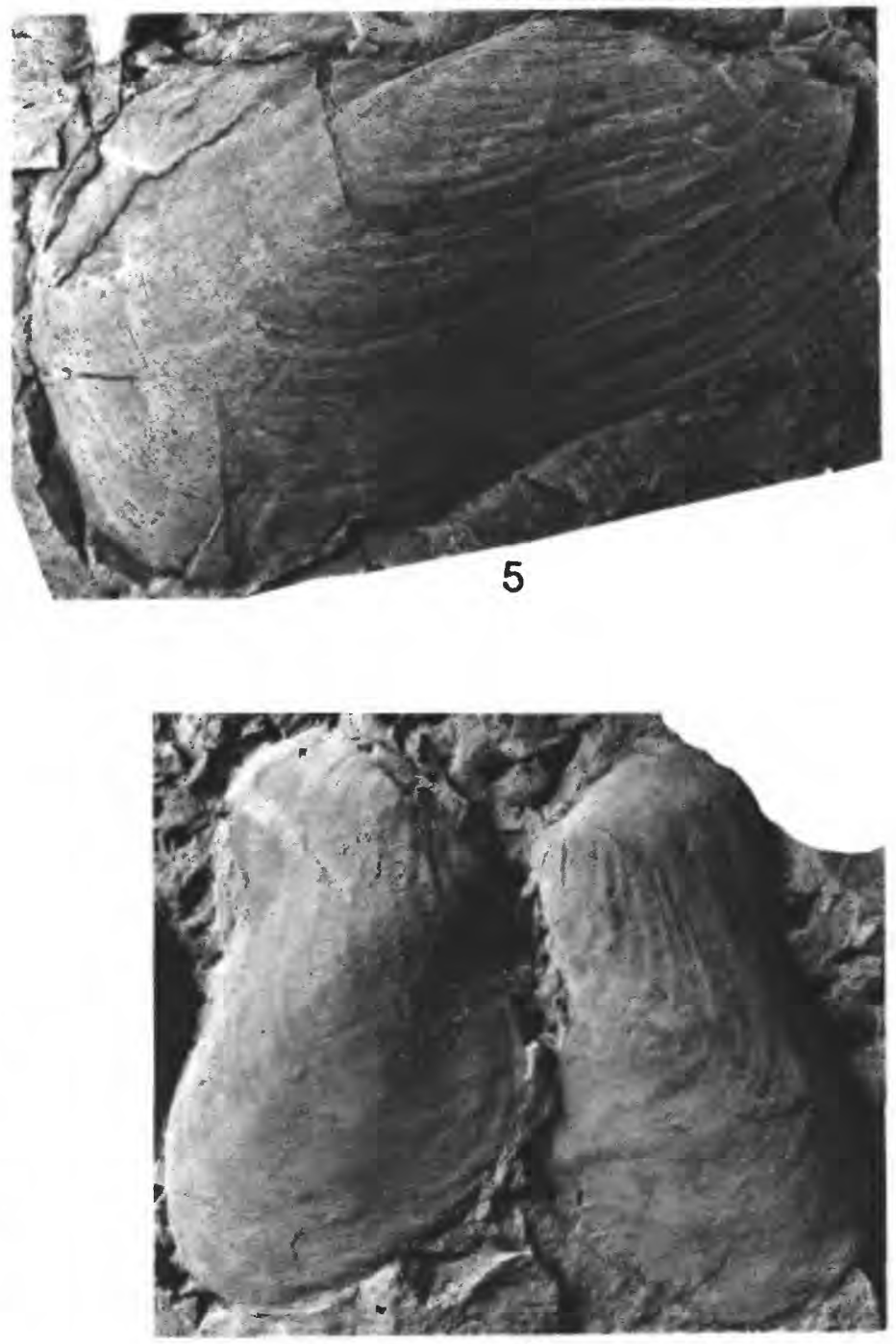

6

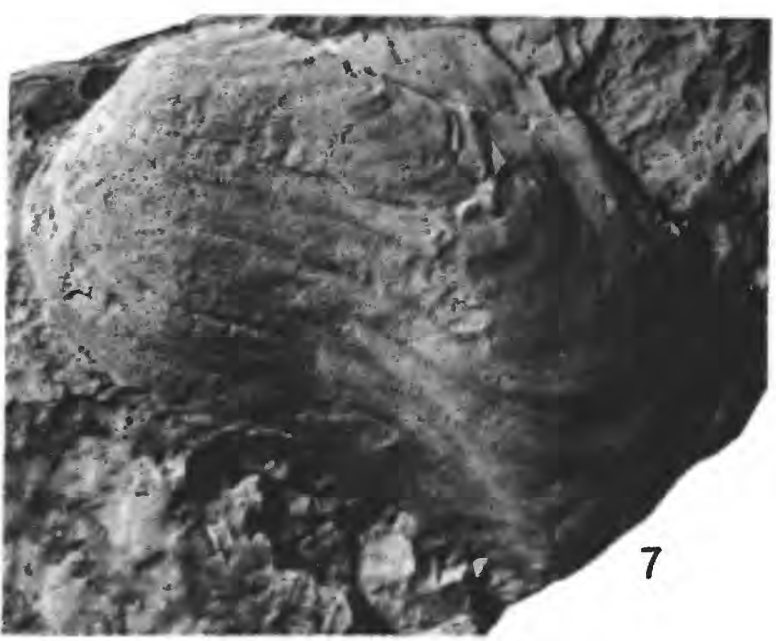




\section{PLATE 14}

Figures 1-4. Spathella hepingensis n. sp. (p. 73)+

1. Right valve composite mold $(\times 2)$. Donggangling Formation (Givetian), Section 3, Bed 23. GXD-555, paratype.

2. Dorsal view of spread valves $(\times 3)$. Horizon and locality the same as in figure 1 above. GXD-553, paratype.

3. Dorsal view of spread valves $(\times 3)$. Horizon and locality the same as in figure 1 above. GXD-554, paratype.

4. Left valve composite mold $(\times 1.5)$. Ertang Formation (Emsian), Section 3, Bed 10. GXD-551, holotype.

5, 6. Spathella sp. (p. 74)+

Left and right valve composite molds $(\times 4)$. Horizon and locality of figure 5 (GXD-556A) is the same as in figure 4 above. Figure 6 (GXD-641) is from the Donggangling Formation (Givetian), Section 3, Bed 23.

7, 10. Modiomorpha paradoxa (Zhang), 1977 (p. 72)+

7. Dorsal view of specimen shown on plate 13 , figure 1 .

10. Left-lateral view of composite mold $(\times 4)$. Horizon and locality the same as in figure 4 above. GXD-552.

8, 9. Modiomorpha concentrica (Conrad), 1838 (p. 71)*

8. Latex replica of ornament of right valve $(\times 2)$.

9. Latex replica of left valve showing weathered hinge $(\times 2.5)$. Horizon and locality the same as in figures 1-3, plate 11. USNM 374565, 374566 . 
GEOLOGICAL SURVEY
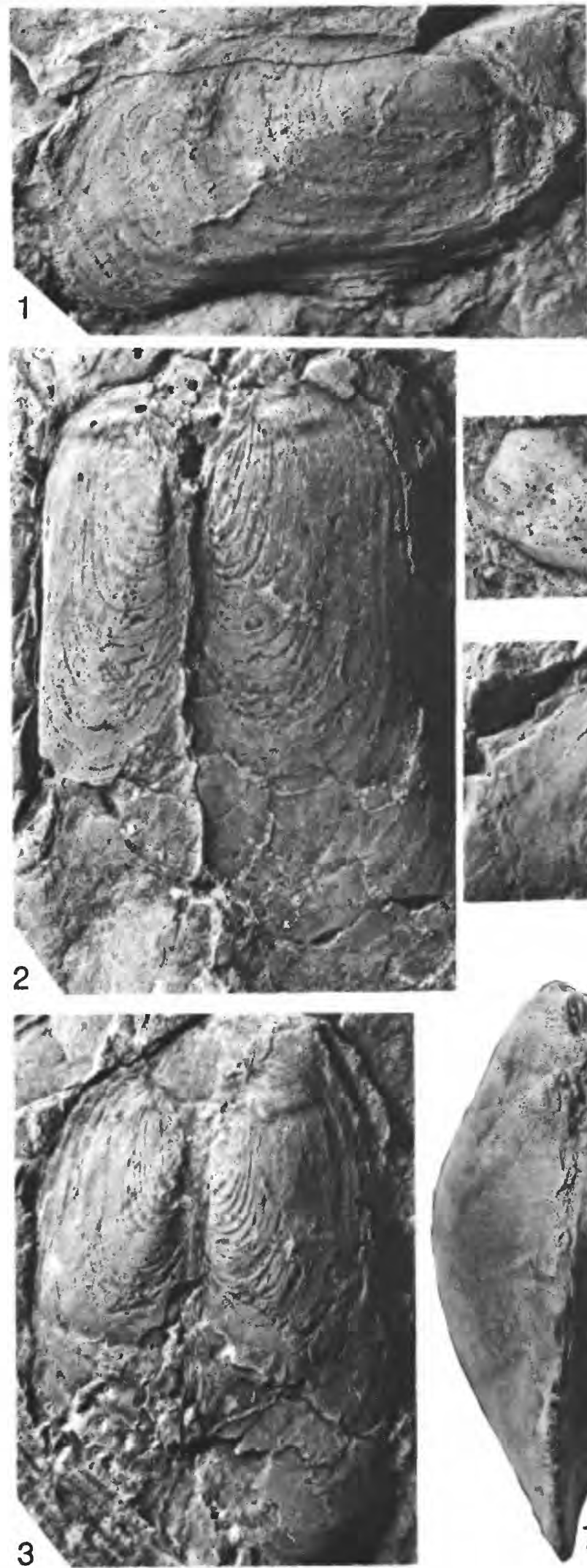

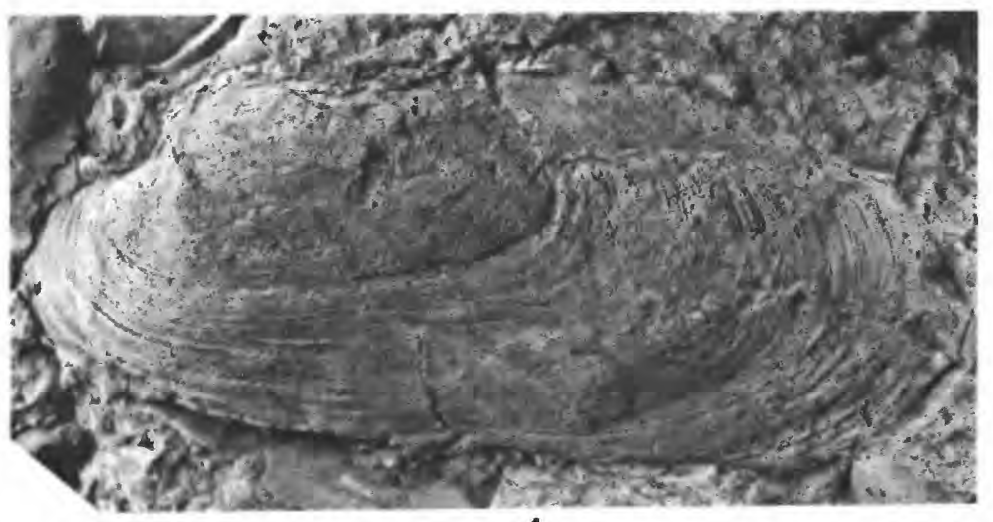

4
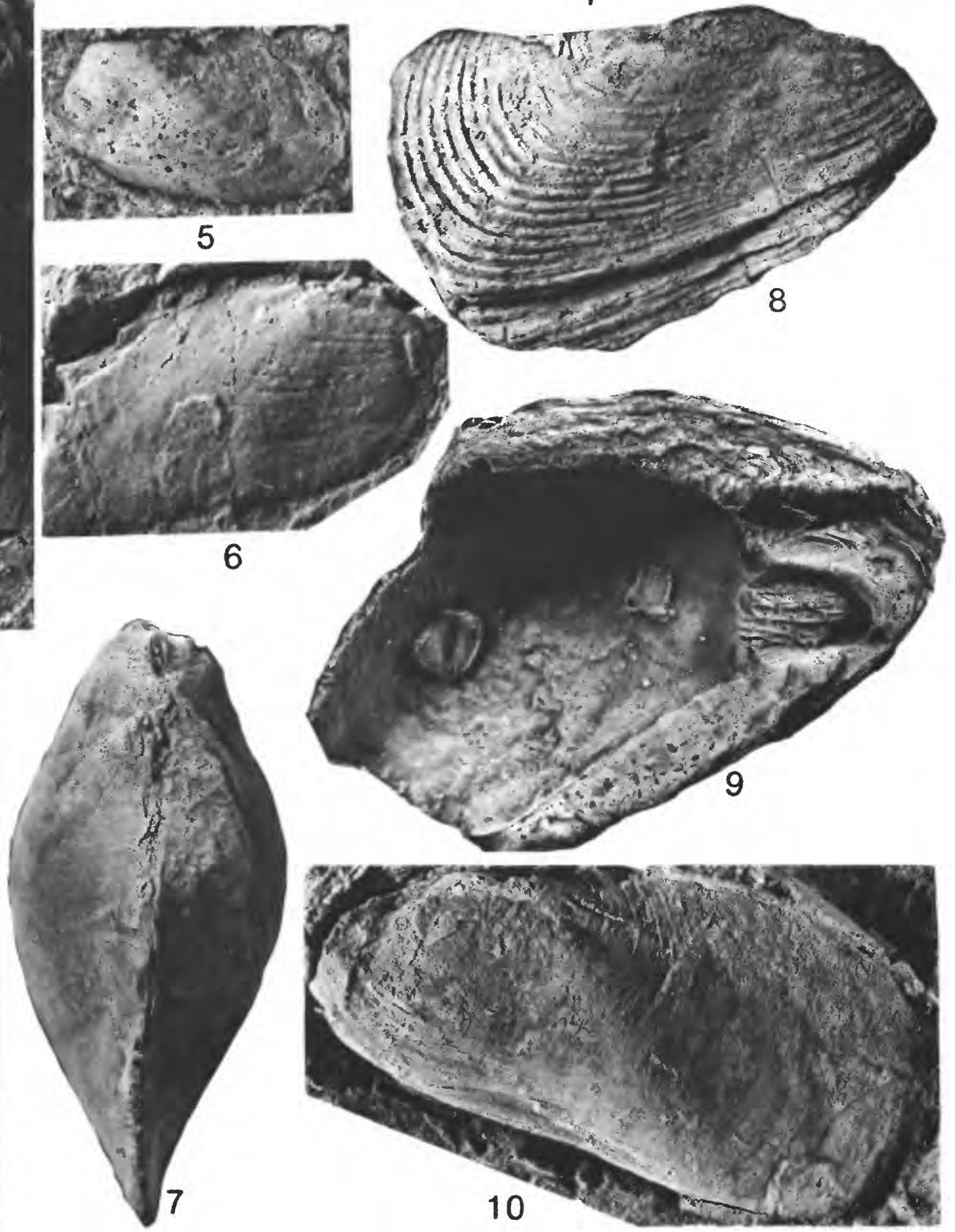

MODIOMORPHA AND SPATHELLA 
PLATE 15

FiguRES 1-9. Modiomorpha harrisae n. sp. (p. 72)+

1. Right-lateral view, composite mold ( $\times 3$ ). Ertang Formation (Emsian), Section 3, Bed 10. GXD-540, paratype (=USNM 374567).

2. Right-lateral view, composite mold $(\times 3)$. Horizon and locality the same as in figure 1 above. GXD-541, holotype.

3. Right-lateral view of composite mold $(\times 3)$. Horizon and locality the same as in figure 1 above. GXD-431, paratype.

4. Right-lateral view of composite mold $(\times 3)$. Horizon and locality the same as in figure 1 above. GXD-532, paratype.

5. Right-lateral view of composite mold $(\times 3)$. Horizon and locality the same as in figure 1 above. GXD-534, paratype.

6, 7. Right-lateral and dorsal views of composite mold $(\times 3)$. Ertang Foration (Emsian), Section 4, Bed 1. GXD-528, paratype.

8. Left-lateral view of internal mold $(\times 3)$. Horizon and locality the same as in figure 1 above. GXD-431A, paratype.

9. Left-lateral view of composite mold $(\times 3)$. Horizon and locality the same as in figure 1 above. GXD-533, paratype. 
GEOLOGICAL SURVEY
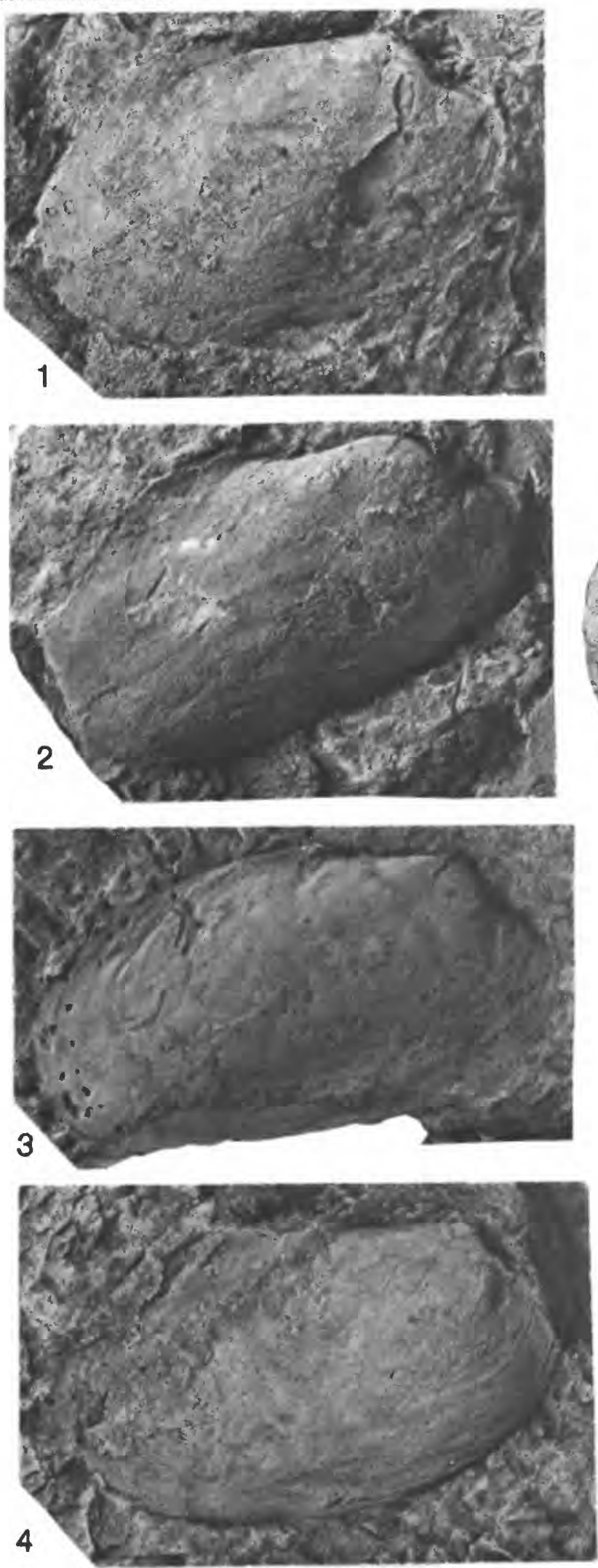

PROFESSIONAL PAPER 1394 PLATE 16
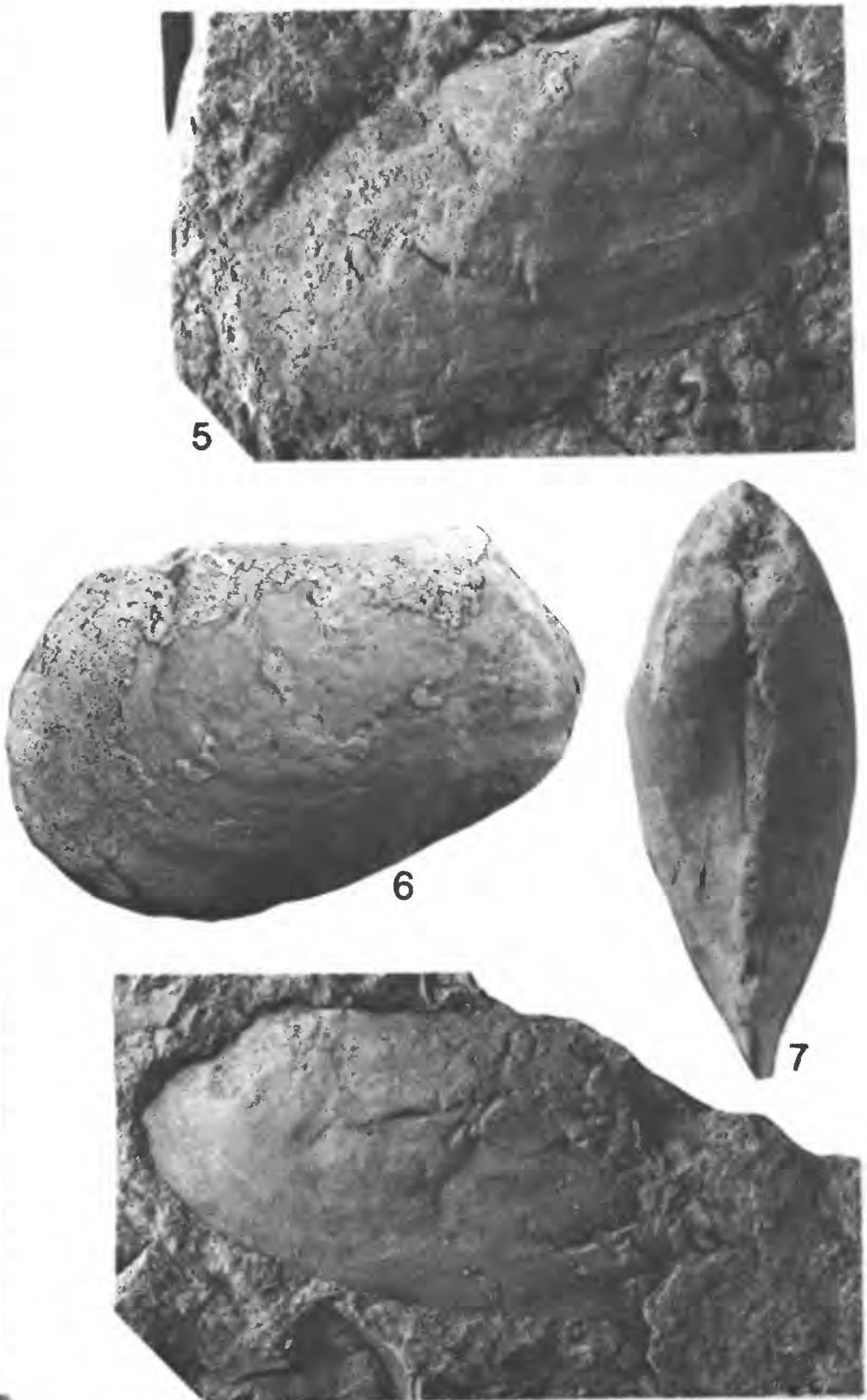

8

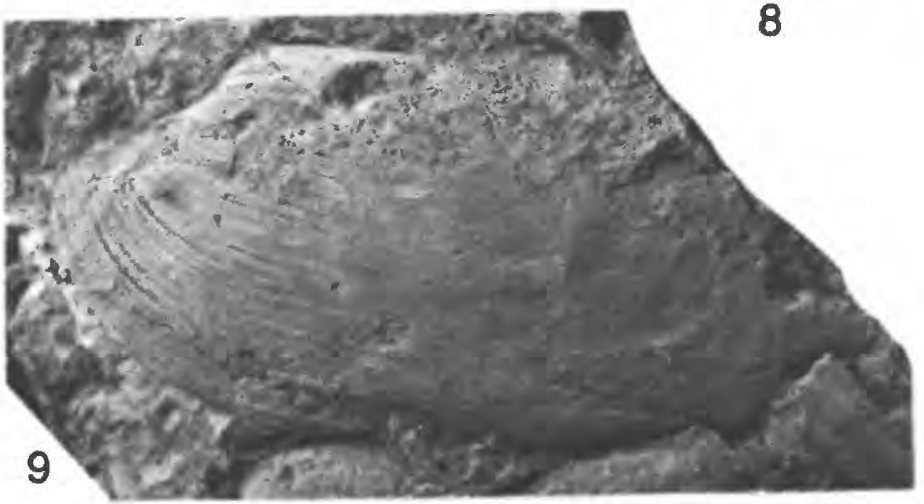


PLATE 16

Figures 1, 3. Spathella sp. (p. 74)+

Left-lateral views of two composite molds $(\times 4, \times 3)$. Horizon and locality the same as figure 4 , plate 14 . GXD-557, -556 .

2. Modiomorpha oblonga (Zhang), 1977 (p. 73)+

Right-lateral view of squashed partial composite mold ( $\times 1.3)$. Ertang Formation (Emsian), Section 4, Bed 31. GXD-520.

4-6. Tusayana? liujuiangensis n. sp. (p. 83)+

4. Right-lateral view of an articulated shelled specimen $(\times 1)$. Donggangling Formation (Givetian), Locality 10. GXD-518, paratype.

5. View of left valve hinge of an articulated specimen, which was broken open, other valve shown in figure 6 below. This view shows cardinal hinge plate (oblique arrow) and posterior lateral tooth (vertical arrow) area of shell between these two destroyed when valves were broken apart (horizontal arrow). Below the cardinal hinge plate is the deeply impressed and small anterior adductor muscle scar $(\times 2)$. Horizon and locality the same as in figure 4 above. GXD-517A, half of holotype.

6. View of right valve hinge, other half of holotype shown in figure 5 above. Most of the hinge of this valve was destroyed when the specimen was broken apart, but there is a suggestion of a lateral socket, and some of the cardinal hinge plate is preserved above the anterior adductor muscle scar (arrow) ( $\times 2$ ). GXD-517B, half of holotype. 
GEOLOGICAL SURVEY
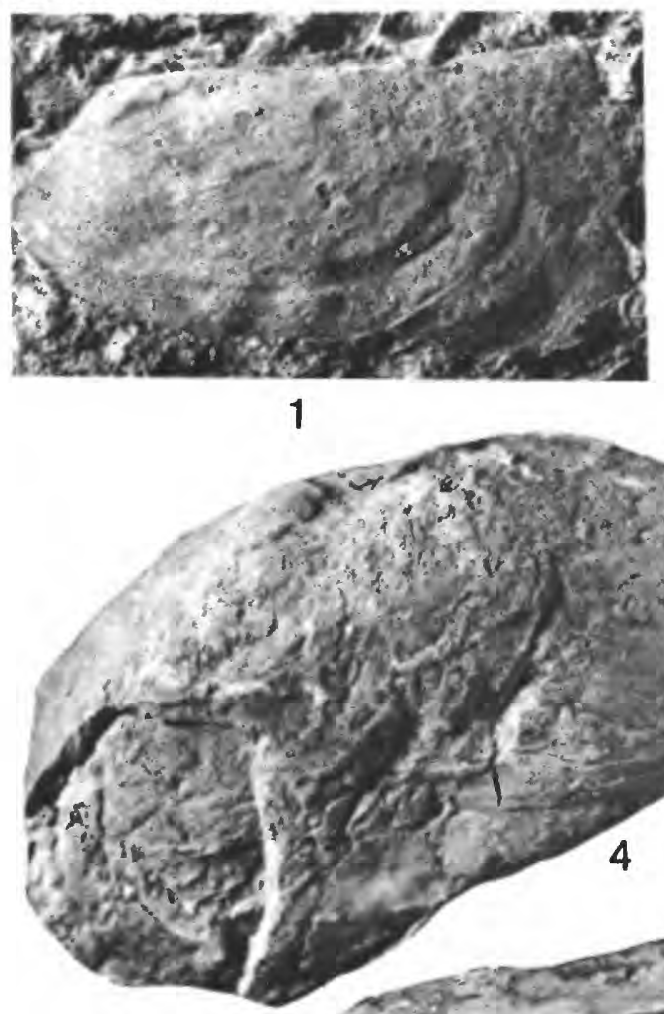

PROFESSIONAL PAPER 1394 PLATE 16
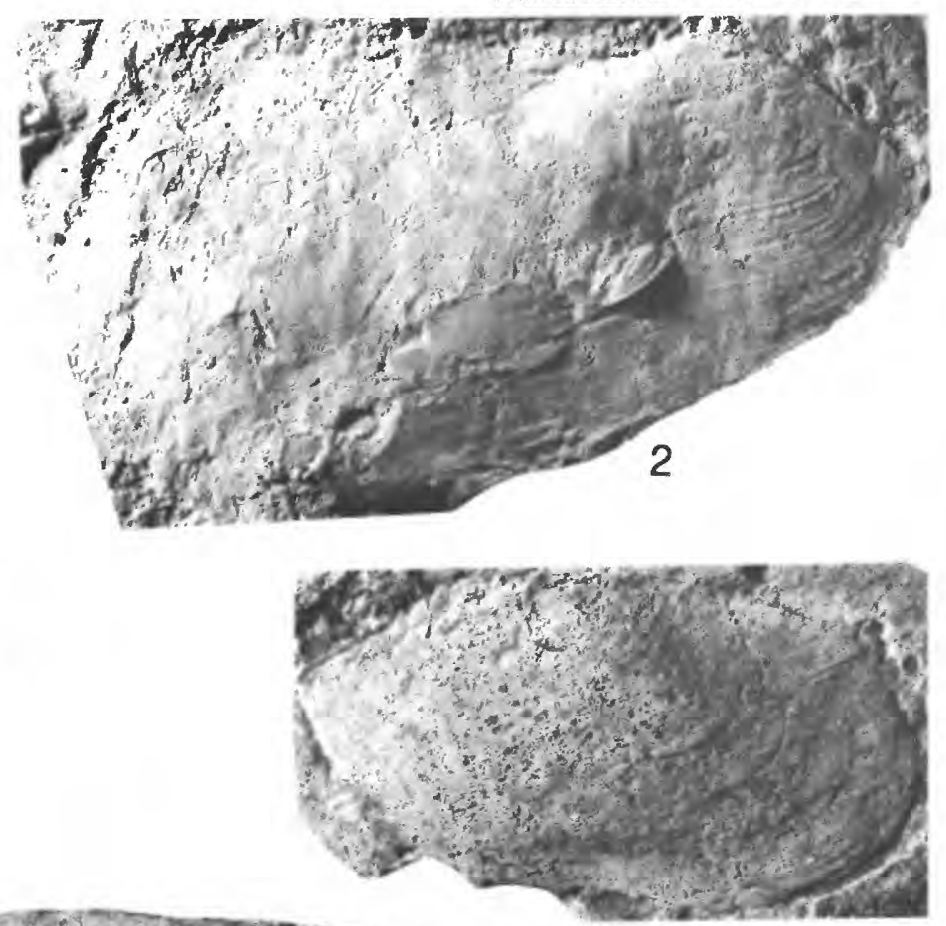

3
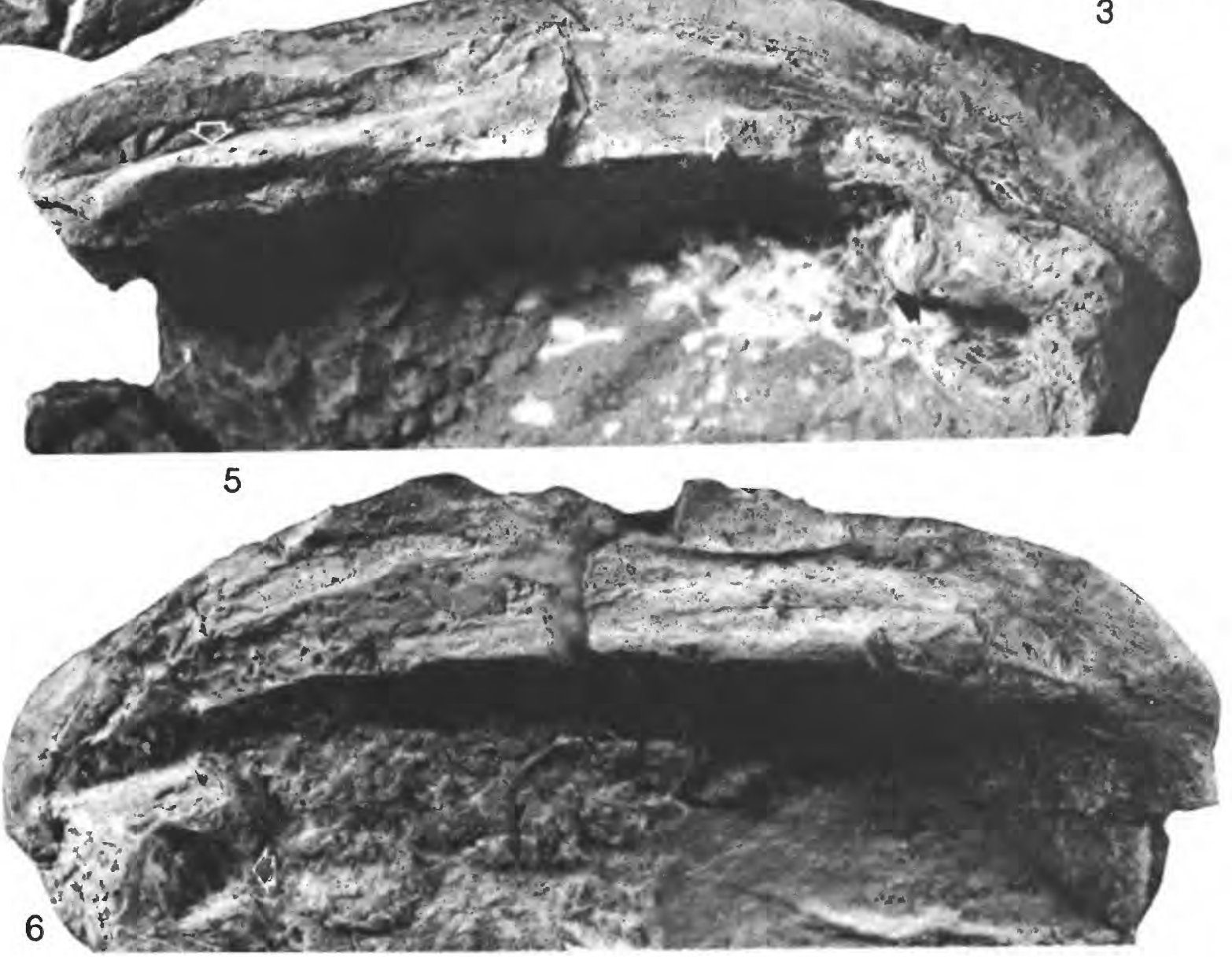

SPATHELLA, MODIOMORPHA, AND TUSAYANA? 


\section{PLATE 17}

Figures 1, 2. Goniophora (Goniophora) sp. A (p. 74)+

1. Flattened and distorted composite mold of right valve $(\times 3)$. Donggangling Formation (Givetian), Section 3, Bed 23. GXD-547.

2. Articulated specimen foreshortened at right angles to bedding $(\times 3)$. Ertang Formation (Emsian), Section 4, Bed 6. GXD-642.

3. Modiomorpha odiata Clarke, 1909 (p. 71)*

Internal mold of left valve showing most of the muscle scars, cardinal tooth (arrow) and lack of lateral teeth $(\times 2)$. Moose River Sandstone (SiegenianEmsian), Matagamon Lake, Maine. NYSM 8910.

4, 5. Modiolopsis modiolaris (Conrad), 1838 (p. 74)*

Internal mold slightly distorted parallel to bedding ( $\times 1.5)$, and composite mold highly foreshortened at right angles to bedding $(\times 2)$. Fairview Formation (Maysvillian, Upper Ordovician), Cincinnati, Ohio. USNM 101514, 46719.

6, 7. Modiomorpha cercurus (Clarke), 1909 (p. 72)*

Left-lateral view of internal mold showing various muscle scars and mantle point attachment scars $(\times 2)$, and enlargement of anterior end showing quick and catch portions of anterior adductor muscle scar (arrows), ( $\times 3$ ). Oriskany Sandstone (Siegenian), Pine Hill near Highland Mills, N.Y. NYSM 8838, syntype. 
GEOLOGICAL SURVEY
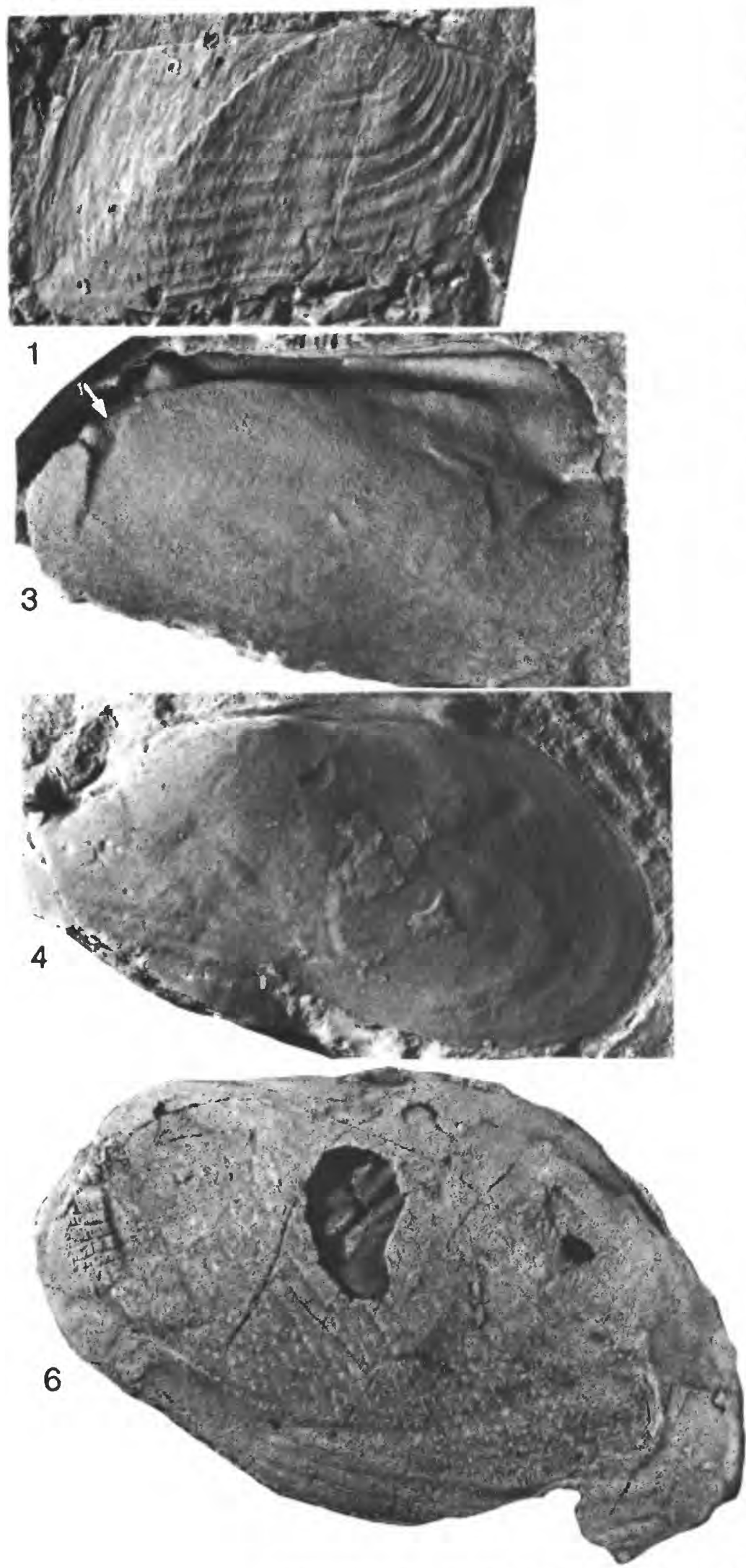

PROFESSIONAL PAPER 1394 PLATE 17

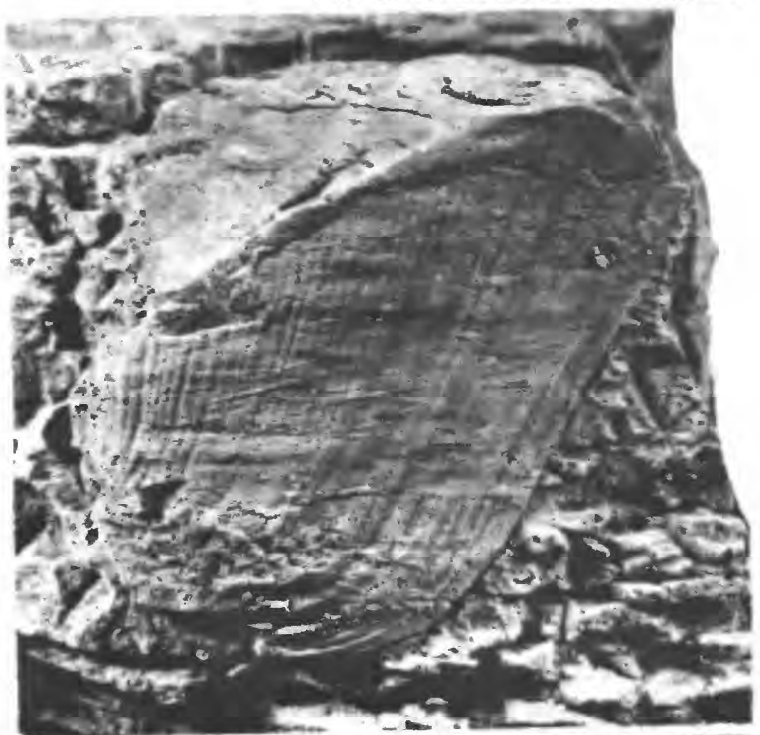

2
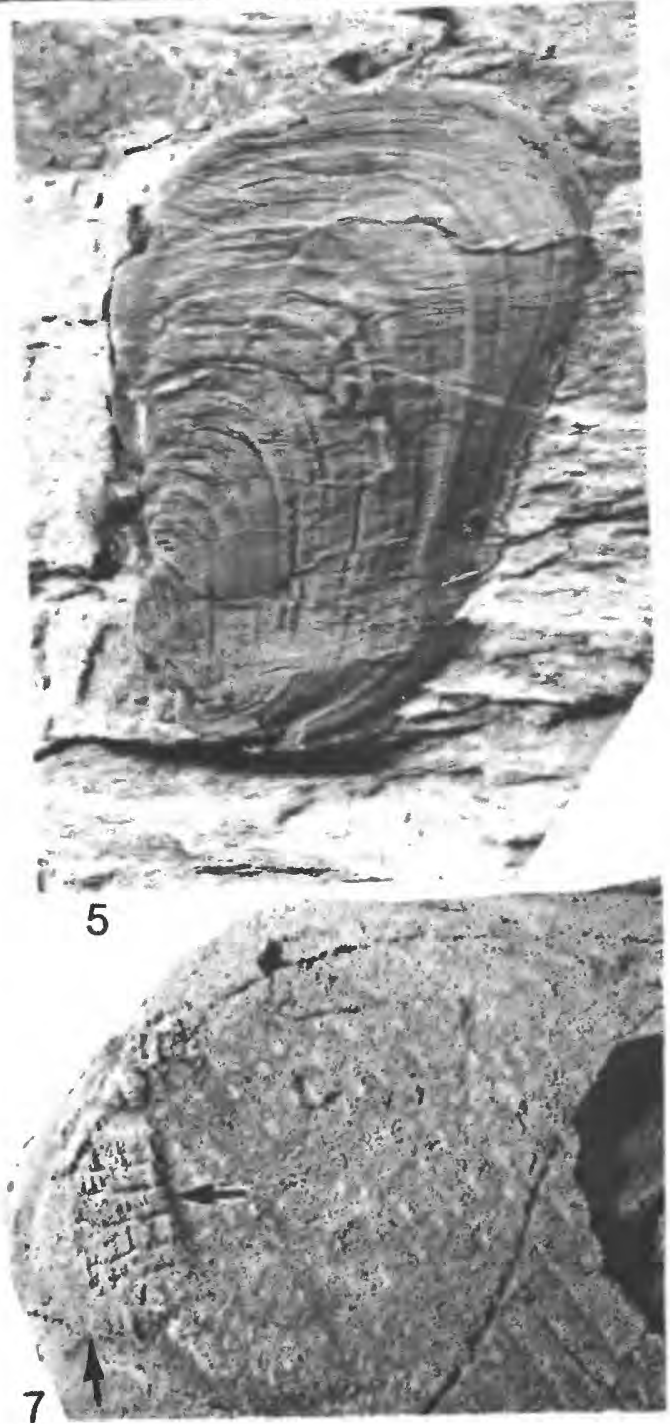

GONIOPHORA (GONIOPHORA), MODIOMORPHA, AND MODIOLOPSIS 


\section{PLATE 18}

FIGURE 1. Goniophora (Goniophora) sp. B (p. 74)+

Right-lateral view of composite mold showing profile $(\times 3)$. Ertang Formation (Emsian), Locality 6. GXD-548.

2-4. Goniophora (Cosmogoniophora) marija n. sp. (p. 74)+

2. Left-lateral view of composite mold showing profile and ornament (× 5). Yingtang Formation (Eifelian), Section 5, Bed 19. GXD-549, holotype.

3. Left-lateral view of weathered composite mold showing profile $(\times 8)$. Horizon and locality the same as in figure 2 above. GXD-545, paratype.

4. Right-lateral view of obliquely distorted composite mold showing ornament $(\times 3)$. Horizon and locality the same as in figure 2 above. GXD-741, paratype.

5-7. Goniophora (Goniophora) spatulata Mansuy, 1913 (p. 74)+

5 , 6. Left-lateral and dorsal views of weathered composite mold $(\times 2)$. Yingtang Formation (Eifelian), Section 5, Bed 22. GXD-543.

7. Right-lateral view of squashed specimen $(X 2)$. Ertang Formation (Emsian), Section 3, Bed 10. GXD-546.

8, 9. Crassatellopsis? sp. A (p. 82)+

Two incomplete left valve interiors showing profile, probable ligament area (oblique arrow in fig. 9), and posterior lateral socket (vertical arrow in fig. 9), ( $\times 3$ ). Both from the Sipai Formation (Emsian), Section 3, Bed 13. GXD-648, -650 . 
GEOLOGICAL SURVEY
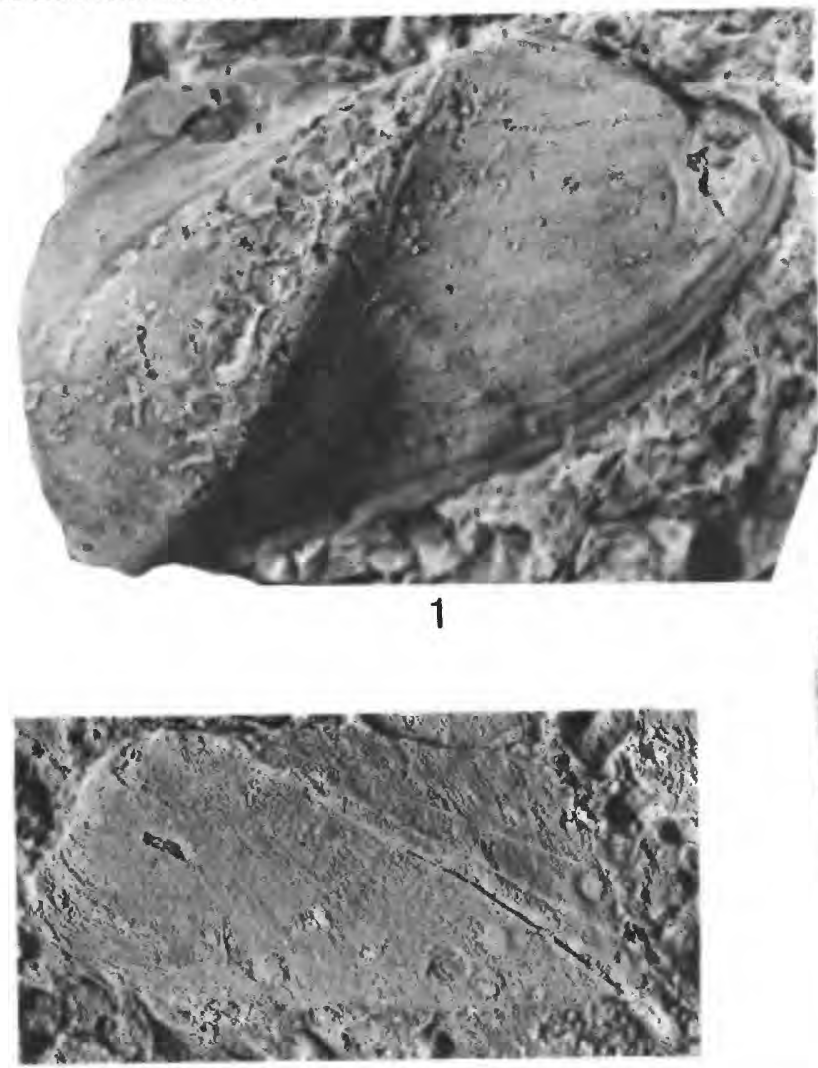

2
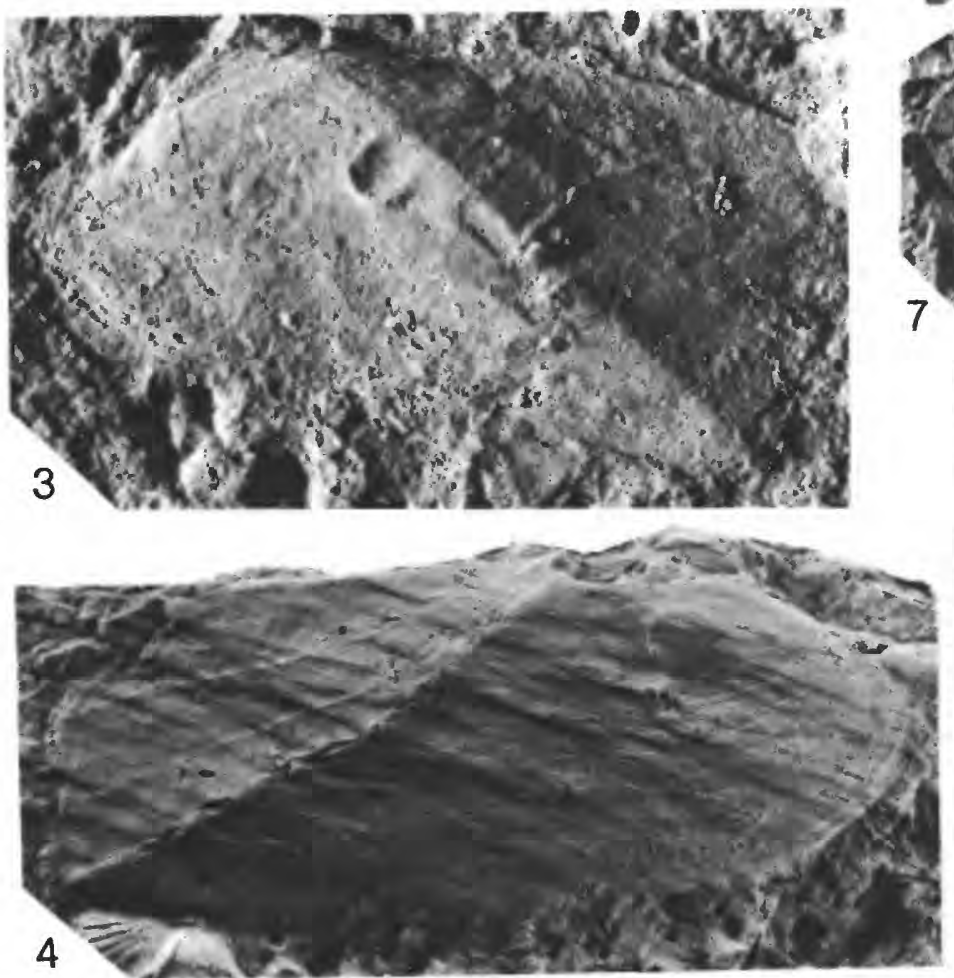

6
PROFESSIONAL PAPER 1394 PLATE 18
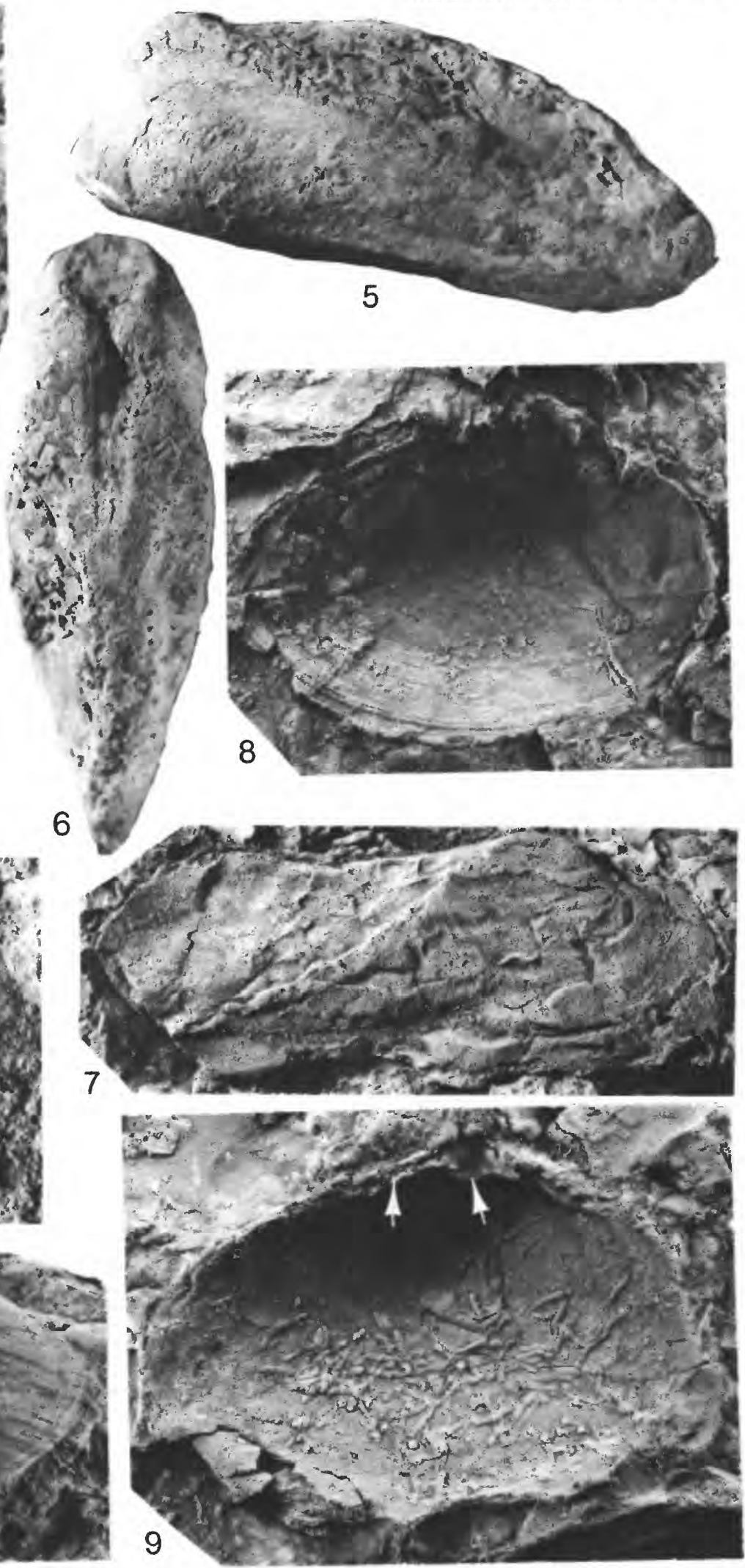

GONIOPHORA (GONIOPHORA), G. (COSMOGONIOPHORA), AND CRASSATELLOPSIS? 


\section{PLATE 19}

Figures 1, 2. Orthonota undulata Conrad, 1841 (p. 76)*

1. Left-lateral view of composite mold showing profile, ornament, and midumbonal sulcus (arrow) ( $\times 2$ ). Delphi Station Shale (Skaneateles, Givetian), Pratt Falls, 5 miles south of Manlius, N.Y. USNM 374622.

2. Dorsal view of spread valves, composite mold, showing ornament and midumbonal sulci $(\times 2)$. The Museum label provides the following information "Devonian, Sherburne, New York." USNM 59900.

3-5. Orthonota carinata Conrad, 1841 (p. 77)*

3. Right valve composite mold showing lateral profile and ornament $(\times 3)$. Lower Ludlowville Formation (Givetian), railroad cut and Stone Mill Brook, 1.5 miles northwest of Earlville, N.Y. USNM 101815.

4. Left-lateral view of composite mold showing profile and ornament $(\times 3)$. Lower Ludlowville Formation (Givetian), at dam, southeast side of Lebanon Reservoir, near Hamilton, N.Y. USNM 383602.

5. Left valve composite mold showing divaricate ornament between upper ribs (arrow) $(\times 3)$. Base of Ludlowville at same locality as figure 3 above. USNM 101815.

6, 7. Modiomorpha mytiloides (Conrad), 1841 (p. 73)*

6. Internal mold of right valve showing profile and anterior adductor muscle scar (arrow) $(\times 2)$. Norway Point Formation (Givetian), Thunder Bay River, 0.75 miles southeast of Four Mile Dam, Alpena County, Mich. USNM 374574.

7. Dorsal view of spread valves showing ornament and profile $(\times 1.5)$. Thunder Bay Formation (Givetian), Partridge Point, 4 miles south of Alpena, Mich. USNM 374575.

8. Mytella guyanensis (Lamarck) (p. 73)

Dorsal profile of spread valves showing ornament for comparison with figure

7 above $(\times 2)$. Holocene, Ecuador. USNM 374629.

9. Goniophora (Goniophora) sp. indet. (p. 74)*

Upper part of Ferron Point Formation, Mich. $(\times 2)$. YPM 16623. 

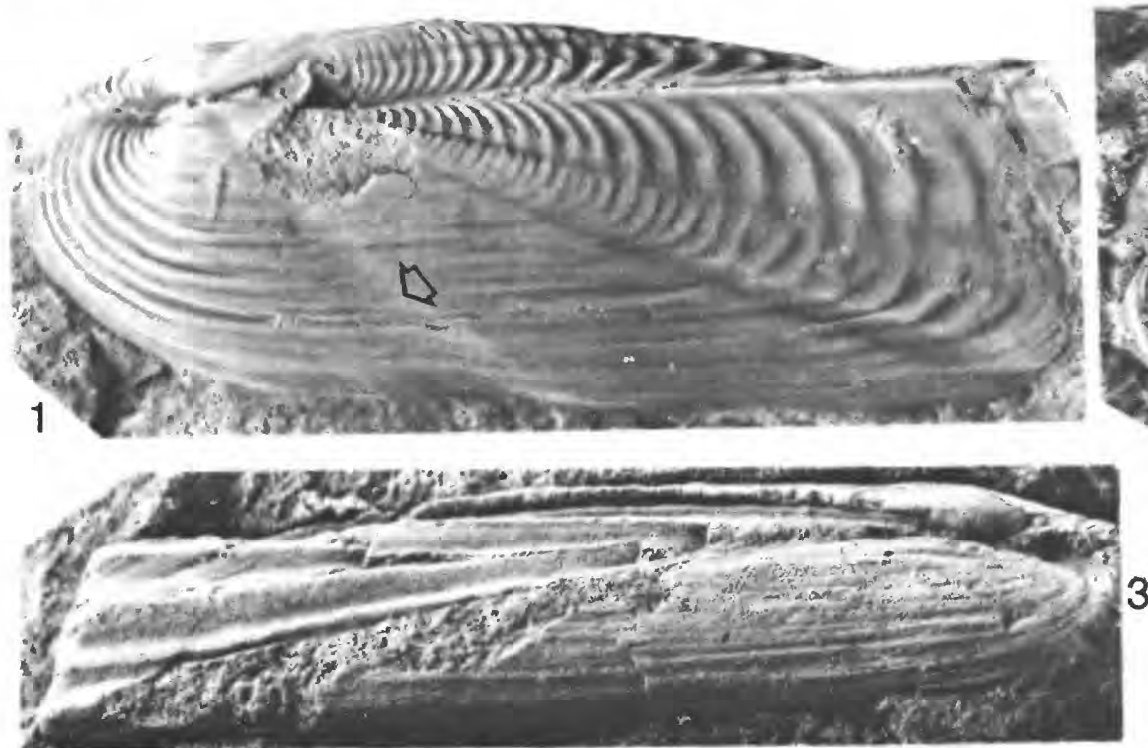

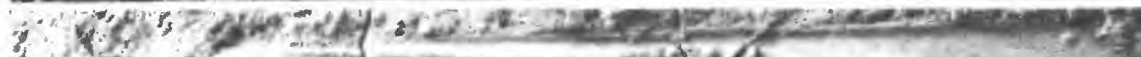
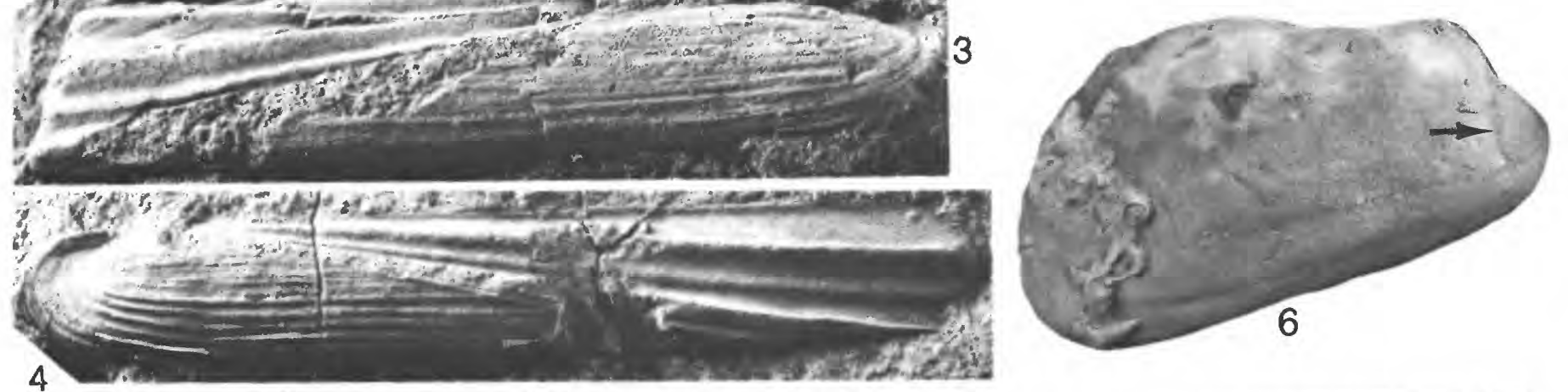

2

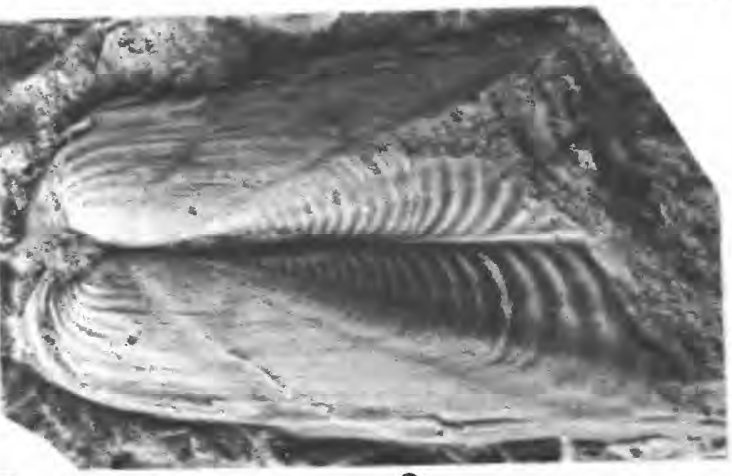

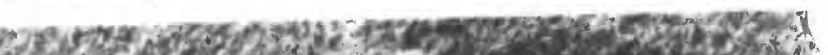

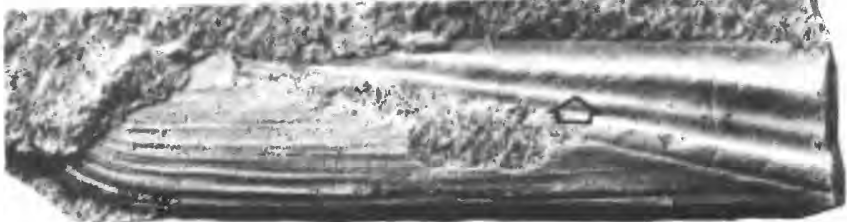

5

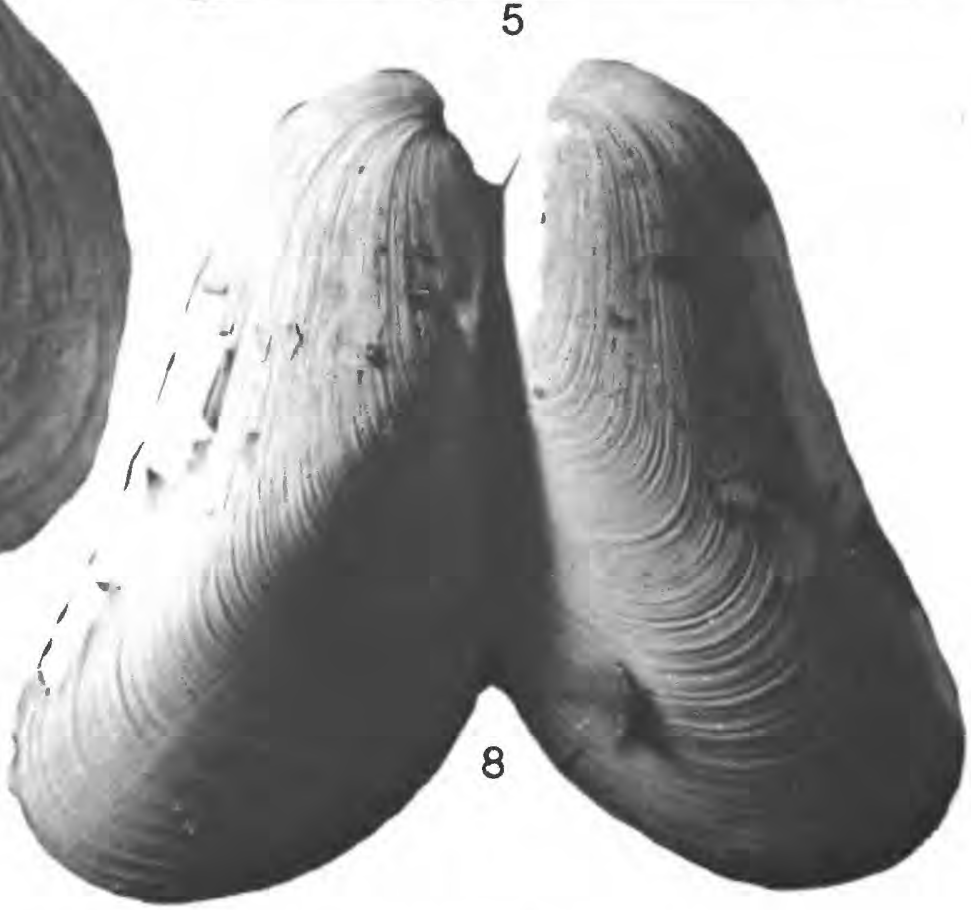

ORTHONOTA, MODIOMORPHA, MYTELLA, AND GONIOPHORA (GONIOPHORA) 


\section{PLATE 20}

Figure 1. Leptosolen biplicatus (Conrad), 1858 (p. 75$)^{*}$

Left-lateral exterior view showing profile and ornament $(\times 1.5)$. Owl Creek Formation (Upper Cretaceous), Owl Creek, Tippah County, Miss. USNM 128167.

2. Modiomorpha mytiloides (Conrad), 1841 (p. 73)*

Composite mold of right valve showing ornament and profile $(\times 2)$. Thunder Bay Formation (Givetian), Partridge Point, 3 miles south of Alpena City line, Mich. YPM 16471.

3. Orthonota carinata Conrad, 1841 (p. 77)*

Composite mold of right valve showing ornament and profile $(\times 3)$. The museum label gives the following data: "Hamilton, Smyrna, Chenango Co., N.Y." USNM 101819.

4-9. Orthonota undulata Conrad, 1841 (p. 76)*

4. Left-lateral view of composite mold showing ornament, profile, and midumbonal sulcus (arrow) $(\times 1.5)$. The museum label gives the following data: "Ham. (Moscow-up. Windom), quarry $2 \mathrm{mi}$. N.W. Georgetown Sta., New York." USNM 101816.

5. Left-lateral view of composite mold showing ornament, profile, and midumbonal sulcus $(\times 2)$. The museum label provides the following information: "Devonian, Sherburne, New York." USNM 374630.

6. Crushed right valve composite mold showing ornament and midumbonal sulcus (arrow) $(\times 1.5)$. Norway Point Formation (Givetian), Norway Dam, NE1/4 sec. 12, T. 31 N., R. 7 E., Alpena County, Mich., USNM 374625 .

7. Left valve composite mold, distorted parallel to bedding showing ornament, midumbonal sulcus (arrow), and profile $(\times 2)$. Horizon and locality the same as in figure 6 above. USNM 374626 .

8. Dorsal view of crushed spread valves, composite mold, showing ornament and midumbonal sulci (arrow) $(\times 2)$. Horizon and locality the same as in figure 6 above. YPM 16473 .

9. Dorsal view of spread valves, external mold, showing ornament and midumbonal sulci $(\times 2)$. Collected from Hamiltonian age Holocene glacial drift, East Meredith, N.Y. USNM 101810. 
GEOLOGICAL SURVEY
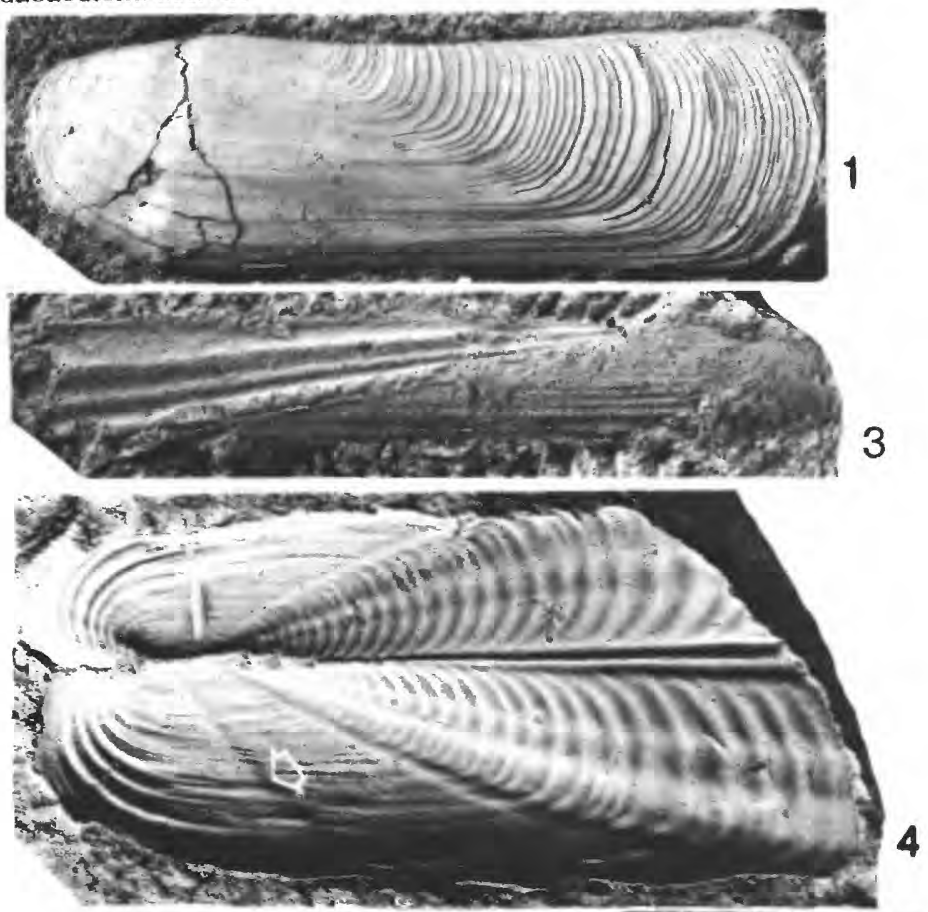

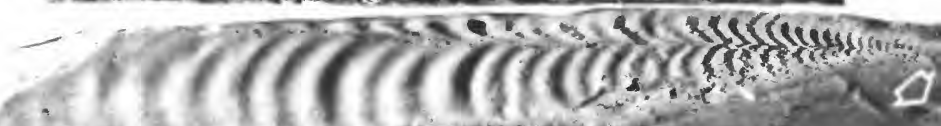

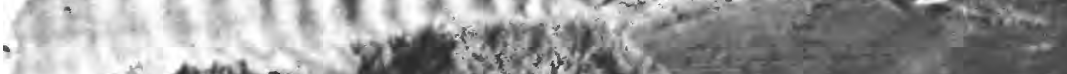

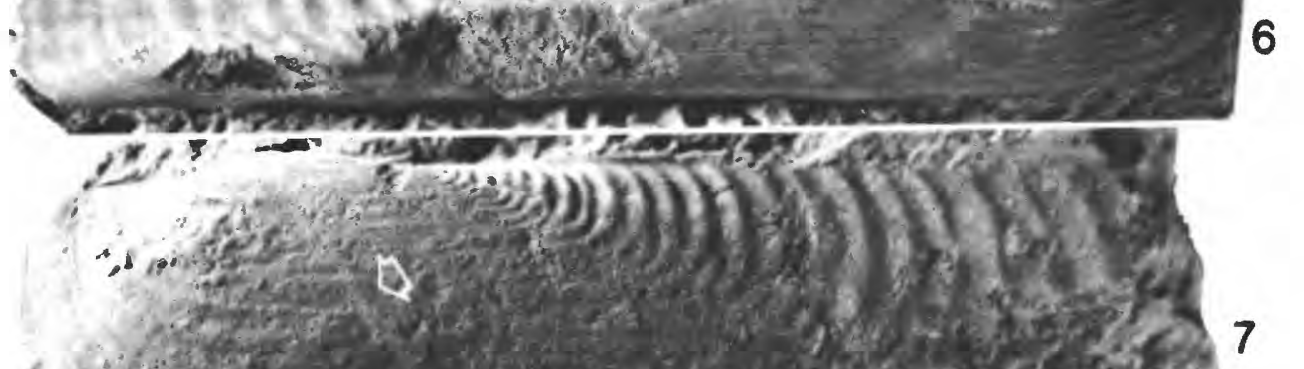

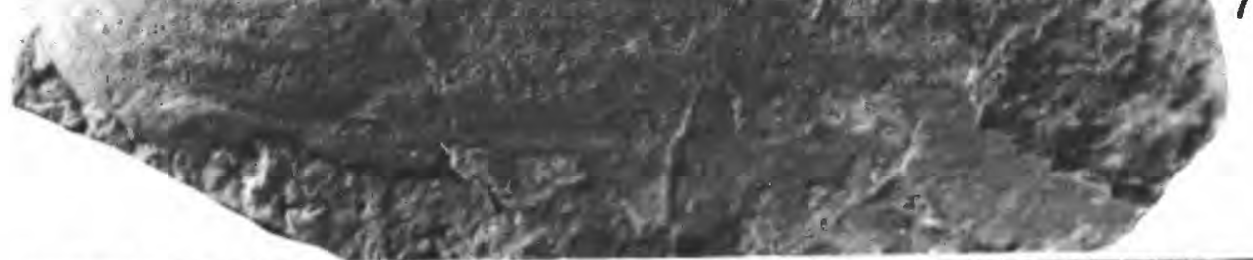

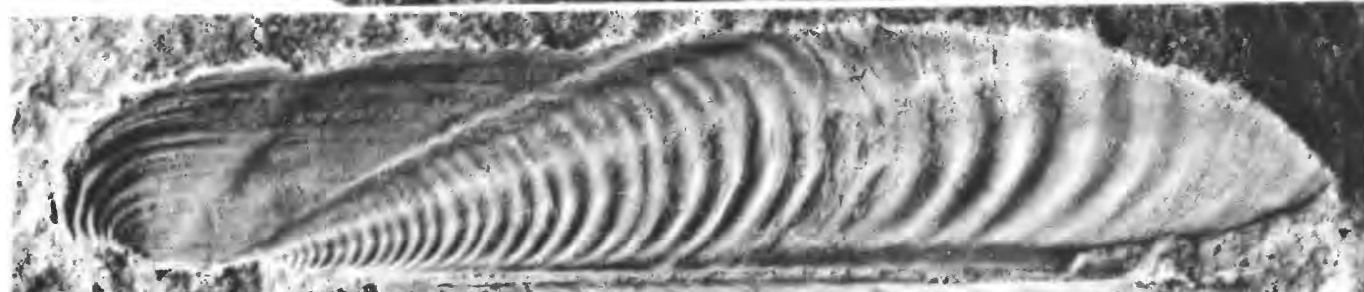

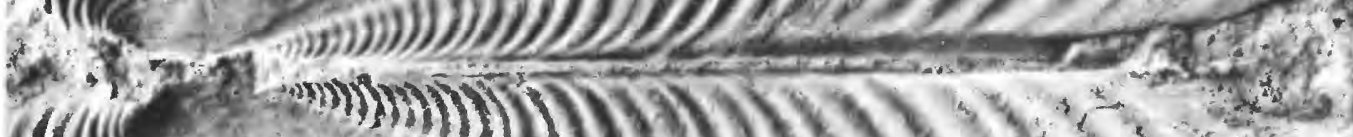

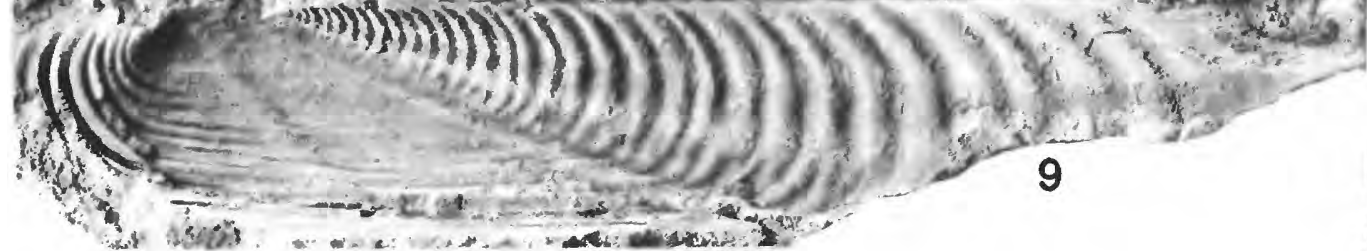

PROFEgSIONAL PAPER 1894 PLATE
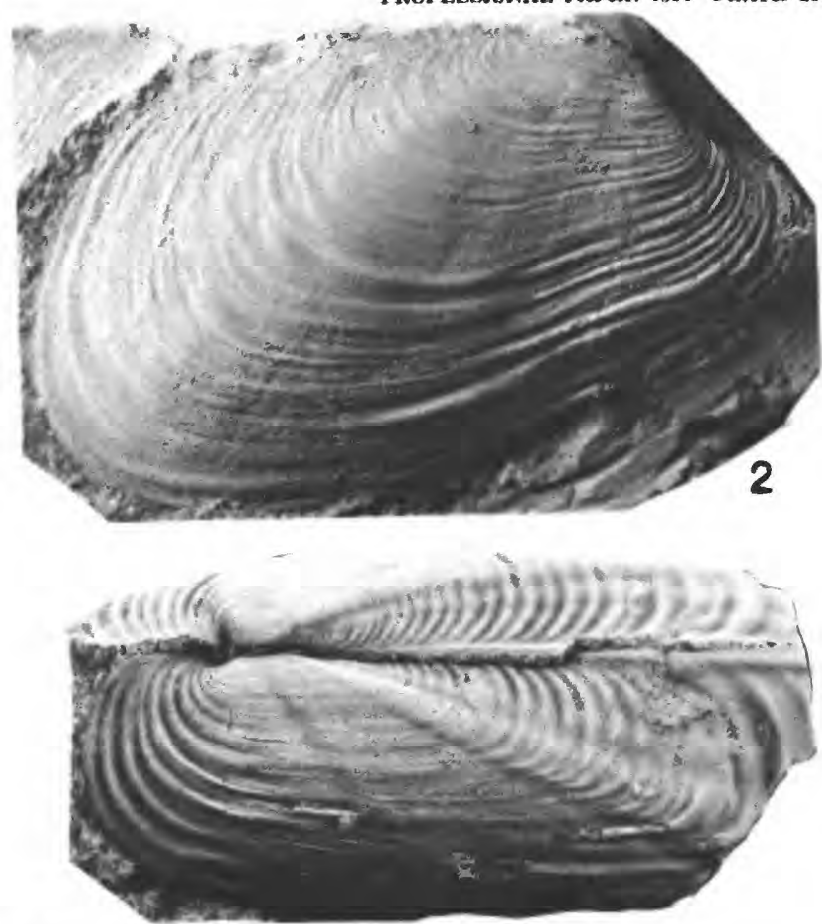

5

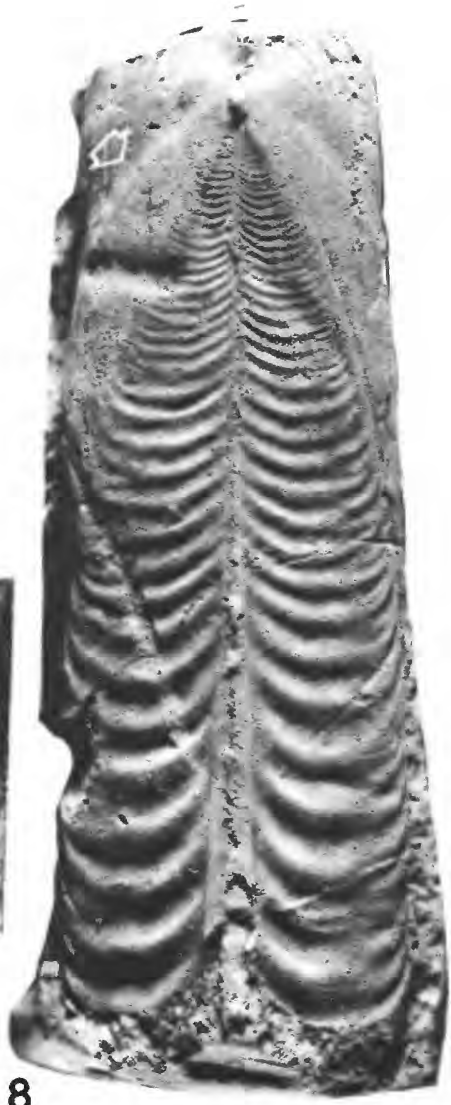

LEPTOSOLEN, MODIOMORPHA, AND ORTHONOTA 


\section{PLATE 21}

Figures 1-9. Paracyclas rugosa (Goldfuss), 1837 (p. 81$)+$

1 , 2. Left-lateral $(\times 5)$ and dorsal views $(\times 7)$ of a shelled specimen showing profiles and ornament. Ertang Formation (Emsian), Section 3, Bed 11. GXD-678 (=USNM 374640).

3. Left-lateral view of composite mold showing ornament and profile $(X$ 3.5). Ertang Formation (Emsian), Section 4, Bed 36. GXD-698.

4. Right-lateral view showing profile and ornament $(\times 7)$. Horizon and locality the same as in figure 3 above. GXD-696A.

5. Right-lateral view of composite mold $(\times 7)$. Ertang Formation (Emsian), Section 4, Bed 11. GXD-693 (=USNM 374641).

6. Right-lateral view of composite mold ( $\times$ 5.5). Ertang Formation (Emsian), Section 3, Bed 10. GXD-699.

7. Right-lateral view of composite mold $(\times 8)$. Horizon and locality the same as in figure 3 above. GXD-690.

8. Distorted right valve composite mold $(\times 4)$. Horizon and locality the same as in figure 3 above. GXD-691.

9. Right-lateral view of composite mold $(\times 7)$. Horizon and locality the same as in figure 3 above. GXD-688. 

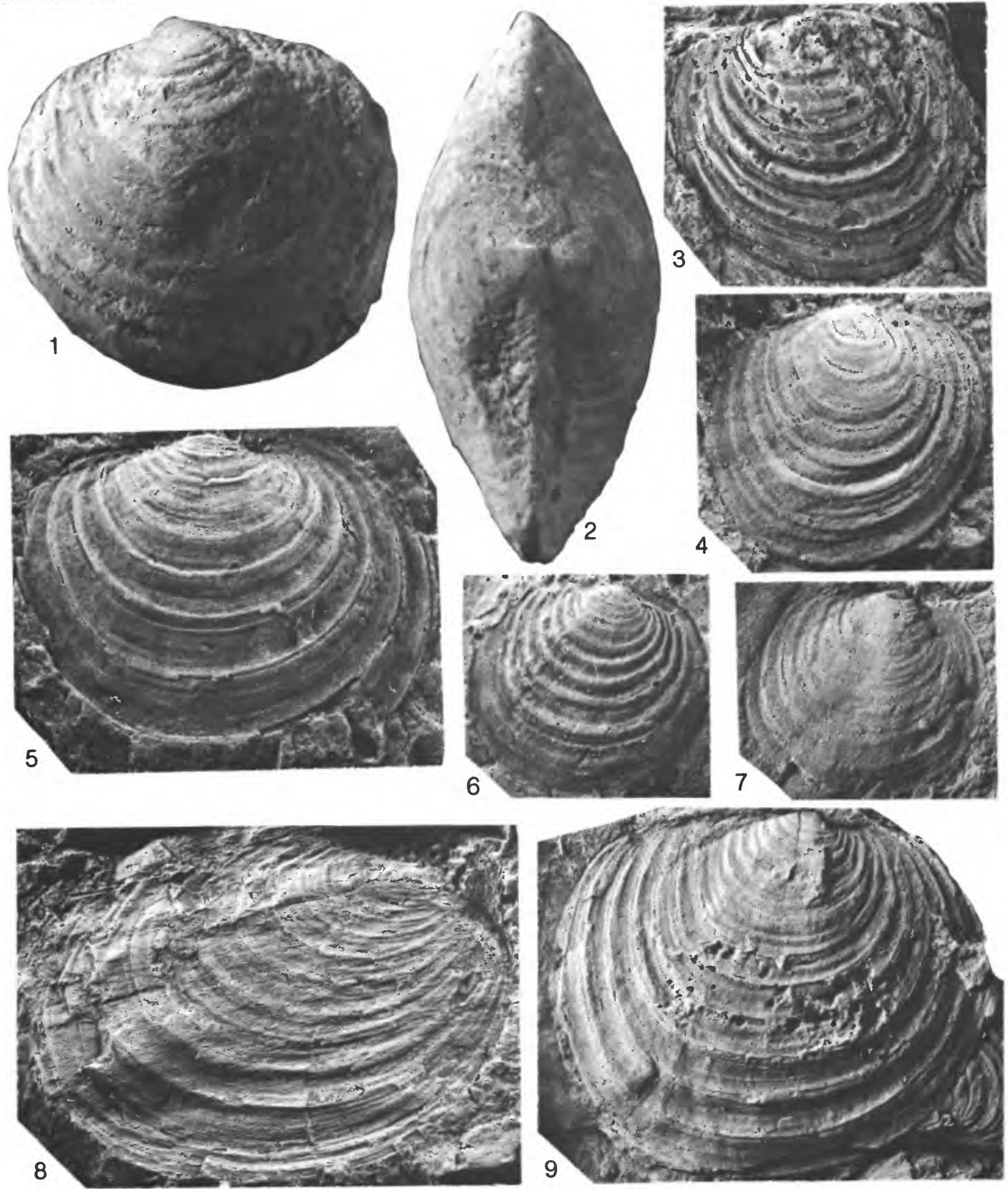


\section{PLATE 22}

Figures 1, 2. Cypricardella? sp. (p. 82) +

Left valve internal $(\times 3.5)$ and external $(\times 3)$ molds. Hengxian Member, Lianhuashan Formation (Gedinnian) Section 1, Bed 5. GXD-768, -756. 3-8. Paracyclas rugosa (Goldfuss), 1837 (p. 81)+

3 , 4. Dorsal and right-lateral views of inflated composite mold $(\times 2.5)$. Ertang Formation (Emsian), Section 2, Bed unknown. GXD-834.

5, 6. Left-lateral and dorsal views of dorsoventrally compressed composite mold ( $\times 3$ ). Donggangling Formation (Givetian), Section 3, Bed 24 . GXD-659.

7. Right-lateral view of composite mold $(\times 4.5)$. Horizon and locality the same as in plate 21, figure 3. GXD-700.

8. Right-lateral view of composite mold $(\times 10)$. Ertang Formation (Emsian), Section 3, Bed 10. GXD-681 (=USNM 374642).

9, 10. Cypricardella? spp. (p. 82)+

9. Weathered left valve internal mold $(\times 3)$. Horizon and locality the same as in figures 1 and 2 above. GXD-754.

10. Right-lateral view of composite mold $(\times 10)$. Nagaoling Formation (Gedinnian), Section 1, Bed 13. GXD-739. 


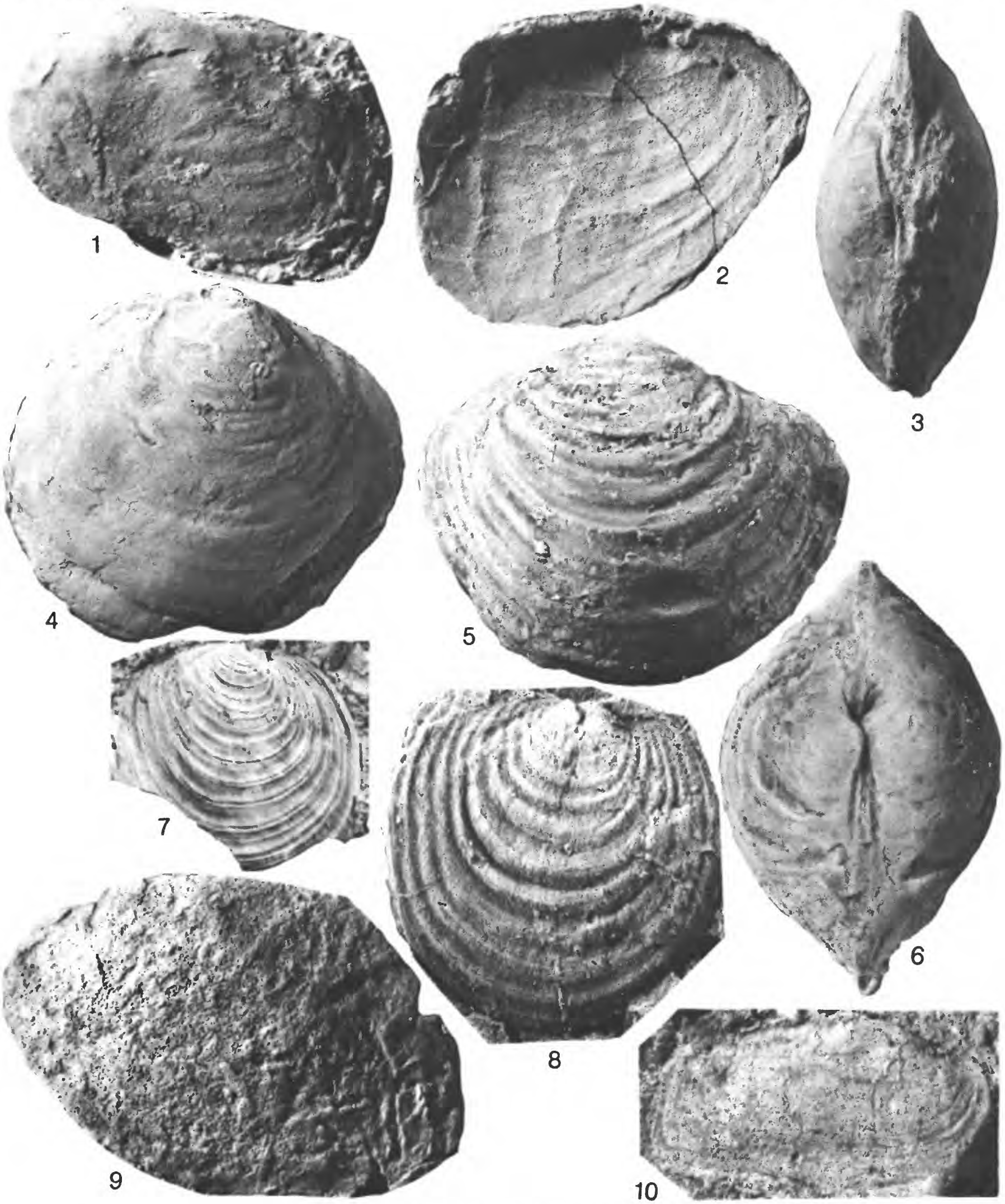

PARACYCLAS AND CYPRICARDELLA? 
PLATE 23

Figures 1-3, 5, 6. Schizodus aff. S. cuneus Hall, 1883 (p. 80)+

1. Dorsal view of spread valves, composite mold ( $\times 3$ ). GXD-595.

2. Dorsal view of spread valves, composite mold (X 5). GXD-603.

3. Left-lateral view of composite mold $(\times 6)$. GXD-604.

5. Right-lateral view of composite mold ( $\times 5)$. GXD-615 (=USNM 374632).

1-3 and 5 from the Nagaoling Member, Nagaoling Formation, Section 1, Bed 10 (Gedinnian).

6. Left-lateral view of composite mold ( $\times 5$ ). Mahuangling Member, Nagaoling Formation (Gedinnian), Section 1, Bed 13. GXD-599.

4, 7. Schizodus aff. S. appressus (Conrad), 1842 (p. 80)+

4. Right-lateral view of squashed composite mold $(\times 2)$. Ertang Formation (Emsian), Locality 9. GXD-593.

7. Left-lateral view of composite mold showing anterior adductor muscle scar (arrow) ( $\times 3$ ). Horizon and locality the same as in figures 1-5 above. GXD-616.

8. Mecynodon aff. $M$. carinatus (Goldfuss), 1837 (p. 84)+

Right valve composite mold showing profile and impression of posterior lateral tooth (arrow) ( $\times 4$ ). Nagaoling Formation (Gedinnian), Locality 7. GXD-640. 
GEOLOGICAL SURVEY
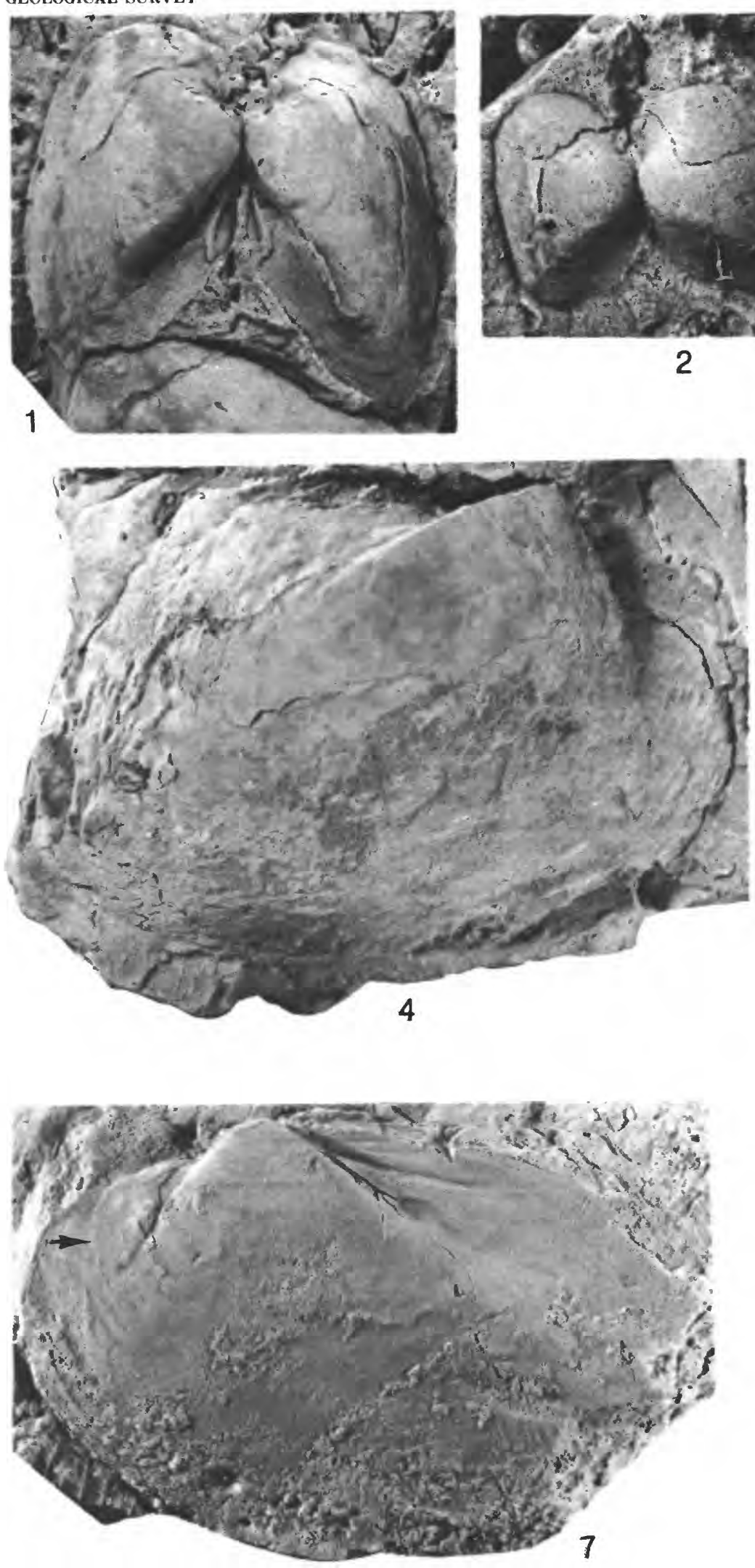

PROFESSIONAL PAPER 1394 PLATE 29
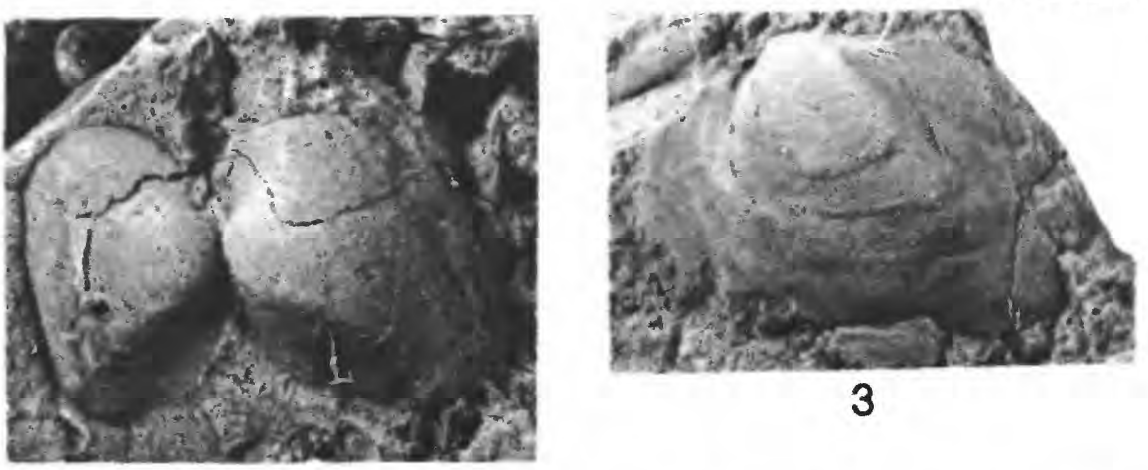

3

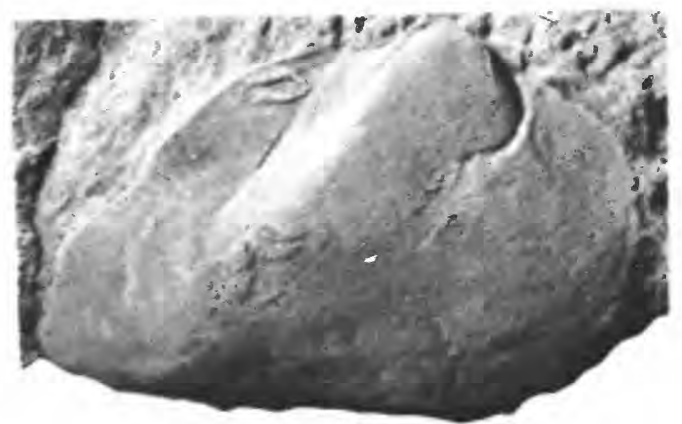

5

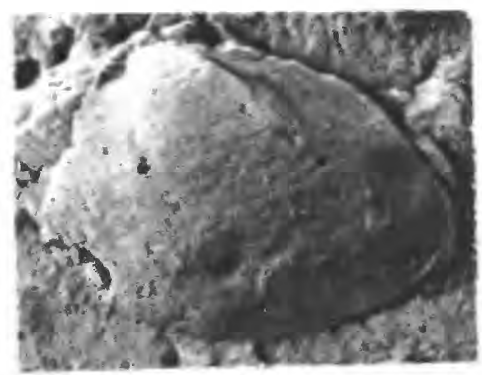

6

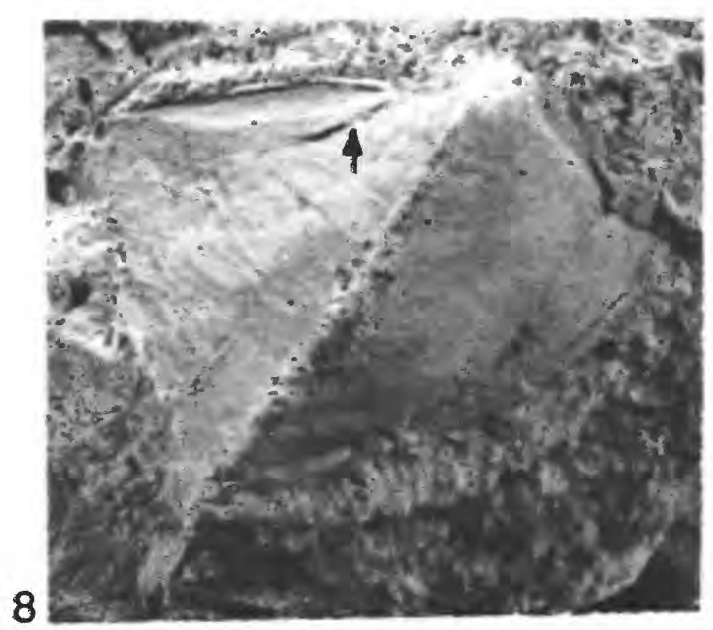




\section{PLATE 24}

Figures 1-7. Nyassa dorsata (Goldfuss), 1840 (p. 80)+

1. Oblique dorsal view of internal mold showing impressions of teeth mediad the beak (arrow) $(\times 4$ ). Panther Mountain Formation (Givetian), 0.5-0.75 miles west, southwest of West Fulton, N.Y. USNM 101706.

2. Left-lateral view of internal mold showing profile, anterior adductor muscle scar (arrow) and some of anterior part of pallial line $(\times 2)$. Horizon and locality the same as in figure 1 above. USNM 374635 .

3. View of anterior end of incomplete internal mold showing anterior adductor (horizontal arrow) and pedal retractor muscle scars (vertical arrow) and impressions of teeth anterior and posterior to beaks (white arrows) $(\times 4)$. Horizon and locality the same as in figure 1 above. USNM 374636.

4, 5. Dorsal and right-lateral views of a weathered internal mold ( $\times 3.5)$. Donggangling Formation (Givetian), Section 3, Bed 24. GXD-620.

6. Left-lateral view of internal mold showing profile (compare with fig. 2) most of pallial line and posterior adductor muscle scar (arrow) ( $\times 3.5)$. Horizon and locality the same as in figure 4 above. GXD-624 (=USNM 374637).

7. Left-lateral view of weathered internal mold showing much of the pallial line and the posterior adductor muscle scar $(\times 3.5)$. Horizon and locality the same as in figure 4 above. GXD-623.

8. Sinodora concava Pojeta and Zhang, 1984 (p. 88)+

Right-lateral view of composite mold showing profile and ornament $(\times 6)$.

Ertang Formation (Emsian), Section 4, Bed 36. GXD-696. 
GEOLOGICAL SURVEY

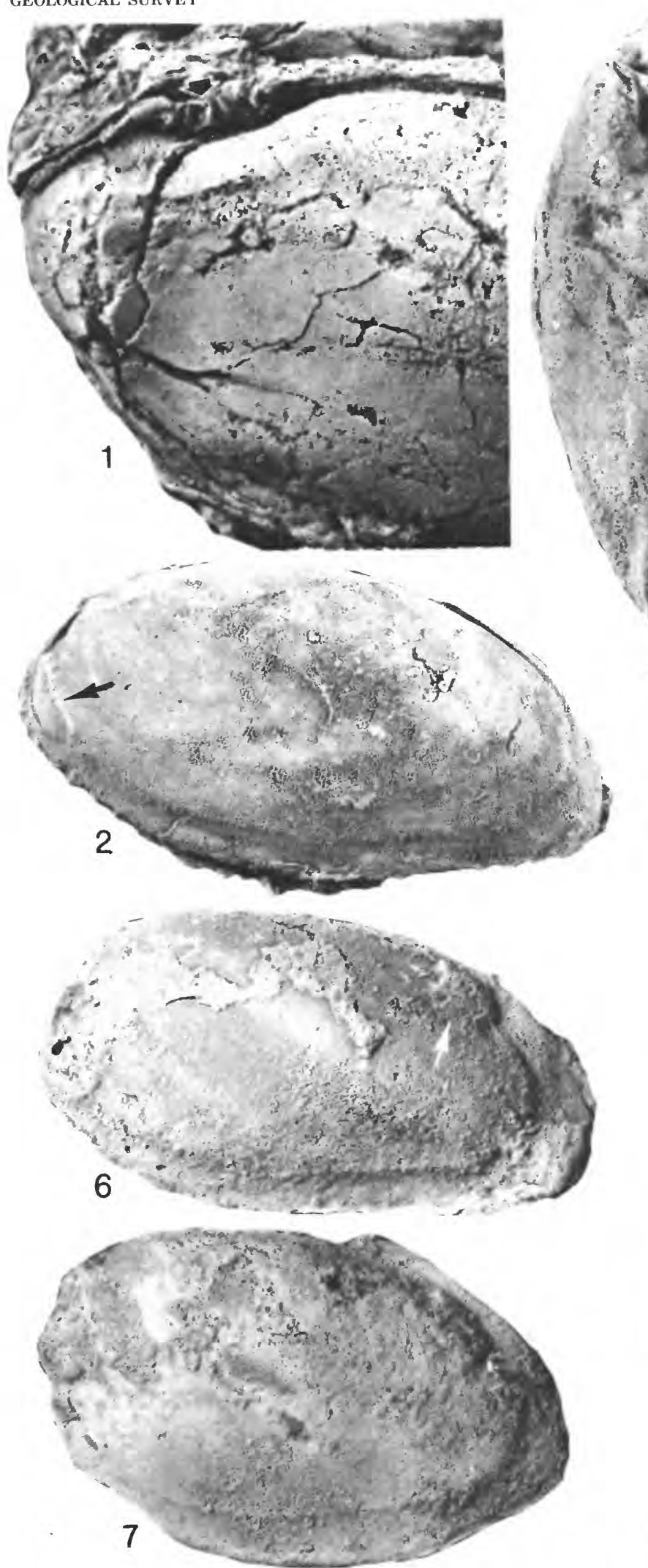

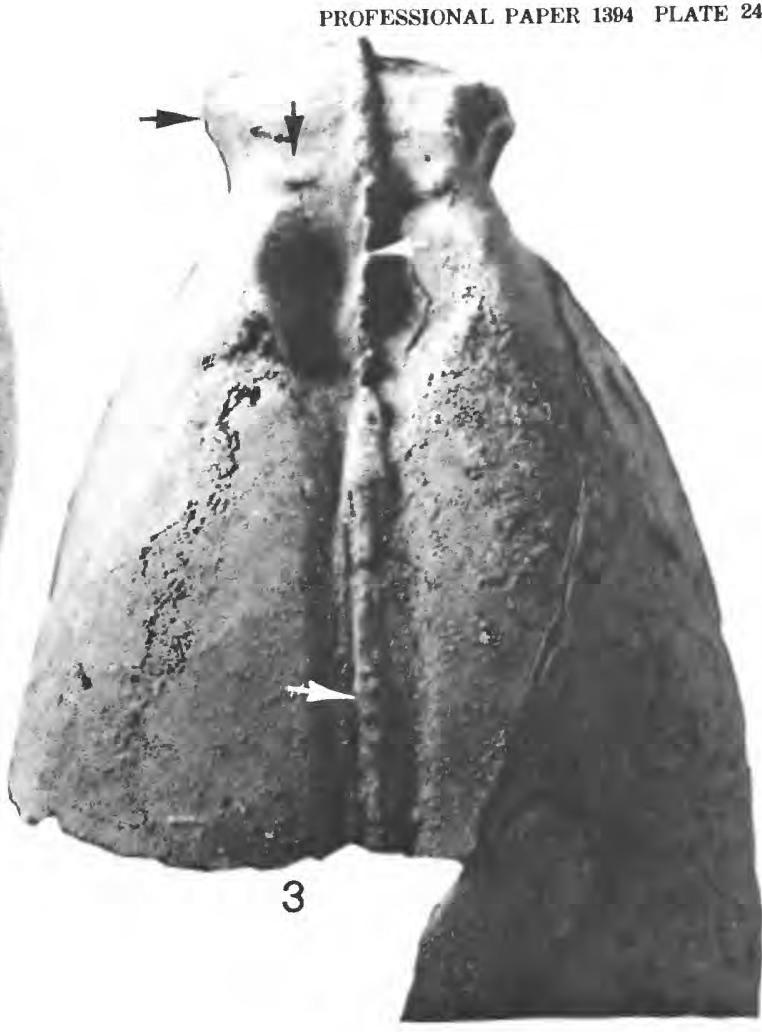

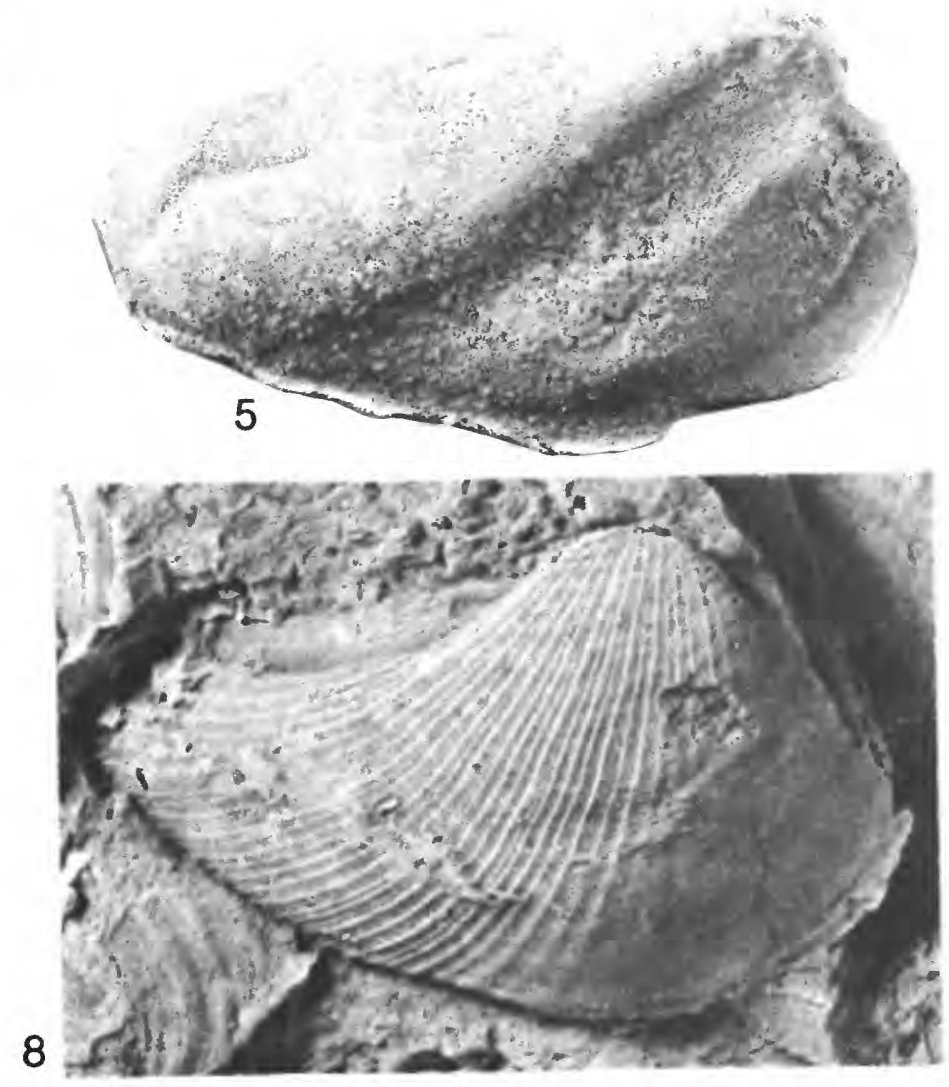

NYASSA AND SINODORA 


\section{PLATE 25}

Figures 1-8. Tanaodon louderbacki Kirk, 1927 (p. 79)+

1, 3. Shelled specimen, left-lateral and dorsal views ( $\times$ 1.5), Middle Devonian, “Tung Kou District," Sichuan, China, paralectotype. USNM 374627.

2. Interior of incomplete left valve, shelled specimen, showing dentition and anterior adductor muscle scar (arrow) $(\times 1.5)$. Horizon and locality the same as in figure 1 above, lectotype. USNM 102049.

4. Right-lateral view of internal mold showing profile ( $\times 1.5$ ). Upper Member, Yingtang Formation (Eifelian), Section 5, Bed 18. GXD-589.

5. Shelled specimen, interior of incomplete left valve showing teeth, posterior pseudolateral teeth with denticles, and anterior part of pallial line (arrow) ( $\times 3$ ). Middle Devonian (Givetian), 25 miles northwest of Charles Towers, Queensland, Australia. Topotype of Neoactinodonta amygdalina Heidecker. USNM 138811.

6 , 7. Shelled specimen, right-lateral and dorsal views $(X 1.5)$. Horizon and locality the same as in figure 5 above. Topotype of Neoactinodonta amygdalina Heidecker. USNM 374633.

8. Shelled specimen, left-lateral view $(\times 1.5)$. Horizon and locality the same as in figure 5 above. Topotype of Neoactinodonta amygdalina Heidecker. USNM 374644. 


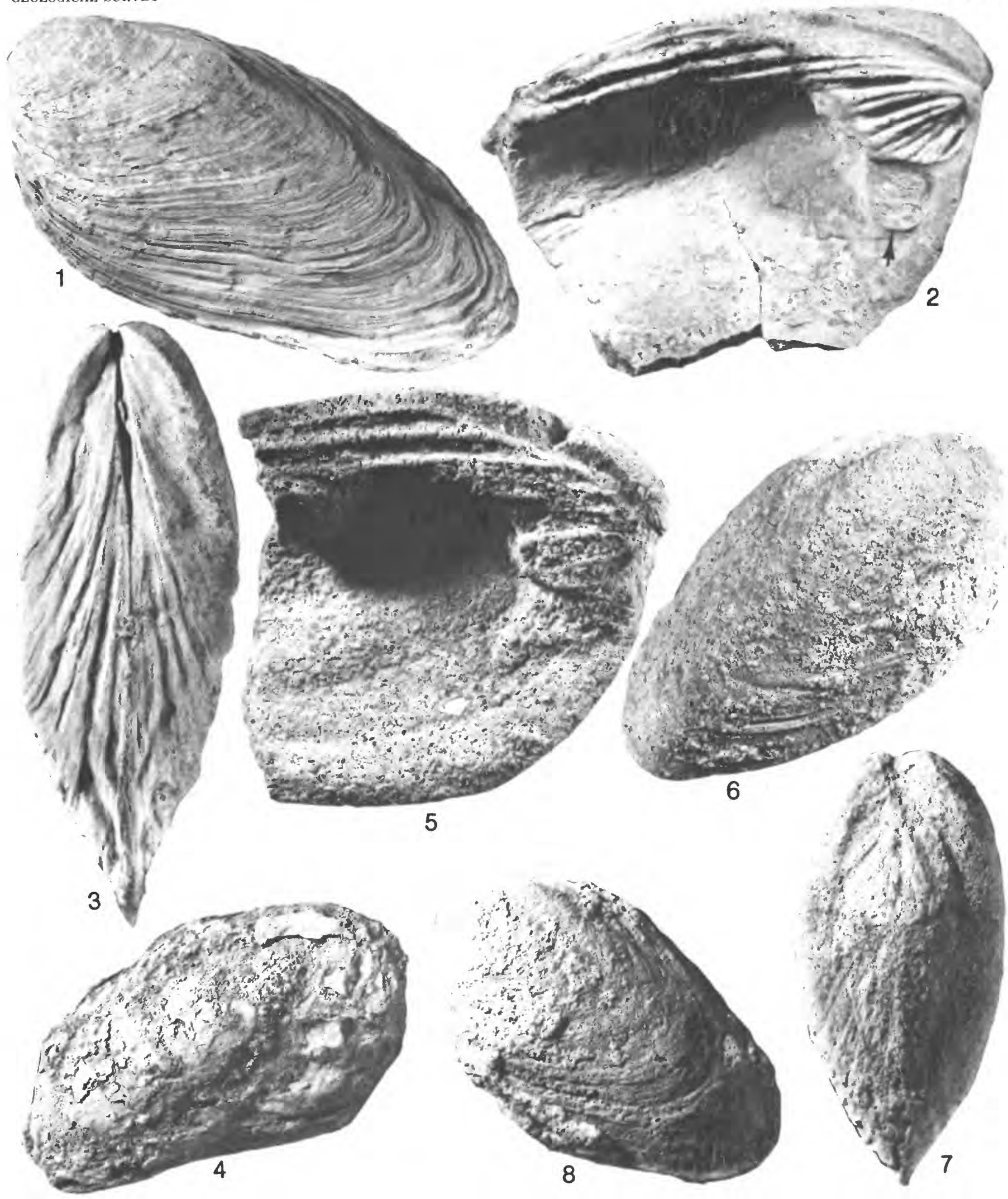




\section{PLATE 26}

Figures 1-8. Tanaodon louderbacki Kirk, 1927 (p. 79)+

1, 8. Internal mold of left valve showing teeth, hinge plate, and remnant of posterior adductor muscle scar (arrow) and enlargement of dentition showing denticles on posterior pseudolateral teeth $(1, \times 4 ; 8, \times 8)$. Horizon and locality the same as in plate 25, figure 4. GXD-582.

2 , 7. Internal mold of left valve, nearly dorsal view, enlargement showing denticles on posterior pseudolateral, teeth and entire specimen showing teeth and anterior adductor muscle scar (arrow) $(2, \times 6 ; 7, \times 3)$. Horizon and locality the same as in plate 25 , figure 4 . GXD-571.

3 , 4. Internal mold of left valve showing anterior adductor muscle scar and numerous teeth; enlargement of teeth shows denticles on pseudocardinal teeth $(3, \times 2 ; 4, \times 4)$. Horizon and locality the same as in plate 25 , figure 4. GXD-575.

5. Internal mold showing anterior adductor muscle scar $(\times 3)$. Horizon and locality the same as in plate 25 , figure 4 . GXD-577.

6. Internal mold, oblique view of teeth showing denticles on posterior pseudolateral teeth $(\times 4)$. Horizon and locality the same as in plate 25 , figure 4. GXD-565. 

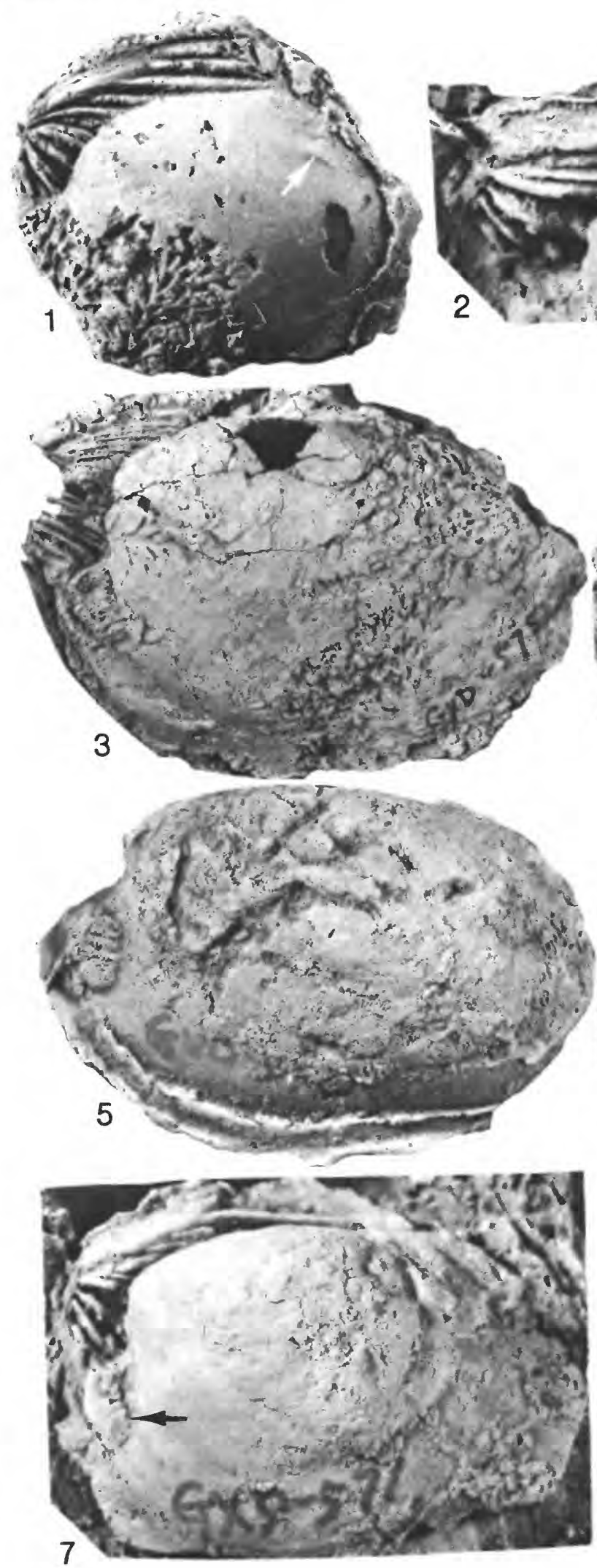

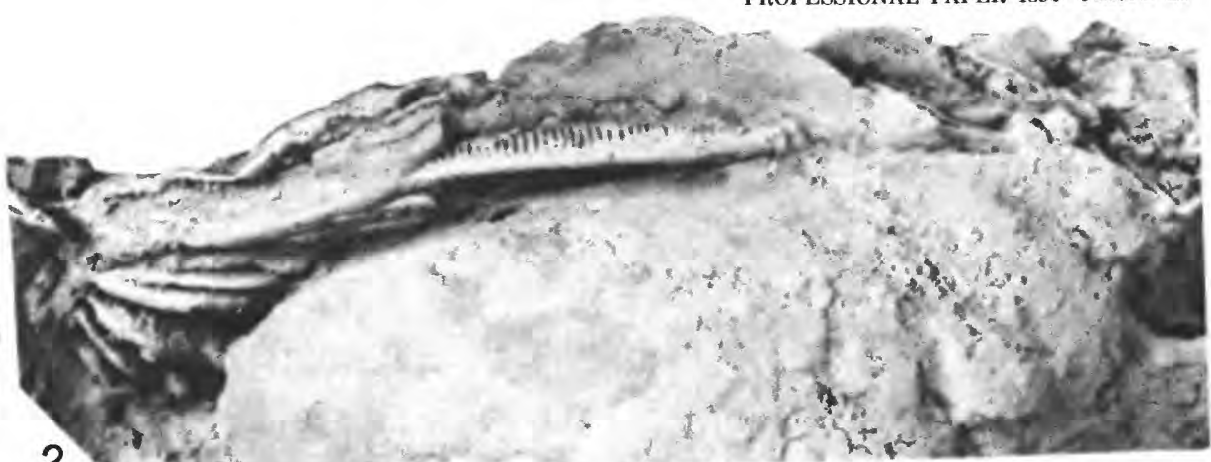

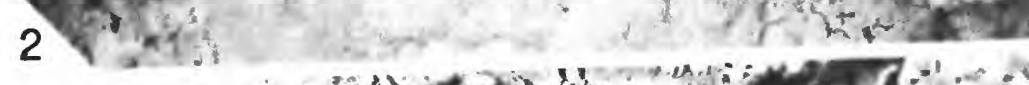

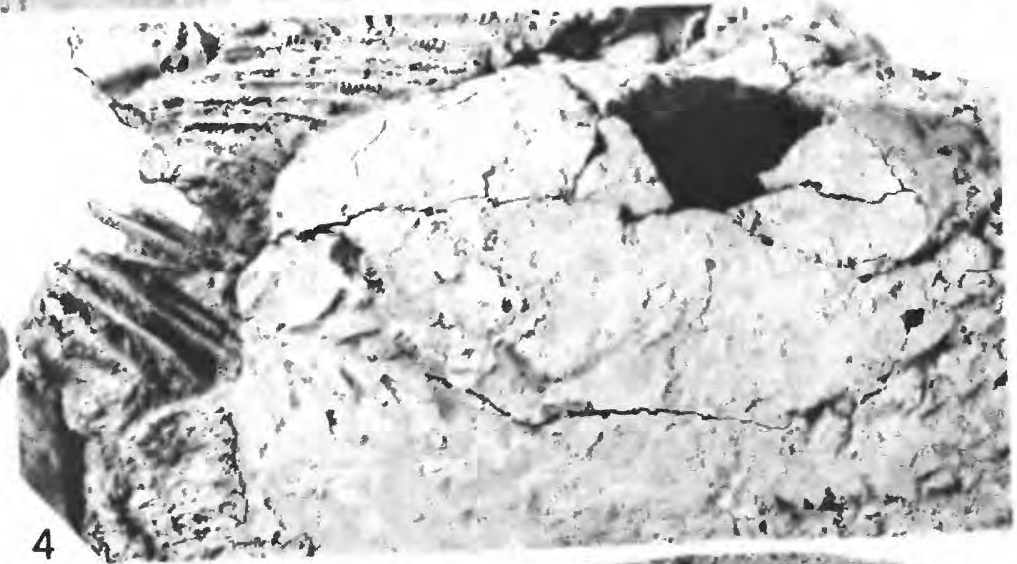

6

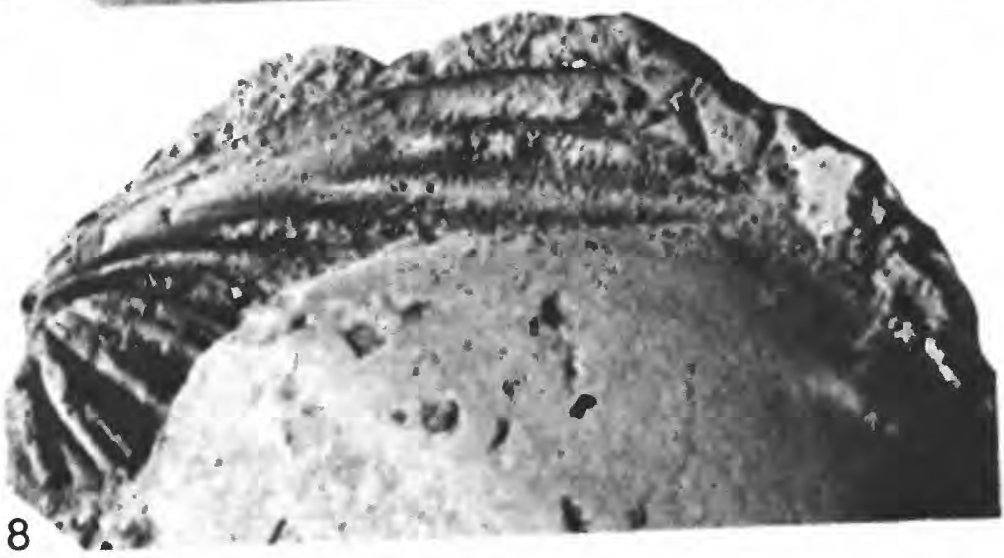




\section{PLATE 27}

FIGURES 1-8. Sedgwickia? yingtangensis n. sp. (p. 88)+

1. Composite mold of left valve ( $\times 3$ ), paratype. GXD-631.

2. Composite mold of right valve ( $\times 3$ ), paratype. GXD-633.

3 . Composite mold of right valve $(\times 3)$, paratype. GXD-628.

4. Composite mold of right valve $(\times 3)$, paratype. GXD-634.

5 , 6. Two composite molds of left valves $(\times 3)$, paratypes. GXD-626, -627 (=USNM 374648, 374649).

7. Composite mold of left valve ( $\times 3$ ), paratype. GXD-629.

8. Composite mold of left valve ( $\times 3)$, holotype. GXD-630.

All specimens from the Yingtang Formation (Eifelian), Section 5, Bed 16. Arrows point to intercalating rugae. 

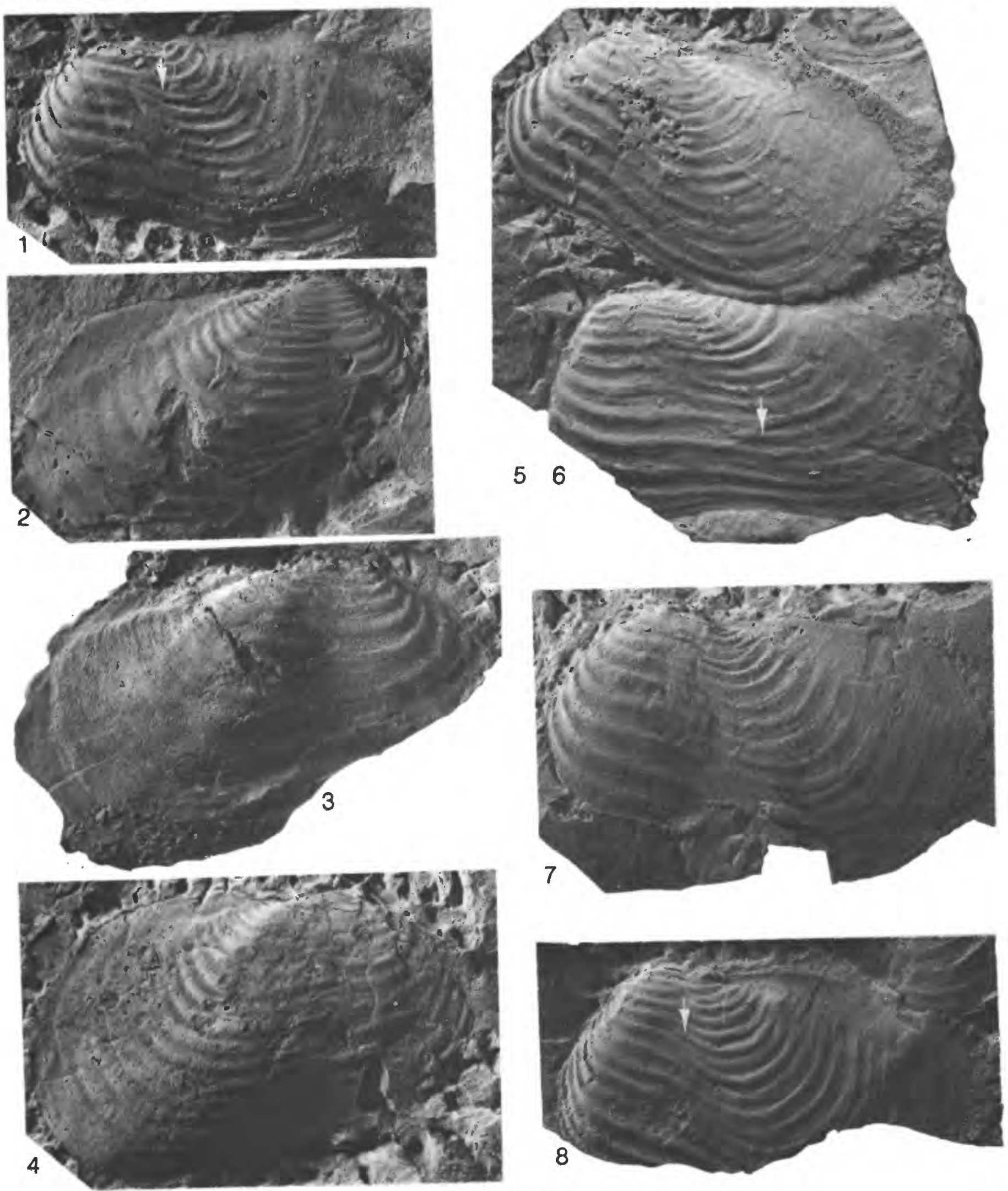


\section{PLATE 28}

Figure 1. Orthonota undulata Conrad, 1841 (p. 76)*

Dorsal view of spread valves of lectotype showing valve profiles, ornament, and midumbonal sulci (arrows) $(\times 1.5)$. Hamilton Group, N.Y. ANSP 61406.

2, 3. Orthonota guangdongensis Zhang, 1977 (p. 77) +

2. Incomplete left valve composite mold showing ornament and lack of midumbonal sulcus $(\times 3)$. Ertang Formation (Emsian), Section 3, Bed 10. GXD-721.

3. Dorsal view of spread valves of composite mold showing profile, ornament, and so forth $(\times 2)$. Sipai Formation (Emsian), Section 3, Bed 13. GXD-720.

4. Radiatodonta? sp. A (p. 75)+

Internal mold of right valve showing profile; the upper part of the umbo has been removed to show the conical structures separated by a groove that are below the umbo (arrow) $(\times 3)$. Nagaoling Formation (Gedinnian), Locality 7 , GXD-619.

5. Sedgwickia sp. (p. 87)*

Right-lateral view of a shelled specimen showing midumbonal sulcus and intercalation of ornament across the sulcus (arrow) $(\times 2)$. Graham Formation (Upper Pennsylvanian), 5.3 miles northeast of Finis, Jack County, Tex. USNM 165772.

6. Grammysioidea sp. indet. (p. 85$)+$

Weathered left valve composite mold $(\times 2)$. Yilan Formation (SiegenianEmsian; Nandan Facies), Locality 12. GXD-725.

7. Grammysioidea sp. indet. (p. 85)+

Crushed right valve $(\times 2)$. Yujiang Formation (Siegenian-Emsian), Section 1, Bed 21. GXD-724. 
GEOLOGICAL SURVEY
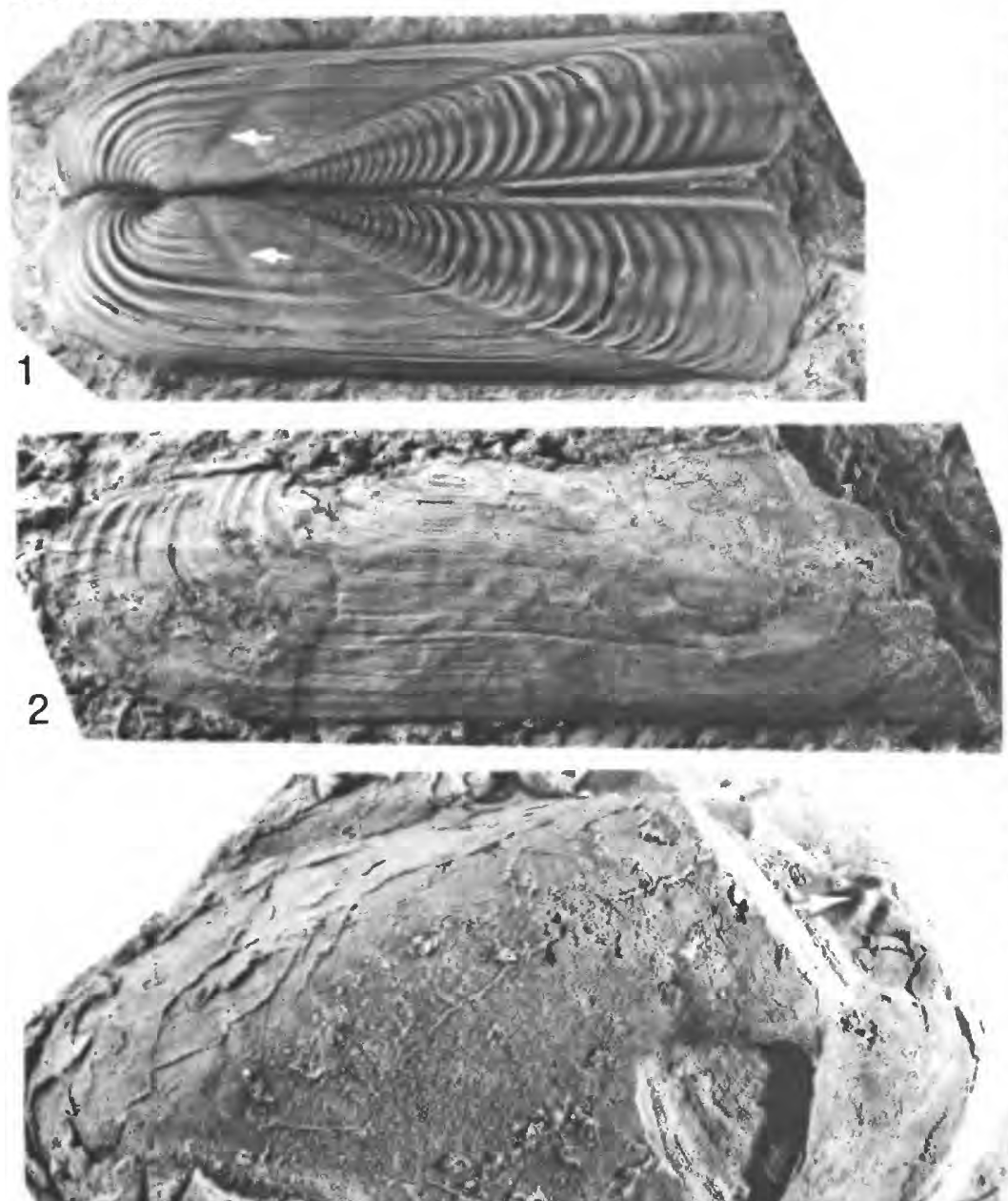

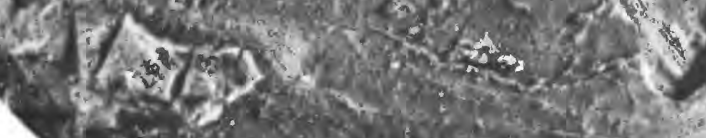

4

$+2$
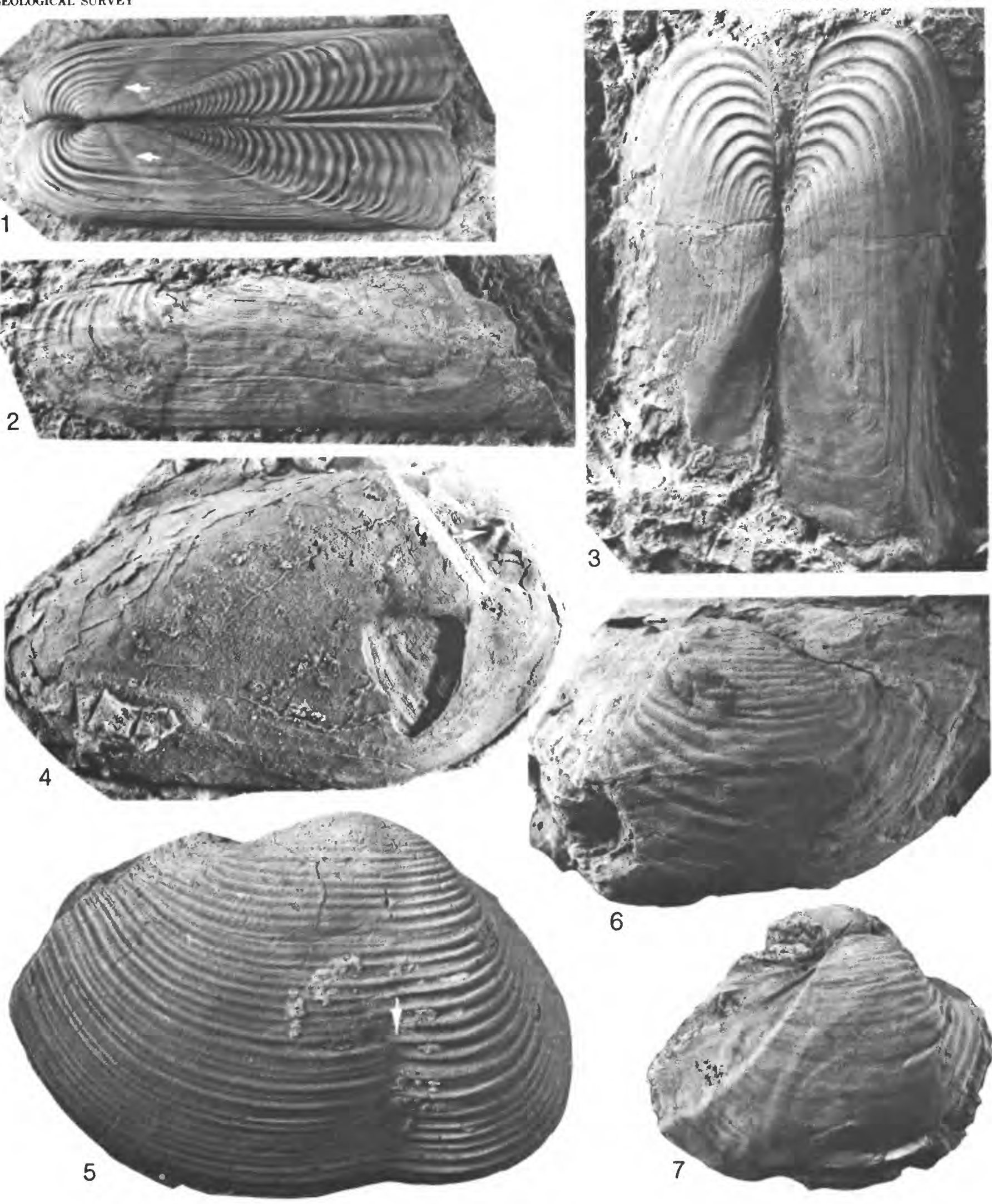

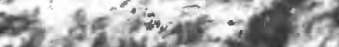

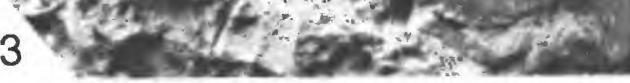

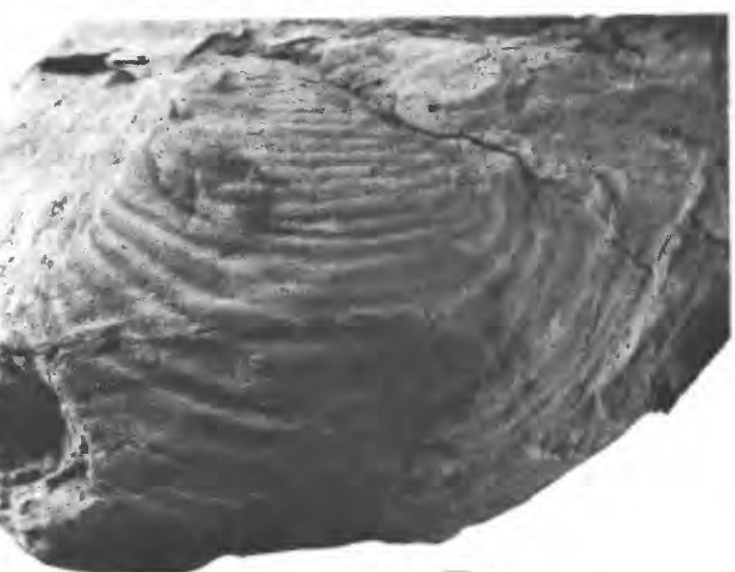

6

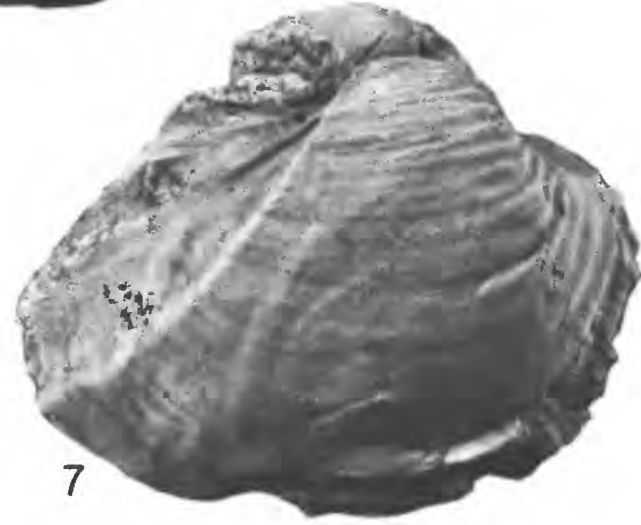

ORTHONOTA, RADIATODONTA?, SEDGWICKIA, AND GRAMMYSIOIDEA 


\section{PLATE 29}

Figures 1-3. Edmondia aff. E. subovata Hall, 1885 (p. 84)+

1. Left-lateral view of incomplete composite mold (X 2). GXD-709.

2. Dorsal view of spread valves of composite mold showing hinge plate furrows (arrow) $(\times 2)$. GXD-704.

3. Dorsal view of spread valves of composite mold showing hinge plate furrows $(\times 2)$. GXD-702.

All specimens from the Donggangling Formation (Givetian), Section 3 , Bed 23.

4-6. Edmondia aff. E. philipi Hall and Whitfield, 1870 (p. 84)+

4,5 . Dorsal and right-lateral views of internal mold showing profiles $(\times 2.5)$. GXD-708.

6. Left-lateral view of internal mold showing profile ( $\times 2$ ). GXD-705.

Both specimens from the Donggangling Formation (Givetian), Section 3 , Bed 23.

7. Grammysioidea sp. indet. (p. 85)+

Right-lateral view of a highly weathered specimen $(X 2)$. Yujiang Formation (Siegenian-Emsian), Locality 11. GXD-723. 
GEOLOGICAL SURVEY
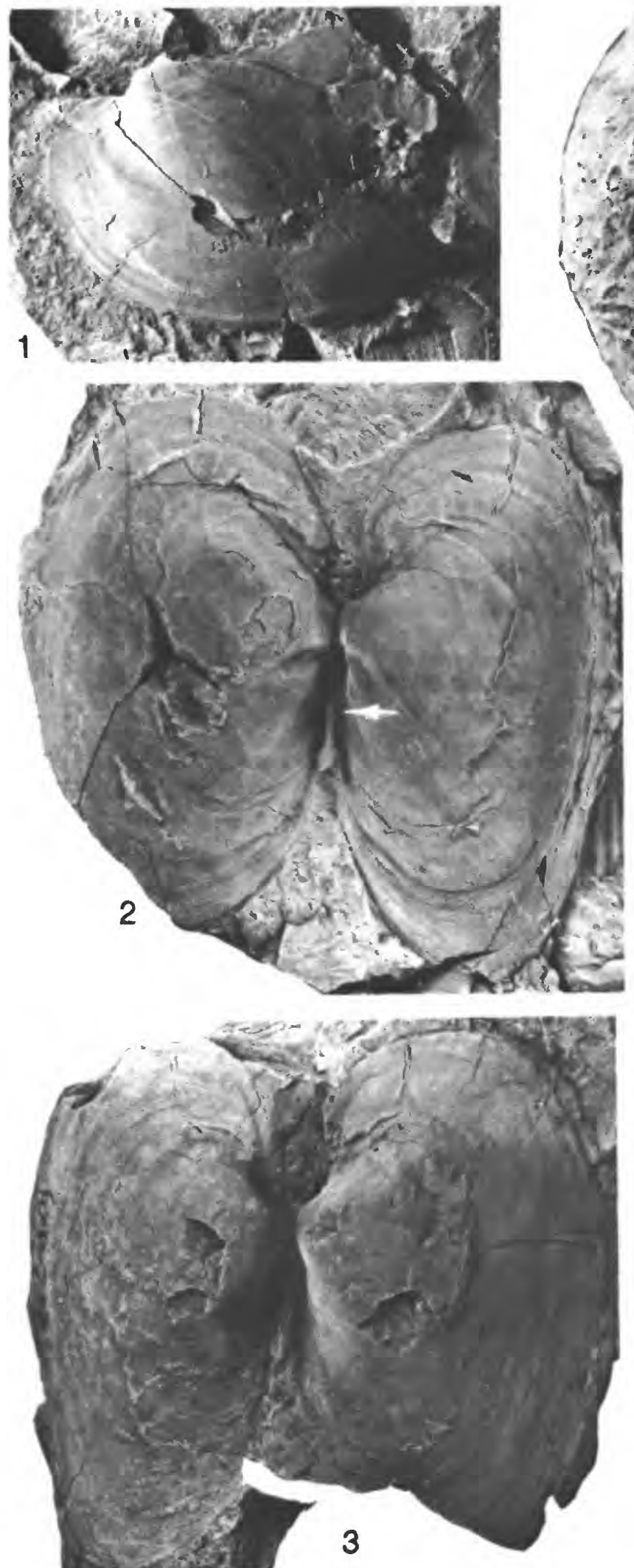

UROFESSIONAL PAPER 1994 PLATE
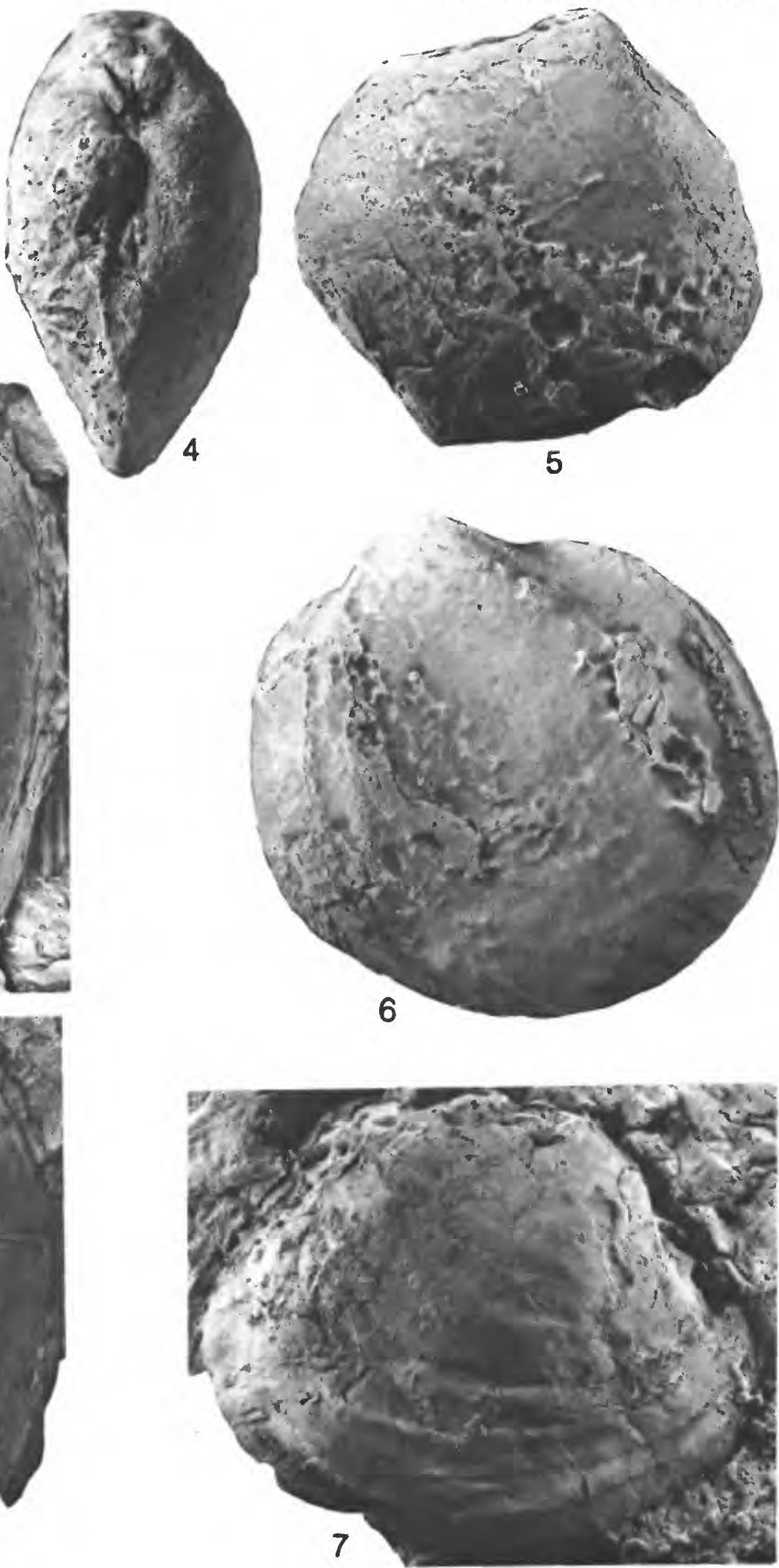


\section{PLATE 30}

Figure

1. Sanguinolites? sp. (p. 87)+

Left-lateral view of an incomplete composite mold $(\times 3)$. Yujiang Formation (Siegenian-Emsian), Section 1, Bed 21. GXD-731.

2. Edmondia aff. E. philipi Hall and Whitfield, 1870 (p. 84 )+

Right-lateral view of internal mold showing profile $(\times 2)$. Donggangling Formation (Givetian), Section 3, Bed 23. GXD-705a.

3, 4. Cardiomorpha? sp. indet. (p. 85)+

Right-lateral view and view of impressions of cardinal teeth (arrows) (umbos removed) of an internal mold ( $\times 2$ ). Yingtang Formation (Eifelian), Section 5, Bed 21. GXD-714.

5-7. Sphenotus yingtangensis n. sp. (p. 86)+

5. Right-lateral view of composite mold showing profile and two posterodorsal ribs (X 4). Paratype, GXD-747.

6. Left-lateral view of composite mold showing profile and posterodorsal ribs (X 3). Holotype, GXD-746.

7. Right-lateral view of composite mold showing profile and two posterodorsal ribs $(\times 3)$. Paratype GXD-740.

All specimens from the Yingtang Formation (Eifelian), Section 5, Bed 16.

8. Sanguinolites? sp. (p. 87)+

Distorted and compressed right valve composite mold $(\times 3)$. Donggangling Formation (Givetian), Section 3, Bed 23. GXD-560. 
GEULUGICAL SURVEY
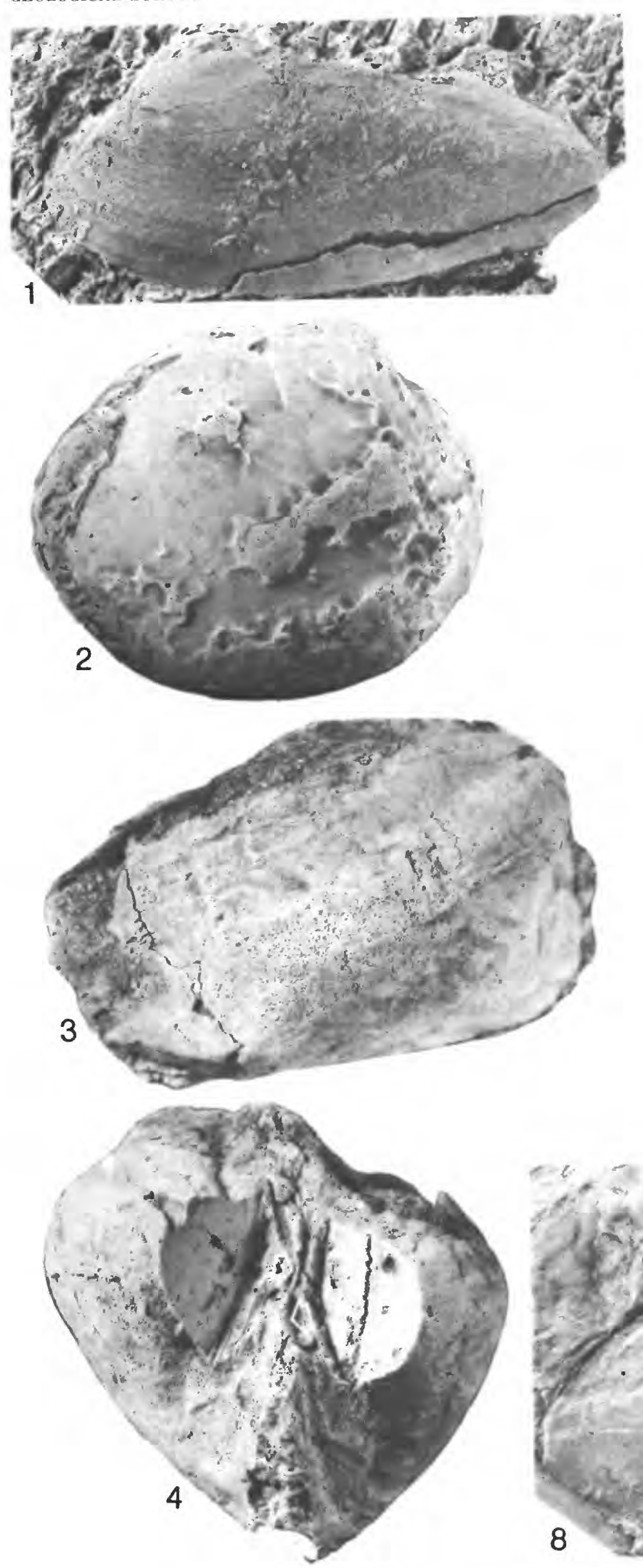

PROFESSIONAL PAPER 1394 PLATE 30
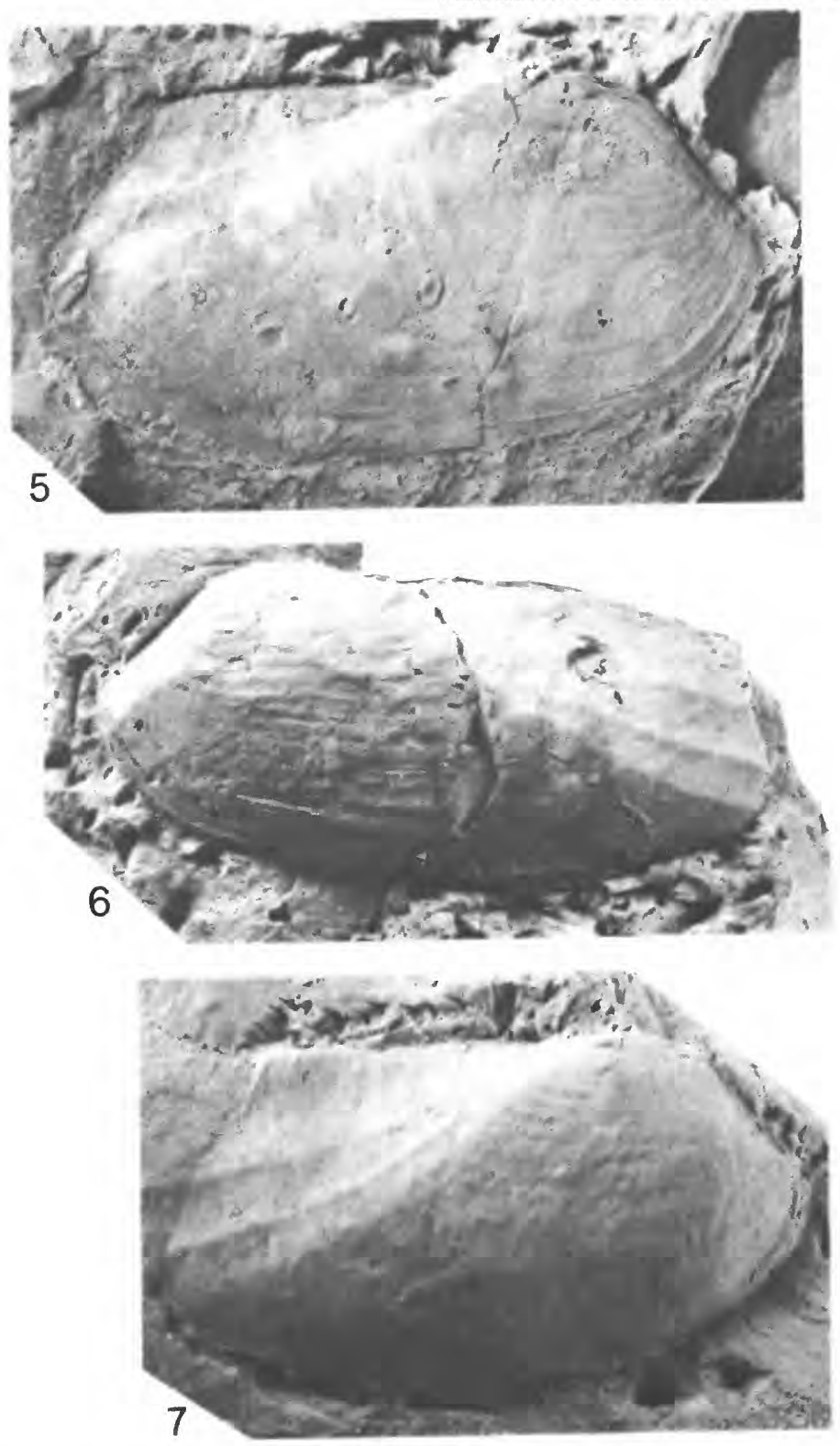

SANGUINOLITES? EDMONDIA, CARDIOMORPHA?, AND SPHENOTUS 


\section{PLATE 31}

Figures 1-6. Sanguinolites nagaolingensis n. sp. (p. 86)+

1. Right-lateral view of composite mold showing lack of posterodorsal ribs and relict comarginal rugae anteriorly and ventrally $(\times 2.5)$. Paratype GXD-726 (=USNM 374650).

2. Right-lateral view of composite mold showing lack of posterodorsal ribs and comarginal rugae ventrally ( $\times 2.5$ ). Paratype, GXD-727.

3. Right-lateral view of composite mold showing relict comarginal rugae anteriorly and ventrally ( $\times 2.5$ ). Paratype, GXD-735.

4. Dorsal view of spread valves of internal mold showing comarginal rugae ( $\times$ 3.5). Paratype, GXD-719.

5 , 6. Left-lateral view $(\times 2.5)$ and enlargement of anterior end $(\times 5)$ showing intercalation (vertical arrow) and bifurcation (horizontal arrow) of comarginal rugae. Holotype, GXD-743.

All figured specimens from the Nagaoling Formation (Gedinnian), Section 1. Bed 13.

7, 8. Cimitaria sinensis n. sp. (p. 87$)+$

7. Dorsal view of poorly preserved spread valves, composite mold $(\times 1)$. Yujiang Formation (Siegennian-Emsian), Section 1, Bed 21. Paratype, GXD-748. (See pl. 35, fig. 1.)

8. Left-lateral view of internal mold showing profile, anterior adductor muscle scar (arrow), and posterodorsal rib $(\times 1.5)$. Ertang Formation, Section 3, Bed 10. Holotype, GXD-718. 
GEOLOGICAL SURVEY
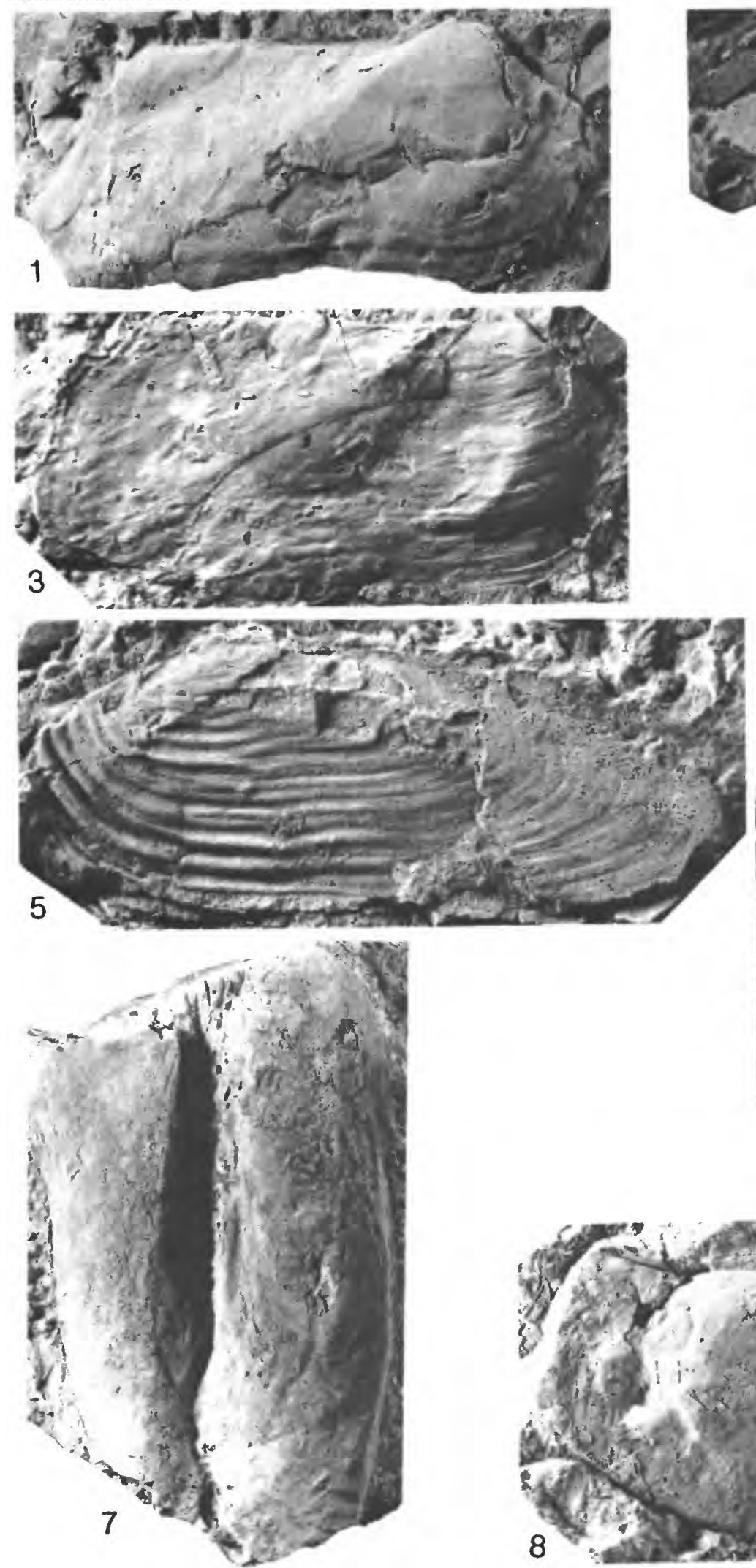

PROFESSIONAL PAPER 1394 PLATE 31
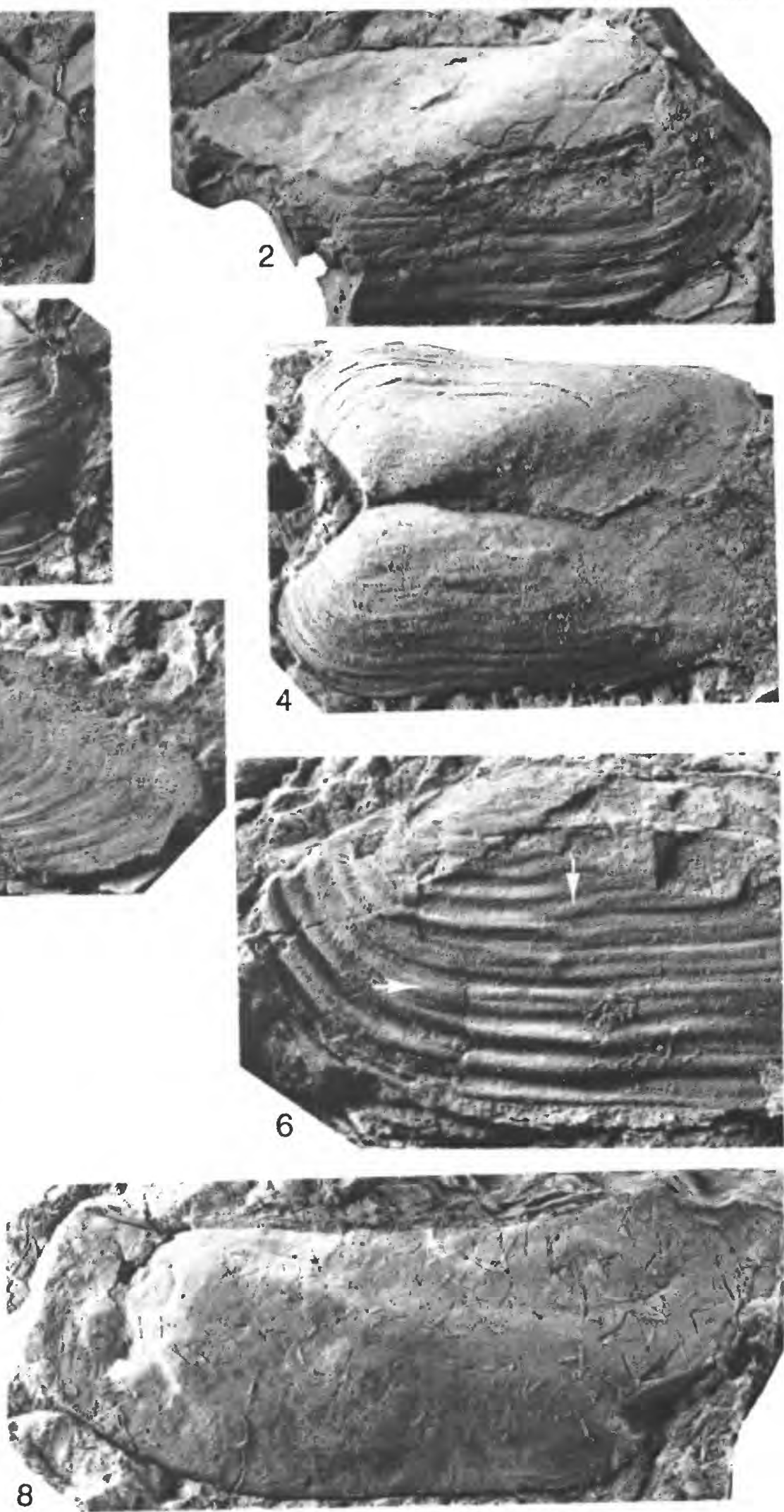

SANGUINOLITES AND CIMITARIA 
PLATE 32

Figures 1-10. Fasciculiptera guangxiensis Zhang, 1977 (p. 89)+

1-4. (1) Right-lateral, (2) anterior, (3) left-lateral, and (4) ventral views of a shelled specimen showing profiles, small spines on umbonal ribs (arrows), and interdigitation of plicae $(1-3, \times 2.5 ; 4, \times 3)$. Donggangling Formation (Givetian), Section 2, bed unknown. Topotype, GXD-190a. (See pl. 33, fig. 2.)

5 ,6. Anterior and right-lateral views of a shelled specimen showing profiles, ribs on the anterior lobe, strong growth lamellae on the umbonal ribs, and costellae $(5, \times 3 ; 6, \times 2.5)$. Horizon and locality the same as in figures 1-4 above. Topotype, GXD-190. (See pl. 33, fig. 4.)

7-9. (7) Right-lateral, (8) dorsal, and (9) anterior views of an internal mold showing profiles, the plicae do not reach the apex, anterior lobe (white arrow) and socket in left valve (black arrow) $(\times 4)$. Donggangling Formation (Givetian), Section 3, Bed 23. GXD-203.

10. Left-lateral view of a complex composite mold showing that ribs reach the beak $(\times 3)$. Horizon and locality the same as in figures 7-9 above. GXD-201. 

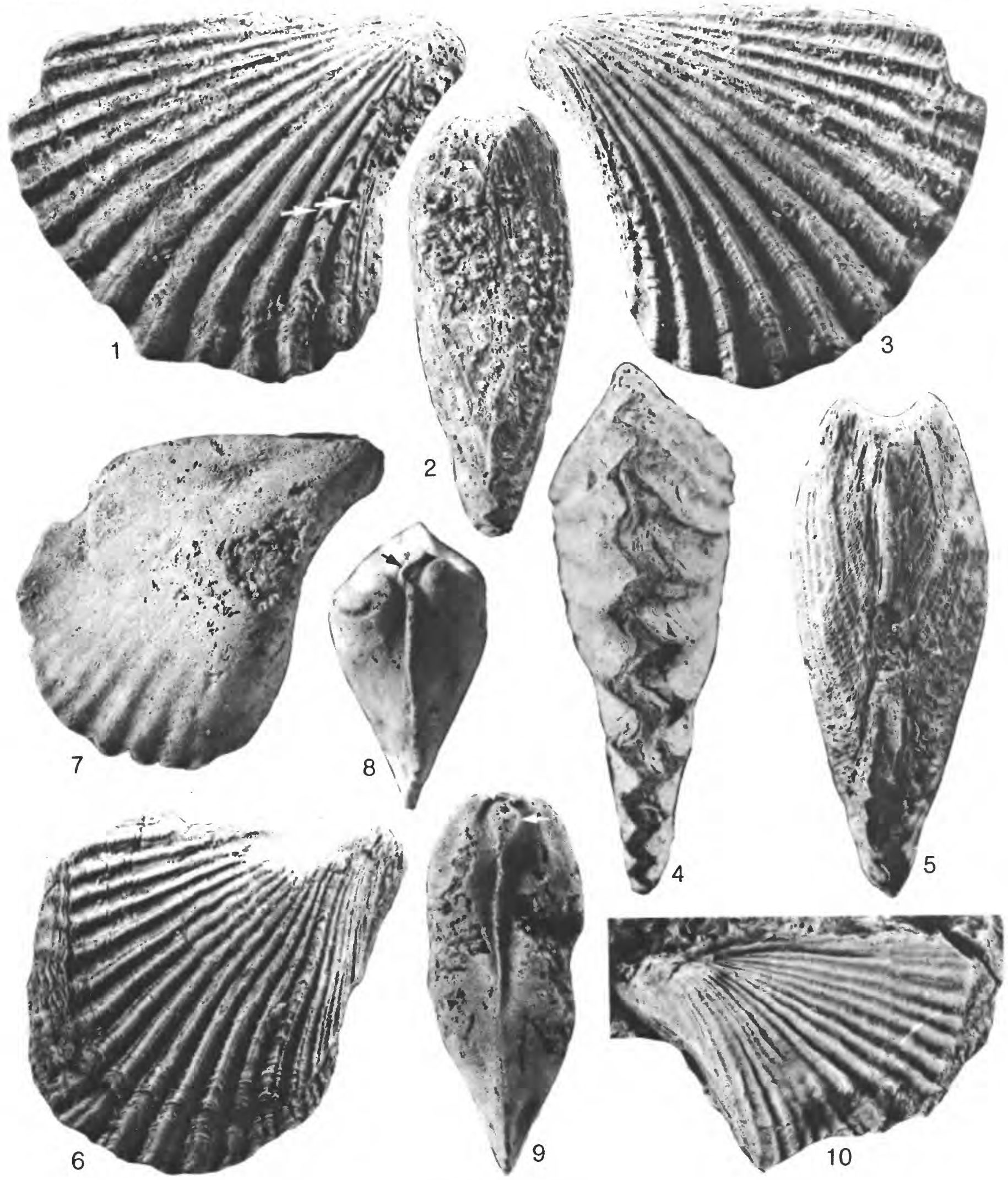

FASCICULIPTERA 


\section{PLATE 33}

Fueures 1-7, Fascieubiphtena guangxiensis Zhang, 1977 (p. 89)+

1. Right-lateral view of a shelled specim showing profile, plicae and costellae, and prominent, growth lamellae on umbonal rib $(X 3)$, Horzon and locality the same as plate 32, figures 1-4. Topotype, GXD-192.

2. Enlargement of spines on the midumbenal rib of right valve of the specimen shown on plate 32 , figure $1(X) 4)$. GXD-190a.

3. Enlargement of the central part of the left valve of a shelled specimen show. ing fascieles of central plicae to either side of which are costellae (X 4). Horizon and locality the same as plate $\$ 2$, figures 1-4. Topotype, GXD-193.

4. Enlargement of the ventral part of the specimen shown on plate 32 , figures 5 and 6 , showing raised growth lamellae which form half rings on the umbonal vilu (arrow) (X) 5) GXD-190.

5. Right-lateral view of a complex eomposite mold showing profile, cost and some costellae $(X 3)$. Horizon and locality the same as plate 32 , figures 7-9. GXD-212 (=USNM 383.610).

6. Right-lateral view of a complex composite mold showing costae and costellaes small posterior wing; and small spines on upper part of umbonal costace $(\times 5)$. Hoxizon and locality the same as plate 32, figures 7-9. GXD-204.

7. Right lateral view of a complex composite moll showing: raised growth lamellae on lower umbocal ribs, and ribs anterion lobe (arrow) $(\times 4)$. Horizon and locality the same as plate 32m figures $7-9$. GXD-200. 
GEOLOGICAL SURVEY

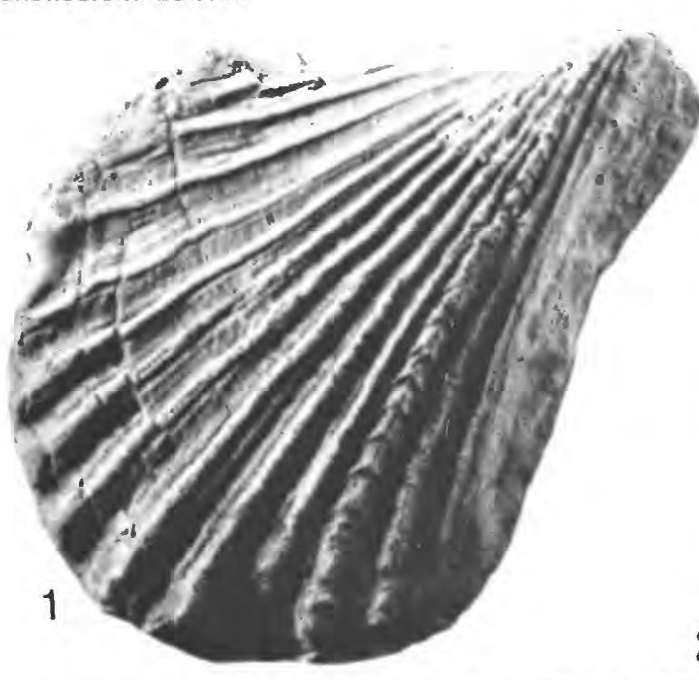

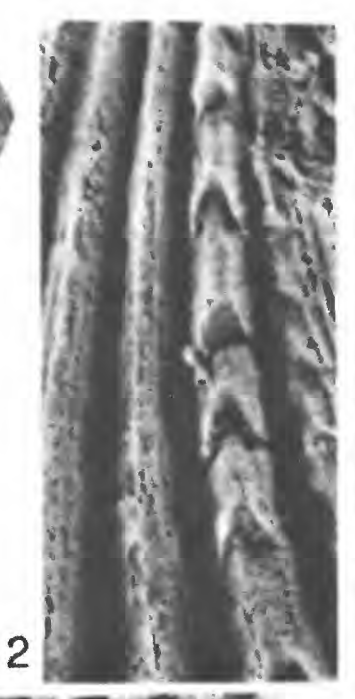

wa

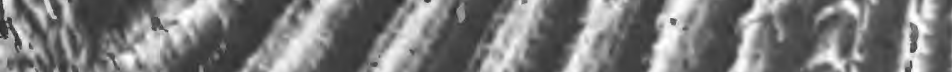

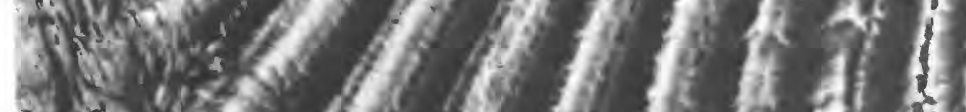
Q

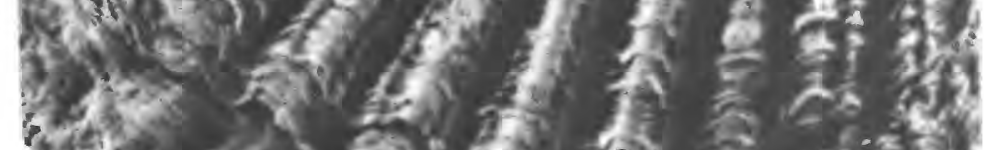

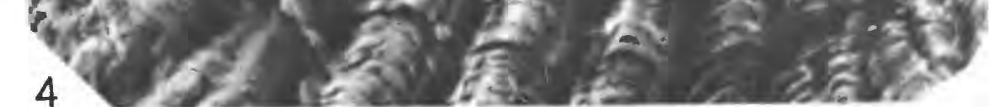

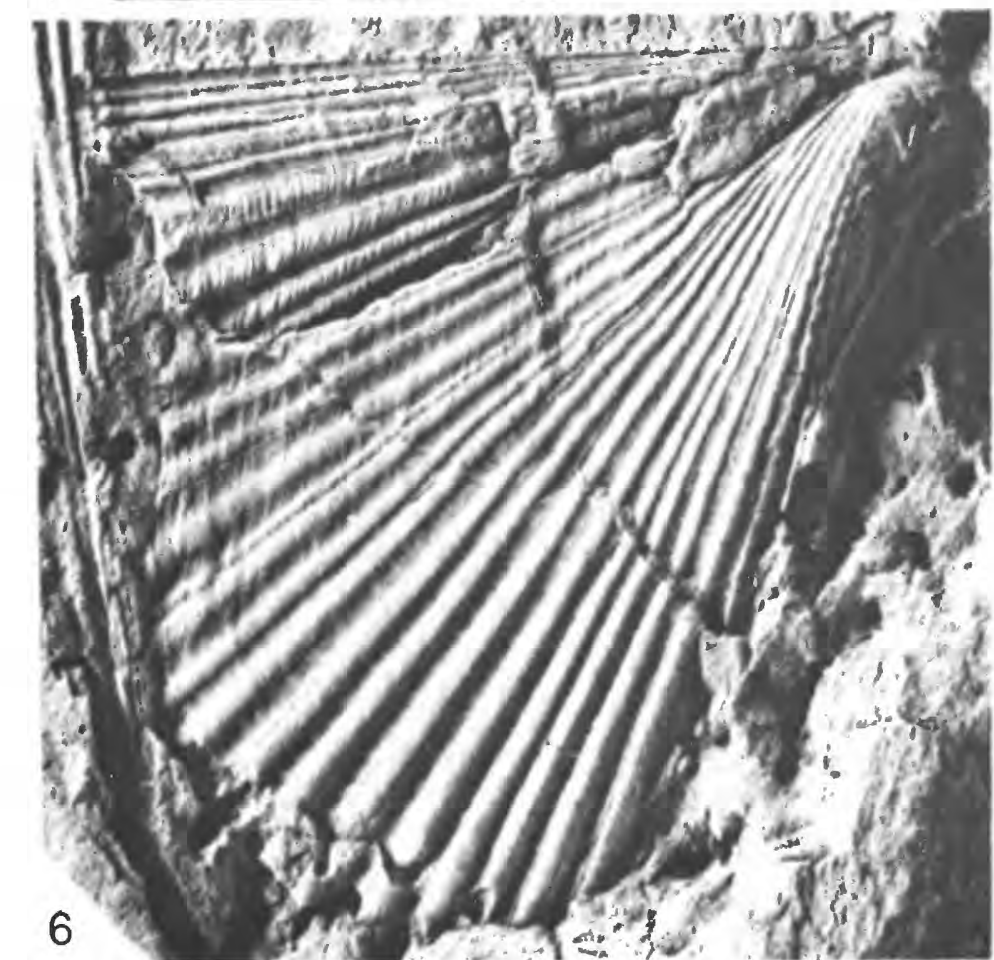

PROFESSIONAL PAPER 1

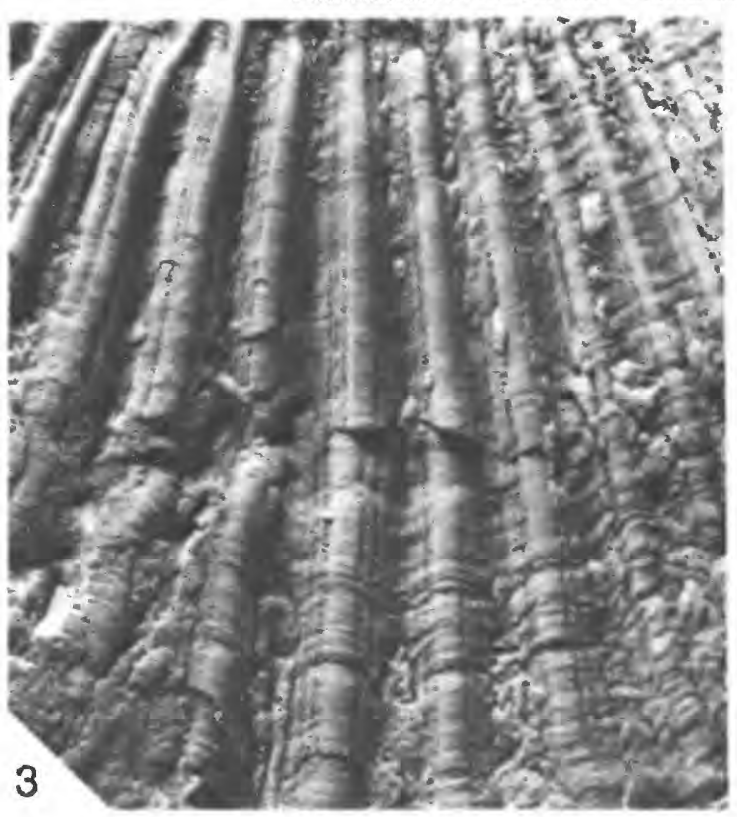

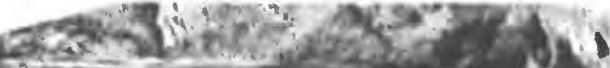
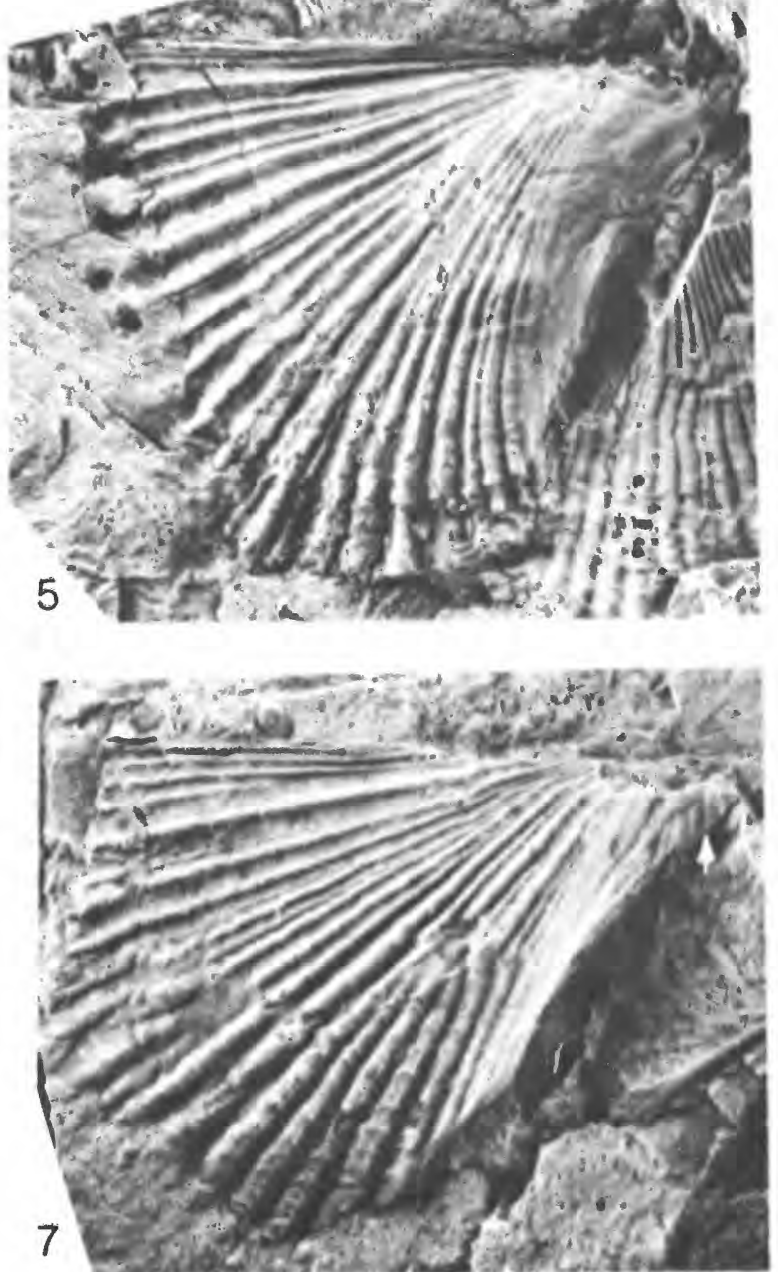


\section{PLATE 34}

Figures 1, 8, 9. Mytilarca cf. $M$. chemungensis (Conrad), 1842 (p. 91)+

1. Right-lateral view of an elongate internal mold $(\times 5)$. Ertang Formation (Emsian), Section 2, Bed unknown. GXD-183.

8. Right-lateral view of a composite mold $(\times 4)$. Yingtang Formation (Eifelian), Section 5, Bed 16. GXD-175.

9. Left-lateral view of a distorted composite mold $(X 5)$. Yujiang Formation (Siegenian-Emsian), Section 1, Bed 21. GXD-181.

2, 3. Mytilarca cf. $M$. oviformis (Conrad), 1842 (p. 92)+

Right-lateral and anterior views of an internal mold, which was compressed parallel to bedding. The deep byssal area is probably accentuated by distortion (X 1.5). Yujiang Formation (Siegenian-Emsian), Section 1, Bed 21. GXD-172.

4-7. Fasciculiptera sp. A (p. 90)+

4. Left-lateral view of a leached complex internal mold showing profile and some increase in the number of ribs on the posterodorsal auricle (× 2.5). Ertang Formation (Emsian), Locality 8. GXD-366.

5. Right-lateral view of a leached complex internal mold showing profile and ribs on the anterior lobe (arrow) ( $\times 3.5)$. Horizon and locality the same as in figure 4 above. GXD-367.

6, 7. Left-lateral view of an incomplete leached complex internal mold showing increase in the number of ribs on the posterodorsal auricle $(6, \times$ $2.5 ; 7, \times 7.5)$. Horizon and locality the same as in figure 4 above. GXD-370. 

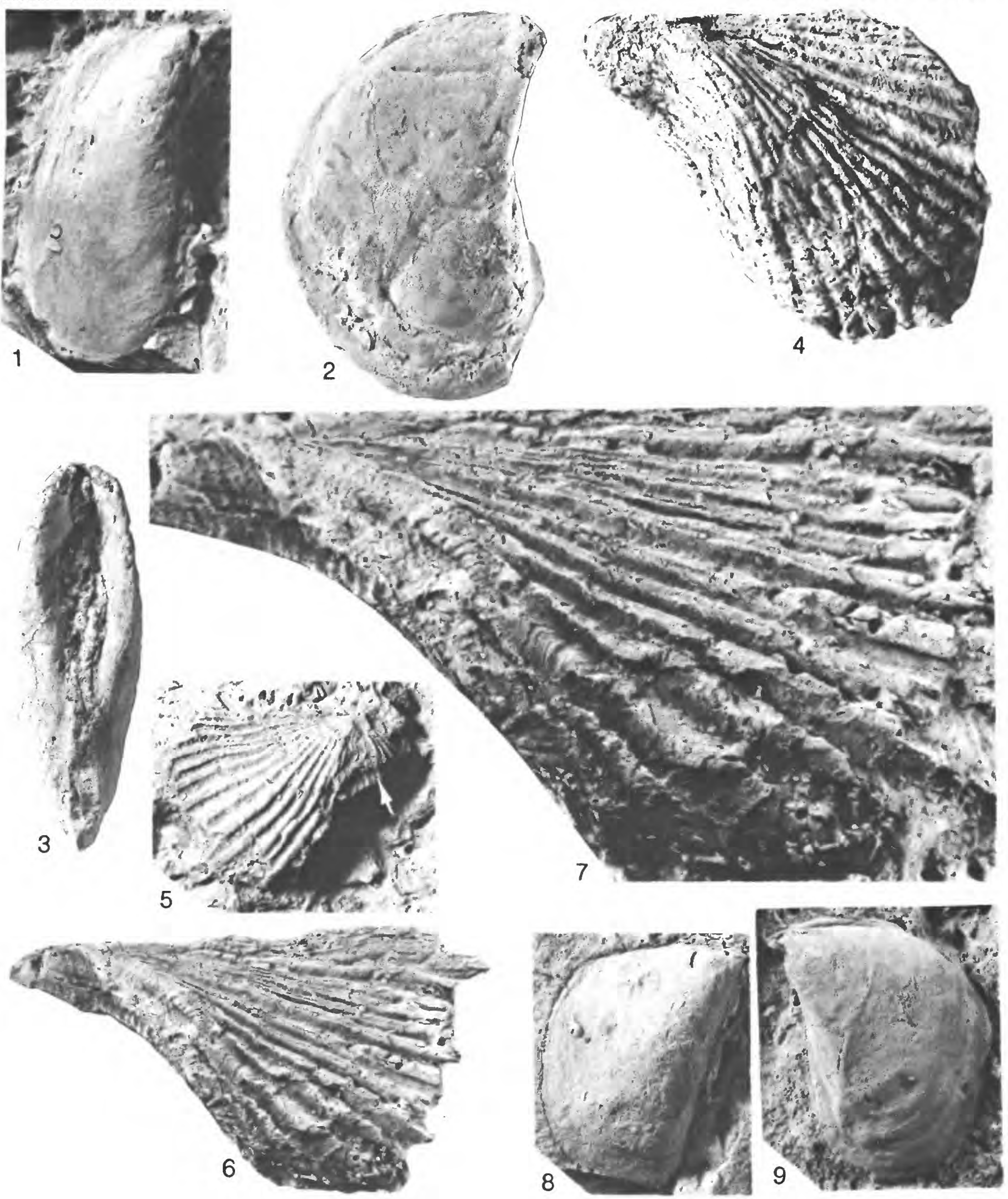

MYTILARCA AND FASCICULIPTERA 


\section{PLATE 35}

Figure 1. Cimitaria sinensis n. sp. (p. 87)+

Right-lateral view showing profile, distortion, and erosion of umbo, of the specimen shown on plate 31 , figure 7 ( $\times 1.5)$. GXD-748.

2. Parallelodon guangxiensis n. sp. (p. 88$)+$

Left-lateral view of a shelled specimen showing profile and ribbing $(\times 4)$. Sipai Formation (Emsian), Section 3, Bed 13. Paratype, GXD-037.

3-5. Mytilarca cf. M. chemungensis (Conrad) (p. 91)+

3. Right-lateral view of internal mold $(\times 5)$. Ertang Formation (Emsian), Section 4, Bed 19. GXD-177.

4. Right-lateral view of a largely exfoliated specimen $(\times 4)$. Ertang Formation (Emsian), Section 4, Bed 17. GXD-182.

5. Right-lateral view of a composite mold $(\times 3)$. Ertang Formation (Emsian), Section 3, Bed 10. GXD-176.

6-10. Carinonychia triangularis n. gen., n. sp. (p. 90)+

6 . Right-lateral view of a leached composite mold showing profile and bifurcating midumbonal costa (arrow) $(\times 4$ ). Ertang Formation (Emsian), Section 3, Bed 10. Paratype, GXD-236.

7. Highly distorted right valve composite mold showing bifurcating midumbonal rib $(\times 2)$. Horizon and locality the same as in figure 6 above. Paratype, GXD-239.

8. Right-lateral view of a dorsoventrally compressed composite mold showing bifurcating midumbonal costa (arrow) $(\times 2.5)$. Horizon and locality the same as in figure 6 above. Paratype, GXD-234.

9, 10. Anterior and left-lateral views of a leached composite mold showing lack of a byssal gape, bifurcation of midumbonal rib, and bifurcation of ribs on the posterodorsal auricle (arrow) $(\times 4)$. Horizon and locality the same as in figure 6 above. Holotype, GXD-235.

11. Carinonychia? sp. A (p. 90)+

Left-lateral view of an incomplete leached composite mold showing bifurcation of the umbonal rib. The specimen is distorted anteriorly and it is difficult to tell whether or not it had a projecting anterior end $(\times 1.5)$. Horizon and locality the same as in figure 6 above. GXD-187. 
GEOLOGICAL SURVEY
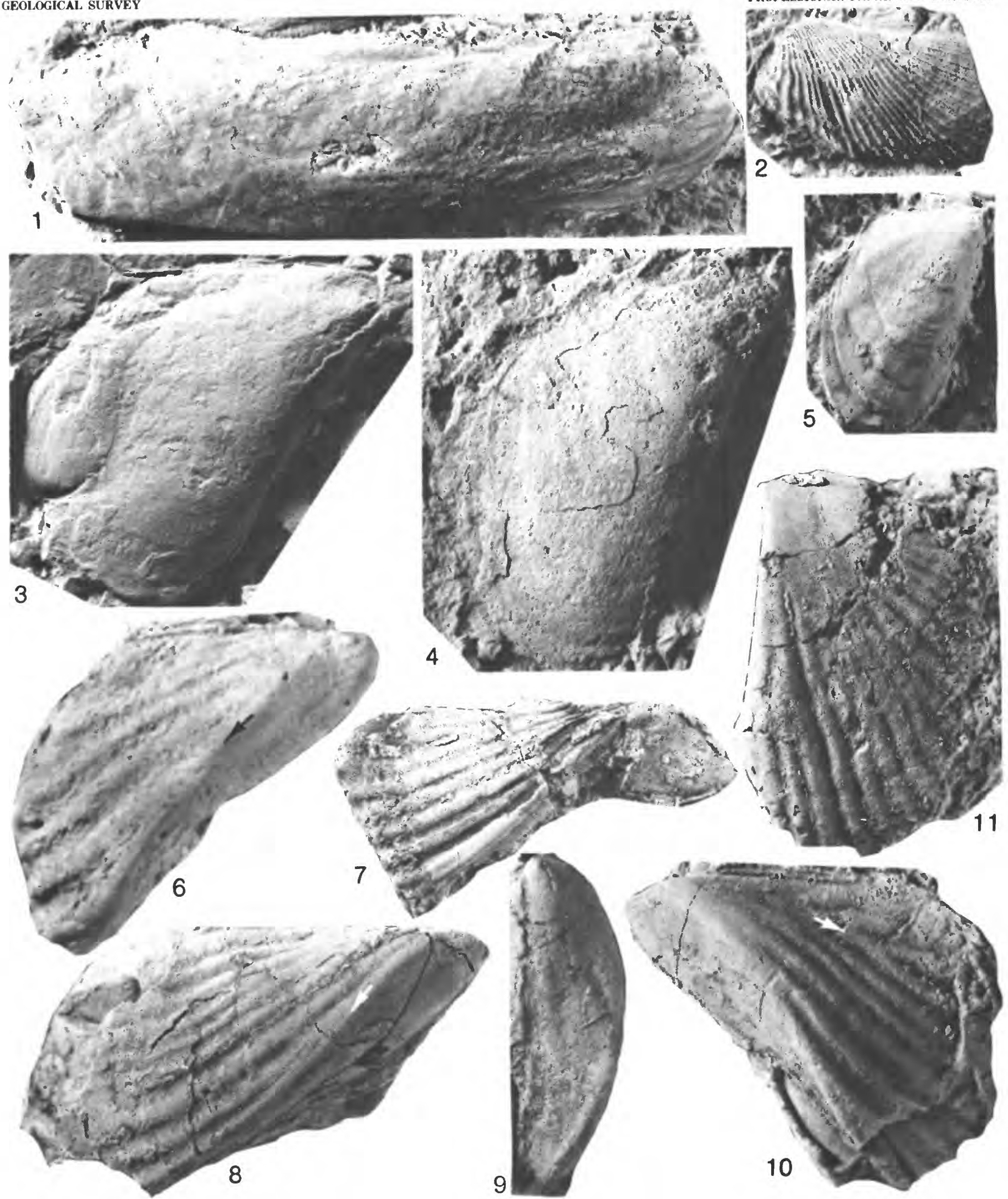

PROFESSIONAL PAPER 1994 PLATE 96

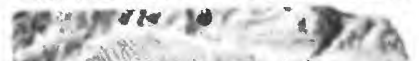

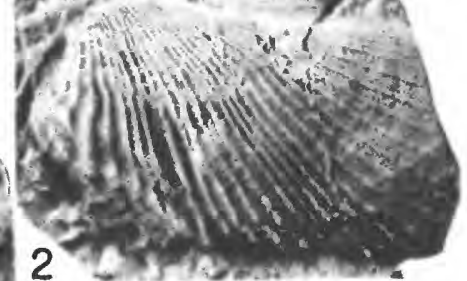

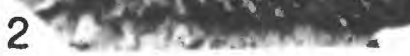

CIMITARIA , MYTILARCA, CARINONYCHIA, CARINONYCHIA?, AND PARALLELODON 


\section{PLATE 36}

Figures 1-6. Nodonychia gordia n. gen., n. sp. (p. 90)+

All specimens distorted in various ways; all are leached composite molds from the Yingtang Formation (Eifelian), Section 5, Bed 22.

1. Right-lateral view of a relatively undistorted specimen showing rugose growth increments, umbonal nodes, and small posterior wing $(\times 2)$. Paratype, GXD-217.

2. Right-lateral view of a specimen showing small posterior wing and umbonal nodes ( $\times 2$ ). Paratype, GXD-219.

3. Right-lateral view of an incomplete specimen showing rugae and umbonal nodes $(\times 2)$. Paratype, GXD-222.

4. Left-lateral view of a specimen showing umbonal nodes and rugae $(\times 2)$. Paratype, GXD-228.

5. Left-lateral view of a specimen showing umbonal nodes $(\times 2)$. Paratype, GXD-229.

6. Left-lateral view of a specimen showing umbonal nodes $(\times 2)$. Paratype, GXD-227. 

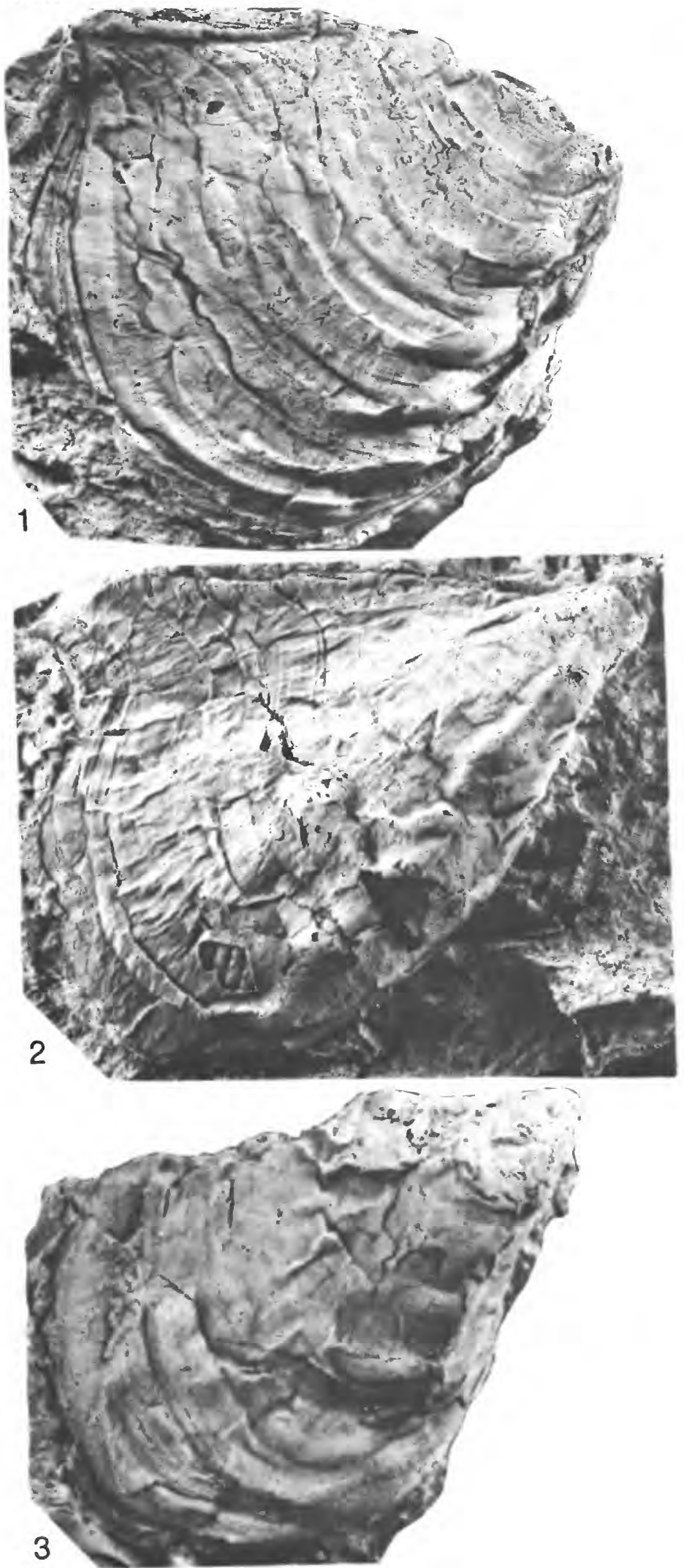

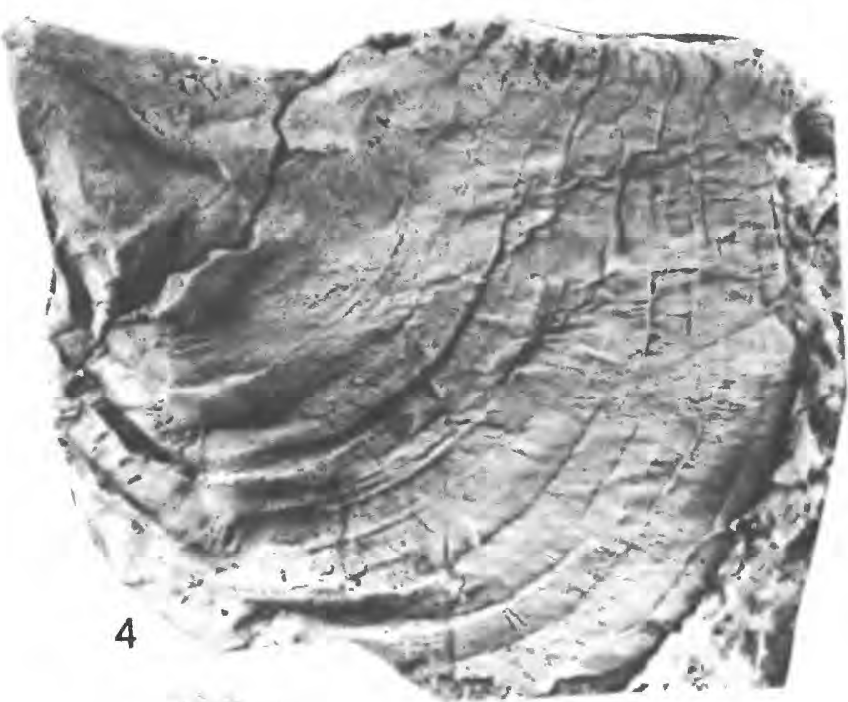

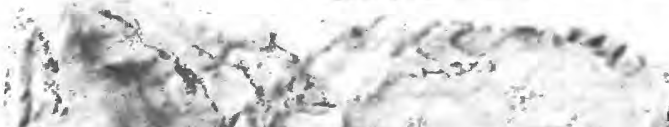

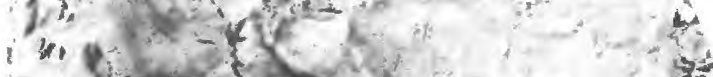

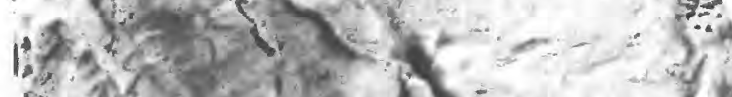

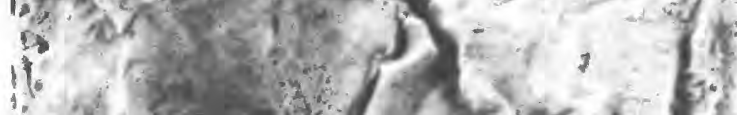

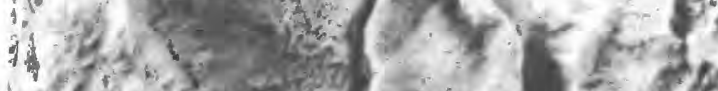

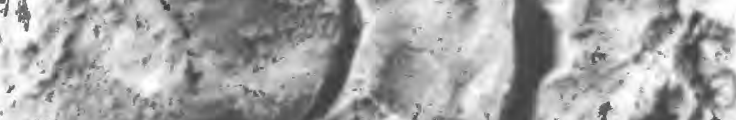

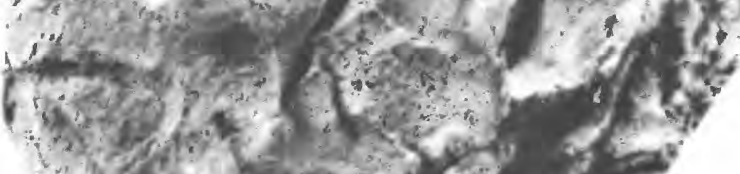
$5 \log ^{2}$

in $=\% \pi$

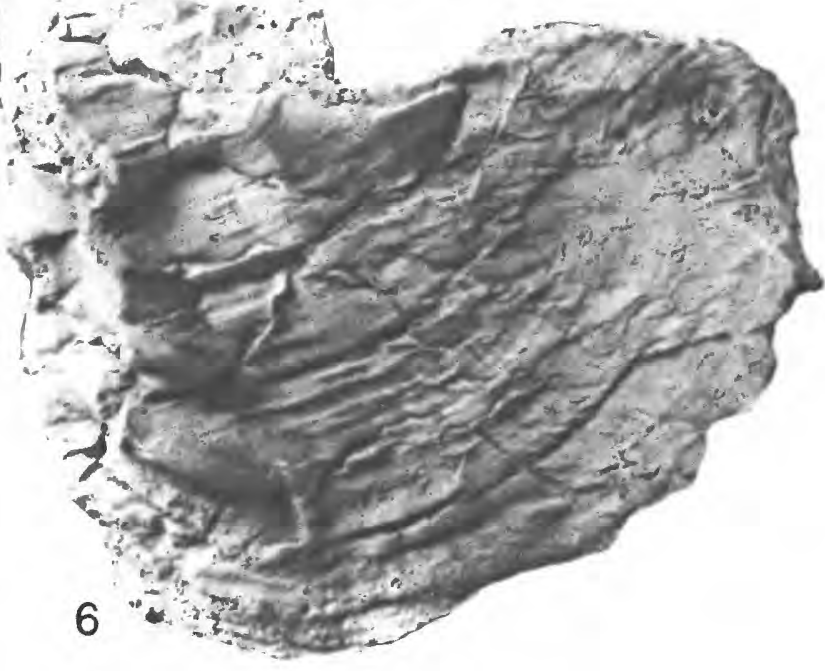




\section{PLATE 37}

Figures 1-7. Nodonychia gordia n. gen., n. sp. (p. 90)+

All specimens are leached composite molds from the Yingtang Formation

(Eifelian), Section 5, Bed 22.

1-3. Anterior, dorsal, and left-lateral views of an articulated, highly distorted specimen showing the umbonal nodes $(\times 2)$. Paratype, GXD-225.

4, 5. Right-lateral view showing umbonal nodes, rugae, and small posterior wing $(\times 2)$, and enlargement of dorsal margin showing remnants of duplivincular ligament grooves (X 4). Holotype, GXD-221.

6 , 7. Right-lateral view showing growth lirae $(\times 2)$ and anterior view showing lack of a byssal gape (X 4). Paratype, GXD-239. 
GEOLOGICAL SURVEY
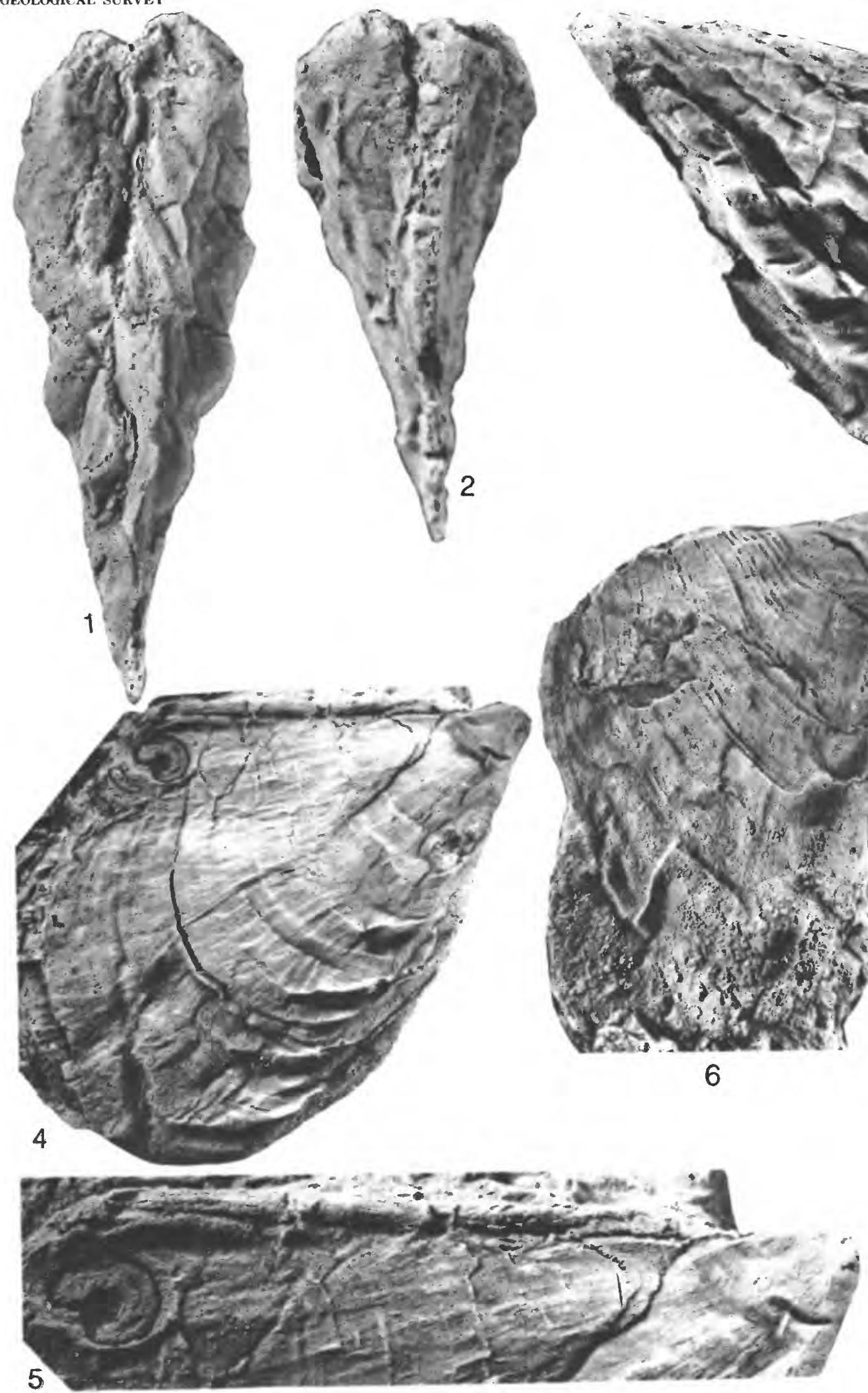

NODONYCHIA
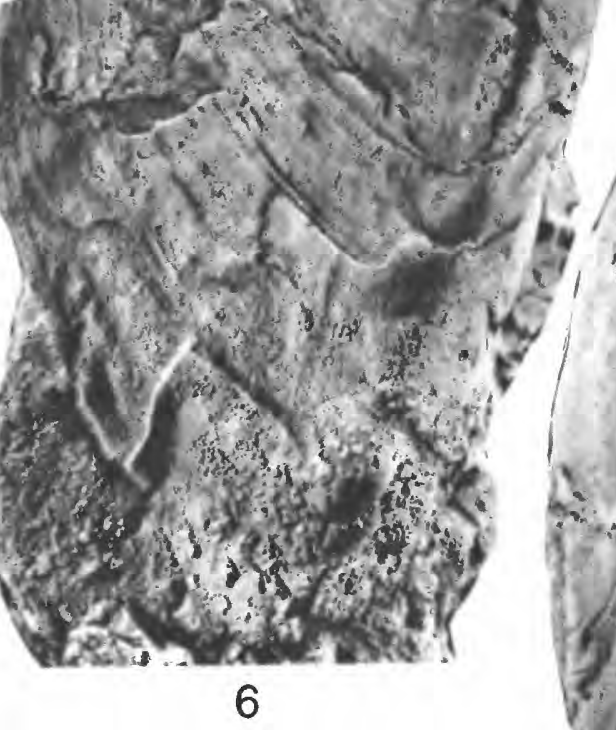
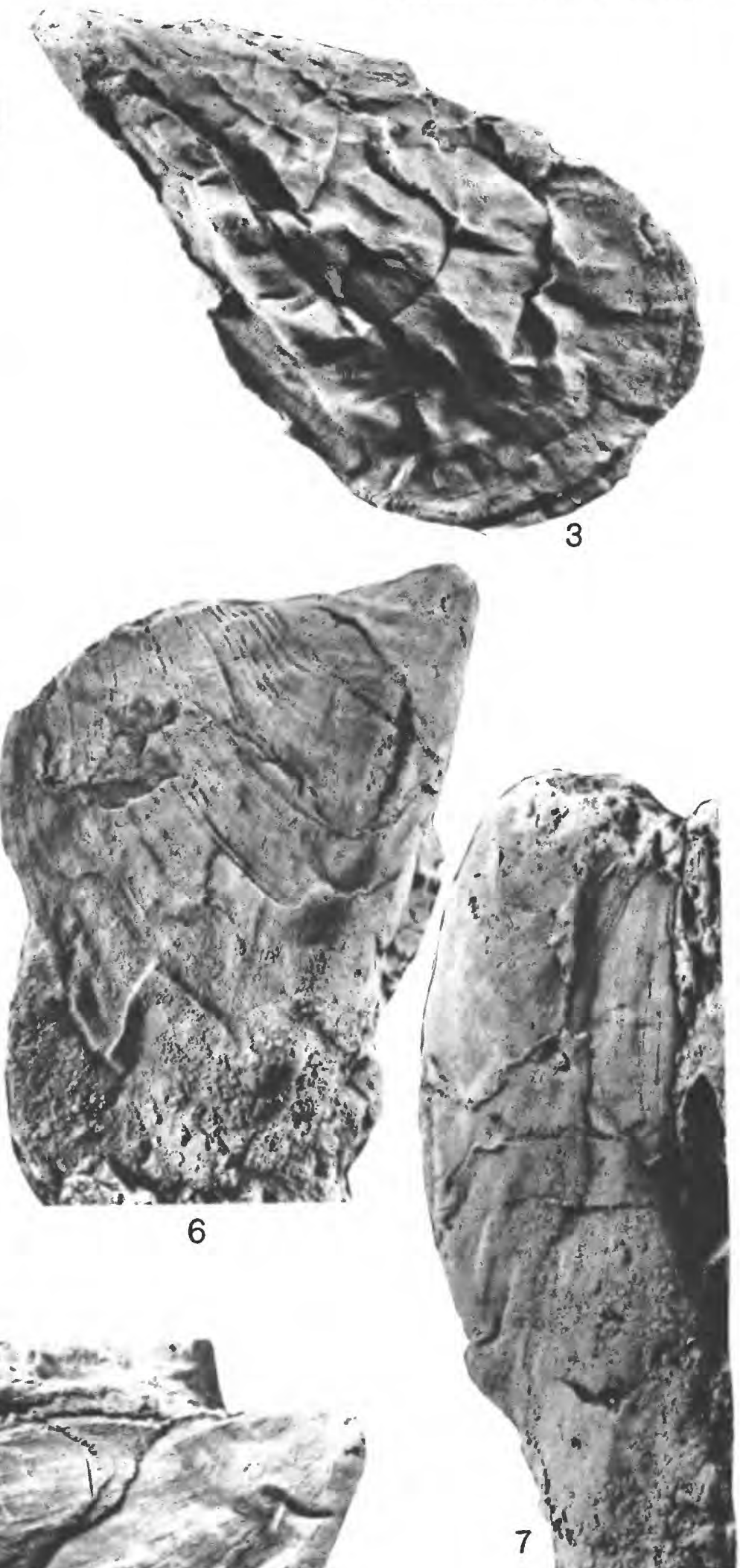


\section{PLATE 38}

Figures 1, 2, 5. Nodonychia gordia n. gen., n. sp. (p. 90)+

1. Right-lateral view showing umbonal nodes and posterior wing $(\times 2)$. Paratype, GXD-824.

2. Right-lateral view showing umbonal nodes, growth lirae, and posterior wing ( $\times 2$ ). Paratype, GXD-825.

5. Left-lateral view showing umbonal nodes and rugae $(\times 2)$. Paratype, GXD-224.

All specimens are leached composite molds from the Yingtang Formation (Eifelian), Section 5, Bed 22.

3, 4, 6, 7. Parallelodon guangxiensis n. sp. (p. 88)+

3. Left-lateral view of a shelled specimen showing profile, ornament, and ribs on anterior auricle $(\times 5)$. Sipai Formation (Emsian), Section 3, Bed 13. Holotype, GXD-038.

4. Right-lateral view of a composite mold showing profile $(\times 3.5)$. Horizon and locality the same as in figure 3 above. Paratype, GXD-644.

6. Right-lateral view of a composite mold showing profile $(\times 2.5)$. Horizon and locality the same as in figure 3 above. Paratype, GXD-646.

7. Right-lateral view of a composite mold $(\times 3)$. Horizon and locality the same as in figure 3 above. Paratype, GXD-651. 
GEOLOGICAL SURVEY
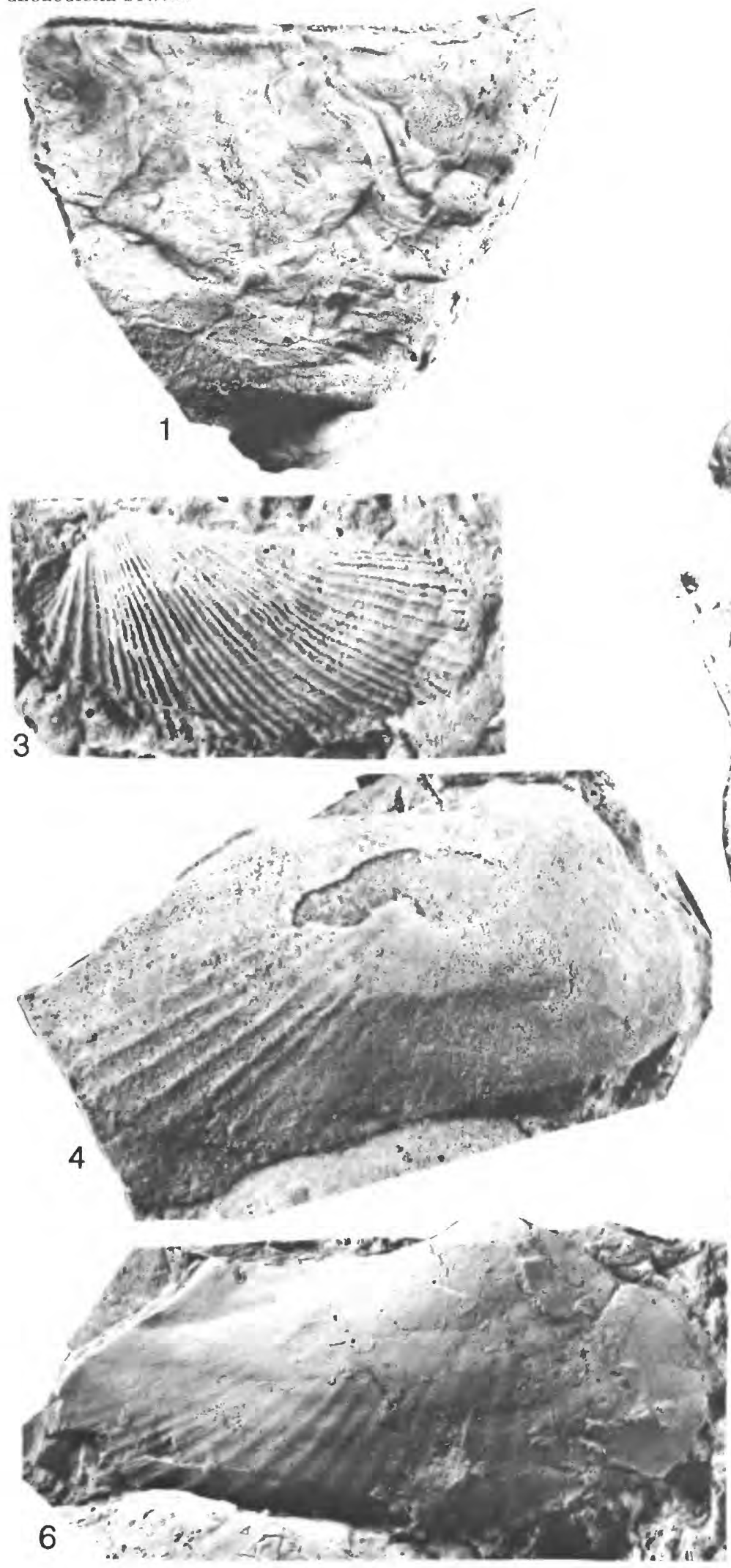

PROFESSIONAL PAPER 1394 PLATE 38
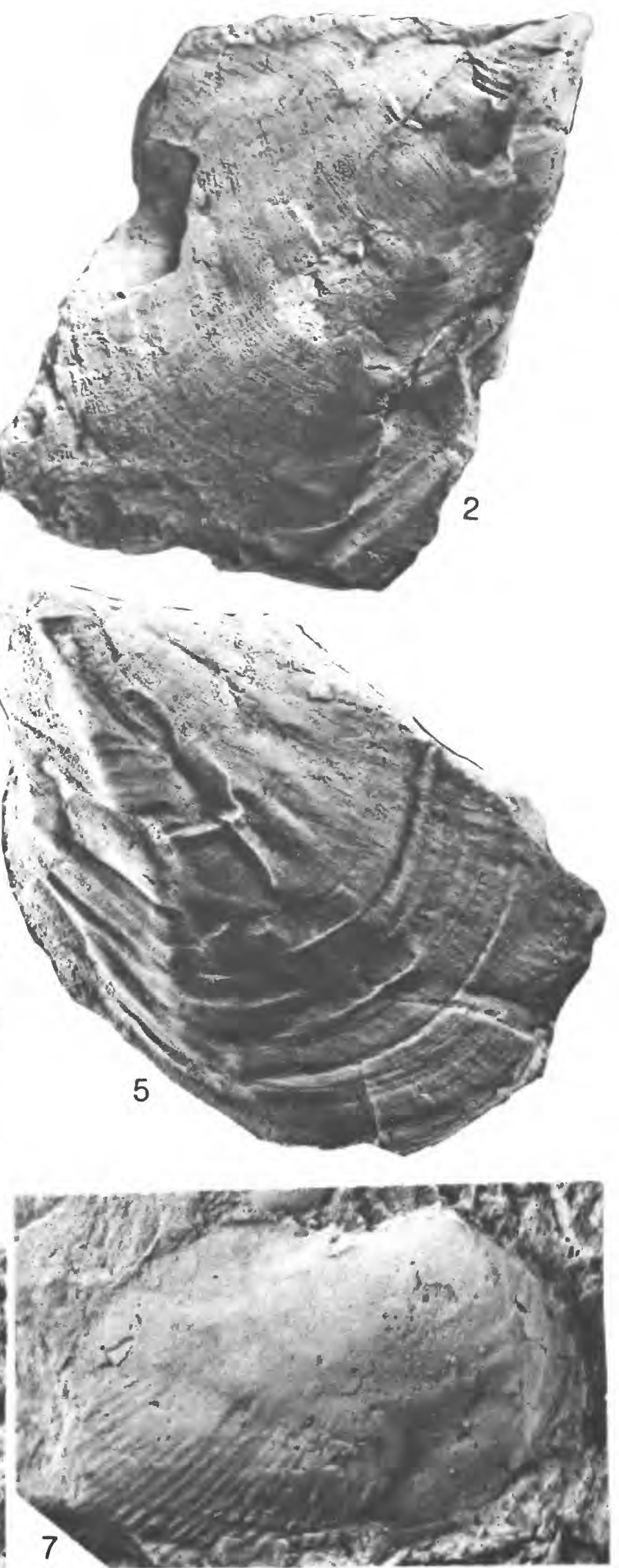


\section{PLATE 39}

Figures 1-3. Caneyella? yujiangensis n. sp. (p. 93)+

Three left valve composite molds showing profile and bifurcate and intercalate radial ornament ( $\times 4 ; \times 4 ; \times 2$ ). Yujiang Formation (Siegenian-Emsian), Section 1, Bed 21. Two paratypes, GXD-279, -281, and holotype, GXD-278. 4-6. Oxytomoidea elegans n. gen., n. sp. (p. 97)+

Three left valve composite molds showing profile, ribs on anterior auricle (fig. 5 , black arrow), coarse primary ribs on body of shell, bifurcation (fig. 5 , white arrow) and intercalation (fig. 6, arrows) of ribs (all $\times 3$ ). Yingtang Formation (Eifelian), Section 5, Bed 16. Three paratypes, GXD-264, -242, -253. 

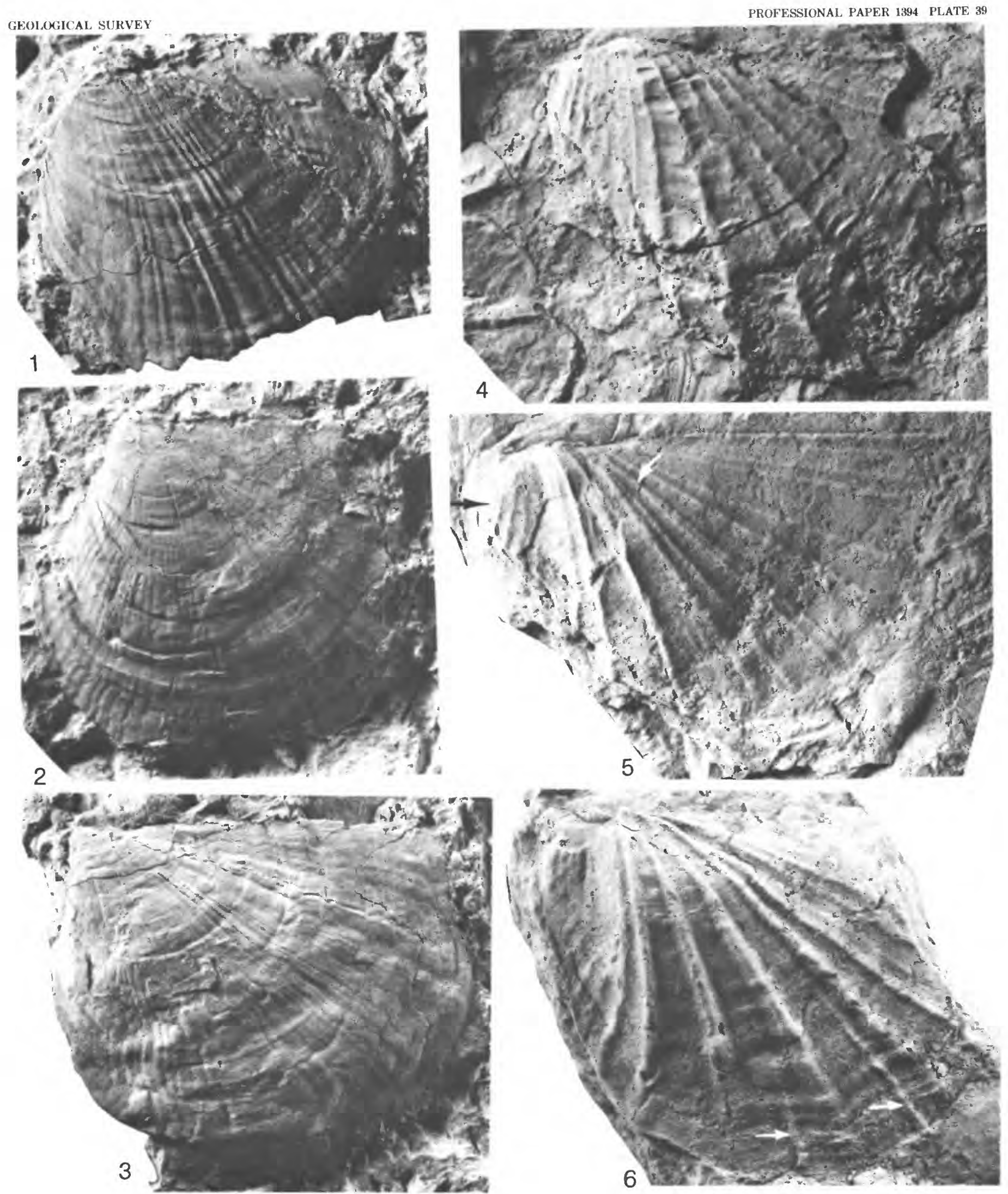

CANEYELLA? AND OXYTOMOIDEA 


\section{PLATE 40}

Figures 1-9. Oxytomoidea elegans n. g., n. sp. (p. 97)+

1,2 . (1) Left valve composite mold showing profile and coarse radial ornament and (2) with central and upper parts removed showing fine radial ornament of underlying right valve $(\times 3)$. Paratype, GXD-243.

3-6. Four right valve composite molds showing fine radial ornament, profile, and anterior auricle $(\times 8 ; \times 12 ; \times 3 ; \times 4)$. Paratypes, GXD-272, -271 , -257 (=USNM 383626), -276 (=USNM 383627).

7. Right valve composite mold showing profile, anterior auricle lacking ribs, byssal notch, and radial ornament increasing by intercalation (short arrow) and bifurcation (long arrow) ( $\times 3$ ). Holotype, GXD-274.

8,9 . Two small left valve composite molds showing profile of young shells $(\times 6 ; \times 4)$. Paratypes, GXD-829, -259 .

All specimens from the Yingtang Formation (Eifelian), Section 5, Bed 16. 
GEOLOGICAL SURVEY
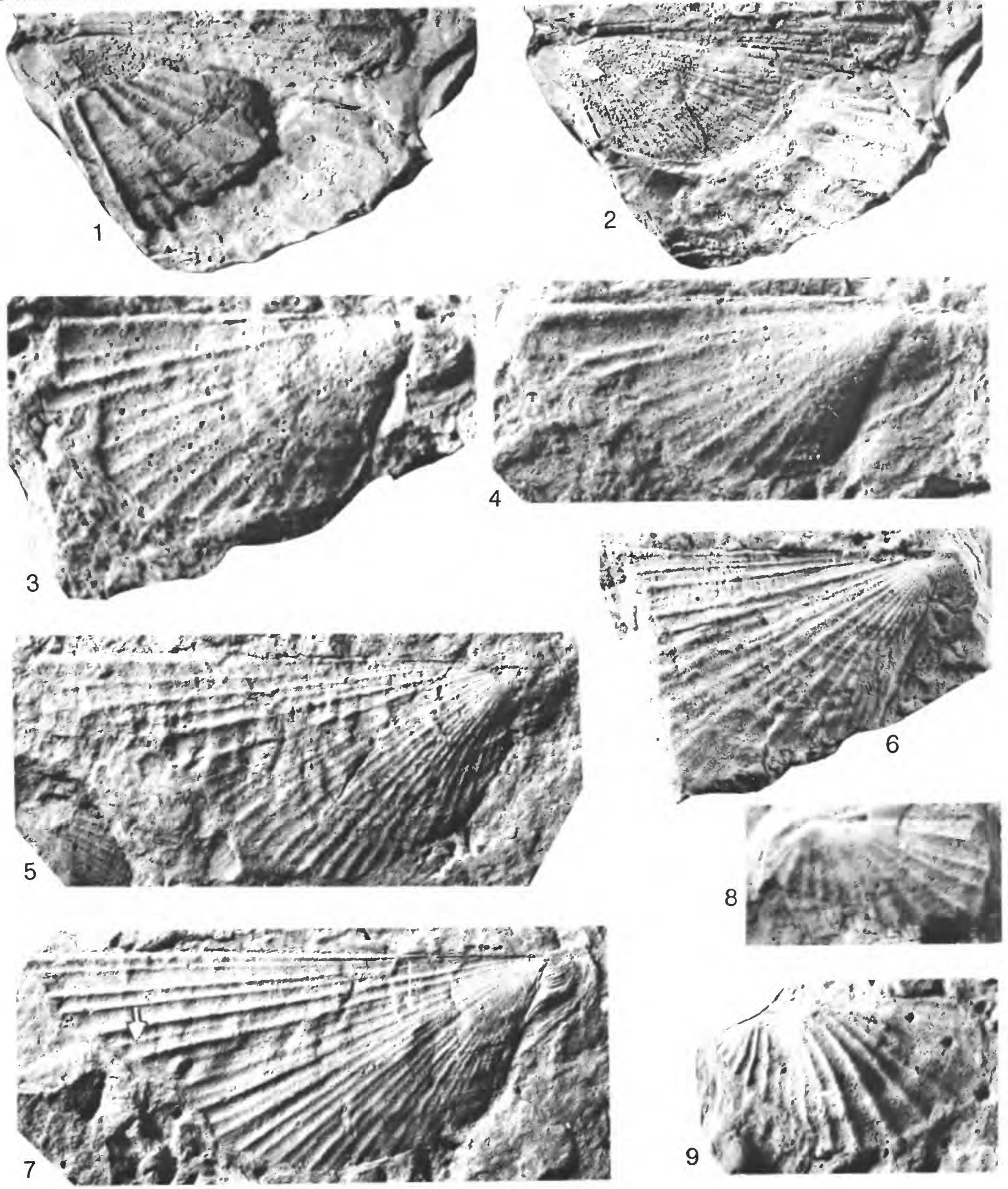


\section{PLATE 41}

Figures 1-7. Oxytomoidea elegans n. g., n. sp. (p. 97)+

1. Two small left valve composite molds (X 7). Paratypes, GXD-273a, b. 2-7. Six left valve composite molds showing profile and ornament $(2-3, \times 3$; 4-7, $\times$ 4). Paratypes, GXD-244, $-241,-268,-263,-261,-258$.

All specimens from the Yingtang Formation (Eifelian), Section 5, Bed 16. 
GEOLOGICAL SURVEY
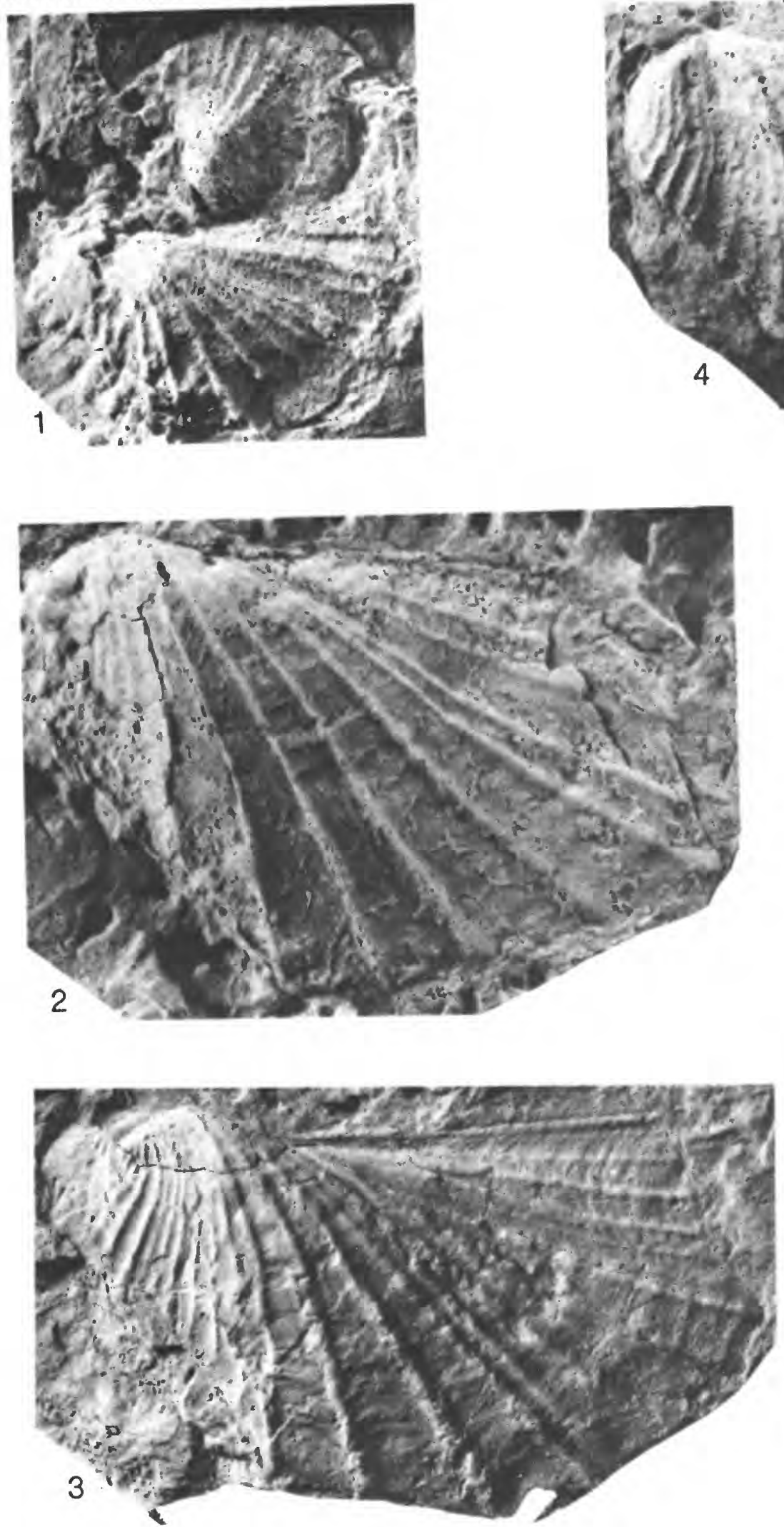

OXYTOMOIDEA
PROFEGSTONAL PAPER 1394 PLATE 41
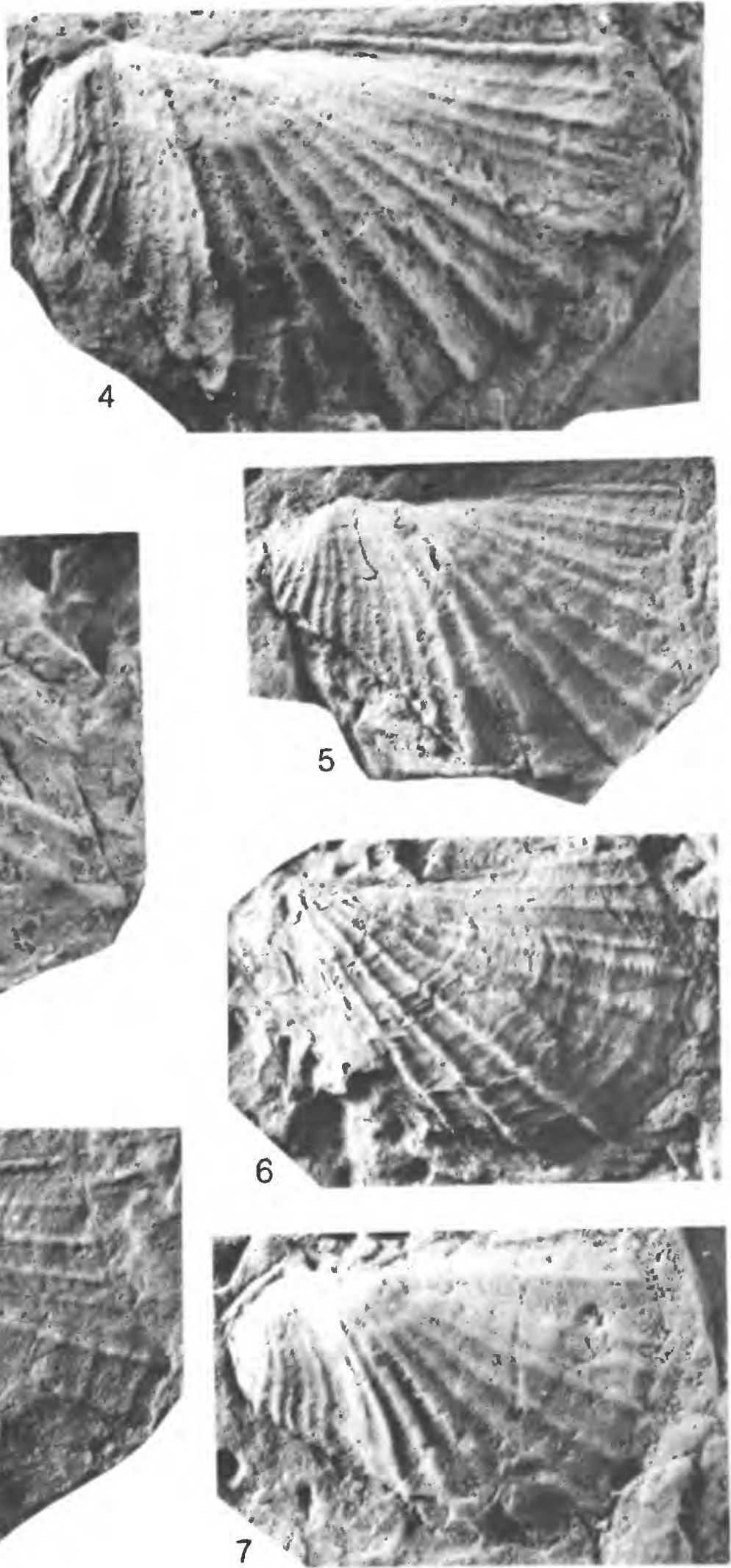


\section{PLATE 42}

Figures 1-5. Limoptera spp. (p. 97)+

1. Right valve composite mold $(\times 2.5)$. Ertang Formation (Emsian), Section 2 , bed unknown. GXD-464.

2. External mold of left valve showing large anterior auricle $(\times 1.5)$. Ertang Formation (Emsian), Section 4, Bed 9. GXD-482a.

3. Composite mold of left valve ( $\times$ 4). Ertang Formation (Emsian), Section 4, Bed 30. GXD-463.

4, 5. Part and counterpart, right valve external mold and left valve composite mold ( $\times 1.5$ ). Ertang Formation (Emsian), Section 4, Bed 9. GXD-484a, b. 
GEOLOGICAL SURVEY
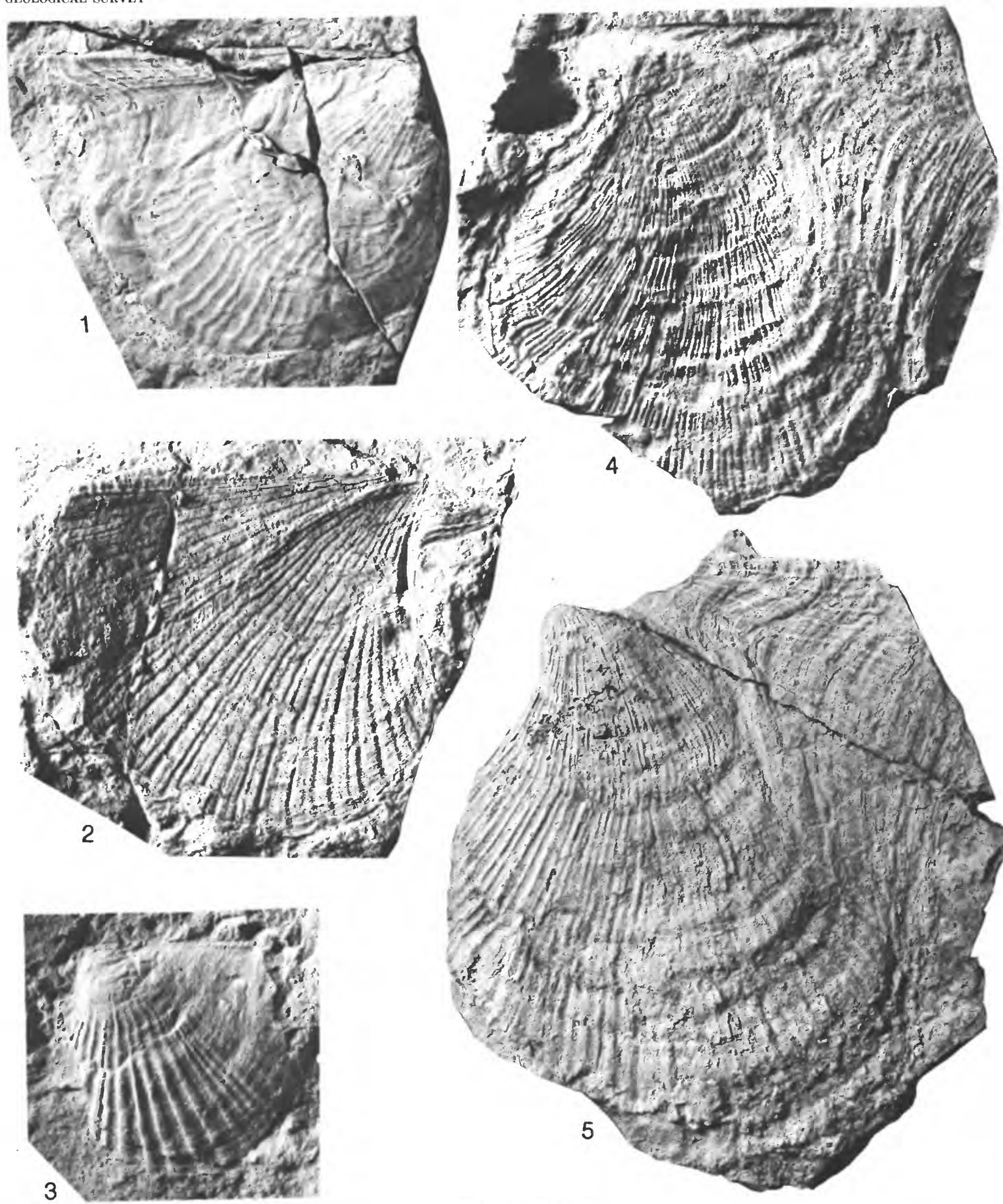


\section{PLATE 43}

Figures 1-5. Actinodesma (Ectenodesma) guangxiensis n. sp. (p. 93)+

1. Composite mold of left valve showing ornament and anterior auricle ( $\times 2$ ). Holotype, GXD-400.

2-4. Composite molds of three left valves showing ornament, profile, and varying lengths of anterior and posterior auricles $(\times 2 ; \times 2 ; \times 1)$. Paratypes, GXD-395, $-397,-394$.

5. External mold of right valve, counterpart showing ornament and posterior auricle ( $\times 2$ ); part figured on plate 48 , figure 4. Paratype, GXD-398.

All specimens from the Donggangling Formation (Givetian), Section 3, Bed 23. 

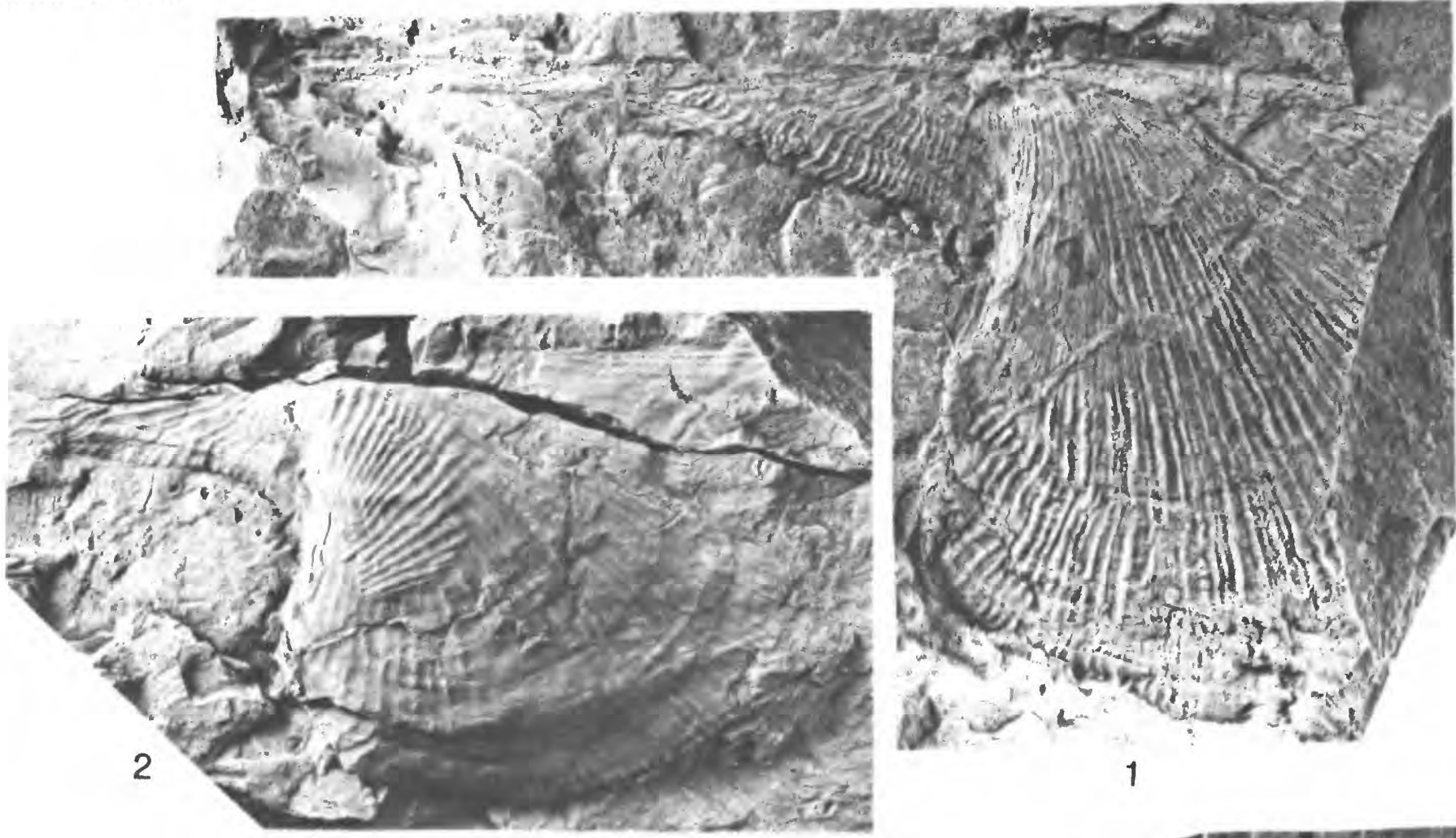

1

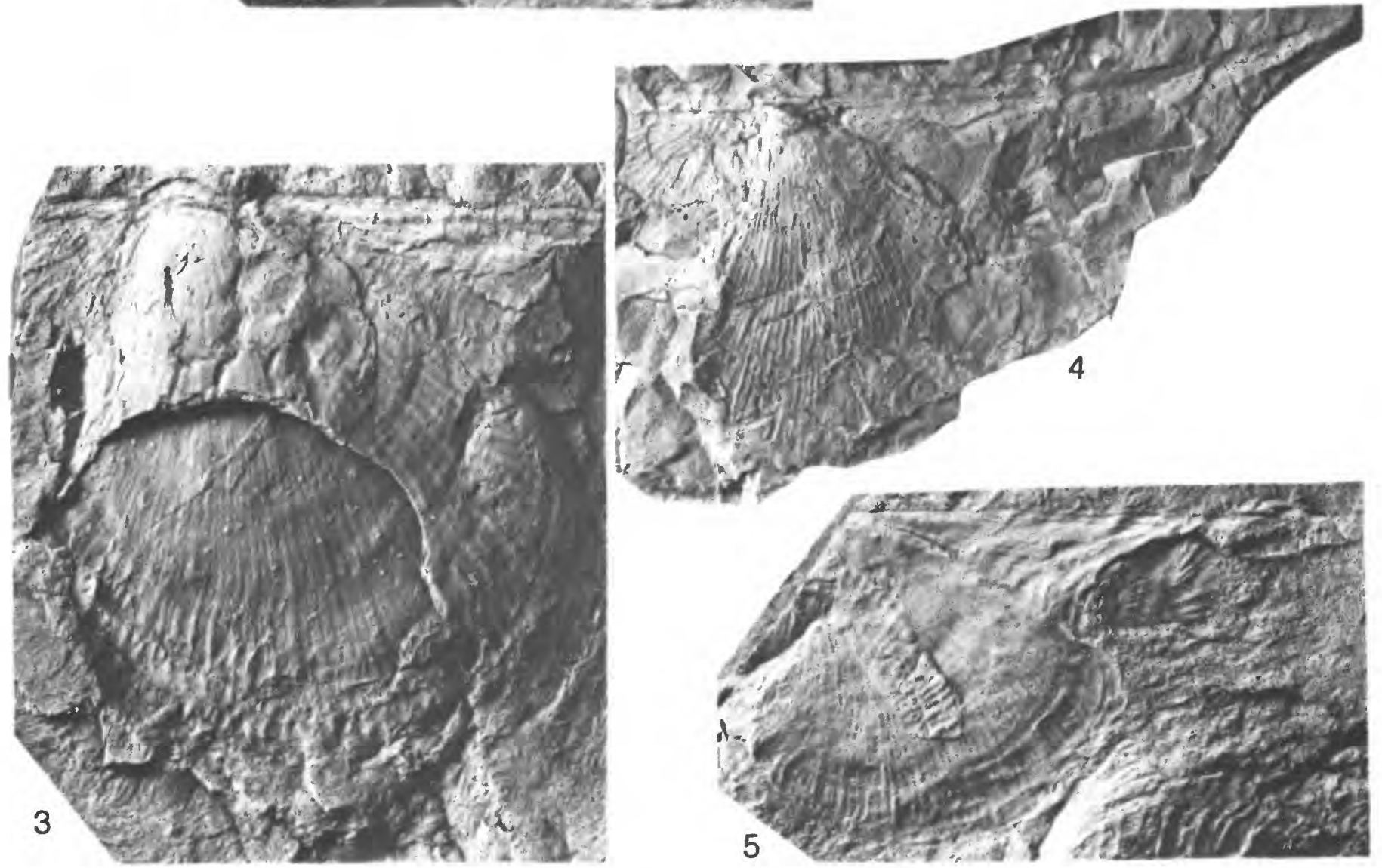

ACTINODESMA (ECTENODESMA) 


\section{PLATE 44}

1-9, 12. Leptodesma (Leptodesma) guangxiensis n. sp. (p. 95)+

1, 2. Part and counterpart, composite and external molds showing profile and ornament of left valve $(\times 5)$. Ertang Formation (Emsian), Section 4, Bed 30. Paratype, GXD-321a.

3. Right valve composite mold $(\times 4)$. Horizon and locality the same as in figures 1, 2 above. Paratype, GXD-321.

4-7. Left valve composite molds ( $\times 9$ ). Ertang Formation (Emsian), Section 4, Bed 11. Paratypes, GXD-320, -371 (=USNM 383625), $-404,-312$.

8 , 9. Two right valve composite molds showing profile, ornament, and impressions of posterior lateral teeth (arrows) $(\times 4 ; \times$ 5). Ertang Formation (Emsian), Section 4, Bed 19. Paratypes, GXD-323, -324 .

12. Right valve composite mold $(\times 4)$. Nagaoling Formation (Gedinnian), Section 1, Bed 10. GXD-306.

10, 11, 13, 14. Leptodesma (Leptodesma) venusta Zhang, 1977 (p. 95)+

Four poorly preserved left valve composite molds $(10,11, \times 5 ; 13,14$,

$\times$ 4). Lianhuashan Formation (Gedinnian), Section 1, Bed 5. GXD-282,

$-287,-286,-284$. 
GEOLOGICAL SURVEY
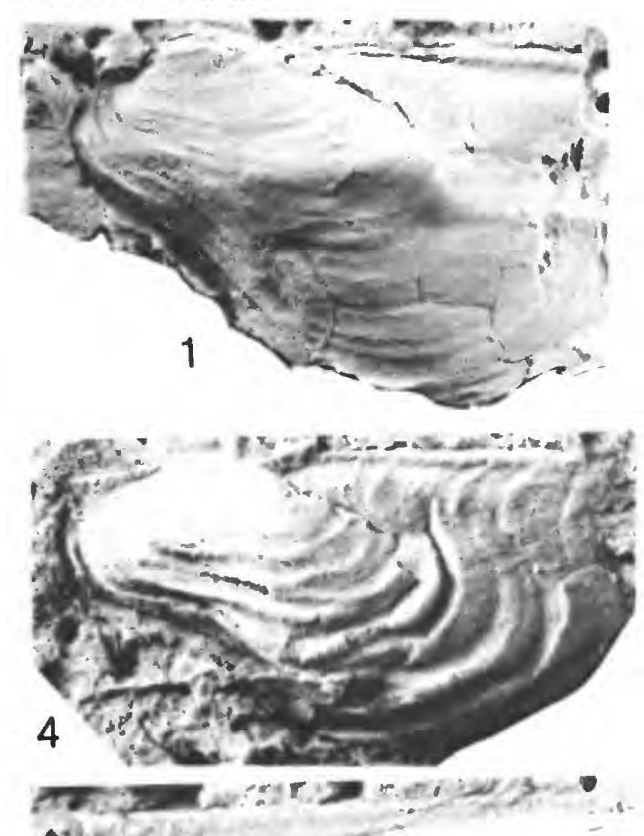
exib i

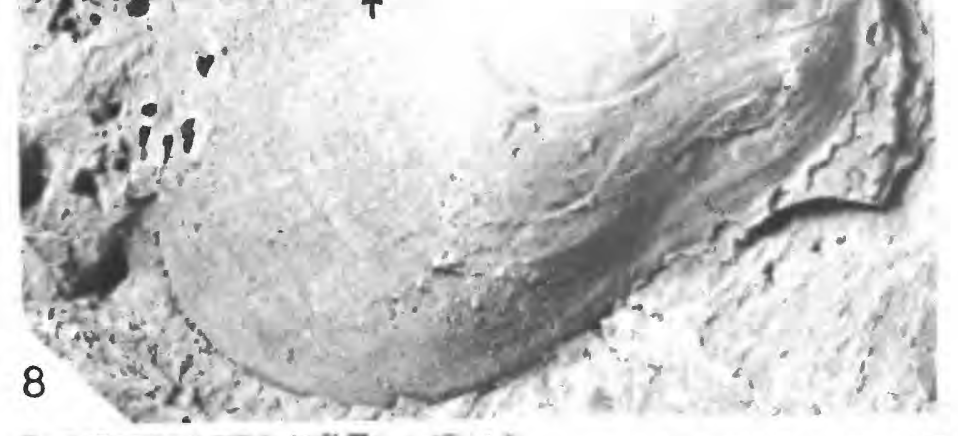

\section{8}
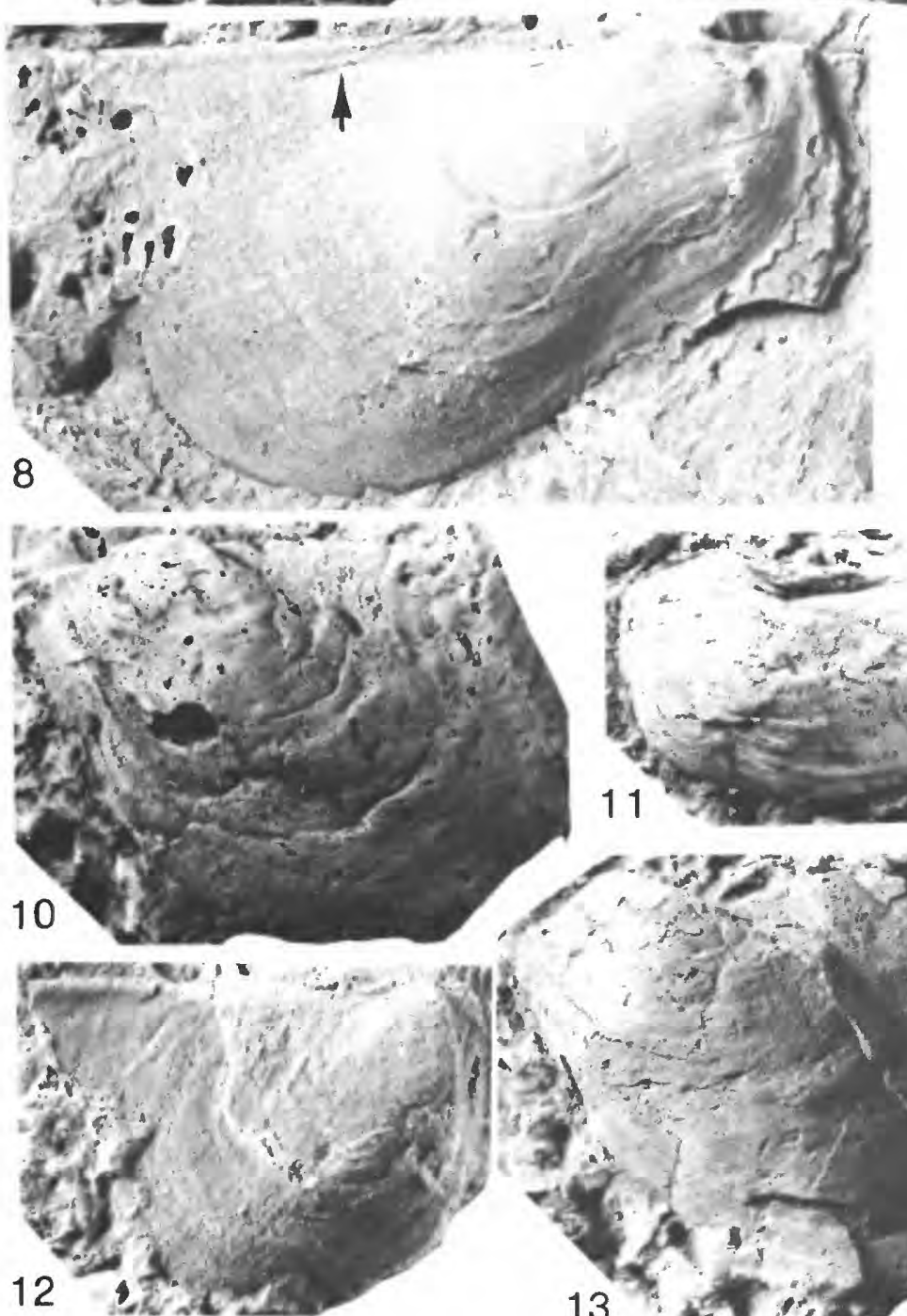
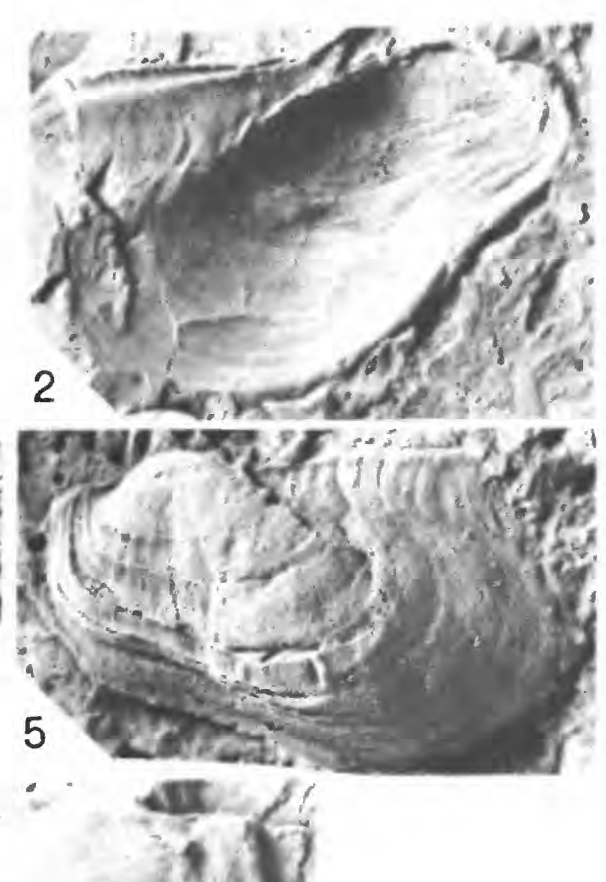


\section{PLATE 45}

Figures 1-11. Leptodesma (Leptodesma) guangxiensis n. sp. (p. 95)+

1. Left valve composite mold showing ornament and profile $(\times 4)$. Ertang Formation (Emsian), Section 4, Bed 32. Paratype, GXD-390.

2-4. Left-lateral, dorsal, and right-lateral views of a partially shelled and articulated specimen $(\times 2.5)$. Ertang Formation (Emsian), Section 4, Bed 6. Holotype, GXD-342.

5, 6. Two left valve composite molds $(\times 4 ; \times 10)$. Ertang Formation (Emsian), Section 4, Bed 11. Paratypes, GXD-333, -337.

7, 8. Left-lateral and dorsal views of a partially shelled specimen $(\times 3)$. Horizon and locality the same as in figures 2-4 above. Paratype, GXD-354.

9-11. Left-lateral, dorsal, and right-lateral views of a partially shelled specimen $(\times 4)$. Horizon and locality the same as in figures 2-4 above. Paratype, GXD-357. 

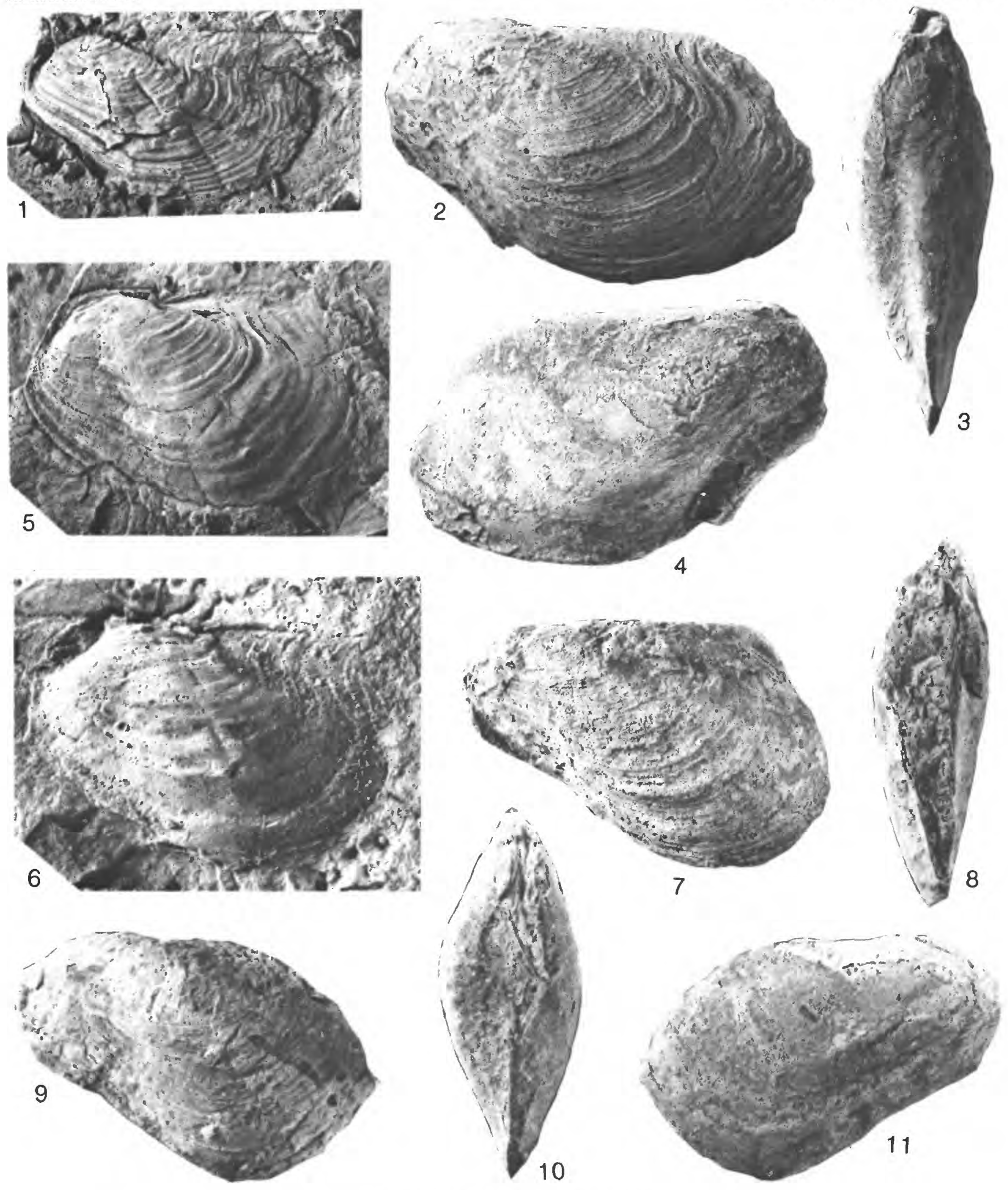

LEPTODESMA (LEPTODESMA) 


\section{PLATE 46}

Figures 1-3. Leptodesma (Leptodesma)? sp. A (p. 95)+

Three left valve partially shelled specimens $(\times 2 ; \times 3 ; \times 4)$. Ertang Formation (Emsian), Section 4, Beds 34, 11, 36. GXD-389, -329, -347 .

4, 5. Leptodesma (Leptodesma) deprati (Mansuy), 1912 (p. 95)+

Two left valve composite molds $(\times 3 ; \times 2.5)$. Nagaoling Formation (Gedinniansiegenian), Section 1, Bed 10.GXD-288 (=USNM 383629), -290.

6, 7. Wuxuanites washingtonensis n. g., n. sp. (p. 99)+

Two left valve composite molds $(\times 4 ; \times 3)$. Ertang Formation (Emsian), Section 4, Bed 34. Paratype, GXD-362, -359 .

8. Wuxuanites lanceolatus n. g., n. sp. (p. 99)+

Right valve composite mold showing ornament and profile $(\times 8)$. Ertang Formation (Emsian), Section 4, Bed 34. Holotype, GXD-363. 
GEOLOGICAL SURVEY
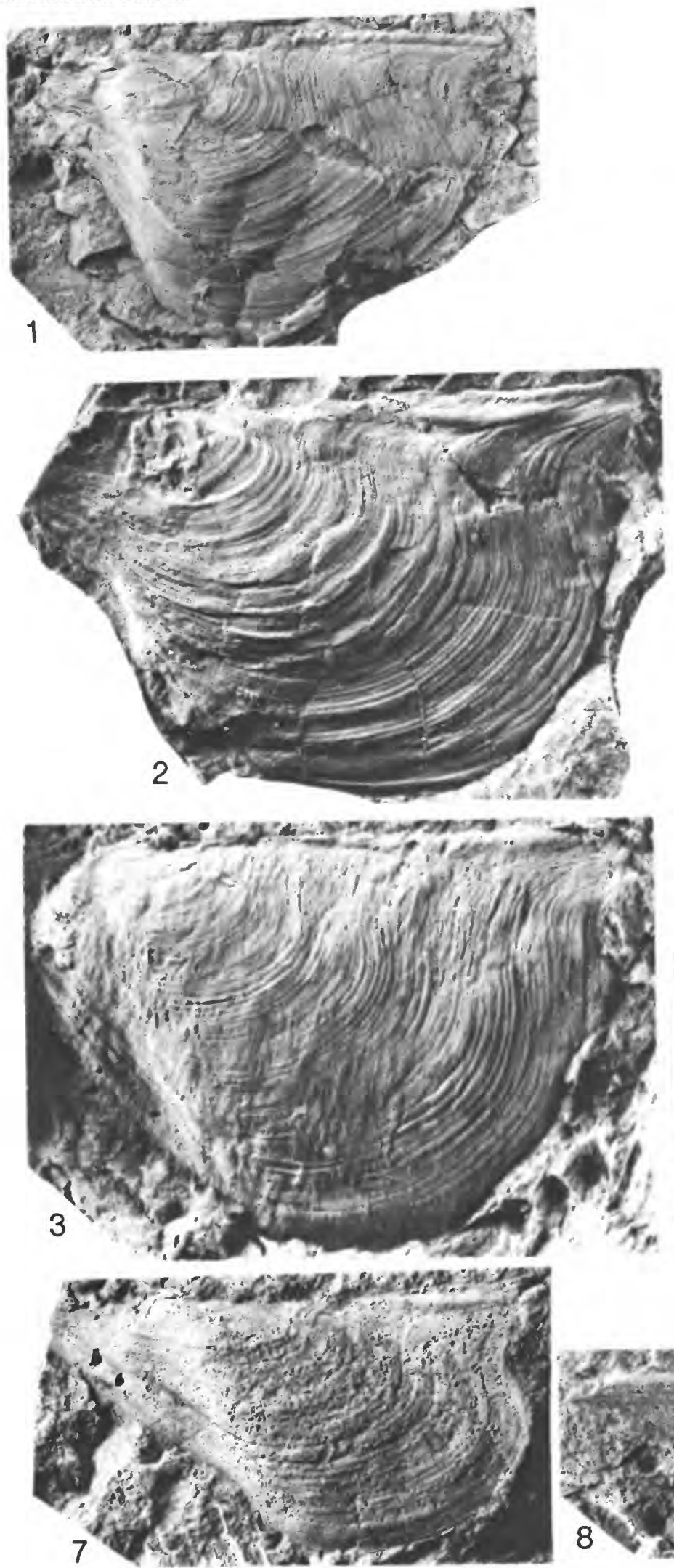

PROFESSIONAL PAPER 1394 PLATE 46
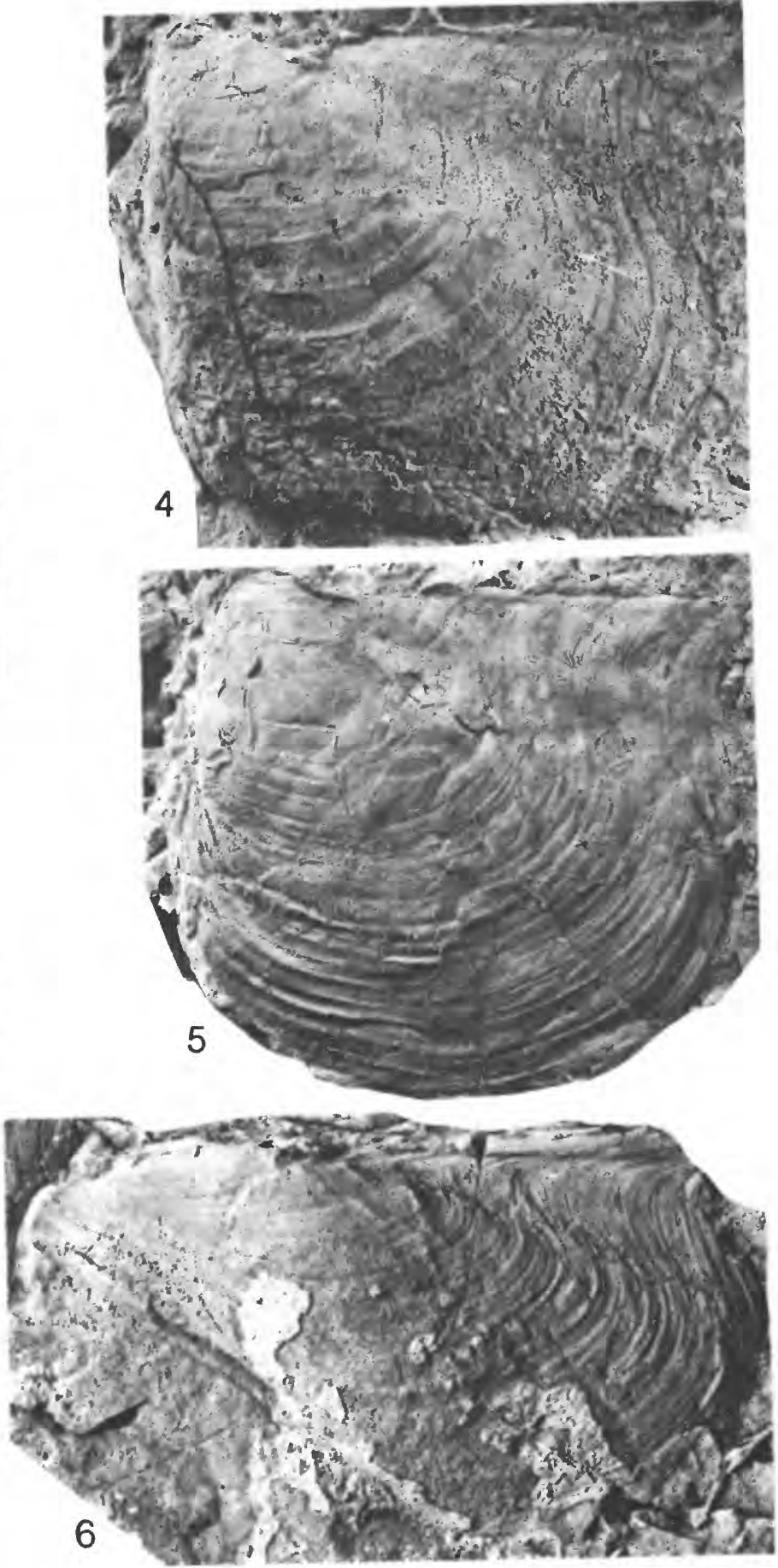

LEPTODESMA (LEPTODESMA) AND WUXUANITES 


\section{PLATE 47}

Figures 1-5, 10. Wuxuanites lanceolatus n. g., n. sp. (p. 99)+

$1,2,4,5,10$. Five left valve composite molds showing ornament and profiles ( $\times 7$ ). Ertang Formation (Emsian), Section 4, Beds 11 and 31, Paratypes, GXD-377, $-388,-386,-382,-375$.

3. Right valve composite mold $(\times 7)$. Ertang Formation (Emsian), Section 4, Bed 11. Paratype, GXD-373.

6, 7. Pterinopecten (Newellipecten) guangxiensis (Zhang), 1977 (p. 100)+

6. Left valve composite mold $(\times 5)$. Yingtang Formation (Eifelian), Section 5, Bed 19. GXD-643.

7. Left valve composite mold ( $\times 4)$. Ertang Formation (Emsian), Section 4, Bed 9. GXD-511.

8, 9. Leptodesma (Leptodesma) venusta Zhang, 1977 (p. 95)+

8. Left valve composite mold ( $\times 4)$. Ertang Formation (Emsian), Section 4, Bed 19. GXD-325.

9. Left valve partially shelled specimen $(\times 2)$. Ertang Formation (Emsian), Section 2, bed unknown. GXD-326.

11. Limoptera sp. (p. 97)+

Right valve composite mold showing ornament and two posterior lateral teeth (arrow) $(\times 2$ ). Donggangling Formation (Givetian), Section 3, Bed 23. GXD-417. 
GEOLOGICAL SURVEY

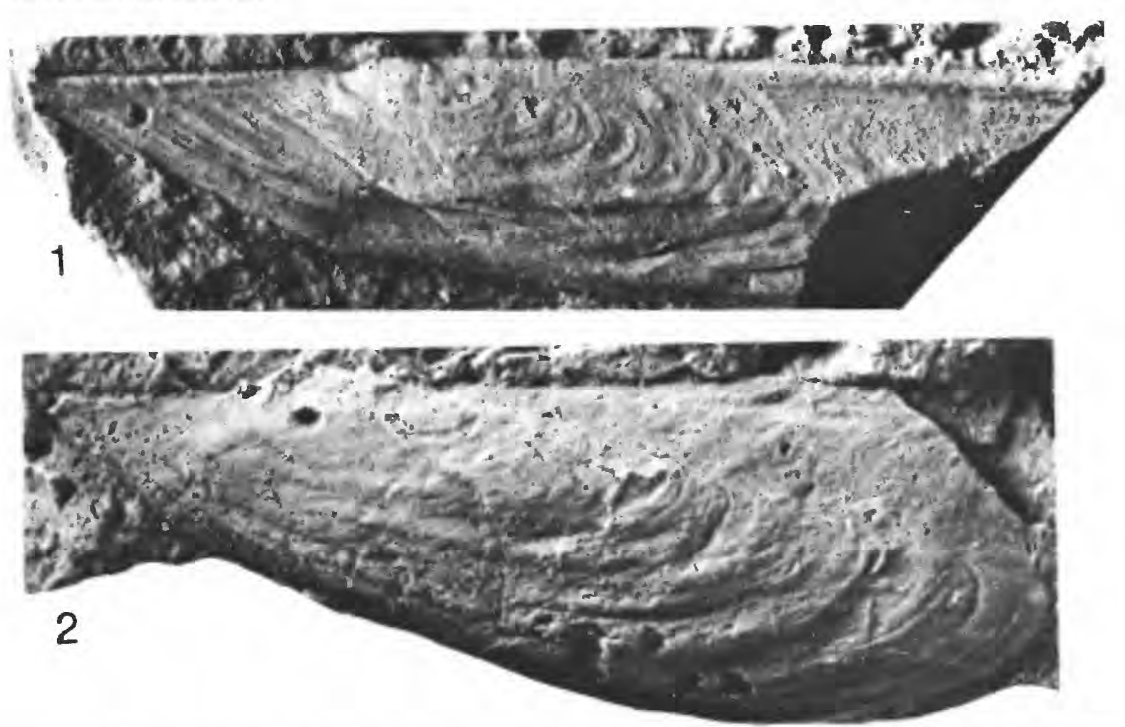

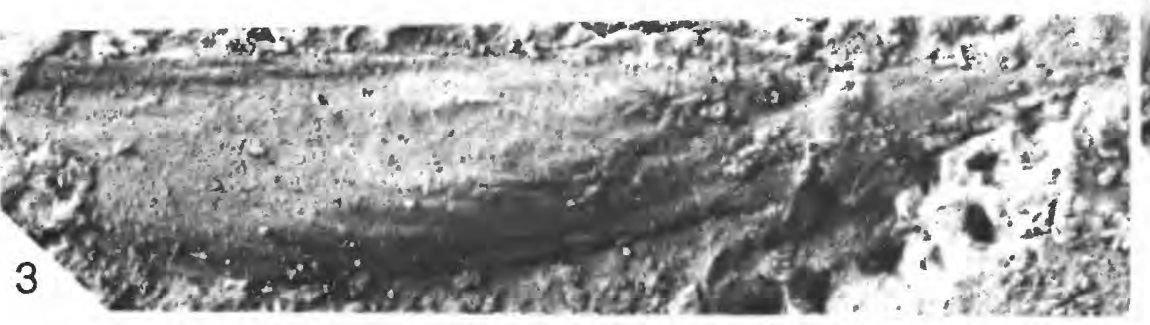

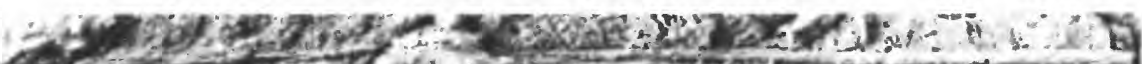

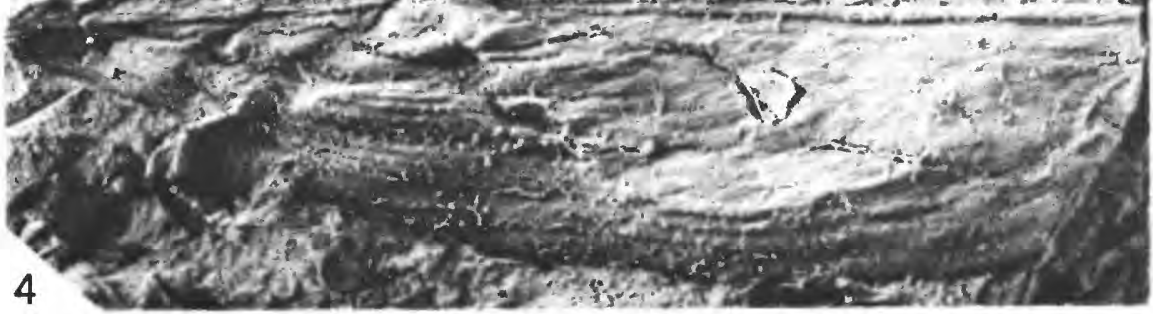

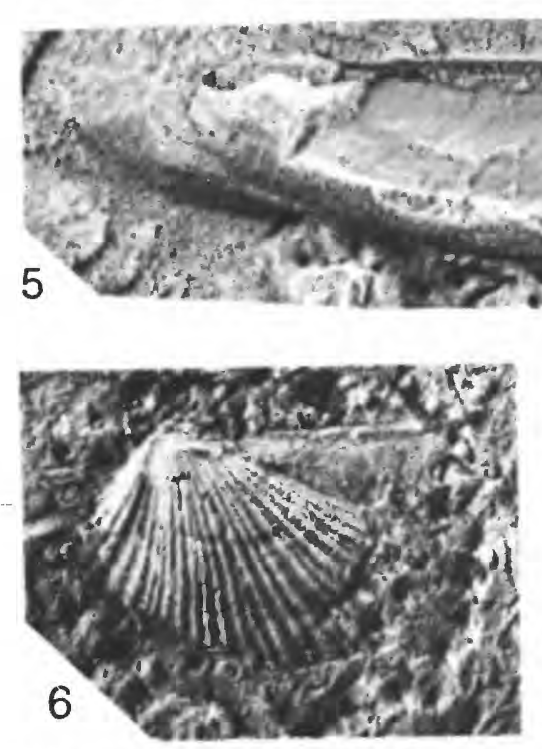

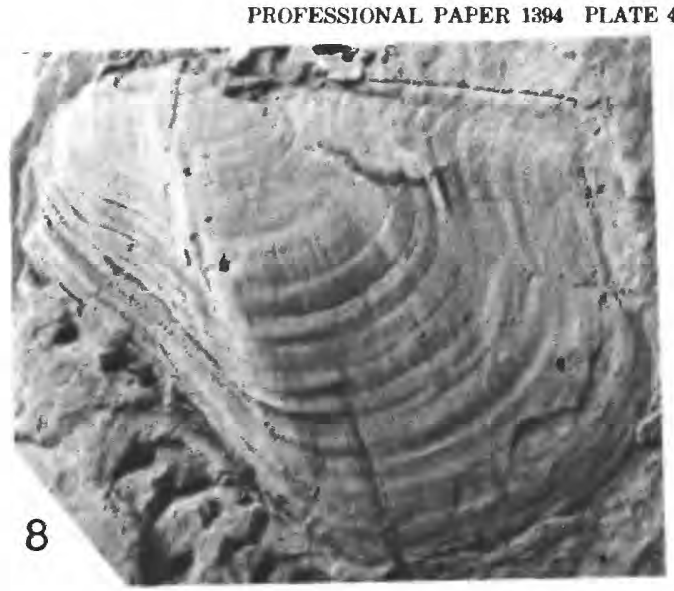
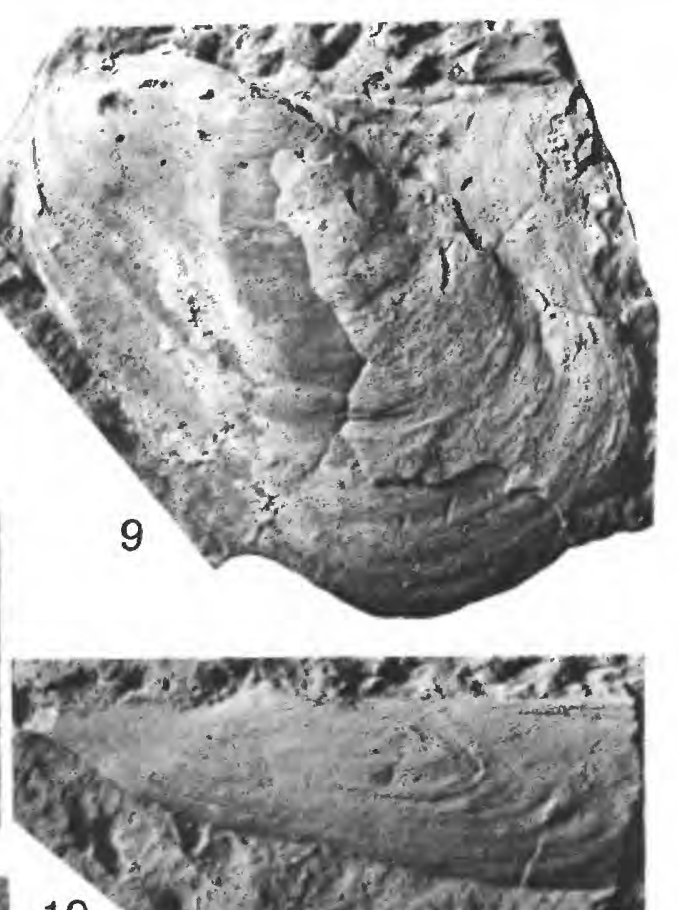

10

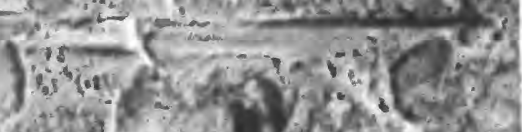

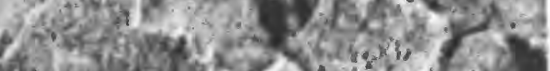
if

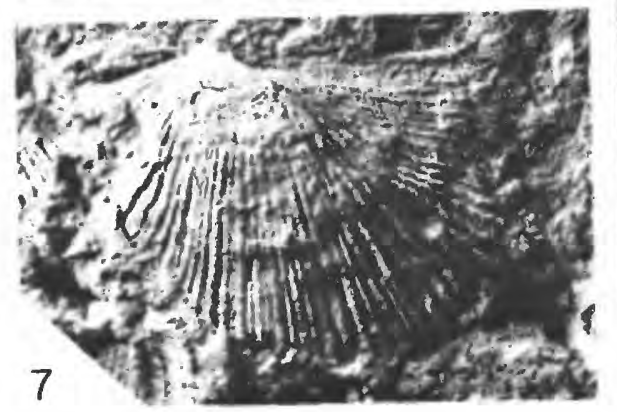

LEPTODESMA (LEPTODESMA), WUXUANITES, LIMOPTERA, AND PTERINOPECTEN (NEWELLIPECTEN) 


\section{PLATE 48}

Figure 1. Limoptera sp. (p. 97)+

Composite mold of left valve $(\times 3)$. Donggangling Formation (Givetian), Section 3, Bed 23. GXD-486.

2, 3. Ptychopteria (Ptychopteria) zhongguoensis Zhang, 1977 (p. 98)+

Right and left valve composite molds $(\times 2 ; \times 2.5)$. Ertang Formation (Emsian), Locality 9. GXD-416, -408 .

4. Actinodesma (Ectenodesma) guangxiensis n. sp. (p. 93)+

Composite mold of right valve showing ornament and posterior auricle $(\times 3)$. Part of specimen figured on plate 43, figure 5. Donggangling Formation (Givetian), Section 3, Bed 23. Paratype, GXD-398.

5. Wuxuanites washingtonensis n. g., n. sp. (p. 99)+

Side-by-each left and right valves showing ornament and profiles (× 4). Ertang Formation (Emsian), Section 4, Bed 32. Holotype, GXD-360. 

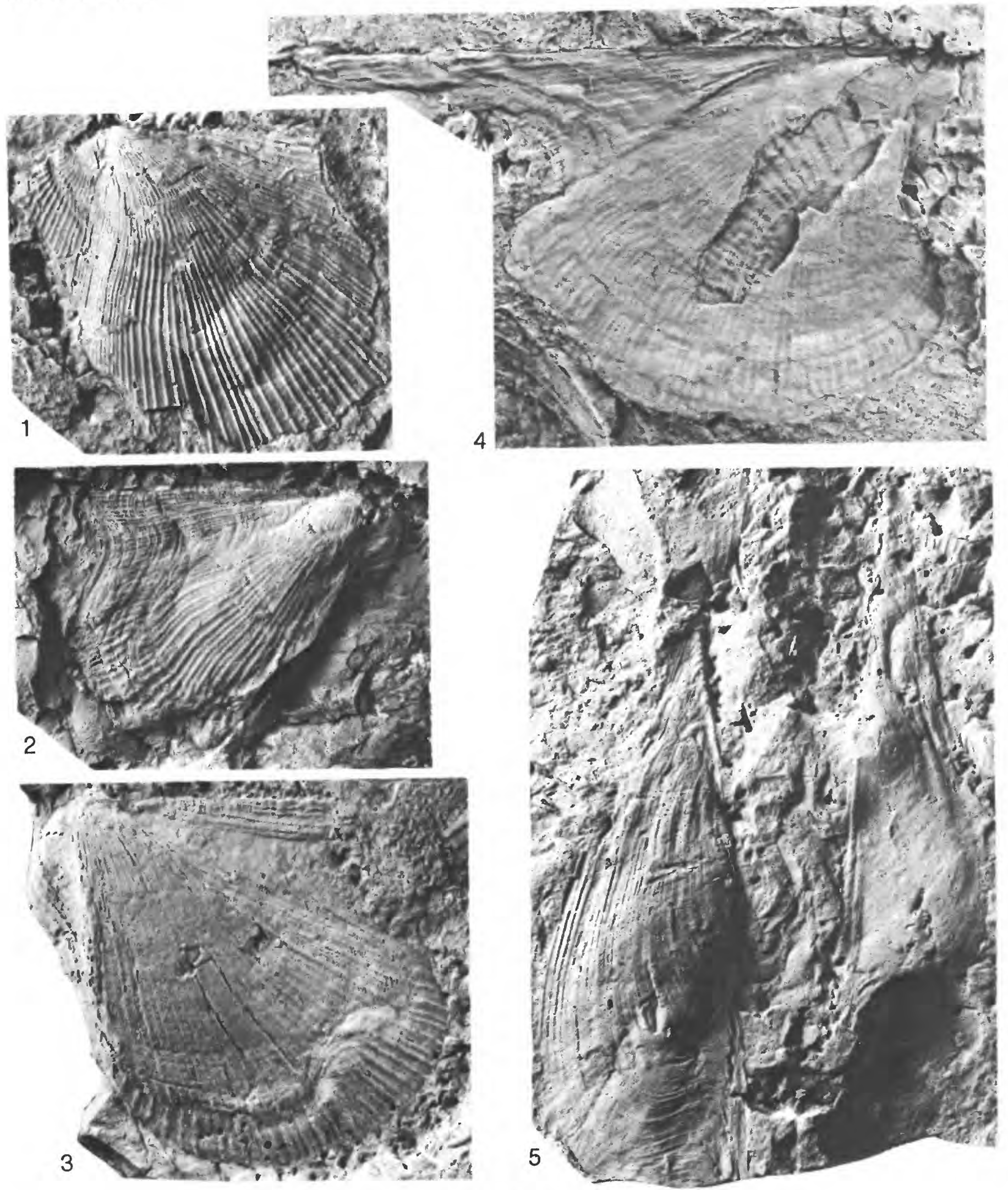

PTYCHOPTERIA (PTYCHOPTERIA), ACTINODESMA (ECTENODESMA), LIMOPTERA, AND WUXUANITES 


\section{PLATE 49}

Figures 1-5, 7. Ptychopteria (Ptychopteria) zhongguoensis Zhang, 1977 (p. 98)+

1-3. Articulated shelled specimen showing ornament and profiles $(\times 2)$. Ertang Formation (Emsian), Locality 6, GXD-414.

4, 5, 7. Right and two left valves, composite molds $(\times 3, \times 2, \times 3.5)$. Ertang Formation (Emsian), Locality 9. GXD-411-413.

6. Limoptera sp. (p. 97)+

Internal mold of left valve showing posterior lateral tooth (arrow) $(\times 2.5)$.

Donggangling Formation (Givetian), Section 3, Bed 23. GXD-399.

8-10. Ptychopteria (Actinopteria) producta n. sp. (p. 98)+

8. Left valve composite mold $(\times 3)$. Yingtang Formation (Eifelian), section 5, Bed 19. Paratype, GXD-446.

9. Left valve composite mold ( $\times 3$ ). Yingtang Formation (Eifelian), Section 5, Bed 16. Paratype, GXD-452.

10. Left valve composite mold ( $\times 3$ ). Horizon and locality the same as in figure 8 above. Holotype, GXD-427. 
GEOLOGICAL. SURVEY

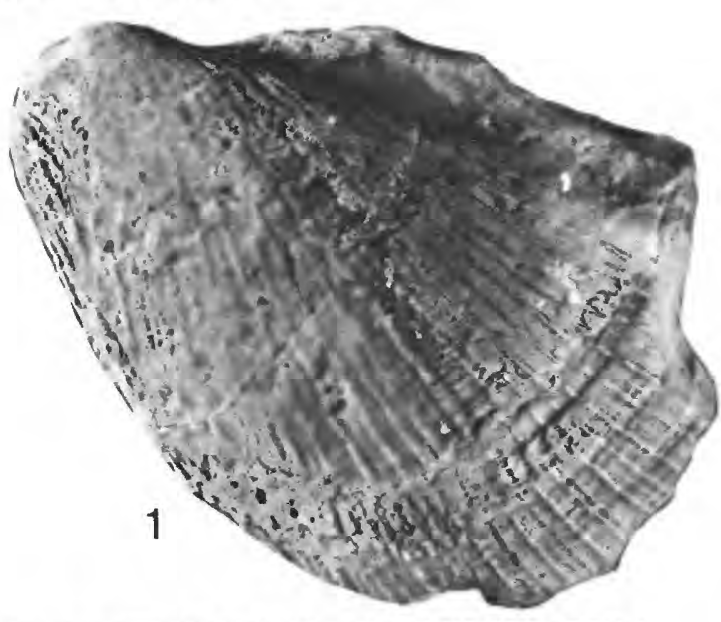

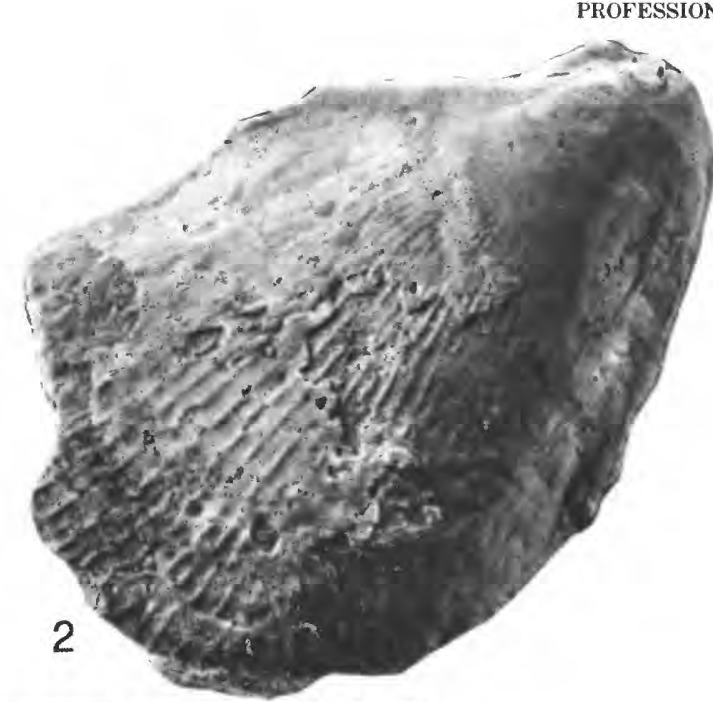
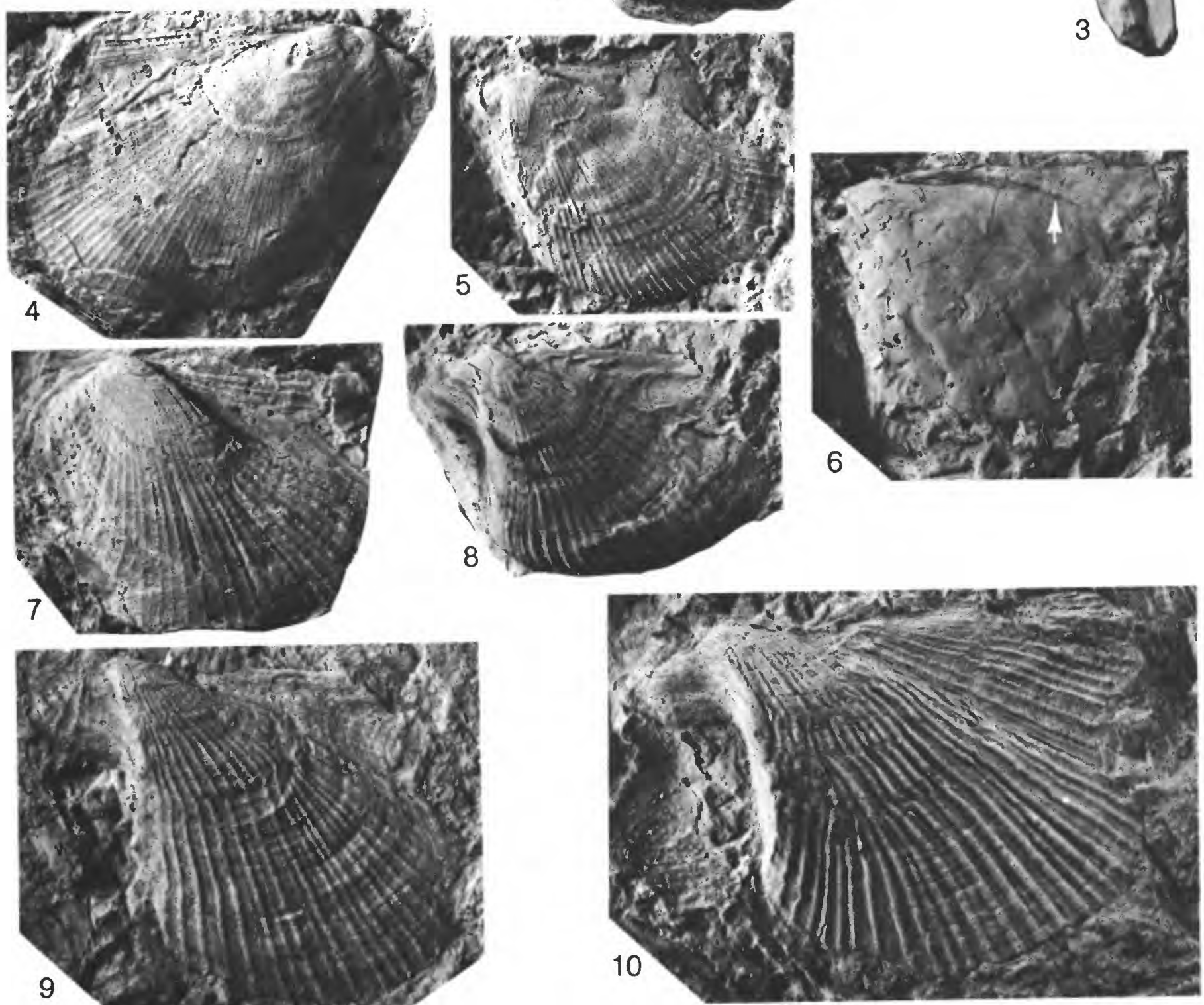

PTYCHOPTERIA (PTYCHOPTERIA), P. (ACTINOPTERIA), AND LIMOPTERA 


\section{PLATE 50}

Figures 1-5. Ptychopteria (Actinopteria) producta n. sp. (p. 98)+

1. Left valve internal mold showing posterior lateral tooth (arrow) $(\times 3)$. Yingtang Formation (Eifelian), Section 5, Bed 22. Paratype, GXD-474.

2. Left valve composite mold $(\times 3)$. Horizon and locality the same as in figure 1 above. Paratype, GXD-497.

3. Right valve composite mold found on same rock chip as holotype (GXD-427; pl. 49, fig. 10) ( $\times$ 3). Yingtang Formation (Eifelian), Section 5, Bed 19. Paratype, GXD-428.

4. Enlargement of umbonal area of left valve internal mold showing imprint of posterior lateral tooth and duplivincular ligament grooves (arrow) $(X$ 6). Horizon and locality the same as in figure 1 above. Paratype, GXD-473.

5. Left valve composite mold showing imprint of posterior lateral tooth (arrow) $(\times 2)$. Yingtang Formation (Eifelian), Section 5, Bed 21. Paratype, GXD-440.

6. Ptychopteria (A.) cf. P. (A.) producta n. sp. (p. 98)+

Left valve of a largely shelled specimen $(\times 1.5)$. Yujiang Formation (SiegenianEmsian), Section 1, Bed 21. GXD-418. 
GEOLOGICAL SURVEY
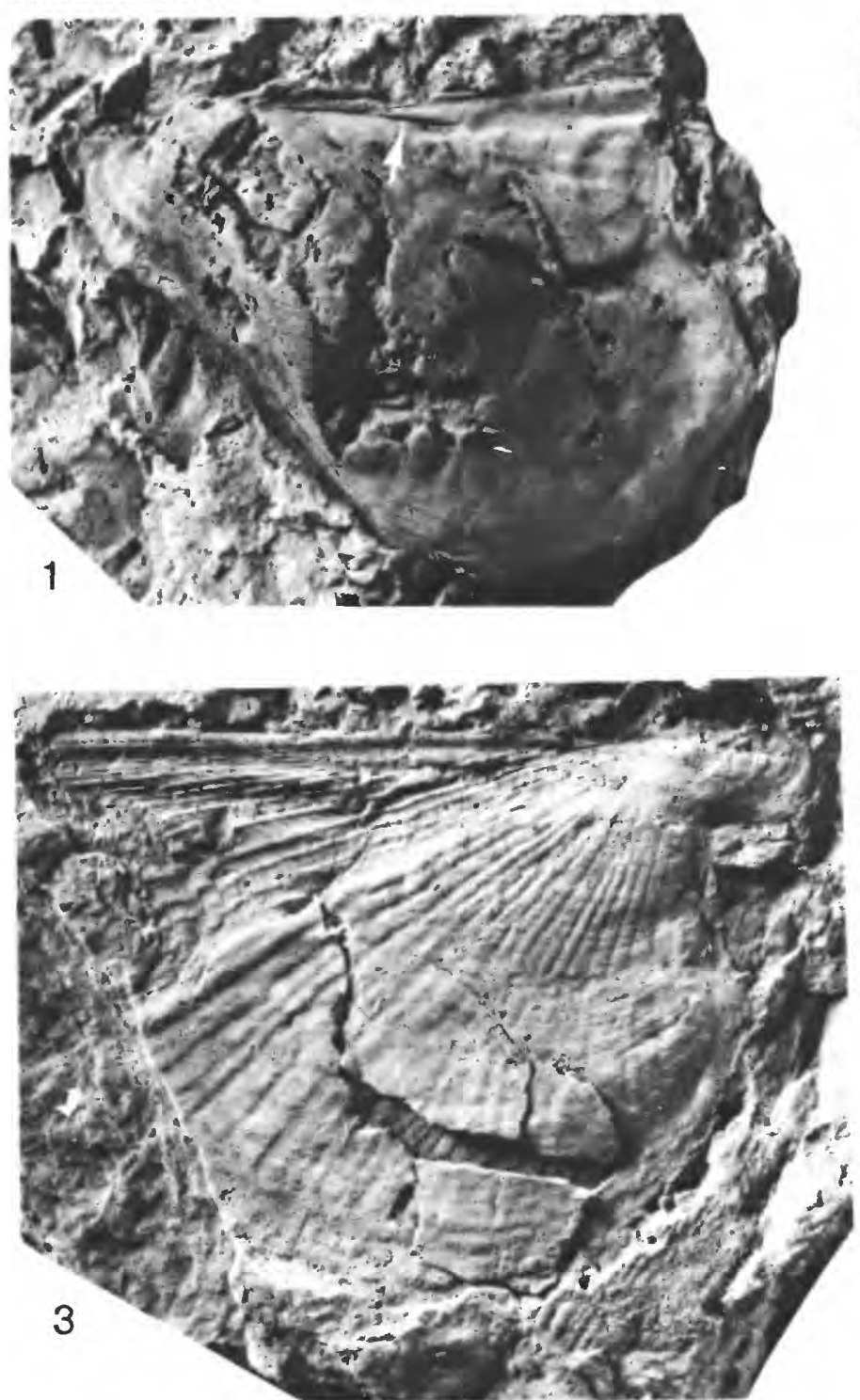

PROFESSIONAL PAPER 1394 PLATE 50
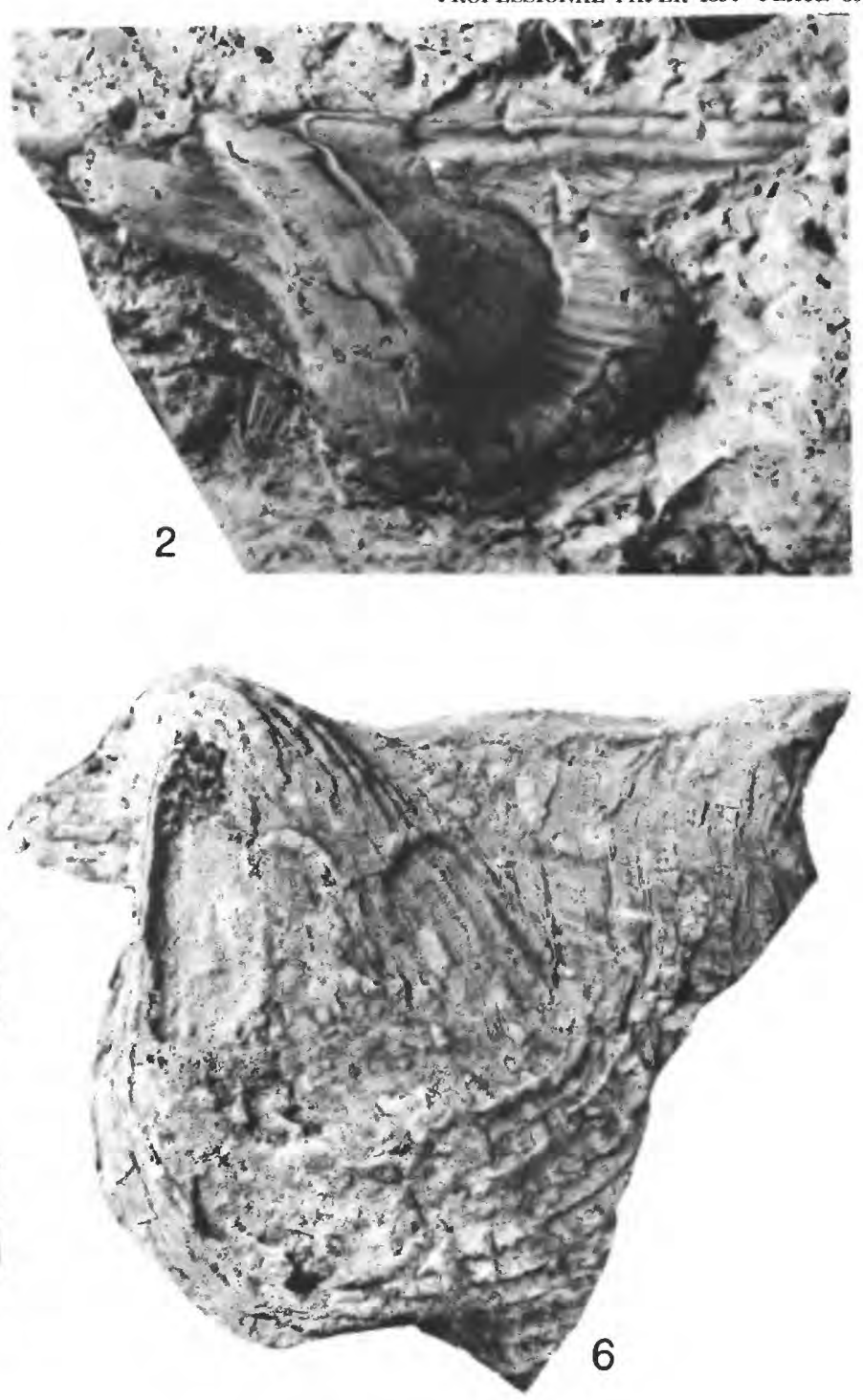
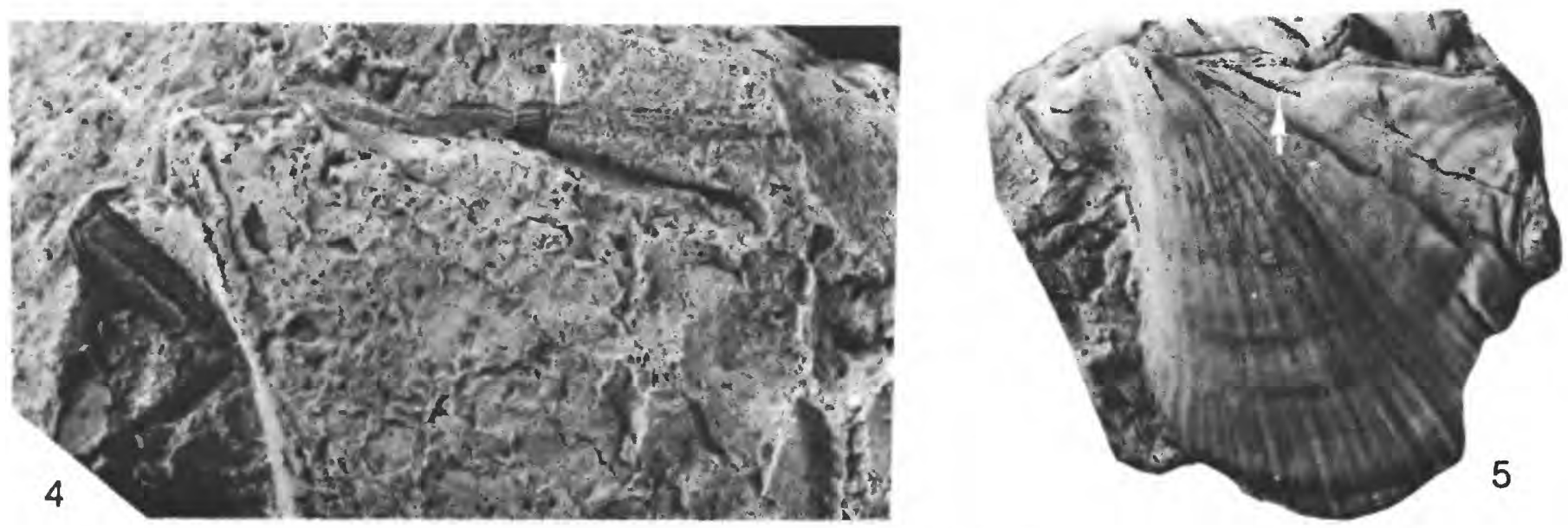


\section{PLATE 51}

Figure 1. Lyriopecten ertangensis n. sp. (p. 101)+

Left-lateral view of composite mold showing profile, posterior auricle, lack of anterior auricle, first order costae, and intercalated second order costellae (arrow) ( $\times$ 1.5). Ertang Formation (Emsian), Section 4, Bed 30. Holotype, GXD-493.

2, 3. Pterinopecten (Pterinopecten) wuxuanensis n. sp. (p. 100)+

2. Left-lateral view of composite mold showing profile, poorly defined posterior auricle, and anterior auricle with ribs $(\times 2)$. Ertang Formation (Emsian), Section 4, Bed 11. Paratype, GXD-512.

3. Left-lateral view of composite mold showing the same features as in figure 2 above and intercalate (short arrow) and bifurcate (long arrow) ribs ( $X$ 2.5). Ertang Formation (Emsian), Section 4, Bed 31. Holotype, GXD-515. 4, 5. Pterinopecten (Newellipecten) guangxiensis (Zhang), 1977 (p. 100)+

4. Left-lateral view of composite mold showing poorly defined posterior auricle, anterior auricle with ribs, profile, and intercalating costellae $(X$ 4). Ertang Formation (Emsian), Section 2, Bed 8. GXD-507.

5. Left-lateral view of composite mold showing the same features as in figure 4 above, arrow marks an intercalated costa $(\times 3.5)$. Ertang Formation (Emsian), Locality 9. Topotype, GXD-510. 
GEOLOGICAL SURVEY

PROFESSIONAL PAPER 1394 PLATE 51

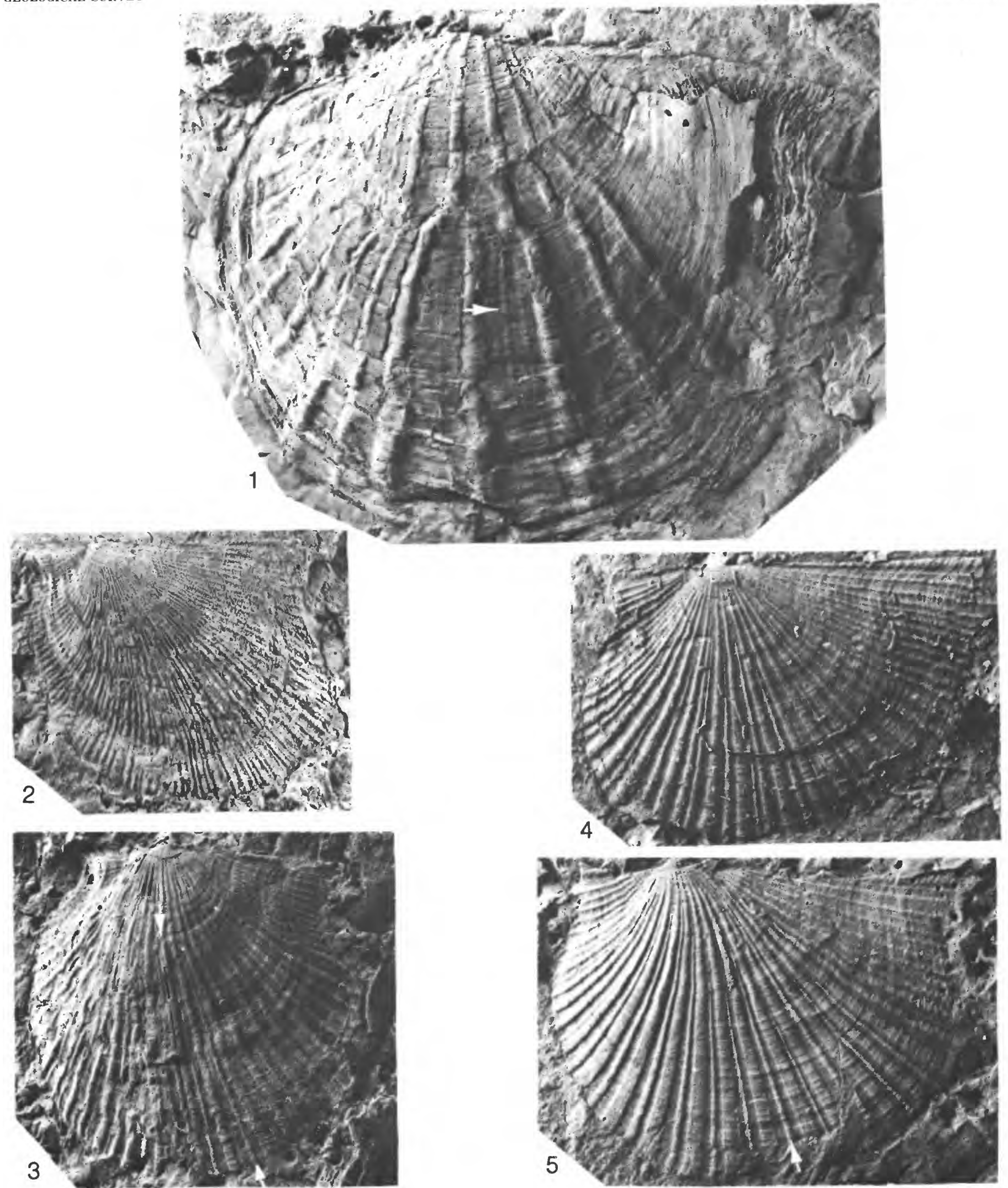

LYRIOPECTEN, PTERINOPECTEN (PTERINOPECTEN), AND P. (NEWELLIPECTEN) 


\section{PLATE 52}

Figures 1, 6, 7. Pterinopecten (Newellipecten) guangxiensis (Zhang), 1977 (p. 100)+

1. Left-lateral view of composite mold showing the same features as shown on plate 51 , figures 4 and $5(\times 2.5)$. Horizon and locality the same as on plate 51, figure 5. Topotype, GXD-509.

6, 7. Left-lateral views of two partially shelled specimens $(\times 4, \times 3.5)$. Horizon and locality the same as on plate 51, figure 5. Topotypes, GXD-505, -506 (=USNM 383617).

$2,4,5$. Lyriopecten ertangensis $\mathrm{n}$. sp. (p. 101)+

2. Left-lateral view of composite mold showing ornament and small posterior auricle $(\times 2)$. Ertang Formation (Emsian), Locality 6 , paratype, GXD-502 (=USNM 383618).

4. Left-lateral view of composite mold showing the same features as in figure 2 above $(\times 2.5)$. Horizon and locality the same as in figure 2 above. Paratype, GXD-499.

5. Left-lateral view of a composite mold showing the same features as in figure 2 above ( $\times 1.5$ ). Horizon and locality the same as on plate 51, figure 1. Paratype GXD-504.

3. Pterinopecten (Pterinopecten) wuxuanensis n. sp. (p. 100)+

Left-lateral view of composite mold $(\times 2.5)$. Horizon and locality the same as on plate 51, figure 3. Paratype, GXD-516. 
PROFESSIONAL PAPER 1394 PLATE 62

GEOLOGICAL SURVEY
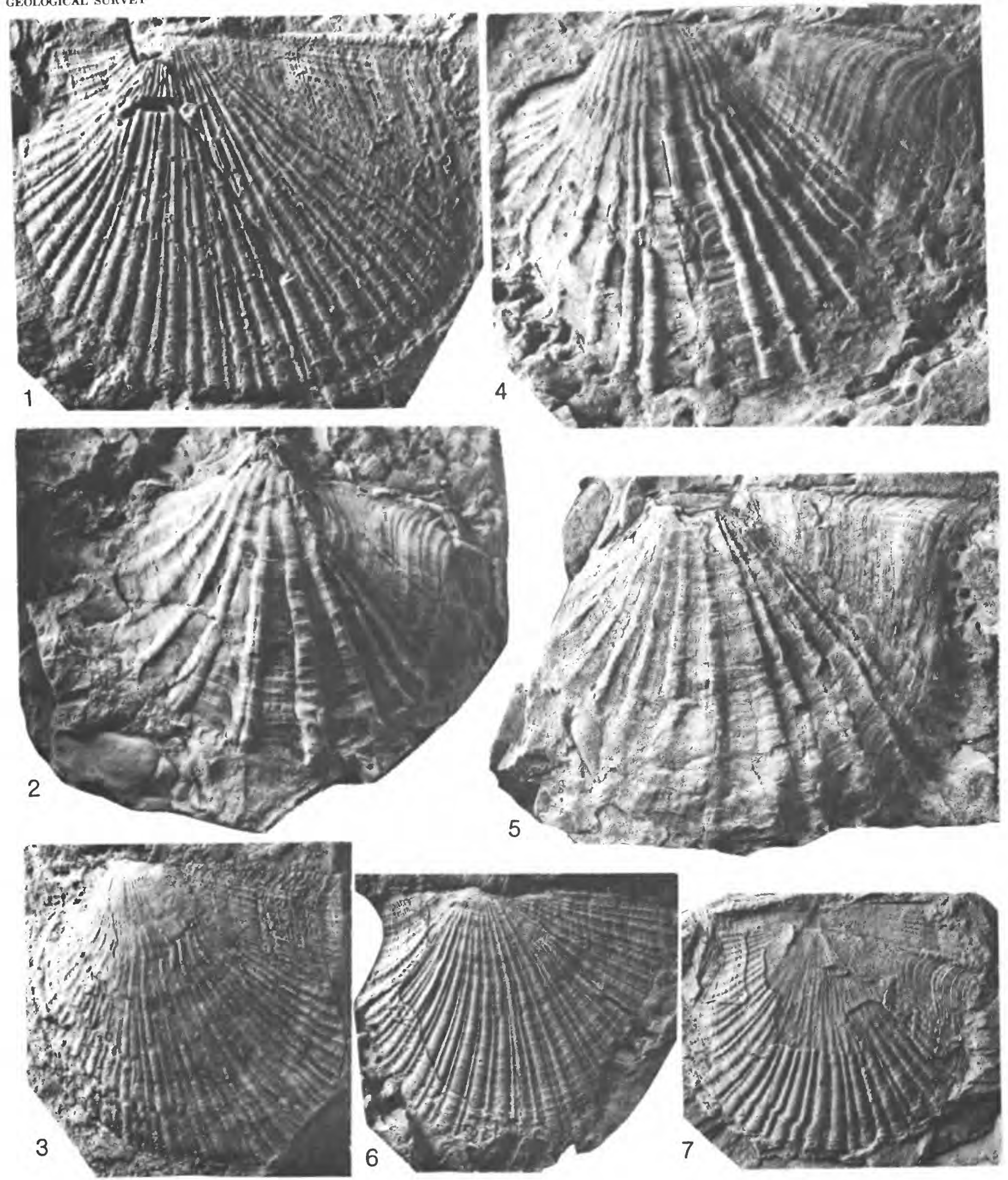

LYRIOPECTEN, PTERINOPECTEN (PTERINOPECTEN), AND P. (NEWELLIPECTEN) 


\section{PLATE 53}

FIGURES 1, 2. Lyriopecten ertangensis n. sp. (p. 101)+

Two left valve composite molds showing ornament and posterior wings, arrows mark subdividing primary ribs $(\times 1.5)$. Ertang Formation (Emsian), Section 4, Beds 30, 19. Paratypes, GXD-495, -501 .

3. Orthonota? parvula Hall and Whitfield, 1870 (p. 77)*

Left-lateral view of an internal mold showing profile and carina $(\times 5)$. Norway Point Formation, Norway Point Dam, Alpena County, Mich. USNM 374643.

4, 5. Paracyclas rugosa (Goldfuss), 1837 (p. 81)*

4. Left-lateral view of a shelled specimen showing ornament and profile $(\times 8)$. Potter Farm Formation, Alpena County, Mich. USNM 383611.

5. Left-lateral view of a shelled specimen showing ornament and profile ( $\times$ 2.5). Gorbut Member, Gravel Point Formation, Cheboygan County, Mich. USNM 383612.

6. Phenacocyclas? sp. A (p. 82)*

Left-lateral view of a composite mold $(\times 2.5)$. Gravel Point Formation, 2.5 miles west southwest of Petoskey, Mich. USNM 374638. 


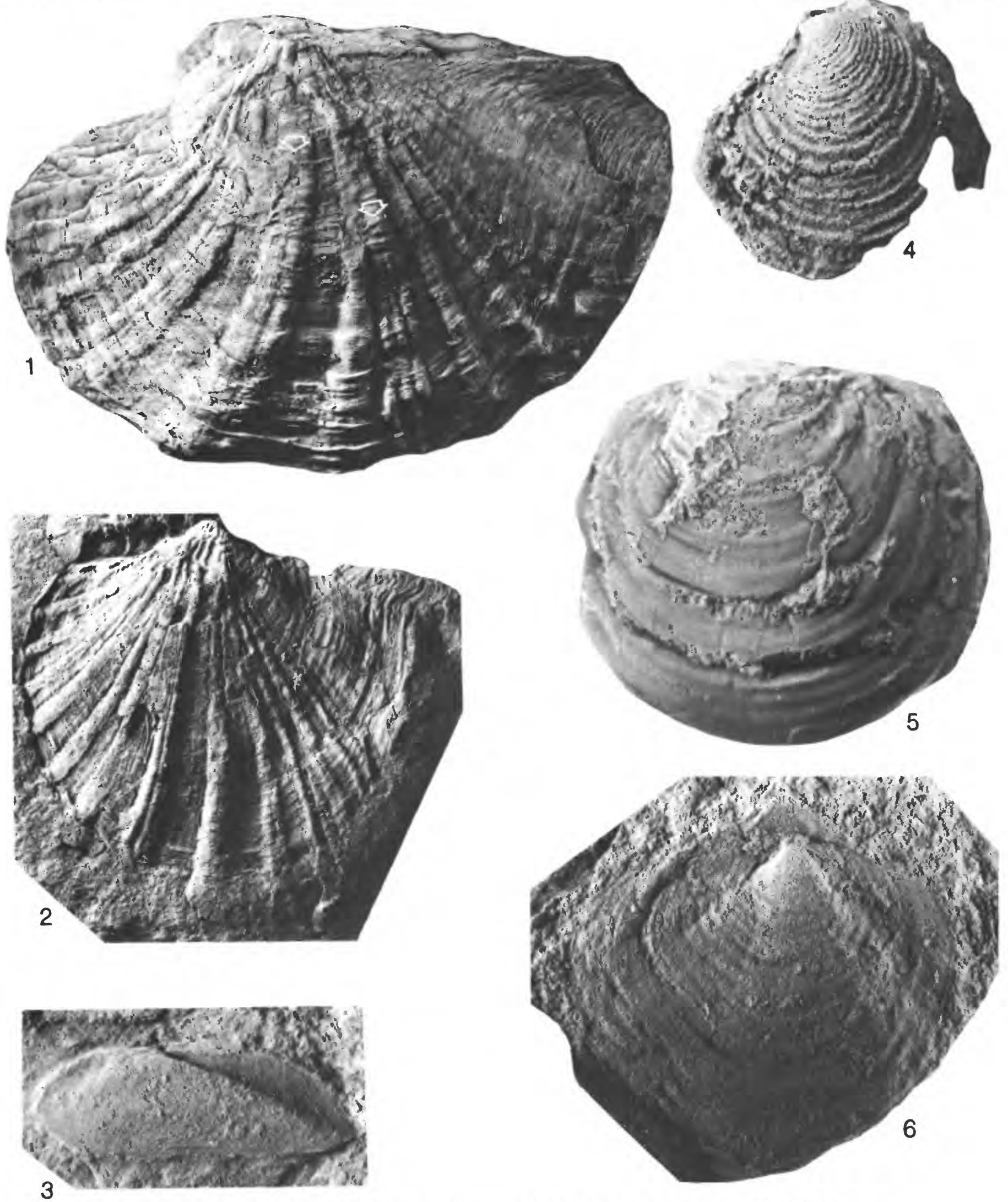

LYRIOPECTEN, PARACYCLAS, PHENACOCYCLAS?, AND ORTHONOTA? 


\section{PLATE 54}

Figures 1-7. Cimitaria recurva (Conrad), 1842 (p. 87 )*

1-4. Part and counterpart internal and external molds. (1, 2) Right-lateral and dorsal views of incomplete internal mold showing midumbonal sulcus (arrow) $(\times 1.5)$. $(3,4)$ External mold of right valve and wax replica of same showing midumbonal sulcus (arrow) and umbonal ridge $(\times 1)$. Upper Alpena Limestone, Four Mile Dam, Alpena County, Mich. USNM 374646, YPM 16498.

5-7. Right-lateral, left-lateral, and dorsal views of a composite mold showing profiles, ornament, and umbonal sulcus (arrow) $(\times 1.5)$. Thunder Bay Limestone, Partridge Point, Alpena County, Mich. USNM 374647.

8, 9. Cypricardinia $\mathrm{sp.} \mathrm{A.} \mathrm{(p.} 83)^{*}$

Left-lateral and right-lateral views of shelled specimens showing comarginal and divaricate ornament and profiles $(\times 8)$. Four Mile Dam Formation, Four Mile Dam, Alpena County, Mich. YPM 16626, 16627.

10. Schizodus sp. A (p. 80$)^{*}$

Left-lateral view of a weathered internal mold $(\times 5)$. Genshaw Formation, Alpena Portland Cement Co., Alpena County, Mich. USNM 374631. 

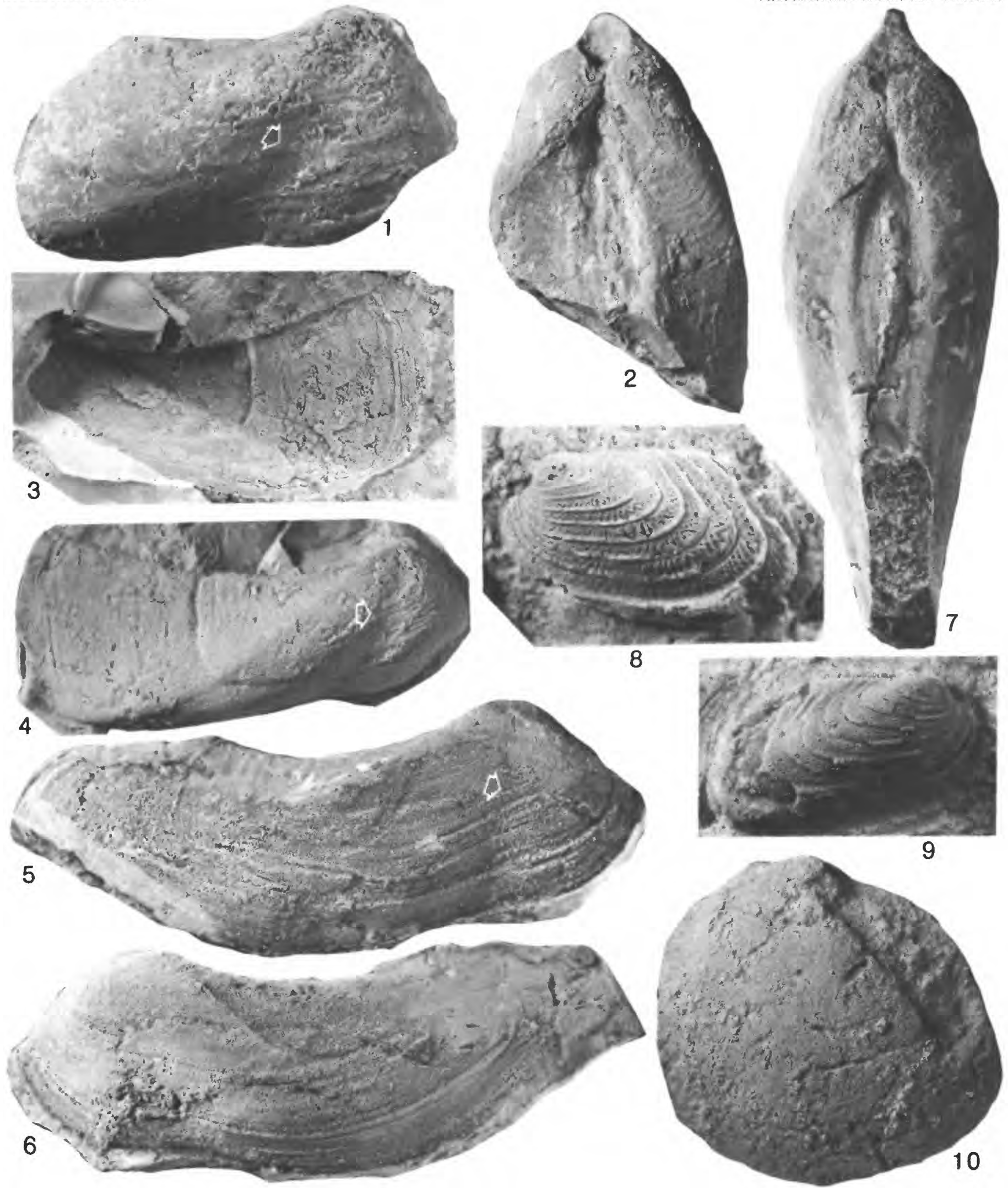

CIMITARIA, CYPRICARDINIA, AND SCHIZODUS 


\section{PLATE 55}

Figures 1-5. Cypricardella gregaria (Hall and Whitfield), 1869 (p. 82)*

1, 2. Hinge line and exterior views of a shelled left valve showing dentition (long arrow marks anterior cardinal tooth), lunule (short arrow), ligament space, ornament and profile $(\times 3)$. USNM 383621.

3. Interior of right valve of a shelled specimen showing dentition (white arrow marks cardinal tooth), lunule (black arrow), ligament space, pallial line, and adductor muscle scars $(\times 3)$. USNM 383622.

4, 5. Hinge line and exterior views of a left valve showing profiles $(\times 3)$. According to the museum label, the hinge-line features seen on this specimen are not accurate because of faulty preparation. USNM 374639 .

All specimens from the Koehler Limestone, Cheboygan County, Mich.

6. Grammysioidea sp. (p. 85$)^{*}$

Right-lateral view of an articulated composite mold $(\times 2.5)$. Norway Point Formation, Four Mile Dam, Alpena County, Mich. USNM 374645.

7. Grammysia sp. (p. 85$)^{*}$

Left-lateral view of a highly distorted composite mold $(\times 1.5)$. Norway Point Formation, Norway Point Dam, Thunder Bay River, Alpena County, Mich. USNM 374644. 

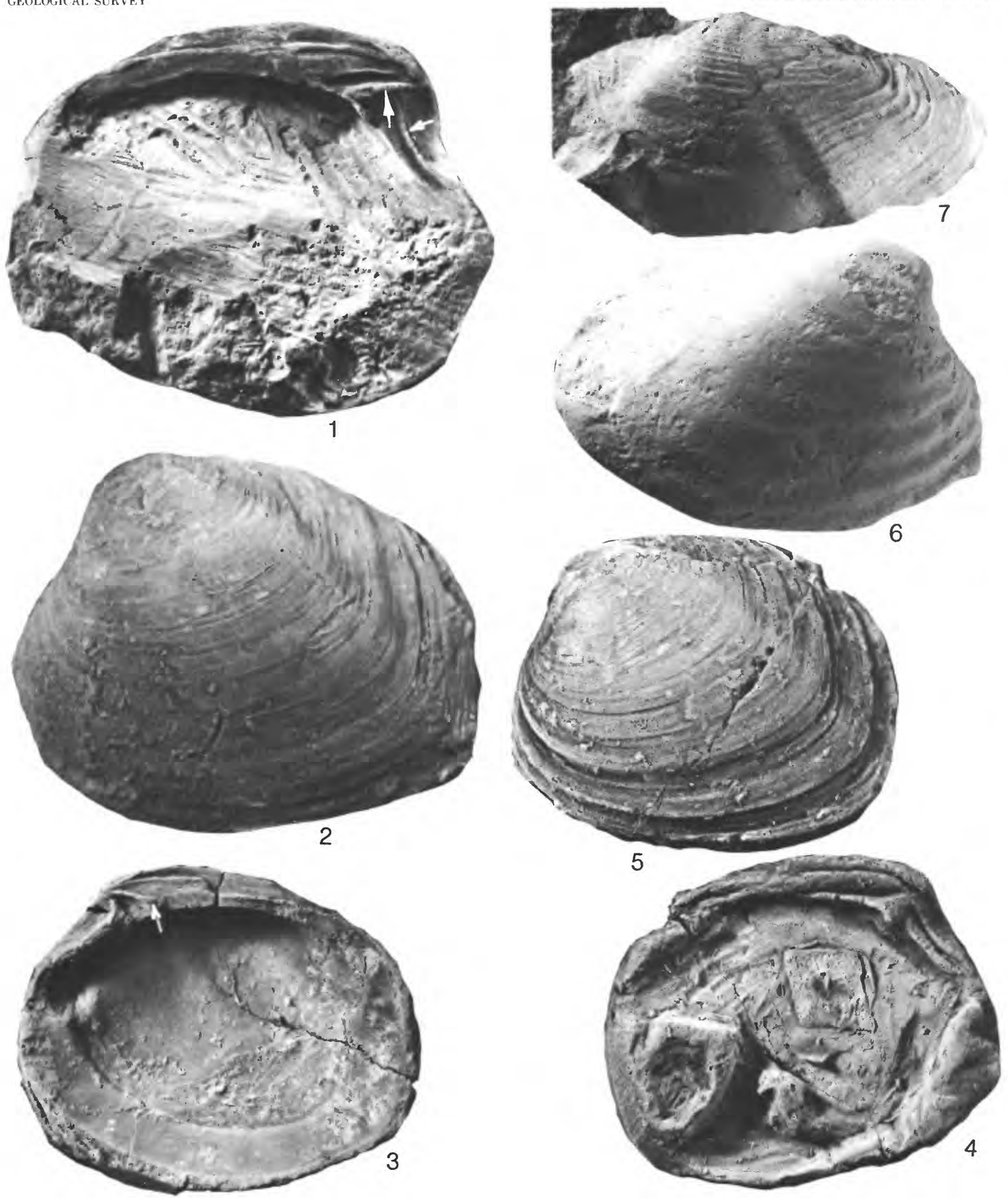

CYPRICARDELLA, GRAMMYSIA, AND GRAMMYSIOIDEA 


\section{PLATE 56}

Figunes 1-4. Cypricardinia sp. A. (p. 83)*

1,2. Enlargement and view of shelled entire right valve showing divaricate and comarginal ornament $(\times 15, \times 10)$. Four Mile Dam Formation, Alpena County, Mich. YPM 16636.

3. Shelled right valve showing ornament $(\times 10)$. Upper Alpena Limestone, Four Mile Dam, Alpena County, Mich. YPM 16468.

4. Right-lateral view of a shelled specimen with an exfoliated outer shell layer and showing only comarginal ornament $(\times 10)$. Lower Alpena Limestone, at quarry of the Michigan Alkali Company, Alpena, Mich. USNM 383613.

5-8. Cypricardella? sp. A (p. 82)*

5. Right-lateral view of internal mold showing profile $(\times 3)$. YPM 16628.

6 , 7. Right-lateral and anterior views of an internal mold showing adductor muscle scars, anterior pedal retractor muscle scars (arrow), pallial line, and impressions of radial mantle muscles (X 3). YPM 16629.

8. Dorsal view of a small internal mold showing an impression of a possible tooth in the left valve $(\times 8)$. All from the Charlevoix Formation, Northern Lime Company Quarry, Petosky, Mich. YPM 16630.

9. Cypricardella gregaria (Hall and Whitfield), 1869 (p. 82)*

Internal mold showing adductor muscle scars, pallial line, and midumbonal sulcus (×3). Horizon and locality the same as in plate 55, figures 1-5. USNM 383651. 
GEOLOGICAL SURVEY
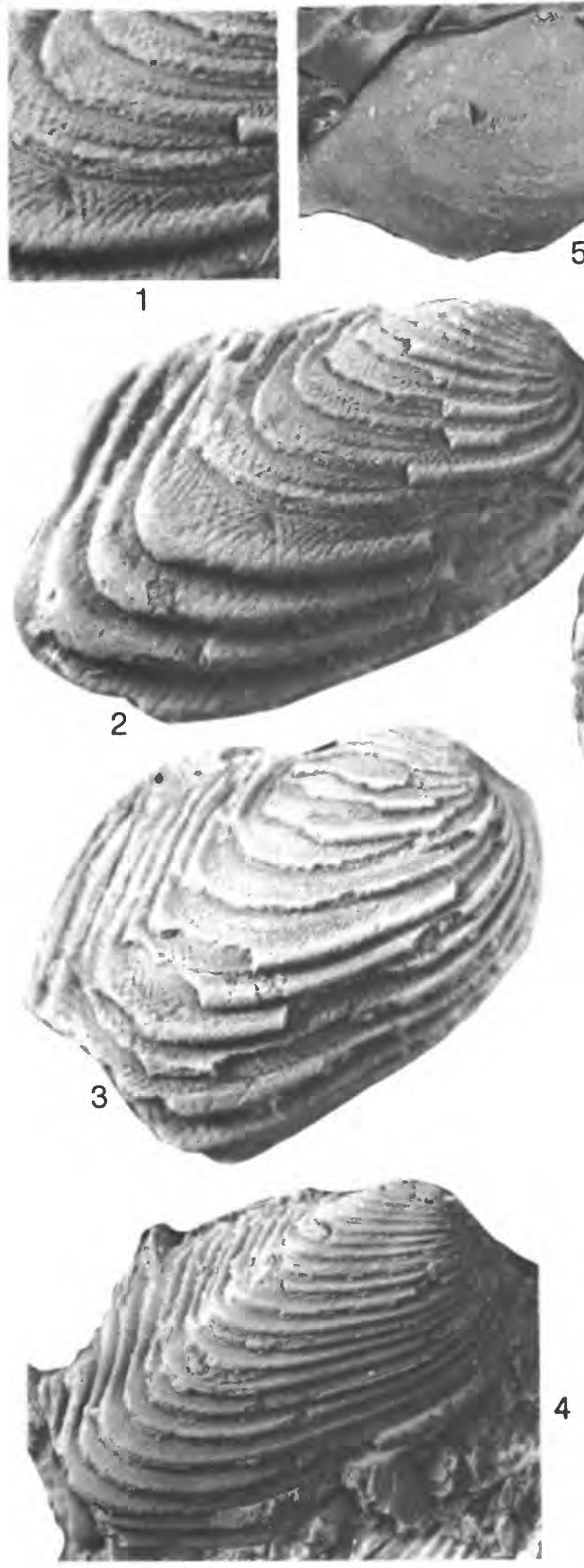
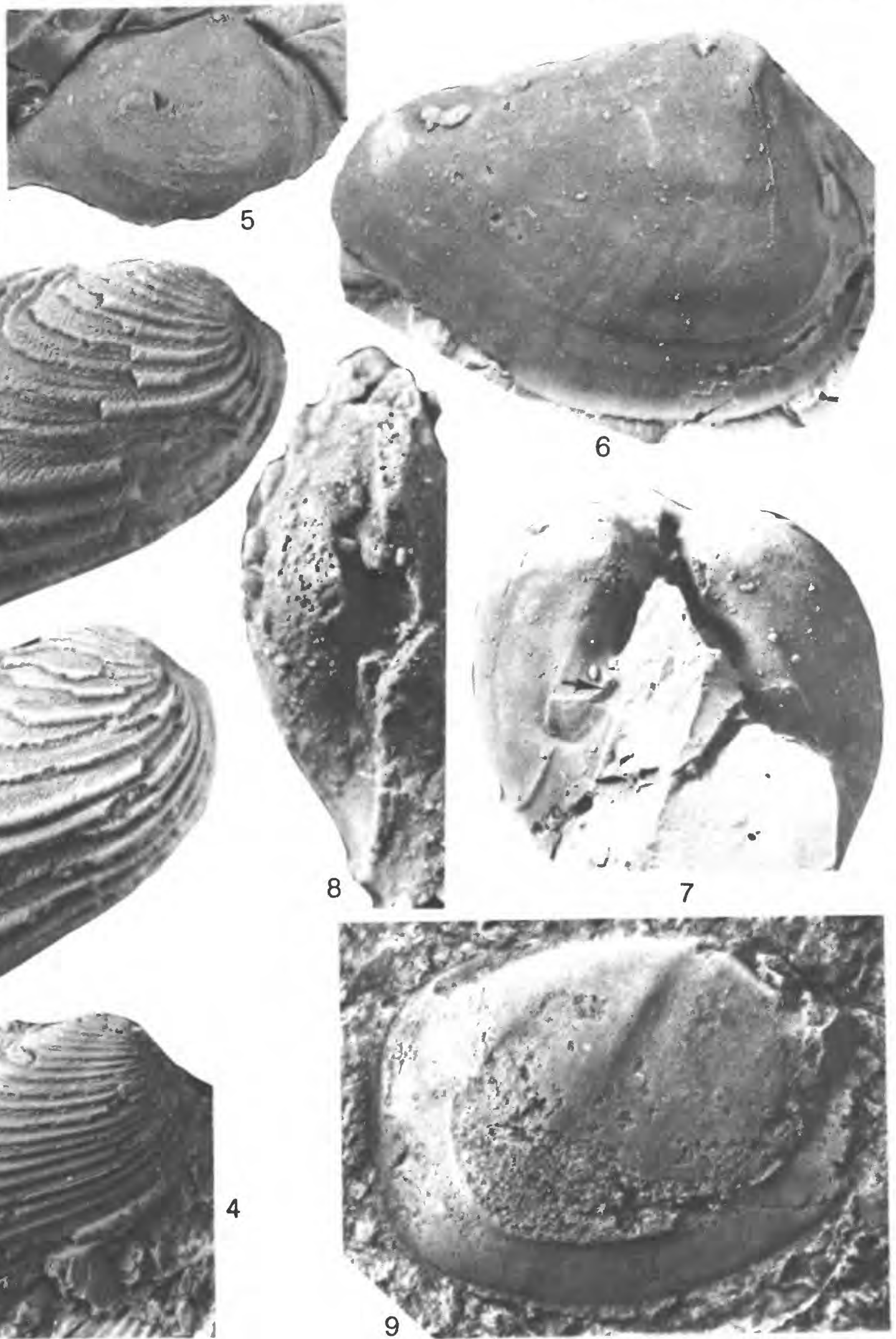

CYPRICARDINIA, CYPRICARDELLA?, AND CYPRICARDELLA 


\section{PLATE 57}

Figures 1, 2. Mytilarca cf. $M$. oviformis (Conrad), 1842 (p. 92)*

1. Left valve composite mold showing growth lines $(\times 1.5)$. Thunder Bay Formation, Partridge Point, 4 miles south of Alpena, Mich. USNM 383608.

2. Left-lateral view showing profile and umbo $(\times 1.5)$. Upper Alpena Limestone, Four Mile Dam, Alpena County, Mich. YPM 16449.

3, 4, 12. Mytilarca cf. $M$. chemungensis (Conrad), 1842 (p. 91$)^{*}$

3,4 . Right-lateral and anterior views of a shelled specimen showing profiles and lack of byssal gape $(\times 3.5)$. Upper Alpena Limestone, Four Mile Dam, Alpena County, Mich. YPM 16441.

12. Right-lateral view of an incomplete shelled specimen showing growth lines $(\times 2.5)$. Four Mile Dam Formation, Four Mile Dam, Alpena County, Mich. USNM 383651

5-8. Sphenotus arcaeformis (Hall and Whitfield), 1869 (p. 86)*

Left valve and three right valve composite molds showing variation in comarginal and radial ornament $(\times 3) .(5,6,8)$ Hamiltonian (Givetian), Delphi Member, Skaneateles Formation, Pratt Falls, 5 miles south of Manlius, Onondaga County, N.Y. USNM 102107, 383614, 383615. (7) Hamiltonian (Givetian), Delphi Falls, Onondaga County, N.Y. USNM 17707. Both of these localities were mentioned by Hall (1885, p. 395), and these specimens are probably topotypes of the type species of Sphenotus.

9-11. Gosseletia triquetra (Conrad), 1838 (p. 92)*

Anterior, right-lateral, and hinge line views of a shelled specimen $(\times 2)$. Lower Bell Shale, quarry of the Michigan Limestone and Chemical Co., east of Rogers City, Mich. USNM 383616. 
GEOLOGICAL SURVEY
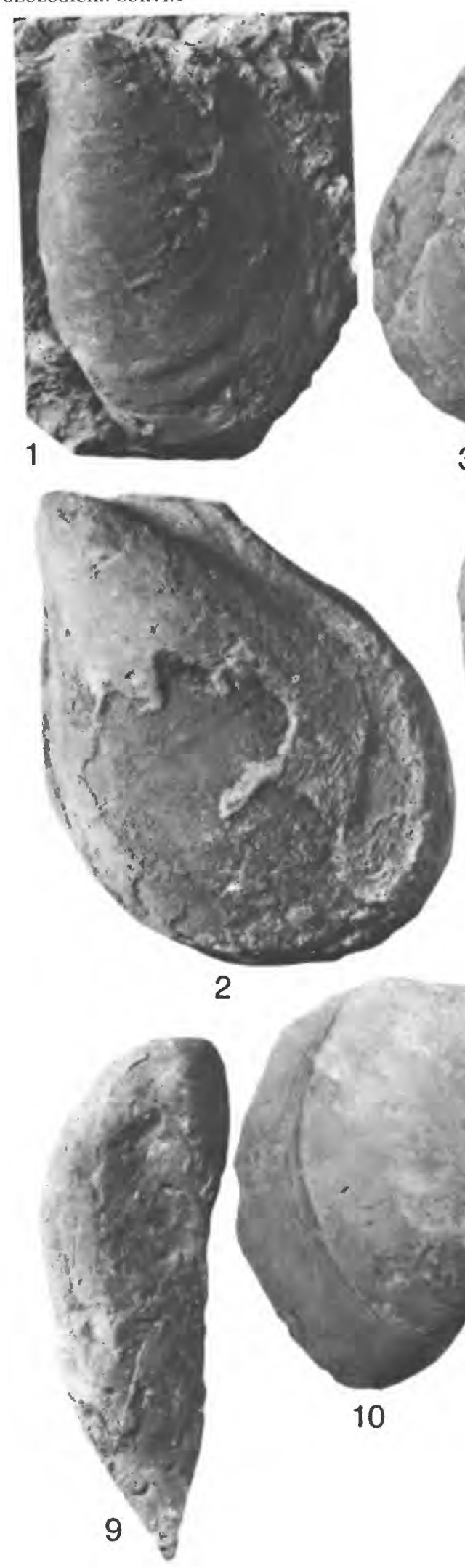
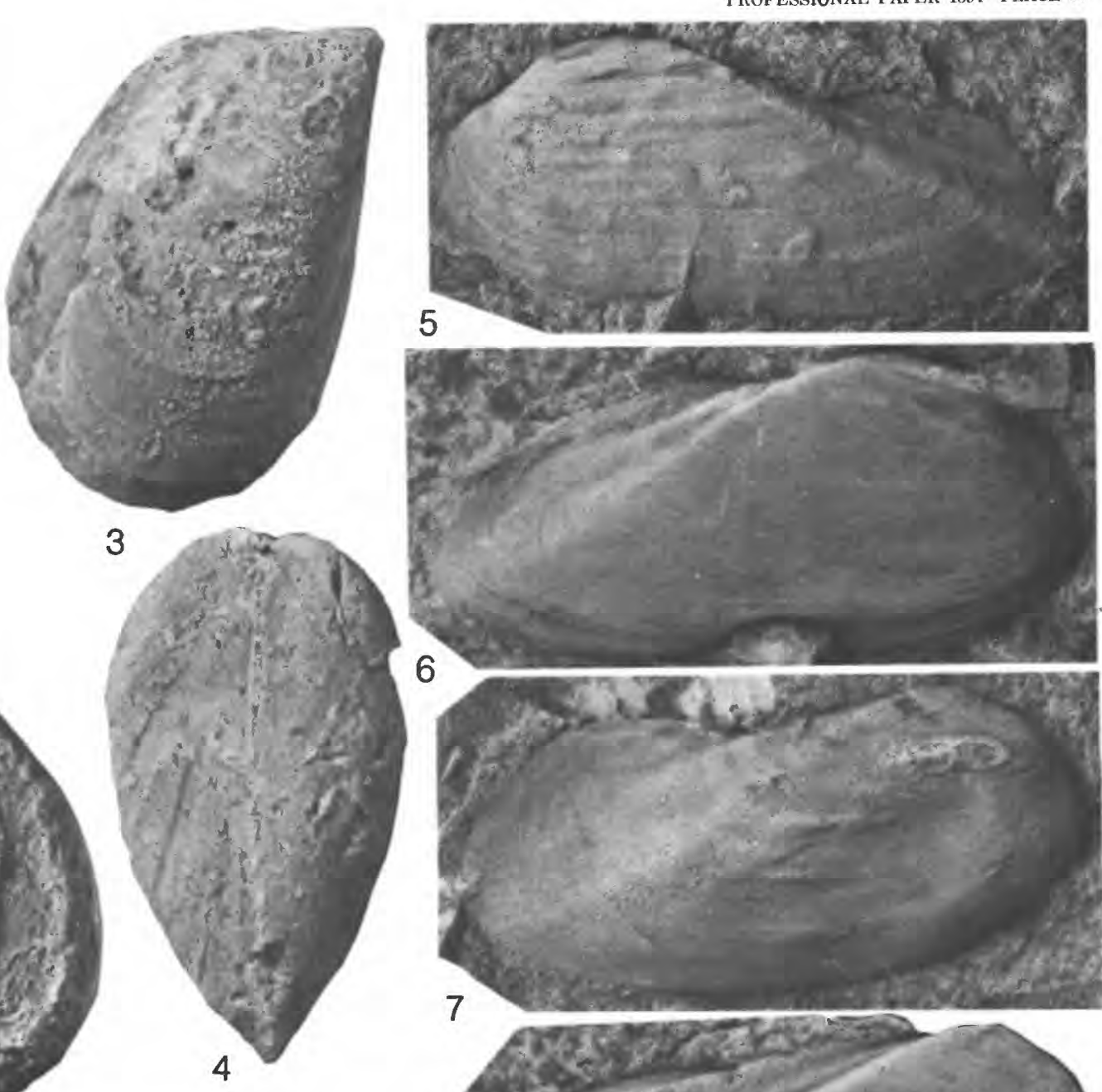

6
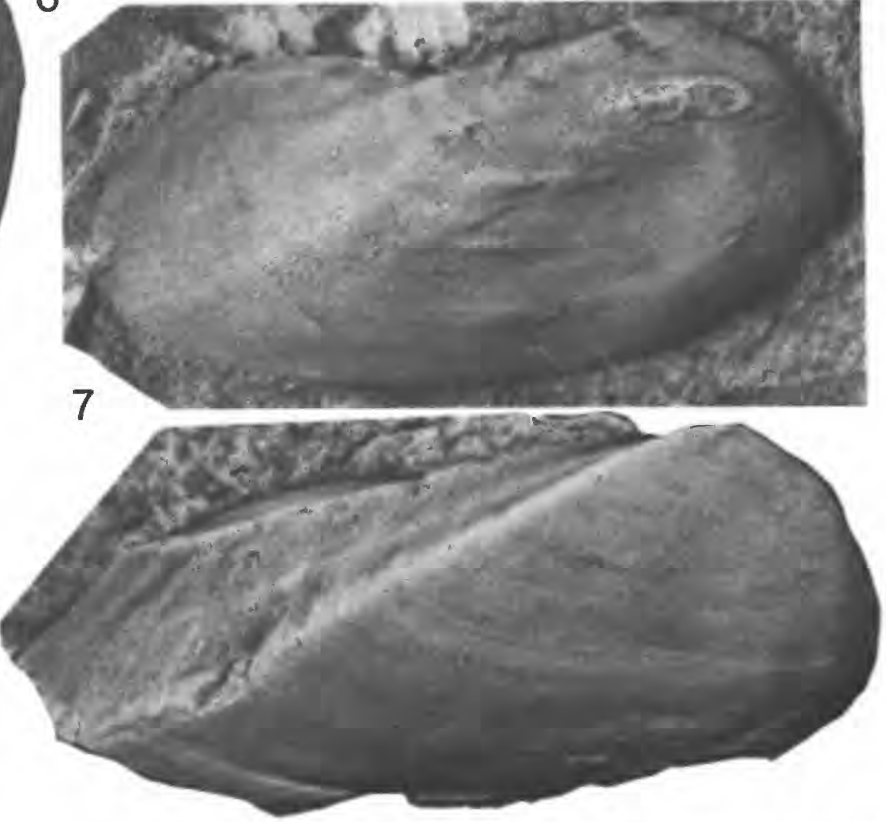

8

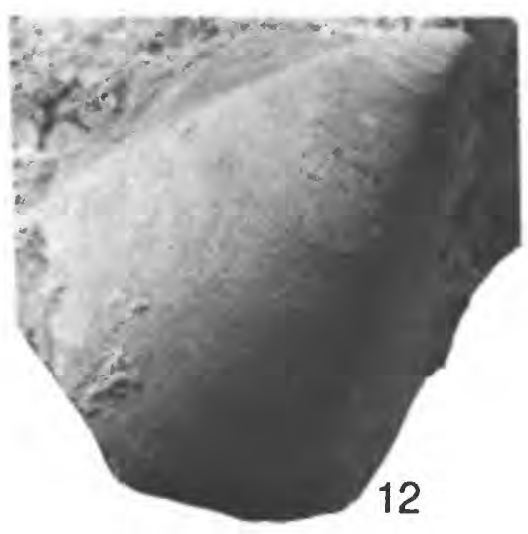

MYTILARCA, SPHENOTUS, AND GOSSELETIA 


\section{PLATE 58}

Figures 1, 2. Pseudaviculopecten exacutus (Hall), 1883 (p. 101)*

1. Right valve exterior of a shelled specimen showing profile and rib increase by intercalation (arrows) ( $\times 3$ ). Four Mile Dam Formation, Four Mile Dam, Thunder Bay River, Alpena County, Mich. USNM 383641.

2. Dorsal view of articulated specimen, anterior end up, showing biconvex valves ( $\times 3$ ). See plate 59, figure 2. Upper Alpena Limestone, Four Mile Dam, Alpena County, Mich. USNM 383642.

3, 4. Lyriopecten cf. L. tricostatus (Vanuxem), 1842 (p. 101)*

3. Left valve exterior of a shelled specimen showing primary simple radial ribs and intercalated secondary radial ribs $(\times 3)$. Upper Ferron Point Formation, from an abandoned shale pit, NW1/4SE1/4 sec. 18, T. 32 N., R. 9 E., Alpena County, Mich. YPM 16465.

4. External mold of left valve showing two orders of radial ribs $(\times 3)$. Gravel Point Formation, quarry of the Penn Dixie Co., Petoskey, Emmet County, Mich. USNM 383619.

5-8. Aviculopecten ornatus Hall, 1883 (p. 102)*

5. Left valve external mold showing increase in ribs by intercalation $(\times 5)$. Formation and locality unknown. YPM 16619.

6. Left valve of shelled specimen showing profile and intercalated secondary radial ribs $(\times 5)$. Formation and locality unknown. YPM 16620.

7. Dorsal view of articulated specimen, anterior up, showing flat right valve with bifurcating radial ribs (arrow) and convex left valve with secondary intercalated radial ribs (arrow) $(\times 5)$. Upper Alpena Limestone, Four Mile Dam, Alpena County, Mich. YPM 16461.

8. Left valve exterior of a shelled specimen showing profile and intercalated secondary radial ribs (arrow) $(\times 5)$. Formation and locality the same as in figure 7 above. YPM 16463. 
GEOLOGICAL SURVEY

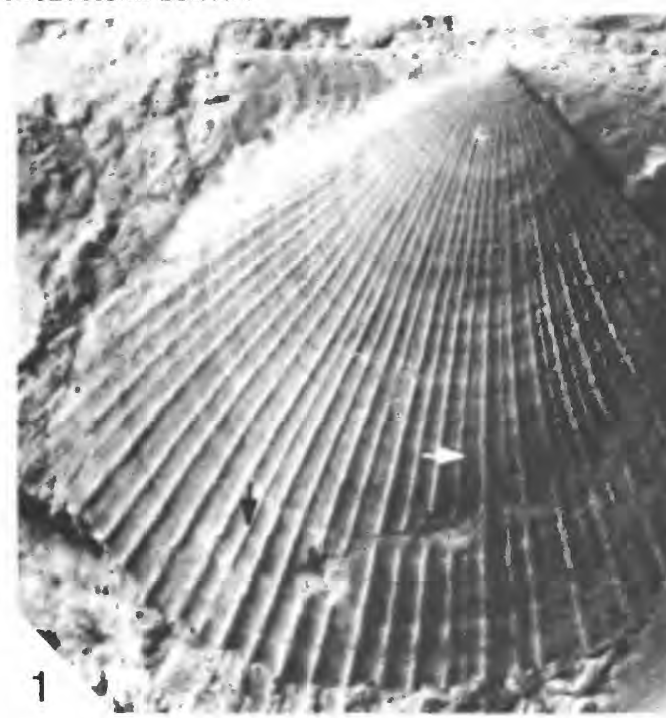

B.n.ty
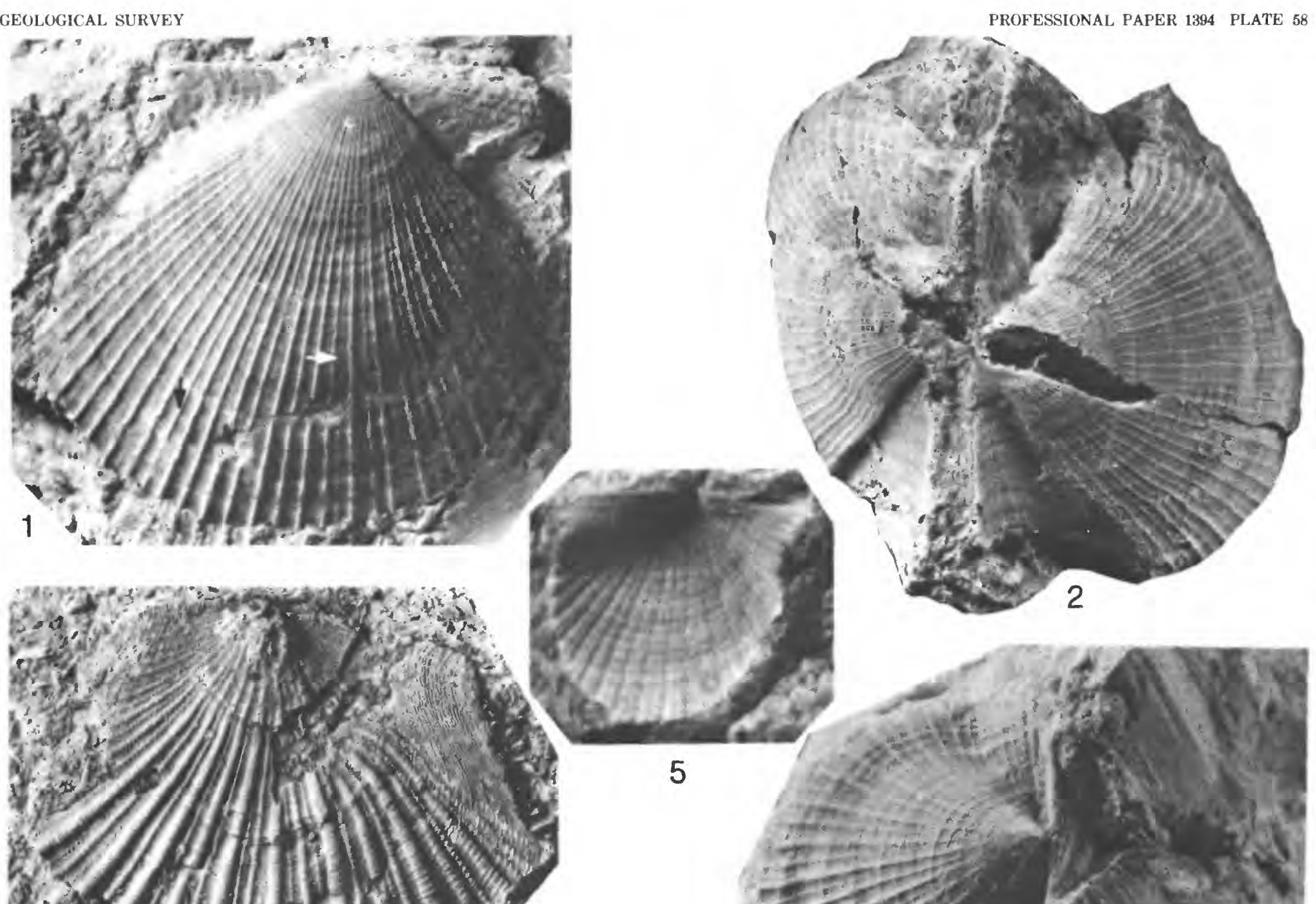

830 .

(3)
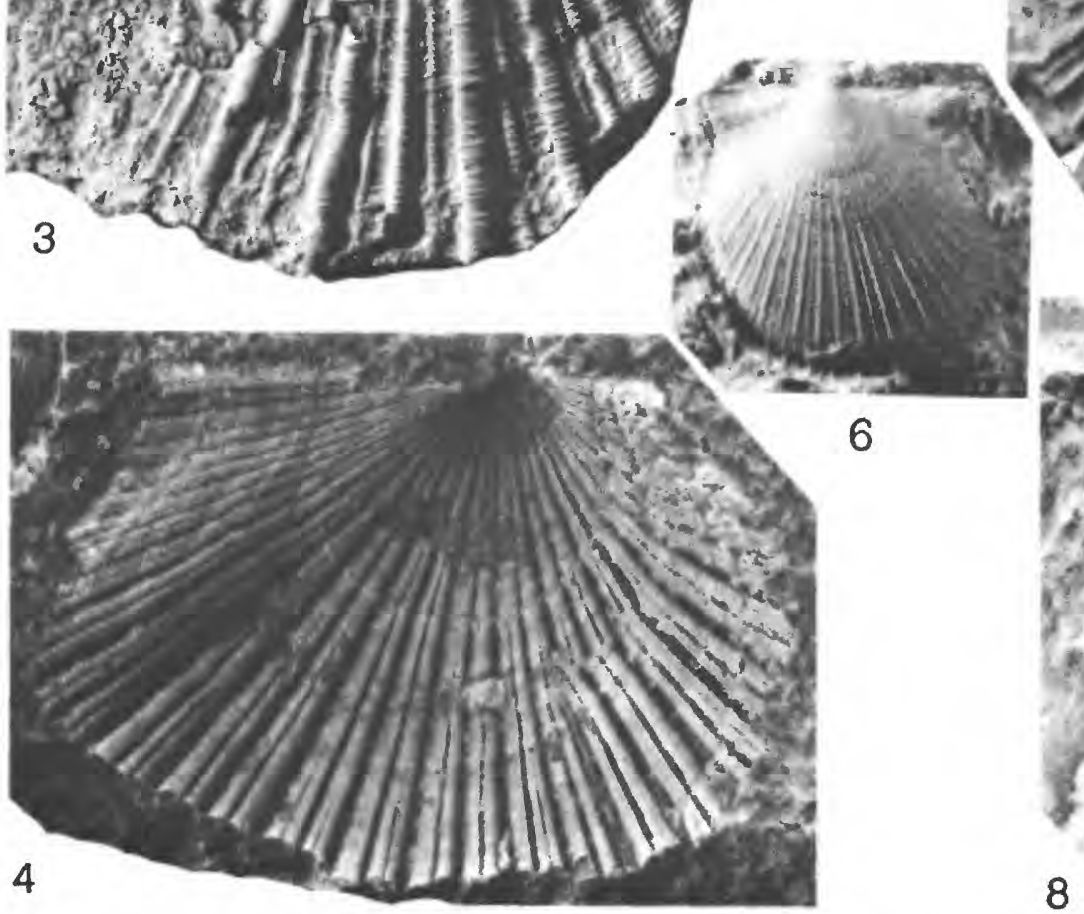

5
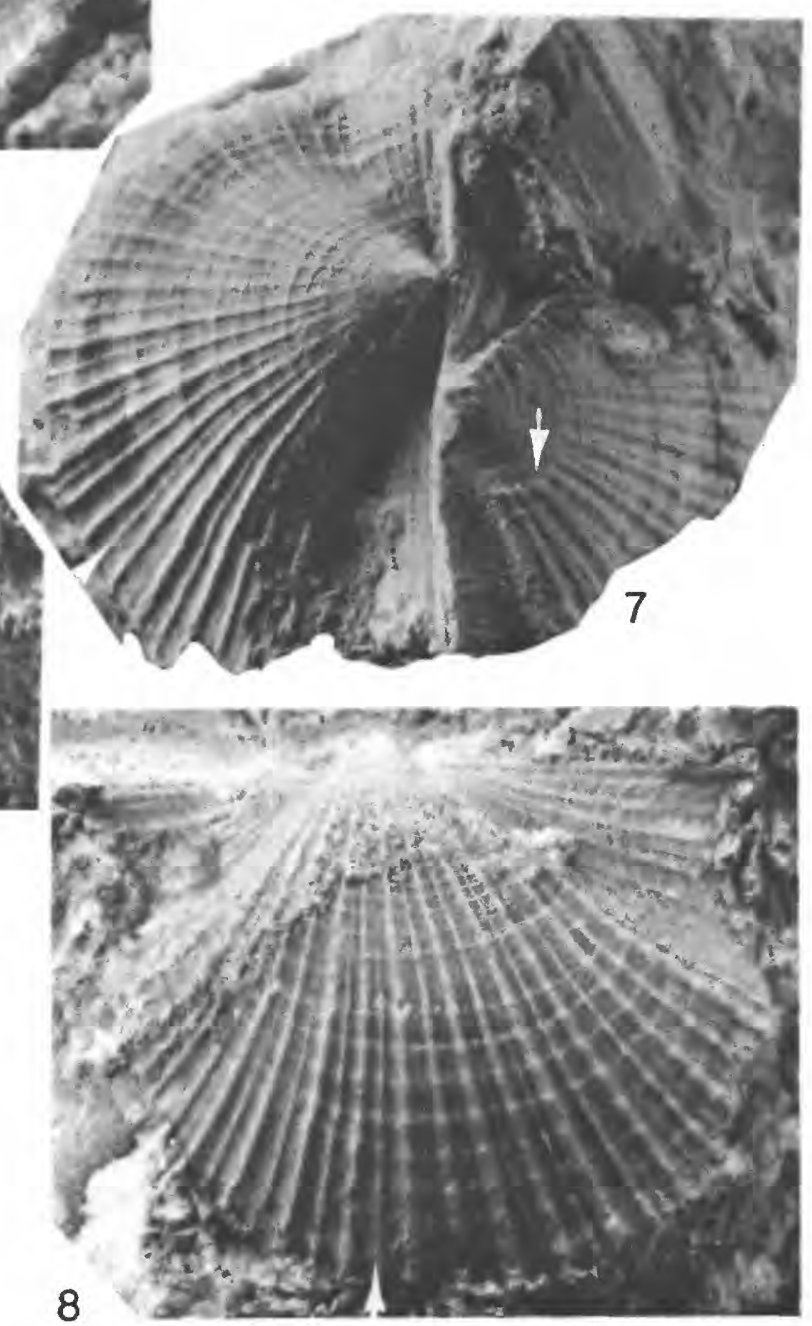

LYRIOPECTEN, PSEUDAVICULOPECTEN, AND AVICULOPECTEN 


\section{PLATE 59}

Figures 1-3. Pseudaviculopecten exacutus (Hall), 1883 (p. 101)*

1. Right valve of a shelled specimen showing radial ribs, auricles, and comarginal rugae $(\times 3)$. Upper Alpena Limestone, Four Mile Dam, Alpena County, Mich. USNM 383643.

2. Left valve of the articulated specimen seen in plate 58 , figure 2 , showing intercalated radial ribs (arrow) (X 3). USNM 383641.

3. Dorsal part of a shelled right valve showing auricles $(\times 3)$. Formation and locality the same as in figure 1 above. USNM 383644.

4-9. Aviculopecten ornatus Hall, 1883 (p. 102)*

4. External mold of skewed, partially articulated valves, right valve on left side of photograph showing byssal notch (arrow) ( $\times 5$ ). Four Mile Dam Formation, Four Mile Dam, Alpena County, Mich. USNM 383645 .

5. Right valve shelled specimen showing auricles and double bifurcation of radial ribs $(\times 4)$. Formation and locality the same as in figure 4 above. USNM 383646.

6. Right valve shelled specimen showing double bifurcation of radial ribs (arrows) $(\times 5)$. Formation and locality the same as in figure 1 above. YPM 16462.

7. External mold of left valve showing secondary intercalated radial ribs and auricles $(\times 5)$. Upper Alpena Limestone, locality unknown. YPM 16621.

8. Left valve shelled specimen showing intercalated secondary radial ribs and cancellate ornament $(\times 5)$. Formation and locality the same as in figure 7 above. YPM 16622.

9. Left valve shelled specimen showing auricles, intercalated secondary radial ribs (arrow), and posterior cancellate ornament $(\times 5)$. Horizon and locality the same as in figure 4 above. USNM 386647.

10. Ptychopteria (Actinopteria) aff. P. (A.) epsilon (Hall), 1883 (p. 98)*

Left valve exterior view showing ornament and posterior auricle $(\times 2)$. Jordan River Formation, 1 mile north of Norwood, on the shore of Lake Michigan, Charlevoix County, Mich. YPM 16435.

11-13. Leptodesma (Leptodesma)? spp. (p. 96)*

11. Left valve composite mold $(\times 4)$. Lower Gravel Point Formation, SE1/4NE1/4, sec. 29, T. 34 N., R. 8 W., 2 miles west of Charlevoix, Mich. USNM 383634.

12,13 . Left valve and dorsal views of a shelled articulated specimen $(\times 6)$. Upper Ferron Point Formation, abandoned shale pit of the Alpena Portland Cement Co., SE1/4SE1/4 sec. 18, T. 32 N., R. 9 E., Alpena County, Mich. USNM 383635. 
GEOLOGICAL SURVFY

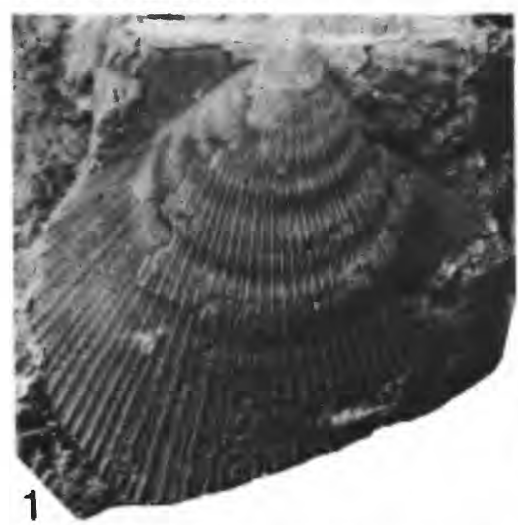

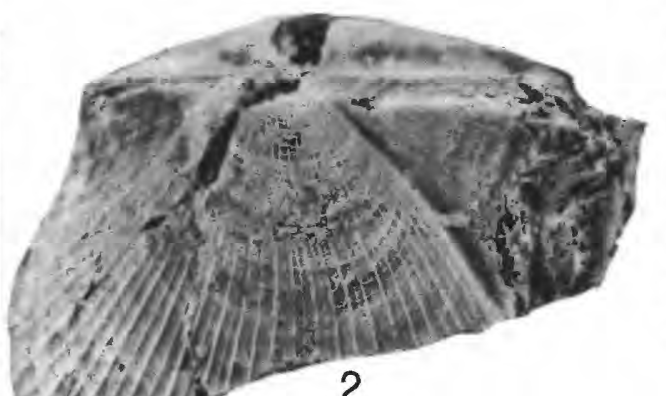
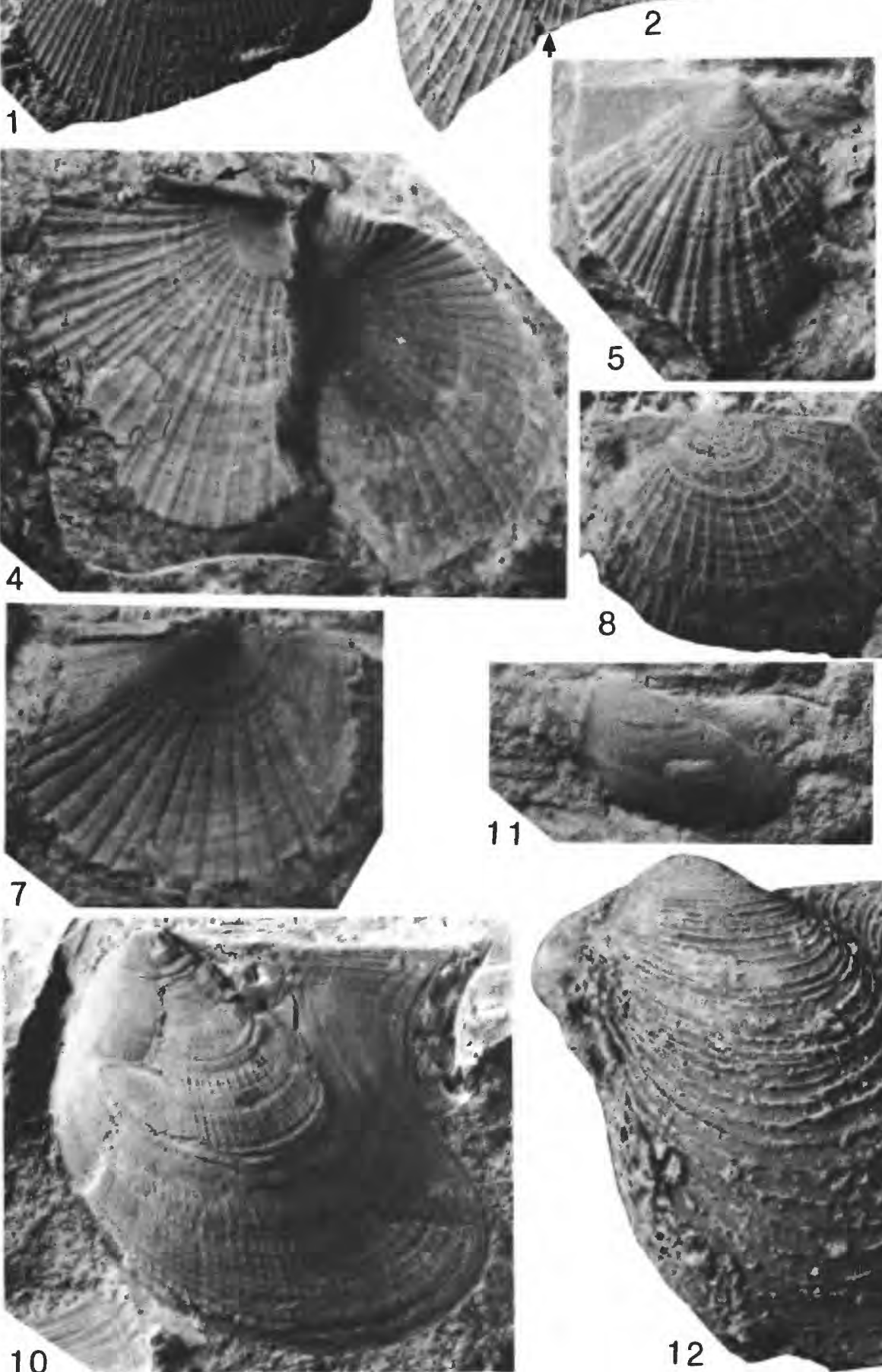

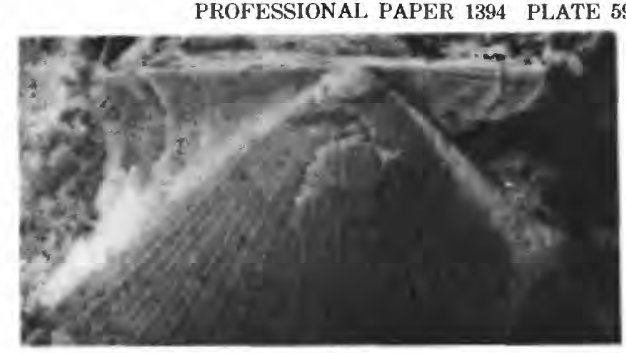

3

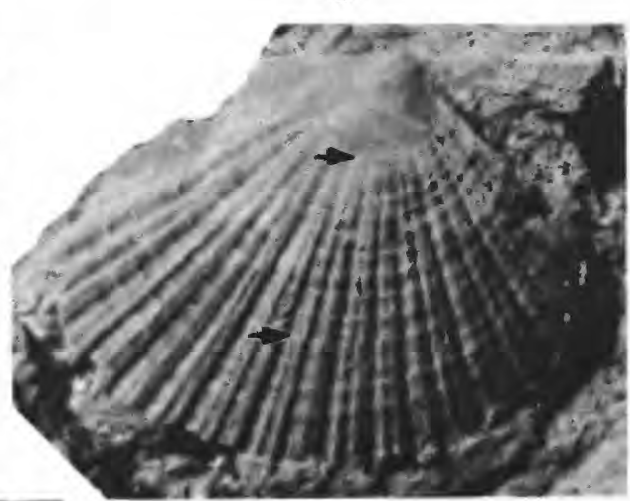

6
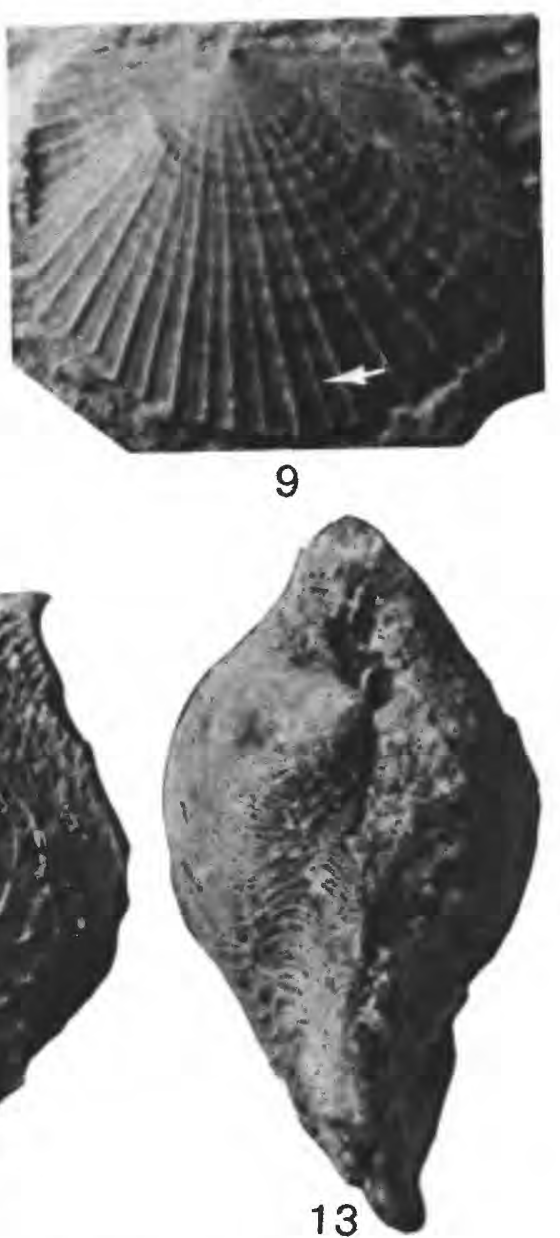

PSEUDAVICULOPECTEN, AVICULOPECTEN, LEPTODESMA (LEPTODESMA)?, AND PTYCHOPTERIA (ACTINOPTERIA) 


\section{PLATE 60}

Figures 1-5. Caneyella richardsoni Girty, 1909 (p. 93)*

1,2 . Left and right valves of the lower syntype seen in figure 5 , showing bifurcate and intercalate radial ribs (arrows). Growth lines show that there is no posterior wing $(\times 5, \times 4)$. USNM 120768 .

3 , 4. Right and left valves of the upper syntype seen in figure 5 , showing bifurcate and intercalate radial ornament (arrows) $(\times 5)$. USNM 383624.

5. Rock chip showing the two syntypes $(\times 2)$. Caney Shale (Upper Mississippian), center of north side of sec. 14, T. 2 S, R. 7 E., Tishomingo quadrangle, Oklahoma.

6, 7. Actinodesma (Ectenodesma) birostratum (Hall), 1883 (p. 92)*

Left valve external mold and latex cast of same, showing multicostellate radial ribs and large anterior and posterior dorsal wings $(\times 2)$. The museum label reads "Devonian (Portage), Bloomsburg, Penn." USNM 100902. 
GEOLOGICAL SURVEY
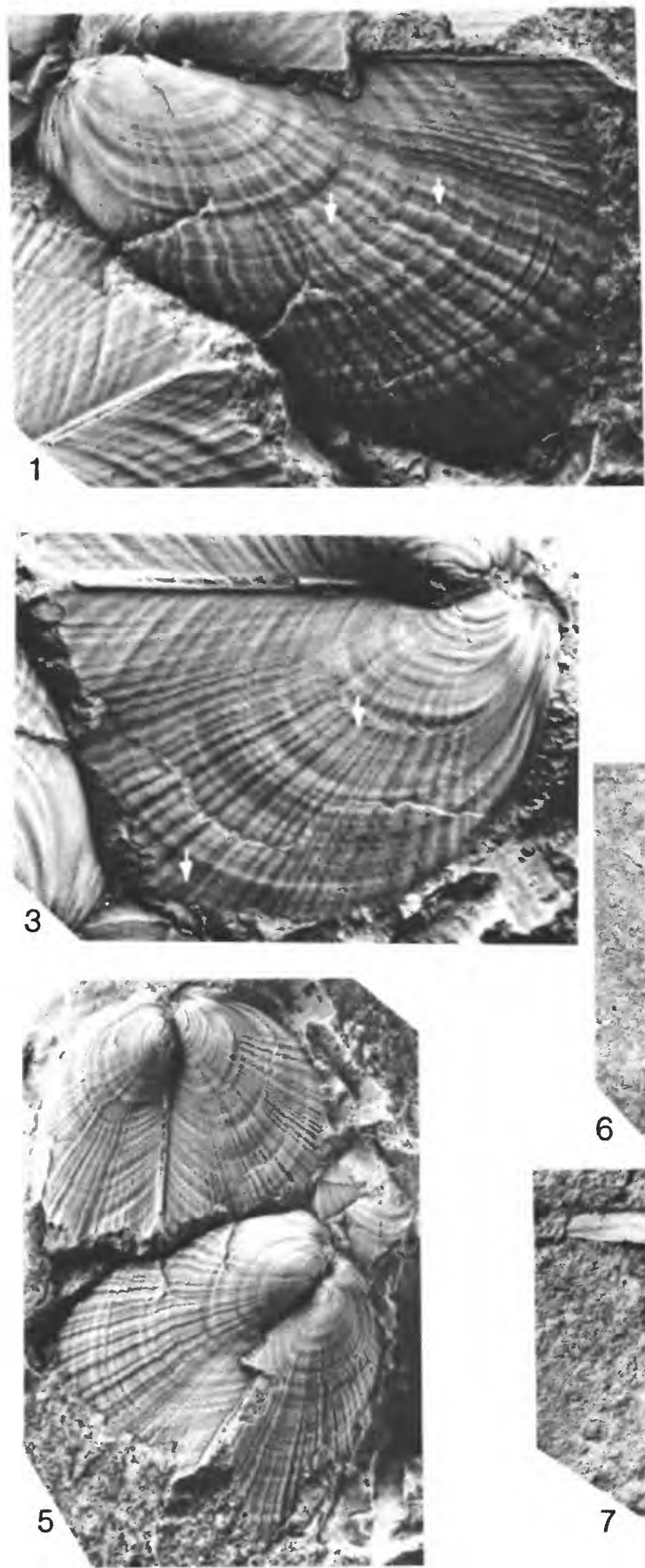

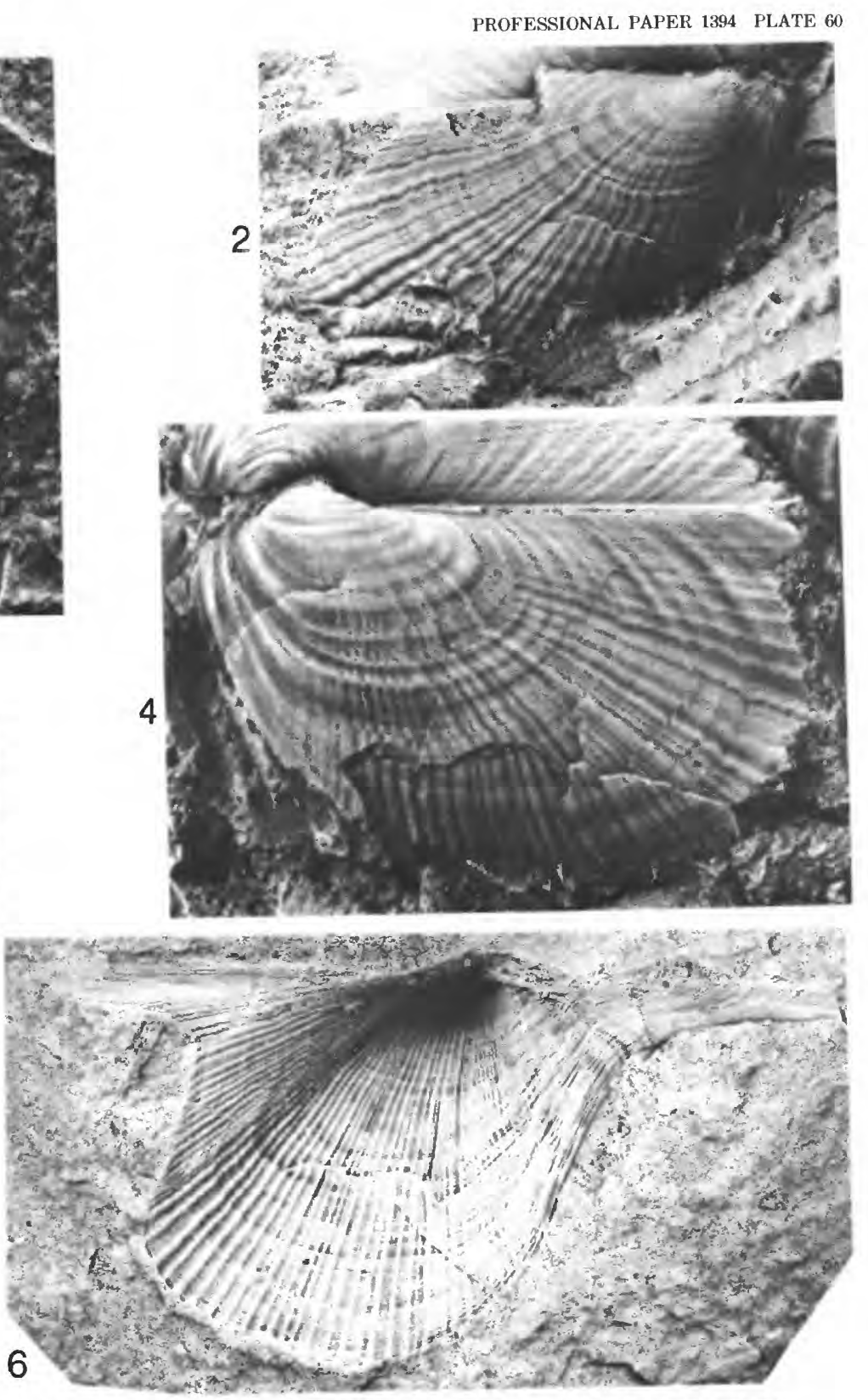




\section{PLATE 61}

Figure 1. Ptychopteria (Actinopteria) aff. P. (A.) epsilon (Hall), 1883 (p. 98)*

Right valve composite mold showing ornament, small anterior auricle, and posterior auricle $(\times 2)$. Jordan River Formation, 1 mile north of Norwood, on the shore of Lake Michigan, Charlevoix County, Mich. YPM 16438.

2-4, 6-8. Limoptera macroptera (Conrad), 1838 (p. 96)*

2-4. Right valve, dorsal, and left valve views of a partially shelled specimen showing simple ribs $(\times 2)$. Genshaw Formation, near center NE1/4 sec. 10, T. 31 N., R. 9 E., Alpena County, Mich. USNM 383630 .

6. Right valve composite mold showing ornament, small anterior auricle, and remnants of duplivincular ligament grooves and ridges along the posterodorsal margin (arrow) $(\times 1)$. Delphi Station Shale (Hamiltonian), U.S. Route 20, 1.5 miles east of Pompey Center, N.Y. USNM 139573.

7, 8. Dorsal and left valve views of a composite mold, showing simple ribs $(\times 1$ ). Silica Shale (Givetian), from a quarry 2.5 miles southwest of Sylvania, Ohio. USNM 383632.

5. Leptodesma (Leptodesma)? sp. (p. 96)*

Poorly preserved, partially shelled left valve $(\times 2)$. Upper Ferron Point Formation, abandoned shale pit of the Alpena Portland Cement Co., SE1/4 sec. 18, T. 32 N., R. 9 E., Alpena County, Mich. USNM 383636. 
GEOLOGICAL SURVEY
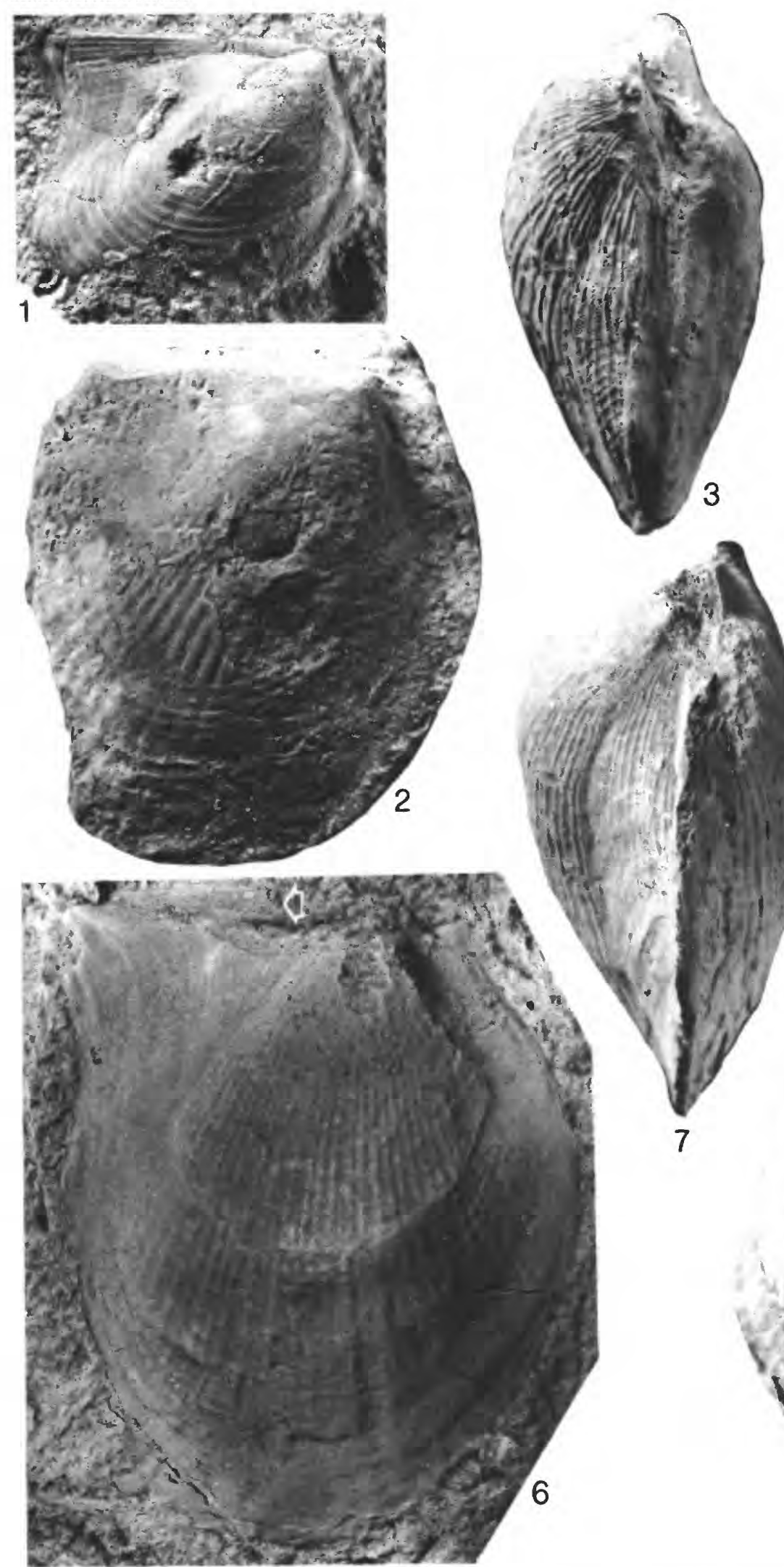

PTYCHOPTERIA (ACTINOPTERIA), LEPTODESMA (LEPTODESMA)?, AND LIMOPTERA
PROFESSIONAL PAPER 1394 PLATE 61
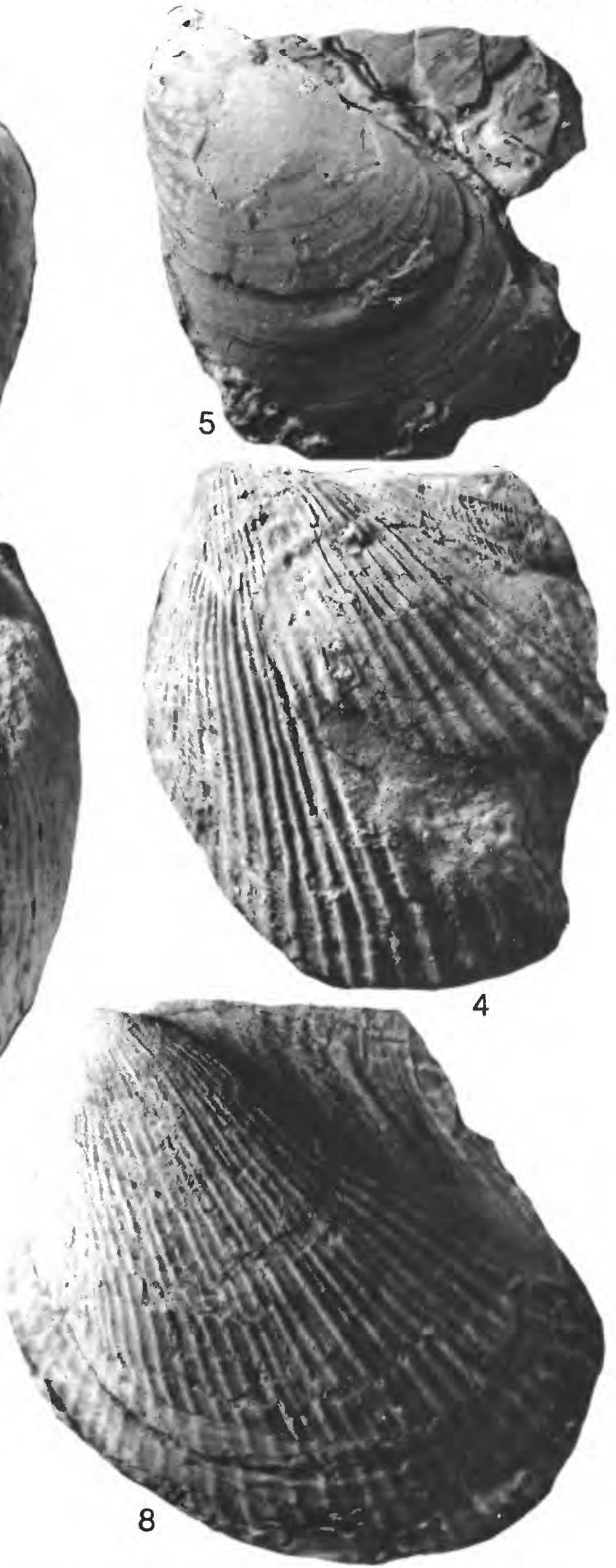


\section{PLATE 62}

Figures 1-3, 7, 8. Limoptera macroptera (Conrad), 1838 (p. 96)*

1,2. Right and left valves of a composite mold showing simple ribs $(\times 1.5)$. The museum label reads "Hamilton, Schoharie Co., New York." USNM 26092.

3 , 7. Left and right valve composite molds from the same lot (USNM 17651) and labeled as coming from the Hall Collection. Left valve not well preserved, right valve shows the small anterior auricle, pallial line and weakly preserved posterior adductor muscle scar (arrow) $(\times 2)$. The museum label reads "Hamilton, Pratts Falls, Onondaga County, New York." USNM 17651a, b.

8. Large, poorly preserved left valve composite mold $(\times 1)$. Lower Alpena Limestone, Long Lake Road, 0.5 miles south of the northeast corner of sec. 27, T. 32 N., R. 8 E., Alpena County, Mich. USNM 383631 .

4-6. Cornellites fasciculatus (Goldfuss), 1836 (p. 94)*

Dorsal view $(\times 2)$, enlargement of ornament on umbo $(\times 5)$, and left valve view $(\times 2)$ of a shelled specimen. See plate 63 , figures 6 . Genshaw Formation, SE1/4 sec. 18, T. 32 N., R. 9 E., Alpena County, Mich. USNM 383648. 
GEOLOGICAL SURVEY
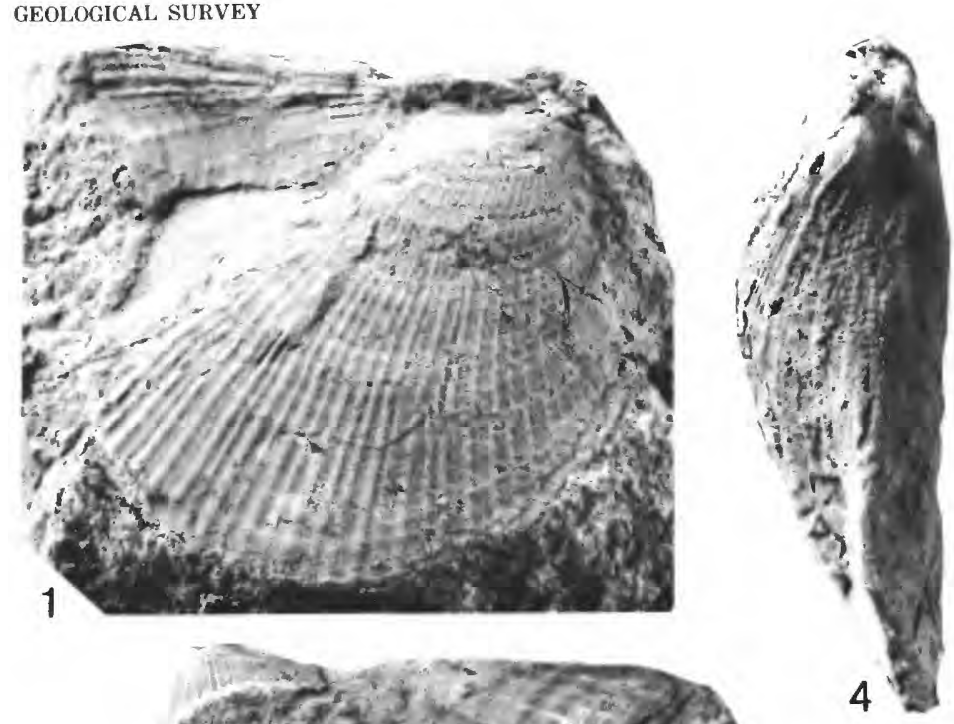

PROFESSIONAL PAPER 1394 PLATE 62
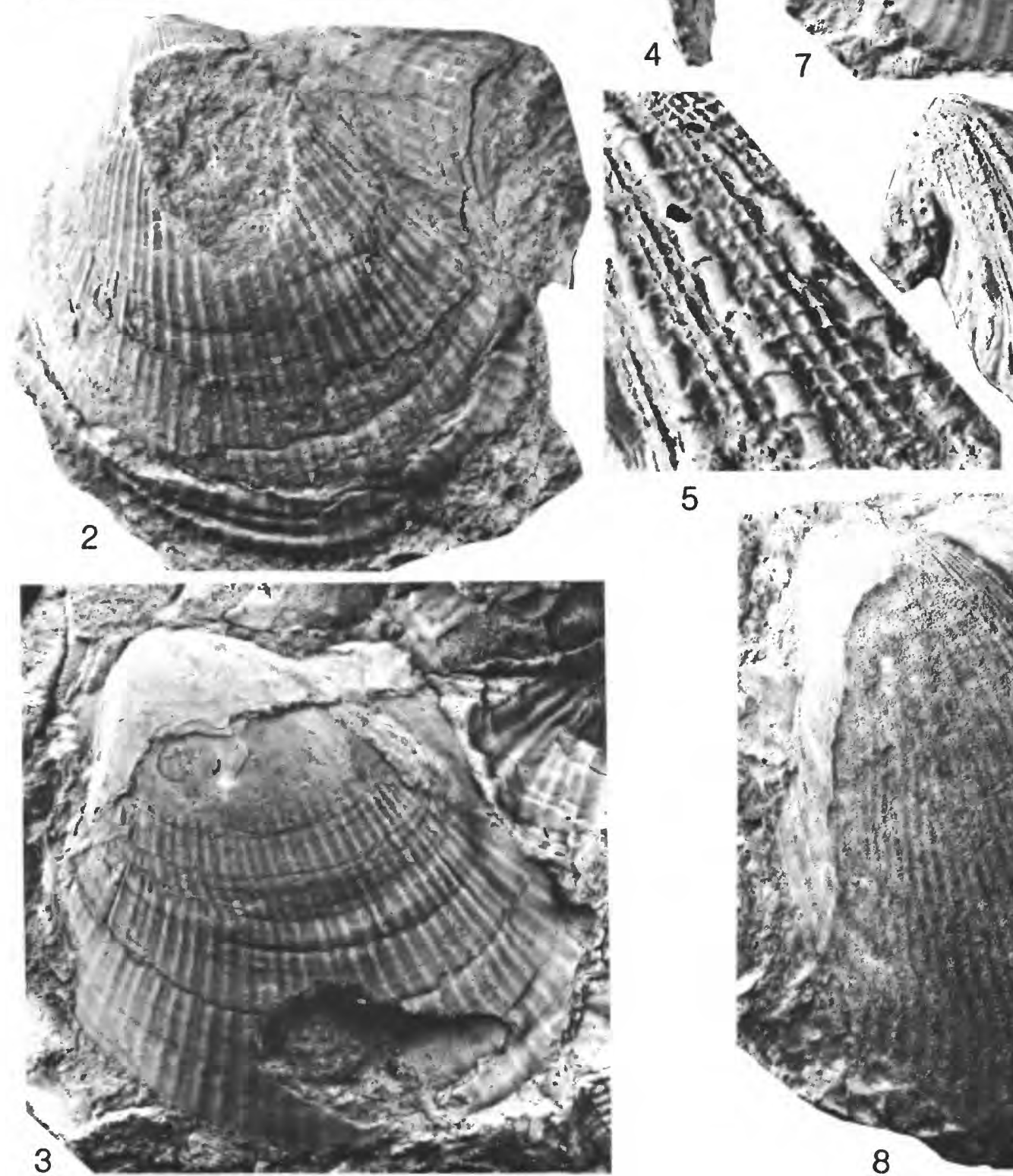

5
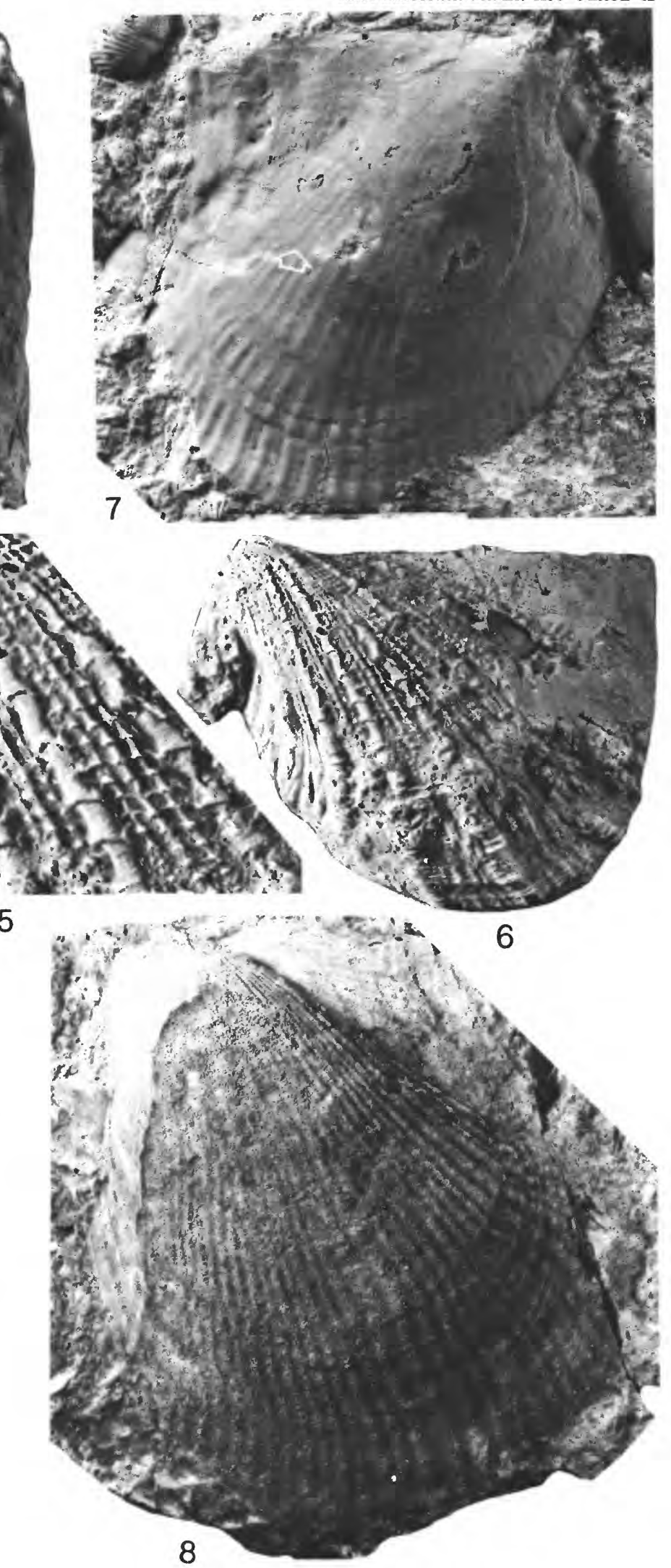


\section{PLATE 63}

Figures 1-10. Cornellites fasciculatus (Goldfuss), 1836 (p. 94)*

1, 2. Right valve internal mold showing pallial line and posterior adductor muscle scar $(\times 2)$ and dorsal view $(\times 3)$. Norway Point Formation, 3 miles southeast of Four Mile Dam, on southwest side of Thunder Bay River, NE1/4NE1/4 sec. 18, T. 31 N., R. 8 E., Alpena County, Mich. USNM 383639.

3 . Left valve showing closely crowded primary ribs; compare with plate 62 , figure 6 , and plate 63 , figures $4,8,10(\times 2)$. Genshaw Formation, abandoned shale pit of the Alpena Portland Cement Co., SE1/4 sec. 18, T. 32 N., R. 9 E., Alpena County, Mich. USNM 383649.

4-5. Left valve view of a shelled specimen showing lamellose growth increments on primary ribs $(\times 2)$, and enlargement of ribs near the posteroventral margin $(\times 4)$. Lower Genshaw Formation, locality unknown. YPM 16623.

6. Right valve of the specimen shown on plate 62 , figures $4-6(\times 2)$. USNM 383648.

7, 8. Enlargement of ornament in upper umbonal area of the left valve seen in figure $8(\times 4, \times 2)$. Genshaw Formation, Rabiteau Farm, NW1/4 sec. 35 , T. 32 N., R. 8 E., Presque Isle County, Mich. USNM 383638.

9, 10. Enlargement of ornament on posteroumbonal slope of the left valve seen in figure 10 , which is encrusted $(\times 6, \times 3)$. Lower Bell Shale, quarry of the Michigan Limestone and Chemical Co., Calcite, Rogers City, Mich. USNM 383650. 

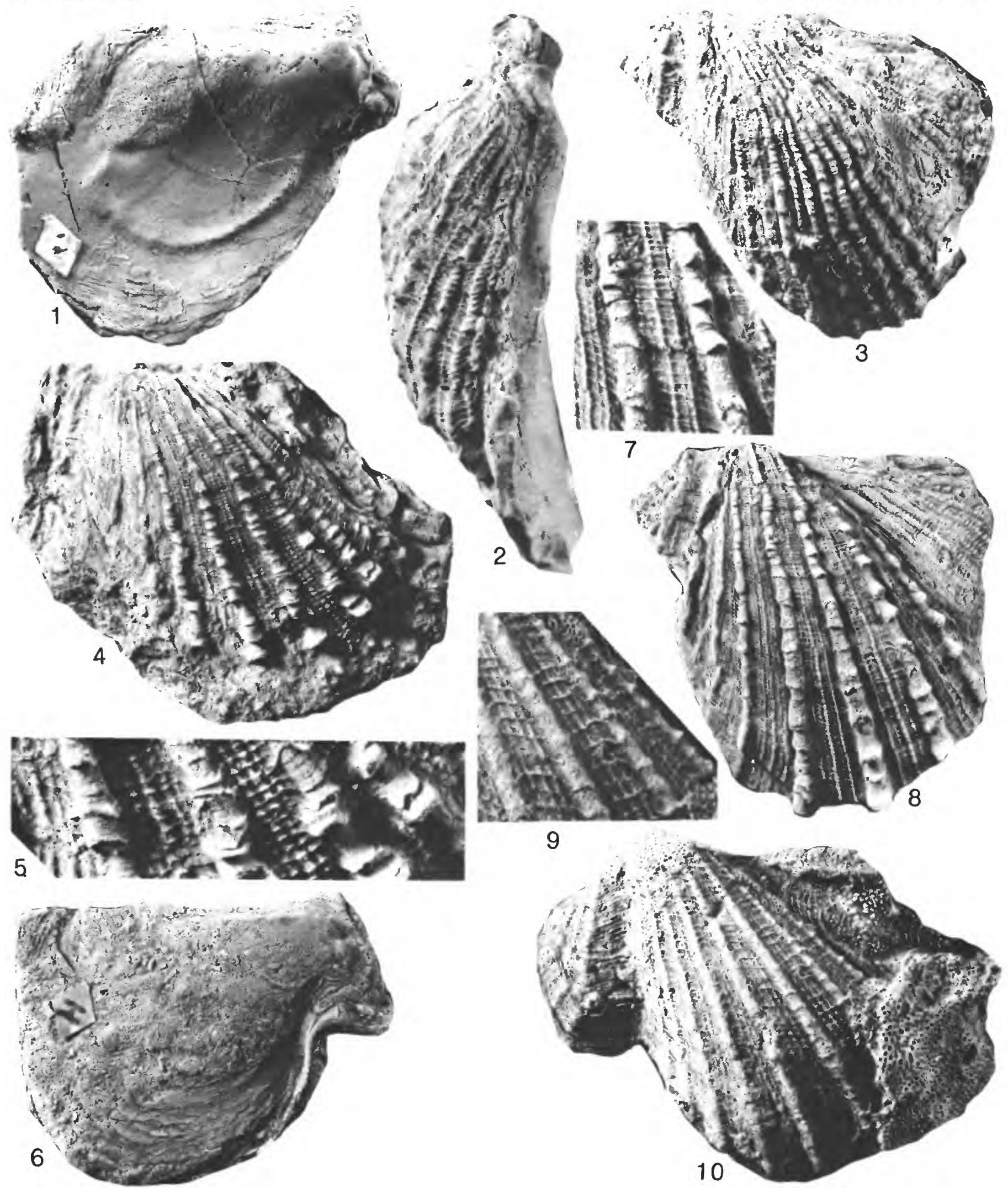

CORNELLITES 


\section{PLATE 64}

FiguRes 1-5. Limoptera macroptera (Conrad), 1838 (p. 96)*

Internal mold, photographed in very oblique light to accentuate muscle scars. In figure 4, highlight is from the upper right.

1. Left valve showing posterior adductor muscle scar (long arrow); posterior byssal-pedal muscle scar (short horizontal arrow); muscle tracks of both scars; pallial line extending both dorsally and anteriorly from the posterior part of the posterior scars (short oblique arrows); and point attachment scars of the mantle, which are most prominent inside the pallial line $(\times 2)$.

2. Enlargement of the features marked by arrows in figure 1 above; muscle tracks indicated by long arrows; pallial retractor muscle scar marked with short horizontal arrow; and pedal elevator muscle scar marked with short oblique arrow $(\times 3)$.

3. Anterior view showing valve inequality, small anterior auricle, and pallial lines (arrows) $(\times 2)$.

4. Right valve showing posterior adductor muscle scar; posterior byssalpedal retractor muscle scar; pallial line extending both dorsally and anteriorly from the posterior part of the posterior scars; point attachment scars of the mantle, which are prominent inside the pallial line; pallial retractor muscle scar (short arrow); and three pedal elevator muscle scars (anteriormost marked with long arrow) (X 3).

5. Dorsal view showing valve inequality, pallial retractor muscle scars (short oblique arrows); anteriormost pedal elevator muscle scars (long arrows); and two cardinal teeth in each valve (marked with short horizontal arrows in right valve) $(\times 3)$. Hamiltonian age rocks, near Garradstown, W. Va. USNM 388222 . 

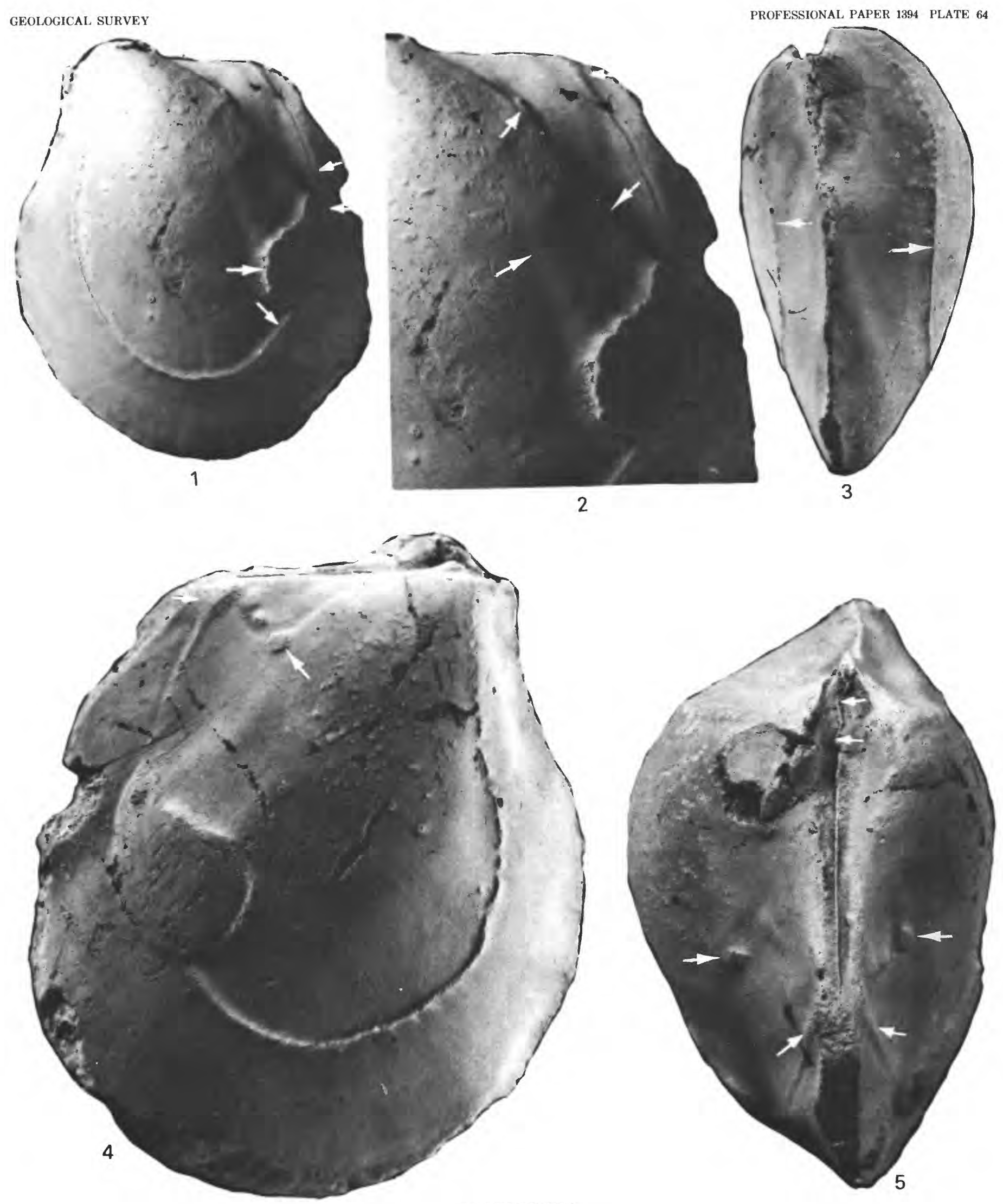

LIMOPTERA 


\section{PLATE 65}

Figure 1. Angular unconformity between Cambrian (hammer) and the Lower Devonian Lianhuashan Formation (Gedinnian). Roadcut about $20 \mathrm{~km}$ east of Section 2.

2. Massive-bedded sandstone of the Lower Devonian Lianhuashan Formation (Gedinnian). The bed marked by the arrow is $2 \mathrm{~m}$ thick. Locality the same as in figure 1 above.

3. Xiayiling Member of the Nagaoling Formation (to right) (Gedinnian-Siegenian) and the Shizhou Member of the Yujiang Formation (to left) (Siegenian-Emsian) at Section 1. The man is standing at the boundary. 

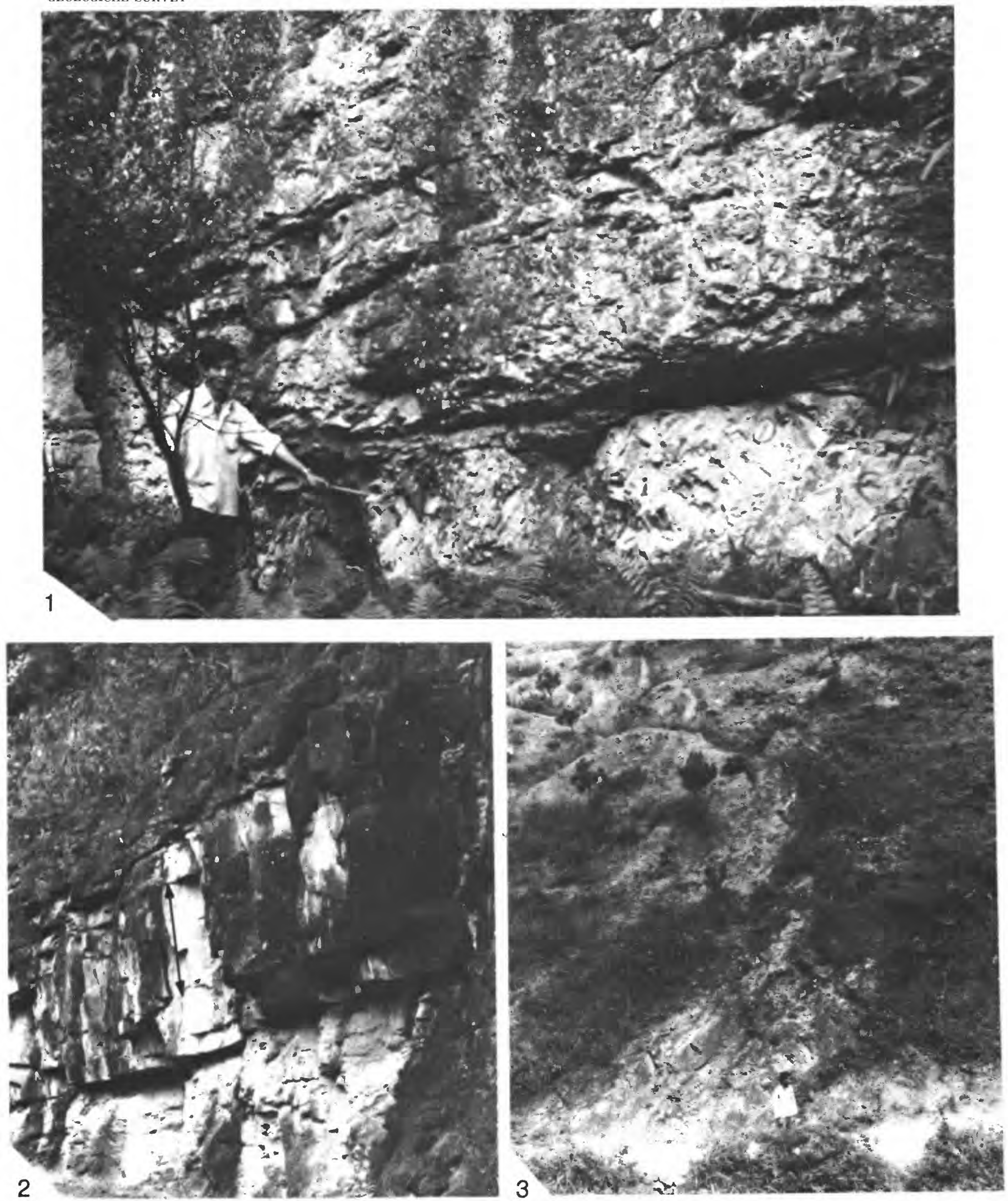


\section{PLATE 66}

FIgURE 1. Mudstone intercalated with limestone of the Yujiang Formation (Siegenian-Emsian). The beds marked by the arrow are $1.5 \mathrm{~m}$ thick. Section 1 .

2. Cliff-forming limestones of the Donggangling (below) and the Liujiang (above) Formations. The arrow points to the Middle-Upper Devonian boundary. The Donggangling (Givetian) is thin to medium bedded, and the Liujiang (Frasnian) is thick to massive bedded. Section 2 .

3. Cliff-forming sandstone of the Lianhuashan Formation (Gedinnian), about $20 \mathrm{~km}$ east of Section 2. Bridge over creek gives scale.

4. Exposure of mudstone and siltstone, interbedded with limestone, of the Nagaoling Formation (Gedinnian). The beds marked by the arrow are $1 \mathrm{~m}$ thick. Section 1 . 
GEOLOGICAL SURVEY
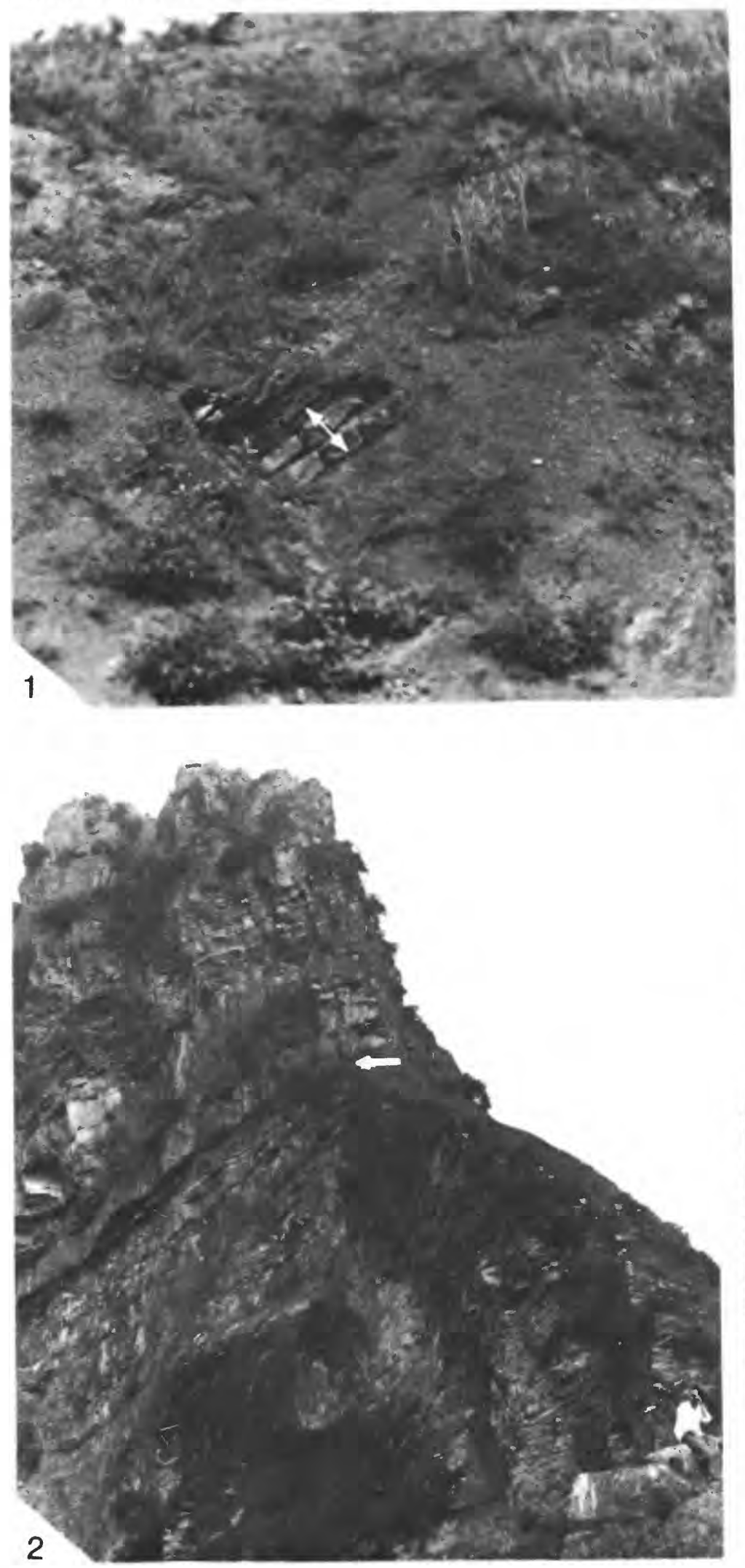

PROFESSIONAL PAPER 1394 PLATE 66
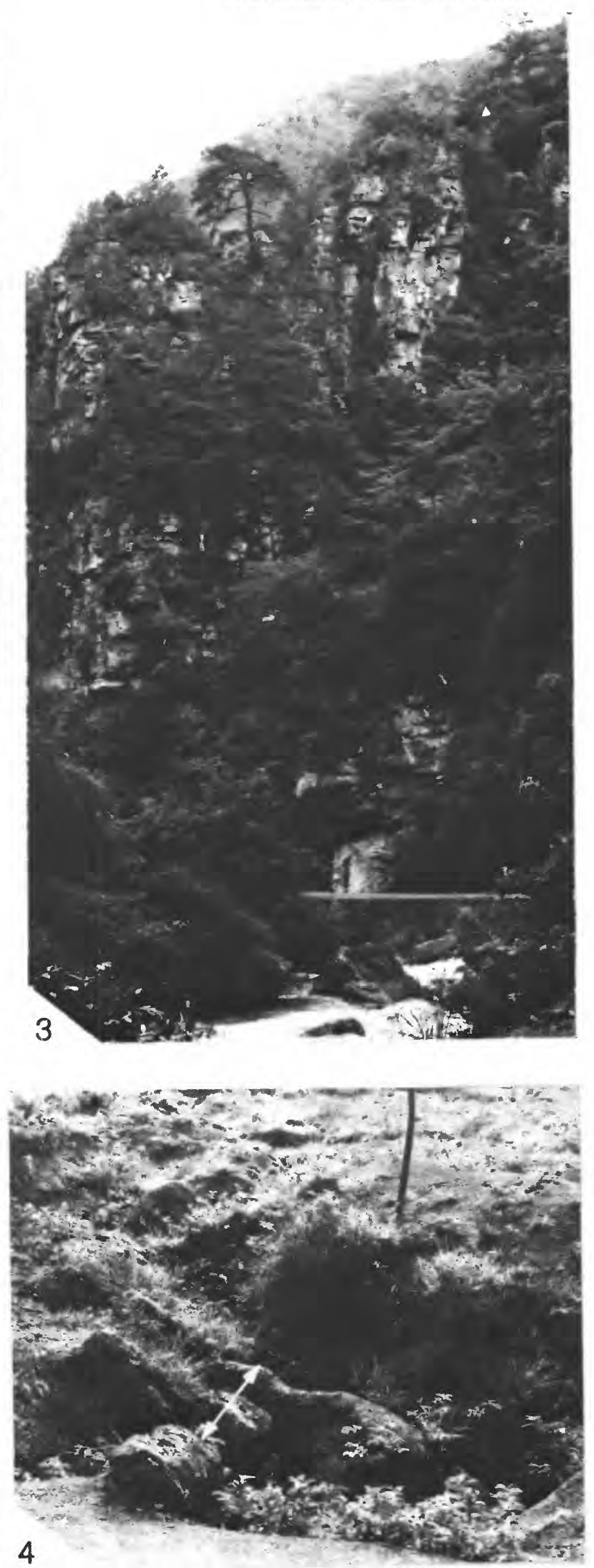